\author{
UNIVERSIDADE DE SÃO PAULO \\ PROGRAMA DE PÓS-GRADUAÇÃO INTERUNIDADES EM ENSINO DE \\ CIÊNCIAS \\ INSTITUTO DE FÍSICA - INSTITUTO DE QUÍMICA \\ INSTITUTO DE BIOCIÊNCIAS - FACULDADE DE EDUCAÇÃO
}

MARIA NEUZA ALMEIDA QUEIROZ

O ensino de Física no Brasil nas décadas de 1960 e 1970:

legislação, currículo e material didático

São Paulo

2016 
MARIA NEUZA ALMEIDA QUEIROZ

\title{
O ensino de Física no Brasil nas décadas de 1960 e 1970: legislação, currículo e material didático
}

\begin{abstract}
Tese apresentada ao Programa de Pós-Graduação Interunidades em Ensino de Ciências da Universidade de São Paulo (PIEC-USP), como requisito para obtenção do título de Doutor em Ensino de Ciências.
\end{abstract}

Área de Concentração: Ensino de Física

Orientadora: Prof ${ }^{\mathrm{a}} \operatorname{Dr}^{\mathrm{a}}$ Yassuko Hosoume

(Versão Corrigida. A versão original em formato eletrônico (pdf) encontra-se disponível na CPG da unidade)

\section{São Paulo}


Autorizo a reprodução e divulgação total ou parcial deste trabalho, por qualquer meio convencional ou eletrônico, para fins de estudo e pesquisa, desde que citada a fonte.

\section{FICHA CATALOGRÁFICA \\ Preparada pelo Serviço de Biblioteca e Informação do Instituto de Física da Universidade de São Paulo}

Queiroz, Maria Neuza Almeida

O ensino de Física no Brasil nas décadas de 1960 e 1970: legislação, currículo e material didático. São Paulo, 2016.

Tese (Doutorado) - Universidade de São Paulo. Faculdade de Educação, Instituto de Física, Instituto de Química e Instituto de Biociências

Orientador: Prof. Dr. Yassuko Hosoume

Área de Concentração: Ensino de Física

Unitermos: 1. Pesquisa Histórica; 2. Ensino - Física; 3. Currículos e Programas Física; 4. Projetos de Ensino - Física; 5. Materiais Didáticos.

USP/IF/SBI-043/2016 


\section{AGRADECIMENTOS}

Primeiramente agradeço a Deus, por tudo.

À minha família, pela compreensão nos momentos de ausência.

À Prof ${ }^{a} \operatorname{Dr}^{a}$ Yassuko Hosoume, por ter me permitido o privilégio de ser sua orientada, por acreditar em minha capacidade, pela paciência e dedicação em todas às vezes que precisei.

Aos colegas do Programa, especialmente a colega Elrismar, pela paciência em escutar minhas lamúrias; Marcos e Kauê, pela ótima convivência e amizade nascente.

À Prof ${ }^{a}$ Dr $^{a}$ Cristina Leite, pela oportunidade de aprendizagem e pela simpatia e cordialidade.

À Renata Ribeiro (Educadora do Instituto de Física da USP); à Marta Máximo (exaluna/colega do Programa); à Professora Deise Miranda (UFRJ); e ao Professor Nilson Garcia (UTFPR): todos, pela imensa contribuição com o envio de materiais empíricos para esta pesquisa - não há palavras suficientes para um agradecimento justo a estas pessoas.

À amiga Dolanei França, pelo apoio e muitas conversas contributivas sobre a temática do trabalho.

À colega e amiga Maria do Socorro, pelo apoio e leitura crítica de um trecho deste trabalho.

Aos colegas do Instituto Federal de Educação Ciência e Tecnologia do Norte de Minas Gerais (IFNMG) - Campus Pirapora, pelo incentivo e apoio (não vou listar para não correr o risco de ser injusta).

Ao IFNMG, pelo apoio financeiro e pela concessão do afastamento de dois anos para realização do curso de doutoramento que resultou nesta pesquisa. 
"Todo sistema de educação é uma maneira política de manter ou de modificar a apropriação dos discursos, com os saberes e os poderes que eles trazem consigo".

(Michel Foucault) 


\section{RESUMO}

QUEIROZ, M. N. A. O ensino de Física no Brasil nas décadas de 1960 e 1970: legislação, currículo e material didático. 367 f. Tese (Doutorado) - Instituto de Física, Faculdade de Educação, Instituto de Química e Instituto de Biociências, Universidade de São Paulo, São Paulo, 2016.

Procurou-se resgatar parte da história do ensino de Física no Brasil nas décadas de 1960 e 1970, quando o sistema educacional se subordinava à primeira Lei de Diretrizes e Bases da Educação brasileira - a LDB/1961, e, posteriormente, a Lei 5.692/1971. Esta primeira LDB provocou significativas modificações no currículo escolar ao descentralizar os programas das disciplinas escolares concedendo aos Estados e suas escolas a flexibilidade para definirem seus currículos mais ajustados às suas peculiaridades; possibilitou a realização de experiências educacionais e concedeu liberdade aos autores de livros didáticos, suprimindo a obrigatoriedade de seguirem um programa oficial. A partir da análise de documentos que orientaram o currículo nas escolas (legislação educacional, propostas curriculares apresentadas pelos Estados brasileiros, propostas de ensino apresentadas por grupos de pesquisadores e Universidades e livros didáticos de expressiva repercussão) editados no período para o nível equivalente ao atual Ensino Médio, buscou-se compreender os princípios (normativos, filosóficos e didático-pedagógicos) que nortearam o ensino de Física, no contexto colocado. No que tange as propostas curriculares específicas, objetivou-se compreender, por meio de uma análise de conteúdo, as concepções de Ciência e de Educação presentes nas mesmas, adotando como direcionamento da análise duas dimensões cognitivas Epistemológica e Educativa. Do estudo na legislação, constatou-se a contradição entre o discurso da Lei e as formas de organização curricular que concedeu pouco espaço às disciplinas científicas, incluindo a Física. Contudo, outros fatores contribuíram para alentar o ensino de Ciências promovendo a entrada de propostas inovadoras no país; propiciaram a elaboração de propostas nacionais e também refletiram no mercado editorial dos livros didáticos. Das orientações curriculares específicas analisadas, os resultados revelam que as mesmas assumem diferentes visões de ciência Física: enquanto umas têm a Ciência como um processo dinâmico e de inerência experimental, ainda que alguns aspectos sejam pouco explorados, outras passam a ideia de ciência neutra, linear, ahistórica e, mesmo propondo experimentos, não enfatiza a inerência experimental da Física; priorizam os conceitos/definições e o formalismo matemático. Na perspectiva educacional, o ensino de Física no contexto estudado assumiu diferentes objetivos, tais como: apresentar ao aluno a ciência dos cientistas (transmissão de conteúdos do corpo de conhecimento da ciência/Física numa abordagem mais informativa); formar futuros cientistas e profissionais da área tecnológica e treinar para o acesso ao ensino superior. Algumas propostas assumiram o pressuposto pedagógico de conceder ao aluno uma participação mais ativa e de maior responsabilidade no seu processo de aprendizagem, e o papel do professor recolocado em uma posição mais periférica no processo educativo com a função de programar e controlar o processo de ensino. Outras permaneceram com as características do ensino tradicional, pressupondo um ensino expositivo auxiliado pelos manuais didáticos.

Palavras-chave: Ensino de Física. Currículo de Física. Projetos de Ensino. Livro Didático. 


\begin{abstract}
QUEIROZ, M. N. A. Physics teaching in Brazil in the 1960s and 1970s: legislation, curriculum and teaching materials. 367 f. Tese (Doutorado) - Instituto de Física, Faculdade de Educação, Instituto de Química e Instituto de Biociências, Universidade de São Paulo, São Paulo, 2016.
\end{abstract}

In this work tried to rescue part of the history of Physics teaching in Brazil in the 1960s and 1970s, when the educational system was subordinated to the first Law of Directives and Bases of Brazilian Education- the LDB/1961 and Law 5.692/1971. This first LDB brought significant changes in the school curriculum when to decentralize school subjects programs giving to the States and their schools the flexibility to define their curricula more suited to their peculiarities; It was possible the development of educational experiences and granted freedom to the textbooks authors, removing the requirement to follow an official program. From the analysis of documents that guided the schools curriculum (educational legislation, curriculum proposals presented by Brazilian states, education proposals submitted by groups from researchers and universities and also significant impact textbooks) published during the period to the equivalent level to the present high school, it was sought to understand the principles (normative, philosophical and didactic pedagogical) that guided the teaching of physics in this appropriate context. Regarding the specific curriculum proposals it was aimed to understand, through a content analysis, the conceptions of Science and Education present in both, adopting as directing the analysis of cognitive dimensions - Epistemological and Educational. From the legislation study, it was possible to find a contradiction between the law discourse and ways of curricular organization that has given little space to the scientific disciplines, including the Physics. However, other factors contributed to encourage the Science teaching promoting the entry of new proposals in the country; they led to the national proposals development and also reflected in the publishing market textbooks. From the analyzed specific curriculum guidelines, the results reveal that they take different views of Physical science: while some of them have science as a dynamic and experimental inherent process, although some aspects are a little explored, others undergo the idea of neutral science, linear, unhistorical and, even when proposed experiments, it does not emphasize the Physics experimental inherence; prioritize the concepts/definitions and mathematical formalism. In the educational perspective, the physics teaching in the studied context took different goals, such as: show to the students the scientists science (transmission of knowledge content in the science/physics in a more informative approach); To train future scientists and professionals in the technological area and as also for access to higher education. Some proposals have taken on the pedagogical presupposed to grant to the student a more active participation and greater responsibility for their learning process, and the teacher role reattached in a more peripheral position in the educational process with the task to program and control the teaching process. Others remained with the teaching traditional characteristics, assuming an expository teaching aided by educational textbooks.

Keywords: Physics Teaching. Physics curriculum. Education Projects. Teaching textbook. 


\section{LISTA DE FIGURAS}

FIGURA 1 - Capa dos manuais do PSSC, Parte I e Guia do Professor Vol. III. 143

FIGURA 2 - Recortes de texto do PSSC referente a exercícios investigativos da seção PARA CASA, CLASSE E LABORATÓRIO (PSSC-LT, Parte II, p. 1920)

FIGURA 3 - Capas dos fascículos iniciais dos Conjuntos de textos e Guia do Professor do PEF

FIGURA 4 - Capa e contracapa do fascículo referente ao capítulo 5 do PEF

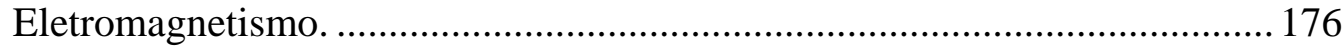

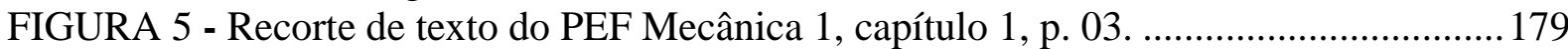

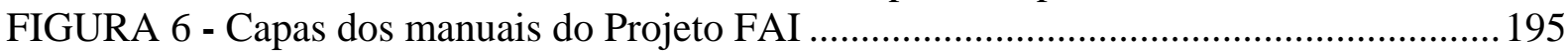

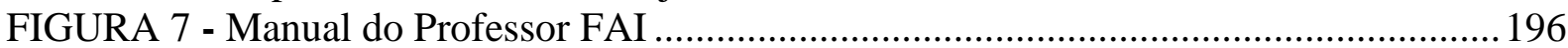

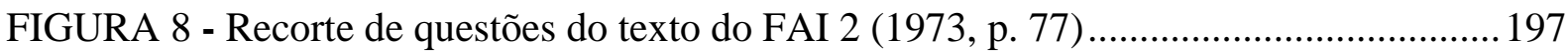

FIGURA 9 - Modelo de Máscara utilizada no desenvolvimento das atividades do projeto

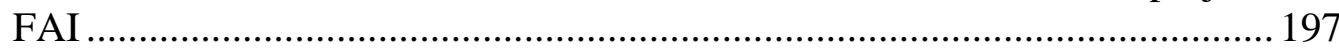

FIGURA 10 - Esquema de organização dos conteúdos no FAI, conforme MP-FAI ..............205

FIGURA 11 - Capa dos documentos localizados referentes à Proposta Curricular do RJ $(1976,1977)$

FIGURA 12 - Grade curricular do $2^{\circ}$ grau na Reformulação de Currículo do Estado do Rio de Janeiro, em 1977.

FIGURA 13 - Grade curricular da parte de Formação Especial referente à Habilitação Básica Eletricidade, do $2^{\circ}$ grau do Estado do Rio de Janeiro, 1977.............. 221

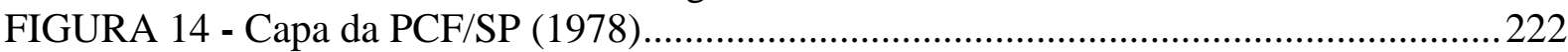

FIGURA 15 - Manuais da coleção de Dalton Gonçalves (1970/1970/1970/1974/1969).......257

FIGURA 16 - Recorte de texto da obra de GONÇALVES (1969, vol.. 5, cap. 13, p. 178)...258

FIGURA 17 - Foto de manuais da coleção de Alvarenga e Máximo (1970/1974/1971) .......259

FIGURA 18 - Foto dos manuais da coleção de Alvarenga e Máximo (1979) ........................262

FIGURA 19 - Foto dos manuais da coleção de Ramalho et al. (1979/1976/1978) .................264

FIGURA 20 - Exemplo de atividade experimental na obra Alvarenga e Máximo (1971, vol. 3, p. 12.)

FIGURA 21 - Recorte de texto da obra de Gonçalves (1970, vol. 2, p. 247). .......................276

FIGURA 22 - Recorte de texto da obra de Ramalho Junior et al. (1979, vol. 1, p. 343), ......278

\section{LISTA DE GRÁFICOS}

Gráfico 1 - Quantitativos anuais de trabalhos com análises de conteúdos em livros didáticos de Física. 


\section{LISTA DE QUADROS}

QUADRO 1 - Descrição das categorias analíticas/elementos

QUADRO 2 - Listas de disciplinas para composição do quadro curricular apresentadas na Indicação de 24.02.1962, nos termos da LDB/1961.

QUADRO 3 - Quadro exemplificativo de variedades admissíveis para a organização curricular do ciclo Ginasial publicado no D.O.U de 24 de abril de 1962 ......... 81

QUADRO 4 - Quadro exemplificativo de variedades admissíveis para a organização curricular do ciclo Colegial publicado no D.O.U de 24 de abril de 1962 ............................... 81

QUADRO 5 - Quadro comparativo da presença de disciplinas da área de Ciências nas reformas educacionais de 1932, 1942 e 1961.

QUADRO 6 - Síntese de dados sobre as cargas horárias semanal das disciplinas e prática educativa obrigatórias nos currículos analisados por Cunha e Abreu (1965).

QUADRO 7 - Carga horária semanal das disciplinas da área Ciências da Natureza nas reformas de 1931 e 1942.

QUADRO 8 - Temas e títulos dos capítulos do PSSC

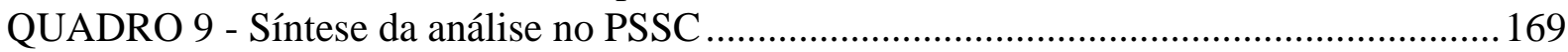

QUADRO 10 - Síntese da análise no PEF e do FAI ...............................................................212

QUADRO 11 - Tópicos de conteúdos de Física da Proposta Curricular do Rio de Janeiro (1977).

QUADRO 12 - Temas e tópicos de Física nas séries do $2^{\circ}$ grau - Habilitações Básicas e Magistério na Proposta Curricular do Estado de São Paulo (1978)............... 239

QUADRO 13 - Síntese da análise nas Propostas Curriculares.............................................247

QUADRO 14 - Organização dos conteúdos na obra LD1 .....................................................28

QUADRO 15 - Organização dos conteúdos nas obras LD2 e LD3 .....................................2282

QUADRO 16 - Organização dos conteúdos na obra de Ramalho Junior et al. (1979, 1976,

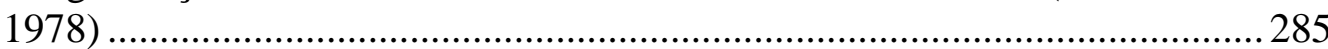

QUADRO 17 - Síntese da análise nos livros didáticos .....................................................291

\section{LISTA DE TABELAS}

TABELA 1- Teses e Dissertações brasileiras em Ensino de Física sobre Livros Didáticos, Projetos de ensino e Currículos oficiais.

TABELA 2 - Número de aulas por semana de Física, Física Aplicada e Eletricidade para as diversas modalidades de escola do $2^{\circ}$ grau do Estado de São Paulo.......... 223

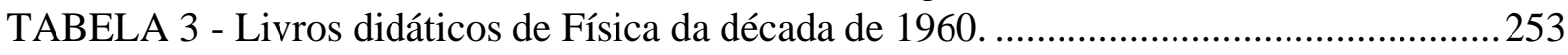

TABELA 4 - Livros didáticos de Física da década de 1970 ..................................................253 


\section{LISTA DE SIGLAS}

AI

CADES

CAPES

CAPES

CBPE

CECINE

CECIRS

CECIMG

CECIGUA

CECISP

CECIBA

CEDOC

CEE

CEE/SP

CFB

CFE

CNME

$\mathrm{CNPq}$

COLTED

CONTAP

DA

DCE

DES

D.O.U

EPEF

EUA

FAE

FNDE

FAI

FAPESP

FENAME

FUNBEC

GETEF

GREF

GP-PEF

GUP

IBECC

IBM

IFUSP

INCE

INEP
Ato Institucional

Campanha de Aperfeiçoamento e Difusão do Ensino Secundário

Campanha Nacional de Aperfeiçoamento de Pessoal de Nível Superior (1951 A 2007)

Coordenação de Aperfeiçoamento de Pessoal (a partir de 2007)

Centro Brasileiro de Pesquisas Educacionais

Centro de Ciências do Nordeste

Centro de Ciências do Rio Grande do Sul

Centro de Ciências de Minas Gerais

Centro de Ciências da Guanabara (Rio de Janeiro)

Centro de Ciências de São Paulo

Centro de Ciências da Bahia

Centro de Documentação em Ensino de Ciências

Conselho Estadual de Educação

Conselho Estadual de Educação do Estado de São Paulo

Ciências Físicas e Biológicas

Conselho Federal de Educação

Campanha Nacional de Material de Ensino

Conselho Nacional de Pesquisa

Comissão do Livro Técnico e do Livro Didático

Conselho de Cooperação Técnica da Aliança para o Progresso

Diretório Acadêmico

Diretório Central dos Estudantes

Diretoria do Ensino Secundário

Diário Oficial da União

Encontros de Pesquisadores em Ensino de Física

Estados Unidos da América

Fundação de Assistência ao Estudante

Fundo de Nacional de Desenvolvimento da Educação Básica

Física Auto-Instrutivo

Fundação de Amparo à Pesquisa do Estado de São Paulo

Fundação Nacional de Material Escolar

Fundação Brasileira para o Desenvolvimento do Ensino de

Ciências

Grupo de estudos em Tecnologia do Ensino de Física

Grupo de Reelaboração do Ensino de Física

Guia do Professor - Projeto de Ensino de Física

Ginásio Único Pluricrricular

Instituto Brasileiro de Educação, Ciência e Cultura

Internacional Business Machines

Instituto de Física da USP

Instituto Nacional do Cinema Educativo

Instituto Nacional de Estudos e Pesquisas 


\begin{tabular}{|c|c|}
\hline INL & Instituto Nacional do Livro \\
\hline IPS & Introductory Physical Science \\
\hline ITA & Instituto Técnico da Aeronáutica \\
\hline LD & Livro Didático \\
\hline LDB & Lei de Diretrizes e Bases \\
\hline LDBEN & Lei de Diretrizes e Bases da Educação Nacional \\
\hline LIVRES & Livros Escolares Brasileiros \\
\hline MEC & Ministério da Educação e Cultura \\
\hline MP-FAI & Manual do Professor - Física Auto-Instrutivo \\
\hline MOBRAL & Movimento Brasileiro de Alfabetização \\
\hline PEF & Projeto de Ensino de Física \\
\hline PEF-MEC & Projeto de Ensino de Física - Mecânica \\
\hline PEF-ELETRIC & Projeto de Ensino de Física - Eletricidade \\
\hline PEF-ELETROMAG & Projeto de Ensino de Física - Eletromagnetismo \\
\hline PCF & Proposta Curricular de Física \\
\hline PCN & Parâmetros Curriculares Nacionais \\
\hline PBEF & Projeto Brasileiro de Ensino de Física \\
\hline PNMEC & Projeto Nacional para Melhoria do Ensino de Ciências \\
\hline PPFU & Projeto Piloto de Física da UNESCO \\
\hline PREMEM & Programa de Expansão e Melhoria do Ensino Médio \\
\hline PNLD & Programa Nacional do Livro Didático \\
\hline PNLEM & Programa Nacional do Livro Didático para o Ensino Médio \\
\hline PPGI & Programa de Pós-Graduação Interunidades em Ensino de Ciências \\
\hline PSSC & Physical Science Study Committe \\
\hline PSSC-LT & PSSC - Livro-texto \\
\hline PSSC-GL & PSSC - Guia de Laboratório \\
\hline PSSC-GP & PSSC - Guia do Professor \\
\hline PSSC-GPL & PSSC - Guia do Professor/laboratório \\
\hline $\mathrm{RC}$ & Referenciais Curriculares \\
\hline SEE & Secretaria de Estado de Educação \\
\hline SEEC & Secretaria de Estado de Educação e Cultura \\
\hline SENAC & Serviço Nacional de Aprendizagem Comercial \\
\hline SENAI & Serviço Nacional de Aprendizagem Industrial \\
\hline SNEF & Simpósio Nacional de Ensino de Física \\
\hline SNEL & Sindicato Nacional de Editores de Livros \\
\hline UNESCO & Organização das Nações Unidas para a Educação, a Ciência e a Cultura \\
\hline USP & Universidade de São Paulo \\
\hline UNICAMP & Universidade de Campinas \\
\hline USAID & Agency for International Development dos Estados Unidos \\
\hline UNE & União Nacional dos Estudantes \\
\hline
\end{tabular}




\section{SUMÁRIO}

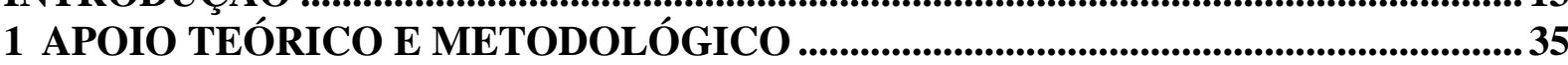

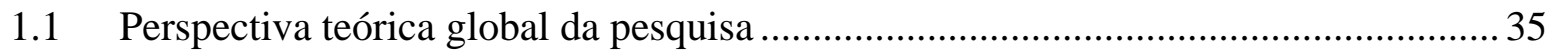

1.1.1 O currículo escolar: uma construção social......................................................35

1.1.2 O currículo como instrumento de estratificação social .......................................... 41

1.2 Perspectiva teórico-metodológica …………………............................................ 46

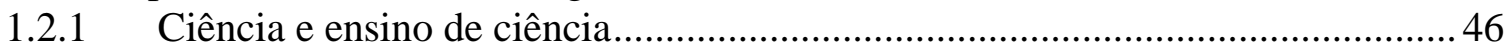

1.2.2 Ideário educativo e o ensino de ciências no contexto investigado ......................52

1.2.2.1 Aprender fazendo .................................................................................. 56

1.2.2.2 Método científico e o ensino por descoberta..............................................57

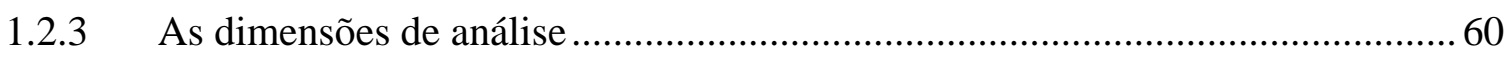

1.2.3.1 Caracterização das dimensões de análise: categorias e elementos..............61

2 AS REFORMAS EDUCACIONAIS E O ENSINO DE CIÊNCIAS NO CONTEXTO INVESTIGADO ....................................................................................63

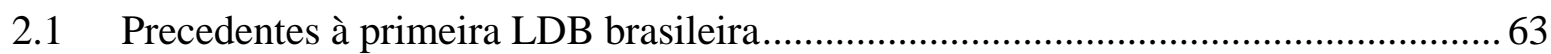

2.1.1 O currículo oficial de Física em meados do século XX ...................................... 71

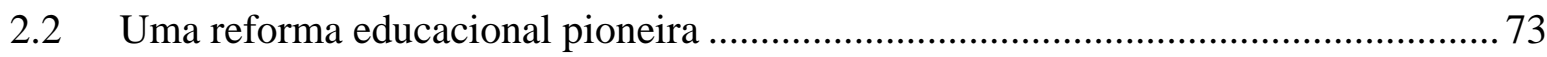

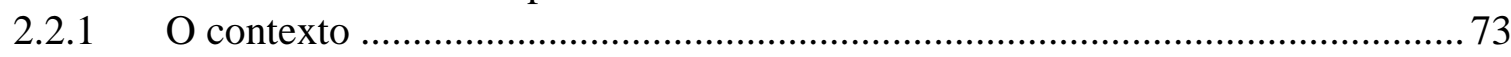

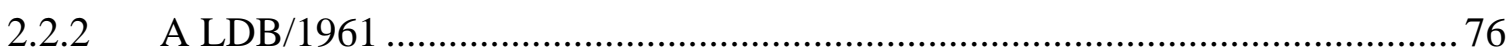

2.2.3 Da organização curricular nos termos da LDB/1961 ......................................78

2.2.4 A presença das Ciências na organização curricular nos termos da LDB/1961 .. 84

2.2.5 O currículo das Ciências na LDB/1961 …………………………………….....98

2.3 O ambiente político em que vigorou a LDB: as influências sobre a educação e

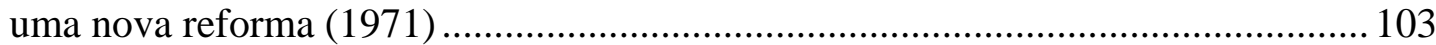

2.3.1 A Lei 5692/1971 ............................................................................ 109

2.3.1.1 A organização curricular nos termos da Lei 5692/1971 ............................ 111

2.3.1.2 As Ciências no currículo e o currículo de Ciências na Lei 5692/1971............. 113

3 INOVAÇÕES/PROPOSIÇÕES NOS CURRÍCULOS DE FÍSICA NO BRASIL -

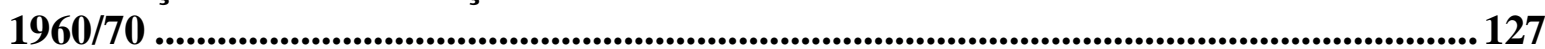

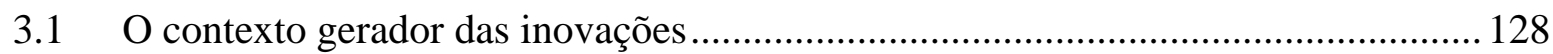

3.2 Os projetos internacionais para o Ensino de Ciências: a gênese ............................... 132

3.3 O precursor dos projetos de ensino de Física internacionais: o PSSC …………....... 135

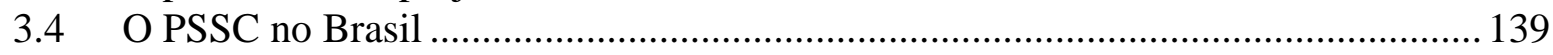

3.4.1 Conhecendo os manuais do PSSC utilizados no Brasil ....................................... 142

4.4.1.1 Caracterização geral dos manuais do PSSC ................................................ 143

4.4.1.2 As dimensões Epistemológica e Educativa no PSSC ............................... 150

3.5 Os Projetos de Ensino de Física nacionais .............................................................. 170

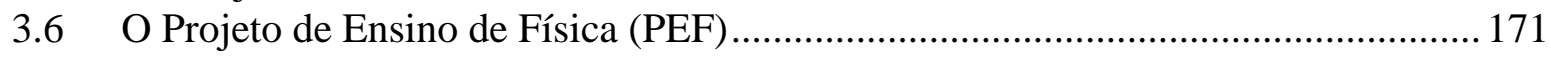

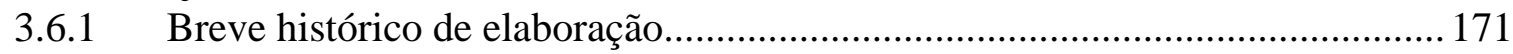

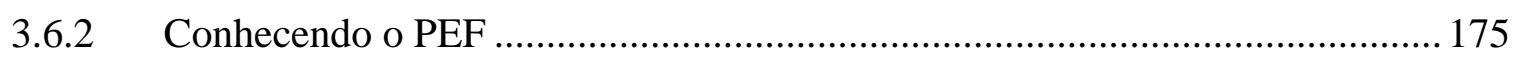

3.6.2.1 Caracterização geral dos manuais do PEF .............................................. 175

3.6.2.2 As dimensões Epistemológica e Educativa no PEF .................................... 180 


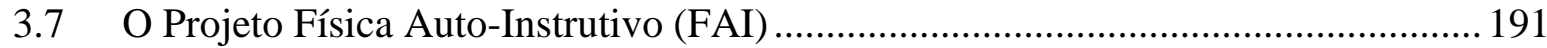

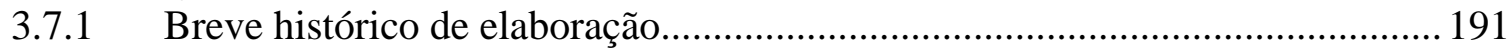

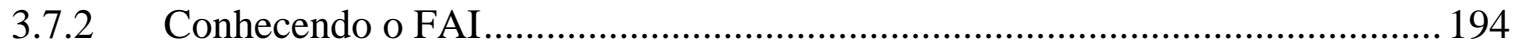

3.7.2.1 Caracterização geral dos manuais do FAI ................................................ 195

3.7.2.2 As dimensões Epistemológica e Educativa no FAI .................................. 198

4 OS CURRÍCULOS OFICIAIS ESTADUAIS - ENTRE INOVAÇÃO E CONTINUIDADE - E O QUE DEVERIA SER ENSINADO NAS ESCOLAS

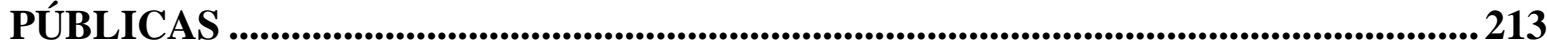

4.1 Conhecendo as Propostas Curriculares (oficiais) de Física...................................... 216

4.1.1 Aspectos gerais das PCF analisadas ............................................................ 216

4.1.2 As dimensões Epistemológica e Educativa nas Propostas Curriculares ........... 226

\section{LIVROS DIDÁTICOS DE FÍSICA - PERMANÊNCIA DO QUE EXISTIA OU}

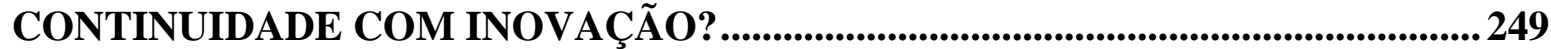

5.1 Síntese da trajetória do Programa do Livro Didático no Brasil ............................... 250

5.2 Os livros didáticos de Física no Brasil no contexto investigado............................ 252

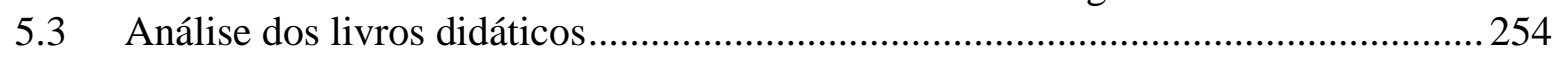

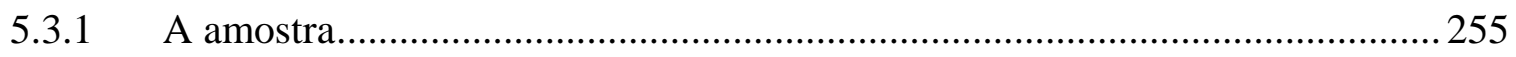

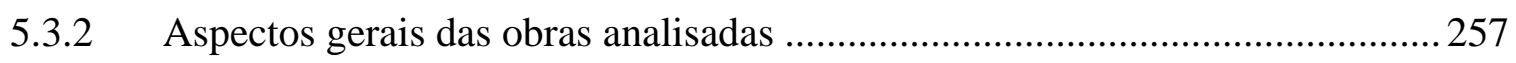

5.3.3 As dimensões Epistemológica e Educativa nos livros didáticos ....................... 265

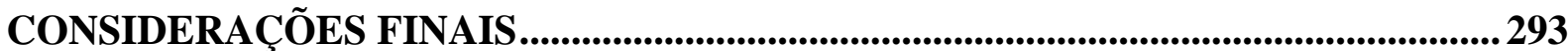

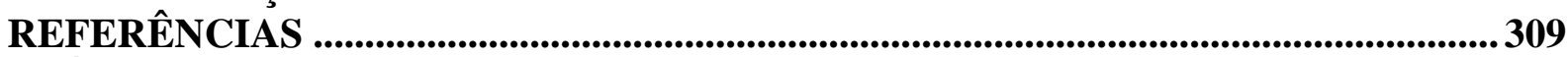

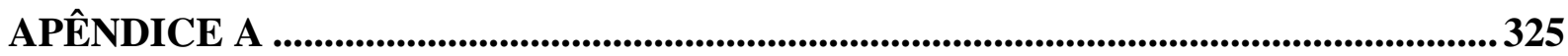

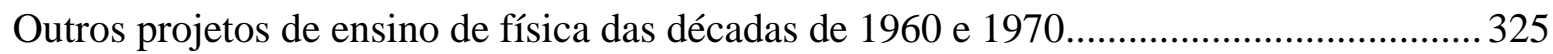

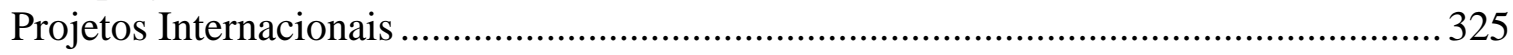

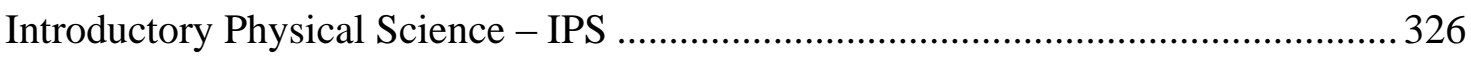

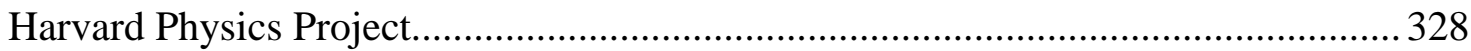

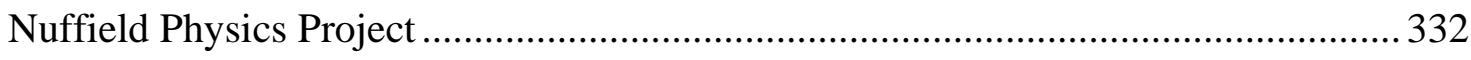

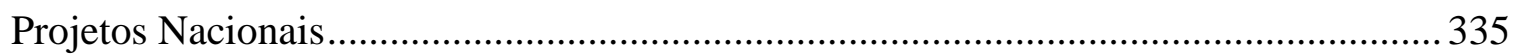

O Projeto Piloto de Física da UNESCO: meio nacional meio estrangeiro.................... 335

Projeto Brasileiro de Ensino de Física (PBEF) ........................................................ 337

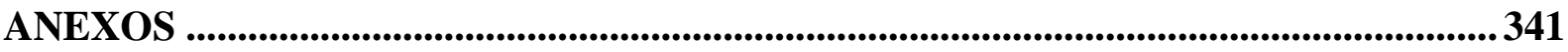

ANEXO I - Programa de Física da Portaria no 966, de 2 de outubro de 1951 .................... 341

ANEXO II - Indicação do Conselho Federal de Educação de 21-02-1962- Normas para o ensino médio nos termos da Lei 4024/1961........................................................... 343

ANEXO III - Quadros exemplificativos do CFE, a que se refere a Indicação de Fevereiro de 1962, trazidos no documento Consolidação da Legislação do Ensino Secundário, após a Lei de Diretrizes e Bases da Educação

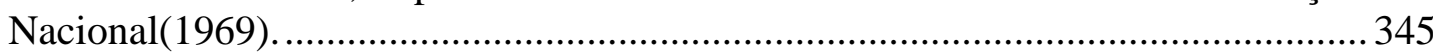

ANEXO IV - Recorte de histórico Escolar de ex-estudante do Estado do Rio de Janeiro 346 ANEXO V - Quadros exemplificativos de organização curricular dos Colégios Pluricurriculares do Estado de São Paulo, a que se refere a Resolução nº 07, de 23.12.1963, do Conselho de Educação do Estado de São Paulo (CEE/SP).............. 347

ANEXO VI - Quadro de Conteúdos Programáticos de Física na Reformulação de Currículos - $2^{\circ}$ Grau do Rio de Janeiro (1977)......................................................... 350

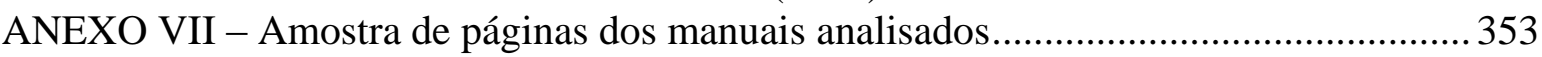




\section{INTRODUÇÃO}

A década que abre o recorte temporal da presente pesquisa - a de 1960 experimentou diversos acontecimentos importantes que afetaram os diferentes setores sociais, no Brasil e no mundo, e mudaram o modo de vida, e de ver a vida, das pessoas. Dentre os muitos eventos podemos citar: o lançamento do primeiro satélite meteorológico pelos Estados Unidos; o primeiro computador eletrônico pela empresa International Business Machines (IBM); a primeira viagem humana ao espaço (o russo Yuri Gagarin); o primeiro transplante de coração na África do Sul; a viagem do homem à Lua; a primeira transmissão de TV em cores no Brasil; a primeira transmissão de TV via satélite; a criação do embrião da Internet - a ArpaNet [e que inovação!!!] e ainda muitos outros.

Além desses eventos de grande envergadura, de abrangência científica e tecnológica, os anos de 1960 acomodaram diversos acontecimentos históricos de ordem social com a insurgência de movimentos sociais, guerras e conflitos. Foi um tempo de vários tipos de protestos, e de fortalecimento de movimentos pela paz (acomodou o Ano Internacional de Direitos Humanos - 1968), pela conquista de direitos fundamentais, como a educação, por exemplo, em várias partes do mundo.

No Brasil, ocorreu um golpe de Estado, em 1964, que aboliu a democracia adotando uma política de restrições de direitos civis, e ocasionando conflitos urbanos violentos, perseguições políticas, prisões arbitrárias, mortes, desaparecimentos de pessoas, etc.; e adoção de um modelo político administrativo consubstanciado na intervenção estrangeira em vários setores do Estado, com destaque para a economia e a educação. O país granjeou uma significativa expansão do processo de industrialização, ao mesmo tempo em que se elevou a concentração de renda (ROMANELLI, 1985) ${ }^{1}$.

Fora do Brasil, um chefe de Estado foi assassinado (John Kennendy), e também um ativista pelos direitos civis (Martin Luther King), ambos nos Estados Unidos. Jovens se rebelaram na França em protestos contra os currículos escolares rígidos e conservadores, e também, contra a superlotação nas universidades e a reforma do ensino superior promovida por um governo extremamente conservador (ARANHA, 1989; ZAPPA; SOTO, 2008). Fato que se refletiu no Brasil e alentou levantes de protestos, sobretudo pelos jovens, contra as

\footnotetext{
${ }^{1}$ A primeira versão da obra História da Educação no Brasil: 1930/1973, de Otaíza de Oliveira Romanelli, foi publicada no início da década de 1970. Citamos nesta tese a $7^{a}$ versão da referida obra, de 1985.
} 
arbitrariedades do regime de governo e por uma reforma universitária coerente com as demandas qualitativas e quantitativas.

Os jovens assumiram a cena, na arte, na música, e nas reinvindicações de ordem social - foi o tempo do "jovem engajado" se manifestando e demarcando posicionamento político (ABREU, 2000).

Não importa a sequência dos fatos aqui mencionados. O que importa é que todos eles (e muitos outros) fizeram da década de 1960 o momento de maior efervescência políticoeconômico-social do século XX, em nível mundial. Impossível tudo isso não afetar um setor de singular importância para a sociedade: a educação escolar.

Nessa conjuntura efervescente vigora a primeira Lei de Diretrizes e Bases da Educação brasileira, promulgada em 20 de Dezembro de 1961 - a Lei nº 4.024/1961 (LDB/1961), representando um marco na Educação nacional, por abranger todos os níveis de ensino. Essa Lei descentralizou alguns princípios de organização do currículo escolar e concedeu aos Estados da federação e suas escolas uma moderada (porém importante) flexibilidade para definir currículos mais ajustados às peculiaridades regionais. O momento era de busca pelo desenvolvimento, e a Educação foi vista como a "mola propulsora".

No contexto de debate do projeto de lei e sanção da LDB/1961, as disciplinas da área Ciências ganharam relativo destaque no âmbito acadêmico brasileiro. Ainda que motivado por fatores externos, ou por pressão de demanda, teve-se o mérito de reconhecer a necessidade de se atentar para a dinâmica rápida do desenvolvimento científico que exige mudanças na forma de lidar com o conhecimento que vai se constituindo. No que se refere à Física, esse reconhecimento pode ser justificado pela sua grande abrangência como ciência, por desempenhar papel básico em todos os fenômenos naturais e possuir grande efeito no desenvolvimento científico e tecnológico de um modo geral. Conhecimento que permeia e altera os diversos ambientes dos quais se organiza a sociedade como um todo (ALMEIDA JUNIOR, 1979).

Conforme coloca Pinho (1965), “A ciência (e, em particular, a Física) sofreu no século XX uma aceleração vertiginosa, e, com presteza nunca vista antes, as grandes descobertas da Física pura encontraram aplicações práticas, que vieram alterar profundamente nossa maneira de viver."2 (PINHO, 1965 apud BRASIL, 1965b, Documenta nº 43, p. 90). Tais transformações justificam as ocorrências de inovações curriculares elaboradas para a

\footnotetext{
${ }^{2}$ Colocação do Professor Alceu de Pinho da PUC/RJ, em relatório sobre a situação do ensino de ciências no Brasil, encomendado pelo Conselho Federal de Educação e que gerou o Parecer no 931 de 12.11 .1965 intitulado Inquérito sobre o ensino de ciências nos estabelecimentos de grau médio.
} 
disciplina Física, a partir da segunda metade da década de 1950, em consequência do movimento pela melhoria do ensino de Ciências em várias partes do mundo, notadamente nos Estados Unidos.

Os efeitos da Segunda Guerra Mundial e o lançamento do primeiro satélite espacial Sputnik, em 1957, pela União Soviética disseminaram influências de diferentes ordens em vários países (CHASSOT, 2004; ZAPPA; SOTO, 2008). Tal evento incandesceu ainda mais a concorrência entre essa potência e os Estados Unidos pelo domínio ideológico, político, econômico e tecnológico do mundo - a Guerra Fria. A educação escolar foi marcadamente o centro das atenções nesse contexto, especialmente a área de Ciências (KRASILCHIK, 1987; CHASSOT, 2004). No Brasil, a exemplo de outros países, preparar futuros cientistas para trabalhar em pesquisas em prol do desenvolvimento científico e tecnológico da nação parece ter sido o ideário educativo maior.

A necessidade urgente de especialistas de pesquisa aplicada, capazes de estudar os
problemas econômicos e técnicos típicos do país, não é contestada por ninguém.
Ora, a formação de tais especialidades deve ser assegurada por pessoas habituadas a
levar muito adiante o estudo das ciências puras, isto porque a ciência pura de hoje
será a ciência aplicada de amanhã. ${ }^{3}$ (PINHO, 1965 apud BRASIL, 1965b,
Documenta n.43, 1965, p. 90-91).

O movimento para revitalizar o ensino de Ciências desencadeado nos Estados Unidos, entremeio às intensas transformações políticas em nível mundial, configurou-se como uma reforma educacional privilegiada para a área, em plano macro, com o apoio de governantes de diversos países, e sob aberto domínio norte-americano. Alguns países aderiram ao movimento de forma mais independente, assumindo reformas com objetivos similares, porém com especificidades, como a Inglaterra, por exemplo.

Para Saad (1990), as ambiciosas reformas educacionais no campo do ensino de Ciências elaboradas nos países de primeiro mundo no período em questão tiveram como objetivo básico "motivar/preparar contingentes crescentes de suas juventudes para poderem participar da corrida rumo ao domínio de vastas áreas da Ciência e Tecnologia.”. Uma exótica "batalha do cérebro", investimentos para formação de "cérebros competitivos e criativos" (SAAD, 1990, p. 05).

Esse movimento de abrangência macro promoveu a experimentação de projetos de ensino de Ciências no Brasil, abarcando o ensino de Física. Fato que contribuiu de forma influente para a abertura do campo de pesquisa na área de ensino de Ciências em geral, e de Física em particular (NARDI, 2005; KRASILCHIK, 1980; FRACALANZA; MEGID NETO, 2006). Esse contexto motivou assim, a institucionalização de importantes grupos de pesquisas

\footnotetext{
${ }^{3}$ Idem nota anterior.
} 
e programas de Pós-Graduação, como exemplo, a inserção da linha de pesquisa em Ensino de Física no Programa de Pós-Graduação em Física da Universidade Federal do Rio Grande do Sul (UFRGS), em 1967 (NARDI, 2005), e o Programa de Pós-Graduação Interunidades em Ensino de Ciências, criado no Instituto de Física da Universidade de São Paulo (USP), em 1973, na modalidade Ensino de Física e complementado com as modalidades Ensino de Química, no ano de 1998, e Ensino de Biologia, no ano de 2005. (NARDI, 2005; UNIVERSIDADE DE SÃO PAULO, 2015).

O primeiro projeto de ensino de Física experimentado era estrangeiro, o Physical Science Study Committee (PSSC). O PSSC foi um projeto curricular desenvolvido na segunda metade da década de 1950 nos Estados Unidos, e trazido ao Brasil em 1962, por meio do Instituto Brasileiro de Educação, Ciência e Cultura - Organização das Nações Unidas para a Educação, a Ciência e a Cultura (IBECC-UNESCO) com apoio do Ministério da Educação e Cultura (MEC), tendo sido adotado primeiro no estado de São Paulo como projeto-piloto.

O modelo de ensino do PSSC foi alvo de críticas por educadores brasileiros que o consideraram inadequado à realidade do país (ALVARENGA, 1991; KRASILCHIK, 2000; GASPAR, 2004). O mesmo ocorreu com outros projetos de ensino de Física que adentraram o país nas décadas de 1960-70, mas que nem chegaram a ser experimentados sistematicamente, como por exemplo, o Introductory Physical Science (IPS), o Projeto Harvard e o Projeto Nuffield (CARVALHO, 1972; PINHO-ALVES, 2000; outros). Atribui-se a esses projetos a motivação para a criação de projetos brasileiros mais compatíveis com a realidade nacional. Ocorre então, na década de 1970, a elaboração de projetos originados no Brasil com aplicação em muitas escolas do país. Os de maior evidência foram o Projeto de Ensino de Física (PEF) e o Física Auto-instrutivo (FAI), elaborados no Estado de São Paulo, com maioria de participantes vinculados à Universidade de São Paulo (USP).

Paralelamente à elaboração e difusão dos projetos de ensino no Brasil, em cumprimento aos preceitos da LDB/1961, acrescida de suas regulamentações e uma nova reforma em 1971 (a Lei 5.692/1971), algumas secretarias estaduais elaboraram seus currículos específicos para o ensino de primeiro e segundo graus, como exemplo, os Estados do Paraná (1972 a 1977 - primeiro grau), Minas Gerais (1973/1976 - primeiro grau), Rio de Janeiro (1976/1977 - primeiro e segundo graus) e São Paulo (1975/1978 - primeiro e segundo graus).

Além dos projetos e dos currículos oficiais, especialmente na década de 1970, evidencia-se a presença dos livros didáticos nas salas de aula (CHIQUETTO; KRAPAS, 2012), e em posição de destaque - são eles as propostas curriculares reais, o currículo praticado na escola, os verdadeiros guias de ensino do professor (GOODSON, 1995; WUO, 
2000; CHOPPIN, 2004; DELIZOICOV, ANGOTTI, PERNAMBUCO, 2007). Nesse período, a produção de livros didáticos é fortemente apoiada pelo governo federal, através de órgãos vinculados ao MEC (HÖFLING, 2006).

Em resumo, o período no qual se insere o recorte temporal desta pesquisa acomodou diversas ações de grande relevância para o ensino das Ciências no Brasil, das quais apontamos: a criação de instituições como o IBECC/SP, a Fundação Brasileira para o Desenvolvimento do Ensino de Ciências (FUNBEC) e os Centros de Ciências; o empenho de pesquisadores que assumiram a revitalização do ensino de Ciências escolar, abrindo espaço para a inserção de novos métodos de ensino a partir da tradução de projetos estrangeiros e elaboração de projetos nacionais, a maioria com enfoque nas atividades experimentais; a criação dos Programas para melhoria do ensino básico em geral - Programa de Expansão e Melhoria do Ensino (PREMEN) e do ensino de ciências em particular - Projeto Nacional para Melhoria do Ensino de Ciências (PNMEC); mudanças na legislação com vistas a adequar o sistema educacional às demandas do mercado provocando ajustes dos currículos com o advento da LDB/1961; mudanças no processo de editoração de materiais didáticos com o surgimento de editoras comerciais, refletindo nas metodologias dos livros didáticos ajustandoos à demanda para ingresso no ensino superior (KRASILCHIK, 1980).

\section{Objetivos, questão de estudo e material}

Até a promulgação da LDB/1961, o ensino de Física, assim como das outras disciplinas, era direcionado por um programa mínimo (lista de conteúdos) definido nos termos das reformas anteriores, sendo a Reforma Capanema (1942), a última precedente. Das regulamentações da LDB/1961, por meio do Conselho Federal de Educação (CFE), extinguiuse a obrigatoriedade dos currículos no formato de "Programas de disciplinas" determinados pelo poder público central e auferiu liberdade para as escolas elaborarem os seus programas. $\mathrm{O}$ que se determinou como currículo foi uma quantidade de disciplinas obrigatórias para compor a matriz curricular, e outra parte diversificada livre aos sistemas estaduais e às preferências das escolas. Teoricamente, uma abertura para os sistemas estaduais organizarem os seus currículos mais coerentes com as especificidades regionais.

O estudo aqui apresentado teve como objetivo geral conhecer, analisar e sistematizar parte da história do ensino de Física no Brasil, no contexto das décadas de 1960 e 1970, enfocando, principalmente, os diversos referenciais curriculares que nortearam o ensino da referida disciplina. 
Trata-se de um momento bastante particular da história da educação brasileira em que estão presentes vários referenciais curriculares orientadores do ensino de Física: projetos de ensino nacionais e internacionais, propostas curriculares oficiais e livros didáticos de diversos autores. Destarte, nosso objetivo principal centrou-se na seguinte questão de pesquisa: Que concepções de Ciência e de Educação estão presentes nos referenciais curriculares orientadores do ensino de Física, elaborados no contexto das décadas de 1960 e 1970?

Para responder à questão colocada, propusemos uma análise de conteúdo nos principais referenciais curriculares editados no período; análise esta direcionada por dimensões/categorias pré-definidas, buscando identificar elementos que pudessem revelar as concepções assumidas nos mesmos.

No plano metodológico, trata-se de uma pesquisa histórico-documental, que tem como fontes principais a Lei de Diretrizes e Bases da Educação (Lei n ${ }^{\circ}$ 4.024/1961) e a Reforma do ensino de $1^{\circ}$ e $2^{\circ}$ graus de 1971 (Lei $\mathrm{n}^{\circ}$ 5.692/1971) com suas normas regulamentadoras (Indicações, Pareceres, Resoluções, Leis estaduais, Atos, etc.) e proposições curriculares de Física - documentos orientadores da prática pedagógica - nos diferentes formatos: projetos de ensino, currículos oficiais dos Estados da Federação e Livros Didáticos.

Nos termos do objetivo principal de nosso estudo, neste corpus documental, as legislações educacionais emanadas do poder público a partir de 1961 são componentes de extrema importância, uma vez que tais documentos se traduzem em elementos do currículo em sua totalidade, e foi por meio delas que se deu a abertura para que se processassem as inovações no currículo de Ciências, em particular, de Física, inclusive nos livros didáticos e projetos de ensino do período em questão.

Quanto aos documentos orientadores da prática pedagógica, propusemos analisar alguns referenciais curriculares ${ }^{4}$ (RC) de Física para o ensino médio (Colegial/Segundo grau) editados nas décadas de 1960 e 1970.

Dentre os diversos projetos de ensino de Física surgidos nas referidas décadas, optamos por analisar três: o PSSC, pela sua imponente representação do que foi a inovação para o ensino de Física no Brasil; e os projetos nacionais PEF e FAI, por terem sido os mais difundidos no país, sendo bastante conhecidos e mencionados nas pesquisas em ensino de Física.

\footnotetext{
${ }^{4}$ Trataremos neste texto como "referenciais curriculares" documentos que pressupõem uma orientação para a prática educativa em sala de aula, sejam oficiais/obrigatórios (como as propostas curriculares oficias), sejam materiais curriculares apresentados como propostas de livre adesão pelas escolas e/ou professores (Projetos de Ensino e Livros Didáticos).
} 
Os demais projetos de ensino de Física que adentraram no país no período, tendo ou não sido traduzidos e implementados, e ainda outros elaborados no Brasil, são importantes fontes de referência para compreender as motivações e características dos projetos de ensino brasileiros. Sendo assim, são abordados como componentes da história do ensino de Física no Brasil, porém, sem análise de conteúdo dos mesmos.

Quanto às propostas curriculares oficiais de Física, em uma primeira delimitação, optamos por investigar as dos Estados que, segundo Moreira (2001), foram pioneiros em promover importantes reformas educacionais inovadoras desde a segunda década do século XX: São Paulo; Rio de Janeiro (enquanto Distrito Federal); Bahia e Minas Gerais. Contudo, não localizamos as propostas curriculares de Física da Bahia e de Minas Gerais, ficando como objeto de estudo os currículos oficiais do Estado de São Paulo (1978) e Rio de Janeiro (1977).

A julgar pela ausência de pesquisas que analisem propostas curriculares estaduais da época, para o segundo grau, ou qualquer referência da existência de tais propostas em pesquisas da área, suspeitamos que a grande maioria dos Estados não tenha elaborado seus currículos oficiais para as disciplinas desse nível de ensino. Identificamos alguns a partir da década de 1980, entretanto, trata-se de um período que extrapola nosso recorte temporal de investigação, e, portanto, não serão tratados nesta pesquisa. Embora nós tenhamos delimitado o estudo para os Estados de São Paulo e Rio de Janeiro, e para o nível de segundo grau (antes, Colegial), não contrapõe nossos objetivos citar informações relacionadas às reformas educacionais para o nível de primeiro grau ou sobre organização de quadros curriculares de outros Estados brasileiros, para os dois níveis, a título de exemplos.

Quanto aos livros didáticos, delimitamos nossa análise para obras de maior relevo no mercado editorial nas décadas definidas para estudo, sendo elas: "Física do Científico e do Vestibular", de Dalton Gonçalves; "Física" e "Curso de Física”, da parceria entre Beatriz Alvarenga e Antônio Máximo; e "Fundamentos da Física", do grupo formado pelos autores Francisco Ramalho Jr, Nicolau Gilberto Ferraro, Paulo Antônio de Toledo Soares e José Ivan Cardoso dos Santos. Trata-se de obras didáticas que, por muitos anos, tiveram grande aceitação pelas escolas do país, considerados verdadeiros best-sellers da Física para o ensino médio, conforme pesquisas da área (WUO, 2000; CHIQUETTO; KRAPAS, 2012). Além disso, são produções que permaneceram no mercado editorial por várias décadas ${ }^{5}$, sendo as duas últimas citadas ainda presentes com algumas alterações/inovações incluídas ao longo do

\footnotetext{
${ }^{5}$ O autor Dalton Gonçalves estava presente no mercado editorial desde a década de 1960. Já os demais, ingressaram na década de 1970.
} 
tempo, inclusive para atender às exigências do atual Programa Nacional do Livro Didático (PNLD).

Consideramos a hipótese de que quaisquer influências advindas do movimento renovador do ensino de Ciências iniciado na década de 1950, e das transformações nas legislações educacionais em função do modelo político-econômico desenvolvimentista brasileiro adotado no período, refletiram nos materiais didáticos. Assim, acreditamos que eles poderão assumir o papel de ilustres "contadores de história"; tomamos como desafio decifrar as suas mensagens.

\section{Percursos da pesquisa}

Partindo do projeto inicial, o desenvolvimento desta pesquisa começou com a escolha das disciplinas ${ }^{6}$ a serem cursadas no cumprimento dos créditos no programa de PósGraduação do qual esta se refere. Avocamos a necessidade de compreender melhor o campo em que se insere o nosso foco de investigação, que é o currículo escolar, com toda a sua dinâmica em uma sociedade que se altera a passos largos, regida por interesses de diferentes ordens; conhecer as diversas facetas que figuram as alterações curriculares no campo da Educação ao longo do tempo. Para isso, foi imprescindível aprofundar um pouco nos estudos sobre o processo de escolarização, buscando compreender a relação do currículo escolar com os contextos sociais mais amplos, em diferentes espaços e tempos. As discussões de grupo sobre a história da educação brasileira, das disciplinas escolares, sobre a evolução do currículo de Física, bem como sobre pesquisas em livros didáticos antigos e atuais, ocasionadas no desenvolvimento das disciplinas cursadas, foram de grande relevância para o delineamento desta investigação.

Buscamos as legislações e outros documentos pertinentes ao currículo da escola secundária brasileira, em coletâneas de leis, pareceres, resoluções, etc., em sítios oficiais do governo, bem como em outros que alojam documentos históricos ${ }^{7}$. Pesquisamos ainda em trabalhos que discutem o texto de tais legislações, como por exemplo, Fontoura [1979?] e Nagle (1973). Parte dos documentos oficiais da década de 1960, foram solicitados ao Conselho Nacional de Educação, via e-mail, com obtenção de retorno e envio de alguns.

\footnotetext{
${ }^{6}$ Questões Atuais de Currículo (QAC)", oferecida pela Faculdade de Educação da USP (FEUSP) e "Currículo e Livros Didáticos", oferecida no Programa de Pós-Graduação Interunidades em Ensino de Ciências (PPGI), da qual esta pesquisa se vincula.

${ }^{7}$ O sítio da Revista Brasileira de Estudos Pedagógicos (http://rbep.inep.gov.br/index.php/rbep/issue/archive) e do Grupo de Estudos e Pesquisas "História, Sociedade e Educação no Brasil" da Faculdade de Educação da UNICAMP (http://www.histedbr.fe.unicamp.br/).
} 
Por um longo período, realizamos buscas, quase que diárias, na Internet para localização de livros didáticos e outros manuais curriculares de Física editados no período delimitado para estudo. O ponto mais visitado foi um sítio eletrônico que aglutina vendas de livros usados para vários Sebos espalhados pelo país - o sítio da Estante Virtual. Essa busca tomou como referência o Banco de Dados LIVRES ${ }^{8}$, do qual nos valemos para identificação das obras presentes no mercado editorial do período de estudo. Buscamos ainda os projetos de ensino de Física traduzidos/adaptados e os não traduzidos, os elaborados e implementados no Brasil, no período em questão, entretanto, poucos foram obtidos por esse caminho, sendo eles o FAI e o PBEF. Os demais foram localizados no acervo da Biblioteca do Instituto de Física da USP e na biblioteca do Programa de Pós-Graduação Interunidades em Ensino de Ciências desta mesma universidade, e também, cópias digitalizadas disponíveis na Internet.

Levantamos um número expressivo de livros didáticos, em grande maioria, de obras identificadas no LIVRES referente à década de 1960 e 1970, conforme Tabelas 3 e 4 do capítulo 5. Encontramos ainda outros tipos de materiais didáticos, impressos e digitalizados, para o ensino de Física, editados no período de 1960 a 1970, tais como os Cadernos MEC e os projetos de ensino PSSC, Projeto Nuffield, Projeto Harvard, Projeto Piloto de Física da UNESCO, Projeto de Ensino de Física (PEF), Física Auto-Instrutivo (FAI) e Projeto Brasileiro de Ensino de Física (PBEF). Todos esses projetos são apresentados, no capítulo 3 ou no APÊNDICE A, como parte importante da história do ensino de Física no Brasil. Alguns, com uma descrição mais geral e uma reflexão sinóptica; outros, com uma análise de conteúdo aprofundada.

Além desses materiais, localizamos e obtivemos os textos de duas propostas curriculares para o ensino de Física: a do Estado de São Paulo (1978) e a do Estado do Rio de Janeiro (1977). A primeira foi adquirida na biblioteca da Faculdade de Educação da Universidade de São Paulo, e a segunda por doação de um exemplar do projeto de reforma curricular denominado Reformulação de Currículos- $2^{\circ}$ volume, $2^{\circ}$ Grau do Estado do Rio de Janeiro (1977), pela Professora Deise Miranda, da Universidade Federal do Rio de Janeiro. Além desse documento, adquirimos, por meio de compra em Sebo virtual, um exemplar denominado Reformulação de Currículos - Síntese (1976), que se refere ao primeiro documento de introdução da reforma curricular fluminense.

\footnotetext{
${ }^{8}$ LIVRES (Livros Escolares brasileiros). Banco de Dados que disponibiliza acesso a livros didáticos das diversas disciplinas escolares brasileiras do século XIX aos dias atuais. Coordenado pela Faculdade de Educação da USP em parceria com bibliotecas de outras universidades.
} 
Localizamos ainda documentos de reforma de currículos de mais dois Estados da federação, contudo, referente ao primeiro grau': a orientação de currículo para Ciências Físicas e Biológicas, do Estado de Minas Gerais (1976); e alguns documentos orientadores de currículo do Estado do Paraná (1972 a 1977) incluindo as Ciências Físicas e Biológicas. O primeiro foi adquirido em uma biblioteca de uma escola pública da cidade de DiamantinaMG. Já os documentos referentes à reforma educacional do Paraná foram gentilmente cedidos pela pesquisadora Silvana Matucheski, por meio de arquivos digitalizados.

Conforme Matucheski (2011), o Estado do Paraná, com vistas à implementação da Lei $n^{\circ}$ 5.692/1971, iniciou um processo de reformulação curricular para o ensino de primeiro grau, em 1972, indo até 1977. A autora ${ }^{10}$, que foca o ensino de Matemática, localizou seis documentos de reformulação de currículo do referido grau de ensino desse período, que trata da disciplina. Tais documentos trazem também orientações para a CFB, já que as duas disciplinas pertenciam, naquele contexto legislativo, à mesma matéria (Ciências). Os documentos envolvem orientações sobre quadros curriculares, diretrizes teóricas, diretrizes educacionais para a área de Ciências, objetivos gerais, orientações aos professores, sugestão de programa de conteúdos, etc. Relevante ainda mencionar que, das transcrições das entrevistas feitas pela autora, com pessoas que vivenciaram aquele contexto na condição de técnicos ligados ao órgão/equipe responsável pela política de currículo do referido Estado, é possível identificar a informação de que o processo de reforma curricular do Paraná se inspirou, inicialmente, nas reformas do Estado do Rio Grande do Sul. Entretanto, não se identificam maiores detalhes sobre as reformas curriculares deste último, e não localizamos os documentos de tal reforma.

\footnotetext{
${ }^{9}$ Esses documentos nos servem de referência para compreender a política de currículo adotada pelos Estados nos termos da Lei 5.692/1971, mas não são nossos objetos de análise mais profunda de conteúdo, uma vez que nosso enfoque é o currículo de Física do segundo grau (ou Colegial).

${ }^{10}$ Em contato via e-mail, Silvana Matucheski nos informou que, em suas buscas pelos arquivos originais da reforma do Paraná, referente à década de 1970, não se identificou qualquer informação de reforma curricular para o nível de segundo grau.
} 


\section{Pesquisas em ensino de Física com enfoque nos referenciais curriculares - livro didático, projetos de ensino e currículo oficial}

Ao propor desenvolver uma pesquisa que contemple uma retrospectiva histórica do ensino de Física no Brasil, por meio dos materiais didáticos, torna-se imprescindível contextualizá-la na área em que esta se insere, de modo a situá-la dentre os trabalhos que trazem estudos que contemplem de algum modo tal problemática.

Nesta seção, apresentaremos os resultados de uma busca, no "estado da arte", de pesquisas acadêmicas apresentadas na forma de Teses de Doutorado e Livre-Docência e Dissertações de Mestrado, e que dão relevância à história da disciplina escolar Física pelo estudo de referenciais curriculares (RC) que dão forma ao currículo escolar a ser reproduzido, na perspectiva dos conteúdos, no caso dos livros didáticos, e em qualquer perspectiva, no caso dos projetos de ensino e currículos oficiais estaduais.

O levantamento bibliográfico, que por ora apresentamos, engloba trabalhos defendidos desde a década de 1970 a 2014 . Uma parte dos trabalhos foi localizada no Banco de Teses e Dissertações da Coordenação de Aperfeiçoamento de Pessoal (CAPES) ${ }^{11}$; nos Catálogos "Ensino de Física no Brasil: Dissertações e Teses”, elaborados por pesquisadores do Instituto de Física da USP (IFUSP) ${ }^{12}$; e no catálogo intitulado "O Ensino de Ciências no Brasil: Catálogo Analítico de Teses e Dissertações 1972-1995” da Universidade de Campinas $(\mathrm{UNICAMP})^{13}$.

Os trabalhos do período de 2006 a 2010 e 2013 a 2014 foram localizados via Internet nos sistemas de busca dos sítios da Biblioteca Brasileira de Teses e Dissertações; do Domínio Público e da Rede de Bibliotecas ${ }^{14}$, utilizando palavras-chave. Essa busca nos remeteu a resultados mais completos, visto que com ela obtivemos alguns arquivos de textos dos trabalhos completos. Outra forma de obtenção dos trabalhos foi através do contato direto com os autores e também com algumas secretarias dos programas de Pós-graduação. Alguns

\footnotetext{
${ }^{11}$ No período em que efetuamos a busca pelos trabalhos, o Banco de Teses e Dissertações da CAPES só estava disponibilizando os resumos dos trabalhos de 2011 e 2012.

${ }^{12}$ Elaboração coordenada por Sonia Salém e Maria Regina D. Kawamura do IFUSP, e que reúne referências de dissertações, teses e livre-docência na área de Ensino de Física apresentadas e defendidas em instituições nacionais desde o ano de 1972: volume 1 - 1972-1992; volume 2 - 1992-1995 e volume 3 - 1996-2006, publicados, respectivamente, em 1992, 1996 e 2009, totalizando dados de 891 trabalhos de pesquisa.

${ }^{13}$ Trabalho elaborado sob coordenação dos Professores Jorge Megid Neto e Décio Pacheco, da Universidade de Campinas (UNICAMP). Esse catálogo reúne 572 resumos de pesquisas de mestrado, doutorado e livre-docência, e está disponível na homepage do Centro de Documentação em Ensino de Ciências (CEDOC) que é coordenado pelo FORMAR-Ciências (Grupo de Estudos e Pesquisas em Formação de Professores da Área de Ciências) da Faculdade de Educação da UNICAMP.

${ }^{14}$ Esta fonte de busca está alojada no sítio da Universidade Federal de Passo Fundo, onde disponibiliza links que direcionam para bibliotecas digitais de 33 universidades estaduais, federais e particulares, além de outros links para o Banco de Teses da Capes, Domínio Público e Biblioteca Nacional de Portugal.
} 
trabalhos mais antigos também foram encontrados, em textos completos digitalizados, nos sítios eletrônicos da UNICAMP e da USP.

Em todo o processo de busca dos arquivos eletrônicos nos bancos de dados, utilizamos como palavras-chave os termos "livro didático de Física"; "análise de livro didático de Física"; "Projetos de ensino de Física"; "currículo de Física"; "Proposta Curricular de Física" e "Evolução do Ensino de Física".

Em nossa busca e refino nos bancos de dados que trazem as pesquisas em ensino de Ciências/Física consideramos trabalhos que: 1) analisam conteúdos em livros didáticos de Física do ensino médio (Colegial, $2^{\circ}$ grau ou atual Ensino Médio) e/ou superior em qualquer perspectiva de análise (sincrônica ou histórica); 2) tratam dos principais projetos de ensino de Física do contexto histórico investigado, destinados ao $2^{\circ}$ ciclo do ensino secundário (posteriormente $2^{\circ}$ grau), e também o $\mathrm{GREF}^{15}$, por ser um projeto que surgiu a partir das tendências de inovação que contagiaram a área de ensino de Ciências; 3) tratam de estudos (sincrônicos ou históricos) sobre currículo oficial do ensino médio com foco na disciplina Física.

Nossas buscas alcançaram os resultados ${ }^{16}$ constantes na tabela a seguir.

TABELA 1- Teses e Dissertações brasileiras em Ensino de Física sobre Livros Didáticos, Projetos de ensino e Currículos oficiais.

\begin{tabular}{|c|c|c|c|c|c|}
\hline $\begin{array}{l}\text { TIPO DE REFERENCIAL } \\
\text { CURRICULAR }\end{array}$ & Total de trabalhos & \multicolumn{2}{|c|}{$\begin{array}{l}\text { Objeto principal } \\
\text { de estudo? }\end{array}$} & \multicolumn{2}{|c|}{ Perspectivas } \\
\hline & & Sim & Não & Sincrônica & Histórica \\
\hline Livros Didáticos de Física & $91(\mathrm{M}-80) ;(\mathrm{D}-11)$ & 51 & 40 & 79 & 12 \\
\hline Projetos de ensino de Física. & 23 (M - 16); (D - 7) & 14 & 9 & 17 & 6 \\
\hline Currículos oficiais de Física & $8(\mathrm{M})$ & 5 & 3 & 4 & 4 \\
\hline
\end{tabular}

Fonte: Dados da pesquisa

Na Tabela 1, os trabalhos podem estar inseridos em mais de uma categoria, ou seja, dentro do quantitativo de trabalhos que trazem análises de conteúdos nos livros didáticos,

\footnotetext{
${ }^{15}$ GREF - Grupo de Reelaboração do Ensino de Física formado no Instituto de Física da USP na década de 1980. O GREF foi formado por um grupo de professores da rede estadual de ensino de São Paulo e coordenado por docentes do Instituto de Física da USP com o objetivo de elaborar uma proposta de ensino de Física para o ensino médio ( $2^{\circ}$ grau). A proposta pedagógica do projeto fundamenta-se na contextualização dos conteúdos de Física e na valorização da experiência cotidiana dos alunos, buscando assim, propiciar uma visão da Física que leve à compreensão e atuação na realidade. O material criado pelo GREF apresenta uma forma mais lúdica e com linguagem simples de fácil compreensão para os alunos e busca sempre estabelecer relações entre ciência, tecnologia e sociedade (GREF, 2015).

${ }^{16}$ Reconhecemos as limitações para apurar quantitativos exatos de trabalhos defendidos no período delimitado, sobre as temáticas em questão, mormente no que se refere aos trabalhos mais recentes que não constam nos catálogos da UNICAMP/CEDOC e do IFUSP. O Banco de Dados da CAPES seria um modo seguro de obter dados mais reais, já que informações sobre trabalhos Strictu Sensu defendidos são fornecidas a CAPES anualmente. Entretanto, não foi possível contar com esse recurso de busca para os anos anteriores a 2011 e posteriores a 2012. Apesar disso, consideramos que os dados obtidos nos fornecem indicativos apreciáveis para a compreensão do desenvolvimento quantitativo das pesquisas na linha de análise de conteúdo em RC.
} 
representados na segunda coluna/segunda linha, pode ter trabalhos que, além do livro didático, tratam também de projetos de ensino ou reformas e propostas curriculares.

Choppin (2004) afirma que trabalhos na perspectiva histórica ganharam ênfase a partir de 1970 nos países ocidentais, especialmente em termos de análise de conteúdos, por permitirem compreender as finalidades do ensino, seus conteúdos e métodos, inclusive para a disciplina de Física, antes "negligenciada" (CHOPPIN, 2004, p. 555 - 558). Ainda assim, se encontram em número restrito no Brasil, trabalhos que analisam livro didático de Física nessa linha. Em nossas buscas localizamos somente 12 (doze) trabalhos que reúnem elementos que permitem classificá-los na linha de estudos históricos, dentre um total de 91 (noventa e um), o que corresponde a aproximadamente $13 \%$ do total de trabalhos que analisam livros didáticos de Física para o ensino médio e/ou superior, com enfoque nos conteúdos. O preterimento desse tipo de pesquisa se manifesta também para o caso dos projetos de ensino e currículos oficiais.

Conforme os dados apurados, tem-se que a maioria dos trabalhos são pesquisas que analisam os RC na perspectiva sincrônica, ou seja, poucas pesquisas tratam da história da disciplina Física por meio dos materiais didáticos. Essa pouca quantidade de trabalhos na perspectiva histórica, consonante com o que é constatado por Hosoume et al. (2011), é apontado como um fator contraproducente, pois "demonstra a pequena relevância dada à história da disciplina Física em pesquisas sobre LD, conhecimento de base para uma compreensão mais crítica dos currículos atuais." (HOSOUME et al.., 2011, p. 03).

Outro dado a pontuar é que, do total de trabalhos localizados, 51 (cinquenta e um) têm como enfoque principal os livros didáticos. Os demais abordam outras temáticas sobre o ensino de diversos temas da Física: laboratório didático experimental, projetos ou propostas alternativas de ensino, currículo, etc., e inclui o livro didático, muitas vezes, atribuindo-lhe um "papel coadjuvante" (HOSOUME et al., 2011).

Comparando nossos resultados com os de Hosoume et al. (2011), que englobou trabalhos defendidos no período de 1970 a $2009^{17}$, percebe-se que houve uma inversão no que tange ao enfoque, a partir de 2010, aumentando a quantidade de trabalhos que tem como objeto principal o livro didático de Física. Nessa perspectiva de investigação, Hosoume et al (2011) localizaram em todo o período anterior a 2010, 26 (vinte e seis) trabalhos (37\%) de um

\footnotetext{
${ }^{17}$ O texto do trabalho de Hosoume et al, 2011 não traz o período de abrangência do levantamento, contudo, fomos informadas, por uma das autoras do trabalho, que se trata do período que vai da década de 1970 ao ano de 2009.
} 
total de 71 (setenta e um) ${ }^{18}$. Já em nosso levantamento, de um total de 33 (trinta e três) trabalhos que trazem análise de conteúdo, defendidos no período de 2010 a 2014, 22 (vinte e dois) tem o livro didático de Física como objeto principal da pesquisa, o que corresponde a um percentual de aproximadamente $67 \%$ dos trabalhos do período.

Este dado indica ainda o aumento do interesse pelo livro didático como objeto de estudo na perspectiva dos conteúdos. Interesse este que, segundo Choppin (2004), se incrementou desde o final dos anos de 1970, com aumento progressivo. Somando às pesquisas que se dedicavam à crítica ideológica e cultural dos livros didáticos, surgiram nessa década as que procediam com análises dos conteúdos "segundo uma perspectiva epistemológica ou propriamente didática.” (CHOPPIN, 2004, p.555). Nossos dados, ilustrados no gráfico a seguir, confirmam essa evolução quando observamos as décadas.

Gráfico 1 - Quantitativos anuais de trabalhos no estado da arte com análises de conteúdos em livros didáticos de Física.

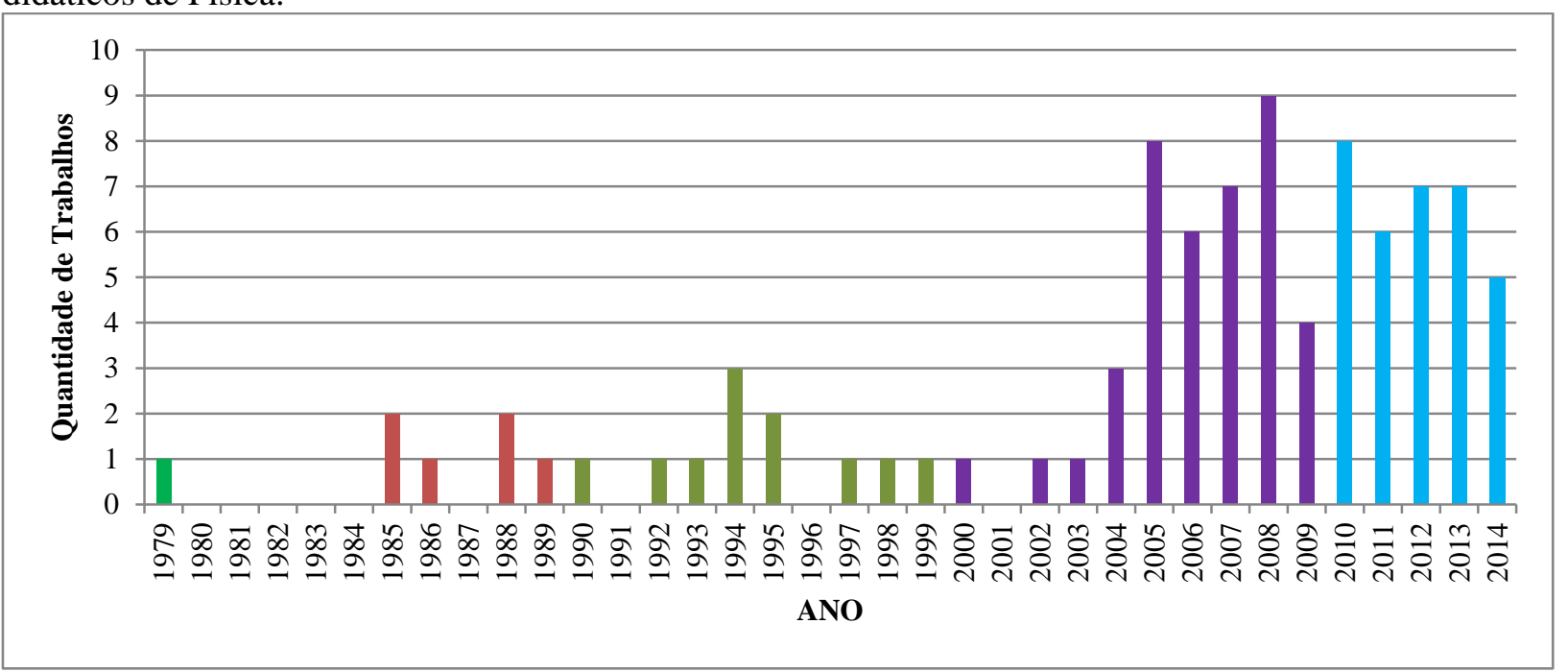

Fonte: Dados da pesquisa

Os dados revelam que, ano a ano, até 2004, os quantitativos pouco variaram, indo de 1 a 3 trabalhos por ano, sendo que em alguns anos não se identificam pesquisas que trazem análise de conteúdos em livros didáticos, e que uma expansão maior ocorreu a partir do ano de 2005. Observa-se ainda que a evolução é progressiva e com diferenças significativas entre uma década e outra. A década de 2010 indica guardar essa progressividade, uma vez que, em quatro anos, a quantidade de trabalhos já corresponde a aproximadamente $80 \%$ do quantitativo de trabalhos da década anterior.

\footnotetext{
${ }^{18}$ A referida pesquisa, diferentemente da nossa, não enfocou somente trabalhos que trazem análise de conteúdo nos livros didáticos de Física. Isso justifica, pelo menos em parte, a diferença quantitativa entre o nosso levantamento (58 trabalhos) e o de Housome et al (2011) (71 trabalhos), no que se refere ao período de 1970 a 2009.
} 
Consonante com o objetivo deste presente trabalho, que tem o livro didático como uma das fontes de estudo - embora atribuindo a este mais do que um papel coadjuvante nossa pesquisa se identifica com os trabalhos que contemplam a perspectiva histórica e com enfoque nos aspectos internos ao texto. Nessa linha, em que a análise de referenciais curriculares de Física inclui livros didáticos editados em outro contexto histórico-temporal, que não o do pesquisador, e que, de alguma forma evidencia a evolução do ensino da disciplina Física, localizam-se os trabalhos de Moura (1985), Almeida Filho (1992), Wuo $(2000)^{19}$, Pinho-Alves (2000), São Paulo (2004), Tavares (2005), Nicioli Jr. (2007), Sampaio (2004), Flores (2010), Bandeira Filho (2010), Beneti (2014) e Martins (2014). São pesquisas que, a partir da análise dos conteúdos escolares nos livros didáticos publicados em determinados momentos da história, "buscam compreender a complexidade do livro didático no ensino de Física, não apenas como mediador da prática pedagógica, mas também como representante do conhecimento de um momento da história." (MARTINS; HOUSOME, 2007, p. 1108).

Quanto aos projetos de ensino, os dados nos revelam que essa categoria de material curricular é pouco estudada em quaisquer perspectivas que se considere, sendo a maioria dos trabalhos com estudos sincrônicos que trazem reflexões sobre a implementação/avaliação dos projetos ainda no contexto de difusão deles, por autores que participaram da elaboração/aplicação dos mesmos, como por exemplo: Carvalho (1972); Caniato (1973); Violin (1976); Nassif (1976); Bittencourt (1977); Pacca (1976); Saad (1977). Além disso, nota-se análise crítica dos projetos anteriores e apresentação de uma nova proposta, mas ainda no contexto, ou pelo menos em tempo próximo - Dib (1972); Gaspar (1982). Observa-se que as pesquisas sobre projetos de ensino foram, em grande maioria, defendidas até o final da década de 1990.

Em nosso levantamento, consideramos o GREF como projeto de ensino somente quando este foi analisado nessa perspectiva, como por exemplo, em Sátiro (1989), Ambrózio (1990); Toscano (1991); Pereira (1995); Piassi (1995); Del Carlo (1997); Santos (2010) e Lyra (2006). Outros trabalhos incluem os livros do GREF na categoria dos demais livros didáticos que analisam, usando os mesmos critérios de análises. Podemos considerar que a maioria dos trabalhos que tem o GREF como objeto principal de estudo se encaixam na categoria de pesquisas sincrônicas.

\footnotetext{
${ }^{19}$ A Dissertação de Wagner Wuo foi defendida em 1999, mas o livro resultante desta foi publicado no ano 2000.
} 
Embora o material elaborado pelo grupo GREF ainda seja bastante utilizado, se adequando bem aos objetivos de ensino atuais, e os livros do projeto ainda sejam editados (reimpressos), a nosso ver, trata-se de um material histórico com potencial de ser, atualmente, objeto de estudo na perspectiva diacrônica (histórica). Na perspectiva que confere um maior enfoque ao referido projeto, têm-se os trabalhos de Lyra (2006) e de Santos (2010). O primeiro objetivou avaliar se os textos de Leituras de Física, produzidos pelo GREF, possibilitam o desenvolvimento de algumas competências relacionadas ao conceito de calor, nos termos das recomendações dos atuais Parâmetros Curriculares Nacionais. O segundo teve como objetivo construir um roteiro didático que se constituiu num percurso histórico epistemológico para o tema entropia. No desenvolvimento, analisou-se como esse conceito é apresentado em livros didáticos do atual Ensino Médio (os do PNLEM/2007), bem como em dois projetos de ensino: o PSSC (década de 1960) e o GREF (década de 1980).

O trabalho de Piassi (1995) analisou também o GREF ainda no contexto de difusão do mesmo, mas por abordar outros projetos de ensino da década de 1960 e 1970, pode ser considerado na categoria de estudos históricos. Buscou-se caracterizar a Física comumente abordada no ensino secundário através da análise do livro didático "Os Fundamentos da Física" de Ramalho et al., e dos projetos de ensino FAI, PEF, PSSC e GREF, apontando a concepção e o projeto de escola que caracterizou cada proposta, traçando paralelos entre conteúdos, métodos e objetivos.

Outros trabalhos que abordam projetos de ensino de Física das décadas de 1960 e 1970, cabíveis de serem considerados como estudos históricos, são as pesquisas de Moura (1985), Silva (1989) e Pinho-Alves (2000).

Moura (1985) traz uma retrospectiva histórica sobre a evolução da presença da Física no currículo do ensino secundário brasileiro e evidencia os aspectos relevantes para a área nas reformulações do ensino de 1930, 1942, 1961 e 1971. O estudo abrange a evolução do currículo de Física do $2^{\circ}$ grau no Brasil, desde a criação do Colégio D. Pedro II, em 1938, e debate as razões de sua inviabilidade no momento atual à pesquisa realizada (década de 1980). Discorre sobre algumas legislações de currículo e analisa sucintamente alguns livros de física do início do século XX. Aborda, de forma descritiva, e focada nos aspectos mais gerais, os principais projetos de ensino de Física das décadas de 1960/1970.

Silva (1989) discute a função do laboratório didático no ensino de Física no $2^{\circ}$ grau. Realiza análise de conteúdo em algumas propostas e projetos de ensino de Física (PEF, PSSC e Projeto Nuffield), buscando identificar elementos, implícitos ou explícitos, que refletem os aspectos relativos à educação, concepção de ciência, aprendizagem e linguagem nos referidos 
materiais, bem como na prática dos professores. Propõe uma estrutura para o laboratório e busca mostrar a contribuição que esta pode dar para a atuação dos professores.

Pinho-Alves (2000) apresenta um estudo analítico, também sobre o laboratório didático de Física, a partir de três fontes: livros-texto didáticos até 1950, projetos de ensino de Física estrangeiros e nacionais - PSSC, Projeto Piloto da UNESCO, Harvard, Nuffield, PEF, FAI, PBEF e GREF -, e investigações apresentadas nos Simpósio Nacional de Ensino de Física (SNEF), até 1999, e nos Encontros de Pesquisadores em Ensino de Física (EPEF), até 1998, procurando caracterizar a concepção de ensino de laboratório predominante ao longo do tempo.

Constata-se que, no que se refere aos projetos de ensino de Física, poucos trabalhos articulam elementos que os caracterizam como estudos históricos. Do mesmo modo, poucos trabalhos têm os projetos de ensino como objeto principal de estudo. A maioria aborda-os de forma mais descritiva, evidenciando o contexto de surgimento, as concepções filosóficas e teórico-metodológicas e as listas de temas gerais trazidos, algumas vezes, buscando identificar a presença de algum tópico de conteúdo da Física ou tipo de atividade didática, não se atendo às análises mais profundas das características internas aos textos, que podem ter muito a dizer sobre como se concebeu a ciência/Física em um dado momento da história. De um modo geral, os projetos são abordados como parte do contexto de evolução do currículo de Física, analisado por meio dos livros didáticos.

À princípio pode parecer que nosso estudo recai nessa mesma perspectiva. No entanto, esclarecemos que, embora tenhamos proposto analisar projetos de ensino juntamente com livro didático e currículo oficial, em nossa perspectiva de análise os três tipos de RC têm igualdade de relevância, ao buscarmos por meio de uma análise mais profunda, abstrair a história da disciplina Física a partir dos conteúdos das diferentes formas em que as orientações curriculares chegaram (ou poderiam ter chegado) às escolas.

São ainda mais escassos trabalhos que analisam o currículo oficial de Física, especialmente com estudos históricos, e os resultados de nossas buscas nos levam a crer que não existem estudos sobre propostas curriculares estaduais (ou programas de conteúdos) do período de 1960 a 1970. Dos trabalhos localizados, quatro trazem elementos que podem lhes classificar como estudos históricos: Moura (1985); Sampaio, (2004); Martins, (2014) e Beneti (2014). Todos analisam também livros didáticos. Destes, um aborda, também, os projetos de ensino - o de Moura (1985) -, e somente este abrange o nosso recorte temporal de estudo.

Observamos que a maioria das pesquisas que analisam RC de Física, identificadas como históricas, tem como enfoque os livros didáticos. Os projetos de ensino e programas de 
conteúdos (ou currículo oficial) são abordados como objeto complementar ou como parte da contextualização do momento histórico analisado. Observa-se ainda que, pouco se explora as determinações das legislações educacionais quanto à definição da presença da ciência/Física no currículo, bem como sobre as recomendações/orientações legais acerca dos conteúdos da referida disciplina.

As pesquisas históricas aqui destacadas trazem diferentes ênfases, mas convergem no propósito de mostrar a história da disciplina escolar Física no Brasil por meio dos materiais didáticos. Em seu conjunto, essas pesquisas nos revelam muito da dinâmica que envolve as transformações no currículo escolar, em razão das relações políticas, econômicas e sociais que permeiam a elaboração deste, nos diferentes contextos, conforme sinalizam Goodson (1995), Apple (1997), Sacristán (2000), e outros teóricos críticos do currículo. As pesquisas destacadas apontam:

$\rightarrow$ Influências de propostas inovadoras e do contexto educacional em vigor nas visões de ciência do momento (MOURA, 1985; SILVA, 1989; PINHO-ALVES, 2000; WUO, 2000);

$\rightarrow$ Relação entre poder e ensino de Física; saber científico e saber de referência, sendo o conhecimento científico ensinado dependente do momento histórico, o que define os objetivos do ensino num dado contexto (ALMEIDA FILHO, 1992; WUO, 2000; SÃO PAULO, 2004; FLORES, 2010; BENETI, 2014);

$\rightarrow$ Influência externa (estrangeira) no modo de apresentar a Física escolar nos livros e nas aulas da escola brasileira (SAMPAIO, 2004; TAVARES, 2004; NICIOLI Jr.,2007; MARTINS, 2014);

$\rightarrow$ Interesses financeiros na elaboração dos materiais didáticos (FLORES, 2010), o que influenciou o modo como os conteúdos foram apresentados.

Ainda que tenhamos focado em pesquisas na forma de teses e dissertações, consideramos, com justiça, dar mérito de modo especial a dois trabalhos que, a nosso ver, abriram caminho para resgatar pontos de extrema relevância da história do ensino de Física, em particular, e de Ciências de um modo geral, em nosso país; ainda que tais trabalhos não tratem de análises de conteúdos. Falamos dos trabalhos de Almeida Jr. (1979, 1980) e Krasilchik (1980), que serão, por muitas vezes, mencionados no presente texto.

Os trabalhos de Almeida Jr. (1979; 1980), em dois artigos publicados na Revista Brasileira de Ensino de Física, fazem uma bela "viagem no tempo" e mostram a evolução do ensino de Física desde o Brasil colônia até a década de 1970, fechando com a análise das primeiras reuniões sobre ensino de Física, que ocorreram a partir do início da década de 1970 
- Simpósio Nacional de Ensino de Física (SNEF). O estudo tem como foco o currículo e suas reformulações e traz importantes pontos aos quais recorreremos em alguns momentos da presente pesquisa.

Krasilchik (1980), em uma publicação no livro Inovação Educacional no Brasil, em um capítulo intitulado "Inovações no ensino das Ciências", faz uma retrospectiva histórica que vai de 1950 a 1980 discorrendo sobre os eventos que caracterizaram o movimento renovador do ensino de ciências.

Cabe ressaltar ainda a presença de trabalhos mais recentes, apresentados por meio de artigos em eventos da área de Física ou publicados em revistas voltadas para o ensino, tratando do resgate da história do ensino de Física, em estudos sobre referenciais curriculares das décadas de 1960 a 1980, por professores, graduandos e pós-graduandos de diversas universidades do país. Lembramos, por exemplo, os trabalhos de Gaspar (2004), Garcia (2006), Garcia, Garcia e Higa (2007), Perini, Ferreira e Clemente (2009), Chiquetto (2011), Chiquetto e Krapas (2012) e Pena (2012). São trabalhos que se somam para registrar a história do ensino de Física no Brasil e configura grande importância para a compreensão do ensino desta disciplina em um período de densas transformações nas formas de se pensar o ensino de Ciências/Física.

Ainda assim, a quantidade de trabalhos que analisam documentos históricos referentes ao currículo de Física pode ser considerada escassa. Isso nos permite vislumbrar que nossa pesquisa se coloca como importante contribuição para as pesquisas da área, pois traz o diferencial de analisar os temas da Física de modo mais abrangente, em três tipos de RC (livros didáticos, projetos de ensino e propostas curriculares oficias) que fizeram parte do processo educacional, levando em conta os aspectos das legislações do ensino do período estudado.

\section{Estrutura da tese}

O presente texto se constitui desta introdução, cinco capítulos e considerações finais. Nesta Introdução, tratamos de apresentar a proposta de pesquisa evidenciando alguns aspectos do contexto político-social em que se insere o nosso objeto de investigação, bem como a questão principal de estudo, os objetivos e delimitações da pesquisa. Com a finalidade de situar o nosso estudo no campo das pesquisas em ensino de Física, apresentamos um breve levantamento no estado da arte de trabalhos que analisam materiais curriculares com foco nos 
conteúdos, dando maior relevância aos que trazem análises na perspectiva histórica. Descrevemos ainda os percursos abrangidos no desenvolvimento deste trabalho.

No capítulo 1, apresentamos a perspectiva teórica global de nosso estudo, mostrando as concepções sobre o conceito de currículo e sua relação com o poder mais amplo, por parte de alguns teóricos do assunto, com maior ênfase às ideias de Ivor Goodson (1995). Objetivamos com isso compreender o nosso objeto de estudo. Apresentamos também uma sustentação teórico-metodológica para a análise dos referenciais curriculares escolhidos para uma exploração mais aprofundada, tomando como referência as proposições de Delizoicov, Angotti e Pernambuco (2007) a respeito das dimensões interativas do conhecimento escolar. Debruçamo-nos um pouco sobre o estudo das concepções de ciência e na de método científico de alguns filósofos, uma vez que tais concepções podem ser apuradas a partir dos elementos da análise de nossas fontes empíricas, possibilitando-nos compreender o processo de produção da ciência e o papel do sujeito nesse processo, e como as orientações curriculares e os materiais didáticos expressam tal interação. Buscando ampliar nossa compreensão dos aspectos que definem as dimensões adotadas, apresentamos ainda, uma breve discussão sobre as visões de educação e ciência no contexto investigado, quando o sistema de ensino se submeteu às diversas ideias pedagógicas, assumindo certo hibridismo conceptual.

No capítulo 2 discorremos sobre as reformas de ensino do sistema educacional brasileiro no contexto estudado. Retrocedemos com um breve histórico das reformas que antecederam a primeira Lei de Diretrizes e Bases da Educação Brasileira, com o objetivo de compreender o grau de importância concedido às Ciências, em que se inclui a Física, nas reformas educacionais da década de 1930 à de 1970. Tomamos como ponto de partida, o ano de 1930 por este representar um divisor de águas no modelo político e econômico brasileiro e que refletiu no sistema educacional. Retroceder nesse aspecto, extrapolando um pouco o nosso recorte temporal de investigação, nos permitiu compreender a historicidade das legislações que modificaram o currículo de Ciências, particularmente o de Física, no contexto histórico que propusemos explorar.

No capítulo 3, adotando inicialmente um discurso predominantemente descritivo, buscamos resgatar a história do movimento renovador para o ensino de Ciências no Brasil, que configurou como um período assaz fecundo para o ensino de Física. Apresentamos aspectos mais gerais da história dos projetos de ensino de Física, nacionais e estrangeiros, que fazem parte desse enredo, sendo alguns deles (PSSC, PEF e FAI) tomados como fonte de análise de conteúdo nesta pesquisa. Neste capítulo trazemos os resultados de tal análise nos referidos projetos, sustentada pelo enfoque teórico-metodológico adotado. 
Os capítulos 4 e 5 tratam dos demais tipos de referenciais curriculares que fazem parte de nossas fontes empíricas: as propostas curriculares oficiais e o livro didático. No capítulo 4 apresentamos as propostas curriculares oficiais identificadas em nosso levantamento de documentos históricos, bem como os resultados de nossa análise de conteúdo das mesmas. No capítulo 5, apresentamos os livros didáticos de Física presentes no mercado editorial das décadas de 1960/1970, e, do mesmo modo, a análise de uma amostra de quatro produções didáticas de relevância no período. Ambos os referenciais tiveram suas análises sustentadas pelo mesmo enfoque teórico-metodológico adotado no estudo dos projetos de ensino mencionados anteriormente.

Por fim, apresentamos nossas considerações finais com algumas reflexões acerca dos resultados e sugestões/pretensões para a continuidade de pesquisas na linha histórica, na perspectiva dos conteúdos, buscando ampliar as fontes empíricas que deram forma ao currículo da disciplina Física no contexto de vigência da LDB/1961 e da Lei nº 5.692/1971. 



\section{APOIO TEÓRICO E METODOLÓGICO}

\subsection{Perspectiva teórica global da pesquisa}

Nosso objeto de estudo são as orientações curriculares para o ensino de Física, inseridas em uma política curricular mais ampla. Política esta, orientada por um arsenal de documentos - Leis, Decretos, Resoluções, Pareceres, Atos, Indicações, Propostas Curriculares, Livros Didáticos, etc., o que denota a relevância dada ao processo de definição do currículo escolar. Desse modo, consideramos relevante buscar a compreensão sobre concepções de currículo nas ideias de alguns teóricos do assunto. Embora mencionemos outros autores, tomaremos como embasamento maior as contribuições do teórico inglês Ivor Goodson, pela sua veemente defesa aos estudos históricos do currículo como forma de compreender os meandros que permeiam o processo de escolarização e que definem os mecanismos de seleção e de organização dos conteúdos escolares.

\subsubsection{O currículo escolar: uma construção social}

$\mathrm{Na}$ visão de diversos autores, o currículo é foco principal de qualquer reforma educacional. É crescente a relevância do currículo nas discussões, pesquisas e legislações no âmbito educacional. Considerado como parte essencial do processo de formação do indivíduo em qualquer período de escolarização, é construído a partir do contexto social, histórico, político e cultural da sociedade, mediado pelo professor e sua prática educativa (SACRISTÁN, 2000). Apesar disso, ainda numa concepção superficial, para muitos educadores, o currículo se limita ao conjunto de conteúdos das disciplinas, recursos e procedimentos pedagógicos de um determinado curso ou etapa escolar.

Definir o currículo em seus múltiplos contextos de produção não é uma tarefa fácil. O que se tem feito é ensaiar diferentes acepções para este importante artefato educacional. Pela complexidade do tema, os autores se revezam em convergências e divergências de ideias ao tentarem conceituar currículo. O caráter polissêmico do termo currículo lhe atribuiu diversos sentidos dependendo dos objetivos que se pretende com o processo educativo. Assume o significado de estratégias para promover a formação escolar, de avaliação, metas, alocação de recursos financeiros, demarcação de status de uma área de conhecimento, experiências desenvolvidas na escola, conjunto de matérias, seleção de conhecimentos 
sistematizados de uma cultura mais ampla, métodos de ensino, e outros, encerrado em torno das ideias de sequência e totalidade. Nesse sentido, Goodson entende o currículo como:

[...] curso aparente ou oficial de estudos, caracteristicamente constituído em nossa era por uma série de documentos que cobrem variados assuntos e diversos níveis, junto com a formulação de tudo - 'metas e objetivos', conjuntos e roteiros - que, por assim dizer, constitui as normas, regulamentos e princípios que orientam o que deve ser lecionado. (GOODSON, 1995, p. 117).

Essas definições ainda implicam em diferentes sentidos, ou intenções, dependendo do contexto em que são discursadas. Pode perpassar pela ideia de controle em um contexto espaço-temporal, mas assumir também a ideia de conhecimento com finalidade de formação para o desenvolvimento intelectual, social, político, etc. (viés progressista), em outro contexto.

Segundo Goodson (1995), a questão etimológica do conceito de currículo, dado o seu significado de origem, traz implicações na sua reconceptualização no processo de escolarização. Segundo o autor, o termo currículo é originado da palavra latina Scurrere, que significa correr ou um curso (ou percurso). Assim, as decorrências do termo aludem a este o significado de curso a ser seguido (GOODSON, 1995; SACRISTÁN, 2000). Segundo Goodson, é dessa origem que a palavra currículo aflorou como concepção de escolarização.

Pensar o currículo somente como um curso a ser seguido, é uma visão um tanto simplista. Currículo, nesta perspectiva, exclui considerar os contextos, os conflitos e tensões gerados em sua criação. É preciso levar em conta o preenchimento desse percurso. Diversas forças externas ao contexto social de reprodução do currículo detêm o poder de definir o que deve ser o curso a ser seguido. Nessa visão de currículo como prescrição, classe e currículo se justapõe para criar uma sequencialização do processo de escolarização como algo dividido em partes, em que se vai galgando níveis (GOODSON, 1995).

Conforme cita Goodson, a justaposição de classe/currículo remonta a um passado bem longínquo. Esse autor, citando Mir (s.d.), esclarece que, em 1509, no College of Montaign em Paris, já se encontrava a divisão de alunos em classes "por estágios e níveis de complexidade crescente de acordo com a idade e o conhecimento exigido dos alunos" (MIR, s.d. apud GOODSON, 1995, p.31).

Goodson mostra que os padrões de organização e controle sempre estiveram presentes na emergência do currículo. Assim, o significado atribuído e firmado para o termo currículo está imbuído de pretensões e tem em sua base o controle que é de determinar o que deve ser ensinado e para quem se destinam tais conhecimentos. 
Apple (1997) opina que a política que visa legitimar um conhecimento tido como válido para uma determinada sociedade, em um determinado contexto, é uma luta travada por grupos poderosos e movimentos sociais que anseiam inculcar novos valores, ou consolidar velhos hábitos, dependendo da ideologia dos concorrentes. Conforme esse autor, currículo e poder se relacionam de modo conflitante à medida que o que está em jogo não é apenas qual conhecimento será legitimado, mas principalmente o conhecimento de quem será considerado importante e legítimo para ser transmitido. Apple afirma que: "Os meios e os fins envolvidos na prática e na política educacionais são o resultado de lutas empreendidas por poderosos grupos e movimentos sociais para tornar o seu conhecimento legítimo, para incrementar seu poder na arena social mais ampla.” (APPLE, 1997, p.24).

Ainda que haja acordos e compromissos, estes ocorrem em diferentes níveis, o que não implica igualdade de poder. Os compromissos não são estáveis e deixam margens para ações democráticas, de modo que as preocupações dos menos poderosos passam a ser fator de relevância para os grupos dominantes na formulação dos currículos e nos processos de ensino e avaliações nas escolas.

Nesse mesmo sentido, Goodson (1995) coloca que a legitimação do conhecimento constituído por determinado grupo (ou grupos) envolve amplos objetivos de ordem social, política e econômica que, segundo o autor, pressupõem a existência de conflitos permanentes em torno do que prevê o currículo para uma determinada classe social; um "testemunho visível, público e sujeito a mudanças" e constitui em legitimação de uma escolarização envolvendo sempre interesses financeiros, atribuição de status e, também, classificação profissional (GOODSON, 1995, p.21).

Na mesma linha sociológica, Moreira (1997) coloca que o currículo se traduz em forma de desenvolvimento de "processos de conservação, transformação e renovação de conhecimentos historicamente acumulados" (MOREIRA, 1997, p.11) pelas sociedades ao longo do tempo e serve também para socializar os aprendizes na direção de valores tidos como desejáveis.

Esses autores assumem a complexidade de significação mais precisa desse artefato escolar nos diferentes níveis de produção, de modo que não definem explicitamente conceitos que interpretam as diferentes naturezas do currículo escolar. Assumindo essa complexidade, Goodson apresenta as visões de alguns autores como Jackson, Maxine Greene e Young e Whitty sobre o conceito dual de currículo: o oficialmente determinado e o praticado nas escolas. Intencionando mostrar a diferença entre as definições "pré-ativa" de currículo e 
realização "interativa", caracterizada por Jackson $(1968)^{20}$, Goodson apresenta outras definições de currículo, ou melhor, mistificações, a partir das visões de Greene ${ }^{21}$ (1971) e Young e Whitty ${ }^{22}$ (1977).

Segundo Goodson (1995), Greene traz um conceito dual de currículo que pressupõe, por um lado, a ideia dominante de currículo como algo criado por alguém ou alguns e devendo ser dominado por outros (alheios ao processo), e por outro lado, o currículo, numa visão interativa, como "uma possibilidade que o discente tem como pessoa concreta, principalmente interessada em dar sentido ao mundo em que de fato vive" (GREENE, 1971 apud GOODSON, 1995, p.18 e p.106).

Young e Whitty (1977) também defendem duas concepções de currículo: “currículo como fato" (externo à escola) e "currículo como prática" (processos cotidianos da escola). Para esses autores, o currículo como fato é mistificado como algo incompreensível e incontrolável pelas pessoas, e que é superficialmente tratado em sala de aula. Colocam que "O 'currículo como fato' precisa ser considerado como uma realidade social, historicamente específica, expressando relações particulares de produções entre pessoas" (YOUNG; WHITTY, 1977, p. 237 apud GOODSON, 1995, p.18 e p.106).

O conceito de "currículo como prática", conforme Young e Whitty, também é mistificado como sendo somente o resultado de "intervenções e ações subjetivas de professores e alunos". Segundo esses autores, o currículo visto dessa forma "reduz a realidade social de currículo" e impede o entendimento dos aspectos históricos da constituição dos saberes, o que inclui as matérias escolares. Colocam ainda que: "Ao sermos impedidos de poder situar historicamente os problemas da educação contemporânea, ficamos também impossibilitados de entendê-los e controlá-los." (YOUNG; WHITTY, 1977 apud GOODSON, 1995, p.18 e p.106).

Moreira (1997) também reconhece as dificuldades em conceituar currículo e justifica isso por ser um conceito que traz diferentes e abundantes definições. Dentre essas definições, ele destaca algumas que julga serem as mais usuais - conhecimento escolar e experiência de aprendizagem. A primeira se refere ao que a escola ensina (ou o que deve ser ensinado) e o que o aluno aplica. A segunda é o que se norteia pelas teorias educativas: pedagogias centradas no aluno; a forma de ensino em detrimento do conteúdo; ênfase nas diferenças individuais; ações do aluno em destaque; o currículo como o conjunto de experiências

\footnotetext{
${ }^{20}$ JACKSON, P. Life in Classrooms. Nova Iorque, Holt Rinehart and Winston Inc, 1968.

${ }^{21}$ GREENE, M. Curriculum ad Consciousness. The Record, 1971.

${ }^{22}$ YOUNG, M.F.D; WHITTY, G.. Society State and Schooling: Readigns on the Possibilities for radical Education. Falmer Press, 1977.
} 
vivenciadas pelo aluno. $\mathrm{O}$ autor chama a atenção para a presença constante de ideias comuns nessas duas definições de currículo, como por exemplo, a apresentação de conhecimentos, experiências de aprendizagem, assimilação e reconstrução.

Moreira (1997) apresenta outra perspectiva de currículo com foco na estruturação e suas inter-relações. O currículo como Plano. Nessa definição está presente o exagero na preocupação com os objetivos curriculares, regras de formulação dos objetivos, atenção nas relações entre os objetivos internos ao currículo e os objetivos educacionais mais amplos, e ainda, seleção, ordenação e hierarquização dos elementos do currículo. Essa foi a concepção de currículo (influência behaviorismo) que permeou os anos de 1960/1970 no sistema educacional brasileiro.

Ainda segundo Moreira (1997), os debates no campo do currículo em torno das diferentes definições fazem surgir novas ênfases que aumentam o leque de significados: o foco nos conteúdos e atividades determinadas no documento escrito, e o foco no que realmente é praticado em sala de aula. Daí o surgimento de definições similares às colocadas por Goodson (1995), que distinguem o currículo em dois tipos: currículo formal e currículo real ou em ação (ou currículo pré-ativo/prescrito e currículo ativo/interativo/como prática, como assume Goodson). O currículo formal é o prescritivo, aquilo que vem determinado de instâncias superiores para ser transmitido aos alunos e que advém de conhecimentos mais universais acumulados pelas sociedades, estando carregados de nuances políticas, sociais e econômicas. O currículo real ou em ação, como coloca Moreira (1997), refere-se ao que realmente é praticado nas escolas e mais especificamente nas salas de aula, diante de suas especificidades estruturais e de suas relações interpessoais.

Sacristán (2000) também debate as várias acepções de currículo evidenciando a impossibilidade de definir um conceito que é abstrato por natureza. Ele afirma:

O currículo é uma práxis antes que um objeto estático emanado de modelo coerente de pensar a educação ou as aprendizagens necessárias das crianças e dos jovens, que tampouco se esgota na parte explícita do projeto de socialização cultural nas escolas. (SACRISTÁN, 2000, p.15).

A concepção desse autor converge com a de outros, já citados, quanto ao jogo de interesses que submergem a definição do currículo escolar. Para ele, "os currículos são a expressão do equilíbrio de interesses e forças que gravitam o sistema educativo num dado momento, enquanto que através deles se realizam os fins da educação no ensino escolarizado" (SACRISTÁN, 2000, p.17).

As ideias dos autores citados reforçam a importância de estudar o currículo numa perspectiva construcionista histórica, possibilitando a compreensão da existência de uma 
variedade de áreas e níveis em que o currículo é elaborado. Conforme ressalta Goodson, a construção pré-ativa do currículo é pouco conhecida, o que torna difícil qualquer estudo mais completo sobre as relações entre a prescrição e a fase prática.

No Brasil, no que tange a disciplina escolar Física, essa constatação ainda é pertinente, dada a ínfima quantidade de pesquisas que analisam o currículo prescrito para o ensino desta disciplina, conforme constatamos.

Goodson recomenda que o currículo prescrito deva ser analisado criticamente para que não haja o risco de aceite como algo pronto e imutável. Aceitando os pressupostos do currículo (tradicional), sem questioná-lo, é assumir algo que poderia ser objeto de contínuo conflito talvez até pela falta de aplicabilidade ou pela discrepância entre o real e o ideal.

Importante ressaltar que, conquanto o currículo escolar envolva conflito de interesses internos à sociedade para transmissão de valores dominantes, este não se ocupa apenas da inculcação desses valores, conforme salienta Sacristán e Pérez Gómez (1998). Essa ideia é também compartilhada por Goodson (1995). Pela sua natureza ampla, e, de certa forma, de desenvolvimento incontrolável no contexto escolar, pela reelaboração intencional na prática do professor que seleciona o que, como e quando deve ser ensinado, pela reação à forma e conteúdo do ensino, não se pode afirmar que o currículo em sua essência inculca somente valores alheios aos aprendizes.

$\mathrm{Na}$ prática, na sua forma oculta, o currículo transmite, reforça e inclui valores cultivados no modo de vida dos estudantes e dos professores. Não há como negar a influências contextuais imediatas no processo de ensino-aprendizagem. Como concorda Tura (2002, p. 156): “a escola é um local privilegiado de ideias, de encontros, de legitimação de práticas sociais, de integração entre gerações, de articulação entre diversos padrões culturais e modelos cognitivos".

Nesse sentido, Moreira (1997) reforça que essa visão reducionista de currículo como somente expressão de poder, vem sendo desmistificada com os debates sobre o currículo oculto, e que tal visão "está sendo substituída por uma perspectiva mais complexa, na qual contradições, conflitos e resistências vêm a desempenhar papel de relevo.” (MOREIRA, 1997, p. 14).

O papel do professor na construção dessa forma de currículo é inegavelmente importante, uma vez que este transforma o conteúdo do currículo adequando-o ao seu público. Muitas vezes essa adequação é influenciada também pelos saberes docentes. Nesse processo de transformação, a influência entre o currículo e o professor é recíproca. Assim, os professores não são apenas seguidores da prescrição, mas sim agentes transformadores que 
podem, com uma revisão constante de sua prática pedagógica, e, pela reação de aceitação e aprendizagem dos alunos, promover mudanças curriculares, até mesmo no nível pré-ativo (GOODSON, 1995; SACRISTÁN; PÉREZ GÓMEZ, 1998).

Ainda que as concepções sobre currículo escolar, dos autores mencionados, apresentem, na essência, algumas divergências, nota-se evidente uma convergência em torno da imagem de currículo escolar como algo que, por sua natureza, é carregado de conotações ideológicas e políticas, que alimenta um jogo de interesses de diversos segmentos sociais, muitas vezes, desconhecido pelos atores que o encenam no interior dos muros escolares.

\subsubsection{O currículo como instrumento de estratificação social}

Segundo Moreira (1997), as discussões no campo do currículo se ampliaram a partir dos anos de 1970 com o surgimento de uma abordagem mais crítica na busca de superar o currículo tradicional dominante (técnico-prescritivo). Essas discussões emergiram na Inglaterra e nos Estados Unidos, voltadas para entender as relações de estratificação do conhecimento e estratificação social, e os processos de seleção e de organização do conhecimento escolar.

Retomamos a Goodson (1995) para compreender melhor as relações do currículo com a ordem social vigente em determinado contexto, com um interessante debate do autor que mostra como o currículo pode ser um instrumento de controle e diferenciação social e a relação desta diferenciação de classe com as matérias escolares. Com isso, ele propõe mostrar a influência de acontecimentos sociopolíticos ocorridos no passado, na visão de mundo e consciência da sociedade atual. O seu objetivo é reconceitualizar as pesquisas curriculares a partir de um estudo crítico da produção social do currículo constituído ao longo da história. O autor coloca que "[...] ao estudar os períodos históricos, o importante é gerar insights nas mundividências sustentadas por grupos culturais e subculturais distintos" (GOODSON, 1995, p.85).

Goodson cita alguns exemplos que ilustram a importância de considerar o currículo como construção social e fruto de intensos conflitos. Um deles se refere aos rumos tomados na definição da matéria ciência escolar na escola da Inglaterra no século XIX. Com esse exemplo, ele elucida a forma como as forças no poder definem o "lugar do indivíduo" na sociedade por meio do processo de escolarização. Assim, analisa a questão dos arrolamentos internos do currículo, ou seja, sua forma, em que emerge a relação entre matéria escolar e forma de conhecimento num contexto social interessado. Para conceituar de forma mais 
generalizada o estudo das matérias escolares, o autor descreve alguns conceitos sobre "mentalidades" que vigoraram como meio de classificação de escolarização na Europa no século XIX.

O autor cita a pesquisa de Shapin e Barnes ${ }^{23}$ (1976), em que dissertam que, no período de 1770 a 1850, na Inglaterra, diferentes mentalidades foram atribuídas às pessoas dependendo de que classe social elas provinham, e tais mentalidades estavam interligadas às relações de trabalho. Julgava-se que nas classes mais elevadas da sociedade encontravam-se pessoas de capacidade de pensamentos mais abstratos, refinados e complexos, ou seja, "mais inteligentes".

Debatendo essas ideias de capacidades de pensamento dos indivíduos das classes superiores e inferiores, Shapin e Barnes (1976) discriminaram três elementos divergentes e excludentes. O primeiro é que as ordens inferiores coordenavam seus pensamentos a partir dos sentidos e da percepção do concreto, enquanto que as ordens superiores se beneficiavam da inteligência, da retórica e da capacidade de abstrair. O segundo é a simplicidade de pensamento das ordens inferiores em contrapartida com a complexidade e sofisticação do pensamento das ordens superiores. A terceira dicotomia evidencia a ideia da diferença de respostas dadas na medida em que adquirem experiência e conhecimento.

Nesse processo, segundo os padrões de classificação impostos, a classe inferior responderia de forma passiva ao conhecimento, não se apoderando disso para estabelecer relações entre diferentes informações e elevar sua capacidade de pensamento, enquanto que a classe superior responderia ativamente às experiências e conhecimentos adquiridos para suplementar seus conhecimentos pré-existentes. Com base nessa concepção, criou-se a ligação entre as classes inferiores e o conhecimento específico e contextualizado.

Dessa forma, a classe inferior, segundo esta classificação, não agiria sobre o conhecimento e o utilizaria apenas para execução de trabalhos mecânicos que não lhes exigiriam maiores generalizações. A visão de conhecimento contextualizado remetia a situação de exploração do trabalho com a preocupação de desestimular qualquer possibilidade de resistência. A história nos revela que essa visão era equivocada, pois é sabido de onde (de quais classes) surgiram as importantes lutas sociais que desencadearam grandes conquistas (de variadas naturezas) em vários lugares do mundo.

$\mathrm{O}$ conhecimento descontextualizado destinado às classes superiores, que a princípio era o ideal deles, segundo os autores citados por Goodson, tornava-os também passivos com o

\footnotetext{
${ }^{23}$ SHAPIN, S.; BARNES, B. Head and Hand: Rhetorical Resources in British Pedagogia Writing, 1770-1850. Oxford Review of Education, 1976.
} 
tempo. A preocupação era de que o conhecimento fosse adequadamente distribuído para que nas relações de comunicação entre as classes não tivesse o risco de que o conhecimento se tornasse meio de reação para promover a "desordem”, mesmo que fosse apenas temporária.

No intuito de continuar com o poder nas mãos dos pertencentes às classes superiores, favorecendo mais o intelecto do que o trabalho manual, na década de 1850, o processo de escolarização secundária inglesa se aliou às universidades que por sua vez, já serviam às classes dominantes. O objetivo disso era criar conselhos de exame que continuaram servindo como forma de classificação.

A característica do currículo foi institucionalizada e este tinha o poder de diferenciar. A escolarização secundária foi classificada, em 1868, em três graus que dependia do tempo em que o estudante permanecia na escola. Segundo Goodson:

\begin{abstract}
Em 1868, a escolarização até os 18 ou 19 anos de idades destinava-se aos filhos ou de indivíduos simplesmente ricos, independentemente da profissão por eles exercida, ou de profissionais, homens de negócio, cujos rendimentos os situassem no mesmo nível. Esses alunos seguiam um currículo essencialmente clássico. O segundo grau (até os 16 anos de idade) destinava-se aos filhos da "classe mercantil". O currículo para esses alunos era de orientação menos clássica e já um tanto prática. O terceiro grau (até os 14 anos de idade) destinava-se aos filhos de "pequenos proprietários agrícolas, pequenos comerciantes [e] artesãos superiores". O currículo para esses alunos baseava-se nos três "R", mas ministrava conhecimentos até um nível bastante elevado. Essas graduações cobriam o ensino secundário. Enquanto isso, a maioria dos estudantes da classe operária recebia apenas uma educação em nível de escola elementar e aprendiam rudimentos nos três "R" ${ }^{24}$ (GOODSON, 1995, p.89).
\end{abstract}

Após a criação dos conselhos de exames, a diferenciação entre ordens sociais e currículos destinados a cada uma se efetivou hierarquizando o processo de escolarização de modo que os mais favorecidos financeiramente se beneficiavam de uma educação que promovia o desenvolvimento intelectual para aproveitamento em momentos futuros, enquanto que as classes desfavorecidas eram contempladas com um currículo adequado a uma aprendizagem mecânica voltada para a prática imediata.

Essa história do currículo britânico não é estranha à nossa ainda mais recente. Ressalte-se a clara intenção da legislação educacional brasileira, de 1942, que explicitamente dissertou sobre a finalidade do ensino secundário: "formar individualidades condutoras, [...] desenvolver nos alunos a capacidade de iniciativa e de decisão e todos os atributos fortes da vontade." (BRASIL, 1942, Art. 23). Como forma de selecionar, essa legislação ampliou ainda mais os exames, passando a existir em três ordens: admissão, suficiência e licença ${ }^{25}$.

\footnotetext{
${ }^{24} \mathrm{O}$ termo "três 'R" $\mathrm{R}$ " significa read, write and count (ler, escrever e contar).

${ }^{25}$ Esses termos serão explicados no capítulo 2.
} 
Retomando o caso da Inglaterra, com o passar dos anos, surgiram desafios a esta forma hierarquizada de currículo, sendo o mais eminente a inclusão da ciência como matéria escolar. Por ser esta uma forma de conhecimento inegavelmente contextualizada, seria então propício à classe inferior. A ciência até então era considerada como informação desinteressada e a inclusão da mesma no currículo das ordens inferiores funcionou como um teste para verificação de interesse em conhecimento escolar. $\mathrm{Na}$ verdade, para alguns, a inclusão já representava a possibilidade de aproximação de mentalidades das classes, conforme cita Shapin e Barnes (1979) uma fala de um "senhor rural” proferida em 1825: “[...] se as classes operárias devem aprender ciências, o que irão aprender as classes média e superior para se preservar a devida proporção?” (SHAPIN; BARNES, 1979, p.239 apud GOODSON, 1995, p. 90).

As preocupações do "senhor rural" se mostraram procedentes uma vez que algumas experiências com a inclusão do ensino da matéria ciências nas classes operárias, alguns anos depois, se mostraram bem sucedidas. Um exemplo, citado por Goodson, fala da formação do currículo escolar de ciências denominado "Ciências de coisas comuns". Nesta modalidade de currículo, as experiências cotidianas formavam a base do conhecimento para a ciência escolar. Esta estrutura curricular era aplicada em escolas elementares da classe operária na Inglaterra, em 1842, e se mostrou eficiente por ser significativa e prática. Enquanto isso, outras definições de ciência escolar eram defendidas por interesses do poder e destinado às classes superiores. O sucesso da "Ciência de coisas comuns" provocou vexame para a classe dominante quando um garoto pobre e cocho, pertencente à classe operária respondeu de forma lúcida e inteligente a questionamentos feitos a ele. Tão logo se constatou tal sucesso, a ciência foi excluída do currículo elementar (GOODSON, 1995).

Apesar de as experiências cotidianas terem se mostrado como aspecto importante na construção do conhecimento científico na situação colocada pelo autor, esta forma de currículo não foi tomada como "tradição", pois colocava em risco a primazia superior. O conceito de tradição remete a algo que se define pela repetição, através de normas aceitas ou expressas. No caso do currículo, deve-se evidenciar que a tradição pode ser inventada, como sustenta o autor, defendendo um jogo de interesses sociopolíticos que geralmente se edifica pela falta de questionamento.

Goodson faz uma afirmação sobre invenção de tradição (ou uma tentativa de invenção) que calha com o que ocorreu com a área de Ciências no Brasil, nas décadas 1960/1970 - a integração das disciplinas científicas na área de estudo "Ciências Físicas e Biológicas” (que abordaremos em capítulo mais adiante). Ele afirma: “[...] Com efeito, esta 
linguagem, é com frequência empregada quando as 'disciplinas tradicionais' ou 'matérias tradicionais' são justapostas, contra alguma inovação recente sobre temas integrados ou centralizados na criança.” (GOODSON, 1995, p. 27).

Goodson ressalta que, embora o currículo seja um exemplo perfeito do qual se inventa tradição, esta não é, como qualquer outra, pronta e imutável. Essa forma de tradição pode ser construída e reconstruída, desde que não se ignore a história e a construção social do currículo. A ciência de coisas comuns na Inglaterra não virou tradição, assim como a nossa ciência integrada, embora deva ressaltar, por díspares razões inerentes a cada contexto espaço-temporal.

A partir dos exemplos supracitados, Goodson sugere a necessidade de uma análise crítica do currículo focada na forma como o currículo foi elaborado, sua história e construção social. Para ele, torna-se importante recorrer ao passado para compreender os conflitos que permearam a construção do currículo, evitando que os estudos sobre escolarização não deixem "sem questionamento e sem análise uma série de prioridades e hipóteses que foram herdadas e deveriam estar no centro do nosso esforço para entender teoricamente e operacionalizar na prática a escolarização" (GOODSON, 1995, p.28 e p.113).

A definição de currículo como um conjunto de matérias é demarcada nas reformas educacionais brasileiras das décadas de 1960-1970. Pela polissemia do termo na literatura acadêmica, torna-se complexo expressar claramente quando se quer referir ao conjunto de disciplinas ou matérias ou ao detalhamento do que é apresentado como objeto de conhecimento em cada uma destas entidades do currículo. Dada a abrangência e complexidade do que se entende por currículo, não há como concebê-lo metodologicamente em sentidos distintos, uma vez que os diversos sentidos atribuídos se entrelaçam. Sendo assim, consideramos pertinente esclarecer os significados atribuídos ao termo em algumas partes do presente texto. Adotaremos os termos "quadro curricular", "organização curricular", ou ainda "matriz curricular", sempre que necessário, para designar um conjunto de matérias ou disciplinas de um currículo. Entretanto, o termo "currículo" pode aparecer acompanhado de outros que esclareçam o sentido dado a ele no contexto. Por exemplo, "currículo do Colegial” se refere ao conjunto de matérias ou disciplinas. Já ao mencionar o currículo mais específico de Física, ou de outras disciplinas, referindo-se aos programas de conteúdos (temas e tópicos), com seus objetivos e orientações metodológicas, o termo virá acompanhado do nome da disciplina, como exemplo, "currículo de Física”. 


\subsection{Perspectiva teórico-metodológica}

O objetivo principal desta pesquisa foi compreender as concepções de ciência e de educação que permearam os documentos orientadores das atividades em ensino de Física nas salas de aula no contexto das décadas de 1960 e 1970. Para fundamentar teoricamente a análise de conteúdo nesses documentos referenciamo-nos no trabalho de Delizoicov, Angotti e Pernambuco (2007) no que diz respeito aos aspectos cognitivos das relações entre os sujeitos em sala de aula e destes com o objeto do conhecimento, focando a discussão sobre as dimensões epistemológica e educativa.

Fizemos uma breve incursão em alguns trabalhos citados por estes autores, bem como em outros, dando foco ao debate das ideias sobre o processo de construção da ciência, ao papel do sujeito nesse processo e à forma de comunicação do conhecimento científico no âmbito escolar. Esse entendimento se faz relevante à análise dos currículos de Física no que concerne às concepções de ciência e educação.

Perpetramos também uma breve discussão acerca das principais concepções pedagógicas presentes no período delimitado para estudo. Em tese, tais concepções influenciaram os modelos de currículo objetos de nossa análise.

\subsubsection{Ciência e ensino de ciência}

Ao discutir os aspectos cognitivos das interações em sala de aula, Delizoicov, Angotti e Pernambuco (2007) partem das ideias de alguns filósofos e/ou historiadores da ciência e/ou cientistas e/ou educadores, para esclarecer as implicações das diferentes formas de conceber a ciência, ou seja, o modo como o conhecimento é construído e perpetuado entre indivíduos de uma mesma época (mesmo grupo ou grupos diferentes), ou de uma época à outra; e a forma como este é (ou deve ser) transmitido na escola.

Distintos filósofos da ciência, dentre eles, Thomas Kuhn, Karl Popper e Gaston Bachelard, em suas análises epistemológicas sobre a produção do conhecimento científico, embora com conjecturas díspares, são unânimes quando consideram a importância da relação do sujeito com o objeto do conhecimento $^{26}$ e defendem que não há neutralidade epistemológica nessa relação. Assim, concordam com a insustentabilidade de teorias que têm a supremacia ora no objeto, ora no sujeito do conhecimento para explicar o desenvolvimento

\footnotetext{
26 As teorias do conhecimento denominam sujeito do conhecimento àquele que conhece, e objeto do conhecimento, àquilo que se quer conhecer (Delizoicov, Angotti e Pernambuco, 2007, p. 177).
} 
da ciência. Criticam a forma como a ciência se eterniza no registro da história da produção de novos conhecimentos, pois tem secundarizado essa relação, tratando-a como neutra, acabada e desvinculada do seu contexto de criação (DELIZOICOV; ANGOTTI; PERNAMBUCO, 2007).

Thomas Kuhn (1998), físico e historiador da ciência, em sua célebre obra A estrutura das revoluções científicas, remete críticas à forma como os conhecimentos da ciência são transmitidos às novas gerações. Ressalta que, raramente o processo de evolução do conhecimento é relatado de forma fidedigna nos manuais científicos elementares e avançado.

\begin{abstract}
Mesmo os próprios cientistas têm haurido essa imagem principalmente no estudo das realizações científicas acabadas, tal como estão registradas nos clássicos e, mais recentemente nos manuais que cada nova geração utiliza para aprender seu ofício. Contudo, o objetivo de tais livros é inevitavelmente persuasivo e pedagógico; um conceito de ciência deles haurido terá tantas probabilidades de assemelhar-se ao empreendimento que os produziu como a imagem de uma cultura nacional obtida através de um folheto turístico ou um manual de línguas. (KUHN, 1998, p. 19-20).
\end{abstract}

Kuhn (1998) introduz os conceitos de "ciência normal" e "paradigma" para explicar suas posições a respeito de como se dá o desenvolvimento da ciência. O autor chama de "ciência normal" a um período em que as pesquisas se baseiam em realizações consolidadas, ancoradas em modelos descobertos no passado, reconhecidas durante algum tempo, por alguma comunidade científica específica, e que proporciona os fundamentos da prática dos pesquisadores. O conceito de "paradigma" de Kuhn, refere-se a "um termo estreitamente relacionado com 'ciência normal"' (KUHN, 1998, p. 30), que a caracteriza, bem como define o método da pesquisa dentro dos padrões e regras compartilhadas e comprometidas por aqueles que comungam em um campo científico específico ou uma comunidade científica mais ampla.

Segundo ele, "esse comprometimento e o consenso aparente que produz são prérequisitos para a ciência normal, isto é, para a gênese e a continuação de uma tradição de pesquisa determinada" (KUHN, 1998, p. 30-31). Além disso, um paradigma seria um sinal de maturidade no desenvolvimento de um determinado campo científico, e a mudança de um paradigma a outro caracteriza a revolução científica, sendo isso "o padrão usual de desenvolvimento da ciência amadurecida" (KUHN, 1998, p. 32), já que "o novo paradigma implica uma definição nova e mais rígida do campo de estudos” (KUHN, 1998, p. 39).

Kuhn define esses conceitos a partir das características das grandes realizações científicas, sem precedentes e abertas, como o advento da Mecânica Newtoniana, por exemplo, posteriormente confrontada por um novo modelo, a Teoria da Relatividade Geral de Einstein. Outro exemplo célebre de mudança de paradigma de domínio maior foi a 
substituição da teoria geocêntrica de Ptolomeu pela teoria heliocêntrica de Copérnico. Na visão de Kunh, o conhecimento científico é construído em um processo de descontinuidade, rupturas e progressão não cumulativa (exceto no período de "ciência normal"), e que o contexto é assaz relevante para a fundamentação e o progresso da ciência.

As proposições de Kuhn (1998) evidenciam o caráter processual da ciência, a coletividade versus individualidade, a verdade provisória, a participação do sujeito no processo de desenvolvimento do conhecimento, uma vez que as mudanças de paradigmas envolvem sua atuação em medida bastante subjetiva.

Karl Popper (1975), filósofo austríaco, em sua obra A lógica da pesquisa científica, fala das maneiras distintas de raciocínio que têm sido usadas para se chegar à conclusão de como ocorre a construção das teorias científicas e critica veementemente o empirismo lógico defendido pelo Círculo de Viena ${ }^{27}$, que assegura "que todo conhecimento possível pode ser obtido por intermédio da lógica, da matemática e das ciências empíricas." (DELIZOICOV; ANGOTTI; PERNAMBUCO, 2007, p. 179).

O empirismo lógico tem origens nas ideias do filósofo inglês Francis Bacon (15611626) ao defender que, na construção da ciência, o filósofo natural deveria buscar novas práticas e novas políticas ao estudar a natureza para ter domínio sobre ela. Sua proposta é de que o estudo da natureza ocorresse pela investigação, com base em experiências, e que tais experiências deveriam ir além de meras observações e análises empíricas aleatórias: "um método sistemático para guiar a busca, o aprimoramento e a expansão daquilo que era investigado" (BRAGA; GUERRA; REIS, 2004, p. 54). Esse filósofo foi o primeiro a formalizar o conceito de "método científico".

$\mathrm{Na}$ perspectiva de Bacon, o processo de estudo da natureza consiste em inquiri-la como em um tribunal. Compeli-la a fornecer respostas ao problema colocado. Defende o método indutivo puro nessa investigação. Para ele, o estudo dos fenômenos parte de um fato concreto, observável na experimentação, ou seja, do particular, por meio de resultados experimentais (acumulados), e avança para o mais global, para generalizações, em um processo ascendente "capaz de permitir a formulação de leis e o estudo das causas dos fenômenos investigados", ou seja, às descobertas das verdades sobre a natureza em sua integralidade. (BRAGA; GUERRA; REIS, 2004, p. 55).

Para Bacon, a experimentação é a única forma de adquirir o conhecimento sobre o mundo. Tais ideias, em favor do método experimental ganharam adeptos, principalmente no

\footnotetext{
${ }^{27}$ Grupo organizado em 1907, na cidade de Viena, na Áustria, composto por filósofos, matemáticos, físicos e outros estudiosos.
} 
final do século XIX, no auge do movimento positivista. A primazia concedida ao objeto nas concepções baconeanas acabam por minimizar o papel do sujeito na construção do conhecimento.

A concepção de método científico de Bacon nem sempre se traduz nas formas como as diversas ciências produzem os seus conhecimentos. Esse é um dos argumentos de Popper (1975) contra a indução ao tentar mostrar que a ciência não se justifica somente em termos lógicos. Popper não aceita a premissa de que o conhecimento parta de um enunciado particular para produzir verdades universais, pois, segundo ele, "qualquer conclusão colhida desse modo sempre pode revelar-se falsa: independentemente de quantos casos de cisnes brancos possamos observar, isso não justifica a conclusão de que todos os cisnes são brancos." (POPPER, 1975. p. 27-28). Assim, um enunciado particular poderia valer em algumas situações e em outras divergir da realidade. Além das generalizações superficiais, os resultados das observações, sob a ótica da indução, segundo Popper, pode gerar diferentes teorias compatíveis com tais dados.

Assim, Popper defende o método científico numa perspectiva hipotético-dedutiva, em que se formulam hipóteses (partindo de uma reflexão teórica) sobre a natureza do mundo e as submete a testes rigorosos. São os testes de refutação (raciocínio dedutivo) da teoria. Nessa perspectiva, os experimentos têm a finalidade de refutar a hipótese e não provar a sua validade, pois Popper acredita que somente a falseabilidade de uma teoria pode ser provada e não a sua validade definitiva. A falseabilidade consiste em usar de enunciados aceitos para comprovar "um buraco" na teoria. Segundo esse autor, a possibilidade de uma teoria ser falseada confere a esta a condição de ser considerada algo científico. Se o contrário, subentende-se que não é uma teoria científica. Ainda para ele, uma teoria tem uma validade provisória e precisa ser constantemente testada.

Nas críticas ao empirismo lógico baconeano, Popper denota sua visão de não neutralidade do sujeito em relação ao objeto de conhecimento, pois, para ele, "não há saber na ausência de saber" (POPPER, 1975, p.104). Contudo, mantém, também, uma visão linear de construção do conhecimento já que passa a ideia de que, por motivo de refutações sucessivas das teorias, a ciência se constrói de forma cumulativa.

Nota-se um ponto importante de convergência entre as ideias de Popper e Kuhn: o fato de conceber a ciência como algo mutável, passível de ser contestada. Entretanto, para Kuhn, as mudanças ocorrem por revoluções, ou seja, não é cumulativa e se constrói com rupturas. Kuhn não acolhe a ideia de refutação e imediata invalidação de uma teoria, e substituição por outra, não pelo menos dentro do período de "ciência normal”. 
Para esse filósofo, nesse período, não há proposição de novidades (fatos e teorias), mas pode haver descobertas de novos fenômenos dentro das fronteiras de seus paradigmas. Ele acredita que a anomalia de uma teoria leva os cientistas a buscar explicações e acomodações dentro do paradigma vigente e não o abandono da teoria, de imediato, por motivo de um enunciado contraditório. Se as anomalias, em algum modelo consolidado, colocam em dúvida a validade de um paradigma, é forçosa a adoção de outro. São as rupturas que mudam a visão de mundo de uma comunidade científica como um todo (revoluções maiores), ou de um grupo mais específico (revoluções menores).

Gaston Bachelard - cientista, filósofo e epistemólogo - também discute o processo de evolução da ciência, bem como da apropriação do conhecimento oriundo desse processo, por parte dos estudantes. Embora as ideias de Bacherlard (1996) convirjam com algumas premissas formuladas por Kuhn (1998), por exemplo, a ideia de processos descontínuos, o discurso analítico desse autor se aproxima em maior nível do processo educativo formal mais elementar: a sala de aula. Exemplificando particularmente o conhecimento em ciência Física, Bachelard também critica a forma como o conhecimento científico tem sido registrado e repassado ao longo da história. Contudo, suas críticas são mais específicas ao ensino de nível mais básico.

\footnotetext{
Os livros de física, que há meio século são cuidadosamente copiados uns dos outros, fornecem aos alunos uma ciência socializada, imóvel, que, graças à estranha persistência do programa dos exames universitários, chega a passar como natural; mas não é; já não é natural. Já não é a ciência da rua e do campo. [...]; as experiências e os livros agora estão, pois, de certa forma desligados das observações primeiras. (BACHELARD, 1996, p.30).
}

Ao denunciar o desligamento das experiências e das observações primeiras nos livros de Física, o autor evidencia a importância do papel do sujeito do conhecimento com suas experiências cotidianas, no processo de apropriação do conhecimento científico.

Para Bacherlad (1996), o progresso da ciência, do ponto de vista psicológico, deve ser analisado buscando compreender o problema do conhecimento científico em termos de obstáculos epistemológicos, que, numa leitura mais simples podem ser interpretados como linguagens que entravam o progresso de desenvolvimento do pensamento científico, tanto nas gêneses das pesquisas científicas quanto na sala de aula, onde os resultados desse conhecimento científico são recontextualizados. Segundo esse autor, um dos obstáculos epistemológicos mais significativos no ensino de conteúdos científicos na escola é a experiência primeira, qual seja a "experiência colocada antes e acima da crítica - crítica esta que é, necessariamente, elemento integrante do espírito científico. Já que a crítica não pode 
intervir de modo explícito, a experiência primeira não constitui, de forma alguma, uma base segura" (BACHELARD, 1996, p. 29).

Freire (1996) também defende a existência desse conhecimento pré-existente, proveniente do mundo vivencial do sujeito aprendiz, que ele chama de curiosidade ingênua, e considera esse conhecimento como ponto de partida para o processo educativo. Entende a passagem dos saberes da cultura primeira para os saberes científicos como uma superação que, segundo ele, se dá na medida em que a curiosidade ingênua passa a ser curiosidade criticizada, tornando-se 'curiosidade epistemológica, [que] metodicamente 'rigorizando-se' na sua aproximação ao objeto, conota seus achados de maior exatidão." (FREIRE, 1996, p.15).

As ideias de Bachelard e Freire a respeito da cultura inicial dos aprendizes corroboram com as de Georges Snyders ${ }^{28}$ (1988 apud Delizoicov, Angotti e Pernambuco 2007) que também reconhece a fragilidade dos conhecimentos da cultura inicial do aluno, denominada por ele de cultura primeira. Snyders entende que esta cultura deve ser ponto de partida para a transformação ${ }^{29}$. Ele defende ainda que os critérios de seleção dos conhecimentos universais que constituem o rol dos conteúdos escolares devem buscar essa articulação, e que os conhecimentos empíricos provenientes da experiência de vida do sujeito, do senso comum, do modo de ver o mundo, é também baseado em uma relação de não neutralidade entre este e o objeto de conhecimento, e, por sua vez, é também uma construção processual, como ocorre com a evolução da ciência.

Conforme reforçam Delizoicov, Angotti e Pernambuco (2007), as premissas epistemológicas debatidas "impedem que se considerem os conhecimentos - incluindo os universalmente compartilhados, tais como as teorias científicas - como prontos, acabados e, sobretudo, absolutamente verdadeiros.” (DELIZOICOV; ANGOTTI; PERNAMBUCO, 2007, P. 186).

Os autores defendem ainda que os conteúdos programáticos selecionados para o currículo escolar, balizados por esses conhecimentos constituídos como patrimônio universal, "reflitam, também, o processo de produção do conhecimento de modo que se explore a historicidade do conhecimento veiculado e se explicite seu caráter simultaneamente verdadeiro e provisório [...], uma verdade temporal.” (p. 186). É imprescindível nessa historicidade, evidenciar o papel do sujeito na produção do conhecimento e, numa perspectiva

\footnotetext{
${ }^{28}$ SNYDERS, G. A alegria na escola. São Paulo: Manole, 1988.

${ }^{29}$ Segundo Aranha (1989), George Snyders defendia a necessidade da transmissão da cultura dominante (o saber burguês, não a ideologia) às crianças do povo, que, reelaborada, poderia ser um meio de promover a emancipação.
} 
educativa, que essa relação sujeito-objeto seja considerada também nos métodos de abordagem desse conhecimento ao ser recontextualizado na escola.

No contexto das décadas de 1960 e 1970 conviveram diversos pressupostos pedagógicos, como exemplo, o pragmatismo de John Dewey, o behaviorismo de Frederic Skinner, a ideia de currículo baseado na estrutura fundamental do conhecimento de um campo de estudo, de Jerome Bruner e o cognitivismo de Jean Piaget (e também de David Ausubel). Tais pressupostos foram, ora claramente, ora implicitamente assumidos nas políticas educacionais do período, influenciando nos métodos de ensino e nos materiais didáticos. Tais pressupostos serão brevemente abordados na seção que segue.

\subsubsection{Ideário educativo e o ensino de ciências no contexto investigado}

Na década de 1960, ao lado do aumento da demanda por educação escolarizada, intensificada em meados do século XX, em razão do crescimento populacional, sobretudo nas áreas urbanas, e ainda, da extensão da obrigatoriedade escolar - o "acesso à escola do maior número possível de educandos" (BRASIL, 1961, Art. 93) - tem-se a necessidade de formação para atendimento das diferentes estruturas ocupacionais que foram surgindo em função dos avanços científicos e tecnológicos (NOGUEIRA, 1990). A educação ganha foco que aponta para a necessidade de uma formação de bases mais científicas, de forma a proporcionar a resolução dos problemas cotidianos decorrentes de tais avanços.

A Pedagogia Tecnicista, como nomeia Saviani (1986), ganha destaque num momento em que se buscou adequar o sistema educacional às exigências e demandas industriais e tecnológicas da época, ou seja, uma educação articulada com o sistema produtivo capitalista. Essa tendência pedagógica surge em meados do século XX e traz a influência do positivismo nascente no século anterior, no cientificismo pós Segunda Grande Guerra, e também da psicologia americana behaviorista (ARANHA, 1989).

A teoria behaviorista tem como principal expoente defensor o psicólogo Frederic Skinner. Este se baseava em ideias de outros dois teóricos, Ivan P. Pavlov (1849-1936) e John B. Watson (1878-1958), sobretudo neste último. Watson defendia a ideia de que o ambiente é tudo, e capaz de mudar o indivíduo. Muda-se o ambiente, muda o indivíduo. Na perspectiva de Watson, defendida por Skinner, o ambiente condiciona o ser humano e o meio condiciona o seu comportamento que pode ser manipulado, manipulando-se o meio, o que daria ordem e regularidade ao comportamento. Para os behavioristas, o comportamento humano pode ser 
controlado pelo padrão estímulo-resposta, ou seja, uma manipulação que deve ocorrer através de estímulos externos - reforços imediatos (FERRARI, 2015).

Skinner defendia que na educação escolar dever-se-ia produzir materiais em que o aluno pudesse aprender sozinho. Para ele, uma criança pode aprender sem ser ensinada, desde que tenha reforço positivo para lhe proporcionar interesse em prosseguir em seu processo de aprendizagem. Um dos excertos da obra do autor, citado por Alves (2010) traz essa perspectiva.

O processo de adquirir competência em qualquer campo precisa ser subdividido em um grande número de pequenos passos, e o reforço precisa depender da realização de cada passo. Esta solução para o problema de criar um repertório complexo resolve também o problema de manter o comportamento fortalecido. Poder-se-ia naturalmente recorrer às técnicas de programar o reforçamento, já estabelecidas no estudo de outros organismos, mas, no estado atual do nosso conhecimento das práticas educacionais, a programação mais eficiente parece ser a que decorre da preparação do material a ser aprendido. Tornando cada passo sucessivo o menor possível, a frequência de reforço decorrente pode ser elevada ao máximo, enquanto que as consequências aversivas de cometer erros ficam reduzidas ao mínimo. Qualquer reforço suplementar deveria provavelmente ser programado dentro de um dos esquemas tradicionais (SKINNER ${ }^{30}, 1972$, p. 18-20 apud ALVES, 2010, p.64).

$\mathrm{Na}$ abordagem pedagógica fundamentada nas ideias de Skinner, os conteúdos de ensino são baseados na objetividade, em modelos de treinamento que sequencia os conteúdos e atividades pelas regras do "passo a passo" (Instrução Programada), e que tem a concepção de aprendizagem baseada na mudança de comportamento. O planejamento é feito pelos moldes sistêmicos, com operacionalização de objetivos e avaliação vinculada a estes (SAVIANI, 1986).

Para Garcia e Azevedo (1984, p. 33), nessa abordagem de ensino em que os novos conhecimentos supostamente decorrem do "relacionamento entre uma resposta e um reforço", o reforço é estratégia que visa conduzir o aluno a atingir os objetivos esperados. Os autores entendem que os objetivos educativos (os esperados) são ajuizados com base na expectativa social: “Aluno ajustado é aquele que mais respostas certas dá, o que tem mais sucesso. Ajustado às regras e normas escolares, estará ajustado às regras e normas sociais." (GARCIA; AZEVEDO, 1984, p, 33).

As ideias de ensino de Skinner ganharam destaque no sistema educacional brasileiro a partir da década de 1960, principalmente na área de Ciências da Natureza. Alinharam-se bem com o modelo de ensino tecnicista, já presente na referida década, e cristalizado na Educação na década de 1970 com o advento da profissionalização do ensino médio. Período

\footnotetext{
30 SKINNER, B.F. Tecnologia do Ensino. São Paulo: Herder, Ed. da Universidade de São Paulo, 1972. Tradução de Rodolpho Azzi.
} 
em que se tentou adequar o sistema educacional à demanda industrial e as diversas categorias ocupacionais no mercado de trabalho, consonantes com os interesses políticos e econômicos do momento.

Conforme salienta Saviani, a perspectiva de educação baseada na Pedagogia Tecnicista, o diálogo entre aluno e professor é técnico e prioriza-se a transmissão do conhecimento por métodos "eficazes". As concepções, objetivos e formas de ensino se voltam para a técnica, promovendo mudanças nos conteúdos, materiais e processos de ensino nas salas de aula, de forma que, tanto o aluno quanto o professor passa a ocupar um papel secundário, dando lugar para a organização racional dos meios de garantir a eficiência (SAVIANI, 1986).

Concomitante ao behaviorismo skinneriano no sistema educacional tem-se também, marcadamente, a influência de Jerome Bruner com a proposta de reformulação dos currículos baseada na "estrutura da disciplina". Para Bruner (1978) ${ }^{31}$, a compreensão da estrutura fundamental do conhecimento, por parte do aluno, seria um requisito mínimo para o uso e aplicabilidade desse conhecimento nas diversas situações cotidianas ou como aporte de novos saberes. Ao ilustrar suas convicções argumenta que, "a atividade intelectual é a mesma em toda parte. [...] a diferença é de grau, não de natureza. Ao estudar física, o aluno é um físico; e é mais fácil aprender física comportando-se como um físico, do que fazendo qualquer outra coisa.” (BRUNER, 1978, p. 12-13). Aqui conforta a ideia de formação do jovem cientista.

Bruner (1978, p. 31) se revela arrojado ao afirmar que "qualquer assunto pode ser ensinado com eficiência, de alguma forma intelectualmente honesta, a qualquer criança, em qualquer estágio de desenvolvimento". Essa concepção sobre o processo de aprendizagem é concomitante, também, com outra teoria que era resgatada e debatida: a teoria construtivista baseada na epistemologia genética de Jean Piaget. Nesta, a questão da aprendizagem está nas etapas de desenvolvimento cognitivo da criança, que, segundo a teoria piagetiana, obedece a estágios operatórios característicos de determinadas fases da evolução mental com um amadurecimento gradativo das estruturas de pensamento até atingir a capacidade plena de raciocínio, em tese, na adolescência, quando atinge o período operatório-formal (LOPES, 1996). Para Piaget, a criança precisa ser estimulada a experimentar, errar e aprender com os erros, e gradativamente ir construindo o seu arcabouço de conhecimentos.

Bruner não assume discordar da teoria de Piaget e busca ilustrar que sua ideia é condizente com o construtivismo baseado na psicologia evolutiva. Segundo Bruner (1978),

\footnotetext{
31 A primeira edição desta obra foi publicada em 1960.
} 
"[...] toda ideia pode ser representada de maneira honesta e útil nas formas de pensamento da criança em idade escolar, e que essas primeiras representações podem, posteriormente, tornarse mais poderosas e precisas com maior facilidade, graças a essa aprendizagem anterior." (BRUNER, 1978, p. 32). Assim, Bruner defende a participação ativa do estudante no processo de aprendizagem, que deve ser colocado em situação de desafio condizente com cada novo conhecimento a ser descoberto e apreendido.

No mesmo ínterim em que Bruner defendia tais ideias, David Ausubel propõe sua teoria da Aprendizagem Significativa. Esta foi apresentada pelo seu idealizador, nos Estados Unidos, em 1963, época em que as ideias behavioristas predominavam, mas só foi introduzida no Brasil na década de 1970. Ausubel esteve no Brasil no ano de 1975 para debater suas ideias, mas, ao que parece, sua teoria tomou maior dimensão no país, constituindo temas de pesquisas, a partir da década de 1980 (RONCA,1994).

Ao propor o conceito de aprendizagem significativa, Ausubel eleva a importância do que o aprendiz já conhece como fator determinante para o aprendizado de novos conhecimentos, de modo que, na visão dele, quanto mais o indivíduo sabe, mais ele aprende. Tem-se aí uma semelhança com as ideias de Bruner. Na concepção de Ausubel, a aprendizagem significativa se dá por ampliação e reconfiguração de ideias de domínio do aprendiz, capacitando-o a relacionar e acessar novos conhecimentos (RONCA, 1994).

A teoria de Ausubel, do mesmo modo que a de Bruner, foi pensada para o contexto escolar e leva em conta o papel do sujeito ao colocar em evidência a sua experiência epistemológica anterior. O docente tem papel de destaque, não como expositor de conteúdos, muitas vezes sem sentido para o estudante, mas sim de propor situações que favoreçam a aprendizagem. Ao aluno cabe a disposição em encontrar sentido no material que lhe é apresentado, de modo que o novo conhecimento que pode ser propiciado seja ancorado em conhecimentos anteriores (RONCA, 1994). O processo de aprendizagem defendido por Ausubel pauta-se em conhecimento cultural sistematizado. Embora ele considere importante a história do sujeito, não se trata de sua história social, sua visão política, o seu mundo vivencial. O foco é a aprendizagem de conteúdos das diversas áreas do conhecimento, levando em conta os conhecimentos da cultura sistematizada que o aprendiz já traz consigo o que Ausubel denomina de "estrutura cognitiva" (RONCA, 1994, p. 92). 


\subsubsection{Aprender fazendo}

Os pressupostos que guiaram a educação escolar a partir do final dos anos de 1950, no Brasil e em vários países do mundo eram no sentido de colocar o aluno no centro do processo de ensino-aprendizagem. Os objetivos educacionais visados eram de "proporcionar maior liberdade e autonomia ao aluno para participar ativamente de seu processo de aquisição de conhecimentos" (KRASILCHIK, 1987, p.19). Nessa linha, em que predominou o método ativo, no que tange ao ensino de Ciências, houve preponderância do laboratório como recurso auxiliar na compreensão dos conceitos e também como forma de motivar o aluno na busca do conhecimento e no interesse pela Ciência, sustentados pelo discurso do aprender fazendo, que conforme Krasilchik (1987) tinha como meta a racionalidade derivada da atividade científica, ou seja, a preparação do futuro cientista.

O termo "aprender fazendo", a priori, remete às concepções escolanovistas apregoadas por Jonh Dewey e se sustenta também no cognitivismo. Para Dewey, considerar a dinâmica entre ensino e prática cotidiana seria o caminho mais adequado para promover a revolução das ideias individuais, a capacidade de raciocínio e a formação do pensamento crítico (KISHIMOTO, 2011).

No que remete ao ensino de Ciências, Dewey defende um aprender pautado no pensar e agir cientificamente. Uma educação científica que considere a cultura inicial e o ambiente vivencial do aluno. Ao dar importância para a história do sujeito que aprende, Dewey evidencia o seu entendimento sobre a relação da evolução da ciência moderna e o surgimento dos ideais democráticos, e, segundo ele, ambos dão realce ao método experimental (GALVÃO, 1998). Desse modo, Dewey defende o ensino de Ciências como um método, mas não como um conjunto de procedimentos técnicos a partir do que já foi estruturado por um especialista, mas sim como um processo de descoberta, em que o aluno participe; um método que busque "desenvolver e orientar certas disposições intelectuais" (GALVÃO, 1998, 141).

É comum em pesquisas da área, ao se referirem às concepções de ensino das décadas de 1960 e 1970, o termo "aprender fazendo" ser também associado aos métodos de ensino baseados na Pedagogia Behaviorista que tem como ideia central a mudança de comportamento. Desse modo, num contexto em que o behaviorismo se faz marcante, "aprender fazendo" ganha um sentido diferente do que se pode depreender das ideias de Dewey. É reinterpretado como um método de ensino que consiste em colocar o aluno para seguir roteiros de atividades tecnicamente elaborados, com sequência rígida, e ritmo próprio, 
ou seja, ganha sentido de "faça você mesmo", "siga o modelo", "repita o procedimento", enfim, uma "receita", para executar atividades pré-determinadas, com objetivo de transmissão do conhecimento cultural legitimado.

\subsubsection{Método científico e o ensino por descoberta}

Na conjuntura em que aprender fazendo granjeou destaque no ensino de Ciências, os métodos de ensino ganharam uma extrema ênfase experimental como uma aposta de que as práticas investigativas levariam a compreensão ou até mesmo a redescoberta de leis científicas, a partir da execução de roteiros e procedimentos que simulavam o método científico (GASPAR, 2004).

O termo "método científico" aparece em alguns documentos legais que normatizaram as reformas educacionais brasileiras das décadas de 1960 e 1970 e também no pensamento de intelectuais que alvitravam mudanças no processo educacional do país. $\mathrm{Na}$ Indicação que emanou as Amplitudes e Desenvolvimento das Matérias Obrigatórias nos termos da LDB/1961, por exemplo, traz: “[...] Muito se conseguirá não só apreciando-se a contribuição dos cientistas do passado e do presente e lançando-se em relevo a importância da ciência e do método científico para o progresso da humanidade" (BRASIL, 1962e, datilografado, p. 05).

Na década de 1970, essa concepção ainda era a "pedra de toque", conforme traz o Parecer 853/1971 e o Art. $3^{\circ}$ da Resolução no 08/1971 ${ }^{32}$, ao tratar dos objetivos do ensino das matérias, que visara: “c) nas Ciências, ao desenvolvimento do pensamento lógico e à vivência do método científico e de suas aplicações.” (BRASIL, 1971d, Art. $3^{\circ}$ ).

Tal concepção de ensino foi assumida também nos currículos oficiais Estaduais, como exemplo, nas orientações curriculares de Ciências para o primeiro grau dos Estados do Paraná e Minas Gerais:

O método científico, visando solucionar problemas, baseia-se fundamentalmente na experiência. Em qualquer situação a aprendizagem só será eficiente quando o professor utilizar o método experimental que é o método específico das ciências, adaptando-o ao nível dos alunos (PARANÁ, 1975, p. 11, grifo do original).

Esses processos de investigação ("método científico") representam o eixo ou coluna que liga os vários temas, constituindo-se no principal elemento integrador que deve estar presente em todas as séries e unidades do curso. [...]. Ora de maneira informal, ora com maior rigor, mas sempre planejadamente, a preocupação com o emprego do "método científico" e com o desenvolvimento do pensamento lógico deve ser a tônica do curso. (MINAS GERAIS, 1976, p. 32, aspas do original).

\footnotetext{
${ }^{32}$ Documentos que compõe as regulamentações da Lei 5.692/1971. Serão discutidos no próximo capítulo.
} 
Souza (2008, p. 216), ao falar dos debates sobre a finalidade do ensino secundário no final da primeira metade do século XX, afirma que o sentido de cultura se transformou. "A nova concepção colocava a ciência e a técnica no 'clima espiritual do mundo"”. A autora cita Fernando de Azevedo que defende a restauração do sentido da formação intelectual e da não transformação do ensino secundário em educação técnica, e, sobretudo, recomenda não dar à propalada ciência um aspecto utilitarista, mas sim compreendê-la como eixo integrador da cultura. Souza cita um trecho de Azevedo $^{33}$ (1952) em que este generaliza as possiblidades de uso do método científico em todas as ciências:

\begin{abstract}
A aplicação do método científico a todos os estudos desde o das ciências humanas até o das letras; o progresso da ciência que se tornou um "método de conhecimento e de pesquisa", e já faz parte integrante de nossa vida e nossos pensamentos, e o triunfo, afinal, do espírito científico, é que poderão "assegurar a unidade ao nosso ensino de cultura", sacudindo desde um século entre a cultura tradicional das humanidades clássicas e a cultura nova das ciências (AZEVEDO, 1952, p. 139 apud SOUZA, 2008, p. 216).
\end{abstract}

A ênfase no método científico perdurou nas propostas de revitalização do ensino de Ciências ao longo das duas décadas estudadas, muito influenciadas pelas ideias que fundamentaram os projetos de ensino estrangeiros, que tinham como objetivo comum tornar o ensino uma atividade experimental (BARRA; LORENZ, 1986).

Nesse contexto em que a vivência do método científico foi o "carro chefe" na ambicionada formação científica, estava em voga também o ensino pelo método da descoberta, que, em tese, consistia em "ensinar o aluno como fazer perguntas, como buscar evidências, e como avaliar os resultados de suas investigações." ( SCHWAB $^{34}, 1962$ apud LORENZ, 2008, p. 14).

Ao que parece, o conceito de descoberta defendido por Schwab, e também por Dewey, tem um sentido mais próximo do que seria um método científico autêntico (o empirista/indutivista, por exemplo). Segundo Fracalanza, Amaral e Gouveia (1987), esse método foi incorporado no contexto de modo diferente do que se entende por descoberta no processo de evolução do conhecimento em Ciências. Para esses autores, a forma como predominou esse método, a participação do aluno se resumia em executar roteiros passo-apasso, elaborados por especialistas, passando "a falsa noção de que ciência se faz através de uma sequência padronizada de procedimentos e etapas sucessivas" (FRACALANZA; AMARAL; GOUVEIA, 1987, p. 89).

\footnotetext{
${ }^{33}$ AZEVEDO, Fernando. Na batalha do humanismo e outras conferências. São Paulo: Melhoramentos, 1952.

${ }^{34}$ SCHWAB, Joseph. The teaching of science. Cambridge (MA): Harvard University Press, 1962.
} 
Essa estrutura fechada, pré-estruturada para levar o aluno a redescobrir um conhecimento já existente, foi amplamente disseminada como método da redescoberta, e mistificado como sinônimo de método científico, o que é um equívoco, pois a descoberta subentende um processo investigativo aberto. Fracalanza, Amaral e Gouveia (1987) contesta essa ambiguidade, esclarecendo que o verdadeiro método científico "representa uma incursão ao desconhecido, onde usualmente o cientista utiliza ampla variedade de procedimentos técnicos e intelectuais." (FRACALANZA; AMARAL; GOUVEIA, 1987, p.89).

O modo como o método científico foi proclamado subentende que o processo investigativo não seria motivado por um problema novo, desafiante, desencadeador de um "pensamento reflexivo", como defende Dewey ${ }^{35}$ (1952 apud KISHIMOTO, 2011). Como alerta Kishimoto, "a complexidade e a dificuldade de compreensão do pensamento deweyano geram críticas e usos inadequados de suas concepções pelas escolas do movimento escolanovista ao longo do século XX," (KISHIMOTO, 2011, p. 209). O método de ensino difundido naquele período consistia em simular a atividade dos cientistas, repetindo procedimentos já executado por eles, utilizando recursos similares (em contextos ambientais e históricos diferentes), para redescobrir as leis que regem os fenômenos. Fracalanza, Amaral e Gouveia (1987), contrapondo a esse equívoco opinam que:

A postura experimental ou científica, em toda a sua plenitude e complexidade, só
poderá ser desenvolvida no estudante em harmonia com a sua própria inteligência. A
eventual vivência do método científico, ao invés de treinar pequenos cientistas,
deverá estar voltada para colaborar no longo e complicado processo de formação do
pensamento lógico e crítico do estudante. (FRACALANZA; AMARAL;
GOUVEIA, 1987, p.89).

O processo das descobertas científicas é bastante complexo e dinâmico, e segue etapas não necessariamente lineares na busca de soluções consistentes, aplicáveis em qualquer situação, generalizáveis, contudo, não imutáveis. É preciso levar em conta que tal processo é, em geral, influenciado pelo contexto, podendo ainda estar dopado pela projeção de ideias de cunho particular, inclusive na análise dos resultados e nas soluções eleitas para generalizações.

No contexto educacional das décadas investigadas nesta pesquisa, muito se falou em conhecimento científico, inclusive nos documentos legais. Enfatizaram-se os métodos de ensino e consagrou-se o método científico (pautado na experimentação) quase que como "método de vida", ou seja, preconizou-se a "formação de um cientista em cada cidadão" (TAGLIEBER, 1984, p. 96).

\footnotetext{
${ }^{35}$ DEWEY, John. Democracia e educação. Breve tratado de filosofia de educação. Tradução de Godofredo Rangel e Anísio Teixeira. São Paulo: Companhia Editora Nacional, 1952.
} 
Os pressupostos pedagógicos implicavam na reestruturação do papel do aluno e do professor no processo de ensino-aprendizagem e os objetivos do ensino de Física se contemporizaram entremeios às pretensões educativas da época. Nosso foco de investigação se relaciona diretamente com tais pretensões educativas, ao buscar identificar algumas características do ensino do conhecimento físico proposto nos referenciais curriculares disseminados no contexto das décadas de 1960 e 1970.

\subsubsection{As dimensões de análise}

A análise de conteúdo nos referenciais curriculares (RC) que propomos nesta pesquisa buscou compreender as concepções de ciência e de educação perpassadas na reorganização do conhecimento científico no ensino de Física no período investigado. Para direcionar a análise, assumimos as dimensões epistemológica e educativa do conhecimento, como dimensões analíticas.

Nossa análise epistemológica reconhece o conhecimento físico como produto de um processo dinâmico, histórico, uma evolução não linear implicada em ruptura, descontinuidade, inacabamento, permeado de relações contextuais internas e externas à própria Ciência/Física e interpretado a partir da vivência do sujeito em uma interação não neutra na construção de conceitos e teorias. Assim, na dimensão epistemológica buscamos compreender a concepção de ciência assumida nos RC, examinando se a proposta metodológica, a forma de abordagem e o desenvolvimento dos conteúdos da Física nos mesmos conferem significado ao conhecimento científico levando em conta os diversos fatores que caracterizam o dinamismo e a amplitude da sua produção. Compreender ainda se na recontextualização do conhecimento científico constituído, considera o conhecimento que o aluno traz consigo como algo formado por um processo, assim como é o conhecimento científico, embora com caráter processual distinto, mas que não pode ser ignorado.

$\mathrm{Na}$ análise atentamos, também, para os conteúdos selecionados e a forma de encaminhamento, o papel da experimentação e dos modelos explicativos formais. São aspectos dos materiais didáticos e guias curriculares que, em tese, seguem critérios não neutros de modo que a visão de ciência trazida neles está imbuída do contexto histórico-social de seus autores (DELIZOICOV; ANGOTTI; PERNAMBUCO, 2007).

Em uma perspectiva educativa mais ampla, dentre os critérios de escolha dos saberes a serem compartilhados estão os objetivos do ensino de tais saberes em determinado momento da história; objetivos estes, vinculados aos diversos fatores que influenciam as políticas 
educacionais (filosóficos, sociais, políticos, econômicos, culturais, etc.). Desse modo, no que se refere à dimensão educativa, buscamos compreender as concepções de educação/ensino, ou seja, os objetivos do ensino de Física visados nas propostas, a forma como estas articulam o conhecimento físico sistematizado com a cultura inicial do aluno, se considera ou não sua história social. A análise busca compreender ainda como se determinaram os protagonismos discente e docente no desenvolvimento das propostas, considerando os diversos fatores que caracterizaram o momento histórico de elaboração destas.

\subsubsection{Caracterização das dimensões de análise: categorias e elementos}

Predefinimos categorias ${ }^{36}$ (seis ao todo) para as dimensões analíticas adotadas e apontamos alguns elementos que as caracterizam - dado o nosso enfoque - e que poderão proporcionar inferências sobre as concepções de ciência e a visão de educação presente nos materiais objetos de análise. O quadro a seguir traz a descrição dos elementos considerados em cada dimensão/categorias.

QUADRO 1 - Descrição das categorias analíticas/elementos

\begin{tabular}{|c|c|c|}
\hline Dimensões & Categorias & Elementos a considerar \\
\hline \multirow[t]{4}{*}{$\begin{array}{l}\text { Epistemo- } \\
\text { lógica }\end{array}$} & $\begin{array}{l}\text { Ciência como } \\
\text { processo }\end{array}$ & $\begin{array}{l}\text { História da Ciência/Física e a relação Ciência/Física, tecnologia e sociedade } \\
\text { atentando para os seguintes aspectos: processo de construção da ciência como } \\
\text { empreendimento humano; noção de ciência mutável; interatuada com o sujeito } \\
\text { do conhecimento; conectada com o momento histórico; relacionada à tecnologia } \\
\text { e sociedade; outros elementos. }\end{array}$ \\
\hline & $\begin{array}{l}A \quad \text { Física e a } \\
\text { experimentação }\end{array}$ & $\begin{array}{l}\text { Perspectivas das propostas de atividades experimentais nos referenciais, } \\
\text { considerando os aspectos: ideia de experimentos como forma de entendimento } \\
\text { dos conceitos; relevância para a inerência experimental da Física; análise de } \\
\text { dados; significado de medidas das grandezas físicas; experimentos - geradores de } \\
\text { leis da Física ou se considera a existência de um modelo que precede os } \\
\text { experimentos? outros elementos. }\end{array}$ \\
\hline & $\begin{array}{l}\text { Modelos } \\
\text { explicativos } \\
\text { formais }\end{array}$ & $\begin{array}{l}\text { Apresentação do formalismo matemático: síntese de um conhecimento, modelo } \\
\text { explicativo de fenômenos da natureza? Ou ferramenta de desenvolvimento de } \\
\text { cálculos? outros elementos. }\end{array}$ \\
\hline & $\begin{array}{l}\text { Conteúdos/áreas } \\
\text { da Física }\end{array}$ & $\begin{array}{l}\text { Como os conteúdos da Física estão desenvolvidos/propostos, no que se refere a: } \\
\text { semelhanças/diferenças na abordagem e na sequência; temas/assuntos } \\
\text { priorizados; outros elementos. }\end{array}$ \\
\hline \multirow[t]{2}{*}{ Educativa } & $\begin{array}{l}\text { Objetivos do } \\
\text { ensino de Física }\end{array}$ & $\begin{array}{l}\text { Elementos que podem revelar se a educação é propedêutica; se busca fornecer } \\
\text { base para os conhecimentos futuros; ou formação de futuros cientistas; ou } \\
\text { preparação para os exames de vestibular; conhecimento crítico; formação cidadã } \\
\text { e conhecimento para participação consciente na sociedade; outros elementos. }\end{array}$ \\
\hline & $\begin{array}{l}\text { Concepção de } \\
\text { aluno/professor }\end{array}$ & $\begin{array}{l}\text { Perspectiva de ensino-aprendizagem: ensino pré-definido (o aluno como caixa } \\
\text { vazia a ser preenchida-); ou dialógica? (relevância aos conhecimentos do mundo } \\
\text { vivencial); ou conhecimento de conteúdo? Qual o papel do aluno e do professor. }\end{array}$ \\
\hline
\end{tabular}

36 A definição prévia de categorias de análise é, segundo Bardin (2009), um processo válido que consiste em repartir "da melhor maneira possível os elementos à medida que vão sendo encontrados. [...] aplicável no caso da organização do material decorrer directamente dos funcionamentos teóricos hipotéticos.” (BRADIN, 2009, p. 147). 
Os resultados de nossa análise de conteúdo nos RC estarão dispostos da seguinte forma nesta tese:

$\rightarrow$ No Capítulo 3, a partir da Seção 3.4, traremos os resultados da análise de conteúdo nos projetos de ensino;

$\rightarrow$ No Capítulo 4, apresentaremos as propostas curriculares oficiais identificadas, bem como os resultados do estudo nas mesmas;

$\rightarrow$ No Capítulo 5, traremos a análise feita em uma amostra dos livros didáticos de Física (quatro produções) presentes no mercado editorial no contexto investigado.

A opção por registrar os resultados da análise dos diferentes referenciais curriculares em capítulos separados na pesquisa, é, sobretudo, pelo fato de os mesmos trazerem diferentes perspectivas metodológicas. Isso é principalmente evidente quando nos referimos às propostas curriculares oficiais, dadas às características peculiares desses materiais, que não figuram na categoria de manuais didáticos. As propostas curriculares, de um modo geral, referem-se à prescrição a partir de orientações mais gerais e técnicas - diretrizes pedagógicas, lista de tópicos, objetivos específicos, sequência de conteúdos, distribuição por séries, por bimestres, sugestões de estratégias de ensino, carga horária, etc. Algumas podem trazer material complementar, como é o caso da proposta curricular de Física do Estado de São Paulo (1978).

Quanto aos projetos de ensino, embora apresentemos os resultados separados do estudo nos livros didáticos, os consideramos como manuais didáticos, uma vez que nos ativemos somente aos conteúdos dos textos publicados. Mesmo reconhecendo a existência de diferentes definições dadas aos diversos tipos de textos escolares que auxiliam o trabalho pedagógico em sala de aula, estamos, no entanto, adotando o critério de generalização assumido por Fracalanza e Megid Neto (2006), que admitem "a existência de uma dada categoria de publicação que: tem sido usualmente utilizado no ensino formal; desenvolve os conteúdos previstos para uma determinada área do currículo escolar; e, como tal, é referida na pesquisa educacional” (FRACALANZA; MEGID NETO, 2006, p. 16). 


\section{AS REFORMAS EDUCACIONAIS E O ENSINO DE CIÊNCIAS NO CONTEXTO INVESTIGADO}

A presente pesquisa tem como escopo o ensino de Física em um recorte temporal do contexto em que vigorou a primeira Lei de Diretrizes e Bases da Educação brasileira (LDB/1961) e a reforma do ensino primário e médio de 1971, a Lei 5692/1971. Neste capítulo apresentaremos um estudo das referidas reformas nacionais com o objetivo de compreender o papel e o espaço atribuído às disciplinas científicas no currículo, particularmente a Física.

Consideramos importante retroceder no tempo, com um breve esboço histórico das duas últimas reformas educacionais que precederam a LDB/1961 - a Reforma Francisco Campos e a Reforma Capanema - uma vez que estas nos permitem compreender as transformações ocorridas, no que alude ao ensino das Ciências, ao longo do tempo, em termos de propósitos educacionais. Esse esboço nos fornece um pouco da historicidade das legislações educacionais que compõem o nosso aporte teórico/documental.

\subsection{Precedentes à primeira LDB brasileira}

As duas principais reformas do ensino brasileiro precedentes à primeira LDB, ocorridas no século XX, sobrevieram no primeiro Governo de Getúlio Vargas (1930-1945). Nesse período, a Educação é marcada por lutas ideológicas, principalmente entre duas correntes de pensamentos. Por um lado, o movimento liberal renovador, defensores da Escola Nova já amplamente propagada em várias partes do mundo desde os anos de 1920, e que defendiam uma educação laica, gratuita e para todos, sob a gerência de um Estado educador. E por outro, os educadores católicos defensores da escola tradicional sob o domínio da Igreja (ROMANELLI, 1985; ARANHA, 1989).

Tomando como marco a década de 1930, evidencia-se um fato importante para o sistema educacional brasileiro: a criação do Ministério da Educação e Saúde Pública por decreto, em 14 de novembro de 1930, tendo Francisco Campos como seu primeiro titular. Esse órgão constituiu espaço político para uma reforma educacional a nível nacional.

Uma importante reforma elaborada por Francisco Campos ocorreu por meio de decretos, em 1932, e abrangeu a criação do Conselho Nacional de Educação; a organização do ensino superior; a criação da Universidade do Rio de Janeiro; a organização do ensino secundário e a organização do ensino comercial. 
O sistema educacional dualista em vigor no início dos anos de 1930, com o ensino primário vinculado às escolas profissionais, para os pobres, e o ensino secundário com preparo para os ensinos superiores, para os ricos, não correspondia ao momento de expansão econômica industrial que o Brasil vivenciava. O progresso industrial e econômico alavancado no país, nas primeiras décadas do século $\mathrm{XX}$, trouxe grandes transformações políticas, econômicas e sociais que aceleraram o processo de urbanização, e, consequentemente, aumento da demanda por educação gratuita e para todos (NUNES, 1962; ROMANELLI, 1985).

Para Nunes (1962), esse sistema educacional era incompatível com a nova situação, de forma que o ensino secundário, como se apresentava, estava em desequilíbrio com a realidade brasileira do momento. Além disso, os sistemas de ensino eram estaduais, sem articulação com o sistema central, que por sua vez não era obrigatório, limitando-se ao Distrito Federal e servia apenas de modelo para os Estados da federação (ROMANELLI, 1985; ARANHA, 1989). Os decretos que constituíram a Reforma Francisco Campos deram uma estrutura orgânica ao sistema educacional brasileiro, tendo como um dos objetivos subordinar os Estados da federação ao controle do governo federal.

No contexto dessa reforma, em países da Europa e nos Estados Unidos, novos debates de ideias sobre educação surgiam em prol de uma escola mais afinada com as necessidades sociais, que permitisse o desenvolvimento cultural e consequentemente o desenvolvimento individual, dando condições para uma participação democrática de todos os cidadãos nas sociedades em que viviam.

No Brasil, a maior influência para esse movimento denominado de Movimento da Escola Nova veio do filósofo norte americano John Dewey, que corroborava bastante com o ideário de uma escola menos clássica e mais pragmática (SOUZA; MARTINELLI, 2009). Tais ideias foram sintetizadas em um documento elaborado e publicado em 1932, intitulado de Manifesto dos Pioneiros da Educação Nova. Segundo Nunes (1962, p. 107), o manifesto "procurou condensar as aspirações do momento e adaptar a educação às transformações que aqui se processavam [...]". O conteúdo de tal documento, assinado pelos mais eminentes educadores nacionais, configurou tema de debates que permearam as legislações educacionais a partir daí, e estiveram presentes, inclusive, nas discussões que culminaram com o primeiro projeto da primeira LDB brasileira.

O Manifesto trazia a proposta de um Plano de Reconstrução Nacional que abrangesse um ponto considerado nevrálgico pelos educadores: o ensino secundário. Assim, apresentava a proposta de uma reforma educacional que rompesse com o separatismo entre os níveis de 
ensino e com a segregação de classes quanto ao acesso à educação. Almejou-se ainda a superação de métodos de ensino tradicionais, centrados no professor, para a adoção de métodos que colocassem o aluno mais envolvido no processo de ensino-aprendizagem.

É uma reforma integral da organização e dos métodos de toda a educação nacional, dentro do mesmo espírito que substitui o conceito estático do ensino por um conceito dinâmico, fazendo um apelo, dos jardins de infância à Universidade, não à receptividade, mas à atividade criadora do aluno. A partir da escola infantil (4 a 6 anos) à Universidade, com escala pela educação primária (7 a 12) e pela secundária (12 a 18 anos), a "continuação ininterrupta de esforços criadores" deve levar à formação da personalidade integral do aluno e ao desenvolvimento de sua faculdade produtora e de seu poder criador, pela aplicação, na escola, para a aquisição ativa de conhecimentos, dos mesmos métodos (observação, pesquisa, e experiência), que segue o espírito maduro, nas investigações científicas. (AZEVEDO et al., 2010, p.53-54).

O país vivenciava um novo modelo político-econômico - transição do modelo agrário exportador para o urbano-industrial - e com um importante representante do movimento renovador à frente do Ministério da Educação e Saúde Pública - o ministro Francisco Campos. É nesse "momento de grande efervescência doutrinária, no setor educacional, entre os lideres católicos e não católicos” (NUNES, 1962, p. 107), que uma reforma educacional é instaurada.

O ensino secundário foi reestruturado por meio do Decreto ${ }^{\circ} 19.890$, de 18.04.1931, com uma proposta de ensino que trazia um discurso progressista, embora a prática seguisse na contramão dessa ideia. Na exposição de motivos, o autor da reforma discursa:

A finalidade exclusiva do ensino secundário não há de ser a matrícula nos cursos
superiores; o seu fim, pelo contrário, deve ser a formação do homem para todos os
grandes setores da atividade nacional, constituindo no seu espírito todo um sistema
de hábitos, atitudes e comportamentos que o habilitem a viver por si mesmo e a
tomar, em qualquer situação, as decisões mais convenientes e mais seguras.
(CAMPOS $^{37}, 1931$, p. 03 e 05 apud NUNES, 1962, p. 108).

Reorganizou-se o ensino secundário em dois cursos (ciclos) seriados: fundamental com cinco séries e complementar com duas séries. O primeiro ciclo tinha o caráter de formação básica geral e o segundo de preparação para cursos superiores específicos de três grupos: Direito; Medicina, Odontologia e Farmácia; Engenharia e Arquitetura (BRASIL, 1931).

Em contrassenso às ideias dos pioneiros da Educação Nova e às demandas pela educação em massa, a reforma revelou "uma política educacional baseada numa concepção ideológica autoritária” (ROMANELLI, 1985, p. 142) e excludente. Com um caráter rígido, ditou formalmente os currículos e programas para aplicação em todas as escolas brasileiras, centralizando o sistema educacional através de instrumentos controladores (MOREIRA,

\footnotetext{
${ }^{37}$ CAMPOS, Francisco. Exposição de Motivos. Ministério da Educação e Saúde Pública. Rio de Janeiro, 1931.
} 
2001). Os programas das disciplinas eram elaborados pela Congregação do Colégio Pedro II e submetidos ao Ministério da Educação e Saúde Pública, que os expediam (BRASIL, 1931). O colégio D. Pedro II, desde a sua criação, em 1838, serviu de modelo para os colégios provinciais e particulares no que tange ao currículo das disciplinas, embora não se possa afirmar que tal modelo, no período em que se serviu dele, fora rigidamente seguido, dada as diferenças estruturais das demais escolas do país em relação a esse colégio.

Para Nunes (1962), a reforma Francisco Campos não tinha como prosperar. Pelo caráter enciclopédico dos programas das disciplinas, bem como pelo tempo que seria destinado à formação geral (5 anos), privilegiava somente a elite. A autora aponta ainda a questão da base escolar inicial - o ensino primário - inadequada à exigência da primeira série do ciclo fundamental (Ginasial), e o despreparo dos professores. O descaso dispensado aos cursos profissionais, uma vez que só organizou o ensino comercial - ainda assim, desarticulado com o ensino secundário, efetivando a inflexibilidade entre os diversos ramos do ensino - representou um ponto de estrangulamento no ensino médio. (NUNES, 1962).

Concordando com Nunes (1962), Romanelli (1985) salienta que o contexto social do país, com uma parte da população urbana ainda sem acesso ao ensino primário e a população rural ainda analfabeta, denunciava a finalidade de uma reforma com currículo tão vasto, de avaliação extremamente rígida e extensa e de controle centralizado.

No que se refere às Ciências nota-se um diferencial nessa reforma: a organização curricular evidenciou um predomínio de disciplinas de cunho científico sobre as clássicas, contrapondo à tradição de ensino humanista que vigorava até então. A área de Ciências passou a ser representada por disciplinas em todas as séries do ensino secundário, como Sciencias physicas e naturaes nas duas primeiras séries, e, a partir da terceira série, como Physica, Chimica e História Natural (BRASIL, 1931). Cabe ressaltar que, na estrutura do ensino secundário nas reformas anteriores, as disciplinas da área de Ciências não apareciam em todas as séries, e, de um modo geral, só eram incluídas a partir da $3^{\mathrm{a}}$ ou $4^{\mathrm{a}}$ séries (NUNES, 1962).

O ensino secundário permaneceu como preparatório para estudos superiores com vistas à formação acadêmica de profissões liberais, em consonância com as concepções e necessidades das classes dominantes da época, que abastada financeiramente, "contentavamse assim com uma cultura geral, concebida nos moldes de uma sociedade aristocrática pouco desenvolvida cientificamente.” (ALMEIDA JUNIOR, 1980, p.62).

Além do currículo propedêutico e excludente, tinha-se ainda o problema da formação acadêmica dos professores das disciplinas científicas que se apresentava insuficiente e 
precária. No caso específico de Física, afirma Almeida Junior (1980, p.64): "era lecionada por engenheiros, médicos, outros estudantes e até mesmo por bacharéis em Pedagogia e Ciências Sociais". Segundo o autor, a criação da Faculdade de Filosofia, Ciências e Letras da Universidade de São Paulo (FFCL-USP), em 1934, embora tenha representado um alento ao ensino de Ciências escolar, não suprimiu esse problema. A falta de "um treinamento práticodidático mais eficiente" nos cursos de formação, diplomava professores que, além do precário domínio em termos conceituais, eram incapacitados para trabalhar com a Física enfatizando o caráter inerentemente experimental da mesma (ALMEIDA JUNIOR 1980, p.64). Fato que avigorava o descompasso existente entre o que propunha o sistema educacional e as necessidades socioeconômicas de um país que ensejava a industrialização. Assim, "as escolas superiores continuavam com um ensino dirigido no interesse do diploma e não em proveito intelectual do indivíduo nem da ciência." (ALMEIDA JUNIOR, 1980, p. 62).

Outra reforma do ensino ocorreu em 1942, na gestão do ministro Gustavo Capanema. Esta ocorreu em um período em que as influências dos escolanovistas estavam mais enfraquecidas durante o Estado Novo ${ }^{38}$. Em decorrência da Constituição de 1937, pautada em tendências nacionalistas autoritárias, o dever do Estado para com educação, como defendia o movimento renovador, é atenuado para dar ênfase à liberdade de ensino que dava abertura ao retorno do domínio da iniciativa privada, principalmente das instituições católicas.

Por meio de Decretos-Leis, Gustavo Capanema iniciou uma reforma que reorganizou todos os níveis de ensino, deu ênfase ao ensino profissional e reestabeleceu a postura conservadora na educação, adjudicando a esta um caráter clássico e humanístico. A primeira parte da reforma ocorreu ainda durante o Estado Novo com a criação do Serviço Nacional de Aprendizagem Industrial (SENAI), a organização do Ensino Industrial, a organização do Ensino Secundário e a do Ensino Comercial, por meio de Decretos-leis entre janeiro de 1942 e dezembro de 1943. A segunda parte ocorreu com o Ministério da Educação e Saúde sob os comandos de Raul Leitão da Cunha e Ernesto de Sousa Campos, respectivamente, no Governo de Eurico Dutra. Com mais quatro Decretos-leis, entre janeiro e agosto de 1946,

\footnotetext{
38 O "Estado Novo" foi um período de domínio político sob o Governo ditador de Getúlio Vargas que vigorou de 1937 a 1945, consubstanciado em estratégias de convencimento e terror ao comunismo, marcando, sob muitas controvérsias, a sociedade brasileira. O período foi caracterizado por um arsenal de medidas antidemocráticas que incluíam perseguições políticas, censura aos meios de comunicação, repressão às manifestações políticas e sociais, controle dos sindicatos e redução de direitos civis. Por outro lado, no aspecto social, concede benefícios à classe trabalhadora, tais como a criação de leis trabalhistas garantindo vários direitos aos trabalhadores, criação da Justiça do Trabalho, da carteira de trabalho, salário mínimo, descanso semanal remunerado, jornada de trabalho de oito horas, entre outros. Nada obstante, essas "políticas populares" do Governo são interpretadas como uma forma de controle social para suprimir as possibilidades de levantes de greve que, influenciados por operários de origem europeia, configurou parte dos movimentos da Revolução de 1930 (ROMANELLI, 1985).
} 
deu-se sequência à reforma, organizando o Ensino Primário, o Ensino Normal, o Ensino Agrícola e criando o Serviço Nacional de Aprendizagem Comercial (SENAC). Tais decretos são conhecidos como Leis Orgânicas do Ensino, e, embora não tenham sido todos sancionados na gestão ministerial de Gustavo Capanema ${ }^{39}$, a reforma como um todo é amplamente denominada na história da educação brasileira como Reforma Capanema.

O ensino secundário, organizado pelo Decreto-Lei № 4.244, de 9 de Abril de 1942, foi reestruturado em dois ciclos. O primeiro com a mesma denominação anterior - Ginasial porém com quatro séries, o segundo subdividido em dois cursos: clássico e científico, com três séries cada um. No currículo houve um predomínio de disciplinas de humanidades, evidenciando a ênfase humanística. Os cursos do segundo ciclo não tinham caráter de especialização, e ambos permitiam o acesso ao ensino superior.

No que se refere ao acesso ao ensino superior a partir de cursos profissionais, também manteve restrições. Somente no ano de 1950, a Lei no 1.076/1950 veio minimizar o dualismo ao permitir acesso ao segundo ciclo do secundário aos egressos do primeiro ciclo do ensino comercial, industrial ou agrícola, desde que os candidatos prestassem "exame das disciplinas não estudadas naqueles cursos e compreendidas no primeiro ciclo do curso secundário" (BRASIL, 1950, Art. $1^{\circ}$ ); e acesso ao ensino superior para os egressos dos cursos comerciais técnicos devendo os candidatos passarem por exames de vestibulares, de modo a comprovar "o nível de conhecimentos indispensável à realização dos aludidos estudos" (BRASIL, 1950, Art. $2^{\circ}$ ).

A Lei $n^{\circ} 1.821 / 1953$ e sua regulamentação (Decreto $\left.n^{\circ} 34.330 / 195\right)$ veio nivelar os diversos cursos de grau médio para efeito de matrículas no curso Colegial e em qualquer curso superior (pelo concurso vestibular), buscando abrandar a descomunal corrida aos cursos secundários e o desinteresse da população pelos cursos técnico-profissionais, já que "o grau 'de doutor' sempre foi, no Brasil, uma forma de ascensão social, bem como o certificado de curso secundário" (NUNES, 1962, p. 119).

Outro aspecto da segregação presente na Lei Orgânica que reformou o ensino secundário era a exigência de exames rígidos de admissão para ingresso no $1^{\circ}$ ciclo do ensino secundário e do profissional, mantendo a seletividade histórica do sistema educacional brasileiro. Além dos exames de admissão, havia ainda os rigorosos exames de suficiência e de licença. Os exames de suficiência tinham como finalidade habilitar o aluno de qualquer série para promoção à série imediata; e ao aluno da última série, habilitar para prestação dos

\footnotetext{
${ }^{39}$ Gustavo Capanema esteve à frente do Ministério dos Negócios da Educação e Saúde Pública, no período de 1934 a 1937, e do Ministério da Educação e Saúde, no período de 1937 a 1945.
} 
exames de licença (BRASIL, 1942, Art. 47). Por sua vez, os exames de licença eram de duas categorias: uma se referia aos exames para conclusão do primeiro ciclo (Ginasial), e a outra, os exames de licença clássica e exames de licença científica, para conclusão dos estudos, respectivamente, do curso clássico e do curso científico (BRASIL, 1942, Art. 55).

A reforma do ensino secundário realizada por Gustavo Capanema à frente do Ministério dos Negócios da Educação e Saúde Pública ratificou a criação de currículos mínimos rígidos e enciclopédicos na forma de programas de disciplinas, pelo poder público, para os diversos níveis de ensino e prevaleceu com o controle das escolas através dos especialistas educacionais. Inicialmente, a organização dos programas das disciplinas ficou a cargo de "[...] uma comissão geral ou por comissões especiais, designadas pelo Ministro da Educação" (BRASIL, 1942, Art.18). Em 1951, o então Ministro da Educação e Saúde Ernesto Simões Filho retomou a sistemática anterior, incumbindo novamente a congregação do Colégio D. Pedro II da elaboração dos programas das diversas disciplinas do curso secundário (BRASIL, 1951a).

Para Nunes (1962), a Reforma Capanema foi um retrocesso na Educação brasileira e, assim como a anterior, também não correspondeu à realidade socioeconômica a qual o país vivenciava com o processo de industrialização, nessa conjuntura, bem mais avançado e fortalecido. A reforma se mostrou nitidamente inconsistente com a situação econômica, entretanto muito afinada com o momento político vigente no país, sob gerência de um regime que mesclou autoritarismo e populismo.

No que se refere às Ciências, a área passou a ser representada somente a partir da terceira série do Ginasial, com a disciplina Ciências Naturais. A Física aparece no Colegial, no curso clássico, nas segunda e terceira séries, e no científico nas três séries.

Quanto às orientações para o currículo do ensino de Ciências, o discurso na exposição de motivos é suntuoso, no que tange aos métodos de ensino, na medida em que levanta críticas aos métodos tradicionais de transmissão imitativa do conhecimento. A estruturação curricular e as orientações sobre o currículo das disciplinas denotam, claramente, a contradição entre o discurso e o que se proporcionou como condicionantes da prática. Do discurso, têm-se:

O estudo das ciências - A reforma coloca o problema do estudo das ciências em termos convenientes.

No curso ginasial, a matemática e as ciências naturais serão estudadas de modo elementar. Seria antipedagógico sobrecarregar os alunos, nessa primeira fase dos estudos secundários, com estudos científicos aprofundados.

Ao estudo das ciências, num e noutro caso, orientará sempre o princípio de que não é papel do ensino secundário formar extensos conhecimentos, encher os espíritos adolescentes de problemas e demonstrações, de leis e hipóteses, de nomenclaturas e 
classificações, ou ficar na superficialidade, na mera memorização de regras, teorias e denominações, mas cumpre-lhe essencialmente formar o espírito científico, isto é, a curiosidade e o desejo da verdade, a compreensão da utilidade dos conhecimentos científicos e a capacidade de aquisição desses conhecimentos.

$[\ldots]$

No ensino científico, mais do que em qualquer outro, falhará sempre irremediavelmente o processo do erudito monologar docente, a atitude do professor que realiza uma experiência diante dos alunos inexpertos como se estivesse fazendo uma representação, o método de inscrever na memória a ciência dos livros. Nas aulas das disciplinas científicas, os alunos terão que discutir e verificar, terão que ver e fazer. Entre êles e o professor é necessário estabelecer um regime de cooperação no trabalho, trabalho que deverá estar cheio de vida e que seja sempre, segundo o preceito deweyano, uma "reconstrução da experiência".

Se as ciências forem ensinadas assim, sob a influência das coisas concretas, em contato com a natureza e a vida, de um modo sempre ativo, formarão, tanto nos alunos do curso científico como nos do curso clássico, uma conveniente cultura científica, que concorra para definir-lhes a madureza intelectual e que os habilite aos estudos universitários de qualquer ramo. (BRASIL, 1942, Exposição de Motivos).

A visão de educação, pelo menos em nível de discurso, ampara-se nos pressupostos da Educação Nova seguindo o preceito deweyano como se extrai da citação. As concepções de ensino se respaldam nos métodos ativos, muito aclamados no Manifesto dos Pioneiros da Educação Nova (1932). Tais métodos correspondiam a um ideário educativo que deslocasse o aluno das margens do processo de ensino para assumir o centro das atenções pedagógicas, de forma a possibilitá-lo uma maior participação no seu próprio processo de aquisição do conhecimento, com autonomia e liberdade.

Promover um ensino nesses termos requereria liberdade de planejamento por parte do professor. Na contramão disso, os programas das disciplinas foram rigidamente determinados por comissões centrais designadas pelo Governo Federal. Além disso, as avaliações eram de controle igualmente rígidos, das quais cabia ao Ministério da Educação "a adoção de critérios e processos" que assegurassem "o aumento da objetividade na verificação do rendimento escolar e no julgamento dos exames" (BRASIL, 1942, Art. 30, § Único). Ademais, uma educação com pressupostos fortemente alicerçados na "autonomia e liberdade" estaria bastante contraditória com o modelo político daquele momento histórico.

Embora trazendo a denominação de curso "científico" para uma das modalidades do segundo ciclo, ainda assim prevaleceram em quantitativo as disciplinas humanísticas, conforme se constata na organização determinada pelo Decreto-Lei. Sobre esse aspecto da reforma, Nunes (1962) critica: “A predominância do ensino do latim ${ }^{40}$, em detrimento das ciências físico-naturais, decorria da finalidade que, vimos, o ministro Capanema atribuía ao ensino secundário." (NUNES, 1962, p. 114).

\footnotetext{
${ }^{40}$ Segundo Maria Tetis Nunes (1962), o latim estava presente nas quatro séries do ginasial, com 3 aulas semanais na primeira e segunda séries e 5 aulas semanais nas terceira e quarta séries.
} 
A reforma traduziu bem as contradições que permeavam o cenário sociopolítico da época. Por um lado, um governo nacionalista e autocrata interessado em formar “individualidades condutoras” (BRASIL, 1942, Art. 23), e por outro, uma elite preocupada em manter os privilégios de classe e pouco interessada em desenvolvimento científico (ALMEIDA JUNIOR, 1979).

Apesar das inconsistências das duas reformas mencionadas em relação à situação pela qual passava o país em cada momento em que se deram, e da prevalência do ensino humanístico, mesmo quando o discurso da lei parecia querer mudar essa lógica, as duas reformas que citamos até aqui, inegavelmente, representaram certo grau de desenvolvimento para as carreiras científicas. A Ciência passa a ser vista como disciplina de trabalho, saindo do "terreno das aventuras" de alguns poucos interessados em arriscar experiências educativas, para mais tarde conferir importância imperativa no currículo escolar do país (SANTA CATARINA, 1991). O conhecimento científico passou a ser visto como aspecto essencial nessa esperada formação, justificado, sobretudo, pelas demandas de um país sensibilizado pela "moderna economia industrial" (NUNES, 1962, p.119).

\subsubsection{O currículo oficial de Física em meados do século XX}

Lorenz e Vechia (1986), ao analisar os itens de conteúdos das disciplinas que constituíram o núcleo do componente curricular da área de Ciências, no período de 1838 a 1971, observam que ocorreu pouca mudança nos conteúdos estudados, mesmo nas reformas consideradas inovadoras, como as de 1855, 1857, 1911 e 1915. Assim, sem significativas alterações, o currículo de Física para todo o território nacional chegou à década de 1950 com indicação de estudo dos tópicos de conteúdos conforme o que determinou a Portaria ${ }^{\circ}$ 966, de 02 de Outubro de 1951, o que apresentamos no ANEXO I desta tese.

Ainda em 1951, a Portaria $\mathrm{n}^{\circ} 1.045$ de 14 de Dezembro, publicada no Diário Oficial de 22 de Fevereiro de 1952, deliberou as instruções metodológicas para todas as disciplinas do quadro curricular, sendo que, para a Física, tais instruções significaram somente um maior detalhamento dos tópicos listados no anexo da Portaria n 966/1951. Os tópicos de conteúdos e seus detalhamentos, nos termos das referidas Portarias, vigoraram como orientação curricular até o ano de 1961, quando da publicação da primeira LDB brasileira que deu maior flexibilidade de organização dos quadros curriculares às escolas, bem como de elaboração dos programas de conteúdos a serem ministrados. 
Conquanto algumas experiências de inovação no ensino de Ciências tenham iniciado no final da década de 1940, no que concerne à Física, estas se refletiram mais na questão da prática experimental, não representando mudanças nos temas tradicionalmente desenvolvidos. Além disso, as atividades experimentais eram do tipo demonstrativo, em geral, pelo professor, muitas vezes, despreparado para atuar nesta perspectiva (ALMEIDA JUNIOR, 1980). A prática experimental ficava em segundo plano no próprio currículo: “Todas as vezes que o curso comportar a presença dos alunos no gabinete de física em horas extracurriculares, serlhes-á facultado o uso de aparelhos, bem como a execução dos seguintes trabalhos [apresenta uma lista de propostas de experimentos]" (BRASIL, 1951, Anexo da Portaria no 966).

Sobre a prevalência de atividades experimentais demonstrativas, Pinho-Alves (2000) encontra justificativa no fato de que "Os antigos laboratórios escolares, com sala ambiente própria, possuíam um acervo de material experimental restrito, geralmente, a um exemplar de cada experimento, implicando que a prática experimental se resumisse em demonstrações realizadas pelo professor." (PINHO-ALVES, 2000, p.22). Ainda segundo esse autor, o material experimental era bastante caro e de difícil aquisição e reposição.

É fato que nesse período as escolas poderiam contar com outros recursos inovadores, como por exemplo, a cinematografia, pois estavam disponíveis no mercado cinematográfico filmes educativos que abordavam temas tratados na Física do ensino secundário e presentes no currículo oficial, sobretudo a partir de 1936, com a criação do Instituto Nacional do Cinema Educativo (INCE) (BONETTI, 2013) ${ }^{41}$. Conforme aponta Bonetti, as inovações propiciadas pelo cinema educativo foram importantes para o ensino de Física nas salas de aula, entretanto cabe ressaltar que, estas, assim como os recursos para atividades experimentais, possivelmente, não atingiram a maioria das escolas brasileiras, por questões estruturais, ficando mais restritas a algumas escolas das capitais, principalmente do Estado de São Paulo e Rio de Janeiro. Assim, o desenvolvimento do currículo para a maioria das escolas se amparava de fato nos livros didáticos, de modo que a configuração de sequência de conteúdos específicos nos termos das Portarias $n^{\circ}$ 966/1951 e $n^{\circ} 1.045 / 1951$ era obedecida também pelos autores desse recurso pedagógico (MARTINS; HOUSOME, 2007) que, além

\footnotetext{
${ }^{41}$ Bonetti (2013) mostra que, somente no ano de 1936, o INCE produziu oito filmes com temas da Física, sendo eles: "A medida de tempo", "Medida de massas - Balanças", "Máquinas - Roldanas, plano inclinado e cunha", "Ar atmosférico", "Barômetros", "Força Hidráulica", "Manômetros" e "Microscópio composto". Ainda segundo o autor, outros dois filmes que estabeleciam as relações Física/tecnologia/sociedade foram produzidos nesse mesmo ano. A produção de filmes educativos pelo INCE continuou até meados da década de 1960. Nesse período, identifica-se um número significativo de filmes que abordam assuntos de Astronomia e Física, mormente desta última, abrangendo temas de Mecânica, Termologia, Eletricidade e Magnetismo, além de outros que traziam conhecimentos físicos ligados a Indústria, Tecnologia e Sociedade, Higiene e Saúde e Pesquisa e divulgação científica (BONETTI, 2013, p. 109-111).
} 
de seguir as determinações legais, buscavam atender ao que era exigido nos exames de acesso ao ensino superior.

\subsection{Uma reforma educacional pioneira}

\subsubsection{O contexto}

As transformações políticas, econômicas e sociais vivenciadas no Brasil em meados do século XX demandaram uma escola capaz de atender a uma quantidade maior de cidadãos, "forçando" tentativas para a adoção de uma educação escolar mais democrática, uma vez que, até então, frequentar escola era um privilégio bastante restrito à elite. Além disso, o contexto exigiu uma formação escolar mais ampla, que permitisse não somente a continuação em estudos superiores, mas também uma preparação para a vida social, especialmente para atender a um mercado produtivo mais evoluído tecnologicamente.

O cenário político-econômico mundial vivia o delicado momento de transição do Pós-Guerra para a bipolarização mundial nos contextos sociopolítico e econômico, a batalha política e ideológica denominada Guerra Fria. O Brasil vivia o auge do Movimento Populista, quando ocorre o retorno de Getúlio Vargas ao poder em 1951, e desta vez pelo voto direto, depois de já ter protagonizado um marcante período (1930-1945) de governo autocrata. Assume mais uma vez o caráter desenvolvimentista nacionalista, dando continuidade à política de seu governo anterior (ROMANELLI, 1985).

Nesse segundo Governo de Vargas, a criação de algumas instituições no início dos anos de 1950, com vistas a dar condições de continuidade ao processo desenvolvimentista, tiveram impactos positivos na Educação de um modo geral. Falamos das agências públicas e instituições de fomento criadas em 1951: o Conselho Nacional de Pesquisa $(\mathrm{CNPq})^{42}$ e a Campanha Nacional de Aperfeiçoamento de Pessoal de Nível Superior (Capes) ${ }^{43}$. Tais agências tiveram e ainda têm papel importante no desenvolvimento e consolidação da pósgraduação stricto sensu no Brasil. Além dessas agências, no que tange ao ensino médio, foi instituída, em 1953, a Campanha de Aperfeiçoamento e Difusão do Ensino Secundário (CADES); segundo Souza (2008, p. 213), “com a finalidade de promover atividades de aperfeiçoamento de professores e pessoal técnico". Foi criado ainda um fundo para auxiliar o

\footnotetext{
${ }^{42}$ Nomenclatura atual - Conselho Nacional de Desenvolvimento Científico e Tecnológico.

${ }^{43}$ Nomenclatura atual - Coordenação de Aperfeiçoamento de Pessoal de Nível Superior.
} 
desenvolvimento do ensino secundário, dando apoio às escolas privadas para concessão de bolsas de estudos para o ensino secundário (SOUZA, 2008).

Os movimentos populares (greves e movimentos sociais) insurgidos em décadas anteriores e, alentados cada vez mais pelo crescimento acelerado da população urbana e os problemas decorrentes disso, somado ao temor da classe dominante quanto às ações do governo para responder a essas demandas, são fatores cruciais para o desencadeamento da crise política no governo. Juntou-se a isso a desconfiança sobre Getúlio Vargas como governo ditador e à pressão de muitas forças políticas, acusações de corrupção e até mesmo de crime de atentado contra um opositor político ${ }^{44}$. Suscita-se que tais fatores tenham sido as razões que levaram Vargas a interromper seu mandato, em 24 de agosto de 1954, de forma trágica, com o suicídio que marcou a história política do país (ROMANELLI, 1985).

De 1954 a 1956, o país passa por três governos até o início do governo de Juscelino Kubitschek (JK), em 1956, também eleito pelo voto direto (ROMANELLI, 1985). O final da década de 1950 e início de 1960 é um período caracterizado por uma ideologia política desenvolvimentista. Acentuou-se a implantação da indústria pesada no Brasil, impulsionando ainda mais o desenvolvimento industrial. Embora mantendo o modelo político do populismo, em contraposição à política econômica do governo anterior (Governo de Eurico Dutra), no governo de JK "abrem-se as portas da economia nacional ao capital estrangeiro" (ROMANELLI, 1985, p. 83), retomando de forma mais acentuada a política econômica praticada por Dutra. O mandato de JK é reconhecido como um período de crescimento econômico e estabilidade política com o apoio de partidos da direita e da esquerda. No entanto, os aumentos da inflação, da concentração de renda e da dívida externa foram fatores que aguçaram a insatisfação popular que se insurgia em manifestações.

Nesse ínterim, segundo Souza (2008), discutiu-se na Câmara dos Deputados, a possibilidade de uma nova Lei Orgânica do Ensino Secundário ${ }^{45}$. Conforme essa autora, debates se acirraram sobre a inclusão ou exclusão de disciplinas no currículo, bem como novos objetivos para uma Educação com viés mais prático voltado para o mercado de trabalho. Ressalte-se que, nesse período, um anteprojeto de LDB já hibernava no congresso desde 1948. E é também neste contexto que se acendeu intensamente o debate sobre tal anteprojeto de lei.

\footnotetext{
${ }^{44} \mathrm{O}$ atentado da Rua Toneleros.

45 Nesse período, o sistema educacional era regido pelos Decretos-Leis da Reforma iniciada por Gustavo Capanema, conforme já mencionado neste texto.
} 
A Constituição em vigor naquele período, a de 1946, caracterizada pelo liberalismo democrático pós-Estado Novo, dava maior ênfase à Educação tarefando o poder público de promover o ensino primário, gratuito e para todos, e os secundários (ou ulteriores) para os que não pudessem arcar com os estudos. Além disso, previu um percentual de recursos mínimos que seriam destinados à Educação, proposta de organização educacional descentralizada administrativa e pedagogicamente, ainda que sob "os olhos" da União, e normatização quanto ao ingresso para cargos do magistério (BRASIL, 1946b). Isso representou um grande progresso em relação à Constituição anterior (de 1937) que nem mesmo mencionava o direito à educação (BRASIL, 1937), onde a noção de direito cedeu espaço à noção de assistência (CURY, 1991).

A Carta Magna de 1946, em alguns aspectos, aproximava-se mais da de 1934, e refletia a luta dos educadores iniciada nos anos de 1930, dando maior esperança para um possível desenvolvimento de políticas educacionais mais democráticas e de maior alcance social. As ideias da Escola Nova estavam bastantes presentes, e é inspirado na doutrina dessa Constituição que começa a germinar a primeira LDB brasileira (FAZENDA, 1985). Correspondendo ao que promulgava a Carta Magna em seu Art 5º XV, alínea d, que preceituou como competência da União legislar sobre as diretrizes e bases da educação nacional, em 1948, um anteprojeto de lei de Diretrizes e Bases da Educação Nacional, elaborado por educadores adeptos do movimento renovador (escolanovistas), foi encaminhado ao Congresso.

Segundo Nunes (1962), o projeto inicial da LDB cuidava de todos os graus de ensino e, ao contrário das reformas anteriores, buscava uma maior inter-relação entre eles. Ainda segundo a autora, o sistema proposto no anteprojeto conciliava "a tradição francesa de centralização rígida da escola secundária, até então dominante, com a tradição descentralizadora norte-americana, apregoada por muitos de nossos teóricos da educação." (NUNES, 1962, p. 116).

Romanelli (1985, p. 173-174) coloca: "Em síntese, era um anteprojeto que, embora merecesse ressalvas, não 'pecava pela base'. Estava dentro do espírito da Constituição e refletia bem as mudanças por que passava a sociedade brasileira".

A primeira LDB brasileira (Lei $N^{o}$ 4.024/1961) é sancionada em um ambiente político conturbado, logo após a assunção de João Goulart como presidente da república. O presidente eleito foi Jânio Quadros, mas este renunciou com sete meses de mandato. A renúncia instaurou uma crise no país, e, após um breve período de Governo provisório e de lutas políticas com a oposição dos militares, em setembro de 1961, João Goulart (vice de 
Jânio Quadros) assume a presidência iniciando sob um regime de governo parlamentarista ${ }^{46}$, que após plebiscito, retorna ao regime presidencialista e governa até 31 de março de 1964, quando é deposto por um Golpe Militar.

\subsubsection{A $L D B / 1961$}

A primeira LDB brasileira, promulgada em 20 de Dezembro de 1961, representou um marco na Educação do Brasil, pois foi a primeira legislação educacional que, sozinha, tratou de todos os ramos e níveis do ensino. Essa Lei, gestada por longos 13 anos, efetivou-se distanciada dos objetivos iniciais do primeiro anteprojeto. Todo o processo que culminou com o texto publicado envolveu períodos de estudos por comissões parlamentares, arquivamentos, reabertura com amplos debates na imprensa e entre os intelectuais e simpatizantes do movimento renovador, representantes das congregações religiosas - especialmente a Igreja Católica - e dos movimentos estudantis, e ainda, após vários substitutivos do projeto, pareceres, emendas, etc., com visões e interesses diferentes sobre a educação escolar (ROMANELLI, 1985).

Esse processo nos remete ao que vários teóricos do currículo ressaltam a respeito das reformas educacionais: os conflitos ideológicos, o jogo de interesses e disputa de poder que permeiam a definição dos princípios que devem conduzir o processo de escolarização (GOODSON, 1995; APPLE, 1997; SACRISTÁN, 2000; e outros).

A LDB/1961 praticamente manteve a estrutura tradicional do ensino, com poucas inovações em relação à legislação anterior e organizou o sistema da seguinte forma:

$\rightarrow$ Educação Pré-Primária (para menores de 7 anos);

$\rightarrow$ Ensino Primário - com duração de no mínimo 4 séries anuais, obrigatório a partir dos 7 anos de idade;

\footnotetext{
${ }^{46}$ A posse de João Goulart como presidente não agradou a um grupo de militares que o associava às "forças comunistas". Outro grupo, também de militares, defendia os ditames da Constituição que determinava a assunção, uma vez que Goulart foi eleito como vice-presidente por voto popular. O impasse foi resolvido com um acordo que gerou uma emenda constitucional instaurando o regime parlamentarista a partir de agosto de 1961. Uma saída política para controlar o governo, já que assim, João Goulart não teria plenos poderes para governar. A necessidade de reformas a serem implementadas, difíceis de serem levadas adiante nesse regime, fez com que o governo decidisse, em 1963, por chamar o povo a um plebiscito para decidir sobre a permanência ou não do regime parlamentarista. $\mathrm{O}$ resultado pelo presidencialismo voltou a conferir poderes plenos a João Goulart.
} 
$\rightarrow$ Ensino Médio - subdividido em dois ciclos, o Ginasial de 4 anos e o Colegial de 3 anos, abrangendo, entre outros, os cursos secundários, técnicos e de formação de professores para o ensino primário e pré-primário;

$\rightarrow$ Ensino Superior - nos mesmos moldes da legislação anterior.

Em relação ao acesso do ensino primário para o secundário, manteve-se a seletividade por meio do exame de admissão, conforme o traz o Artigo 36: "O ingresso na primeira série do $1^{\circ}$ ciclo dos cursos de ensino médio depende de aprovação em exame de admissão, em que fique demonstrada satisfatória educação primária, desde que o educando tenha onze anos completos ou venha a alcançar essa idade no correr do ano letivo." (BRASIL, 1961).

Ainda que tenha extinguido os rigorosos exames de suficiência e de licença, presentes no sistema de ensino da reforma anterior, não eliminou a seletividade que representava um exame de acesso de um nível de ensino a outro, em um contexto de grande expansão da demanda por educação, principalmente a classe menos favorecida, que via a escolarização como condição de mobilidade social.

A Lei tratou da flexibilidade entre os ramos do ensino adotando a equivalência de cursos, conforme traz em seu Artigo 12: "Os sistemas de ensino atenderão à variedade dos cursos, à flexibilidade dos currículos e à articulação dos diversos graus e ramos." (BRASIL, 1961). O Artigo 34 também pressupõe essa flexibilidade ao ditar que "O ensino médio será ministrado em dois ciclos, o ginasial e o Colegial, e abrangerá, entre outros, os cursos secundários, técnicos e de formação de professores para o ensino primário e pré-primário." (BRASIL, 1961).

Sobre esse aspecto, Nagle (1973) tem uma análise negativa e opina que a flexibilidade e equivalência entre os ramos do ensino estabelecido desde o início da década de 1950 com as alterações ${ }^{47}$ das Leis Orgânicas do Ensino, não consolidadas na prática, se mantiveram com a LDB/1961. Isso se deveu às dificuldades de adaptações entre os diversos ramos e as condições estruturais das escolas do país. De tal modo que, para esse autor, a lei não deu conta de suprimir a segregação e dualismo do sistema escolar brasileiro.

Vários autores, tais como, Fontoura [1979], Romanelli (1985), Saviani (1986), Aranha (1989) e Pimenta e Gonçalves (1990) concordam que a LDB/1961 já nasceu ultrapassada. A Lei manteve os interesses privatistas em educação, não exprimiu as influências dos diversos movimentos sociais da época, nem tão pouco refletiu a situação

\footnotetext{
${ }^{47}$ Lei $^{\circ} 1.076 / 1950$ e Lei ${ }^{\circ} 1.821 / 1953$.
} 
econômica do país, que ao longo do tempo de tramitação do seu projeto, angariou aumento do parque industrial, crescimento da economia, e, principalmente, da demanda por educação básica.

A LDB/1961 criou órgãos normativos, como o Conselho Federal de Educação ${ }^{48}$ (CFE) e os Conselhos Estaduais de Educação (CEE), com objetivos que pressupunham a descentralização e diversificação do disciplinamento do sistema escolar, o que, segundo Nagle (1973), não se protagonizou de fato. Esse autor afirma que faltou ao CFE estabelecer conjuntos de normas específicas decorrentes das normas gerais fixadas na LDB. Ao invés disso, tal órgão se ateve a resolver problemas pontuais que iam surgindo. Sem normas específicas, os CEE não logravam condições para exercerem o papel que lhes cabia.

Se por um lado, a LDB/1961 não alterou significativamente a estrutura do sistema tradicional de ensino marcado pelo dualismo, por outro, dada à flexibilidade do currículo, uma vez que não fixou um currículo rígido e centralizado, foi uma oportunidade - segundo Romanelli (1985), uma oportunidade perdida - de organização dos sistemas de ensino estaduais e regionais mais coerentes com as necessidades das diferentes realidades brasileiras, que, de uma forma ou outra, sentia as consequências do processo de desenvolvimento do país nos mais diferentes aspectos: sociais, políticos, econômicos, tecnológicos, culturais, etc.

\subsubsection{Da organização curricular nos termos da LDB/1961}

Um aspecto considerado marcante e positivo da $\mathrm{LDB} / 1961$, em muitas pesquisas que tratam do tema, foi a flexibilidade concedida aos sistemas estaduais e aos estabelecimentos de ensino para organizarem os seus currículos mais aproximados das especificidades regionais, ainda que tal flexibilidade tenha sido bastante comedida, e que, além disso, não tenha sido levada a termo da forma como foi ditada na Lei, conforme veremos mais adiante. Ao que parece, a flexibilidade ocorreu de fato, quanto à elaboração dos currículos das disciplinas, ou seja, os programas de conteúdos, que deixaram de ser ditados de cima para baixo, contrariando, em parte, os ditames da Lei que, em letra, ainda manteve a centralização dessa atribuição no Conselho Federal de Educação e nos conselhos estaduais, no que se referia às disciplinas obrigatórias (BRASIL, 1961, Art. 35, § 2º).

\footnotetext{
${ }^{48}$ Esse órgão de natureza consultiva e normativa para questões educacionais passou por alterações em sua denominação ao longo da história da educação, bem como em suas funções mais específicas. A Reforma Francisco Campos, em 1931, criou o Conselho Nacional de Educação (CNE). A Lei 4.024/1961 criou o Conselho Federal de Educação (CFE), extinto em 1994. Em 1995 foi criado o Conselho Nacional de Educação (CNE) - mesma denominação que tinha na reforma de 1931 - por meio de Medida Provisória. Este último está em atividade até os dias atuais.
} 
A concepção de currículo nos termos da LDB/1961 tem sentido de "conjunto de todas as atividades exercitadas e vividas pelo aluno sob a direção da escola e no sentido dos objetivos por ela visados. Assim, abrange disciplinas, práticas educativas, formação moral e cívica, atividades complementares e orientação educativa e vocacional.” (BRASIL, 1969, p.17).

Quanto à organização curricular, a LDB/1961 traz em seu Artigo 35:

Art. 35. Em cada ciclo haverá disciplinas e práticas educativas, obrigatórias e optativas.

$\S 1^{\circ}$ Ao Conselho Federal de Educação compete indicar, para todos os sistemas de ensino médio, até cinco disciplinas obrigatórias, cabendo aos conselhos estaduais de educação completar o seu número e relacionar as de caráter optativo que podem ser adotadas pelos estabelecimentos de ensino.

$\S 2^{\circ} \mathrm{O}$ Conselho Federal e os conselhos estaduais, ao relacionarem as disciplinas obrigatórias, na forma do parágrafo anterior, definirão a amplitude e o desenvolvimento dos seus programas em cada ciclo.

$\S 3^{\circ} \mathrm{O}$ currículo das duas primeiras séries do $1^{\circ}$ ciclo será comum a todos os cursos de ensino médio no que se refere às matérias obrigatórias. (BRASIL, 1961, grifo nosso).

Em atendimento à Lei, o Conselho Federal de Educação publicou em 24 de Abril de 1962, a Indicação s/nº (homologada pelo Ministro de Educação e cultura em 21.02.1962 ANEXO II) contendo orientações quanto à organização curricular e a "Fundamentação" para as disciplinas do currículo. Tal indicação trazia a lista de disciplinas obrigatórias para todos os sistemas do ensino médio (âmbito nacional), bem como a lista de disciplinas complementares e optativas para o sistema federal de ensino. Embora, pelo discurso da Lei, tenha-se descentralizado parte do currículo, foi o Conselho Federal de Educação que sugeriu as disciplinas obrigatórias que seriam complementadas pelos Conselhos Estaduais, visto que tais Conselhos ainda não haviam sido formados (cf. Indicação de Fevereiro/1962, Art. $3^{\circ}$, $§ 1^{\text {o }}$ ). As opções de disciplinas para organização dos quadros curriculares das escolas do sistema federal de ensino brasileiro, definidas/sugeridas pelo Conselho Federal de Educação são as que apresentamos no quadro a seguir. 
QUADRO 2 - Listas de disciplinas para composição do quadro curricular apresentadas na Indicação de 24.02.1962, nos termos da LDB/1961.

\begin{tabular}{|c|c|c|}
\hline & $\begin{array}{ll}\text { Nível } & \text { do } \\
\text { Ensino } & \\
\text { Médio } & \end{array}$ & $\begin{array}{l}\text { Disciplinas e Práticas Educativas definidas/sugeridas pelo } \\
\text { CFE }\end{array}$ \\
\hline $\begin{array}{l}\text { Disciplinas obrigatórias } \\
\text { (todas da coluna } 3 \text {, conforme Art. } 1^{\circ} \text { da } \\
\text { Indicação.) } \\
\text { O número de séries indicadas constitui } \\
\text { o máximo, conforme Parágrafo único } \\
\text { do Art. } 1^{\circ} \text {. }\end{array}$ & $\begin{array}{l}\text { Ginasial } \\
\text { Colegial }\end{array}$ & $\begin{array}{ll}\text { 1. } & \text { Português (sete séries); } \\
\text { 2. } & \text { História (seis séries); } \\
\text { 3. } & \text { Geografia (cinco séries); } \\
\text { 4. } & \text { Matemática (seis séries); } \\
\text { 5. } & \text { Ciências (sob a forma de iniciação à ciência, } 2 \text { séries, sob a } \\
& \text { forma de ciências físicas e biológicas, } 4 \text { séries). }\end{array}$ \\
\hline $\begin{array}{l}\text { Disciplinas complementares do } \\
\text { sistema federal } \\
\text { (Apenas uma das opções da coluna 3) }\end{array}$ & $\begin{array}{l}\text { Ginasial } \\
\text { Colegial }\end{array}$ & $\begin{array}{l}\text { 1. Desenho e Organização Social e Política Brasileira; } \\
\text { 2. Desenho e uma língua estrangeira moderna; } \\
\text { 3. Uma língua clássica e uma língua estrangeira moderna; } \\
\text { 4. Ou duas línguas estrangeiras modernas, em ambos os } \\
\text { ciclos; } \\
\text { 5. Uma língua estrangeira moderna e filosofia (no } 2^{\circ} \text { ciclo) }\end{array}$ \\
\hline \multirow[t]{2}{*}{$\begin{array}{l}\text { Disciplinas de escolha pelos } \\
\text { estabelecimentos de ensino } \\
\text { (apenas duas optativas da coluna } 3 \text {, } \\
\text { sendo } 1 \text { por série) }\end{array}$} & Ginasial & $\begin{array}{l}\text { 1. Línguas estrangeiras modernas; } \\
\text { 2. Música (canto orfeônico); } \\
\text { 3. } \\
\text { 4. } \\
\text { 5écnicas comerciais; } \\
\text { 5. }\end{array}$ \\
\hline & Colegial & $\begin{array}{l}\text { 1. Línguas estrangeiras modernas; } \\
\text { 2. Grego; } \\
\text { 3. Desenho; } \\
\text { 4. } \\
\text { 5. } \\
\text { 6stuneralogia e geologia; } \\
\text { 7. } \text { Psicologia; } \\
\text { 8. Literat } \\
\text { 9. Introdução às artes; } \\
\text { 10. Direito usual; } \\
\text { 11. Elementos de economia; } \\
\text { 12. Noções de contabilidade; } \\
\text { 13. Noções de biblioteconomia; } \\
\text { 14. Puericultura; } \\
\text { 15. Higiene e dietética }\end{array}$ \\
\hline $\begin{array}{l}\text { Práticas Educativas } \\
\text { (Educação Física }+1 \text { optativa pela } \\
\text { escola) }\end{array}$ & $\begin{array}{l}\text { Ginasial } \\
\text { Colegial }\end{array}$ & 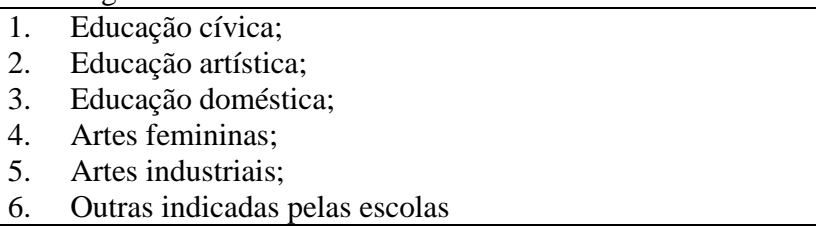 \\
\hline
\end{tabular}

Fonte: BRASIL (1962a, p. 4557-4558)

O Conselho Federal de Educação autorizou eleger disciplinas do grupo das obrigatórias de um tipo de currículo, para configurar como optativas em outro tipo (BRASIL, 1962a, Art. 5º Parágrafo único, p. 4557).

A Indicação do CFE se refere ao currículo do ensino secundário ginasial e colegial acadêmico. Para os cursos técnicos e os de formação de professores pré-primário e primário, os currículos deveriam seguir, além das diretrizes da LDB, as instruções e leis especiais atinentes a cada modalidade de curso (BRASIL, 1962a, Art. $7^{\circ}$, p. 4557). O documento apresenta breves orientações, bastante gerais, intituladas "Fundamentação", para as disciplinas obrigatórias. No que tange à Matemática e Ciências o documento traz somente: 
Matemática e Ciências - disciplinas universais, por seu valor formativo e por sua utilidade prática. Pareceu bem à Comissão insistir em que aos alunos das duas primeiras séries ginasiais se ministre, de preferência iniciação à Ciência como visão de conjunto que lhes proporcione as bases para ulteriores desenvolvimento e diversificações, sobretudo nas ciências físicas e biológicas. (BRASIL, 1962a, p. 4557).

Como orientação de organização de quadros curriculares a Indicação apresenta quadros exemplificativos elaborados pela Comissão de Ensino Médio, com variedades admissíveis (quatro hipóteses ${ }^{49}$ ), nos termos da LDB/1961, os quais transcrevemos a seguir, de cópia do documento original.

QUADRO 3 - Quadro exemplificativo de variedades admissíveis para a organização curricular do ciclo Ginasial publicado no D.O.U de 24 de abril de 1962.

CICLO GINASIAL (Variedades admissíveis)

\begin{tabular}{|c|c|c|c|c|c|c|c|c|c|c|c|c|c|c|c|c|c|c|}
\hline & & \multicolumn{4}{|c|}{$1^{\mathrm{a}}$ hipótese } & \multicolumn{4}{|c|}{$2^{\mathrm{a}}$ hipótese } & \multicolumn{4}{|c|}{$3^{\mathrm{a}}$ hipótese } & \multicolumn{4}{|c|}{$4^{\mathrm{a}}$ hipótese } \\
\hline & & Séries $\longrightarrow$ & I & II & III & IV & I & II & III & IV & I & II & III & IV & I & II & III & IV \\
\hline \multirow{6}{*}{$\begin{array}{l}\text { Disciplinas } \\
\text { indicadas } \\
\text { pelo } \\
\text { Conselho } \\
\text { Federal }\end{array}$} & 1 & Português & $\mathrm{x}$ & $\mathrm{x}$ & $\mathrm{X}$ & $\mathrm{X}$ & $\mathrm{x}$ & $\mathrm{x}$ & $\mathrm{x}$ & $\mathrm{x}$ & $\mathrm{x}$ & $\mathrm{x}$ & $\mathrm{x}$ & $\mathrm{x}$ & $\mathrm{x}$ & $\mathrm{x}$ & $\mathrm{x}$ & $\mathrm{x}$ \\
\hline & 2 & História & $\mathrm{x}$ & $\mathrm{X}$ & $\mathrm{X}$ & $\mathrm{X}$ & $\mathrm{X}$ & $\mathrm{X}$ & $\mathrm{X}$ & $\mathrm{X}$ & $\mathrm{X}$ & $\mathrm{x}$ & $\mathrm{X}$ & $\mathrm{X}$ & $\mathrm{x}$ & $\mathrm{x}$ & $\mathrm{X}$ & $\mathrm{x}$ \\
\hline & 3 & Geografia & $\mathrm{X}$ & $\mathrm{x}$ & $\mathrm{X}$ & - & $\mathrm{X}$ & $\mathrm{x}$ & $\mathrm{x}$ & - & $\mathrm{x}$ & $\mathrm{x}$ & $\mathrm{x}$ & - & $\mathrm{x}$ & $\mathrm{X}$ & $\mathrm{X}$ & - \\
\hline & 4 & Matemática & $\mathrm{x}$ & $\mathrm{X}$ & $\mathrm{X}$ & $\mathrm{x}$ & $\mathrm{X}$ & $\mathrm{X}$ & $\mathrm{x}$ & $\mathrm{X}$ & $\mathrm{X}$ & $\mathrm{x}$ & $\mathrm{x}$ & $\mathrm{X}$ & $\mathrm{x}$ & $\mathrm{x}$ & $\mathrm{X}$ & $\mathrm{x}$ \\
\hline & 5 & Ciências (Iniciação & $\mathbf{x}$ & $\mathbf{x}$ & - & - & $\mathbf{x}$ & $\mathbf{x}$ & - & - & $\mathbf{x}$ & $\mathbf{x}$ & - & - & $\mathbf{x}$ & $\mathbf{x}$ & - & - \\
\hline & & $\begin{array}{l}\text { a Ciências ou } \\
\text { C. Fís. e Biol.) }\end{array}$ & - & - & - & $\mathbf{x}$ & - & - & - & $\mathbf{x}$ & - & - & - & $\mathbf{x}$ & - & - & - & $\mathbf{x}$ \\
\hline \multirow{6}{*}{\multicolumn{2}{|c|}{$\begin{array}{l}\text { Disciplinas } \\
\text { Complementares } \\
\text { do } \\
\text { Sistema Federal }\end{array}$}} & Organiz. Social & - & - & $\mathrm{x}$ & $\mathrm{X}$ & - & - & - & - & - & - & - & - & - & - & - & - \\
\hline & & política brasil. & & & & & & & & & & & & & & & & \\
\hline & & 1a. L.estr. mod. & - & - & - & - & - & - & $\mathrm{x}$ & $\mathrm{x}$ & - & - & $\mathrm{x}$ & $\mathrm{x}$ & - & - & $\mathrm{x}$ & $\mathrm{x}$ \\
\hline & & 2a. L.estr. mod. & - & - & - & - & - & - & - & - & - & - & - & - & - & - & $\mathrm{x}$ & $\mathrm{x}$ \\
\hline & & Língua Clássica & - & - & - & - & - & - & - & - & - & - & $\mathrm{x}$ & $\mathrm{x}$ & - & - & - & - \\
\hline & & Desenho & - & - & $\mathrm{x}$ & $\mathrm{x}$ & - & - & $\mathrm{x}$ & $\mathrm{x}$ & - & - & - & - & - & - & - & - \\
\hline \multirow{2}{*}{\multicolumn{2}{|c|}{$\begin{array}{l}\text { Disciplinas } \\
\text { indicadas pelos } \\
\text { estabelecimentos }\end{array}$}} & 1a. optativa & $\mathrm{x}$ & $\mathrm{x}$ & - & - & $\mathrm{x}$ & $\mathrm{x}$ & - & - & $\mathrm{x}$ & $\mathrm{x}$ & - & - & $\mathrm{x}$ & $\mathrm{x}$ & - & - \\
\hline & & 2a. optativa & - & - & $\mathrm{x}$ & $\mathrm{x}$ & - & - & $\mathrm{x}$ & $\mathrm{x}$ & - & - & $\mathrm{x}$ & $\mathrm{x}$ & - & - & $\mathrm{x}$ & $\mathrm{x}$ \\
\hline
\end{tabular}

Fonte: BRASIL (1962a, p. 4558)

QUADRO 4 - Quadro exemplificativo de variedades admissíveis para a organização curricular do ciclo Colegial publicado no D.O.U de 24 de abril de 1962.

CICLO COLEGIAL (Variedades admissíveis)

$\left(1^{\mathrm{a}}\right.$ e $2^{\mathrm{a}}$ séries $)$

\begin{tabular}{|c|c|c|c|c|c|c|c|c|c|}
\hline & \multirow[b]{2}{*}{$x^{2}$} & & & & & & & & \\
\hline & & \multicolumn{2}{|c|}{$1^{\mathrm{a}}$ hipótese } & \multicolumn{2}{|c|}{$2^{\mathrm{a}}$ hipótese } & \multicolumn{2}{|c|}{$3^{\mathrm{a}}$ hipótese } & \multicolumn{2}{|c|}{$4^{\mathrm{a}}$ hipótese } \\
\hline & Séries $\longrightarrow$ & I & II & I & II & I & II & I & II \\
\hline \multirow{5}{*}{$\begin{array}{l}\text { Disciplinas indicadas } \\
\text { pelo } \\
\text { Cons. Federal }\end{array}$} & Português & $\mathrm{x}$ & $\mathrm{x}$ & $\mathrm{x}$ & $\mathrm{x}$ & $\mathrm{x}$ & $\mathrm{x}$ & $\mathrm{x}$ & $\mathrm{x}$ \\
\hline & História & $\mathrm{x}$ & $\mathrm{x}$ & $\mathrm{x}$ & $\mathrm{x}$ & $\mathrm{x}$ & $\mathrm{x}$ & $\mathrm{x}$ & $\mathrm{x}$ \\
\hline & Geografia & - & - & $\mathrm{x}$ & $\mathrm{x}$ & $\mathrm{x}$ & - & $\mathrm{x}$ & - \\
\hline & Matemática & $\mathrm{x}$ & $\mathrm{x}$ & - & - & - & - & - & - \\
\hline & C. Fís. e Biol. & - & - & $\mathbf{x}$ & $\mathbf{x}$ & - & $\mathbf{x}$ & $\mathbf{x}$ & $\mathbf{x}$ \\
\hline \multirow{7}{*}{$\begin{array}{l}\text { Disciplinas } \\
\text { Complementares do } \\
\text { Sistema Federal }\end{array}$} & Física & $\mathbf{x}$ & $\mathbf{x}$ & - & - & - & - & - & - \\
\hline & Química & $\mathbf{x}$ & $\mathbf{x}$ & - & - & - & - & - & - \\
\hline & Biologia & $\mathbf{x}$ & $\mathbf{x}$ & - & - & - & - & - & - \\
\hline & Filosofia & - & - & - & - & - & - & $\mathrm{x}$ & $\mathrm{x}$ \\
\hline & L. estr. mod. & - & - & $\mathrm{x}$ & $\mathrm{x}$ & $\mathrm{x}$ & $\mathrm{x}$ & $\mathrm{x}$ & $\mathrm{x}$ \\
\hline & L. clássica & - & - & - & - & $\mathrm{x}$ & $\mathrm{x}$ & - & - \\
\hline & Desenho & - & - & $\mathrm{x}$ & $\mathrm{x}$ & - & - & - & - \\
\hline \multirow{2}{*}{$\begin{array}{l}\text { Disciplinas indicadas } \\
\text { pelos } \\
\text { estabelecimentos }\end{array}$} & 1a. optativa & $\mathrm{x}$ & - & $\mathrm{x}$ & - & $\mathrm{x}$ & $\mathrm{x}$ & - & $\mathrm{x}$ \\
\hline & 2a. optativa & - & $\mathrm{x}$ & - & $\mathrm{x}$ & $\mathrm{x}$ & $\mathrm{x}$ & $\mathrm{x}$ & $\mathrm{x}$ \\
\hline
\end{tabular}

Fonte: BRASIL (1962a, p.4558)

\footnotetext{
${ }^{49}$ No documento do CFE, o termo "hipótese" têm sentido questionável, indicando assumir o significado de "alternativas" de organização da matriz curricular.
} 
Cabe lembrar que, a partir do texto da Indicação, quando se tratasse dos sistemas estaduais, as disciplinas complementares do segundo bloco nos quadros acima apresentados, seriam indicadas pelos Conselhos Estaduais de Educação e as optativas (terceiro bloco) pelos estabelecimentos de ensino dos estados da federação. Entretanto, até que fossem criados os Conselhos Estaduais, as disciplinas complementares indicadas para o sistema federal de ensino poderiam "ser sugeridas aos Estados pelo Ministro da Educação”. (BRASIL, 1962a, p. 4557). Neste caso, a lista de disciplinas sugeridas são as mesmas dispostas no Quadro 2, que apresentamos anteriormente.

Nota-se pelo Quadro 3 que, para o Ginasial, as disciplinas Português, História e Matemática configuram como núcleo comum aparecendo em todas as séries nas quatro alternativas de organização curricular. Para o Colegial (Quadro 4), esse núcleo comum se reduz a duas disciplinas: Português e História. O termo "núcleo comum" aparece na Indicação que traz esses quadros com a perspectiva de conjunto de disciplinas presentes em todas as séries em qualquer uma das alternativas de organização curricular sugerida pelo Conselho Federal de Educação. Isso indica que a disciplina Ciências Físicas e Biológicas (CFB) e seus desdobramentos em Física, Química e Biologia não fazem parte do "núcleo comum" nessa reforma curricular.

A nosso ver, fazer parte do núcleo comum no quadro da educação geral sublinha o grau de importância concedida à disciplina - se há fundamento nisto, podemos dizer que a CFB (e seus desdobramentos) acabou, de certa forma, sendo marginalizada no currículo.

Os quadros exemplificativos não apresentam sugestões de organização curricular para a $3^{\text {a }}$ série do ciclo Colegial, entretanto o texto do documento esclarece que esta série inclui de quatro a seis disciplinas, sendo uma delas, obrigatoriamente, Língua Portuguesa (BRASIL, 1962a). Essa orientação estava prevista na LDB/1961 em seu Art. 46, § 2º que traz:

A terceira série do ciclo colegial será organizada com currículo diversificado, que vise ao preparo dos alunos para os cursos superiores e compreenderá, no mínimo, quatro e, no máximo, seis disciplinas, podendo ser ministrada em colégios universitários. (BRASIL, 1961, Art. 46).

O Parecer $n^{\circ}$ 53, de 09.03.1962, que veio tratar especificamente dessa questão, não indicou as demais disciplinas da $3^{\text {a }}$ série, além de Língua Portuguesa que já estava determinada como obrigatória. Deixou livre a escolha do currículo, vista pelo CFE como etapa culminante do ensino secundário, seja para prosseguimento em estudos superiores, seja como etapa final dos estudos escolares. O referido Parecer traz: 
Das disciplinas de cada tipo curricular, existe uma desde já obrigatória - a língua portuguesa, à vista do que decidiu êste Egrégio Conselho, no art. $4^{\circ}$ da Indicação de março 50 último, referente às "normas para o ensino médio". As demais dependem das exigências de curso superior e, bem assim, das que se relacionem com a posição que tem a terceira série, - de cúpula da educação secundária. (BRASIL, 1962c, Documenta, p. 45).

Em síntese, o Parecer no 53/1962 se limitou a explicitar a finalidade propedêutica conferida à etapa final do ensino secundário anunciada na LDB, deixando livre a composição do currículo da $3^{\mathrm{a}}$ série, a partir da lista de disciplinas trazida na Indicação de Fevereiro de 1962.

Outra observação sobre as organizações curriculares dos quadros trazidos nesta mesma Indicação se refere à Educação Física, que não aparece em nenhuma das opções dos quadros exemplificativos, embora o texto do documento determine que esta seja uma prática educativa obrigatória. Não informa, assim como na LDB/1961, se seria obrigatória em todas as séries, ou somente em algumas do ensino médio.

Em 1969, o Ministério de Educação e Cultura, por meio da Diretoria de Ensino Secundário (DES), publicou um documento denominado "Consolidação da Legislação do Ensino Secundário, após a Lei de Diretrizes e Bases da Educação Nacional”. Esse documento traz o ementário de pronunciamentos do Conselho Federal de Educação e Atos Oficiais relativos ao Ensino Médio, publicados na Revista Documenta $^{51}$ de números 1 a 90.

Conforme a estrutura do referido documento, observa-se que os conteúdos dos pronunciamentos e Atos do Conselho Federal de Educação, proferidos após a LDB, foram aglutinados em um texto único organizado em artigos, parágrafos, incisos e alíneas, com o objetivo de melhor orientar os estabelecimentos de ensino quanto à solução dos problemas pedagógico-administrativos (BRASIL, 1969, p. 09). Assim, as orientações emanadas foram transcritas sem alterações textuais, indicando que as mesmas permaneciam em vigor ainda no final da década de 1960. Deste modo, as diretrizes quanto à organização curricular permaneceram centralizadas no Conselho Federal de Educação, ao que indica, até a reforma da LDB, em 1971.

Esse documento traz os quadros exemplificativos presentes na Indicação de Fevereiro de 1962, sem alteração da distribuição das disciplinas nas alternativas de organização curricular, porém com acréscimo de três linhas (ANEXO III). A primeira linha

\footnotetext{
${ }^{50} \mathrm{Na}$ verdade, a Indicação com as "Normas para o Ensino Médio" foi homologada em Fevereiro de 1962, e não em Março como afirmado neste trecho e foi publicada no D.O.U em 24 de Abril de 1962.

${ }^{51}$ A Revista Documenta, criada em 1962, era a revista oficial do antigo Conselho Federal de Educação (CFE), e ainda é do atual Conselho Nacional de Educação (CNE), que desde sua criação, tem publicado as deliberações dos Conselheiros, tais como: Pareceres, Indicações e Estudos Especiais.
} 
acrescentada consta Práticas Educativas indicando a Educação Física como uma "opção obrigatória" em todas as séries do ensino médio para alunos menores de 18 anos, podendo a escola incluir mais uma que poderia ser uma das opções de uma lista - a mesma constante na Indicação de Fevereiro/1962, ou outras a critério da escola (BRASIL, 1969). A segunda linha do quadro mostra a carga horária semanal máxima para as séries, no caso, 24 horas para todas. A terceira linha apresenta o título Atividades Complementares de Iniciação Artística, mas não indica o tipo, carga horária ou série, aparentando se referir às atividades extracurriculares não computadas nas 24 horas semanais.

Importante esclarecer os conceitos de disciplinas e práticas educativas trazidos na LDB/1961, já que no texto da norma, tais termos parecem estar dentro de um mesmo campo lexical. Segundo traz o Parecer no 131/1962 de 30.07.1962:

\footnotetext{
Entende-se por disciplina a atividade escolar destinada à assimilação de conhecimentos sistematizados e progressivos, passíveis de mensuração e que é condição de prosseguimento de estudos. [...] Por práticas educativas as atividades que correspondem às necessidades de ordem física, artística, cívica, moral e religiosa e que colocam o acento principal na maturação da personalidade com a formação de hábitos correspondentes, embora necessitem também da assimilação de certos conhecimentos (BRASIL, 1962d, PARECER nº 131/1962, Documenta n $^{\circ} 7,1962$, b
}

Assim, disciplina assume natureza mais objetiva e está relacionada ao conhecimento sistematizado a ser transmitido na escola para assimilação por parte do aluno e requer mensuração da aprendizagem. Já a prática educativa pressupõe maior subjetividade e prioriza o desenvolvimento da personalidade, da formação de valores, caráter, hábitos, etc. Não requer avaliação quantitativa, e tende a uma maior possibilidade de afinamento com interesses mais localizados, ainda que algumas delas, a Educação Física (obrigatória) e a Educação Cívica (optativa), por exemplo, se revelaram posteriormente como recurso de controle visando interesses, a fortiori, políticos.

\subsubsection{A presença das Ciências na organização curricular nos termos da LDB/1961}

O Artigo $1^{\circ}$ da LDB/1961 suscita conferir importância ao conhecimento científico como parte do contexto social do aluno, inserindo o tema como uma das finalidades da educação nacional. O referido artigo, em sua alínea "d", traz como finalidade: “o preparo do indivíduo e da sociedade para o domínio dos recursos científicos e tecnológicos que lhes permitam utilizar as possibilidades e vencer as dificuldades do meio." (grifo nosso). O Artigo 93 reforça tal importância quando coloca que os recursos financeiros destinados ao sistema de ensino público deveriam assegurar, entre outras prioridades, "o desenvolvimento do ensino 
técnico-cientifico" (BRASIL, 1961, Art. 93). Entende-se que, para que tal finalidade fosse levada a termo por meio das normas que regulamentaram a LDB, as disciplinas científicas deveriam lograr destaque em termos de presença e carga horária nos currículos das escolas.

Voltando ao Quadro 3, copiado da Indicação de Fevereiro/1962 do CFE, podemos constatar que, em todas as alternativas admissíveis sugeridas para o sistema federal de ensino, a área de Ciências está representada no ciclo ginasial em três das quatro séries, sendo contemplada em menor quantidade de séries do que a disciplina História. No Colegial (Quadro 4), disciplinas da área são obrigatórias em até duas séries, sendo que uma "hipótese" (a terceira) de organização curricular, as Ciências estão presentes em somente uma série como CFB. Somente uma hipótese sugerida para o Colegial traz a Ciência desdobrada em Física, Química e Biologia. Nas demais aparecem como CFB.

Nenhuma alternativa combinada (Ginasial e Colegial), contempla Ciências no limite máximo de quantidade de séries (6 séries) como possibilita o Artigo $1^{\circ}$ da Indicação ${ }^{52}$. Considerando o fato de que a disciplina Português estava prevista como obrigatória para a $3^{\mathrm{a}}$ série, esta e as demais disciplinas obrigatórias, com exceção das Ciências, alcançam o limite máximo previsto na Indicação em pelo menos uma alternativa. Disciplinas da área Ciências aparecem em, no máximo, 5 (cinco) séries em todo o ensino médio, nas alternativas sugeridas.

Em três das alternativas admissíveis para o Colegial não consta a disciplina Matemática (2 $2^{\mathrm{a}}, 3^{\mathrm{a}}$ e $4^{\mathrm{a}}$ "hipótese"). Assim, dependendo da opção para a organização curricular, as disciplinas científicas seriam pouco evidenciadas. Arriscamos conjecturar que tais alternativas (sem Matemática) não tenham sido assentidas pelas escolas brasileiras, uma vez que isso pudesse prejudicar o aluno que pretendesse prestar exames para acesso ao ensino superior.

Como fato, temos um exemplo do Estado do Rio de Janeiro, em que se pode verificar que a opção da escola foi pela " 1 a hipótese" sugerida pelo Conselho Federal de Educação. Analisamos um histórico escolar de uma cidadã que cursou o ensino médio no período de 1960 a 1967 em uma escola da rede pública de ensino do Estado do Rio de Janeiro (ANEXO IV). Os históricos dessa época não informavam carga horária, mas somente as disciplinas cursadas e notas finais $^{53}$. Constata-se que a ex-estudante cursou a disciplina Ciências nas $3^{\mathrm{a}} \mathrm{e}$ $4^{a}$ séries (trata-se de um caso que pegou a transição da reforma de 1942/1946 para a

\footnotetext{
${ }^{52}$ Art. $1^{\circ}$ - Constituirão disciplinas dos sistemas do ensino médio: Português (sete séries); História (seis séries); Geografia (cinco séries); Matemática (seis séries); Ciências (sob a forma de iniciação à ciência, 2 séries, sob a forma de ciências físicas e biológicas, 4 séries). (BRASIL, 1962a, p. 4557, grifo nosso).

${ }^{53}$ Analisando outro histórico de um ex-estudante de uma escola do Estado de Minas Gerais, constatou-se que também não apresenta carga horária até 1971.
} 
LDB/1961; tinha-se a disciplina Ciência nas duas últimas séries do Ginasial). No segundo ciclo, totalmente cursado na vigência da LDB/1961, além de outras disciplinas, cursou Matemática, Física, Química e Biologia nas $1^{\mathrm{a}}$ e $2^{\mathrm{a}}$ séries, e Física e Química na $3^{\mathrm{a}}$. Isso indica que a escola adotou a primeira das alternativas do quadro de variedades admissíveis contido na Indicação/1962 do CFE, em que as disciplinas das Ciências aparecem desdobradas em Física, Química e Biologia e que traz a disciplina Matemática. Essa cidadã se licenciou em Física. Como a $3^{\mathrm{a}}$ série seria de livre escolha da escola, podendo atender as perspectivas de preparo para cursos superiores (BRASIL, 1962b), fica subentendido, pelo exposto, que o currículo cursado nessa série foi direcionado para tal finalidade ( $3^{\mathrm{a}}$ série: Português, Matemática, Física, Química e Desenho).

Para efeito de ilustração sobre a presença de Ciências escolar nas reformas educacionais de 1930, 1942 e 1961, apresentamos o quadro a seguir, que nos possibilita comparar a situação da área nas três reformas educacionais. 
QUADRO 5 - Quadro comparativo da presença de disciplinas da área de Ciências nas reformas educacionais de 1932, 1942 e 1961.

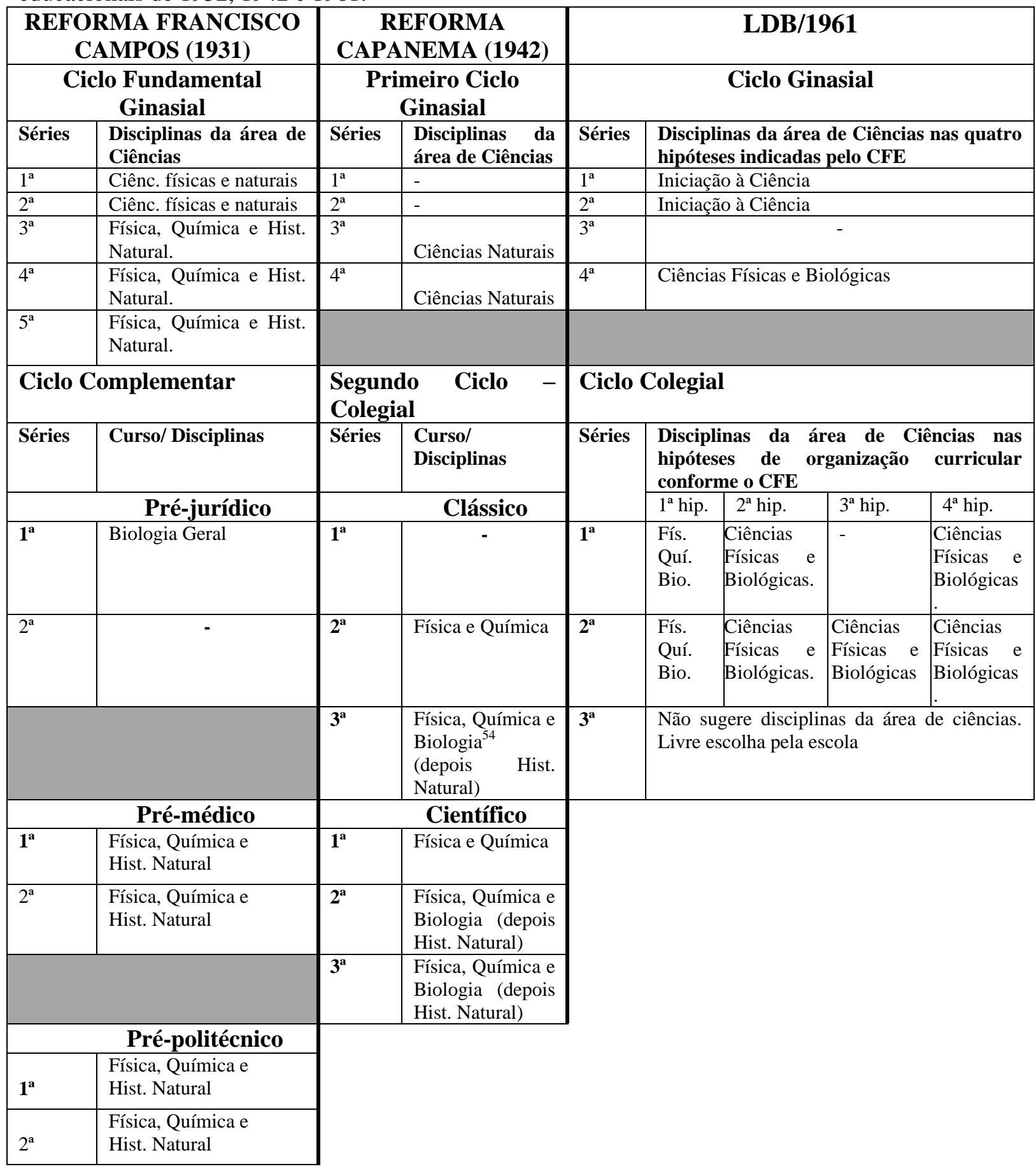

Fonte: BRASIL (1931; 1946a; 1951b; 1962a)

\footnotetext{
${ }^{54}$ Na Portaria no 05/1946 traz Biologia; já na Portaria no 966/1951 esta aparece como História Natural, como era antes, nos termos da Reforma de 1931.
} 
Comparando a Indicação do CFE, com as reformas anteriores, nota-se que não houve aumento da presença da área de Ciências no currículo, principalmente quando se compara com a reforma de 1931, que indicava disciplinas da área em todas as séries do ensino secundário, com exceção para a opção do curso complementar Pré-jurídico, que só trazia uma disciplina da área em uma série. Em quantidade de séries anuais abrangidas por disciplinas da área de Ciências (como obrigatórias), eram seis ou sete na Reforma Francisco Campos, quatro ou cinco na Reforma Capanema (ambos os casos dependendo do curso do $2^{\circ}$ ciclo) e quatro ou cinco a partir de 1961 (dependendo da alternativa adotada dentre as variedades admissíveis) conforme as orientações do CFE, nos termos da LDB. Quanto à Física, o quadro indica que também foi mais presente na reforma de 1931.

Importa ressaltar que a Indicação de Fevereiro de 1962, do CFE, autorizou a escolha de disciplinas que figuravam como obrigatórias em um tipo de currículo, para compor como optativas em outro tipo. Sendo assim, ficou a critério das escolas a inclusão [ou não] de disciplinas do rol das obrigatórias, como as da área de Ciências, por exemplo, como optativas no currículo escolar. Não temos dados para afirmar se isso ocorreu nas escolas públicas do país, todavia, a julgar pela escassez de profissionais habilitados (ALMEIDA JUNIOR, 1980; KRASILCHIK, 1980), suspeita-se que as disciplinas da área de Ciências não foram privilegiadas como substitutas das optativas. Podemos conjecturar, juntamente com Romanelli (1985), que as sugestões do CFE para o sistema federal foram acatadas também nos demais sistemas de ensino.

\footnotetext{
A possibilidade de os Estados e os estabelecimentos anexarem disciplinas optativas ao currículo mínimo estabelecido pelo Conselho Federal de Educação foi, sem dúvida, um progresso em matéria de legislação. Dissemos em matéria de legislação e dissemos bem, porque, na prática, as escolas acabaram compondo o seu currículo de acordo com os recursos materiais e humanos de que já dispunham, [...]. Quanto ao ensino secundário, a situação se agravava com o quadro de variações de currículo admissíveis, propostos pelo Conselho Federal de Educação para o sistema federal de ensino. Em vez de criar possibilidade de escolha, o Conselho acabou propondo quatro modelos de currículo, os quais, por sua vez, pouco se diferenciavam entre si e, o que é pior, acabaram sendo adotados pela maioria de nossas escolas. (ROMANELLI, 1985, p. 181-182, grifo itálico da autora, grifo negrito nosso).
}

É judicioso ponderar que, talvez, a distribuição por série nos quadros analisados não retrate fidedignamente a evidência dada às Ciências na organização curricular, uma vez que, mesmo estando presentes em menos séries, estas podem ter sido agraciadas com maior carga horária nas séries que as contemplaram. Entretanto, dados de uma pesquisa realizada em 1963, pela Diretoria do Ensino Secundário (DES), do MEC, representados por Nádia Cunha e Jayme Abreu (1965) da Divisão e Estudos e Pesquisas Educacionais do Centro Brasileiro de 
Pesquisas Educacionais (CBPE) desmistifica a ideia de que o ensino de Ciências tenha tido evidência nos currículos escolares com o advento da LDB/1961; ideia esta constantemente ratificada em vários trabalhos de pesquisa em ensino da área, como em Abrantes (2008), Bocasanta (2013), Rodrigues (2013) e outros, sendo que a maioria se referencia na afirmação de Krasilchik (2000), que coloca:

A Lei 4.024 - Diretrizes e Bases da Educação, de 21 de dezembro de 1961, ampliou
bastante a participação das ciências no currículo escolar, que passaram a figurar
desde o $1^{\circ}$ ano do curso ginasial. No curso colegial, houve também substancial
aumento da carga horária de Física, Química e Biologia. (KRASILCHIK, 2000,
p.86).

A DES/MEC realizou um levantamento dos currículos ginasiais secundários de escolas particulares de várias partes do país, estruturados após a vigência da LDB/1961. Segundo Cunha e Abreu (1965), foram analisados 1409 currículos, oferecidos por 1356 ginásios secundários da rede particular, o que, naquela época, correspondia a 53,1\% do total de colégios da rede particular do país (CUNHA; ABREU, 1965, p.308). Os resultados mostraram uma prevalência extrema de carga horária destinada às disciplinas de Português e Matemática, sendo a soma destas, equivalente a mais da metade da carga horária total das disciplinas obrigatórias. Um fato bastante evidenciado pelos pesquisadores foi a constatação da pouca ênfase dada à Ciência. Em vários trechos do texto analítico essa preocupação é evidente.

Os autores apresentam quadros que mostram a situação das cargas horárias para as disciplinas e prática educativa, obrigatórias. Os dados apresentados se referem às somas totais dos 1409 currículos analisados. A partir dos quadros de Cunha e Abreu (1965), elaboramos, no quadro a seguir, uma síntese dos dados por eles apresentados. Tais dados nos revelam o lugar das Ciências nos currículos analisados por esses autores.

QUADRO 6 - Síntese de dados sobre as cargas horárias semanal das disciplinas e prática educativa obrigatórias nos currículos analisados por Cunha e Abreu (1965).

\begin{tabular}{l|l|l|l}
\hline Disciplinas Obrigatórias & $\begin{array}{l}\text { \% sobre o total geral da carga } \\
\text { horária dos 1409 currículos }\end{array}$ & $\begin{array}{l}\text { Carga horária total das } \\
\text { 4 séries (em horas) }\end{array}$ & $\begin{array}{l}\text { Carga horária por } \\
\text { série (em horas) }\end{array}$ \\
\hline Português & $29,6 \%$ & 20,0 & 5,00 \\
\hline Matemática & $25,5 \%$ & 16,3 & 4,00 \\
\hline História & $13,8 \%$ & 9,0 & 2,25 \\
\hline Ciências & $\mathbf{1 1 , 4 \%}$ & $\mathbf{7 , 1 2}$ & $\mathbf{1 , 8 3}$ \\
\hline Geografia & $10,9 \%$ & 7,0 & 1,75 \\
\hline $\begin{array}{l}\text { Prática Educativa } \\
\text { Educação Física }\end{array}$ & $8,8 \%$ & 5,4 & 1,35 \\
\hline
\end{tabular}

Fonte: (CUNHA; ABREU, 1965, RBEP. V.44, n.100, 1965, grifo nosso).

\footnotetext{
${ }^{55}$ Dados aproximados.

56 Modificamos a forma de apresentação dos dados de tempo "horas+minutos" para somente "horas", sem alteração dos valores apresentados nos quadros originais de Cunha e Abreu (1965). Dados aproximados.
} 
Os dados do Quadro 6 revelam que, das disciplinas obrigatórias, somente a Geografia possui carga horária inferior às Ciências. Os autores chamam a atenção para o fato de a disciplina História possuir carga horária maior que Ciências, e também, pela ausência de Ciências na terceira série do ensino ginasial, estando os currículos analisados consonantes com os quadros exemplificativos indicados pelo CFE na Indicação de Fevereiro/1962.

Não deixa de ser assinalável a maior carga horária semanal dedicada à história em relação a ciências, como também o fato de não haver, em todos os currículos da amostra, o ensino de ciências na terceira série e o de geografia na quarta série. [...] Admite-se que esse tipo de currículo sem estudo de "Ciências" na terceira e sem Geografia na quarta série adviesse de filiação estrita a modelos de currículo emanados do Conselho Federal de Educação, constantes da Circular n. ${ }^{\circ} 1 / 62$, da Diretoria do Ensino Secundário, com a referência "Variedades Admissíveis" nos quais, em quatro hipóteses configuradas como "admissíveis", não há ensino de Ciência na $3^{\mathrm{a}}$ nem de Geografia na $4^{\mathrm{a}}$ série. (CUNHA; ABREU, 1965, p. 299).

Além da questão da pouca Ciências nos currículos analisados, Cunha e Abreu (1965) evidenciam ainda a maciça presença do Latim em detrimento de disciplinas ou práticas educativas mais instrumentais, conforme colocam os autores:

A presença de Latim com 346 inclusões contra apenas 10 de (ao menos expressamente) Dactilografia, o maior ensino de História do que de Ciências (sem entrar na análise de como ensinadas), são índices da remanescência na escola de padrões culturais arcaicos, mais polarizados no sentido do ornamental do que no do instrumental. Nesse caso concreto, como situação fatual, é possível devam também ser levadas em conta situações profissionais de professôres herdados da antiga escola de letras. Por outro lado, nessa dominância de línguas (que é necessário tenha sentido mais prático do que formal) e história e subpresença de ciências e de disciplinas variáveis ou práticas educativas que requeiram maiores gastos no equipamento para seu ensino, há também indício indisfarçável da pobreza brasileira ou de situações em que a preocupação pela eficiência pedagógica não será talvez o supremo valor. (CUNHA; ABREU, 1965, p. 308, grifo nosso).

Não se trata de desmerecimento por uma ou outra disciplina. As críticas dos pesquisadores se assentam no ideário contextual de uma escola que carecia de estar identificada com o momento de mudança de modelo econômico que o Brasil vivenciava. No contexto em questão, já não cabia mais um ensino erudito, sem funcionalidade prática, conforme colocam:

Nessa fase transitiva de nossa cultura percebe-se o hiato existente entre o ginásio secundário comum, como instituição formal e o substrato real no qual deve atuar. Se coubera no caso um "slogan" promocional poder-se-ia recomendar para escolas secundárias comuns, de primeiro ciclo, em consonância com a cultura geral do nosso tempo: mais ciência, mais dactilografia e menos latim! Esse "slogan", que deverá chocar os saudosistas da belle époque, tem toda via completo sentido no contexto ao qual se aplicaria: uma escola modernizada, de cultura geral comum, uma escola para todos, que tenha deixado de ser monopólio de uma clientela aristocrática e formalista para dar lugar à predominância, nos seus propósitos, do instrumental sôbre o ornamental. (CUNHA; ABREU, 1965, p. 306 - 307, grifo itálico dos autores, grifo negrito nosso). 
Os referidos dados, de 1963, embora aludam às escolas da rede particular, levam-nos a crer que situação similar possa ter ocorrido nas escolas da rede pública, pois, em tese, estas tendem a seguir as indicações das instâncias superiores. Ao esclarecer a abrangência das normas oriundas da Diretoria do Ensino Secundário, com relação às escolas federais, e das Secretarias de Educação, com relação às escolas estaduais e particulares, o Parecer $\mathrm{n}^{\circ}$ 12/1962, de 04.03.1962, traz que todas estas instituições estão subordinadas às normas comuns aos estabelecimentos do mesmo Estado ou da mesma região (BRASIL, 1962b, p.84). Conforme é esclarecido em outro documento ${ }^{57}$ do MEC que cita o referido Parecer, o termo "Escolas federais" no texto do mesmo "é puro eufemismo". Na realidade, tal termo se refere a todos os estabelecimentos filiados ao sistema federal (BRASIL, 1969, p. 14). Desse modo, as escolas particulares seriam subordinadas aos Sistemas Estaduais, que por sua vez, se respaldavam (e ainda se respaldam) nas normas federais para elaborarem as suas.

Acreditamos que tal interpretação nos autoriza considerar os dados da pesquisa de Cunha e Abreu (1965) como apropriados para o entendimento da relevância dada às Ciências nos currículos brasileiros do início da década de 1960 (após a LDB), de um modo geral, ainda que se refiram às escolas particulares.

Um ponto importante a ressaltar é que o levantamento da DES/MEC ocorreu para o curso Ginasial. Assim, não se pode afirmar categoricamente que o mesmo ocorreu com as disciplinas científicas do curso Colegial em todo o país. Entretanto, alguns exemplos podem ser considerados para que se tenha uma ideia da presença das disciplinas científicas nos currículos após a LDB/1961, inclusive no Colegial.

$\mathrm{O}$ primeiro que citaremos se refere à organização curricular do Ginásio Único Pluricurricular (GUP) criado no Estado de São Paulo, em 1963.

A Resolução no 07, de 23.12.1963, do Conselho de Educação do Estado de São Paulo $(\mathrm{CEE} / \mathrm{SP})^{58}$, estabeleceu normas para a organização dos currículos dos cursos de grau médio para aquela modalidade de ginásios ${ }^{59}$ que estava sendo criada, inspirada na experiência dos Colégios Vocacionais iniciados em 1962, adotando um sistema integrado com diversificações que abrangiam os diferentes ramos do $1^{\mathrm{o}}$ e $2^{\mathrm{o}}$ ciclos: cursos secundário, técnico (industrial, comercial, agrícola, de economia doméstica), artístico e de formação de professores primários. As orientações quanto às disciplinas obrigatórias, complementares do Conselho

\footnotetext{
${ }^{57}$ Consolidação da Legislação do Ensino Secundário, após a Lei de Diretrizes e Bases da Educação Nacional (1969)

${ }^{58}$ O CEE/SP foi criado pela Lei ${ }^{\circ} 7.940$ de 7 de Junho de 1963.

${ }^{59}$ Embora essa modalidade de escola tenha recebido o nome de Ginásio, esta acomodava os cursos Ginasial e Colegial.
} 
Estadual e optativas pelas escolas foram as mesmas dadas pelo CFE na Indicação de Fevereiro/1962. Apresenta listas de disciplinas e orientações quanto à escolha para compor o currículo. Tal Resolução traz também alguns quadros exemplificativos similares aos sugeridos pelo CFE na referida Indicação (ANEXO V).

Para o Ginasial e Colegial Secundário são sugeridas três alternativas. No que se refere ao Ginasial são somente opções de organização sem nenhuma orientação especial, exceto pela quantidade de séries que contempla a disciplina Geografia, em uma das opções aparece em três, e nas demais, em duas. Quanto ao restante das disciplinas, em termos de séries, aparecem em quantidades iguais, variando a distribuição: Português e Matemática em todas as séries (em todas as orientações); História em três séries (em todas as orientações); Geografia em duas ou três, e CFB em duas séries (em todas as orientações). Essa configuração corrobora o que constatou Cunha e Abreu (1965) nas escolas particulares do país, quando se observa que a disciplina CFB aparece em menor quantidade de séries do que a disciplina História. Nesse caso, dependendo da opção escolhida pela escola, perdia também para a Geografia, ocupando a última posição em termos de presença (cf. ANEXO V).

Para o Colegial, as três alternativas sugeridas se referem às orientações de curso denominadas "eclética, científica e clássica". Não se identificam definições precisas sobre tais orientações no documento. Pelas sugestões de composição dos currículos para as disciplinas obrigatórias nessas orientações, fica subentendido que na primeira há um equilíbrio quantitativo de disciplinas científicas e humanidades. Na segunda, predominam as disciplinas científicas, e, na terceira, as de humanidades. No "clássico", por exemplo, não sugere a Matemática, mas traz CFB. No "eclético" e no "científico" não traz História e Geografia como no clássico, mas sim Estudos Sociais. O que diferencia o "eclético" do "científico", é a CFB, que aparece em uma série para o "eclético", e em duas para o "científico".

Para os cursos técnicos, os quadros exemplificativos apresentam somente uma sugestão de organização curricular no que se refere às disciplinas obrigatórias indicadas pelo CFE, bem como as definidas pelo CEE/SP, deixando em aberto a escolha das optativas a partir de listas de disciplinas específicas de cada ramo de ensino (uma quantidade significativa de opções). Orienta ainda sobre a possibilidade de escolher como optativas, disciplinas do grupo das obrigatórias do ensino Colegial secundário.

Conforme consta no texto da Resolução nº 07/CEE-SP/1963, Ciências Físicas e Biológicas está presente da seguinte forma:

$\rightarrow$ Ciclo Ginasial: obrigatória (Iniciação) em duas séries $\left(1^{\mathrm{a}}\right.$ e $\left.2^{\mathrm{a}}\right)$ em todas as opções sugeridas; 
$\rightarrow$ Curso Colegial Secundário: obrigatória nas orientações "eclético" e "clássico", em uma série $\left(2^{\mathrm{a}}\right)$, e na orientação “científico", em duas séries $\left(1^{\mathrm{a}}\right.$ e $\left.2^{\mathrm{a}}\right)$;

$\rightarrow$ Curso Colegial Técnico Industrial: obrigatória em uma série (apresenta um quadro exemplificativo que sugere na $1^{\mathrm{a}}$ série);

$\rightarrow$ Curso Colegial Técnico Comercial: CFB como uma sugestão de escolha para optativa concorrendo com Língua Moderna, Filosofia, Sociologia e Desenho;

$\rightarrow$ Curso Colegial de Formação de Professores Primários: como obrigatória em uma

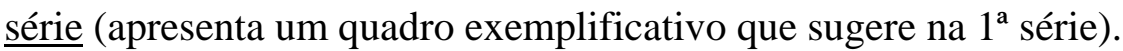

(SÃO PAULO, 1963, RBEP, V.44, n.100, 1965, p. 108-111).

As orientações para o GUP não apresentam carga horária para as disciplinas, e nos permitem conclusões somente quanto à presença de Ciências no currículo em termos de número de séries contempladas. Entretanto, outro exemplo, também referente ao Estado de São Paulo, fornece-nos evidências mais consistentes de que o currículo não logrou significativas mudanças ao longo da década de 1960. Trata-se da reforma do ensino médio Colegial Secundário e Normal ocorrida pela Lei Estadual $n^{\circ} 10.038$ de 05.02.1968 ${ }^{60}$. Tal reforma diversificou o segundo ciclo do ensino médio em Colégio Secundário, Colégio Técnico (Comercial, Agrícola, Industrial e outros) e Colégio Normal, seguindo a linha do GUP. As instruções de aplicação das normas da Resolução que regulamentou o currículo nessa reforma foram dadas pelo Ato $\mathrm{n}^{\mathrm{o}} 24$ de 29.02.1969, que traz em seu Art. $2^{\mathbf{o}}$ quatro possibilidades de organização do currículo comum nas duas primeiras séries do ensino Secundário e Normal para todos os estabelecimentos de ensino oficiais e particulares do Estado de São Paulo, com determinação expressa de adoção de apenas uma das opções. As opções dadas foram:

I - Português, Matemática, Geografia, História, Ciências Físicas e Biológicas, uma língua [Latim, Francês ou Inglês] e uma disciplina optativa.

II - Português, Matemática, Geografia, História, uma Ciência Física ou Biológica, uma língua [Latim, Francês ou Inglês] e uma disciplina optativa.

III - Português, Matemática, Estudos Sociais, Ciências Físicas e Biológicas, uma língua [Latim, Francês ou Inglês] e uma disciplina optativa.

IV - Português, Matemática, Estudos Sociais, uma Ciência Física ou Biológica, uma língua [Latim, Francês ou Inglês] e uma disciplina optativa. (SÃ PAULO, 1969, Art. $2^{\circ}$, grifo nosso).

Compreende-se que, nas opções de configurações curriculares impostas, a Ciência está representada em qualquer uma delas em duas séries do Colegial, como $\underline{\mathrm{CFB}}$ ou como umas das disciplinas científicas específicas. Entretanto, para as opções II e IV limitou-se representá-la por somente uma das "subdisciplinas" da área. Conforme o documento, a

\footnotetext{
${ }^{60}$ Regulamentada pelo Decreto Estadual nº 50.133/1968 e Resolução CEE/SP n n 36/1968.
} 
ciência física se refere à Física e Química, e a biológica se refere à Biologia (SÃO PAULO, 1969, Art. $2^{\circ}$ ). Ao eleger uma das opções dentre as II e IV, a Física poderia nem ser contemplada. O mesmo poderia ocorrer com a Química e a Biologia se a Física figurasse no currículo. Quanto à carga horária, o Artigo $7^{\circ}$ do referido Ato, traz:

Artigo $7^{\circ}$ - Nas duas primeiras séries do ciclo colegial secundário e normal os estabelecimentos de ensino oficiais manterão para as disciplinas obrigatórias e optativas a seguinte carga horária semanal mínima:

a) Português - três aulas em cada série.

b) Matemática - duas aulas em cada série.

c) Geografia - duas aulas em cada série.

d) História - duas aulas em cada série.

e) Estudos Sociais - quatro aulas em cada série.

f) Ciências Físicas e Biológicas - quatro aulas em cada série.

g) Disciplina científica isolada (caso previsto no parágrafo $2^{\circ}$ do Artigo $2^{\circ}$ ) três aulas em cada série.

h) Língua - duas aulas em cada série.

i) Cada disciplina optativa - duas aulas em cada série.

(SÃO PAULO, 1969, grifo nosso).

Observa-se que a carga horária das disciplinas científicas, se isoladas, é de três aulas $^{61}$ semanais em cada série, considerando a adoção do limite mínimo. Tendo em vista o número de disciplinas que deveria compor o quadro curricular (7 disciplinas), e a carga horária total de 24 a 27 aulas semanais, incluindo as práticas educativas (com carga horária semanal mínima para o conjunto delas, de 3 aulas em cada série), não nos parece provável que a carga horária de cada disciplina obrigatória tenha ultrapassado o limite mínimo previsto, em quantidade significativa.

Cabe ressaltar que, adotando as opções que trazem CFB, a carga horária de quatro aulas semanais para a mesma configuraria uma média de 1,33 aulas para atividades de cada "subdisciplina" (Física, Química, Biologia), caso as atividades de tal disciplina fossem assim desenvolvidas em sala de aula. Convém ressaltar ainda que, estando a CFB já inserida na ideia de "área de estudo" nesse contexto, ainda que fosse para a $3^{\text {a }}$ série, é admissível pressupor que, em sala de aula, uma ou outra subárea tenha sido privilegiada, no caso das opções de organização curricular I e III.

Ainda sobre o Estado de São Paulo, em pesquisa sobre o Ensino da Física na Grande São Paulo, realizado no final da década de 1960 e início da década de 1970, Carvalho (1972) apresenta um levantamento da carga horária de Física nas escolas da capital, em três tipos delas: Institutos Estaduais de Educação (IEE), Colégios e Escolas Normais Estaduais (CENE) e Colégios Estaduais (CE). Os dados da autora mostram que a carga horária era maior nos grandes estabelecimentos de ensino, variando a média de 9 a 10 horas/aulas semanais no total

\footnotetext{
${ }^{61}$ Tempo de cada aula $=50 \mathrm{~min}$
} 
das três séries (como exemplo, 3-2-4 ou 3-3-4), contudo, estes estabelecimentos representavam somente $18,6 \%$ do total da rede de ensino da capital. Nos demais colégios analisados a média era de 8 horas/aulas semanais no total das três séries (2-2-4).

Um segundo exemplo se refere à reestruturação curricular do Estado do Paraná, em 1962. O currículo foi reestruturado de forma que o primeiro ciclo contemplou o curso Ginasial e Ensino Técnico-Comercial grau Ginasial, e no segundo ciclo, o Colegial foi dividido em Educação Geral (orientação clássica e científica) e Profissionalizante (Comercial,...). Em um documento denominado Currículos do Ensino Médio - Fixados pela S.E.C. para os estabelecimentos estaduais de ensino médio no ano letivo de 1962 (PARANÁ, 1962a) encontramos as grades curriculares do curso Ginasial e Ensino Técnico-Comercial grau Ginasial; Colegial (orientação científica, orientação clássica, Curso Normal grau Colegial e Ensino Técnico-Comercial de Grau Colegial) determinadas pela Portaria (estadual) $n^{\circ}$ 873/1962, para as escolas estaduais paranaenses seguirem no ano de 1962 (PARANÁ, 1962, p. 09-14). Conforme as grades curriculares, o ensino de Ciências está presente da seguinte forma, com as cargas horárias semanais:

$\rightarrow$ Ginasial: Iniciação às Ciências - $1^{\mathrm{a}}$ série (2 aulas); $2^{\mathrm{a}}$ série (2 aulas), tanto nos cursos diurnos, quanto noturnos; CFB - $4^{\mathrm{a}}$ série diurna ( 3 aulas); $4^{\mathrm{a}}$ série noturna (2 aulas).

$\rightarrow$ Ginasial Ensino Técnico Comercial: Iniciação às Ciências - $1^{\mathrm{a}}$ série ( 3 aulas); $2^{\mathrm{a}}$ série (3 aulas); CFB - $4^{\mathrm{a}}$ série diurna e noturna (2 aulas).

$\rightarrow$ Colegial orientação clássica - Não tem Ciências

$\rightarrow$ Colegial Orientação científica: Física - nas três séries, diurno e noturno, com 3 aulas em cada série; Química - com 2, 2 e 3 aulas, respectivamente, nas três séries, diurno e noturno; Biologia - nas $2^{\mathrm{a}}$ e $3^{\mathrm{a}}$ séries, diurno com 3 aulas em cada série e noturno com 2 aulas.

$\rightarrow$ Colegial Normal: Ciências - nas $1^{\mathrm{a}}$ e $2^{\mathrm{a}}$ séries, diurno com 3 aulas em cada série e noturno com 2 aulas em cada.

$\rightarrow$ Colegial Técnico-Comercial: CFB - somente na $1^{\text {a }}$ série com 2 aulas, diurno e noturno.

Observa-se dessa organização curricular, que as aulas de Ciências variam entre duas e três aulas semanais, dependendo do curso/orientação e do turno. Quanto à presença nas séries, variam de 0 a 3 séries. No Ginasial seguiram-se à risca as sugestões do CFE (Indicação de Fevereiro/1962) não contemplando Ciências na $3^{a}$ série. Outra observação notável na grade curricular, é que, corroborando as conclusões de Cunha e Abreu (1965), as Ciências se apresentam em menor evidência em relação a todas as demais disciplinas obrigatórias, ou 
seja, ocupa a última posição em termos de presença e carga horária ${ }^{62}$. No segundo ciclo, a situação não se difere dos demais exemplos já citados e também do currículo da reforma nacional anterior (Reforma Capanema).

Um terceiro exemplo se refere à organização curricular de uma escola de Curso Normal da cidade de Diamantina-MG. Analisamos históricos escolares de alunos que cursaram o ciclo Ginasial de 1964 a 1967, e Colegial, $1^{\text {a }}$ série, no ano de 1968. Não foi possível verificar a carga horária, pois os históricos dessa época não trazem tal informação. Em um modelo de formulário/histórico exatamente igual ao modelo utilizado pela escola do Rio de Janeiro (já citado), observa-se que não havia Ciências na $3^{\text {a }}$ série, o que evidencia a consonância com os modelos de currículo do CFE. Observamos ainda que, na $1^{\text {a }}$ série do Colegial não aparecem disciplinas da área de Ciências, ou seja, não contempla Física, Química ou Biologia.

As situações descritas, especialmente a do Estado de São Paulo (1963), sendo um caso de proposta experimental inovadora em um contexto político-econômico-social em que o conhecimento científico impetrava atenção, sancionam a ideia de que não se deu tanta evidência às disciplinas científicas em termos de presença e carga horária nos currículos do ensino secundário.

Se compararmos a distribuição de carga horária dos currículos citados, com as reformas educacionais nacionais imediatamente precedentes à LDB/1961, podemos constatar que não houve aumento. No quadro curricular obrigatório vigente até a LDB (BRASIL, 1951), disciplinas da área variavam de duas a três aulas semanais em cada série (cf. Quadro 7). Para o Colegial, cada série contemplava no mínimo duas disciplinas científicas específicas de Ciências da Natureza e estas estavam presentes em no mínimo duas séries.

\footnotetext{
62 Importante pontuar que, em um colégio desse Estado ocorreu a adoção de cargas horárias semanais maiores para as disciplinas das Ciências da Natureza. Entretanto, parece tratar-se de um caso especial e isolado. Referimo-nos ao currículo do Colégio Estadual do Paraná que sofreu alterações na estrutura curricular via Portaria Estadual No $1.749 / 1962$ de 11 de maio de 1962, por solicitação da própria instituição, aproveitando-se da flexibilidade apregoada na LDB/1961, como também na Portaria que definiu os currículos do Estado para ano de 1962 (Portaria n ${ }^{\circ}$ 873/1962). Esse colégio solicitou e granjeou aprovação para uma estrutura curricular organizada por "tendências" no primeiro ciclo (Tendência à História; Matemática e Ciências; Tendência às Línguas e Tendência às Línguas Clássicas), e por "ramos" no segundo ciclo, com proposta de cursos de orientação científica e cursos de orientação clássica. O ramo Ciências no segundo ciclo trazia como proposta os cursos: Ciências Matemáticas; Ciências Biológicas e Curso Eclético. O ramo Humanidades contemplava os cursos: Ciências Sociais; Geografia e História e Línguas. Nessa estrutura, disciplinas das Ciências se apresentavam com cargas horárias semanal que variavam de 2 a 3 aulas no primeiro ciclo, e de 4 a 6 no segundo ciclo (PARANÁ, 1962). Curioso é que, no primeiro ciclo, na Tendência História, a disciplina Ciências aparece com carga horária maior do que na Tendência Matemática Ciências. Esse paradoxo se repete no segundo ciclo, sendo as cargas horárias de Química e Física maiores no curso Ciências Biológicas do que no curso Ciências Matemática.
} 
QUADRO 7 - Carga horária semanal das disciplinas da área Ciências da Natureza nas reformas de 1931 e 1942.

\begin{tabular}{|c|c|c|c|c|c|c|c|c|c|c|c|c|c|c|c|c|c|c|c|c|c|c|c|c|}
\hline \multirow[b]{4}{*}{$\begin{array}{l}\text { Séries/ } \\
\text { Discip. }\end{array}$} & \multicolumn{11}{|c|}{ Reforma Francisco Campos } & \multicolumn{13}{|c|}{ Reforma Capanema } \\
\hline & \multirow{2}{*}{\multicolumn{5}{|c|}{$1^{\circ}$ ciclo }} & \multicolumn{6}{|c|}{$2^{\circ}$ ciclo } & \multirow{2}{*}{\multicolumn{4}{|c|}{$1^{\circ}$ ciclo }} & \multicolumn{9}{|c|}{$2^{\circ}$ ciclo } \\
\hline & & & & & & \multicolumn{2}{|c|}{$\begin{array}{l}\text { Pré- } \\
\text { Juríd. }\end{array}$} & \multicolumn{2}{|c|}{$\begin{array}{c}\text { Pré- } \\
\text { Médico }\end{array}$} & \multicolumn{2}{|c|}{$\begin{array}{l}\text { Pré- } \\
\text { Polit. }\end{array}$} & & & & & \multicolumn{3}{|c|}{$\begin{array}{l}\text { Clássico o/ } \\
\text { grego }\end{array}$} & \multicolumn{3}{|c|}{$\begin{array}{c}\text { Clássico s/ } \\
\text { grego }\end{array}$} & \multicolumn{3}{|c|}{ Científico } \\
\hline & $1^{2}$ & $2^{2}$ & $3^{\mathrm{a}}$ & $4^{2}$ & $5^{2}$ & $1^{2}$ & $2^{2}$ & $1^{2}$ & $2^{\mathbf{a}}$ & $1^{2}$ & $2^{2}$ & $1^{2}$ & $2^{2}$ & $3^{2}$ & $4^{2}$ & $1^{2}$ & $2^{2}$ & $3^{\mathbf{a}}$ & $1^{2}$ & $2^{2}$ & $3^{2}$ & $1^{2}$ & $2^{a}$ & $3^{2}$ \\
\hline $\begin{array}{l}\text { Ciên. } \\
\text { fisicas } \\
\text { e nat. }\end{array}$ & 2 & 2 & - & - & - & - & - & - & - & - & - & & & & & & & & & & & & & \\
\hline $\begin{array}{l}\text { Ciên. } \\
\text { Nat. }\end{array}$ & & & & & & & & & & & & - & - & 2 & 3 & - & - & - & - & - & - & - & - & - \\
\hline Fisica & - & - & 2 & 2 & 2 & - & - & 5 & 5 & 3 & 4 & - & - & - & - & - & 2 & 2 & - & 2 & 2 & 3 & 3 & 3 \\
\hline Quí. & - & - & 2 & 2 & 2 & - & - & 6 & 6 & 4 & 5 & - & - & - & - & - & 2 & 2 & - & 2 & 3 & 3 & 3 & 3 \\
\hline $\begin{array}{l}\text { Hist. } \\
\text { Nat. }\end{array}$ & - & - & 2 & 2 & 3 & - & - & 6 & 6 & 4 & 4 & & & & & - & - & 3 & - & - & 3 & 3 & 3 & 3 \\
\hline $\begin{array}{c}\text { Bio. } \\
\text { Geral }\end{array}$ & - & - & - & - & - & 3 & - & - & - & - & - & & & & & & & & & & & & & \\
\hline
\end{tabular}

Fonte: SOUZA, 2008, p. 153 e 162; BRASIL, 1951, RBEP, vol. XVI, Out.-Dez. de 1951, n. 44, p. 251-253.

As situações mostradas indicam que, em termos de carga horária e presença, em relação à Reforma de 1931 , houve redução, e em relação à de $1942^{63}$, ou manteve uma situação similar, ou também reduziu o espaço das Ciências no currículo do ensino médio, dependendo da opção de organização curricular.

Talvez os exemplos citados não sejam suficientes para concluir por uma regra geral. Contudo, considerando as limitações impostas pelas normas oriundas da LDB/1961, quanto ao número de disciplinas e práticas educativas obrigatórias e à carga horária total semanal para cada série, nos admite pensar que a situação em todo o país, reminiscente de uma educação humanística (CUNHA; ABREU, 1965), e ainda carente de professores preparados para ministrar as disciplinas da área científica, especialmente a Física (BRASIL, 1965a, Parecer n 931; ALMEIDA JUNIOR, 1979; BONETTI, 2013), não apresente significativas diferenças. É preciso ressaltar ainda a influência que o Estado de São Paulo tinha (e ainda tem) nas diretrizes educacionais nacionais. Assim, não seria exagero admitir que seus currículos tivessem sido tomados como exemplo por outros estados da federação.

Os exemplos aqui apresentados, sobre a presença das Ciências da Natureza no currículo escolar a partir da LDB/1961, se ativeram à situação da década de 1960. Mais adiante, mencionaremos mais alguns dados sobre essa temática, no que se refere à década de 1970, na vigência da Lei 5.692/1971.

\footnotetext{
${ }^{63}$ Estamos considerando aqui o que traz a última Portaria que definiu os quadros curriculares vigentes até à promulgação da LDB/1961, a Portaria $n^{\circ}$ 966/1951. Localizamos uma anterior, Portaria $n^{\circ}$ 05/1946, que traz outras cargas horárias (em alguns casos, um pouco maiores) para as disciplinas das Ciências, bem como diferença de nomenclatura para uma delas: a Biologia, que voltou a ser História Natural na Portaria de 1951.
} 


\subsubsection{O currículo das Ciências na LDB/1961}

Ainda que a LDB previsse que seria atribuição do CFE intervir no desenvolvimento dos programas das disciplinas obrigatórias, conforme traz em seu Art. 35, este órgão institucional se limitou à definição de quais deveriam ser essas disciplinas obrigatórias, e determinou um rol de disciplinas complementares e optativas para a composição do currículo. Desse modo, não foram indicados programas de ensino das disciplinas (listas de temas e tópicos de conteúdos), como ocorria no sistema de ensino das reformas anteriores. A respeito disso, a flexibilidade é clara na LDB ao colocar:

Art. 20. Na organização do ensino primário e médio, a lei federal ou estadual atenderá:

a) à variedade de métodos de ensino e formas de atividade escolar, tendo-se em vista as peculiaridades da região e de grupos sociais;

b) ao estímulo de experiências pedagógicas com o fim de aperfeiçoar os processos educativos. (BRASIL, 1961).

Atendendo parcialmente ao texto da Lei, o CFE ateve-se às recomendações gerais publicadas por meio da Indicação s/n\%62 da Comissão de Ensino Primário e Médio (CEPM), em outubro de 1962, onde consta:

$[\ldots]$

II - os programas de Português, Matemática, História, Geografia e Ciências e o das atividades de Educação Física serão organizados pelas escolas de nível médio, com observância das recomendações desta indicação, ora formuladas em caráter provisório, sem prejuízo de inovações que se lhe possam acrescentar, desde que influídas pelo mesmo espírito desta indicação.

III - É assegurada plena liberdade aos autores de livro didático. (BRASIL, 1962e, p.01, datilografado)

Ressalte-se que, embora o texto mencione que as recomendações foram formuladas em caráter provisório, não identificamos outras orientações posteriores, nessa perspectiva. Transcrevemos a seguir um excerto do documento oficial referente às recomendações gerais para o ensino de Ciências, o qual analisaremos sucintamente.

\section{CIÊNCIAS}

VII - As disciplinas "Iniciação à Ciências" e Ciências Físicas e Biológicas" não devem ser consideradas predominantemente em seu conteúdo ou quantidade de matéria exigida.

O essencial é a orientação didática do curso que deverá ter em vista o desenvolvimento de hábitos e atividades peculiares aos que se dedicam à pesquisa científica, principalmente à capacidade de iniciativa e de invenção.

Assim sendo, os métodos usados no ensino não são menos importantes do que os fatos ou leis ensinados, com o que não se pretende subestimar a importância dos conhecimentos, senão evitar que se continue a insistir na simples memorização de noções.

Muito se conseguirá não só apreciando-se a contribuição dos cientistas do passado e do presente e lançando-se em relevo a importância da ciência e do método científico para o progresso da humanidade, mas também, e principalmente, reduzindo-se as aulas puramente expositivas, incentivando-se o hábito de consulta à 
biblioteca adequada ao nível dos alunos e estimulando-se as atividades individuais, tais como a observação e a experimentação próprias, a construção de aparelhos científicos, a organização de coleções, o preparo de quadros, murais, a realização de excursões, etc.

Para a execução desses objetivos, disporá o professor dos mais variados temas, que serão escolhidos de acordo com os recursos de que dispuser.

$\mathrm{O}$ ar, a água, o solo, a luz, o calor, o som, a eletricidade e o magnetismo, entre outros, levarão o aluno a compreender a importância do meio, a necessidade de explorar os recursos naturais e as possibilidades de sua utilização.

Como segunda fase, o estudo dos seres vivos, plantas e animais sem consideração excessiva dos aspectos morfológicos e sistemáticos, proporcionará rico material para melhor entendimento das relações entre a vida e o meio, bem como o conjunto de funções indispensáveis à existência de qualquer organismo, pondo-se em evidência o modo pelo qual animais e plantas obtêm os alimentos e os utilizam, principalmente como fonte de energia para todas as suas necessidades e a maneira pela qual se opera a adaptação do organismo como um todo ao seu meio. De tudo isso chega-se ao homem, para situá-lo entre os demais seres vivos, como uma espécie na qual as funções atingem o maior grau de desenvolvimento, sem se deixar de mostrar a importância da conservação da saúde e os meios de consegui-la, segundo os preceitos da higiene pessoal e social.

Cumpre, finalmente, assinalar que deve ser dada ampla liberdade aos professores, por forma que possam ministrar a disciplina sem nenhuma preocupação de seguir normas pré-adotadas e o ensino se torne vivo e dinâmico e se ajuste aos interesses dos alunos e as variadas condições locais nas escolas das diferentes regiões do país.

No $2^{\circ}$ ciclo, a diversificação da matéria Física, Química e Biologia, para os currículos que dão maior amplitude aos estudos científicos, permitirá a sistematização e o aprofundamento necessários à preparação dos alunos que desejam dedicar-se às carreiras de maior conteúdo de ciências experimentais.

Embora devam os programas, nestes casos, acentuar a precisão dos conhecimentos e dos métodos, não se deve abandonar a mesma orientação pedagógica indicada de contato direto dos alunos com as experiências e a realidade estudada. (BRASIL, 1962e, datilografado, p. 04-05).

É notável a pretensão de conceder ao ensino de ciências características do processo de produção do conhecimento científico, ou seja, a simulação dos processos de investigação dos cientistas. Assim, idealizou-se o aluno como um pequeno cientista em sala de aula.

No que alude ao ciclo ginasial, notam-se alguns pressupostos da "Escola Nova", na medida em que incentiva o processo de ensino e aprendizagem mais centrado nos interesses do aluno, com ênfase na redescoberta, na contextualização, na atividade do aprendiz por meio de métodos e estratégias que estimulam o espírito científico e certa independência no processo de aprendizagem. A ênfase na aprendizagem de conceitos a partir da realidade imediata, da experimentação, da curiosidade, em detrimento das fórmulas prontas e memorização de informações pouco úteis, foi uma promessa das propostas de inovação da época.

Para o Colegial, as recomendações mantêm os aspectos da educação propedêutica, evidenciando a preocupação com o prosseguimento nos estudos superiores, mantendo assim, coerência com os anseios da sociedade da época, em especial as camadas médias e superiores, que tinham o ensino secundário e superior como possibilidade de galgar ou acrescentar posições de status, também no mercado de trabalho, conforme assinala Romanelli (1985). 
A contar dos anos 50, sobretudo da segunda metade da década, a penetração mais intensa das multinacionais complexificou as categorias ocupacionais e criou uma demanda de recursos humanos para preencher essas categorias, cada vez mais hierarquizadas. (ROMANELLI, 1985, p.208).

As orientações gerais não interpretam a abrangência da disciplina $\mathrm{CFB}$, de modo que a trata na mesma dimensão de Iniciação às Ciências. Em que pese esta nova configuração para a disciplina, cabe questionar a abrangência implicada e o que ocorreu na prática.

Tornou-se evidente a necessidade de um profissional com formação pluridisciplinar para lecionar tal cadeira, o que não existia na época, uma vez que os cursos de formação eram mais específicos. O problema se tornou uma demanda pungente. Realidade vivenciada também para as áreas dos Estudos Sociais e das Letras. Fato que levou o Conselheiro do CFE, Newton Sucupira, a propor, em 1964, a reformulação das licenciaturas e a criação dos cursos de curta duração de Ciências, Estudos Sociais e Letras, realizáveis em "três anos", em caráter experimental e emergencial. Tal proposta se deu por meio da Indicação ${ }^{64} \mathrm{~s} / \mathrm{n}^{\circ}$ aprovada em 9 de outubro de 1964 pelo CFE, proposta pelo conselheiro Newton Sucupira intitulada "Sobre o exame de suficiência e formação do professor polivalente para o ciclo ginasial" que versou sobre a carência de professores de determinadas disciplinas e em algumas regiões do país (NASCIMENTO, 2012).

No que tange às Ciências, justificando a proposta, o Conselheiro afirma:

Mas é no setor das Ciências Naturais e da Matemática onde se verificava a maior escassez de professores qualificados, justamente, por causa do número reduzido de cursos para esta ciência. [...]. Além disso, as melhores faculdades nos cursos de Física, Química, História Natural e Matemática, se preocupam quase que exclusivamente em formar puros pesquisadores, sem levar em conta as exigências específicas da formação intelectual do mestre da escola secundária. Daí resulta um licenciado desinteressado do magistério secundário, orientando-se, de preferência, para o ensino superior, a pesquisa, ou se dedicando a outras ocupações mais vantajosas na linha de sua especialidade. [...] O Conselho ao determinar as cinco matérias obrigatórias criou uma nova disciplina, Ciências Físico-Biológicas, a qual se liga Iniciação às ciências. Como o nome está a indicar o seu conteúdo deve abranger noções de Física, Química e Biologia. Seria conveniente a instituição de uma licenciatura especialmente destinada à formação de professores desta disciplina. (SUCUPIRA, 1964 apud NASCIMENTO, 2012, p. 345).

A Indicação trazia ainda a proposta de que, os professores, uma vez formados nesses cursos, "poderiam posteriormente tirar os créditos necessários à licenciatura que os habilitasse ao ensino definitivo do ciclo colegial ou do curso superior" (SUCUPIRA, 1964 apud NASCIMENTO, 2012, p. 346). Consubstanciados nessa indicação, foram criados os cursos de curta duração de Ciências, Estudos Sociais e Letras com o objetivo de formar professores polivalentes para atuar no primeiro ciclo.

${ }^{64}$ SUCUPIRA, Newton. Sobre o exame de suficiência e formação do professor polivalente para o ciclo ginasial. Documenta, n. 31, p. 107-111, 1964. 
As normas para os cursos de licenciatura curta polivalente das áreas mencionadas foram ditadas em pareceres distintos, de 1965 a 1966. Para a área de Ciências se deram pelo Parecer $n^{\circ} 81$ de 12 de fevereiro de 1965 que novamente reforçou a necessidade de dar atenção especial à área:

Destas licenciaturas é a de Ciências, sem dúvida, a que se apresenta em caráter prioritário, não somente em face da sensível falta de professôres neste setor, como também em virtude da natureza peculiar da disciplina Ciências Físicas e Biológicas, à qual se liga Iniciação à Ciência, matérias obrigatórias criadas pelo Conselho. Como o nome está a indicar, o conteúdo dessa matéria abrange os campos da Física, Química e Biologia. Ocorre que o seu mestre ou procede dos cursos de Física ou Química ou História Natural, resultado daí que um dos setores é sempre sacrificado. (BRASIL, 1965a, Documenta, 1965, p. 96).

Assim, de 1965 a 1974 existiram as licenciaturas específicas da área de Ciências e a de curta duração de natureza polivalente em Ciências criada pelo Parecer nº 81/1965. Desse modo, a formação do profissional para lecionar Ciências no Ginasial (depois $1^{\circ}$ grau) poderia ocorrer de duas formas. Em 1974, através do Parecer nº 1.687/1974 e Resolução no 30/1974 (que tratou exclusivamente das Ciências), o CFE determinou a unificação ${ }^{65}$ das Licenciaturas específicas da área de CFB (Física, Química e Biologia) e Matemática, convertendo-as em uma única, a Licenciatura de Ciências, que concedia habilitação geral em Ciências (a Licenciatura de $1^{\circ}$ grau) e habilitação plena que, além da habilitação geral, conduzia a habilitações específicas para atuar no $1^{\circ}$ e $2^{\circ}$ graus. Esta última, como aprofundamento em uma das subáreas, concedia habilitação específica para Matemática, Física, Química ou Biologia, e outras que poderiam ser acrescentadas pelo CFE (BRASIL, 1974b).

Essa modalidade de formação foi muito criticada pelas universidades, sociedades científicas e associações de classe, o que levou o CFE a revogar ${ }^{66}$, em 1978, a obrigatoriedade de unificação dos cursos de formação de professores das áreas de Ciências da Natureza e Matemática para a modalidade de licenciatura em Ciências. Revogou-se a obrigatoriedade, mas não se proibiu o oferecimento de cursos nesses moldes. Assim, muitas universidades, principalmente da rede privada, continuaram oferecendo tais cursos, inclusive em convênios com governos estaduais para a formação emergencial de professores nas regiões de maior carência de profissionais. Conforme coloca Gatti e Barreto (2009):

Com o objetivo do aperfeiçoamento da formação de docentes do ensino básico, o CFE aprovou a Indicação $\mathrm{n}^{\circ}$ 8/86, em meados dos anos 1980, que propunha a extinção dos cursos de licenciatura curta apenas nas grandes capitais do país, tendo em conta as melhores condições de oferta de cursos superiores nessas localidades e o caráter de transitoriedade atribuído pela lei a esses cursos. (GATTI; BARRETO, 2009, p. 40).

\footnotetext{
${ }^{65}$ O cumprimento dessas novas determinações foi imposto pela Resolução CFE nº 37/1975.

${ }^{66}$ Resolução CFE n ${ }^{\circ} 05$ de 15.06.1978.
} 
A modalidade de formação em Licenciatura Curta Polivalente foi, legalmente e definitivamente, extinta somente com o advento da atual LDB, a Lei 9.394/1996, que dita em seu Artigo 62:

Art. 62. A formação de docentes para atuar na educação básica far-se-á em nível superior, em curso de licenciatura, de graduação plena, em universidades e institutos superiores de educação, admitida, como formação mínima para o exercício do magistério na educação infantil e nos 5 (cinco) primeiros anos do ensino fundamental, a oferecida em nível médio na modalidade normal. (BRASIL, 1996 Redação dada pela Lei nº 12.796 , de 2013).

A Resolução CES n. ${ }^{\circ}$ 2, de 19 de maio de 1999, que dispõe sobre a plenificação de licenciaturas curtas por faculdades e faculdades integradas do sistema federal de Ensino, confirma tal extinção em seu Art. $1^{\circ}$ que traz: "Os cursos de licenciatura de curta duração previstos na Lei 5.692, de 1971, estão extintos pela Lei 9.394, de 1996, assegurados os direitos dos alunos." (BRASIL, 1999, Art. $1^{\circ}$ ).

O problema do ensino de Ciências no Brasil era fato reconhecido, e o projeto formativo perpassou pelo ideário de mudanças que alcançassem uma ciência escolar mais sedutora, capaz de envolver o aluno, de convencê-lo da importância do conhecimento científico para o progresso do país, e até mesmo de atraí-lo para o campo das pesquisas em prol da nação (BRASIL, 1965b, Parecer n 931; ALMEIDA JUNIOR, 1979).

O problema é que estas questões se depararam com outras que necessitariam de muita vontade política para superar. A falta de estrutura das escolas e a precária formação dos professores são fatores que entravam esse propósito formativo. Foi assim no passado e ainda é um problema do presente. A nosso ver, não parece possível aperfeiçoar a formação científica com tão pouco tempo escolar destinado a cada disciplina. Por questões políticas e estruturais, o tempo de permanência diária do aluno na escola era, e ainda o é, muito restrito comparado à quantidade de conteúdos pretendidos na organização do currículo. Em contrassenso a esse fato, almejou-se (almeja?) uma formação compatível com as imposições dos avanços científicos e tecnológicos que se processavam (processam). 


\subsection{O ambiente político em que vigorou a LDB: as influências sobre a educação e uma nova reforma (1971)}

A década de 1960 foi um momento de importantes mudanças na cultura brasileira marcada pelo empenho de muitos jovens em mudar velhos costumes herdados da sociedade colonial aristocrática, e alguns não tão velhos, da tecnocracia impositiva decorrente do pós- $2^{\mathrm{a}}$ Guerra Mundial. Começava uma luta mais participante, algumas pacíficas - se apoiando, por exemplo, "na arte engajada entendida como veículo de conscientização das massas" (NAPOLITANO, 2001) - outras nem tanto serenas, ambas com o ideário de uma sociedade mais justa e igualitária. Conforme Delgado (2011):

[...] nos anos 60, houve um enorme crescimento de movimentos políticos transformadores nas mais variadas formas de arte cuja finalidade era a busca da conscientização do povo às questões políticas, à ação coletiva e a crítica social, aos problemas do latifúndio, da miséria, da fome, do autoritarismo, em alguns casos, para a revolução socialista. (DELGADO, 2011, p.128).

Vislumbrava-se que a educação e a arte seriam aberturas para conscientizar o povo sobre os problemas políticos e sociais e de inculcar princípios de participação, liberdade e direitos. Obviamente, essa nova configuração de sociedade idealizada, escolarizada e politizada não iria conviver pacificamente com o regime de governo que se instaurara a partir de 1964.

O Regime de Governo (ditadura militar), iniciado a partir de 31 de março de 1964, com o golpe que depôs o Presidente João Goulart, frustrou esse ideário de educação e suprimiu as liberdades democráticas conquistadas desde o fim do Estado Novo, solapando direitos constitucionais e praticando uma indiscriminada violação da democracia, com ações juridicamente legitimadas pelos Atos Institucionais (AI) ${ }^{67}$.

A política de restrição de direitos se institucionalizou por meio de leis de exceção os Atos Institucionais - que validaram um arsenal de medidas coercitivas que envolveram: cassação de mandatos legislativos, suspensão de direitos políticos, afastamento dos "subversivos" do serviço público, eleições indiretas para presidente e extensão do tempo de mandato, dissolução de partidos políticos e oficialização do bipartidarismo ${ }^{68}$, ampliação dos poderes do presidente para decretar Estado de Sítio, independente de aprovação do Congresso Nacional, e intervenção nos cenários políticos estaduais, entre outras. Ainda nesse período

\footnotetext{
${ }^{67}$ Atos Institucionais - Conjunto de leis promulgadas pelo governo sem necessidade da aprovação do congresso nacional.

${ }^{68}$ Para sustentar uma aparência democrática, junto a essas medidas, oficializou o bipartidarismo. De um lado, tinha-se o partido que apoiava o governo, a Aliança Renovadora Nacional (ARENA). Do outro, o partido de oposição fraca e controlada, o Movimento Democrático Brasileiro (MDB) (ROMANELLI, 1985).
} 
"menos duro,"69 governado por um grupo menos radical, foi criada uma Assembleia Constituinte que resultou em uma nova Constituição, em 1967, que reforçou a influência do Poder Executivo sobre o Legislativo e Judiciário, dando ainda mais centralidade nas decisões do governo.

Para a viabilidade do projeto desenvolvimentista que caracterizou o modelo econômico adotado pelos militares, a educação foi vista como expediente de grande relevância, uma vez que a modernização da economia pautada na industrialização crescente, e positivamente afetada pelo desenvolvimento tecnológico, demandava recursos humanos com formação mais especializada. Mas não uma educação conforme o ideário dos "jovens engajados". Ela teria que estar atrelada aos interesses da ordem social vigente. Ou seja, uma educação menos liberal e mais tecnicista, que pudesse servir ao projeto político e econômico (ROMANELLI, 1985).

Com esse objetivo, e justificando-se pela crise do sistema educacional desencadeada, principalmente pelas demandas por mais vagas na universidade, o Governo realizou, a partir de 1964, acordos com os Estados Unidos ampliando ainda mais a participação internacional na gerência do país. São os famosos acordos entre o Ministério da Educação e Cultura - MEC e a Agency for International Development dos Estados Unidos - AID, os acordos MECUSAID (ROMANELLI, 1985), que, embora famosos, não foram a priori muito transparentes, e, segundo Aranha (1989), só se tornaram públicos em 1966.

Convém ressaltar que, a influência americana nos diversos setores do país, no que inclui também a Educação, por meio de acordos e projetos, já vinha ocorrendo de longa data, inclusive no período em que vivificou o "extremo" nacionalismo de Vargas (MOREIRA, 2001).

Conforme descreve Romanelli (1985), citando Alves ${ }^{70}$ (1968), foram assinados, ao todo, doze acordos entre o MEC e seus órgãos vinculados e a AID nos períodos de 1964 a 1968, abrangendo todo o sistema de ensino, do nível primário ao superior, bem como os ramos acadêmicos e profissionais, com maior atenção ao acadêmico. Submeteu-se o sistema educacional a uma reestruturação administrativa de caráter empresarial, trazendo para a Educação concepções tayloristas de planejamento, racionalidade técnica, eficiência, produtividade e controle (ROMANELLI, 1985; ARANHA, 1989).

\footnotetext{
69 O período da ditadura militar experimentou tempos de repressão mais moderada e estações mais "pesadas" gerenciados entremeio a conflitos internos nas Forças Armadas, que desde o início estava dividida entre dois grupos de militares. Por um lado, o grupo linha dura que defendia a permanência do comando militar no poder, e por outro, um grupo menos radical interessado no retorno da normalidade política e jurídica e de um governo civil. Esse período menos duro vigorou de 1964 a 1967 (ROMANELLI, 1985; ARANHA, 1989).

${ }^{70}$ ALVES, Márcio Moreira. Beabá do MEC-USAID. Rio de Janeiro: Ed. Gernasa, 1968.
} 
De um modo geral, esses acordos envolviam assessoria técnica americana, com treinamento de pessoal docente e técnico brasileiros no Brasil e nos Estados Unidos, objetivando o planejamento do ensino, elaboração de planos específicos e outras ações de natureza técnica e pedagógica. Alguns desses acordos visavam ainda um "melhor entrosamento" entre os diferentes níveis de ensino. Os alcances dessa intervenção externa afetaram ainda, sobremaneira, o currículo nas escolas por meio de um acordo específico que visava o "controle do conteúdo geral do ensino através do controle de publicação e distribuição de livros técnicos e didáticos." (ROMANELLI, 1985, p. 213).

Dentre os doze acordos assinados, quatro ${ }^{71}$, explicitamente, mencionavam o ensino médio (ou ensino secundário), entretanto, todos contemplaram medidas que, de alguma forma, abrangeram esse nível de ensino, uma vez que eles, "embora implicassem assistência a setores específicos, possuíam uma estrutura única, perceptível através de aspectos comuns" (ROMANELLI, 1985, p. 213).

Os resultados desses acordos no sistema educacional brasileiro se consolidaram por meio de políticas públicas, dentre as quais descreveremos, a seguir, as de maior relevância.

Por meio de dois decretos - Decreto-Lei no 53 de 18.11.1966 e Decreto-Lei no 252 de 28.02.1967 - a intervenção estadunidense resultou em alterações nas universidades com normas para contenção de recursos, colocando em prática os princípios da economia e produtividade e reestruturação do ensino com a criação de unidades menores, os departamentos, para reunir disciplinas afins, manifestando claramente os aspectos da mentalidade empresarial.

Esses dois decretos tinham como objetivo a contenção, sendo o primeiro de gastos, e o segundo, de manifestações políticas. Neste último era explícita a intenção de desmontar os movimentos estudantis que tinham como célula as turmas (SAVIANI, 1986). Em tese, a departamentalização forçosamente manteria os estudantes mais ocupados tendo que se desdobrarem para cursar as disciplinas nas diferentes unidades das universidades. $O$ documento tratou de coibir os movimentos, em geral coordenados pela já ilegalizada UNE, que passou a atuar na clandestinidade desde 1964, com o advento da Lei Suplicy de

\footnotetext{
${ }^{71}$ Segundo acordo - Acordo MEC-CONTAP ${ }^{71}$-USAID [Ministério da Educação/ Conselho de Cooperação Técnica da Aliança para o Progresso e a Agência Norte Americana para o Desenvolvimento Internacional] para melhoria do ensino médio (31/03/1965). Quinto acordo - Acordo MEC-CONTAP-USAID de Assessoria para a expansão e aperfeiçoamento do Quadro de Professores do Ensino Médio no Brasil (24/06/1966). Nono acordo Acordo MEC-SNEL-USAID [Ministério da Educação/Sindicato Nacional de Editores de Livros e a Agência Norte Americana para o Desenvolvimento Internacional] de Cooperação para Publicações Técnicas, Científicas e Educacionais (06/01/1967). Décimo acordo - Acordo MEC-USAID (17/01/1968) - Extensão e complementariedade do segundo acordo MEC-USAID, que tratava do desenvolvimento do Ensino Médio (Planejamento do Ensino Secundário e Serviços Consultivos).
} 
Lacerda $^{72}$. Manteve-se, porém, sob medidas de controle, o Diretório Acadêmico (DA) e o Diretório Central dos Estudantes (DCE).

Em Dezembro de 1967 é criado o Movimento Brasileiro de Alfabetização (MOBRAL) (Lei $\mathrm{n}^{\circ}$ 5.379/1967). A proposta do projeto foi de alfabetizar funcionalmente jovens e adultos, evadidos da escola ou que nunca a tivesse frequentado. A respeito disso, cabe um adendo para esclarecer a "gênese" desse projeto, conforme apresentamos no boxe a seguir.

No início dos anos de 1960, a educação popular, não formal e de adultos ganha corpo com a difusão de diversos movimentos para escolarização de cidadãos em condições de marginalização social, com destaque: os Centros Populares de Cultura (CPC), ligados à UNE; o Movimento de Educação de Base (MEB), ligado à Igreja Católica; e o Movimento de Cultura Popular (MCP), por iniciativa da Prefeitura de Recife (ARANHA, 1985). Neste último está a origem do movimento Paulo Freire de Educação de Adultos (SAVIANI, 2008).

Em um cenário onde diversas teorias de cunho pedagógico são debatidas, surge o Método Paulo Freire, que não é uma teoria, mas sim uma concepção pedagógica, mas que se revelou voltada para a mudança de pensamento das estruturas, objetivando o estabelecimento de uma ponte entre a escola e a comunidade, a comunidade e os movimentos sociais e este às justas frentes de lutas populares. Freire elaborou seu método e começou a implantá-lo no início da década de 1960, com a proposta de alfabetizar adultos em um decurso de tempo de 40 horas. Nessa proposta, as nomenclaturas sala de aula são substituídas por "Círculo de Cultura", professor por "mediador" e alunos por "equipe de trabalho", atrelados à troca de experiências das realidades vividas (práxis pedagógica).

A alfabetização idealizada por Freire deveria ir além da mera leitura e escrita de palavras e textos; tinha também como propósito despertar o ser político do indivíduo. Assim, partia da realidade imediata do aprendiz, com o uso de palavras geradoras pertencentes ao universo vocabular do mesmo. Um exemplo disso é a famosa palavra "tijolo" nesse contexto inovador de alfabetização, que ganhou atenção por ser a primeira palavra geradora utilizada em círculos de cultura, em Brasília, nos anos de 1960 (BRANDÃO, 2005). A palavra remetia também a questão social e política que traduzia a realidade dos estudantes trabalhadores de uma cidade em construção. Muitos trabalhavam na construção de casas, mas nem mesmo possuíam uma casa própria. Os debates nos círculos de cultura levavam à reflexão sobre a situação social em que se encontravam, e os ensejos políticos que a consubstanciava.

O método freireano revelou-se eficiente na transição da condição de analfabetos a alfabetizados elementares, com condições de ler e escrever palavras atribuindo-lhes significados condizentes como o seu mundo vivencial. O método primava pelo reforço das relações escola-comunidade, e em longo prazo plantaria a semente do senso crítico nos grupos formados.

Freire recebeu apoio do governo populista da época, que viu nesse empreendimento uma forma de obtenção de eleitores aptos ao voto (BOTELHO, 2010). No plano das intenções políticas, sua proposta foi tomada para objetivos díspares de sua concepção ideológica. Os trabalhos de Freire buscavam uma alternativa às ações meramente "desenvolvimentistas", na qual fossem priorizadas mudanças estruturais na política brasileira. Como educador, seguia a linha de raciocínio de que caso não houvesse mudanças estruturais no cenário político e econômico, com o passar dos anos os episódios de injustiça social se intensificariam, aliadas à exclusão e desigualdade. E para que essas mudanças pudessem ser processadas, seria preciso conscientizar o homem de seu lugar na história por meio da educação.

O método freireano rendeu-lhe reconhecimento internacional, fazendo com que seu trabalho se destacasse por voltar-se à educação das camadas sociais mais carentes, dos métodos de alfabetização de adultos, até a necessidade da formação de consciência crítica do indivíduo. Enfrentou resistências políticas a este ideário educativo no Brasil, e interrupção de seu trabalho de alfabetização de grande massa, a partir de 1964, já que suas concepções não convergiam com a política e, consequentemente com a proposta de educação que se estabeleceu após o golpe militar.

\footnotetext{
${ }^{72}$ A UNE foi colocada na ilegalidade pela Lei ${ }^{\circ} 4.464$, de 9 de novembro de 1964, conhecida como Lei Suplicy de Lacerda. Essa mesma Lei instituiu legalmente o Diretório Acadêmico (DA), restrito a cada curso, e o Diretório Central dos Estudantes (DCE), no âmbito da universidade. Essa foi uma das primeiras medidas repressivas contra os movimentos estudantis, e objetivou um alcance nacional para eliminar quaisquer tentativas de movimentações políticas da categoria.
} 
Os objetivos discursados, para o MOBRAL, eram de promover a leitura, a escrita e o cálculo para condicionar a integração do aprendiz na sua comunidade, e a melhora da condição social dos mesmos. O discurso metodológico se aproximava das ideias de Paulo Freire. Dissemos discurso, pois indica ter sido somente isto, uma desconstrução do método freireano, uma vez que não havia uma convergência ideológica com esse educador.

Assim, numa versão deturpada do método de Freire, no MOBRAL utilizava-se de palavras geradoras comuns a todos os contextos sociais de estudantes que se enquadravam no projeto, com procedimentos uniformizados para todo o território nacional, com os mesmos recursos materiais. Desse modo, não considerava as especificidades regionais. O MOBRAL vigorou até 1985 e, embora não trazendo resultados tão satisfatórios, deu abertura para outros projetos de objetivos semelhantes - em contextos políticos diferentes - que foram surgindo até chegar à política pública denominada Educação de Jovens e adultos (EJA) que atualmente integra o sistema de ensino brasileiro.

No ano de 1968 surgem as políticas de amparo à expansão do ensino médio e superior com a criação do Fundo Nacional do Desenvolvimento da Educação (FNDE) (Lei 5.537/1968). O estabelecimento de critérios para a expansão do ensino superior se deu com o Decreto $n^{\circ} 6.341 / 1968$, e a fixação de normas para o aumento de matrículas nas universidades pelo Decreto-Lei 405/1968. Este último regulamentava a concessão de auxílio para a expansão do ensino vinculada à exigência de diretrizes em que assegurassem a produtividade, a eficiência e o pleno aproveitamento da capacidade instalada.

Ainda neste mesmo ano é promulgada a Lei 5.540/1968 que reformou o ensino superior, fixando normas de organização e funcionamento e sua "articulação com a escola média”. A articulação com a escola média pareceu se manifestar em somente três artigos (Artigos 17, 21 e 30). O primeiro trata das condições de ingresso em cursos de graduação, o segundo menciona a questão dos conhecimentos comuns presentes no currículo dos diversos ramos do ensino para serem cobrados nos vestibulares, e, por fim, o terceiro fala da formação de professores para o segundo ciclo do grau médio, bem como de outros segmentos profissionais da educação fundamental e média.

Art. 17. Nas universidades e nos estabelecimentos isolados de ensino superior
poderão ser ministradas as seguintes modalidades de cursos: a) de graduação,
abertos à matrícula de candidatos que hajam concluído o ciclo colegial ou
equivalente e tenham sido classificados em concurso vestibular. [...]
Art. 21. O concurso vestibular, referido na lêtra a do artigo 17, abrangerá os
conhecimentos comuns às diversas formas de educação do segundo grau sem
ultrapassar êste nível de complexidade para avaliar a formação recebida pelos
candidatos e sua aptidão intelectual para estudos superiores.[...]
Art. 30 . A formação de professôres para o ensino de segundo grau, de disciplinas
gerais ou técnicas, bem como o preparo de especialistas destinados ao trabalho de 
planejamento, supervisão, administração, inspeção e orientação no âmbito de escolas e sistemas escolares, far-se-á em nível superior. [...] (BRASIL, 1968, grifos nossos).

É interessante observar que, a referida Lei já traz a nova denominação que receberia o ciclo Colegial na reforma de 1971 - ou seja, segundo grau. Seria uma antecipação de intenções com as reformas articuladas nos acordos MEC-USAID? O Parecer $n^{\circ}$ 853/1971, ao argumentar em favor da configuração curricular nos termos da Lei 5.692/1971, responde que não:

Acontece que a "educação de segundo grau" da Lei ${ }^{\circ}$ 5.540/68 correspondia ao conjunto de estudos representado pelos anteriores ciclos ginasial e colegial, enquanto na Lei $\mathrm{n}^{\circ} 5.692 / 71$ a expressão cobre apenas o que era colégio. (BRASIL, $1971 \mathrm{c}$, Documenta $\mathrm{n}^{\circ} 132$, p. 189, grifo em aspas dos autores).

A Lei não cuidou de resolver o problema dos excedentes, que só veio ocorrer em junho de 1971, por meio do Decreto $\mathrm{n}^{\circ}$ 68.908/1971, que determinou o concurso vestibular pelo processo classificatório com o aproveitamento dos candidatos até o limite das vagas fixadas no edital (BRASIL, 1971a). Isso eliminou de vez essa temática que era pauta importante de reivindicações dos estudantes, e uma questão pendente desde a década de 1950, quando as vagas nas universidades não comportaram mais os candidatos que atingiam a nota mínima, exigida para ingresso nas universidades públicas. Na verdade não resolveu o problema dos excedentes, mas sim um problema que incomodava o governo.

Os acordos previam ainda a intervenção na política nacional do livro didático, que ocorreu por meio do Decreto $\mathrm{n}^{\circ} 59.355$ de 4.10.1966, quando é instituída a Comissão do Livro Técnico e do Livro Didático (COLTED). Conduzida pelo Acordo entre o Ministério da Educação, o Sindicato Nacional de Editores de Livros e a Agência Norte Americana para o Desenvolvimento Internacional (MEC/SNEL/USAID), de 6 de janeiro de 1967, essa comissão teve como objetivo a distribuição de livros às bibliotecas escolares em todos os níveis de ensino (KRAFZIK, 2008). Segundo Alves (1968 apud Romanelli, 1985):

Por esse acordo, seriam colocados, no prazo de 3 anos, a contar de 1967, 51 milhões de livros nas escolas. Ao MEC e o SNEL incumbiram apenas responsabilidades de execução, mas os técnicos da USAID, todo o controle, desde os detalhes técnicos de fabricação de livro, até os detalhes de maior importância como: elaboração, ilustração, editoração e distribuição de livros, além da orientação das editoras brasileiras no processo de compra de direitos autorais de editores não-brasileiros, vale dizer, americanos. (ALVES, 1968 apud ROMANELLI, 1985, p. 213).

Outra política pública de grande impacto no ensino, talvez o maior decorrente dos acordos MEC/USAID, foi a reformulação da escola de nível primário e médio por meio da Lei 5.692/1971, da qual trataremos na próxima seção.

Para Romanelli, ocorreu uma revolução no ensino brasileiro no período do Regime Militar, e isso constituiu um fato inédito. Com um modelo de ensino questionável, mas 
consonante com o imperativo do modelo econômico desenvolvimentista adotado, trouxe para a educação uma perspectiva instrumental com a nítida finalidade de atender à expansão econômica. Segundo a autora, “[...], pela primeira vez, desde que se iniciou o que muitos chamam de Revolução Brasileira, o Estado se impôs a tarefa de organizar a educação com base em sua política de desenvolvimento econômico" (ROMANELLI, 1985, p. 223).

Nesse sentido, no que tange à educação fundamental e média, o modelo educacional desenvolvido, especialmente a partir da reforma de 1971, deu ênfase aos saberes instrumentais consonantes com os valores da sociedade da época. Uma sociedade preponderantemente urbana, em um contexto de acelerado desenvolvimento industrial, e experimentando os triunfos dos avanços tecnológicos.

\subsubsection{A Lei 5692/1971}

A intenção de reformar a escola primária e média estava presente nos acordos MECUSAID e foram reforçadas por relatórios de técnicos brasileiros que compunham comissões designadas pelo Governo Federal, entre os anos de 1967 e 1968 - a Comissão Meira Matos e o Grupo de Trabalho da Reforma Universitária. A primeira tinha como objetivo emitir pareceres, planejar e propor medidas para sustentar a aplicação das diretrizes governamentais, supervisionar, coordenar, e, de certa forma, coagir, no âmbito das universidades.

A segunda, "estudar a forma da Universidade brasileira, visando a sua eficiência, modernização, flexibilidade administrativa e formação de recursos humanos de alto nível para o desenvolvimento do país" (ROMANELLI, 1985, p. 222). Ancorados nos acordos MECUSAID, essas comissões tiveram contribuições profundas na política educacional do governo militar.

Romanelli chama a atenção para os diferentes enfoques das propostas de reforma do ensino médio nesses documentos. Segundo a autora, enquanto os acordos MEC-USAID focavam na escola fundamental, propondo uma integração entre a educação primária e média, os relatórios das comissões brasileiras propunham uma reformulação do ensino médio, mais especificamente do segundo ciclo desse nível de ensino, para que este cuidasse de conter a pressão por mais vagas na Universidade. O caminho proposto para isso seria uma mudança nos objetivos do ensino médio, que passaria a promover uma formação profissional. Como pode ser constatada na Lei 5.692/1971, de 11 de Agosto de 1971, os dois enfoques estão presentes, embora não necessariamente em consonância, nem tão pouco alcançaram os resultados esperados. 
Um trecho do texto de Cury et al. (1982) sintetiza o processo de curta gestação da Lei 5692/1971:

A gênese da Lei refletiu as condições políticas do País que, à época de sua elaboração, não permitiam o envolvimento de amplos setores da população na discussão e na definição de diretrizes para a educação, ou qualquer outro setor da vida social.

A sistemática adotada foi a criação de um Grupo de Trabalho — formado por 9 pessoas - para, no prazo de 60 dias, apresentar seus estudos e ante-projeto. Esse ante-projeto foi apreciado pelo CFE no prazo de 5 dias e remetido ao Congresso Nacional para discussão conjunta em regime de urgência, no prazo de 40 dias (BRASIL, 1971, p. 199).

A exigüidade do período de planejamento foi possível porque as diretrizes já estavam explicitadas em diversos documentos: pronunciamentos do governo, acordos MEC/USAID, Indicação n ${ }^{\circ}$ 48/67 do Conselho Federal de Educação, Relatório do Grupo de Trabalho da Reforma Universitária e IV Conferência Nacional de Educação, entre outros. (CURY et al.., 1982, p. 42).

A Lei 5.692/1971, cujo projeto de elaboração não teve maiores debates no âmbito educacional, praticamente substituiu a LDB/1961, e, embora não seja uma LDB, reformou a Educação primária e média brasileira e vigorou até 1996.

Segundo Fontoura [1979?, p.19], um entusiasta desta reforma, tal Lei é "mais do que uma reforma, é a maior revolução de todos os tempos na Educação Brasileira". O autor argumenta a importância da reforma defendendo que a mesma declinou de vez com a educação humanística, abrindo espaço maior para uma educação mais pragmática. Esse autor, sem esconder a sua simpatia por essa lei, traz algumas ponderações que bem justificam a necessidade que impôs uma nova forma de pensar a Educação, a partir dos anos de 1950, devido à mudança de modelo econômico do país.

Para ele, a LDB/1961 não deu conta de reverter "a estrutura teórica, livresca, decorativa, do nosso ensino; divorciado da realidade brasileira e dos anseios do nosso povo." [FONTOURA, 1979?, p. 24]. Fontoura critica a educação elitista que se manteve com finalidade maior de conceder o grau de doutor que era "uma marca de classe, determinando um bom 'status' social." [FONTOURA, 1979?, p. 20, ênfases do autor]. Em defesa da necessidade das mudanças trazidas na Lei, ele coloca:

Eis que, de repente, dando o Brasil o grande salto para a Era Industrial, verifica-se que, nesta nova era, o técnico é tão necessário quanto o doutor. Como fazer tecnologia sem técnicos? Do ponto de vista numérico, se uma empresa necessita de dez engenheiros, sem dúvida precisa de cem técnicos. [FONTOURA, 1979?, p. 24, grifo do autor].

Nagle (1973) também demonstra ser um simpatizante da reforma de 1971, e no que se refere aos ramos e níveis do ensino, afirma que "a Lei 5692/71 torna solidárias as escolas primária e média e acaba com a existência de ramos da escola média” (NAGLE, 1973, p. 18). Defende ainda que tal Lei veio abolir barreiras e eliminar "a organização por compartimento 
estanques, organização dualista que separava, como tem sido repetido, a escola da elite da escola do povo, a educação acadêmica da profissional.” (NAGLE, 1973, p. 18).

Com posicionamento contrário ao que defende Nagle (1973) e Fontoura [1979?], opinam Saad (1977), Cury (1982), Aranha (1989), e ainda outros, que, a sistemática proposta na Lei 5692/1971 e a falta de suporte para a implementação da mesma não desfez o dualismo do ensino. Para Aranha (1989), manteve-se a escola de rico separada da escola de pobre, “já que a elite, mais bem preparada, passa a ocupar as vagas das melhores universidades" (ARANHA, 1989, p. 258), mantendo assim, a seletividade - o status quo. Nesse mesmo sentido, Saad (1977) e Cury (1982) têm opiniões similares:

É a consagração do caráter elitista do ensino brasileiro, visto que as melhores vagas de nossas universidades serão ocupadas por aqueles que, dispondo de recursos econômicos que lhes possibilitem o acesso às escolas particulares, terão melhores oportunidades para se preparar eficientemente a fim de vencerem a barreira do vestibular, que os alunos de nossas escolas oficiais. (SAAD, 1977, p.102).

Embora a proposta da profissionalização compulsória tenha tido a louvável intenção de corrigir as distorções do ensino médio, eliminando a dualidade de uma escola "para os nossos filhos" e outra para os demais, não se conseguiu diminuir a distância entre trabalho de decisão e trabalho de execução. (CURY, 1982, p. 45, grifo aspas do autor).

A Lei 5692/1971 simplificou a divisão dos graus de ensino, unindo a escola primária com o primeiro ciclo da escola média (o Ginasial), denominando tal junção de $1^{\circ}$ grau, com duração de oito anos, e eliminou o exame de admissão que conferia acesso entre tais níveis. $\mathrm{O}$ Colegial e as escolas profissionais foram transformados em $2^{\circ}$ grau, e tal grau de ensino passou a ter caráter de profissionalização compulsória. $\mathrm{O}$ ensino de $1^{\circ}$ grau também se revestiu de um aspecto mais técnico, uma vez que obrigatoriamente passou a constituir-se numa iniciação para o trabalho, nas suas séries finais.

\subsubsection{A organização curricular nos termos da Lei 5692/1971}

Quanto à estruturação curricular nos termos da Lei 5692/1971, esta ficou a encargo do CFE definir, nos mesmos moldes da LDB/1961. Sobre esse aspecto, a Lei traz:

Art. $4^{\circ}$ Os currículos do ensino de $1^{\circ}$ e $2^{\circ}$ graus terão um núcleo comum, obrigatório em âmbito nacional, e uma parte diversificada para atender, conforme as necessidades e possibilidades concretas, às peculiaridades locais, aos planos dos estabelecimentos e às diferenças individuais dos alunos.

$\S 1^{\text {o }}$ Observar-se-ão as seguintes prescrições na definição dos conteúdos curriculares:

I - O Conselho Federal de Educação fixará para cada grau as matérias relativas ao núcleo comum, definindo-lhes os objetivos e a amplitude. (BRASIL, 1971b). 
A composição do currículo nos termos dessa Lei é, sem dúvida, muito complexa. Em atendimento às determinações do texto legal, e para esclarecer tamanha complexidade, o CFE elaborou um documento, o Parecer no 853/1971 de 12 de novembro de 1971, no qual, em anexo, trazia o projeto da Resolução $n^{\circ}$ 08/1971, que foi publicada em $1^{\circ}$ de Dezembro de 1971, para taxar a matéria.

Consta na Resolução nº 08/1971:

Art. $1^{\circ} \mathrm{O}$ núcleo comum a ser incluído, obrigatoriamente, nos currículos plenos de ensino de $1^{\circ}$ e $2^{\circ}$ graus abrangerá as seguintes matérias: a) Comunicação e Expressão; b) Estudos Sociais; c) Ciências.

$\S 1^{\circ}$ Para efeito da obrigatoriedade atribuída ao núcleo comum, incluem-se como conteúdos específicos das matérias fixadas:

a) em Comunicação e Expressão - A Língua Portuguesa;

b) nos Estudos Sociais - a Geografia, a História e a Organização Social e Política do Brasil;

c) nas Ciências - a Matemática e as Ciências Físicas e Biológicas. (BRASIL, 1971d, Documenta n ${ }^{\circ} 133$, p. 399, grifos nossos).

Segundo Nagle, essa Lei traz algumas alterações nos sentidos dos tradicionais conceitos que geralmente definem o currículo nas organizações do ensino ao longo da história. Antes, concebido como conjunto de matérias ou disciplinas passa a ter um sentido mais amplo. O termo matéria passou a englobar as disciplinas, áreas de estudo e atividades.

Conforme consta na Lei, disciplina tem o sentido que sempre teve - conhecimento sistematizado - e foi recomendado que a aprendizagem se desenvolvesse predominantemente sob essa perspectiva. As áreas de estudo se referem à integração de conteúdos afins de modo que a aprendizagem se faça pelo equilíbrio entre a experiência vivida pelo estudante e o conhecimento da cultura sistematizada. As atividades definem-se pela aprendizagem a partir do conhecimento cotidiano, do palpável, do global ao micro. As atividades surgem das combinações entre as áreas de estudo formadas pelas combinações das disciplinas (NAGLE, 1973; FONTOURA, 1979?). A proposta implicou, segundo Fontoura, em um tripé indissociável. O desenvolvimento do currículo deveria se dar de forma gradativa, partindo do conhecimento empírico, do ocasional, sem dispensar alguns saberes formais, seguindo com o amadurecimento das ideias até a formulação de pensamentos mais elaborados, pelo aluno, que pressupunha uma compreensão mais profunda do conhecimento sistemático e abstrato; e também não deveria dispensar a conexão com o real (BRASIL, 1971b). 


\subsubsection{As Ciências no currículo e o currículo de Ciências na Lei 5692/1971}

As modificações nas diretrizes da educação escolar acarretadas com a Lei 5692/1971 mudaram substancialmente a configuração e distribuição/carga horária das disciplinas da área de Ciências para se ajustarem ao modelo de ensino adotado. Ciências ganha destaque como parte do núcleo comum obrigatório em todo o país, assumindo o caráter de matéria tanto no $1^{\circ}$, quanto no $2^{\circ}$ grau.

No caso da Física, por exemplo, esta aparece embutida na parte da educação geral, de caráter obrigatório, em $\mathrm{CFB}$, que é tratada nessa Lei como uma área de estudo da matéria Ciências no nível de $1^{\circ}$ grau, e como disciplina no $2^{\circ}$ grau.

Cabe observar que, na LDB/1961, conforme já mostrado neste capítulo, CFB aparece nas indicações do CFE como uma das disciplinas obrigatórias que poderia compor as alternativas admissíveis de organização curricular. Embora esta pudesse ser escolhida para configurar no currículo do curso Colegial ao optar por uma das três alternativas nas quais ela estava presente, havia, no entanto, outra possibilidade de organização do quadro curricular em que esta aparecia desmembrada em disciplinas específicas: Física, Química e Biologia.

Já na Lei 5692/1971, CFB passa a ser área de estudo ou disciplina (da matéria Ciências), dependendo do nível de ensino, e também não se apresenta mais como uma opção para compor o currículo do segundo ciclo (nessa conjuntura, $2^{\circ}$ grau), mas sim uma inclusão obrigatória. Em síntese, CFB faz parte do núcleo comum da Educação Geral.

Julgamos interessante observar que, no Estado de São Paulo, em 1968, por meio do Decreto Estadual no 50.133/1968 e da Resolução CEE/SP nº 36/1968, já ocorrem alterações nessa linha para o ensino de Física. Nesse Estado, o Colegial assumiu uma nova sistemática com a criação dos Colégios Integrados, com organização unificada e pluricurricular. Assim, as duas primeiras séries passaram a ter currículo comum para o ensino secundário e normal (podendo sê-lo também para os demais ramos do Colegial), e a $3^{\text {a }}$ série se diversificou em orientações básicas: científica, clássica e eclética (perspectiva já presente na organização curricular do Ginásio Único Pluricurricular, criados em 1963, já mencionados neste texto). Nessa última série a organização curricular foi estruturada em área de estudo, conforme a orientação básica de opção de cada escola.

Deste modo, CFB tornou-se disciplina obrigatória nas $1^{\mathrm{a}}$ e $2^{\mathrm{a}}$ séries do Colegial secundário e normal (adotando a linha do GUP), podendo ser "tresdobradas em disciplinas autônomas: Física, Química, Biologia", conforme o Art. $5^{\circ}, \S 2^{\circ}$ do referido decreto. Para a $3^{\text {a }}$ 
série, determinou-se a organização em área de estudo (Art. $9^{\circ}$ ), sendo uma delas CFB, de modo que a Física ficou embutida na referida área.

Essa alteração, em que CFB se torna área de estudo na última série, configurou-se como uma prévia do que ocorreria na reforma de 1971, para todos os sistemas de ensino do país, e indica a forte influência do Estado de São Paulo na política curricular do país.

Os suportes legislativos da Lei 5.692/1971 - o Parecer 853/1971 e sua resolução acessória (Resolução $\mathrm{n}^{\circ}$ 08/1971) - falam do desenvolvimento do currículo da matéria Ciências que leva à visão nítida da Física como subárea das "Ciências Exatas e Biológicas",73 (sic). O documento traz:

No início da escolarização, as Ciências (p. ex.) só podem ser tratadas em termos de atividades, isto é, como vivência de situações e exercícios de manipulação para explorar a curiosidade, que é a pedra de toque do método científico. Sempre que oportuno, essas experiências já podem ser objeto de uma incipiente sistematização partida mais do aluno que do professor, embora sob a direção estimulante deste último. À medida que se esboçam certos setores ainda não claramente individualizados e tais sistematizações se tornam mais freqüentes, pelo amadurecimento natural do educando, já temos a área de estudo (Ciências Exatas e Biológicas, p. ex.); e nessa progressão se chegará à predominância do sistemático sobre o ocasional, com visão cada vez mais nítida de cada subárea (Matemática, Física, Química, Biologia, p. ex.) ou disciplina. (BRASIL, 1971c, Documenta ${ }^{\circ}$ 132, p. 170).

Tal Parecer reforça ainda que a Física poderia assumir um caráter instrumental na parte de Educação Especial, deixando claro essa nova conformação para a disciplina:

A Física e a Geografia são disciplinas gerais, porém ganharão evidentes conotações instrumentais, e portanto especiais, quando encaradas à luz de habilitações em Mecânica e Geologia. Tanto a Física, a Geografia e a línguas, como a Matemática ou a História, são suscetíveis de definir-se diretamente como especialidades no ensino superior. (BRASIL, 1971c, Documenta $\mathrm{n}^{\circ} 132$, p. 173).

Mais a frente, em menção ao projeto que gerou a Resolução no 08/1971, o Parecer

traz:

Ao fixar o último aspecto, no parágrafo único do artigo $5^{\circ}$ e na alínea c do artigo $6^{\circ}$, teve-se muito presente a relatividade, já assinalada, dos conceitos de geral e especial e, para objetivá-la, admitiu-se que as Ciências Físicas e Biológicas do $2^{\circ}$ grau, "conforme as habilitações profissionais pretendidas pelos alunos", sejam desdobradas em disciplinas instrumentais da parte especial e, como tais, integrem também esta parte. (BRASIL, 1971c, Documenta n 132, p. 183).

Passaremos a analisar o referido artigo da Resolução.

Art. $5^{\circ}$ - No escalonamento a que se refere o artigo anterior, conforme o plano do estabelecimento, as matérias do núcleo-comum serão desenvolvidas:

$[\ldots]$

\footnotetext{
73 O termo "exatas" aparece aqui ao exemplificar uma área de estudo, entretanto, na Resolução no 08/1971, Art. $1^{\circ}, \S 1^{\circ}$, alínea $a$, a área de estudo desdobrada da matéria Ciências, é Ciências Físicas e Biológicas e não Ciências Exatas e Biológicas.
} 
II - No ensino de $2^{\circ}$ Grau, sob as formas de Língua Portuguesa e Literatura Brasileira, História, Geografia, Matemática e Ciências Físicas e Biológicas, tratadas predominantemente como disciplinas e dosadas segundo as habilitações profissionais pretendidas pelos alunos.

Parágrafo Único - Ainda conforme as habilitações profissionais pretendidas pelos alunos, as Ciências Físicas e Biológicas referidas no inciso II, poderão ser desdobradas em disciplinas instrumentais da parte especial do currículo e, como tais, integrar também esta parte. (BRASIL, 1971c, Documenta n $^{\text {13 }}$ 132, p. 192, grifos nossos).

O Artigo acima transcrito deixa claro que $\mathrm{CFB}$, um dos conteúdos específicos da matéria Ciências, deveria ser tratada como disciplina, ou seja, da mesma forma que as demais listadas (Língua Portuguesa e Literatura Brasileira, História, Geografia, Matemática). Isto, a princípio, leva a entender que a mesma não seria desdobrada nas três disciplinas científicas específicas - Física, Química e Biologia - para qualquer situação. Note que as demais disciplinas das matérias Comunicação e Expressão e Estudos Sociais já aparecem desmembradas para serem tratadas como disciplinas. Já CFB, que juntamente com a Matemática compõe a matéria Ciências, não aparece desmembrada, o que pressupõe tratá-la como disciplina na forma integrada. Note ainda que, conforme o Parágrafo Único desse mesmo Artigo permitiu-se o desdobramento de CFB em disciplinas "instrumentais", dependendo da habilitação profissional, mas na parte de Formação Especial.

O Parecer do CFE nº 871, de 11 de Agosto de 1972, que veio esclarecer o que a Lei 5.692/1971 define como núcleo comum e parte diversificada, nos ajuda a compreender melhor essa complexa doutrina de currículo da reforma. Traz o entendimento de que a educação geral se compõe de disciplinas do núcleo comum, bem como de disciplinas da parte diversificada, e que a parte diversificada também está presente na formação especial. Na introdução, o referido Parecer traz que: "Se de fato não se pode negar que núcleo comum será todo voltado para a formação geral, é, por outro lado, verdadeiro que nem só do núcleo comum advirão os conteúdos de educação geral, podendo eles originarem-se, complementarmente, da parte diversificada." (BRASIL, 1972, PAR 871, Documenta $\mathrm{n}^{\text {o }}$ 141, p. 357).

Esse Parecer apresentou uma lista de conteúdos específicos relacionados às matérias, para a escolha pelos estabelecimentos de ensino do sistema federal, e que deveriam constituir a parte diversificada do currículo de $1^{\circ}$ e $2^{\circ}$ Graus no campo de educação geral. No que se refere à matéria Ciências, foram indicados os seguintes "conteúdos específicos": Física, Química, Biologia, Nutrição, Puericultura, Socorros de Urgência, Noções de Astronomia, Geometria Descritiva. Cabe lembrar que, na Resolução no 08/1971, o termo “conteúdos 
específicos" se refere aos componentes curriculares das três matérias fixadas, e poderiam ser tratados como área de estudo ou disciplina.

O Parecer $n^{\circ}$ 871/1972 mostra que o desmembramento de CFB em disciplinas específicas acabou sendo permitido também na parte de educação geral. Entretanto, há um detalhe que chama a atenção. Uma análise paralela nesse Parecer e na Resolução nº 08/1971 leva a entender que, na modalidade desmembrada, as disciplinas Física, Química e Biologia não configurariam como núcleo comum, mas sim, parte diversificada da educação geral, passíveis de serem (ou não) escolhidas para compor os currículos das escolas.

Ao que parece, as sugestões para o sistema federal, ao serem acatadas pelos sistemas estaduais, foram equivocadamente interpretadas, uma vez que encontramos vários quadros curriculares da década de 1970, em que Física, Química e Biologia figuram como sendo do núcleo comum e não da parte diversificada. Isso denota que houve um descumprimento da lei na sua forma literal; fato que, de certa forma, atenuou o descaso para com as disciplinas científicas específicas.

No que se refere às disciplinas da parte diversificada da formação especial, outros Pareceres e Resoluções ${ }^{74}$ trataram do tema. A Física aparece representada nesta parte, em alguns currículos estaduais, com nomenclatura de caráter instrumental, como exemplo, Física Aplicada, e também fragmentada em temas, tais como: Eletricidade, Análise de Circuitos, Eletrônica, e outras.

O Parecer n ${ }^{\circ} 785 / 1986$ e Resolução nº 06/1986 (15 anos depois da reforma), ao trazerem novas determinações a respeito do núcleo comum, revogando a Resolução $\mathrm{n}^{\circ}$ 08/1971, mudam a categoria das disciplinas específicas desmembradas das CFB, colocando estas, formalmente, no grupo do núcleo comum. O Artigo $6^{\circ}$ da Resolução $n^{\circ}$ 06/1986, traz:

Art. $6^{\circ}$ - Cabe a cada estabelecimento organizar o seu plano de curso atendendo que as matérias do núcleo comum sejam desenvolvidas:

[...]

II- NO ENSINO DE $2^{\circ}$ GRAU

Língua Portuguesa, Literatura, com maior ênfase para a Brasileira, Matemática, História, Geografia, Física, Química, Biologia e Língua Estrangeira Moderna, serão tratadas como disciplinas. [...]. (BRASIL, 1986b, Res. nº 06/1986, grifos nossos).

Nota-se a mudança textual quando se compara o Art. $5^{\circ}$, inciso II, da Resolução $n^{\circ}$ 08/1971, com o que trata do mesmo tema na Resolução $n^{\circ}$ 06/1986. Antes, para o $2^{\circ}$ grau, tinha-se CFB tratada como disciplina do núcleo comum; depois passaram a ser Física, Química e Biologia tratadas como disciplinas dessa parte do currículo.

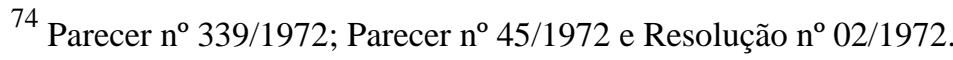


Esses documentos (de 1986) trazem ainda outra alteração importante na composição do currículo: a separação da Matemática da matéria Ciências, que segundo o Parecer $\mathrm{n}^{\circ}$ 785/1986, deixou-a menos "genérica". Assim, Matemática passou a ser também matéria, podendo ser tratada como área de estudo ou disciplina dependendo do nível de ensino.

Retomando o Parecer $\mathrm{n}^{\circ}$ 853/1971, são notáveis as ideias, ora implícitas, ora explícitas, da adoção dos princípios administrativos trazidos nos Acordos MEC-USAID, consolidados no Decreto-Lei $\mathrm{n}^{\circ}$ 53/1966, e também na Lei 5.540/1968 - a Reforma Universitária, que visou, dentre outras questões, a redução de gastos na administração do sistema educacional nas universidades.

Conforme ressalta Fiod (1983), a reforma do ensino médio, em 1971, ao estabelecer a profissionalização para o ensino de $2^{\circ}$ grau, estava consonante com a reforma do ensino superior ocorrida em 1968, que, além da adoção de princípios da administração empresarial nas escolas, propunha a terminalidade para o ensino de $2^{\circ}$ grau, com o explícito objetivo de conter a demanda por vagas nas universidades. Em articulação com as medidas de contenção presentes nas legislações emanadas a partir dos Acordos MEC-USAID, em que o princípio da economia se faz ponto relevante, o Parecer $n^{\circ} 853 / 1971$ traz:

Com isto, haverá um professor nos anos iniciais e quatro ou cinco daí por diante, no $1^{\circ}$ grau, num total de cinco ou seis onde antes se exigiam onze ou mais. Imaginando um desenvolvimento à base de $4+4$ nos dois sistemas, apenas para facilitar a comparação, veremos que em oito anos, numa só "turma", havia 44 pequenas "incidências docentes" que poderão agora reduzir-se a 20 ou 24 de maior âmbito. Mesmo no $2^{\circ}$ grau, onde os estudos científicos permaneçam integrados em Ciências Físicas e Biológicas, um só mestre polivalente substituirá os três de hoje. (BRASIL, 1971c, Documenta n ${ }^{\circ} 132$, p. 187).

O referido Parecer argumenta em favor dessa nova configuração para as Ciências, ainda que evidencie as dificuldades decorrentes desta.

[...] A conclusão óbvia, a que já chegou este Conselho, é a de que uma profunda revisão deve ser feita com urgência nos programas de formação do magistério, explorando as muitas aberturas que a lei oferece neste particular. Não será, decerto, automaticamente que se alcançarão esses resultados [...]. (BRASIL, 1971c, Documenta $\mathrm{n}^{\mathrm{o}} 132$, p. 187).

Os argumentos em defesa das áreas de estudo ou integração de disciplinas no currículo se estendem ao livro didático, exaltando a economia que as famílias, a escola e a comunidade teriam com a aquisição desse material, uma vez que essa nova perspectiva curricular, em tese, conduziria à elaboração de textos mais concentrados (BRASIL, 1971c, Parecer $\left.n^{\circ} 853\right)$.

As determinações da Resolução no 30/1974 visaram intervir na problemática da falta de professores habilitados/capacitados para lecionar CFB. Entretanto a história nos revela que 
tal medida não foi bem aceita, sendo alvo de muitos debates que resultaram em diversos documentos sobre o assunto, até a extinção completa, em 1996, dessa modalidade de formação de professores estruturados nos moldes da referida resolução.

O fato de Ciências ter sido destacada como uma das três matérias fixadas para a Educação Geral não significou aumento de carga horária de seus conteúdos específicos Matemática e CFB - ou das disciplinas desdobradas desta última. Pelo contrário, em alguns casos, as disciplinas (ou "subáreas" como foi desmembrada nos currículos) sofreram redução de carga horária, sobretudo no $2^{\circ}$ grau, para ajustes dos quadros curriculares, devido à inserção de disciplinas da parte de formação especial ${ }^{75} \mathrm{com}$ a finalidade de atender às habilitações profissionais adotadas pelas escolas (ou pelas Secretarias estaduais). Há casos em que, dependendo da habilitação profissional, nem mesmo consta CFB (ou suas disciplinas específicas) no currículo a partir da $2^{\mathrm{a}}$ série do $2^{\mathrm{o}}$ grau.

Um histórico escolar de um ex-estudante de uma escola de Minas Gerais, que iniciou o Ginasial em 1971, revela que no $1^{\circ}$ ano do curso Ginasial, equivalente à $5^{\mathrm{a}}$ série do $1^{\mathrm{o}}$ grau, o aluno cursou Ciências, entretanto o documento não traz informação de carga horária. A partir da $6^{\mathrm{a}}$ série, cursado na vigência da Lei 5.692/1971, a disciplina Ciências aparece com 60, 90 e 90 horas anuais, respectivamente, para a $6^{\mathrm{a}}, 7^{\mathrm{a}}$ e $8^{\mathrm{a}}$ séries. Convertendo em aulas semanais, 60 horas correspondia a 2 aulas semanais e 90 horas a 3 aulas. O $2^{\circ}$ grau foi cursado no período de 1975 a 1978 com habilitação de Técnico em Contabilidade. Interessante observar que CFB aparece somente no $1^{\circ}$ ano, desdobrada em Física ${ }^{76}$, Química e Biologia, com cargas horárias semanais de 3, 3 e 2 aulas, respectivamente. Nesse período em que o ex-estudante cursou o $2^{\circ}$ grau, estava em vigor o Parecer $n^{\circ} 45 / 1972$, que determinava a prevalência da formação especial nesse nível de ensino. Possivelmente, por esta razão, privilegiaram-se as disciplinas dessa parte do currículo.

No Estado do Paraná, os quadros curriculares ${ }^{77}$ de 1971, após a sanção da Lei 5692/1971, trazem para o Curso Normal, por exemplo, a Física, a Química e a Biologia somente na $1^{\mathrm{a}}$ série e com duas aulas semanais, no núcleo comum da Educação Geral. Para um curso da área Industrial, têm-se CFB no núcleo comum com carga horária total de 270

\footnotetext{
75 Identificam-se quadros curriculares em que disciplinas das Ciências, em uma configuração instrumental, aparecem com cargas horárias maiores que na Educação Geral.

${ }^{76}$ A respeito disso, no que se refere à Física, Moura (1985) afirma que por volta do ano de 1976 , cerca de $3 / 4$ dos cursos de $2^{\circ}$ grau em Minas Gerais contemplava tal disciplina em uma das três séries e menos de $1 / 5$ trazia a disciplina nas três séries.

${ }^{77}$ Quadros presentes nos Anexos do trabalho de TENÓRIO (2009). Nos quadros não constam o ano letivo. O autor traz como legenda o ano de 1971, mas supomos que a vigência de tais grades curriculares foi para o ano de 1972 em diante, já que a Lei 5.692/1971 foi publicada no mês de agosto.
} 
horas para todo o curso. Esse quantitativo equivale a uma distribuição média de três aulas semanais por série.

Enfim, três aulas semanais para trabalhar assuntos de Física, Química e Biologia. Ainda para esse curso $^{78}$, que consideramos um caso bem peculiar, contempla a Física e a Química como disciplinas da parte diversificada da Formação Especial com 120 e 90 horas total, respectivamente. Esse quantitativo corresponde para a Física, por exemplo, a quatro aulas semanais distribuídas nas três séries, o que corresponde uma média semanal por série de 1.33 aulas (caberia a seguinte distribuição: 4 aulas acumuladas em uma série; ou 2+2 ou 3+1 em duas séries; ou 2+1+1 em três séries). Para o Curso Técnico em Agropecuária, apresentam Física, Química e Biologia, no núcleo comum da Educação Geral, com cargas horárias de duas aulas nas $1^{\mathrm{a}}$ e $2^{\mathrm{a}}$ séries e uma aula semanal na $3^{\mathrm{a}}$ série.

Caju (2005) traz em seu trabalho grades curriculares de alguns cursos técnicos de uma escola do Estado do Rio de Janeiro, referente ao ano de 1973. A Física aparece como disciplina específica na parte de Educação Geral com duas aulas semanais nas $1^{\mathrm{a}}$ e $2^{\mathrm{a}}$ séries, assim como a Química e a Biologia. Os quadros apresentados pela autora não mostram a separação entre disciplinas do núcleo comum e parte diversificada da Educação Geral.

O Projeto de Reformulação de Currículos do Estado do Rio de Janeiro ${ }^{79}-2^{\circ}$ grau (1976/1977) mostra que em 1977 a situação da disciplina no currículo permaneceu a mesma. O documento traz a grade curricular contendo as disciplinas de educação geral e parte da formação especial (denominada instrumental), e, em separado, as grades curriculares de 10 habilitações adotadas pela Secretaria de Estado de Educação e Cultura/RJ. Na grade curricular, a CFB aparece desdobrada em disciplinas específicas - Física, Química e Biologia - no núcleo comum, com cargas horárias semanais de duas aulas em cada série, estando Física e Química presentes nas três séries e Biologia somente na $1^{\mathrm{a}}$ e $2^{\mathrm{a}}$ séries. A Física se faz presente, fragmentada, na Formação Especial na Habilitação Básica de Eletricidade, sob a denominação Eletricidade, com carga horária semanal de quatro e seis horas/aulas, nas $2^{\mathrm{a}}$ e $3^{\mathrm{a}}$ séries, respectivamente. Nas demais habilitações básicas, não apresentam a Física e nem CFB.

No currículo de Física do Estado de São Paulo $(1978)^{80}$, a Física aparece também como disciplina desdobrada das CFB no núcleo comum, com duas aulas semanais nas $1^{\text {a }}$ séries de todas as habilitações e modalidades de Formação Profissionalizante, e com duas aulas semanais na $2^{\mathrm{a}}$ série na Formação Profissionalizante Básica, Setor Terciário e

\footnotetext{
${ }^{78}$ Curso Desenhista de Estrutura.

${ }^{79}$ Essa Proposta Curricular será discutida com maiores detalhes no capítulo 4.

${ }^{80}$ Idem nota anterior.
} 
Habilitação do $2^{\circ}$ grau Magistério. Para a Formação Profissionalizante Básica do Setor Primário, aparece a partir da $2^{\mathrm{a}}$ série como disciplina instrumental Física Aplicada com três aulas semanais em cada série. Para a Formação Profissionalizante Básica do Setor Secundário, têm-se a Física Aplicada nas $3^{\mathrm{a}}$ e $4^{\mathrm{a}}$ séries, com três e quatro aulas semanais, respectivamente; e como disciplina específica profissionalizante Eletricidade na $3^{\mathrm{a}}$ série desta mesma formação básica, com duas aulas semanais (SÃO PAULO, 1978, p. 9-10).

Como se depreende dos exemplos citados, a Física, como disciplina da Educação Geral, bem como as demais disciplinas científicas específicas, a partir da Lei 5.692/1971 aparece com carga horária relativamente pequena, na maioria dos casos, duas aulas semanais em cada série. Há casos, como o dos cursos de uma escola mineira analisada e o do Curso Normal do Estado do Paraná, que só apresentam disciplinas científicas na $1^{\text {a }}$ série do $2^{\circ}$ grau.

Novamente, os discursos da Lei e suas normas não se efetivaram. Não se deu a devida evidência às disciplinas que levariam à formação de uma cultura científica condizente com as questões sociais que se faziam presentes. Além dos avanços científicos e tecnológicos que se processavam no mundo, outras questões decorrentes disso se impunham como necessidade de discussões passando a demandar uma atenção maior às disciplinas da área de Ciências. Elas deveriam servir como instrumento de preparação dos estudantes para “compreender a natureza, o significado e a importância da tecnologia para sua vida como indivíduos e como membros responsáveis da sociedade.” (KRASILCHIK, 2000, p. 89). Para tanto, a função das disciplinas científicas no currículo precisariam estar muito além de uma mera aplicação técnica.

No que se refere ao currículo das disciplinas, a Lei 5692/1971 também não ditou a elaboração de programas de ensino centralizados pelo poder público federal. Essa questão nem mesmo é mencionada na Lei. Deixou a questão em aberto, implicando que esse encargo ficaria para os sistemas estaduais e os estabelecimentos de ensino. Limitou-se a tarefar o CFE a fixar "as matérias relativas ao núcleo comum, definindo lhes os objetivos e a amplitude".

O Parecer no 853/1971, bem como a Resolução decorrente deste, traz esses objetivos mais gerais do núcleo comum, dos quais, para o ensino das Ciências visou "o 'desenvolvimento do pensamento lógico e a vivência do método científico', sem deixar de pôr em relevo as tecnologias que resultam de suas 'aplicações"," (BRASIL, 1971c, Documenta $\mathrm{n}^{\circ}$ 132, p. 177, aspas do original).

O Parecer traz ainda os objetivos específicos para cada uma das matérias fixadas, sendo para as Ciências o que transcrevemos a seguir: 
[...] a Matemática e a Ciências Físicas e Biológicas têm por função tornar o educando capaz de explicar o meio próximo e remoto que o cerca e atuar sobre ele, desenvolvendo para tanto o espírito de investigação, invenção e iniciativa, o pensamento lógico e a noção da universalidade das leis científicas e matemáticas. Repetimos que não se despreza o conhecimento feito e compendiado, e sim que a ele se deverá chegar pela redescoberta dos princípios gerais em relação aos quais, em cada caso, o conhecimento é funcionalmente uma aplicação. (BRASIL, 1971c, Documenta $\mathrm{n}^{\mathrm{o}} 132$, p. 179).

Conforme o Parecer nº 853/1971, há uma significativa diferença do que se entende por definição das “amplitudes”, entre as duas legislações - a LDB/1961 e a Lei 5692/1971. Os Conselheiros levantam críticas ao fato de a LDB/1961 determinar imposição do núcleo comum, com a determinação das disciplinas obrigatórias, indicação das complementares e definição das amplitudes e desenvolvimento dos programas de ensino. Segundo o Parecer:

Com tal formulação, nada praticamente se deixava à iniciativa de escolas e professores, quanto às disciplinas obrigatórias, se os aspectos que deviam ensinar e a forma de desenvolvê-los — as antigas "instruções metodológicas" — continuariam a ser artificialmente ditados de cima. (BRASIL, 1971c, Documenta $\mathrm{n}^{\circ} 132$, p. 182, grifo aspas do autor).

Como já relatado neste texto, o CFE em 1962 se abnegou de intervir na elaboração dos programas das disciplinas conforme previa a LDB/1961, emitindo somente algumas instruções gerais. Fato que não passou despercebido nas críticas assentadas no Parecer $n^{\circ}$ 853/1971: "Não fora a maneira flexível como exerceu este Conselho a atribuição que lhe era cometida e, decerto, nenhum progresso teria havido então sobre o regime de 1942." (BRASIL, 1971c, Documenta no 132, p. 182).

E conclui:

Já agora, segundo o artigo $4^{\circ}\left(\S 1^{\circ}\right.$ inciso I) da Lei 5.692/71, o CFE fixa "as matérias relativas ao núcleo comum, definindo-lhes os objetivos e a amplitude". Há, portanto, duas diferenças fundamentais a considerar, se pusermos de lado as mudanças de nomenclatura: a preocupação dos objetivos, que importou avanço inegável, e a supressão dos "programas de ensino" e de seu "desenvolvimento". A amplitude passou a referir-se às matérias, e não mais a programas, caracterizando-se a sua definição como um estabelecimento da posição relativa do núcleo no conjunto do currículo. (BRASIL, 1971c, Documenta $\mathrm{n}^{\circ} 132$, p. 182, grifos aspas do autor).

A Lei 5692/1971 passou por alterações em seus objetivos gerais, como por exemplo, na questão da profissionalização compulsória para o $2^{\circ}$ grau. Essa obrigatoriedade foi diminuída com o Parecer $n^{\circ} 76 / 1975$, do CFE, que numa reinterpretação da Lei, redefiniu o número de habilitações básicas para escolha na composição dos cursos de $2^{\circ}$ grau nas escolas, e trouxe mudanças na divisão entre a educação geral e a formação especial, atenuando as exigências em relação a esta última no $2^{\circ}$ grau, dando maior alento à formação geral.

Esse Parecer inseriu a categoria de formação por área de atividade com possibilidade de posterior treinamento específico a partir de estágios ou no próprio emprego, alterando as 
determinações do Parecer $n^{\circ}$ 45/1972 que previa habilitações para uma ocupação definida. Esse fato representou o começo do declínio da profissionalização compulsória do $2^{\circ}$ grau.

Destacam-se alguns pontos relevantes da Lei 5692/1971 que a diferencia da LDB/1961:

$\rightarrow$ Suprimiu a dualidade do sistema de ensino ao determinar a profissionalização compulsória do ensino de $2^{\circ}$ grau (terminalidade);

$\rightarrow$ Extinguiu de vez os exames de admissão;

$\rightarrow$ Estendeu a obrigatoriedade do ensino público gratuito para oito anos;

$\rightarrow$ Permitiu a matrícula por disciplina, dando a oportunidade de conclusão de curso do $2^{\circ}$ grau em no mínimo dois anos e no máximo cinco anos;

$\rightarrow$ Criou a possibilidade de extensão dos cursos do $2^{\circ}$ grau para quatro séries.

Em matéria de lei, os pontos listados acima são, sem dúvida, aspectos que poderiam representar uma reforma de fato. Entretanto, conforme coloca Fazenda (1985) e Aranha (1989), a maioria deles se tornou "letra morta". A grande demanda por vagas, a falta de estrutura física das escolas e de recursos humanos preparados para a nova sistemática de educação profissionalizante foram obstáculos ao cumprimento da Lei.

O aspecto referente ao primeiro ponto acima destacado foi, sem dúvida, o mais criticado. No que tange à profissionalização do ensino de $2^{\circ}$ grau, criou-se uma grande quantidade de habilitações, muitas pertencentes a uma mesma área de atividade específica, ao que parece, com o intuito de aproveitamento das condições estruturais das escolas, que eram bastante precárias.

As perdas parecem ter sido mais desastrosas para as escolas da rede pública, uma vez que estas, segundo Cury (1982, p.43),

[...] ofereciam a maior parte do ensino profissionalizante nas áreas do setor secundário e do setor primário, que são os mais dispendiosos, em função de salas especiais e de equipamentos necessários, enquanto na rede particular predominam os ambientes tradicionais já existentes e o preparo para o setor terciário.

Muitas escolas buscaram saída adotando cursos da área terciária, a exemplo das escolas particulares que já tinham preferência por cursos da referida área, por demandarem menores custos e exigências curriculares na implementação, além de permitirem melhor aproveitamento dos recursos humanos disponíveis. Em consequência disso, eclodiu no mercado um grande quantitativo de técnicos disponíveis à mão-de-obra barata, principalmente provindos dos Cursos Técnicos em Contabilidade, Administração e Secretariado. No discurso de suprir às demandas do mercado, acabou-se por gerar uma situação no país em que a oferta de emprego, para algumas áreas (principalmente do setor terciário), era muito menor do que a 
mão-de-obra disponível (ARANHA, 1996); ressalte-se, com formação acadêmica de qualidade questionável.

Quanto aos currículos das habilitações básicas oferecidas pelos estabelecimentos de ensino, os dispositivos da Lei acabaram incentivando o mascaramento dos mesmos ao permitir o desdobramento dos conteúdos da Educação Geral em disciplinas instrumentais da parte de Formação Especial (CURY, 1982). Disciplinas sofreram mudanças de nomenclatura para parecerem "técnicas ou instrumentais", mas na verdade, na prática, em termos de conteúdo, continuavam a serem as mesmas que os professores vinham ministrando até então.

Conforme Aranha (1989), as escolas de elite, ou seja, as particulares, burlaram a lei, e, embora apresentassem um "programa oficial" atentando às exigências legais, continuavam com suas propostas pedagógicas voltadas para a preparação para o vestibular, de modo que continuaram propedêuticas, "enquanto as escolas oficiais [rarefaziam] seus programas com disciplinas mal ministradas, descuidando ainda mais da formação geral.” (ARANHA, 1989, p. 258).

Movimentos em prol da eliminação do $2^{\circ}$ grau profissionalizante, como o que ocorreu em 1978, por educadores reunidos no XVI Congresso Nacional de Estabelecimentos de Ensino, bem como os posicionamentos da Confederação Nacional dos Estabelecimentos de Ensino Particular de $1^{\circ}$ e $2^{\circ}$ graus e da Confederação de Professores do Brasil, que defendiam o fortalecimento das disciplinas básicas do currículo, foram fatores de grande relevância para o fim dessa modalidade de ensino (PILETTI, 1988).

$\mathrm{O}$ encerramento do caráter profissionalizante do $2^{\circ}$ grau ocorreu com a Lei $\mathrm{n}^{\mathrm{o}} 7.044$ de 18 de outubro de 1982, quando o termo "qualificação para o trabalho" presente no Artigo $1^{\circ}$ da Lei 5.692/71, foi substituído por "preparação para o trabalho".

O significado prático dessa mudança de termo, embora o termo "preparação para o trabalho" ainda pressupusesse foco na formação profissional, foi a desobrigação de o $2^{\circ}$ grau ter como finalidade a habilitação profisssional, uma vez que "a preparação para o trabalho, no ensino de $2^{\circ}$ grau, [poderia] ensejar habilitação profissional, a critério do estabelecimento de ensino" (BRASIL, 1982, Art. $4^{\circ}, \S 2^{\circ}$ ).

As mudanças determinadas na Lei 7.044/1982 - ao colocar a profissionalização do $2^{\circ}$ grau como uma opção, e não uma obrigação - significaram o retorno dos dois tipos de escolas para o $2^{\circ}$ grau: a de educação geral (propedêutica) e as escolas técnicas profissionalizantes. Assim, reestabeleceu-se "a dualidade de ensino, característica inerente à estrutura educacional brasileira" (FIOD, 1983, p.95). 
Segundo o Parecer no 785/1986, a Lei 7.044/1982 não invalidou os pareceres emanados do CFE em cumprimento da Lei 5.692/1971. Assim, o significado do termo preparação para o trabalho na conjuntura da nova Lei assume diversas conotações, além daquelas presentes nas normatizações da Lei anterior, tais como orientação vocacional, responsabilidades com as tarefas de estudo, "preparação ampla da inteligência", incentivo ao desabrochar de virtualidades interiores, preparação para estudos posteriores, etc. (CUNHA, 2005). Nesse sentido, Cunha coloca:

A preparação para o trabalho poderia ser entendida de modo tão lato, que estaria plenamente atendida por uma escola de $2^{\circ}$ grau, especializada na preparação para os exames vestibulares, que oferecesse aos alunos informações sobre os cursos de nível superior, promovesse visitas às empresas, palestras de professores e profissionais, assim como propiciasse a realização de testes vocacionais. (CUNHA, 2005, p. 206).

A Lei 5.692/1971, suas normas regulamentadoras, com suas diversas alterações, vigoraram até 1996, quando foi promulgada uma nova LDB que atualmente dita as regras da Educação Nacional: a Lei 9.394 de 20 de Dezembro de 1996 (LDB/1996).

Após diversas emendas, atualmente, a estrutura da educação básica na LDB/1996 se apresenta da seguinte forma: "Art. $4^{\circ}$ [...] I - educação básica obrigatória e gratuita dos 4 (quatro) aos 17 (dezessete) anos de idade, organizada da seguinte forma: a) pré-escola; $b$ ) ensino fundamental; c) ensino médio" (BRASIL, 1996; 2013). Nessa estrutura, o ensino fundamental substituiu o $1^{\circ}$ grau e o ensino médio, o $2^{\circ}$ grau.

Conforme traz o Art. 22. "A educação básica tem por finalidades desenvolver o educando, assegurar-lhe a formação comum indispensável para o exercício da cidadania e fornecer-lhe meios para progredir no trabalho e em estudos posteriores." (BRASIL, 1996; 2013). No que tange ao ensino médio, equivalente ao antigo $2^{\circ}$ grau, em que a Física está inserida como disciplina da base nacional comum, o Artigo 36 sintetiza os princípios de currículo em vigor.

Art. 36. O currículo do ensino médio observará o disposto na Seção I deste Capítulo e as seguintes diretrizes:

I - destacará a educação tecnológica básica, a compreensão do significado da ciência, das letras e das artes; o processo histórico de transformação da sociedade e da cultura; a língua portuguesa como instrumento de comunicação, acesso ao conhecimento e exercício da cidadania;

II - adotará metodologias de ensino e de avaliação que estimulem a iniciativa dos estudantes;

$[\ldots]$

$\S 1^{\circ}$ Os conteúdos, as metodologias e as formas de avaliação serão organizados de tal forma que ao final do ensino médio o educando demonstre:

I - domínio dos princípios científicos e tecnológicos que presidem a produção moderna;

II - conhecimento das formas contemporâneas de linguagem; [...] (BRASIL, 1996; 2013). 
A LDB/1996 também não centralizou a elaboração dos conteúdos programáticos das disciplinas, embora determine algumas diretrizes para inclusão de temas considerados relevantes, e que não constituem disciplinas específicas, mas que devem ser integrados aos diversos conteúdos do currículo. As orientações são bem amplas, e a maioria delas devem se integrar também ao ensino de Física, uma vez que tal disciplina tem papel de relevo na escola ao propiciar condições ao aluno cidadão de participar ativamente na construção de uma sociedade contemporânea democrática e socialmente responsável, no que se refere ao uso das tecnologias oriundas das pesquisas científicas. Ressalte-se ainda a importância das interações cognitivas e afetivas em sala de aula, como parte integrante de uma formação mais ampla. Orientações mais específicas em termos de conteúdos das disciplinas, porém, não obrigatórias, deram-se por meio dos Parâmetros Curriculares Nacionais, publicados pelo MEC a partir de 1998. Não nos prenderemos a detalhes sobre tais documentos, uma vez que fogem ao escopo deste trabalho.

Remetendo à questão da formação profissional para habilitação técnica de nível médio, com a atual LDB, passa-se a permitir duas formas: articulada com o Ensino Médio de modo que "atendida a formação geral do educando, poderá prepará-lo para o exercício de profissões técnicas" (BRASIL, 1996; 2008, Art. 36-A); em curso subsequente à conclusão do ensino médio (BRASIL, 1996; 2008, Art. 36-B,II).

Essa articulação com o Ensino Médio que concede a habilitação técnica poderá ser feita por meio de curso integrado com matrícula única em um mesmo estabelecimento de ensino, sendo o curso planejado de modo a conduzir o aluno à habilitação profissional técnica; ou concomitante ao ensino médio, com matrículas distintas no mesmo estabelecimento de ensino ou em estabelecimentos de ensino distintos (BRASIL, 2008).

Cabe ressaltar que essa Lei e suas emendas criaram outras possibilidades de educação profissional, podendo esta ser desenvolvida em diversos níveis de escolaridade, como exemplo, para jovens e adultos que não concluíram os seus estudos na idade certa. Assim, educação profissional objetiva não somente uma habilitação técnica de nível médio, mas sim a formação inicial e continuada que pressupõe a qualificação e a requalificação para os cidadãos em qualquer idade e escolaridade. A educação profissional ganha o complemento de "e tecnológica" a partir da Lei no 11.741/2008 e, "no cumprimento dos objetivos da educação nacional, integra-se aos diferentes níveis e modalidades de educação e às dimensões do trabalho, da ciência e da tecnologia." (BRASIL, 2008, Art. 39).

Com uma significativa alteração em relação à Lei 5.692/71, que preconizava uma dupla função para o $2^{\circ}$ grau, habilitação técnica e função propedêutica, a nova LDB amplia a 
abrangência de toda a educação escolar, e não somente do ensino médio, vinculando-a ao mundo do trabalho e à prática social. Outro aspecto de grande relevância se refere à extensão da obrigatoriedade para com a educação, agora denominada de Educação Básica e que abrange a faixa etária dos 4 aos 17 anos de idade. O termo "básica" traz novo significado para a educação formal, o que pressupõe novas formas de organização do sistema educacional (CURY, 2008). 


\section{INOVAÇÕES/PROPOSIÇÕES NOS CURRÍCULOS DE FÍSICA NO BRASIL - 1960/70}

No capítulo anterior enfatizamos as disciplinas da área de Ciências quanto à presença delas nas organizações curriculares das reformas educacionais que comporta nosso referencial teórico/documental, sendo possível comparar a evolução dessa presença a partir de 1931. Abordamos ainda às orientações metodológicas mais gerais para a área nas reformas de 1961 e 1971, evidenciando a inexistência de imposição legal de programas mínimos para as disciplinas da referida área.

A partir deste capítulo (Capítulos 3, 4 e 5) o nosso foco converge para a disciplina Física, em sua característica particular de disciplina sistemática específica, que nas reformas curriculares investigadas se encontra no currículo das séries finais da educação escolar básica, em geral, nas três últimas. Doravante, passaremos a tratar de aspectos referentes às orientações curriculares específicas para o ensino de Física no ensino médio, ocorridas no recorte temporal delimitado neste estudo, apresentadas nas formas de projetos de ensino, propostas curriculares oficiais e livros didáticos - ou seja, os currículos de Física. O que consideramos aqui como currículos de Física, se assenta na concepção de currículo como um conjunto de saberes e conhecimentos, específicos da ciência/Física, socialmente produzidos e legitimados como cultura válida, e que são transmitidos na forma de conhecimento escolar sistematizado, em um determinado momento da história (GOODSON, 1995; APPLE, 1997; SACRISTÁN, 2006).

Neste capítulo enfocaremos os projetos de ensino de Física que configuraram como importantes inovações curriculares trazendo novas visões de ensino de Ciências e motivando um maior interesse pela pesquisa em ensino de Física no país a partir da década de 1960. Conforme nosso propósito de investigação, iniciaremos na Seção 3.4, a sistematização dos dados de um estudo mais acurado nos referenciais curriculares orientadores da prática pedagógica que estiveram presentes no contexto educacional investigado. Análise esta, direcionada pelas dimensões/categorias/elementos já expostos no segundo capítulo. Nos capítulos seguintes (4 e 5) daremos continuidade ao estudo dos referenciais curriculares abrangendo os demais tipos tomados como objetos de análise em nosso estudo. 


\subsection{O contexto gerador das inovações}

Almeida Junior (1979), ao escrever sobre a evolução do ensino de física no Brasil fazendo um retrospecto desde o Brasil colônia até a década de 1970, ressalta a influência alemã na escola brasileira nos fins do século XVIII. O autor se refere às Realshulen (escolas reais), um tipo de escola surgida na Alemanha, paralela aos colégios clássicos de estudos preponderantemente literários. Essas escolas tinham um currículo mais científico que literário e tinham como público alvo “cidadãos que não encontravam no estudo quase que exclusivamente das línguas e literaturas antigas o preparo básico para as diversas carreiras profissionais" (HAIDAR, 2008, p. 117). Segundo Haidar, ainda que de forma tímida, essa filosofia educacional alemã refletiu na reforma do curso dos estudos do Colégio da Corte, na década de 1850.

Para Almeida Junior (1979), no que se refere à Física, essa influência trouxe desenvolvimento, evidenciando a necessidade de experiências e demonstrações práticas dos princípios estudados. Conquanto esta estratégia de ensino fosse centrada no professor - pois os experimentos eram demonstrativos e manipulados por ele, sem interação e participação direta do aluno - não se pode negar o mérito de ensaiar a inserção da experimentação nas aulas de Física no Colégio D. Pedro II, ainda que isto não tenha provocado mudanças nos métodos de ensino de Física nas escolas do país.

A questão da experimentação nas aulas de Física (mesmo que como demonstração) parece ter passado por um processo de hibernação durante longos períodos, como pode ser observado nos programas oficiais do Colégio D. Pedro II, que ditava as regras do currículo oficial para as escolas brasileiras até 1961. Do apanhado de programas curriculares do período que compreendeu as décadas de 1850 a 1950, organizados por Vechia e Lorenz (1998), constata-se que indicação de "parte prática" no currículo só aparece nos programas das reformas de 1925, 1929 e de 1951. Na reforma de 1925 e 1929, as atividades práticas eram previstas somente para uma série (o quarto ano). No programa de 1951, correspondente à reforma de 1942, o programa constou de atividades para as três séries do curso científico, entretanto, em horas extracurriculares. Constata-se disto que o preterimento para com as atividades experimentais no ensino de Física é fator histórico.

Considera-se como marco para a inovação no ensino de Ciências no Brasil, que almejou mudar a prática de ensino que praticamente ignorava as atividades experimentais, a criação do Instituto Brasileiro de Educação, Ciência e Cultura (IBECC), em 1946, no Rio de Janeiro. Esta instituição, que se configurou como uma Comissão Nacional da Organização das 
Nações Unidas para a Educação, a Ciência e a Cultura (UNESCO) no Brasil, teve como objetivo agenciar projetos na área de Ciências na busca de promover a universalização da mesma, considerando as necessidades locais (KRASILCHIK, 1987; NARDI, 2005; ABRANTES; AZEVEDO, 2010). Em 1950, essa experiência foi estendida ao Estado de São Paulo, com a abertura de uma sede, inicialmente nas dependências da Faculdade de Medicina da Universidade de São Paulo (USP).

Barra e Lorenz (1986) afirmam que a Comissão Estadual de São Paulo do IBECC foi criada em 02 de março de 1950. Segundo Abrantes (2008), o início do processo de criação da comissão estadual ocorreu em 1947, sob a determinação do governador de São Paulo Adhemar de Barros (1947-1951) que informou ao IBECC, via ofício, a constituição de um grupo incumbido de tal tarefa. Segundo esse autor, "Somente três anos após, em março de 1950, [...], nasce a Comissão Estadual de São Paulo do IBECC. [...]”. (ABRANTES, 2008, p.133).

As atividades dessa instituição coordenaram a integração de experiências individuais de professores/pesquisadores, que há algum tempo já buscavam alternativas para melhorar o ensino de Ciências nas salas de aula. Krasilchik (1980, p.164) afirma que "os objetivos iniciais do trabalho [do IBECC] eram principalmente o de atualizar os conteúdos então ensinados nas escolas secundárias, e tornar o ensino prático". Para o alcance disso, pretendeu que o projeto de mudança se apoiasse em "pelo menos três linhas de ações: produção de livros e textos, produção de equipamentos e atuação juntos aos professores" (KRASILCHIK,1980, p. 165).

As ações do IBECC e posteriormente da Fundação Brasileira para o Desenvolvimento do Ensino de Ciências (FUNBEC) envolveram a elaboração de Kits para atividades práticas, tradução e elaboração de projetos de ensino, criação de clubes de ciências, exposições científicas, Programas de TV, concursos científicos, Feira de Ciências, treinamento de professores, produção de livros didáticos, entre outras (ABRANTES; AZEVEDO, 2010).

O trabalho dessa instituição contou com algumas políticas públicas desencadeadas pelo governo federal, que permitiram a realização de diversas ações que caracterizaram o que é considerado como "movimento renovador do ensino de ciências" no Brasil (cf. KRASILCHIK, 1980; 1987; 2000). A partir de 1965, por iniciativa do MEC, foram criados os Centros de Treinamento de Professores de Ciências em vários estados brasileiros. O primeiro foi o do Nordeste, o CECINE, em Recife. Na sequência implantou-se o CECIRS, em Porto Alegre, o CECIMIG, em Belo Horizonte, o CECIGUA, no Rio de Janeiro, o CECISP, em São 
Paulo e o CECIBA, em Salvador (BARRA; LORENZ, 1986). Conforme Barra e Lorenz (1986, p. 1975), o objetivo desses centros era "treinar professores e produzir e distribuir livros-texto e materiais para laboratório para as escolas de seus respectivos estados.". O treinamento de líderes e administradores para atuar nos Centros de Ciências ficou a encargo do IBECC, conforme informam esses autores.

A FUNBEC foi criada em novembro de 1966, como uma fundação de direito privado, com projetos em comum com o IBECC/SP. Na realidade, o que ocorreu foi uma transferência de atividades que vinham sendo desenvolvidas desde 1952, no IBECC/SP, coordenadas pelo Prof. Isaias Raw, que dadas às características do seu empreendimento inovador, precisou driblar as interferências políticas que ameaçavam interrompê-lo. Vivia-se um momento tenso no regime político do país. Assim, a FUNBEC passou a atuar em função complementar ao IBECC/SP (ABRANTES, 2008). Este último atuava na criação de material didático, treinamento de professores e outras ações culturais (simpósios, seminários, feiras de ciências, concursos científicos, etc.). A FUNBEC ocupava-se da industrialização dos materiais criados, projetando, produzindo e comercializando os recursos acessórios a esses materiais, como por exemplo, instrumentos ${ }^{81}$ para atividades experimentais em laboratórios didáticos (BARRA; LORENZ, 1986; ABRANTES, 2008). Em resumo, conforme salienta Abrantes (2008), o FUNBEC tinha atribuições de natureza mais comercial e industrial.

O alcance desse processo de inovação na década de 1960 abrangeu importantes iniciativas de alteração no currículo de Física, com a criação de um primeiro projeto de ensino de Física, no triênio 1962 - 1964 (o Projeto Piloto de Física da UNESCO) com a participação de professores brasileiros, bem como pela tradução e tentativa de adaptação de materiais estrangeiros, ainda na primeira metade da década, dos quais trataremos mais adiante.

A continuação do movimento para renovar o ensino de Ciências, a partir de 1972, ganha reforço com a criação do Programa de Expansão e Melhoria do Ensino (PREMEN) ${ }^{82}$, criado pelo MEC, que teve como objetivo mais amplo contribuir para o ajustamento do currículo às novas exigências preconizadas na Lei 5.692/1971, e também serviu como estratégia de consolidação dos escopos previstos nos famosos acordos MEC-USAID. Conforme afirma Lorenz (2008), com o apoio ao PREMEN, a USAID "proporcionou 50\% dos recursos financeiros e o Ministério da Educação e Cultura proporcionou 20\%. O restante

\footnotetext{
${ }^{81}$ Além de materiais didáticos, o IBECC/FUMBEC-SP planejava e construía também equipamentos médicos para uso da Faculdade de Medicina da USP, tais como eletrocardiógrafos, desfibriladores e monitores cardíacos (ABRANTES, 2008).

${ }^{82}$ Alguns autores se referem a esse programa como PREMEM - Programa de Expansão e Melhoria do Ensino Médio, mas trata-se do mesmo programa PREMEN aqui mencionado.
} 
ficou sob a responsabilidade de cada Estado onde o PREMEN desenvolvia suas atividades." (LORENZ, 2008, p. 18).

O PREMEN tinha como objetivo mais específico reestruturar e aperfeiçoar o ensino de $1^{\circ}$ e $2^{o}$ graus como um todo, com prioridade o ensino de Ciências e Matemática; "responsabilizou-se pelo desenvolvimento de materiais didáticos, adequados para a realidade brasileira, e ao treinamento de professores" (LORENZ, 2008, p.18). Segundo Lorenz, essa política de governo, que ampliou a capacidade de produção de materiais didáticos para o ensino de Ciências, revelou a importância dada à área no projeto desenvolvimentista que se processava no país.

No mesmo ano foi criado o Projeto Nacional para Melhoria do Ensino de Ciências (PNMEC), também pelo MEC, tendo o PREMEN como órgão executor. Os objetivos desse projeto eram bem mais definidos, de modo que o mesmo representou um apoio ainda maior à continuação dos trabalhos de melhoria do ensino de Ciências conduzido pelos Centros de Ensino de Ciências, universidades, agências do governo federal e o IBECC/FUNBEC (LORENZ, 2008), durante todo o restante da década de 1970. Tais objetivos comportavam a elaboração e experimentação de materiais didáticos para o ensino de Ciências no $1^{\circ}$ e $2^{\circ}$ graus, bem como a capacitação de professores da referida área nesses níveis de ensino.

Foi com o apoio advindo desse projeto político que importantes projetos de ensino de Física foram desenvolvidos na década de 1970, sendo os de maior destaque conduzidos por professores do Instituto de Física da Universidade de São Paulo ou grupo de maioria ligada a essa universidade.

As ações iniciadas pelo IBECC/SP na década de 1950, e que deram corpo ao movimento renovador brasileiro para o ensino de Ciências, se estendendo às décadas seguintes, segundo Krasilchik (1980), foram pioneiras em nível mundial, embora tenham surgido outras similares. O movimento teve como meta a transformação curricular de todo um setor do currículo: Ciências do ciclo Ginasial (parte que compôs o $1^{\text {o }}$ grau), e, Física, Química, Biologia e Matemática do Colegial ( $2^{\circ}$ grau). Esse pioneirismo indica ter sido reconhecido mundialmente, conforme coloca o próprio Isaias Raw:

A importância do programa do IBECC de São Paulo na inovação do ensino de
ciências teve reconhecimento amplo fora do Brasil. Eu diria, sem modéstia, que as
iniciativas do IBECC desencadearam a prioridade dada pela UNESCO e pela União
Pan-americana para a importância do ensino de ciência como fator de
desenvolvimento (...). Tornei-me um líder no continente, convidado a participar em
1963 das três reuniões organizadas pela União Pan-americana: a de ensino da física,
de ensino de biologia e do ensino de química. O mesmo ocorreu na Conferência
Internacional sobre a física na educação geral, realizada no Rio de Janeiro, onde
conheci Zacharias e Feyman (sic), e me tornei um dos autores do Why Teach
Physics, editado pelo MIT. Durante algum tempo nós éramos o programa de ensino 
de ciências da UNESCO, que se orgulhava do nome IBECC-UNESCO (RAW ${ }^{83}$, 2005, p. 25 apud ABRANTES; AZEVEDO, 2010, p. 485).

Como bem coloca Krasilchik (1980), a inovação no ensino de Ciências no Brasil constitui tema importante de pesquisa. Pela dinâmica do processo, em que fracassos e sucessos coexistiram, representou oportunidades de grandes aprendizados que têm contribuído para a continuação de ações que visam à melhoria do ensino da área em muitas universidades brasileiras. Além de ter contribuído para a definição de um "campo de estudos sobre a temática, campo este que vem sendo denominado de área de ensino de Ciências, ou área de Educação em Ciências" (NARDI, 2005, p. 15).

\subsection{Os projetos internacionais para o Ensino de Ciências: a gênese}

Os trabalhos que buscaram a revitalização do ensino de Ciências no Brasil na década de 1950 se agregaram a um movimento de nível macro. Nessa década, o ensino de Ciências era alvo de intensos debates e renovação em vários países do primeiro mundo, ainda sob os efeitos da Segunda Guerra Mundial, e, especialmente nos Estados Unidos, que protagonizava, naquele contexto, uma guerra de poder com a União Soviética, pelo domínio ideológico, político, econômico e científico-tecnológico do mundo - a Guerra Fria. A derrota dos Estados Unidos na corrida pela conquista espacial, para a União Soviética, em razão do lançamento do satélite Sputnik, em outubro de 1957, intensificou a disputa. O fato, de certo modo, significou fragilidade política e cientifico-tecnológica dos Estados Unidos.

Segundo Chassot (2004, p. 17), "a corrida espacial se constituía na melhor vitrine para demonstração de superioridade". Uma das ações para contornar a perda, pelo Governo estadunidense, foi a criação da National Aeronautics and Space Administration (NASA), com investimento financeiro compatível ao nível do susto com a derrota. Outras ações radicais envolveram o campo educacional. Chassot coloca:

Os Estados Unidos também buscaram culpados em 1957 por sua desvantagem na corrida espacial. Um apareceu em evidência: a escola. Mais precisamente, o ensino de ciências ou, ainda mais, as deficiências do sistema educacional estadunidense foram apontadas como responsáveis pelas desvantagens tecnológicas. (CHASSOT, 2004, p. 24).

No intuito de corrigir esse "infortúnio", visto como um dos fatores que geraram uma “crise de segurança nacional", o Governo do EUA injetou grandes montantes de recursos em prol das intervenções curriculares, especialmente no ensino de Ciências, para a continuidade

${ }^{83}$ RAW, Isaías. Autobiografia. São Paulo, 2005. Mimeografado. 
de ações que já estavam em andamento, bem como para preparação de outras. Embora muitas pesquisas da área de ensino de ciências marquem as intervenções curriculares estadunidenses como consequência do emblemático fenômeno Sputnik, cabe ressaltar que antes de tal feito já ocorriam debates sobre a necessidade de renovação do ensino de ciências nas escolas, com proposições de novos métodos de desenvolvimento dos conteúdos.

Como exemplo disso, tem-se o Physical Science Study Committee (PSSC), que se iniciou em 1956 e ganhou maior incremento financeiro com a ocorrência do referido evento tecnológico. Cabe pontuar que, nesse contexto, já atuava a National Science Foundation (NSF), "uma agência oficial e independente, criada em 1950, por ato do Congresso Americano, e incumbida da responsabilidade de estabelecer uma política nacional referente à pesquisa básica e ao ensino de Ciências." (LORENZ, 2008, p. 10).

Conforme afirma Chassot,

Essas reformas se centraram no desenvolvimento de projetos para os quais foram recrutadas figuras exponenciais de todas as áreas, inclusive muitos laureados com prêmio Nobel, com o patrocínio vultoso da National Science Foundation para definir conteúdo, estratégia, atividades dos alunos nos laboratórios escolares e equipamentos de baixo custo. (CHASSOT, 2004, p. 25).

Os projetos estadunidenses, desenvolvidos no final da década de 1950 e década de 1960, cobriram toda a grande área de Ciências da Natureza e a Matemática, e os de maior projeção foram: Physical Science Study Committee (PSSC) e Introductory Physical Science (IPS), para a Física; Biological Science Curriculum Study (BSCS), para a Biologia; Chem Study e Chemical Bond Approach (CBA) para a Química e Science Mathematics Study Group (SMSG), para a Matemática. Ainda na área de Ciências da Natureza inclui-se a Geociências que também foi contemplada com um projeto curricular na mesma época, o Earth Science Curriculum Project (ESCP) (AMARAL, 2014).

Além desses projetos, no que tange à Física do segundo ciclo do ensino secundário, outro projeto foi elaborado também nos Estados Unidos, entre 1962 e 1970, entretanto, com repercussão mais restrita se comparado ao PSSC. Referimo-nos ao Projeto Havard, ou "Project Physics Course" da Universidade de Harvard, conhecido também como Harvard Project Physics. Também nesse contexto, a Inglaterra elaborou projetos para a área, financiados pela Nuffield Foundation. O de Física leva o nome da referida Fundação (BARRA; LORENZ, 1986; PINHO-ALVES, 2000; NARDI, 2005; outros).

Talvez a Física, como área de pesquisa e como disciplina escolar, tenha tido a maior prospecção dentre as demais áreas de Ciências da Natureza, nessa batalha pela hegemonia do 
alto conhecimento científico e tecnológico. Maia (1973) cita um trecho de um artigo da Scientific American, de 1958, que traz:

Na discussão pública que se seguiu aos lançamentos dos satélites russos, a palavra
Física ocorreu provavelmente com uma frequência maior que as próprias palavras
'satélites', 'foguetes' e 'míssil'. Muitos conferencistas e escritores chegaram à
conclusão de que o progresso científico e tecnológico da União das Repúblicas
Socialistas Soviéticas poderia ser inteiramente atribuído ao fato de que, naquele
país, todo aluno ao terminar o curso de grau médio possuía 12 anos de estudo de
Matemática e 6 anos de estudos de Física. Parecia, por conseguinte, que tudo o que
os Estados Unidos da América do Norte necessitavam fazer para reconquistar a
antiga e indiscutível liderança científica e tecnológica mundial era introduzir mais
Física e Matemática em suas escolas. (SCIENTIFIC AMERICAN, Abril, 1958 apud
MAIA, 1973, p.10-11).

Dentre todos os projetos de ensino de Física do período histórico em questão, o PSSC indica ter sido o de maior proeminência, tanto dos Estados Unidos, quanto em outros países para os quais o projeto fora transplantado, inclusive para o Brasil. Segundo Carvalho (1972), o PSSC foi traduzido para 15 línguas, sendo o Brasil o pioneiro na tradução em língua estrangeira, do guia de laboratório, em 1961. Pinho-Alves (2000, p. 25) opina que o PSSC foi "um dos mais reconhecidos currículos de Física do mundo".

Compreende-se que o incentivo ao ensino de Ciências surgido nos países desenvolvidos após a Segunda Guerra Mundial, no contexto da Guerra Fria, é marcado por fortes conotações políticas; uma corrida por um sistema educacional eficiente do ponto de vista científico e tecnológico. Corrobora o juízo de ter sido um investimento com foco em longo prazo, com o ideário de preparar futuros cientistas para atuarem em pesquisas em prol da defesa de seus países. Ideário este assumido pelo Brasil, em afinidade com a política dos Estados Unidos. Nesse sentido coloca Almeida Junior (1980):

Com respeito ao ensino médio logo após a segunda guerra, grandes motivações sobrevieram na mentalidade educacional do país [Brasil]. Era necessário preparar contingente de professores e pesquisadores que acelerasse o processo de industrialização, dirigido para uma tecnologia forte capaz de armar e defender a nação. (ALMEIDA JUNIOR, 1980, p. 65).

Conforme ressalta Chassot (2004, p.18), a julgar pelo regime político que transcorria no Brasil a partir de 1964, "visceralmente anticomunista”, é possível compreender a razão de tamanha aceitação e empenho na transferência dos produtos educacionais inovadores dos Estados Unidos. Não há reformas educacionais desinteressadas. Como bem coloca Nunes (1962), as reformas "refletem os interesses das atuais forças sócio-político-econômicas no país" (NUNES, 1962, p. 15).

A introdução e tradução de projetos estrangeiros no Brasil se deram, principalmente, por financiamento da Fundação Ford e apoio da USAID (CARVALHO, 1972; BARRA; LORENZ, 1986). As inovações experimentadas com os referidos projetos se assentam na 
flexibilidade de adoção de novas propostas pedagógicas de ensino legalmente liberada na LDB/1961 (cf. BRASIL, 1961, Art. 20).

No que se refere aos projetos estrangeiros, daremos destaque aos específicos para o ensino de Física, com maior ênfase ao PSSC, pela importância que se impõe ao mesmo, por ser ele o precursor dos projetos de ensino de Física no Brasil.

No APÊNDICE A da presente tese apresentamos uma descrição geral dos demais projetos estrangeiros de ensino de Física aqui mencionados, e que, por delimitação desta pesquisa, não foram analisados.

\subsection{O precursor dos projetos de ensino de Física internacionais: o PSSC}

A ideia de elaboração do PSSC surgiu em 1956 no Massachusetts Institute of Technology (MIT), pelo Professor Jerrold Zacarias. Esse professor, preocupado com o distanciamento entre os fazedores de ciência e os aprendizes da ciência escolar, bem como com o atraso das mudanças no processo educacional em relação às rápidas alterações do conhecimento científico, propôs ao presidente do MIT o planejamento de filmes voltados para o ensino de Física Moderna aos estudantes do ensino secundário "high school”. Além disso, sugeriu que cientistas (físicos pesquisadores) participassem desse empreendimento (CARVALHO, 1972).

O desinteresse pela ciência por parte dos estudantes e o currículo desatualizado, possivelmente, não foram as principais motivações para reformar o currículo escolar de Física nos Estados Unidos da América (EUA). É admissível afirmar que a questão política falou mais alto. A ambição pelo domínio científico e tecnológico que caracterizou a Guerra Fria indica ser a principal motivação para a reforma curricular da área, na qual se incluiu a elaboração do PSSC. Cabe frisar que este feito se iniciou antes do fenômeno Sputnik, que é historicamente uma marca ilustrativa da Guerra Fria.

As preocupações que geraram a iniciativa de reformar o currículo de Física estadunidense indicam terem sido compartilhadas com cientistas norte-americanos, que juntamente com professores de nível secundário e universitário, e ainda, outros profissionais de diversas categorias ocupacionais, trabalharam para o desenvolvimento de um curso de aperfeiçoamento de Física para o ensino secundário. Esse grupo se institucionalizou como

Physical Science Study Committee (PSSC), denominação como é conhecida o projeto desenvolvido por ele. Assinta Marques (2005): 
O objetivo dos pesquisadores era desenvolver o conteúdo da Física de forma rigorosa e com ênfase na experimentação, chegando aos conteúdos modernos e contemporâneos de forma acessível ao nível médio; para tanto utilizaram, em grande parte, modelos criados pelos físicos para representar os fenômenos mais abstratos e difíceis de compreender [...]. (MARQUES, 2005, p. 119).

Os conteúdos dos projetos de ensino desse contexto, segundo Carvalho (1972, p. 03) se assenta em duas linhas gerais: "a ideia de interrogatório, refletindo um aprendizado ativo e continuamente questionado e a ideia de estrutura da disciplina." (grifo da autora). Como ressalta a autora, essas ideias eram popularizadas por Jerome Bruner $^{84}$, desde a Conferência de Woods Hole ${ }^{85}$, em 1959, quando foram debatidas, e posteriormente publicadas em seu livro "O processo da educação", em 1960. Nessa conjuntura, as ideias de Bruner alcançavam destaque e aguçavam discussões entre os estudiosos da aprendizagem de diversas partes do mundo.

Bruner (1978) exalta a iniciativa de conferir aos cientistas a tarefa de elaborar currículos para a escola de nível médio e defende que, para ensinar, é preciso ter domínio da estrutura fundamental do conhecimento a ser comunicado. Assim, esse autor não deixa de evidenciar a necessidade de aprimoramento dos professores, entretanto, quanto à elaboração do currículo, a participação dos cientistas é, para ele, forma de garantir a fidelidade da estrutura fundamental de um determinado campo de ensino. Embora não exclua a importância da participação dos professores e de outros profissionais que estudam o desenvolvimento da criança no planejamento dos currículos, opina que, somente a contribuição "dos estudiosos e cientistas mais capazes" poderá resultar em novos currículos que reflitam a estrutura básica das disciplinas de estudo, de modo que não limite a exposição do conhecimento a ser apreendido. $\mathrm{O}$ autor coloca que:

A experiência dos últimos anos ensinou-nos pelo menos uma lição de importância quanto ao planejamento de um currículo, que seja fiel à estrutura básica da matéria tratada: a de que, para a tarefa, devem-se mobilizar as melhores cabeças em cada disciplinar particular. [...] Apenas pela utilização de nossas melhores inteligências na idealização de currículos, podemos trazer, ao aluno que apenas inicia seus estudos, os frutos da alta cultura e da sabedoria. [...]

O School Mathematics Study Group, os projetos de matemática da Universidade de Illinois, o Physical Science Study Committee e o Biological Sciences Curriculum Study foram elaborados graças à colaboração de homens eminentes nesses diversos campos, obtida em períodos de férias, suplementados em parte por períodos anuais de licença. (BRUNER, 1978, p. 17).

Em várias passagens do livro, O processo da Educação, Bruner cita os projetos estadunidenses, especialmente o PSSC, como exemplos de currículos fiéis à estrutura

\footnotetext{
${ }^{84}$ Segundo Gaspar (2004), Bruner era amigo pessoal do mentor do PSSC, o Professor Zacharias.

${ }^{85}$ Conferência realizada em 1959 com a presença de 35 cientistas, estudiosos e educadores, com o objetivo de discutir formas de melhorar o ensino de ciências nas escolas primárias e secundárias do USA (BRUNER, 1978).
} 
fundamental do campo do conhecimento. Além disso, considera-os como casos de sucesso que poderiam servir de referências para a elaboração de novos currículos compatíveis com a revolução científica e social que se processava naquele contexto histórico.

Isaias Raw concorda com Bruner. Na apresentação da versão brasileira do PSSC, esse cientista coloca que o problema do ensino de Ciências "foi relegado pelo Homem de Ciência até bem recentemente" (RAW apud PSSC, 1963, Parte I, p. 05). Afirma ainda que, nos diversos níveis de ensino, o ensino de Ciências "nem sempre foi entregue aos elementos mais capacitados. 'Educadores' infiltraram-se no ensino de Ciências, e, nada conhecendo de Ciência, de sua evolução e estrutura, tornaram este ensino o mais eficiente método de limitar a evolução cultural e técnica de um povo.”. (RAW apud PSSC, 1963, Parte I, p. 05).

Conforme já mencionado, o início dos trabalhos para a elaboração do PSSC (1956) precedeu ao grande evento que mobilizou o governo americano: o lançamento do satélite espacial soviético, em 1957. Entretanto, após esse ocorrido, os investimentos para a elaboração e execução dos projetos foram intensificados, quando a National Science Foundation (NSF) injetou grande verba para o andamento do projeto (CARVALHO, 1972).

Carvalho (1972, p. 09) lista os objetivos operacionais da estrutura geral do PSSC, definida pelo comitê elaborador do projeto. São eles:

1) Apresentar a física como um assunto unificado, mais interessante, constantemente em modificação.

2) Demonstrar a inter-relação entre experimento e teoria no desenvolvimento da física.

3) Ensinar ao estudante os princípios básicos e leis da física, interrogando a própria natureza; logo, aprendendo, não somente as leis, como também suas evidências e suas limitações.

4) Ampliar a habilidade dos estudantes para ler criticamente, raciocinar, distinguir entre o essencial e o superficial, assim aperfeiçoando a habilidade para aprender.

5) Fornecer uma válida formação aos alunos de curso médio, incluindo aqueles pretendem estudar ciências.

O curso do PSSC foi preparado para execução em tempo escolar de um ano letivo da escola média estadunidense, com 5 a 7 aulas semanais. Devido à sistemática educacional daquele país, em que os alunos têm um ano de Ciências geral, teve-se o cuidado de não exigir pré-requisitos, inclusive no que tange a conhecimentos matemáticos (CARVALHO, 1972, p. 09). Conforme evidencia Carvalho (1972, p.10), “o P.S.S.C. escolheu como assunto as ideias de maior alcance da física, aquelas que contribuem mais para a compreensão do mundo físico.". Pretendeu o projeto que a física fosse "apresentada não como um simples conjunto de fatos, mas basicamente como um processo em evolução, por meio do qual os homens procuram compreender a natureza do mundo físico" (PSSC, 1963, p. 7). 
Tal proposta foi apresentada na forma de textos estruturados em quatro partes (ou volumes) articuladas entre si, incluindo guias de laboratórios, para o aluno e professor. Também organizados em quatro partes, vinculados ao texto que traz os conteúdos, havia ainda os extensos Guias do Professor, que traziam orientações bastante detalhadas sobre a execução do projeto em sala de aula.

Compunham o projeto mais de 50 propostas experimentais que permitiam análises qualitativas e quantitativas com o propósito de inter-relacionar teoria e prática, e pretendia "o desenvolvimento do pensamento físico e para a apreciação do método científico." (CARVALHO, 1972, P. 19). As instruções para a execução de tais atividades, que seriam realizadas por meio de "um conjunto de aparelhos modernos e baratos" (PSSC, 1963, p.07) estavam apresentadas no Guia de Laboratório.

Além das propostas de atividades experimentais, o projeto contou ainda com a elaboração de filmes, em número de quarenta e sete. Tais filmes ${ }^{86}$ faziam parte da unidade de planejamento proposta no projeto e tinha como um de seus objetivos apresentar o curso como um todo, possibilitando a discussão de assuntos que os alunos julgassem mais interessantes, além de dirimir a carga do professor. Stephen White ${ }^{87}$ (s.d. apud BRUNER, 1978) aponta ainda outra importância dos filmes do PSSC, qualificados pelo autor como sendo educativo integrado, e que atende a condição de "estabelecer o nível e o tom do curso". O autor afirma que o filme (nessa categoria) "pode ajudar a assegurar que toda a grande massa de fatos, conceitos, teorias e aplicações que constituem qualquer campo do conhecimento, caiam dentro de um modelo coerente no qual os aspectos mais importantes estarão claramente diferenciados.” (STEPHEN WHITE, s.d apud BRUNER,1978, p. 82).

Além de "apresentar o conteúdo como um todo" e de "estabelecer o nível e o tom do curso", Stephen White ainda acrescenta que,

\begin{abstract}
[...] o PSSC, procura em cada filme, oferecer outras contribuições substanciais ao processo de aprendizagem. Cada fita mostra um cientista real em ação, apresentando-o não como um intelecto desencarnado, mas como um ser humano normal, ativo, ocasionalmente falível, tratando, com rigor e com respeito, de problemas reais, e conseguindo obter, na busca intelectual em que está empenhado, não apenas satisfação, como por vezes, até mesmo entusiasmo. (STEPHEN WHITE, s.d. apud BRUNER, 1978, p. 82).
\end{abstract}

O PSSC indicava ainda como leituras complementares textos de divulgação científica, e uma das mais recomendadas foram os textos da série "The Science Study Series" que figurou como parte do pacote de recursos metodológicos do projeto. A referida literatura

\footnotetext{
${ }^{86}$ A lista com os títulos dos filmes relacionados às quatro partes do PSSC pode ser vista em Bonetti (2013, p. 122-124).

${ }^{87}$ Em relatório sobre os filmes educativos utilizados no PSSC. Bruner não cita dados de referência do relatório.
} 
científica teve um total de 35 publicações nos EUA e era voltada para o público em geral. Conforme sintetiza Pinho-Alves (2000, p.27), o diferencial metodológico do PSSC "estava na pluralidade de seus meios e no sincronismo de sua aplicação".

Segundo Haber-Schaim (2006), o Comitê de Planejamento do PSSC alargou o projeto, tanto no aspecto ascendente como descendente em termos de população-alvo. No sentido ascendente, o autor se refere ao desenvolvimento de material adicional que trouxe temas-chave que ficaram de fora do curso previsto para um ano de duração. Os temas abordados, intitulados de "Advanced Topics Supplement", foram: Momento angular e conservação; termodinâmica estatística para a segunda lei da termodinâmica; cinemática relativista e a extensão das leis da energia e momento de conservação ao domínio relativista; e sistemas quânticos para além do átomo de hidrogênio. A extensão descendente "abordou o tema original central do PSSC, nomeadamente, a evidência para a existência de átomos, conhecido na casa como o 'junior-high project', mais tarde renomeado Introductory Physical Science (IPS)" ${ }^{\wedge 8}$. (HABER-SCHAIM, 2006, p.08, tradução nossa).

\subsection{O PSSC no Brasil}

A inserção do PSSC no Brasil, como informa Carvalho (1972), iniciou em 1961, pelo IBECC, com a tradução/adaptação e publicação do guia de laboratório e confecção de parte dos equipamentos necessários às experiências. Para a disseminação dessa inovação evidenciase o apoio da Ford Foundation, da Campanha de Aperfeiçoamento e Difusão do Ensino Secundário (CADES) e do INEP, que fomentaram o primeiro treinamento de professores universitários e secundários ocorrido na cidade de São Paulo, em 1962, contando com 42 participantes de vários países da América Latina dos quais 19 eram brasileiros. O treinamento foi ministrado por professores universitários vindos dos Estados Unidos, Chile, Costa Rica e uma brasileira, do IBECC, que havia participado de curso preparatório no EUA (CARVALHO, 1972; CANIATO, 1973).

Outros treinamentos e cursos de atualização para professores, sobre o projeto, coordenados pelo IBECC/SP, ocorreram no Brasil no período de 1961 a 1965. No período de 1965 a 1972, os Centros de Ciências assumiram o papel de formadores em serviço, e realizaram cursos, encontros e seminários em que, para a Física, o tema de estudo e discussões era, quase que exclusivamente, o PSSC (CARVALHO, 1972).

\footnotetext{
${ }^{88}$ Uma síntese da história desse projeto se encontra no APÊNDICE A deste trabalho.
} 
As versões dos demais textos do PSSC traduzidos para o português no Brasil, também foi trabalho do IBECC, que coordenou um grupo de professores constituído por maioria ligada ao Instituto de Física da Universidade de São Paulo. Segundo Isaias Raw, o desenvolvimento do amplo programa de tradução dos textos e confecção dos equipamentos de laboratório, contou com o auxílio da Fundação Ford e Fundação Rockefeller, e a colaboração da National Science Foundation e Pan American Union (PSSC, 1963, p.06).

As primeiras traduções ocorreram entre 1961 e 1964, e começaram a ser publicadas em 1963 pela editora da Universidade de Brasília (UnB). Foram adotadas, inicialmente, no Estado de São Paulo, como projeto-piloto (CARVALHO, 1972; KRASILCHIK, 2000). Posteriormente, a editora Edart assumiu a editoração dos livros-texto do projeto, com direitos autorais gerenciados pelo IBECC, encerrando as publicações em 1971.

Segundo Marques (2005, p. 119), a implementação do PSSC como projeto-piloto recebeu o apoio da Secretaria Estadual de Educação do Estado de São Paulo, "que dotou as Escolas do Estado de textos e material experimental para atender a 10 grupos de alunos em sala de aula." O autor coloca que "dentro desse programa da SE, os professores eram treinados pelo CECISP, também ligado ao IBECC/FUNBEC e se comprometiam a levar o Projeto PSSC para a sala de aula” (MARQUES, 2005, p. 119).

$\mathrm{Na}$ apresentação da edição preliminar do projeto, Parte I (1963), Isais Raw informa que o IBECC/SP havia iniciado a tradução dos guias do professor, dos filmes, e também dos “Advanced Topics Supplement” para nível universitário.

Quanto aos Guias do Professor, estes foram traduzidos pela FUNBEC e CECISP e publicados nos anos de 1967 (volumes I e II), 1968 (volume III) e 1970 (volume IV). A condição de venda desses guias estava condicionada à comprovação de atuação como professor de Física no ensino secundário (CARVALHO, 1972, p. 32).

Já os filmes ${ }^{89}$, ao que indica, somente alguns foram traduzidos (dublados) sob coordenação de professores do Instituto de Física da USP (IFUSP). Bonetti (2013), em sua pesquisa de doutorado, localizou em acervos eletrônicos e da cidade de São Paulo, 11 filmes ${ }^{90}$ do projeto dublados para o Português, mas não afirma se somente esse quantitativo foi traduzido. Não localizamos em outras fontes mais informações sobre o quantitativo exato de filmes do projeto traduzidos para o Português.

\footnotetext{
89 Alguns desses filmes ainda podem ser assistidos no seguinte endereço eletrônico: http://pt.mashpedia.com/Physical_Science_Study_Committee. Acesso em 10 Jun. 2015.

${ }^{90}$ Os filmes identificados pelo referido autor são: Pressão da Luz; A velocidade da luz no ar e na água; Inércia; Eventos aleatórios; Momento angular; Energia e Trabalho; Energia mecânica e térmica; Conservação de Energia; A experiência de Millikan; A dilatação do tempo; A massa do elétron. (BONETTI, 2013, p. 122-124).
} 
Alguns textos da "The Science Study Series" ("Série Estudos de Ciência"), que era uma das principais sugestões de leitura complementar do PSSC, também foram traduzidos e publicados no Brasil. Segundo Carvalho (1972), do total de 35 (trinta e cinco) textos da série, 10 (dez) tiveram a tradução para o português e foram publicados pela Edart-São Paulo, ainda na década de 1960 .

No que se refere aos “Advanced Topics Supplement”, não identificamos informações sobre a tradução e publicação dos mesmos em nível editorial. Tivemos informações de traduções para uso restrito por professores em seus cursos de Física, como exemplo, a Escola Preparatória de Cadetes do Ar (EPCAR), de Barbacena-MG, que segundo o Professor Ernesto Von Rückert (atualmente aposentado pela Universidade Federal de Viçosa), traduziu estes textos em forma de apostilas, somente para circulação interna ${ }^{91}$.

Para Alvarenga (1991), o PSSC exerceu "reflexos benéficos" sobre o ensino de Física em vários países, inclusive no Brasil; "provocou uma verdadeira guinada na concepção do ensino de Física, valorizando os aspectos cognitivos da aprendizagem, reduzindo a extensão das informações e aprofundando a compreensão dos conceitos". (ALVARENGA, 1991, p.30). Contudo, dada à estrutura física e administrativa das escolas (falta de laboratórios, bibliotecas, espaços para aulas extras, distribuição dos tempos escolares limitados, etc.), bem como o perfil do alunado e a condição de formação acadêmica dos professores, nosso sistema de ensino não comportou uma inovação nessa perspectiva. Talvez, o último aspecto tenha sido o mais determinante no abandono da implementação do PSSC no Brasil.

Gaspar (2004) afirma que, no Brasil, a aplicação do projeto ficou restrita às escolas onde lecionavam os professores que dele tomaram conhecimento (possivelmente o autor fala dos professores que participaram de cursos específicos sobre o PSSC ou que conheceram o projeto nos cursos de graduação). Ele coloca:

\begin{abstract}
Alguns, embora o conhecessem não animaram a aplicá-lo (esse foi nosso caso) principalmente pela dificuldade de utilização do material experimental entregue às escolas pela Funbec, com muitos Kits incompletos, sem identificação adequada ou qualquer instrução auxiliar além daquela do próprio texto. Acresce ainda o currículo proposto, desvinculado da nossa realidade educacional e para o qual certamente a esmagadora maioria dos professores não estava preparada. (GASPAR, 2004, p. 75).
\end{abstract}

Esse despreparo dos professores, ressaltado na colocação de Gaspar, pode ser justificado, não somente pela falta de conhecimento da estrutura fundamental dos conhecimentos da Física, mas também pela cultura de ensino (prática pedagógica) à qual o

\footnotetext{
91 Informação obtida de uma conta pública de rede social do referido Professor. Disponível em: http://wolfedler.blogspot.com.br/2015_05_10_archive.html Acesso em 23 Dez. 2015.
} 
professor foi submetido em sua formação acadêmica, excessivamente centralizada no professor, com pouca ou total ausência de atividades experimentais.

\subsubsection{Conhecendo os manuais do PSSC utilizados no Brasil}

Apresentaremos nesta seção nossas percepções a respeito do PSSC a partir dos resultados de uma análise de conteúdo dos manuais do projeto traduzidos/adaptados para o português brasileiro, com enfoque nas dimensões interativas (epistemológica e educativa) explicitadas no capítulo 1, onde expusemos nossos procedimentos metodológicos.

Nosso estudo no PSSC recaiu sobre os manuais editados, os livros-texto destinados ao aluno (entre os quais se incluem os Guias de Laboratório), e os Guias do Professor.

Em nossas buscas, constatamos a dificuldade de encontrar exemplares desses materiais à disposição para venda em sebos ou empréstimo nas pouquíssimas bibliotecas que os têm em seus acervos, por se tratar de materiais raros. Estudantes e/ou professores de algumas grandes universidades têm buscado, por meio de projetos de trabalho em disciplinas de Instrumentação para o Ensino de Física, disponibilizar alguns desses materiais na Internet em arquivos digitalizados. São os casos, por exemplo, de estudantes e professores/pesquisadores em ensino de Física da Universidade de São Paulo ${ }^{92}$ e da Universidade Federal de Santa Catarina ${ }^{93}$.

Observamos ainda que nem sempre se encontram publicações das Partes do projeto pertencentes a uma mesma edição/ano. Desse modo, as versões por nós analisadas se referem a diferentes edições e editora. Por ser um projeto traduzido com poucas adaptações, acreditamos não haver significativas alterações entre uma edição e outra, de modo a comprometer os resultados de nossa análise.

Os materiais analisados foram localizados no acervo da biblioteca do Programa de Pós-Graduação em que se deu esta pesquisa. As versões analisadas são:

PHYSICAL SCIENCE STUDY COMMITTEE - PSSC, Física - Parte I. Edição preliminar. Brasília: Editora Universidade de Brasília, 1963.

PHYSICAL SCIENCE STUDY COMMITTEE - PSSC, Física - Parte II. $2^{\mathrm{a}}$ ed..São Paulo: Edart Livraria Editora Ltda, 1966.

PHYSICAL SCIENCE STUDY COMMITTEE - PSSC, Física - Parte III . São Paulo: Edart Livraria Editora Ltda, [1967?].

PHYSICAL SCIENCE STUDY COMMITTEE - PSSC, Física - Parte IV. Brasília: Editora Universidade de Brasília, [196?].

\footnotetext{
92 http://disciplinas.stoa.usp.br/course/view.php?id=2218\&section=4. Acesso em 13 de nov. 2015.

${ }^{93}$ Encontram-se também, arquivos digitais de vários projetos de ensino das décadas de 1960 e 1970 no endereço eletrônico http://acrux.astro.ufsc.br/ lacerda/projetos/PSSC/. Acesso em 13 de nov. 2015.
} 
PSSC - PHYSICAL SCIENCE STUDY COMMITTEE - PSSC - Guia do Professor - Vol. I (1967); Vol. II (1967); Vol. III (1968); Vol. IV (1970). FUNBEC - CECISP. São Paulo.

Utilizaremos as seguintes nomenclaturas para identificar os materiais do PSSC nas citações ao longo de nossa análise: Livro-Texto (PSSC-LT); Guia de Laboratório (PSSC-GL); Guia do Professor (PSSC-GP); Guia do Professor/laboratório (PSSC-GPL), em todos os casos, acrescidos da identificação da parte ou volume a que se refere.

Consideramos importante alertar também que, nas citações de excertos dos textos do projeto, manteremos a grafia original.

\subsubsection{Caracterização geral dos manuais do PSSC}

O material textual do PSSC foi elaborado e estruturado em quatro Partes distribuídas em quatro volumes, o livro-texto (Parte I, Parte II, Parte III e Parte IV), dos quais, para cada Parte existe também um Guia correspondente destinado ao Professor (Vol. I, Vol. II, Vol. III e Vol. IV). A Figura a seguir se refere à capa do livro-texto Parte I e Guia do Professor Volume III.

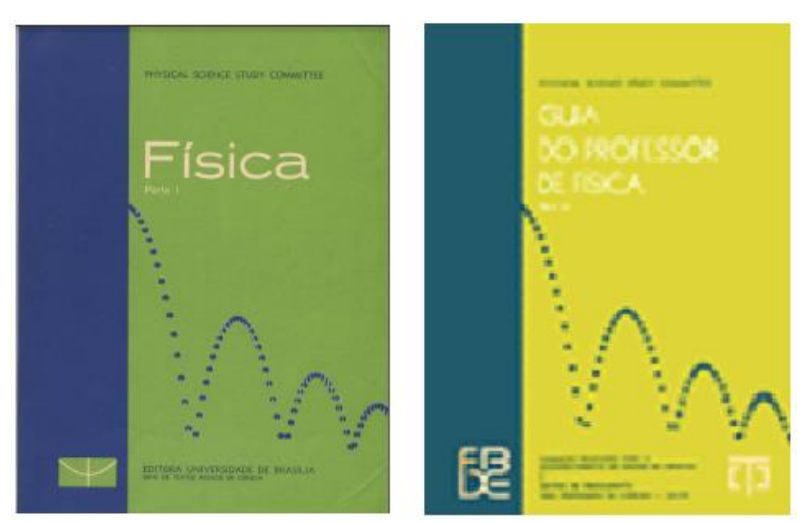

FIGURA 1 - Capa dos manuais do PSSC, Parte I e Guia do Professor Vol. III.

Fonte: Dos manuais analisados

As capas das demais Partes e Guias não se diferem graficamente; dependendo da edição, muda um pouco a grafia do título "Física", mantendo as mesmas cores e desenho.

O livro-texto, apresentado no prefácio como "a alma do curso PSSC”, traz como extensão em cada uma das partes, após o último capítulo, um Guia de Laboratório, com paginação sequencial a do texto principal. Tal guia foi considerado como parte imprescindível na execução do curso, já que a experimentação era a essência do projeto.

A estrutura do livro-texto analisado começa com a apresentação da versão brasileira do projeto assinada pelo Diretor Científico do IBECC-UNESCO - Seção de São Paulo, o 
Professor Dr. Isaias Raw. Na sequência, o prefácio é a tradução do projeto original americano, em que se apresenta uma síntese do processo de elaboração: motivações, defesa do modelo pedagógico adotado, informações sobre os testes de aplicação do projeto a título de experiência nos EUA, e algumas características básicas da estrutura do mesmo no que se refere à distribuição dos temas da Física e a forma como buscou articulá-los ao longo de todo o texto do PSSC. Em seguida apresenta o sumário ${ }^{94}$, que por sua vez traz como título CONTEÚDO.

A Parte I, intitulada "O Universo", é composta por dez capítulos totalizando 207 páginas. A Parte II, "Óptica e ondas", nove capítulos em 144 páginas; a Parte III, "Mecânica", sete capítulos em 157 páginas; e a Parte IV, "Eletricidade e estrutura atômica", com oito capítulos em 227 páginas. Em todos os casos, esses quantitativos de páginas citados excluem o Guia de Laboratório.

Os manuais das quatro Partes possuem uma mesma organização, de modo que cada capítulo é intitulado por um tópico mais amplo e dividido em subtópicos (seções). A maioria dos capítulos traz as seções "PARA CASA, CLASSE E LABORATÓRIO" e "LEITURA COMPLEMENTAR". Há capítulos (poucos) que apresentam somente uma destas (ora uma, ora outra). A primeira trata de exercícios/problemas, alguns fechados de caráter quantitativo e/ou qualitativo, outros de caráter mais investigativo e que requerem uma análise qualitativa e/ou quantitativa. A quantidade de exercícios/problemas é bem expressiva, perto de oito centenas no total das quatro Partes. Alguns (cerca de 40) são proposições de atividades experimentais ou pequenas investigações, que, ora ou outra, instruem recorrer ao guia de laboratório para executá-las. Tais problemas vêm marcados com asterisco (*) indicando que são "projetos para serem feitos em casa" (PSSC-LT, Parte I, p. 36), como nos exemplos a seguir:

\footnotetext{
${ }^{94}$ Sumário no projeto tem sentido de resumo e não de lista de capítulos ou tópicos com ou sem paginação, que nesse caso recebe o nome de Índice.
} 


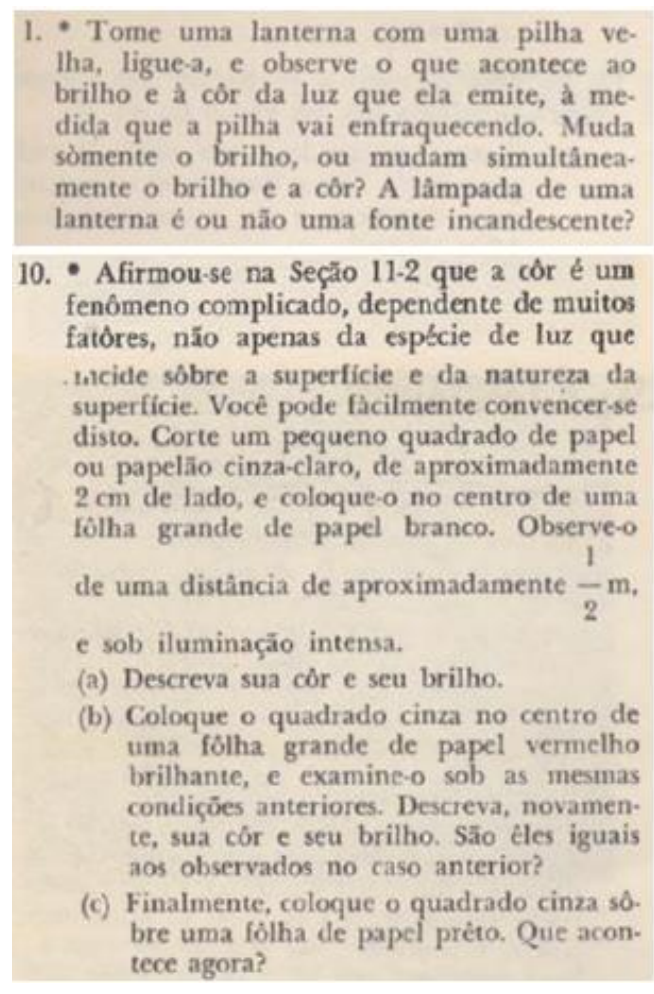

FIGURA 2 - Recortes de texto do PSSC referente a exercícios investigativos da seção PARA CASA, CLASSE E LABORATÓRIO (PSSC-LT, Parte II, p. 19-20)

A seção LEITURA COMPLEMENTAR não se trata de apresentação de textos complementares ao final dos capítulos, mas sim de uma lista de bibliografias sugeridas para pesquisa e leitura, relacionadas ao assunto tratado. Aparecem como sugestões bastante frequentes os textos da The Science Study Series, artigos da Revista Scientific American e o livro do George Gamow “Um, Dois, Três...infinito”, publicado pela Editora Zahar.

Quanto aos Guias de Laboratório, das versões analisadas somente o da Parte I (Edição preliminar, 1963) traz textos de agradecimentos, prefácio, apresentação aos alunos e o índice. Nas demais partes (edições posteriores), os guias não apresentam tais textos introdutórios e o sumário das atividades experimentais, nessas versões, vem na sequência do sumário dos capítulos do livro-texto principal, na mesma página. Talvez, a razão dessa estruturação seja pelo fato de que as demais partes são sequências inseparáveis no projeto, o que dispensaria a necessidade de repetir tais textos introdutórios nos guias de laboratório das mesmas.

Com uma estrutura bastante diferente dos modelos de roteiros comumente encontrados em alguns livros didáticos e manuais de laboratório, as solicitações e orientações para as experiências são apresentadas em texto corrido, ilustrado com esquemas e fotos, e permeado por perguntas em que as respostas seriam dadas a partir dos resultados das observações, obtenção de dados e interpretação qualitativa e/ou quantitativa. 
O Guia do Professor, bastante extenso, é dividido em volumes correspondentes às quatro partes do livro-texto. Além de apresentar instruções para as Partes do projeto, traz ao final do manual, guias de orientação para as atividades de laboratório. No volume I, essa extensão traz o título de "GUIA DO PROFESSOR PARA EXPERIÊNCIAS DE LABORATÓRIO”.

Nos volumes II e III está sob o título "GUIA DO PROFESSOR PARA EXPERIÊNCIAS” seguido da descrição da parte a que se refere; e no volume IV como “GUIA DO PROFESSOR PARA EXPERIÊNCIAS E DEMONSTRAÇÕES, PARTE IV”. Nos três primeiros volumes, os cabeçalhos das páginas ímpares trazem ainda o título de “NOTAS DE LABORATÓRIO”.

No volume IV, o cabeçalho é o próprio título do guia. Tais guias trazem orientações para a execução dos experimentos propostos no Guia de Laboratório do livro-texto do aluno e ainda outros adicionais destinados aos alunos "mais interessados". Em todos os Guias do Professor, nas orientações de laboratório, as experiências são classificadas em nível de prioridade em uma tabela utilizando o símbolo “。” numa escala de 1 a 3 . Indica se a

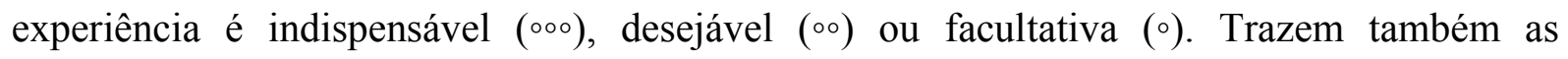
respostas das perguntas colocadas nas propostas de atividades experimentais do Guia de Laboratório do livro do aluno.

Os volumes dos Guias do Professor, publicados em diferentes anos (mas quase consecutivos) apresentam algumas pequenas diferenças na estruturação. O volume I traz textos introdutórios que antecedem o ÍNDICE, intitulados "RECONHECIMENTO", “INTRODUÇÃO AO GUIA DO PROFESSOR” e "O ENSINO DO CURSO DO PSSC". O primeiro texto introdutório descreve o reconhecimento dos participantes na elaboração do material (o original) onde lista os nomes dos mesmos. O segundo explicita as funções do guia, as subdivisões e a forma como os capítulos estão organizados.

Já o terceiro explica as características do curso, formas de desenvolvimento dos textos e orientações quanto ao uso dos problemas da seção PARA CASA, CLASSE E LABORATÓRIO (esclarece que pode não ser possível resolver todos e que o Guia sugere/orienta sobre os mais instrutivos). Ainda neste texto, trata dos diferentes recursos propostos para o curso denominando tais recursos como MATERIAIS (laboratório, filmes, testes, leituras complementares), orienta o planejamento na utilização dos mesmos e ainda fornece outras informações relativas ao projeto.

Quanto aos filmes, recomendou-se que a projeção destes fosse rigorosamente planejada. Ressaltou que, raramente, eles trariam experiências sugeridas para o laboratório, 
dada a relação estreita entre os recursos que constituem os pilares do projeto: texto, laboratório e filmes. Uma das funções dos filmes era mostrar experiências difíceis de serem realizadas pelos alunos e professores, por utilizarem equipamentos mais sofisticados, embora algumas pudessem ser adaptadas ao laboratório nas escolas. E mais...

\begin{abstract}
Além do seu conteúdo, os filmes têm a intenção de mostrar cientistas reais em ação, apresentando-os como intelectuais desmaterializados, mas como sêres humanos normais, ativos e ocasionalmente falíveis, que lidam com problemas reais, tirando satisfação e, às vezes, emoções do seu trabalho. Dêsse modo quase implícito, os filmes tentam mostrar a natureza do cientista e o procedimento científico. (PSSCGP, v. I, p. xii).
\end{abstract}

Os autores afirmam que "Os filmes são escrupulosamente honestos" e que estes relatam experiências realizadas cuidadosamente, tendo sido intencionalmente voltados para o ensino (PSSC-GP, 1967, v. I, p. xii).

Ainda no terceiro texto introdutório, apresenta-se o planejamento do curso conforme o projeto original, ou seja, para desenvolvimento em um ano ${ }^{95}$. Tal planejamento, em uma tabela, traz sugestões para execução do curso em 36 ou 54 semanas, sugerindo o número de semanas para cada Parte e blocos de capítulos.

O Guia da Parte II não traz textos introdutórios, mas possui a mesma estruturação do Volume I a partir do ÍNDICE. Já os Guias referentes às Partes III e IV começam com um único texto introdutório que antecede o ÍNDICE, e tem como título PLANEJAMENTO DO CURSO DE FÍSICA - PSSC PARA O BRASIL. O novo planejamento é assim justificado:

A partir da época em que foi lançado à venda o volume I da Física PSSC, a Fundação Brasileira para o Desenvolvimento do Ensino de Ciências vem acumulando dados para um planejamento realista do curso PSSC, de maneira a tornar possível o uso dos quatro volumes nos nossos três anos do curso colegial. Quando foram publicados os dois primeiros volumes do Guia do Professor, não tínhamos ainda uma base suficiente para fazer um planejamento global realmente exequível.

Agora que o volume IV do aluno já está em uso em numerosas classes, podemos propor o esquema abaixo. (PSSC GP, v. III, p. v).

O texto justifica as alterações esclarecendo que as mesmas foram resultados da experiência adquirida no desenvolvimento do curso nas escolas, bem como das contribuições de professores por meio dos cursos de treinamento promovidos pelos Centros de Ciências e pela FUNBEC.

Antes do quadro de planejamento, apresentam-se algumas condições para a implementação do curso denominadas de Pressupostos Pedagógicos. Conforme extraímos do Guia do Professor (1968, 1970), esses pressupostos indicam que:

\footnotetext{
95 Os autores chamam a atenção em nota de rodapé, que a tradução do planejamento ocorreu de acordo com o projeto original e se referem ao ensino nos EUA (PSSC-GP, 1967, v. I, p. xiv).
} 
$\rightarrow$ A programação recomendada seria específica, para o segundo ciclo do ensino secundário brasileiro, sobretudo no curso "científico", considerado de "razoável nível pedagógico, didático e administrativo";

$\rightarrow \mathrm{O}$ planejamento estaria sujeito a adaptações inerentes às condições regionais;

$\rightarrow$ O professor tivesse participado de algum curso de treinamento do PSSC, de modo a conhecer o método, a orientação e a finalidade do curso;

$\rightarrow$ Considerou-se o calendário de 180 dias letivos com aulas de 50 minutos em um curso colegial dividido em três anos, com 4 aulas semanais no primeiro ano, 4 no segundo e 5 no terceiro;

$\rightarrow$ Haveria a necessidade de a escola possuir laboratório adequado com todos os materiais necessários às experiências do curso.

Esclarece ainda sobre a perspectiva de profundidade ou extensão que deveria ser adotada no caso de adaptação do curso a um tempo mais curto. Nesse caso, recomendou-se não excluir tópicos, já que o curso foi organizado e ordenado de forma integrada. Sugeriu-se diminuir a profundidade de tratamento, pois as unidades estariam inter-relacionadas.

A partir do ÍNDICE, todos os volumes dos Guias do Professor são semelhantes. Traz uma introdução da Parte a que se refere começando com um resumo do que tratam os capítulos abordados, a indicação dos recursos pedagógicos (exceção na introdução da Parte I no volume I) a serem utilizados e o planejamento da mesma em um quadro.

Embora os volumes III e IV do Guia do Professor apresentem um planejamento para o curso diferente dos volumes I e II, de modo que não sugerem duas opções, em termos de números de semanas para execução, ainda assim, para os planejamentos das Partes e dos capítulos mantiveram-se como nos primeiros volumes. Sugeriam duas opções em números de semanas para desenvolvimento, com distribuição de número de aulas a serem ministradas em classe e laboratório, para cada capítulo ou seção, e indicação das experiências a serem realizadas em cada um.

Para cada capítulo, de um modo geral, traz as seções, SUMÁRIO DO CAPÍTULO, PLANEJAMENTO DO CAPÍTULO e MATERIAIS.

O SUMÁRIO trata de um resumo do que é abordado com instruções detalhadas. De modo similar ao planejamento das Partes, em uma tabela traz o PLANEJAMENTO do capítulo, com distribuição das seções em número de aulas em classe e laboratório, bem como indicam as experiências a serem utilizadas, também com duas opções em termos de número de semanas. Em síntese, no que se refere a planejamento, o Guia sugere (em tabelas) 
planejamento para o curso todo, para as Partes e para cada capítulo. Isso faz do Guia um material instrucional bastante detalhado e "carregado" de informações.

Como MATERIAIS necessários ao desenvolvimento de cada capítulo recomendam: o laboratório (indica as experiências), filmes (sugere quais), leituras complementares (idem) e problemas (apresenta uma classificação). Poucos são os capítulos que não trazem nenhuma sugestão de experiência e/ou filme.

No que se refere aos exercícios e problemas propostos no livro do aluno, o Guia indica uma tabela de classificação dos mesmos nos níveis fácil, médio e difícil, e recomendam alguns, enfatizando-os na tabela com “*” (asterisco), por considerarem mais instrutivos.

As instruções para desenvolvimento das Seções dos capítulos trazem a FINALIDADE de cada uma ou grupo delas, o CONTEÚDO das mesmas, a ÊNFASE a ser dada ao desenvolvê-las, instruções sobre o DESENVOLVIMENTO, COMENTÁRIOS e algumas vezes, ADVERTÊNCIAS E PRECAUÇÕES no que se refere ao desenvolvimento de determinados assuntos e também nas práticas de laboratório, e ainda SUPLEMENTOS. Ora ou outra, outros termos, muitas vezes em caixa alta, encabeçam parágrafos que chamam a atenção para algum tópico objetivando esclarecer os objetivos, a forma de desenvolvimento, a profundidade, etc. Buscou-se dar um maior destaque a alguns tópicos do curso considerados de maior relevância, num nível dirigido mais ao professor do que ao aluno.

As respostas dos exercícios e problemas apresentados no livro-texto também são trazidas no Guia do Professor ao final das orientações de cada seção e/ou capítulo, abreviadas e também detalhadas com comentários e resoluções. Sugere ainda atividades complementares intituladas por QUESTÕES, PROBLEMAS ou EXEMPLOS complementares, objetivando estimular discussões.

Nas instruções sobre experimentação, o Guia orienta sobre planejamento, materiais a serem utilizados, a questão da precisão experimental, a importância da análise de dados e resultados. Para a Parte I apresenta sugestão de nove atividades experimentais e recomenda que todas sejam realizadas além de indicar o melhor momento para realizá-las. Na Parte II são 16 (dezesseis) experiências, na Parte III, 14 (quatorze), e na Parte IV, 11 (onze).

Em resumo, as discussões e esclarecimentos trazidos nos Guias visaram fornecer subsídios para dirimir possíveis dúvidas do professor em relação a alguns temas e também sobre o andamento do curso. Como explicita, o objetivo era de auxiliar o professor, e não de impor "regras rígidas e imediatas para o ensino do curso, mas sim dar sugestões, das quais algumas seriam diretamente úteis e outras estimulariam o desenvolvimento de outros assuntos (PSSC-GP, v. I, p. vii). 
Passaremos a descrever os resultados de nossa análise, trazendo elementos que revelam as concepções de ciência e educação nos conteúdos dos manuais do PSSC, com maior atenção ao manual destinado ao aluno.

\subsubsection{As dimensões Epistemológica e Educativa no PSSC}

Conforme colocamos no Capítulo 1, desmembramos a dimensão de análise Epistemológica em quatro categorias (pré-definidas) que direcionaram a identificação de elementos que evidenciam as visões sobre o processo de produção do conhecimento em ciência/Física assumidas no desenvolvimento do PSSC. São elas: Ciência como processo; A Física e a experimentação; Modelos explicativos formais e Conteúdos/áreas da Física.

Para a dimensão Educativa, consideramos elementos que refletem a concepção de educação no que tange aos seus objetivos educacionais mais amplos e, em particular para o ensino de Física, bem como o papel do aluno e do professor no processo de ensino de acordo com o modelo adotado no projeto. Para esta dimensão definimos duas categorias de análise: Objetivos do ensino de Física e Concepção de aluno/professor.

\section{$\underline{\text { Da dimensão Epistemológica }}$}

\section{Ciência como processo}

No prefácio do livro-texto Parte I, os autores trazem o discurso de que no texto do projeto “a física é apresentada [...] como um processo em evolução [...].”. Mas é, sobretudo, no capítulo 1 "O que é Física", onde se têm, com maior clareza, as concepções sobre a natureza do conhecimento assumida pelos autores. Contudo, ao longo dos textos dos demais capítulos (de todas as Partes), encontramos passagens em que tais concepções podem também ser inferidas.

Os autores conceituam a física como "a ciência fundamental da natureza". Na sequência, uma passagem traz a ideia de que o conhecimento em física permanece em aberto, passível de mudanças e avanços: "Ela nos conta o que sabemos a respeito deste mundo, como homens e mulheres descobriram o que conhecemos, e como ainda estão descobrindo nos dias de hoje.". Afirmam ainda que a Física "nos dá a capacidade de prever e planejar, de compreender a de nos aventurarmos no desconhecido." (PSSC-LT, Parte I, p.15). 
Mais adiante um trecho evidencia a ideia de que o desenvolvimento da ciência/Física está sujeito a rupturas e mudanças de paradigmas:

\begin{abstract}
De vez em quando, verifica-se que uma das dependências já terminadas nesta estrutura conhecida como física, é pouco segura ou não mais bastante ampla para novas descobertas, e a dependência é abandonada ou reconstruída. Isto acontece frequentemente, mas os grandes alicerces estão bem assentados e localizados em terreno bastante sólido. Estes alicerces permanecem inalterados, ainda que sobre eles continuem ocorrendo mudanças. (PSSC-LT, Parte I, p.16).
\end{abstract}

Na sequência, alude que o desenvolvimento dessa ciência se dá também pelo processo de "retroalimentação" de ideias: "[...] Novas coisas são feitas a partir do que aprendemos em física. Com novas respostas em física, novas perguntas nunca teriam sido formuladas, se a própria física não tivesse sido posta em prática.” (PSSC-LT, Parte I, p.15).

Em outras passagens do texto, elementos que indicam a concepção da ciência/Física como um processo dinâmico são claramente evidenciados:

\begin{abstract}
Nossos modelos, as teorias físicas agora disponíveis, descrevem muito de nosso mundo. Amanhã, elas se alargarão, tornar-se-ão mais completas, e descreverão mais e mais o mundo natural, à medida que êle fôr sendo desvendado através da experimentação. (PSSC-LT, Parte I, p. 181).
\end{abstract}

[...]. Nesta seção final mencionamos perguntas adicionais sôbre a luz e as ondas, para as quais são conhecidas respostas (pelo menos respostas parciais). Além das perguntas respondidas sôbre a luz, há sempre algumas sem resposta, e há provavelmente muitas questões sobre a luz e as ondas que ainda não aprendemos a perguntar. A formulação de perguntas novas e adequadas constitui frequentemente, a chave de uma física nova e interessante. (PSSC-LT, Parte II, p. 140).

No capítulo 11, Parte II, ao explicar o fenômeno da difração, com atenção para o fato de que a luz sofre pequena curvatura ao passar pelo bordo de um obstáculo, e as situações em que tal fenômeno pode ser observado, indica revelar que o procedimento metodológico adotado pelos autores, para explicar o fenômeno, segue a linha da construção do conhecimento científico na busca de explicações consistentes e verdadeiras: "A explicação não está entretanto, completa. Deveremos acrescentar algo mais antes de estudar em detalhe as bandas escuras e claras." (PSSC-LT, Parte II, p. 17).

No que tange a elementos que consideram a relação do sujeito com o objeto de conhecimento, não é totalmente ausente, mas é, a nosso ver, infimamente presente. Localizamos alguns poucos exemplos, dos quais citamos dois. O primeiro se refere a uma passagem em que os autores utilizam o termo "caixa preta" como analogia ao que é desconhecido:

A curiosidade de abrir as caixas pretas é necessária para o entendimento da física. Mas é também necessário bom senso para saber quando e onde as caixas pretas podem ser usadas com segurança. A confiança na caixa preta vem com a calibração, o uso, a experimentação, e, finalmente, com a abertura da tampa e a verificação do método de operação. O que permanece como caixa preta hoje, será aberto pela 
próxima geração; sua abertura envolverá, porém, o uso hábil de todos os tipos de caixas pretas, caixas pretas que nunca vimos. (PSSC-LT, Parte I, p. 205-206).

A citação faz entender que a interpretação do conhecimento sobre a natureza envolve decisões particulares, hesitações, incertezas e o reconhecimento de que a Ciência não é um produto acabado. O segundo exemplo, em uma seção na sequência do trecho citado, traz a ideia de que a interação do sujeito com o objeto de conhecimento se manifesta, também, de modo bastante prático no estudo dos fenômenos: "Nenhuma medida pode ser feita sem alguma interação com o objeto ou fenômeno medido. [...]. Mesmos os planetas não podem ser medidos sem que sofram uma perturbação, embora diminuta. [...]. ” (PSSC-LT, Parte I, p. 206).

Sobre a relação da Física com outras áreas do conhecimento, ainda no início do primeiro capítulo, há uma seção denominada A FÍSICA E AS OUTRAS CIÊNCIAS DA NATUREZA. Nela descrevem-se alguns exemplos que evidenciam a relação da física com a química, a astronomia, a geologia, a meteorologia, a astrofísica, a geofísica e a biofísica. $\mathrm{Na}$ sequência, uma subseção denominada A física e as engenharias discute o conceito de tecnologia e ressalta as contribuições da Física para o desenvolvimento das engenharias (de rádio, eletrônica, civil e nuclear). Ressalta ainda as contribuições de algumas dessas engenharias nos avanços da própria física, com a elaboração de novos instrumentos que permitem o alargamento dessa ciência, configurando tal relação como uma correspondência biunívoca.

Esse é o trajeto da física. Ela dá origem a outras ciências e a suas proveitosas aplicações, que podemos denominar tecnologia. Estas ciências, tal como filhas agradecidas, retribuíram, frequentemente, dando à física novos materiais, novos instrumentos e novas idéias. (PSSC-LT, Parte I, p. 18).

A Mecânica, transformada pelas contribuições de Galileu, considerada como pedra fundamental do conhecimento em Física, é colocada como exemplo dessa relação com a tecnologia, reconhecendo que os adventos da tecnologia foram propulsores do progresso desse ramo da Física. Ao citar o exemplo do telescópio de Galileu como um marco no campo das observações astronômicas, autentica a coletividade como determinante na evolução do conhecimento: "O novo conhecimento de mecânica levou a um melhor planejamento de máquinas. Vemos pois, que sem o telescópio, a mecânica teria tido um progresso mais lento." (PSSC-LT, Parte I, p. 16).

Ressalta ainda os avanços que permitiram a construção de bombas de vácuo que, por sua vez, propiciaram experiências mais sofisticadas com os elétrons e átomos, bem como aplicações/realizações, tais como as válvulas para rádio e televisão, fabricação do suco 
concentrado de laranja, energia atômica, e ainda outras aplicações caracterizadas também como alicerces da química.

A relação da ciência/Física com a sociedade e o contexto mais amplo não é muito presente, mas pode ser notada, sucintamente, em algumas passagens que citam exemplos da atualidade. Como exemplo, pode-se considerar um trecho que justifica a importância de se aprender Física: "[...] a fisica está atrás das manchetes dos jornais, atrás dos inventos que criam novos empregos, e atrás dos novos problemas que todo cidadão tem de enfrentar." (PSSC-LT, Parte I, p. 21-22).

Quando se trata de contextualização, consideramos as duas formas que a entendemos: 1) a história da evolução do conhecimento físico, evidenciando os conflitos de ideias na interpretação de fenômenos e conceitos no contexto de produção do mesmo; as interferências externas (políticas, econômicas e sociais); 2) a relação desse conhecimento sistematizado, com o momento histórico em que se deu a elaboração do projeto, com as coisas presentes no cotidiano e, ainda, com o mundo vivencial do aluno (sua situação históricosocial).

A contextualização histórica (primeiro caso) não é um aspecto proeminente no texto do projeto, mas aparece de forma resumida disseminada ao longo dos capítulos nas discussões dos temas e tópicos, geralmente citando os expoentes da ciência descobridores ou estudiosos de algum fenômeno e descrevendo as experiências realizadas por estes. Descrições estas que, de um modo geral, não cuidam de mencionar as dificuldades, os erros, as frustações, interrupções, as limitações ambientais, as interferências externas, etc., que os cientistas vivenciavam. Em algumas raras vezes, contempla explicações interessantes sobre modelos matemáticos, como a que discute sobre a forma de chegar à relação da Lei de Snell e Descartes, e que acaba por destacar os desafios do processo de produção do conhecimento. Após a realização de experiências para observar a relação entre o ângulo de incidência e o de refração no fenômeno que ocorre quando a luz atravessa um meio homogêneo, debate sobre as formas de se obter uma função que represente a relação $\hat{\imath}$ e $\hat{r}$, procurando estender a constância da relação $\hat{l} / \hat{r}$.

[...] procuraremos funções que são proporcionais aos ângulos quando êles são pequenos, e que compensem o aumento de $\mathrm{i} / \mathrm{r}$, quando os ângulos se tornam maiores. Não temos certeza, a priori, de que encontraremos tais funções; com efeito, Ptolomeu já tinha dados sôbre a refração, dados êstes usados cêrca de mil anos antes de ser estabelecida uma lei simples e adequada da refração. Finalmente, em 1621, Willerbrord Snell encontrou um bonito modo de descrever a relação entre i e r. A mesma relação foi publicada por Descartes em 1638, na forma que usamos atualmente. (PSSC-LT, Parte II, p.45) 
A nosso ver, esse trecho evidencia que as leis da física não "brotam" facilmente de experiências no laboratório. De posse dos resultados, o cientista ensaia meios de interpretar e representar as relações observadas, muitas vezes baseadas em modelos já consolidados. Isso pode ocorrer em pouco tempo de pesquisa, como também pode demorar anos. Em alguns casos, cientistas elaboram relações matemáticas que descrevem resultados de experiências realizadas por outros, em outro momento da história ${ }^{96}$.

Em termos de extensão, tem-se como exceção o capítulo 22, na Parte III, que trata da Gravitação Universal, onde explora, de modo um pouco mais extenso, a evolução de ideias ao longo da história, ao tratar dos modelos de Universo. Talvez o aspecto histórico tenha sido mais explorado nas leituras sugeridas como complementares, das quais não tivemos como analisar.

Pelo menos parte do segundo tipo de contextualização é bastante presente, com referências a situações/exemplos cotidianos (próximo ou remoto) em que os fenômenos podem ser observados ou em que o conhecimento se aplica, algumas vezes, passando uma ideia um tanto utilitarista da Física. Quanto à relação com o mundo vivencial do aluno, podese afirmar que o projeto não cuidou desse aspecto.

Nota-se certo apelo tecnológico ao citar exemplos de aplicação e utilização de instrumentos mais sofisticados no desenvolvimento da Ciência. Como exemplo, a alusão a instrumentos de maior precisão presentes no contexto de elaboração do projeto, utilizados para observação e obtenção de dados. Instrumentos estes que se tornaram marcas da evolução científica e tecnológica daquele momento.

Os instrumentos da física podem se tornar maravilhosamente complexos. O satélite equipado com aparelhos e seus foguetes de lançamento podem ser considerados como instrumentos do físico que procura estudar as camadas superiores da atmosfera e a chuva de partículas do espaço exterior. (PSSC-LT, Parte I, p. 19-20).

No estudo de Mecânica, na Parte III, novamente esses aparatos tecnológicos são citados, neste caso, como exemplos de aplicação das leis da Mecânica de Newton: "Nós a utilizamos [a Mecânica de Newton] ao projetar foguetes e lançar satélites artificiais." (PSSC-LT, Parte III, p.09).

Importa ressaltar que, quando o PSSC foi efetivamente elaborado, os Estados Unidos já haviam lançado ao espaço o seu primeiro satélite artificial - O Explorer I - quatro meses depois do lançamento do satélite soviético Sputnik 1, em 1957. Desse modo, esses inventos

\footnotetext{
${ }^{96}$ Um exemplo disso, na história da ciência, é a descrição matemática do fenômeno da indução eletromagnética presente nos livros didáticos $(\varepsilon=-\Delta \varphi / \Delta \mathrm{t})$, que leva o nome de Lei de Faraday, mas que na verdade foi elaborada por Franz Ernst Neumann, com posteriores contribuições de Heinrich Lenz, alguns anos depois da descoberta do fenômeno por Michael Faraday.
} 
tecnológicos já eram uma realidade no país dos elaboradores do PSSC, e, possivelmente por isso, são citados como exemplos. Esse apelo tecnológico, no entanto, não cuida de discutir os diversos fatores que envolvem o desenvolvimento da ciência e tecnologia, atentando para as questões éticas, econômicas, sociais, políticas, etc..

Um exemplo interessante que evidencia a relação da ciência com o contexto histórico, além de explorar a relação da Física com outras ciências da natureza, se refere à menção aos estudos a respeito da insulina proteínica, por Sanger e colaboradores, na Universidade de Cambridge na Inglaterra, após a II Guerra Mundial. Os autores ressaltam a incompletude dos estudos e a expectativa por novas descobertas que esclareçam o mecanismo básico da vida. Nessa discussão sobre a química da vida, embora evidencie, sobretudo, os aspectos técnicos da ciência, acaba por exaltar o processo coletivo e multifacetado da mesma, seu caráter inacabado, bem como os desafios inerentes ao desenvolvimento do conhecimento científico.

\begin{abstract}
Aí está um dos mais excitantes ramos da ciência atual: a fronteira além do qual se encontram a física, a química e a biologia; o problema da estrutura e da função das configurações moleculares das coisas vivas. Para os homens e mulheres que se interessam pelo assunto, é êste um momento feliz da história. Antes não estavam ainda forjadas as ferramentas que tornaram possível êste tipo sutil de estudo. Hoje, o enigma permanece sem solução. Mas nesta ou na próxima geração, será provavelmente encontrada a solução dêste problema. (PSSC-LT, Parte I, p. 168169).
\end{abstract}

A relação Física/cultura/arte é praticamente inexistente. Buscando nas entrelinhas, identificamos sutis elementos dessa relação em algumas poucas situações. O trecho a seguir pode ser considerado como exemplo: "Todos os povos tiveram uma unidade de comprimento. Tribos de caçadores, como os índios, o passo, o tiro do arco, e a jornada. [...]." (PSSC-LT, Parte I, p.39).

Outro exemplo que também pode ilustrar essa relação se refere a um relato de ficção científica utilizado para elucidar um debate sobre escalas, questionando a validade de modelos imaginários, muito grandes ou muito pequenos, de estrutura de seres similares ao ser humano.

O viajante imaginário Lemuel Gulliver passou uns tempos agitados em um reino chamado Lilliput, onde todas as coisas vivas - [...] - eram exatamente semelhantes às de nosso mundo, exceto pelo fato de serem formados na escala de uma polegada para um pé. [...]. Gulliver visitou também Brobdingnag, o país dos gigantes, que eram exatamente como os homens, mas doze vezes mais altos. [...]. (PSSC-LT, Parte I, p. 64).

O texto debate a importância de se considerar as escalas e proporções (peso, tamanho, volume, área, etc.) na estrutura das coisas, e ressalta a impossibilidade de existência de determinados tipos de seres semelhantes aos humanos, como os lilliputianos e os gigantes de Brobdingnag, conhecidos de Gulliver. Conforme o autor da ficção, a vida que esses seres 
levavam era equivalente às dos seres humanos no século dezoito. O texto evidencia que, do ponto de vista da ciência, a impossibilidade de existência de tais espécies já era bem compreendida por Galileu, que viveu antes disso. Além das explanações e conclusões importantes a respeito de escalas (foco principal do debate), o texto passa a ideia de que estes seres (muito pequenos ou muito grandes) integram, e somente isto, à imaginação e à criatividade que faz parte da cultura e da arte de um povo.

De nossa análise, pode se afirmar que o projeto assume um discurso que concebe o conhecimento sobre a natureza como um processo em evolução, mutável e inacabado, embora alguns aspectos desse processo sejam pouco explorados, passando a ideia de uma ciência neutra. Um aspecto bastante explorado é a tecnologia, evidenciando-a como símbolo de progresso científico. A ênfase na tecnologia e no estudo de temas ainda recentes no campo científico da época (como a Física Nuclear) acaba evidenciando, ainda que de modo implícito, os interesses políticos e econômicos que permearam o modelo do projeto: um contexto político de extrema preocupação com a segurança nacional, como foi no país dos idealizadores do PSSC.

\section{A Física e a experimentação}

O PSSC é declaradamente sustentado na experimentação. No Guia do Professor, os autores explicitam suas concepções sobre a importância conferida à experimentação no desenvolvimento da ciência:

O curso do PSSC tenta fornecer, num nível introdutório, uma estrutura conceitual da Física contemporânea, e mostra como o conhecimento da Física é adquirido experimentalmente e desenvolvido pela teoria física - como a teoria, por sua vez, dirige e ilumina a experimentação. (PSSC- GP, vol I, p. 02).

Mas qual seria o papel da experimentação no desenvolvimento do projeto?

No prefácio do Guia de Laboratório, a premissa de que a experimentação é componente de destaque, é evidenciada quando diz que:

A física descreve o mundo que nos rodeia. Nós procuramos estabelecer as relações existentes entre as várias facêtas observadas no comportamento da natureza. O laboratório constitui a fonte principal de conhecimento, no sentido de compreensão deste propósito básico da física. (PSSC-GL, Parte I, Prefácio, s.p.).

O caráter experimental do projeto é reforçado ainda no texto introdutório do Guia do Professor Vol. III: "É imprescindivel que o Colégio tenha um laboratório adequado, com todo o material necessário às experiências do curso." (PSSC-GP, v. 3, p.v). 
Das orientações referentes ao laboratório trazidas nos Guias do Professor, deixa claro que as atividades experimentais se equiparam ao texto teórico, em nível de relevância, afirmando que "[...] o trabalho de laboratório se relaciona bastante com o livro-texto e é de igual importância.” (PSSC-GP, v. 1, p. 197). Em outro Guia afirma ainda que, “[...] é muito importante planejar as experiências, em conexão com as seções especificas do texto" (PSSCGP, v. 3, p. 239).

A importância do laboratório é justificada ainda como forma de "remover o muro que existe entre o mundo particular do aluno e da ciência", além de levar ao alcance dos alunos a "reciprocação entre a teoria e a prática, tão característica do desenvolvimento da ciência” (PSSC-GL, Parte I, Prefácio s.p.).

Também no Prefácio, o projeto traz que, “As idéias, os conceitos, e as definições, só têm, na verdade, um sentido efetivo quando baseados em experiências." (PSSC-GL, Parte I, Prefácio, s.p.). Tal afirmação anuncia a concepção de método científico assumida pelos autores - a Física como uma ciência preponderantemente empírico/indutivista. O excerto a seguir reforça essa ideia:

Começamos com uma experiência pessoal precária, como a das batidas do coração, e a transferimos para um instrumento que parece se comportar de maneira mais simples e digna de confiança. Testamos, então, o instrumento, para verificar se êle efetivamente funciona como imaginamos. A física é edificada deste modo, partindo de nossa própria experiência, lançando uma hipótese arrojada, que é frequentemente um verdadeiro passo no escuro (PSSC-LT, Parte I, p. 19).

Outras colocações enfatizam a experimentação como um dos pilares básicos do projeto, talvez o mais importante. Segundo consta, o programa proposto tinha a pretensão de "familiarizar basicamente os alunos com as realidades do mundo físico", de modo que eles pudessem "enfrentar, por si próprios, as principais leis da física” (PSSC-GL, Parte I, Prefácio s.p.). Acrescenta ainda que a perspectiva adotada permite aos alunos investigar os fenômenos, ao invés de simplesmente verificarem conclusões conhecidas.

Ao que parece, a experimentação no PSSC assume a função mais ampla de apresentar ao aluno a "ciência dos cientistas". Um trecho do Guia de Laboratório sintetiza essa ideia principal, que é notada ainda em outras passagens do texto.

Ao realizar experiências cujo resultado, de antemão, lhe é desconhecido, fica o aluno tomado por uma sensação de participação pessoal nas descobertas científicas; tornam-se-lhe mais significativa a ciência e a importância do cientista. (PSSC-GL, Parte I, Prefácio, s.p.).

Ao longo do texto, várias atividades experimentais são propostas, algumas com perspectiva de experimentação mental. A maioria tem natureza mais demonstrativa ou de observação, que indicam ter o objetivo de abordar, esclarecer ou fixar conceitos. Tais 
atividades, de um modo geral, trazem as respostas prontas na sequência, não permitindo maiores reflexões sobre o fenômeno, o que acaba servindo para a memorização de um conceito definitivo. Citemos alguns exemplos, dentre os vários encontrados no texto:

[...] observe, através de uma placa de vidro vermelho, uma fôlha de papel branco, iluminado pela luz do Sol ou por uma lâmpada elétrica. O papel, então, aparece vermelho. (PSSC-LT, Parte II, p.11).

Sua percepção de temperatura pode, também, ser lograda: se você mergulhar uma de suas mãos em um recipiente com água quente, e a outra em água fria, e, depois, mergulhar ambas, simultâneamente, em um recipiente com água morna, a mão "fria" sentirá quente, e a mão "quente", frio. (Se você não fêz esta experiência, faça-a). (PSSC-LT, Parte I, p. 23).

Examine o mostrador luminoso de um relógio, na escuridão completa, mantendo o mostrador a apenas dois ou três centímetros de seu ôlho desarmado. Quando seus olhos se acomodarem à escuridão, você não verá uma luminosidade constante, mas sim uma sucessão contínua e ocasional de flashes individuais de luz. (PSSC-LT, Parte I, p.147).

[...] friccione um bastão de vidro com seda e um plástico com pele. Suspenda um dêles como indica a Figura. 27-1 e aproxime o outro. Você verificará que êles se atraem. (PSSC-LT, Parte IV, p.10).

Há ainda atividades que insinuam a proposta de fazer com que o aluno se comporte como um pequeno cientista. Como exemplo, ao buscar esclarecer o princípio de funcionamento do sonar, após discutir as velocidades da luz e do som, e o uso de tais velocidades para medir distâncias, propõe: "Você pode facilmente realizar sozinho uma experiência de medida de distância com o eco. Meça a velocidade do som, marcando o tempo para uma distância conhecida, e use, então, sons para medir outras distâncias" (PSSC-LT, Parte I, p. 88).

Se por um lado, as atividades experimentais sugeridas ao longo do texto, tem um sentido mais ilustrativo, por outro, na maioria dos experimentos propostos nos Guias de Laboratório, nota-se certa abertura para o aluno interagir com a ciência, discutir procedimentos, fazer análise de dados, além da possibilidade de alargar o campo de discussão sobre os conceitos envolvidos no fenômeno a ser investigado: “[...] as experiências podem levar à responsabilidade de introduzir novos conceitos." (PSSC-GP, v. 2, p. 235). A maioria das atividades são propostas numa vertente mais qualitativa, permeadas por perguntas em que as respostas adviriam das observações e/ou resultados das medidas.

Percebe-se que houve um cuidado em explorar o quesito análise de dados, inclusive incentivou-se que as análises das experiências fossem feitas em casa, após coleta de dados no laboratório, para que se tivesse maior tempo dedicado a essa etapa da experimentação. Conforme traz nas orientações ao professor, “[...] somente colher os dados não constitui uma experiência" (PSSC-GP, v. 1, p 197). No prefácio do Guia de Laboratório, esta recomendação 
é também colocada afirmando que no trabalho de laboratório, "os alunos aprendem que as experiências se originam de uma concatenação de idéias, devendo ser planejadas de forma que seus resultados possam ser interpretados, e que são incompletas, se não analisados." (PSSC-GL, Parte I, Prefácio).

Uma das atividades experimentais do Guia de Laboratório da Parte I, denominada Análise de uma experiência, tem a finalidade de incentivar o aluno a desenvolver a habilidade de analisar dados. Nela apresenta uma tabela de dados referente a uma experiência que consistiu em investigar o tempo que a água contida em uma lata levou para extravasar por um buraco no fundo da mesma. O objetivo foi verificar a relação tempo e o diâmetro do orifício. Não é proposto ao aluno realizar a experiência, mas sim analisar os dados dispostos em uma tabela, com posterior construção de gráficos e conclusão de uma relação matemática. Afirma que a análise de dados pode "possibilitá-lo a tirar conclusões sôbre a natureza do processo que está sendo investigado, e a predizer o resultado de experiências similares.”. E completa: “A apresentação e a análise de resultados experimentais constitui um setor essencial da física." (PSSC-LT, Parte I, p.223).

A experimentação no PSSC parece estar pautada em mais de um método de ensino: o da redescoberta e o tradicional. O primeiro é mais evidente. Apostou-se na participação ativa do aluno, com a expectativa de que, executando as atividades, eles redescobririam as leis que regem os fenômenos, ou seja, chegariam a resultados similares aos dos cientistas do passado: "Os alunos necessitam, somente, de certo encorajamento, a fim de obterem suas próprias respostas; suas perguntas e o material irão auxiliá-los a descobrir a Lei de Newton." (PSSCGP, v. 1, p. 197).

Ainda que algumas das propostas de atividades experimentais não partam necessariamente do conhecimento científico (uma vez que, quase sempre, foram indicadas para ser executadas antes da apresentação dos conceitos que as envolviam diretamente), tinham como objetivo reconstitui-lo. Segundo Amaral (1997), a experimentação desse modo, por visar um alvo conceitual pré-definido e definitivo, resulta em conhecimento acabado.

Outras atividades se conformam ao método tradicional de ensino que, conforme define Amaral (1997), parte claramente de um conhecimento já definido, levando o aluno a repetir procedimentos similares aos feitos pelos cientistas, objetivando verificar leis já então formuladas. Ou seja, o conhecimento científico é "ponto de partida e de chegada" (AMARAL, 1997, p.11). Citemos uma das experiências, como exemplo:

[Experiência II-6] O modêlo corpuscular da luz prediz que a intensidade de iluminação devida a uma fonte pontual será inversamente proporcional ao quadrado da distância à fonte. Testaremos esta previsão, medindo a iluminação a diferentes 
distâncias de uma fonte de luz. [...] Seus resultados confirmam a lei do inverso do quadrado, prevista pelo modêlo corpuscular? (PSSC - GL, Parte II p. 153-154).

Pouco evidencia o fato de que os fenômenos investigados são forjados artificialmente no laboratório (AMARAL, 1997), e, que, na maioria deles, o laboratório não reproduz o ambiente natural em que se manifestam. A respeito disso, localizamos somente a colocação abaixo:

Muitos dos movimentos analizados (sic) por Galileu, e os que Newton estudou mais tarde, eram tão altamente idealizados que pareciam ter muito pouco em comum com os movimentos dos sistemas reais que observamos. [...]. Com equipamento moderno conseguimos fazer experiências que quase realizam as experiências idealizadas por Galileu, sôbre movimento sem fôrça. (PSSC-LT, Parte III, p.12, grifo nosso).

Também, pouco se explora a contextualização histórica referente às ideias e conceitos sobre os fenômenos investigados, sobretudo, os fatores externos. Em alguns casos, limita-se a mencionar de forma muito breve, os cientistas que realizaram as experiências no passado, não explorando nem mesmo os aspectos internalista ${ }^{97}$ do processo.

\section{Modelos explicativos formais}

A respeito dos instrumentos utilizados pela física para decifrar o conhecimento sobre a natureza, o PSSC destaca que o instrumento-chave é a mente do cientista, mas que este utiliza de linguagens para "tornar claro, para si próprio e os outros, o que êle pensa e fêz, e o que pretende realizar” (PSSC-LT, Parte I, p. 18). Umas dessas linguagens é a matemática. “ $A$ matemática, que pode ser considerada como uma linguagem internacional especial de relação e quantidade, extremamente clara e flexível, é, também, um instrumento importante de seu equipamento [do físico] [...]” (PSSC-LT, Parte I, p. 18).

Percebe-se uma expressiva preocupação com as medidas, de modo que títulos de capítulos evidenciam esse destaque: capítulo 2 - Tempo e sua medição, capítulo 3 - Espaço e sua medição, capítulo 10 - Mensuração. Tais capítulos trazem seções que discutem diferentes formas e representação de medidas, unidades, ordem de grandeza, etc., bem como suas limitações. O capítulo 10 traz que: “A mensuração é o meio pelo qual progredimos, pelo qual testamos e refinamos nossos conceitos sôbre o funcionamento do mundo.” (PSSC-LT, Parte I, p.199).

\footnotetext{
${ }^{97}$ Estamos assumindo aqui os conceitos de aspecto internalista e externalista da ciência de acordo com a interpretação de Pereira (1995) que afirma que "a visão internalista, sustenta um enfoque mais voltado para a própria natureza, em que embates se dão em torno de ideias sobre como interpretá-la e percebê-la”. Já a externalista abrange influências de cunho religioso, social, político e econômico, ou seja, os diversos interesses que direcionam os modos como a ciência evolui em determinado contexto (PEREIRA, 1995. p. 48).
} 
Há ainda um capítulo específico que trata das diferentes maneiras de representar os fenômenos - o capítulo 4 - Funções e Escalas. Tal capítulo traz explicações sobre relações matemáticas, tabelas, gráficos, proporções, interpolação, extrapolação, equações, etc. Se inicia pelo seguinte texto: "Muitas das leis da física são expressas de modo mais útil por meio das relações matemáticas, que mostram como uma coisa que se pode medir depende de outras que podemos medir.” (PSSC-LT, Parte I, p. 57).

No referido capítulo, chama-se a atenção para o procedimento de extrapolação que, se por um lado pode induzir ao erro, por outro, possibilita descobertas. Ainda no mesmo capítulo, mais adiante, reforça a importância das relações matemáticas, afirmando que elas "podem ser aproveitadas em fisica para nos informar sobre coisas do mundo físico" (PSSCLT, Parte I, p. 63).

No que se refere aos exercícios e problemas, podemos afirmar que a maioria explora aplicações numéricas, mas, mesmo nesse grupo, encontram-se alguns que exploram também a análise qualitativa.

Constatamos que, de um modo geral, a matemática aparece de forma equilibrada com a parte conceitual, ainda que em alguns capítulos siga a linha tradicional. O diferencial notado é a forma como são apresentadas as equações que descrevem os modelos; geralmente, precedidas de uma explicação detalhada a partir de exemplos ou descrições de experiências realizadas por cientistas. $\mathrm{Na}$ apresentação dos conteúdos, prevalecem as explicações na forma de textos, figuras, esquemas, e citação de exemplos que trazem uma discussão mais qualitativa. Entretanto, cabe pontuar que, na Parte II - Mecânica, as equações ganham destaque. Há capítulos em que sobressai a abordagem quantitativa, onde as equações são bastante evidenciadas ao descrever os conceitos. É o caso, por exemplo, do capítulo $A$ quantidade de movimento e sua conservação. A abordagem desse capítulo, já começa com um apelo quantitativo. Inicia a primeira seção com o conceito de Impulso com a seguinte apresentação:

23 - 1. Impulso. Tente imprimir a mesma velocidade a uma bola de tênis e a um tijolo. Como você sabe, é muito mais difícil mover o tijolo. Se você aplica uma força $\vec{F}$ constante durante o intervalo de tempo $\Delta t$, a variação de velocidade é dada por $m . \Delta \vec{v}=\vec{F} \Delta t$. Assim, para obter-se o mesmo $\Delta \vec{v}$, o produto $\vec{F} . \Delta t$ deve ser tanto maior quanto maior for a massa $m$ que se está tentando acelerar. (PSSC-LT, Parte III, p. 69).

Ocorre que, somente após a apresentação das equações, na página seguinte, é citado um exemplo que ilustra a força impulsiva. Mostra a foto de uma raquete se chocando com uma bola de tênis, e, em um pequeno trecho menciona o exemplo, afirmando ser bastante 
complicado mensurar a força que atua durante a colisão, sendo mais fácil determinar o impulso total pela variação do produto $m . \vec{v}$. O referido exemplo de aplicação se encerra aí.

Apesar de o projeto ter, em maior grau, uma abordagem mais conceitual/qualitativa, a matemática apresentada nem sempre é simples. Alguns tópicos exploram relações de significativa complexidade. A Parte IV, que traz uma interessante abordagem sobre a "Nova Física" nos três últimos capítulos, o nível de complexidade é bastante avançado, mesmo na discussão qualitativa. Contudo, no geral, nota-se um esforço maior em apresentar a matemática como descrição dos fenômenos, mais do que como ferramenta de cálculos.

\section{Conteúdos/áreas da Física}

Conforme já relatado, o material impresso do PSSC foi organizado em quatro grandes temas, um em cada volume ou livro-texto que era destinado ao aluno, e também ao professor, já que o Guia do Professor não trazia o texto do aluno. O quadro a seguir mostra os títulos de cada capítulo das Partes; permite uma visualização geral de como a sequência de conteúdos foi organizada no projeto.

\begin{tabular}{l|ll}
\multicolumn{2}{c}{ QUADRO 8 - Temas e títulos dos capítulos do PSSC } \\
\hline GRANDES TEMAS & \multicolumn{2}{c}{ CAPÍTULOS } \\
\hline Parte I - O Universo & 1. O que é física? & 6. Vetores \\
& 2. Tempo e sua medição & 7. Massa, elementos, átomos \\
& 3. Espaço e sua medição & 8. Átomos e moléculas \\
& 4. Funções e escalas & 9. A natureza de um gás \\
& 5. Movimento ao longo de uma trajetória & 10. Mensuração \\
\hline Parte II - Óptica e e & 11. Comportamento da luz & 16. Introdução às ondas \\
ondas & 12. Reflexão e imagens & 17. Ondas e luz \\
& 13. Refração & 18. Interferência \\
& 14. Lentes e instrumentos ópticos & 19. Ondas luminosas \\
& 15. Modelo corpuscular da luz & \\
\hline Parte III - Mecânica & 20. A lei do movimento de Newton & 24. Trabalho e energia cinética \\
& 21. Movimento na superfície da Terra & 25. Energia potencial \\
22. Gravitação Universal e o Sistema Solar & 26. Calor, movimento molecular e \\
& 23. A quantidade de movimento e sua conservação & conservação de energia. \\
\hline Parte IV & 27. Alguns fatos qualitativos sobre a eletricidade & 31. Indução a ondas eletromagnéticas \\
Eletricidade & 28. A lei de Coulomb e a carga elétrica elementar & 32. Explorando o átomo \\
estrutura atômica & 29. Energia e movimento de cargas em campos & 33. Fótons e ondas associadas à matéria \\
& elétricos & 34. Sistemas quânticos e a estrutura dos \\
& 30. O campo magnético & átomos
\end{tabular}

Fonte: (PSSC, Partes I, II, III e IV, 1963/196-)

Os tópicos da Parte I introduzem as noções fundamentais de tempo, espaço e matéria e a forma como tais grandezas são compreendidas e medidas, apresentando "um amplo quadro do universo". Inicia por medidas do macro e avança para o micro. No macro, toma como sistema o Cosmo, discutindo medidas de grandes distâncias utilizando o processo de triangulação tendo como referência estrelas próximas. Nas pequenas medidas, enfoca o átomo 
e outras partículas elementares. Os temas tratados nessa parte são considerados a base do que será desenvolvido nas demais partes.

O foco da Parte II é o estudo da luz, explorando assuntos comumente tratados nos currículos de física: estudo de sombras; reflexão em espelhos, refração da luz em superfícies ópticas. Além disso, discute os modelos corpuscular e ondulatório da luz e os fenômenos luminosos. Traz o estudo das ondas mecânicas na água, em molas e cordas.

Conforme afirma no prefácio da Parte I, "Durante a primeira metade do curso, a ênfase principal está na cinemática de nosso mundo: onde estão as coisas, qual é o seu tamanho, como se movimentam, e não por que.". Ao que parece, para as Partes I e II, optouse por tratar de assuntos que requer menor grau de abstração.

A parte III, sob o título de Mecânica, traz o estudo do movimento sob um ponto de vista dinâmico. Aborda as leis do movimento de Newton, Gravitação, estudo da Quantidade de Movimento e sua conservação, e Energia e Trabalho. Traz ainda, de modo articulado, um breve estudo sobre Calor a partir do modelo molecular de um gás. Interessante observar o diferencial na forma de tratar os assuntos relacionados a Calor e Temperatura. Na Parte I traz um pouco sobre o tema no estudo da natureza de um gás (capítulo 9), e, na Parte III, no capítulo 26, retoma o assunto, desta feita, de modo mais complexo, com apresentação de algumas relações matemáticas que descrevem os processos.

Não aborda a termometria do modo tradicional, com estudo de escalas termométricas e dilatação de sólidos e líquidos, e nem calorimetria com maiores detalhes. A Termodinâmica também é desenvolvida de modo diferente do que estamos acostumados a ver nos livros didáticos; é discutida numa perspectiva mais qualitativa e mais resumida. $\mathrm{Na}$ abordagem predomina o aspecto microscópico partindo da teoria cinético-molecular da matéria e não discute conceito de Entropia. Não aprofunda no estudo das máquinas térmicas, como por exemplo, não explora exemplos de aplicação das leis da termodinâmica na determinação do rendimento das máquinas.

Na Parte IV o foco é o estudo da eletricidade, além de explorar a física do átomo, outro grande diferencial da proposta. Inicia com abordagem mais qualitativa no capítulo 27 , e prossegue com um estudo mais quantitativo a partir do capítulo 28 , com cálculo das forças elétricas entre cargas. Traz ainda o estudo sobre campos magnéticos produzidos por ímãs e correntes, forças sobre cargas em movimento e leis de indução. Retoma o estudo da luz, para novamente discutir o seu comportamento dual. Aborda o efeito fotoelétrico e ondas associadas à matéria, também, numa percepção mais qualitativa. Esta Parte é finalizada com 
um capítulo que, novamente, se adentra para a escala microscópica explorando a estrutura dos átomos.

As leis de conservação da Energia, da Quantidade de Movimento e da Carga são abordadas, com maior destaque para a primeira, que é mencionada em vários tópicos. A ideia de que a Energia sempre se conserva, dentro de nossa limitada capacidade de observação, é frisada quando afirma que "Todos os acontecimentos físicos, desde a evolução de uma estrêla até a vida de um vaga-lume, são essencialmente transformações de energia. [...] Nosso conhecimento do mundo físico é coerente com uma conservação universal da energia." (PSSC-LT, Parte III, p. 152).

Não localizamos discussão sobre Conservação da Quantidade de Movimento Angular nos livros-texto traduzidos. Esse tópico consta nos "Advanced Topics Supplement", que não foram traduzidos para uso no Brasil, em nível editorial.

A sequência dos conteúdos é bastante diferenciada do modo tradicional de apresentação da Física nos cursos de nível superior e também no ensino médio, que geralmente começa com o estudo da Mecânica subdividida em cinemática e dinâmica, prosseguindo com a Física Térmica, Óptica, Ondulatória e Eletromagnetismo. Em alguns casos, na sequência, aparece a Física Moderna com temas de descobertas do século XX.

No PSSC, a sequência é modificada e alguns tópicos que pertencem a um grande tema, se articulam a outros, como por exemplo, o tópico Calor, que é discutido com assuntos da Mecânica, levando em conta que calor e movimento têm uma relação de interdependência. Outro tema notável é o estudo de Ondas, que começa na Parte II, articula com os conceitos de Energia e Quantidade de movimento na Parte III e é retomada na Parte IV, quando explora o estudo do átomo, discutindo ondas associadas à matéria.

É notável ainda a presença de assuntos que comumente não são tratados no currículo de Física com o nível de profundidade adotado, como por exemplo, os assuntos explorados nos capítulos 8, 26, 32 e 34. São capítulos que trazem tópicos de estudos que focam a matéria em escala microscópica, inclusive alguns desses assuntos são, geralmente, mais comuns no estudo da Química. Por outro lado, percebe-se a ausência de tópicos bem comuns nos tradicionais currículos de Física, como por exemplo, o estudo dos fluidos (hidrostática e hidrodinâmica) na Mecânica, além de outros desdobramentos do estudo do Calor, Ondulatória e Eletromagnetismo.

No prefácio do livro-texto do projeto afirma que, "Os tópicos do curso PSSC são escolhidos e ordenados de modo a evoluir do simples e do comum às mais sutis ideias da física atômica moderna" (PSSC, 1963, p. 08). Em outras passagens esse discurso do simples 
para ideias mais complexas, se mantêm, como exemplo, ao explicar as formas de estudo do movimento em cinemática e dinâmica: "O método da física consiste em analisar primeiramente os casos mais simples, dêles extraindo o que pudermos, e avançar para casos cada vez mais complexos." (PSSC-LT, Parte I, p.114). Mais adiante conclui: "A complicada extensão de ensaio e erro se alicerça sempre na base do simples e bem compreendido." (PSSC-LT, Parte I, p.115).

De nossa análise, contata-se que, em termos de conteúdo, a ideia central do projeto é a Física Nuclear. Isso pode ser depreendido do desenvolvimento do texto do mesmo, uma vez que nota-se a presença de significativa discussão sobre a natureza atômica da matéria. Cerca de quatro capítulos trazem tópicos que exploram o estudo dos átomos e moléculas.

\section{Da dimensão Educativa}

\section{Objetivos do ensino de Física}

Os autores do PSSC pretenderam com o projeto "transmitir um sentido do alcance e do poder das ideias fisicas fundamentais” (PSSC-GP, Parte I, p. XIII). Muitos excertos do texto do projeto já citados nesta análise, e ainda outros que omitimos, passam uma ideia de motivação para promover no aluno o interesse pela atividade científica. Algo do tipo: "você poderá ser um cientista!’. Os fragmentos de texto a seguir são mais alguns que exemplificam essa premissa:

[A física] É como um grande edifício em construção, e não uma estrutura terminada que você apenas deve visitar, levado por um guia. Ainda que algumas partes estejam satisfatoriamente concluídas e sejam igualmente úteis e belas, outras estão somente semi-executadas. Outras, ainda, estão apenas planejadas. Novas partes serão iniciadas e completadas por homens e mulheres ${ }^{98}$ de sua geração, possivelmente por você ou seus colegas. (PSSC-LT, Parte I, p.16).

A formulação de perguntas novas e adequadas constitui frequentemente, a chave de uma física nova e interessante. Talvez você venha a formular uma pergunta chave. (PSSC-LT, Parte II, p. 140).

O raciocínio que você acabou de acompanhar constitui um bom exemplo do modo pelo qual os cientistas se aproximam da verdade, passo a passo. (PSSC-LT, Parte II, p. 17).

Considerando o contexto político em que o projeto foi elaborado, as colocações constantes nos fragmentos de texto acima levam a entender que os objetivos para o ensino de

\footnotetext{
${ }^{98}$ Interessante observar a presença dos termos "homens e mulheres", ao invés de somente "Homem" mesmo que no sentido de "ser humano", em algumas passagens do texto do projeto. De modo peculiar, parece ter tido certo cuidado com a questão das relações de gênero - algo que ainda não era debatido na época.
} 
Física, assumidos no desenvolvimento do PSSC, perpassaram pelo propósito de fazer com que os alunos construíssem certa confiança na ciência, incluindo aí a possiblidade de fazer parte do seleto grupo de "homens da ciência". Um trecho no Guia do Professor indica ter ambicionado convencer o aluno de que estudar Física poderia valer a pena.

Acendem o propósito de encorajar o professor a incentivar os alunos a se interessar pela Física, mostrando que a formação na área poderia ser a garantia de um bom emprego. “Alguns alunos podem estar interessados em encarar a Física como profissão”. Prossegue informando que nos EUA havia naquela época cerca de 20.000 físicos praticantes e que a indústria empregava cerca de 50\% deles, e que, a outra metade, era absorvida pelos colégios universitários, governo, fundações particulares e outras organizações sem fins lucrativos. $\mathrm{O}$ texto afirma ainda que a maioria dos físicos levava uma vida normal, tinham filhos, praticavam esportes, além de outros lazeres, e estavam "economicamente no mesmo nível que professôres universitários”. E complementa: “Oportunidades na profissão são essencialmente ilimitadas, sem relações à raça, religião ou sexo.” (PSSC-GP, v. I, p.5).

A prevalência de alusões a aparatos tecnológicos, como exemplos de aplicações do conhecimento físico em situações cotidianas próximas ou remotas, ocasiona ainda a ideia de que se pretendeu também familiarizar os alunos com as tecnologias, das simples às mais complexas, já que estas eram, naquele contexto, consideradas bens de consumo e símbolo de progresso. Esta seria uma imagem importante a ser disseminada num contexto mundial politico e economicamente polarizado.

No que pese aos objetivos educacionais mais amplos, essa nuance utilitarista da ciência/Física parece ter sido fruto da adoção de um modelo pedagógico que acabou assumindo diferentes vertentes. Além de um currículo centrado, sobretudo, na estrutura fundamental da disciplina (priorizando o conhecimento científico) e na redescoberta como método de ensino (colocando o aluno numa posição mais ativa no processo de ensino), outra ênfase é claramente percebida na forma como se deu as orientações para o desenvolvimento do projeto nas salas de aula e laboratórios. Conquanto discurse, no Guia do Professor, que não se pretendeu a imposição de regras rígidas percebe-se uma ênfase tecnicista, já que foca procedimentos característicos desse princípio pedagógico, que ganha maior força nas décadas de 1960 e 1970. Isso é percebido nas orientações que enfatizavam as sequências das etapas do curso, os objetivos das atividades, temas e tópicos, o momento de desenvolvimento dos recursos pedagógicos; tabelas de planejamento, classificação de graus de dificuldade e prioridades para os exercícios e atividades experimentais, etc. 
Se por um lado, devamos reconhecer os diversos pontos positivos relevantes que circundaram o PSSC, principalmente no que se refere à escolha dos temas e a abordagem inovadora, pela articulação destes, e ainda a diversidade de recursos pedagógicos que integraram o projeto; por outro, é relevante pontuar que o mesmo visou, mormente, conhecimento de conteúdo. $\mathrm{O}$ ensino é, desse modo, principalmente, propedêutico à formação de futuros cientistas ou profissionais da área tecnológica, o que, consequentemente, visa conhecimentos futuros. No Brasil, adequa-se à preparação para o ingresso no ensino superior (a quantidade de exercícios/problemas de caráter fechado corrobora tal possiblidade).

A maioria dos que estudam os fundamentos da física não serão físicos mais tarde. Alguns continuarão seu estudo de física, ou trabalho correlato, na engenharia ou em outras ciências. Quer prossiga ou não [no estudo da Física], você pode encontrar na história da natureza, como os físicos a vêem, muita coisa que o auxiliará a compreender o mundo mutável no qual vivemos. (PSSC-LT, Parte I, p. 21).

Não há preocupação com conhecimentos da cultura inicial do aluno. Como se depreende da citação, a ideia é partir do conhecimento científico sistematizado (a visão dos físicos) para compreender o mundo, mas não o mundo vivencial do aluno. De modo geral, no desenvolvimento dos temas, ou parte de um conhecimento científico mais familiar ao aluno, geralmente citando alguma aplicação da Física em aparatos do cotidiano, ou considera a inexistência desse conhecimento, assumindo uma perspectiva mais informativa. Nas propostas experimentais, pouco é considerada a visão do aluno sobre o fenômeno, com seus conhecimentos oriundos do senso comum.

\section{Concepção de aluno/professor}

As concepções sobre o papel do aluno e do professor no PSSC podem ser depreendidas a partir do modo como o livro-texto conduz a apresentação dos conteúdos. A forma de tratamento é claramente voltada para o aluno, e, em nenhum momento menciona o professor. A "conversa" se dá entre os cientistas (autores) e o aluno. Ainda que o Guia do Professor seja extenso, detalhado, com orientações bastante minuciosas, o professor ocupa o papel de organizador, e muito pouco como orientador no desenvolvimento do projeto. Um executor de tarefas práticas do tipo: escolher os filmes adequados a cada momento e preparar a exibição, dispor os materiais de laboratório, solicitar tarefas de realização de exercícios, escolhendo os mais apropriados para determinados momentos de aprendizagem, e outras atribuições técnicas. 
A ideia de que o aluno foi colocado como centro do processo de ensino é também presente na apresentação do Guia de Laboratório, ao aluno. Transcrevemos tal apresentação na íntegra, pois a mesma, em toda a sua extensão, permite constatar que o projeto apostou na possiblidade de o aluno aprender sozinho, sem intervenção do professor.

\section{AOS ALUNOS}

Êste Guia foi elaborado com o propósito de auxiliá-lo em seu trabalho experimental. Êle oferece uma introdução geral aos problemas visados, dá sugestões técnicas, reservando-lhe, porém, o trabalho de raciocinar. Você trabalhará independentemente, durante a realização de grande parte das experiências. Se seu gôsto coincide com o de muitos outros que já fizeram estas experiências, aprenderá rapidamente, em as realizando, a apreciar êste tipo de trabalho prático.

Você deparará com muitas perguntas ao longo dêste Guia. A resposta a estas questões requererá, por vêzes, que você pense um pouco nos conhecimentos adquiridos anteriormente, ou, então, será necessário efetuar um pequeno cálculo. Outros casos exigirão o prosseguimento da experimentação. Fica a seu critério, em cada caso, decidir o que fazer.

Bons hábitos de trabalho são vantajosos. Leia sempre a descrição completa da experiência, antes de iniciar o trabalho, de sorte a ter uma compreensão nítida do que pretende fazer. Anote cuidadosamente o que ocorre durante a realização da experiência. Possuirá, então, os dados, aos quais poderá recorrer, se necessário, e noções suficientes para saber como proceder em seu trabalho.

Efetuando uma experiência, sempre que preciso, repita as medidas várias vêzes. Diversas leituras são geralmente melhores que uma só. Você decidirá em que casos é necessário um maior número de medidas.

Muitas destas práticas requerem o auxílio de um ou mais participantes. Examine, com seus companheiros, os resultados obtidos. Trabalhando em conjunto na análise dos resultados, você aprenderá mais do que se a efetuar isoladamente.

Não lhe será possível, provavelmente, realizar tôdas as partes de cada experiência. Não se precipite: é mais vantajoso fazer minuciosamente metade dos itens sugeridos, do que completar a experiência de um modo superficial. Parte da análise dos resultados, freqüentemente, pode ser feita em casa.

$\mathrm{Na}$ maioria das experiências, os aparelhos usados são muito simples. Você mesmo pode fazer muitas partes e prosseguir as experiências em sua casa. (PSSCGL, Parte I, Apresentação).

A apresentação faz subentender que o aluno deveria buscar meios de realizar e compreender a experiência por caminhos que não incluía o professor. Prega por um trabalho individualizado, com procedimentos de treinamento e, se necessário, com o auxílio dos colegas. Denota a pretensão de estimular o aluno a desenvolver a forma de trabalho dos cientistas.

O destaque concedido ao aluno se limita à forma como se organizou o processo de transmissão do conhecimento sistematizado, com a participação ativa do mesmo. Essa participação era, geralmente, estimulada na realização das atividades experimentais e também na execução de exercícios que exploravam, além de análises quantitativas, também qualitativas. Como exemplo:

Determine a altura de uma árvore, ou um edifício, em um dia ensolarado. Os dados que você necessita são o comprimento de sua sombra e o da árvore, e sua própria altura. Partindo dêstes dados, pode ser encontrada a altura da árvore, usando-se 
triângulos semelhantes. A posição do Sol modifica seus resultados? (PSSC-LT, Parte I, p.54).

Este é um tipo de exercício que tem o potencial de colocar o aluno em ação para compreender o conteúdo. Não há dados prontos, o aluno deveria efetuar medidas e lançar mão de ferramentas matemáticas relativamente simples para obter o resultado numérico final. Além disso, poderá refletir sobre a variação dos valores das medidas dependendo do horário em que se faz a atividade, mas que não alteram o resultado para a altura da árvore.

Interessante observar que a forma como os experimentos são apresentados, no Guia de Laboratório, leva a entender que o aluno já encontraria os materiais disponibilizados no laboratório para executar as atividades. As orientações do Guia não adiantam o material necessário para cada experiência e pouco explicam sobre as montagens. Isso aparece no Guia do Professor, de modo que a preparação para a atividade experimental seria do docente, concedendo a este, também um papel de assistente no processo de ensino.

No quadro a seguir apresentamos uma síntese de nossa análise no PSSC, com a descrição das categorias e seus resultados.

QUADRO 9 - Síntese da análise no PSSC

\begin{tabular}{|c|c|c|}
\hline Dimensões & Categorias & Resultados \\
\hline \multirow[t]{4}{*}{$\begin{array}{l}\text { Epistemo- } \\
\text { lógica }\end{array}$} & $\begin{array}{l}\text { Ciência } \\
\text { como } \\
\text { processo }\end{array}$ & $\begin{array}{l}\text { Aspectos históricos pouco presente. Considera a Física como um empreendimento humano, } \\
\text { mutável e coletivo, mas não considera os aspectos externos ao processo de produção do } \\
\text { conhecimento (políticos, econômicos, de grupos sociais, religiosos, etc.). Explora aplicações da } \\
\text { Física em aparatos tecnológicos. A tecnologia como símbolo de progresso. Relaciona a Física às } \\
\text { engenharias e outras áreas de Ciências da Natureza. Pouca relação com a sociedade - arte, } \\
\text { cultura, política, economia, etc.. }\end{array}$ \\
\hline & $\begin{array}{l}\text { A Física e a } \\
\text { experimen- } \\
\text { tação }\end{array}$ & $\begin{array}{l}\text { Evidencia a experimentação. Muitos experimentos como forma de entendimento dos conceitos. } \\
\text { Pouco evidencia a existência de um modelo que precede o experimento. Os alunos poderiam } \\
\text { redescobrir as Leis da Física. Explora em nível razoável o significado de medidas das grandezas } \\
\text { físicas e dá significativa relevância à análise de dados. O discurso em defesa da experimentação } \\
\text { traz a ideia de que a Física é uma ciência puramente empírica. }\end{array}$ \\
\hline & $\begin{array}{l}\text { Modelos } \\
\text { explicativos } \\
\text { formais }\end{array}$ & $\begin{array}{l}\text { Prevalece um equilíbrio entre o formalismo matemático e as explicações conceituais. Busca } \\
\text { discutir os significados das grandezas relacionadas nas equações. A matemática tende mais para } \\
\text { uma descrição dos fenômenos do que como ferramenta de cálculos. }\end{array}$ \\
\hline & $\begin{array}{l}\text { Conteúdos/ } \\
\text { áreas da } \\
\text { Física }\end{array}$ & $\begin{array}{l}\text { Sequência diferenciada. Assuntos distribuídos de forma articulada; significativa coerência } \\
\text { interna. Ideias fundamentais da Física. Alguns temas geralmente não explorados em outros } \\
\text { materiais didáticos da época. Ênfase na Física nuclear com bastante discussão sobre a natureza } \\
\text { atômica da matéria. Ausência de alguns temas/tópicos: Termometria; alguns desdobramentos de } \\
\text { Calorimetria e Termodinâmica e de Mecânica (não trata de quantidade de movimento angular em } \\
\text { cinemática e Estudos dos fluídos). Leis de Conservação são discutidas e retomadas em situações } \\
\text { diversas. Abordagem preponderantemente qualitativa. Profundidade conceitual, muitas vezes, } \\
\text { complexa; podendo ser inacessível até mesmo para os professores. }\end{array}$ \\
\hline \multirow[t]{2}{*}{ Educativa } & $\begin{array}{l}\text { Objetivos } \\
\text { do ensino de } \\
\text { Física }\end{array}$ & $\begin{array}{l}\text { Objetivou-se claramente a formação de futuros cientistas. O desdobramento visa também } \\
\text { preparação para prosseguimento nos estudos superiores. Busca passar uma boa imagem da } \\
\text { ciência. Não discute aspectos éticos e nem consequências negativas decorrentes de um } \\
\text { empreendimento cientifico. A ênfase experimental e os detalhamentos técnicos na explicação } \\
\text { sobre as descobertas científicas parecem estimular o pensamento lógico e científico (do ponto de } \\
\text { vista internalista). }\end{array}$ \\
\hline & $\begin{array}{l}\text { Concepção } \\
\text { de aluno/ } \\
\text { professor }\end{array}$ & $\begin{array}{l}\text { O ensino é pré-definido. Requer alguns conhecimentos como pré-requisitos, mas busca sempre } \\
\text { fazer recorrência a estudos anteriores dentro do próprio desenvolvimento do projeto. O aluno é o } \\
\text { centro do processo de ensino; evidencia sua participação ativa nas atividades experimentais. } \\
\text { Ignora a história social do aprendiz. O professor é colocado como organizador e assistente no } \\
\text { desenvolvimento do projeto. }\end{array}$ \\
\hline
\end{tabular}




\subsection{Os Projetos de Ensino de Física nacionais}

Ainda que pese a desconfiança quanto à viabilidade de aplicação dos projetos de ensino estrangeiros, da década de 1960, em um país com condições diversas dos países que os originaram, tais propostas foram responsáveis pela motivação para a criação de projetos brasileiros iniciados no Estado de São Paulo, a partir da referida década.

Na década de 1960, tem-se o Projeto Piloto de Física da UNESCO (1962-1964) elaborado por professores de Física brasileiros em parceria com professores de outros países da América Latina, com a colaboração do IBECC. Esse projeto foi o primeiro no Brasil após o advento do PSSC, e o início dos trabalhos de elaboração do mesmo foi concomitante à finalização do trabalho de tradução e publicação do PSSC por meio da parceira IBECC e Universidade de Brasília (UnB). Mais detalhes sobre a origem e elaboração do Projeto Piloto de Física da UNESCO estão dispostos no APÊNDICE A do presente trabalho.

A inovação curricular para o ensino de Física, em uma nova fase a partir de 1970, a dos projetos genuinamente brasileiros ${ }^{99}$, é, em grande parte, alentada pelo PREMEN e PNMEC criados pelo MEC, em 1972, conforme já citado. Foi com o apoio consubstanciado nessa política pública nacional que importantes projetos de ensino de Física foram desenvolvidos na referida década.

Alguns foram bastante difundidos e até mesmo adotados por muitas escolas do país, tais como, o Projeto de Ensino de Física (PEF), do Instituto de Física da Universidade de São Paulo, iniciado em 1972, coordenado pelos Professores Ernst Wolfgang Hamburger e Giorgio Moscati; e o Projeto Física Auto-Instrutivo (FAI), desenvolvido também no início da década de 1970, pelo Grupo de Estudos em Tecnologia do Ensino de Física (GETEF) - e coordenado pelos professores Fuad Daher Saad, Paulo Yamamura e Kazuo Watanabe.

Outro projeto de ensino de Física nacional surgiu nesse contexto, mas foi pouco conhecido pelas escolas e não teve continuidade na elaboração e publicação de seus textos. Falamos do Projeto Brasileiro de Ensino de Física (PBEF). Esse projeto foi desenvolvido na

\footnotetext{
${ }^{99}$ É preciso destacar que, no ínterim em que se acolhiam os projetos internacionais, no início na década de 1960 já ocorria a produção de material didático genuinamente brasileiro (KRASILCHIK, 1980), dando sequência ao trabalho iniciado ainda na década de 1950. Na segunda metade dessa década ocorreu a produção dos primeiros kits experimentais para a disciplina Química e desenvolvimento do projeto "Iniciação Científica", que visou à produção de kits para auxiliar o ensino de Física, Química e Biologia nos cursos primário e secundário (NARDI, 2005). Destaca-se nesse período a preparação do Projeto Iniciação à Ciência que, segundo Krasilchik (1980), trazia alguns diferenciais em relação aos projetos estrangeiros para o mesmo nível de ensino (o Ginasial), que eram elaborados em textos separados (livro do aluno, manual de laboratório e guia do professor). O projeto brasileiro buscava articular teoria e prática, na medida em que "as atividades práticas não eram separadas do texto, fazendo parte de um conjunto que tornava obrigatória a execução das experiências." (KRASILCHIK, 1980, p. 172).
} 
mesma época que o PEF e o FAI, porém sob os auspícios da FUNBEC e do CECISP e, também com o apoio da Fundação de Amparo à Pesquisa do Estado de São Paulo (FAPESP). Idealizado por Rodolfho Caniato, como tema de sua tese de doutoramento (CANIATO, 1973), teve seus primeiros livros (Unidades) publicados em parceria com a FUNBEC. O PBEF teve restrita aplicação, não teve continuidade de elaboração, e praticamente se limitou à fase de testes. Mais detalhes sobre a origem e elaboração desse projeto também se encontra no APÊNDICE A do presente trabalho.

Nas próximas Seções (3.6 e 3.7) passaremos à apresentação de dois desses projetos de ensino de Física originados no Brasil, escolhidos como fontes de análise de conteúdo. Cada Seção iniciará com uma apresentação sucinta do processo de elaboração do projeto de que se trata, tendo como referência pesquisas da área, sendo algumas de autores participantes da elaboração do mesmo. Na sequência, em subseção, serão apresentados maiores detalhes sobre o projeto a partir de nosso olhar sobre o mesmo; dos resultados de nossa análise de conteúdo direcionada pelas dimensões adotadas e categorias pré-definidas (cf. Capítulo 1 deste trabalho).

\subsection{O Projeto de Ensino de Física (PEF)}

\subsubsection{Breve histórico de elaboração}

O PEF foi desenvolvido no Instituto de Física da Universidade de São Paulo (IFUSP), coordenado pelos Professores Ernst Wolfgang Hamburger e Giorgio Moscati no período de 1970 a 1975.

Bittencourt (1977) descreve e analisa o processo de planejamento, elaboração e difusão do PEF, com ênfase na parte de Mecânica. O autor faz uma pesquisa de campo em escolas da rede estadual de São Paulo para levantar as dificuldades encontradas na utilização de um capítulo do tema. Pacca (1976) também analisa a parte de Mecânica do projeto, com a aplicação em escolas da rede estadual de São Paulo, para identificar o alcance dos objetivos

intermediários e finais do texto. É com base nesses dois trabalhos de autores que participaram da elaboração do PEF que descreveremos as informações gerais sobre o nascimento desse projeto.

Segundo Bittencourt (1977), a inviabilidade do PSSC para a realidade brasileira foi um importante fator motivador para a criação dos projetos nacionais. Conforme esse autor, a utilização do PSSC no Brasil apresentou dificuldades e problemas, tendo sido tema de debates 
acalorados entre críticos e defensores do projeto estrangeiro no I Simpósio Nacional de Ensino de Física (I SNEF), realizado em 1970, na Universidade de São Paulo. Transcrevemos do autor algumas das dificuldades apontadas nos debates:

a) Os professores em geral estavam apegados aos programas tradicionais (por razões de tradição, pressão dos vestibulares, etc,) e não queriam ou não estavam preparados para ministrar tópicos de Física Moderna.

b) Muitos professores passaram a utilizar o PSSC (ou parte dele) apenas como livro de texto sem ministrar o laboratório correspondente (por causa de turmas numerosas, falta de material, tempo de preparar a aula, tradição de ensino livresco ou inabilitação).

c) Não utilização da série de filmes, tanto pela inexistência de projetores e salas de projeção nas escolas, quanto pelos filmes não terem sido dublados em português e existirem poucas cópias disponíveis em todo o Brasil.

d) O curso do PSSC foi programado para a escola americana, na qual o curso de Física tem apenas um ano de duração e é optativo, sendo frequentado por estudantes de idade aproximadamente 17 anos, enquanto que o curso de Física do Colégio (atual $2^{\circ}$ grau) no Brasil era seriado em três anos. O curso de Física do PSSC é difícil para os alunos e, muitas vezes, também para os professores. (BITTENCOURT, 1977, p. 15).

Os debates geraram moções, e dentre elas, uma solicitava a concessão de verbas para a implantação de projetos brasileiros de elaboração de textos e material para o ensino de Física. Após negativa de financiamento por parte da FAPESP e do CNPq, os investimentos vieram por meio de verbas especiais federais destinadas ao IFUSP. Assim, em meados do ano de 1970, os Professores Ernest W. Hamburger, Plinio U. Meneghini dos Santos, Paulo Alves de Lima, Antônio G. Violin, Hydeia Nakano, Judite F. de Almeida, Jesuína L. A. Pacca e Diomar R.S. Bittencourt iniciaram os trabalhos de elaboração do projeto, inicialmente denominado de "Currículo Nacional” (BITTENCOURT, 1977, p. 15).

O projeto, em sua fase inicial, contou com verba do IFUSP, bem como com auxílio financeiro da Fundação de Amparo à Pesquisa do Estado de São Paulo. Posteriormente passou a ser fomentado pela Fundação Nacional de Material Escolar (FENAME) e PREMEN, sendo que a FENAME angariou os direitos autorais do projeto, tendo sido responsável pela publicação e distribuição do material textual e dos conjuntos experimentais (GUIA DO PROFESSOR - PEF, 1980, p.11).

Bittencourt descreve a elaboração desse projeto em nove fases: o projeto inicial (1970-1971); planejamento do trabalho; elaboração de versão preliminar (1970-1976); ensaio em algumas escolas paulistas (1971-1972); avaliação da versão preliminar; elaboração da versão comercial e publicação pela FENAME em 1973/1974; treinamento de professores (1973 a 1975); elaboração do guia do professor, publicado também pela FENAME em 1976; e difusão do projeto. Tais fases ocorreram de 1970 a 1976. A fase de difusão permeia todo o período a partir dos ensaios, incluindo treinamento de professores e implementação da versão 
final nas escolas, especialmente no Estado de São Paulo, a partir de 1976 (BITTENCOURT, 1977).

A equipe final do projeto foi composta por integrantes de vários segmentos acadêmico/universitários, além de professores de ensino secundário, tendo como coordenadores dois professores/físicos nucleares. Participaram do projeto, ao todo, além dos coordenadores, oito professores secundários/universitários, dois professores secundários, um estudante, além de pessoal de secretaria, oficina gráfica, arquiteto e programação visual (BITTENCOURT, 1977).

Uma equipe formada na linha das recomendações filosóficas de Bruner (1978), com a presença de cientistas para definirem um currículo fundamentado na estrutura da disciplina. Segundo Bittencourt, a equipe assumiu essa ênfase no conteúdo, contudo, foi dado amplo destaque à participação dos professores secundários, uma vez que eles seriam os aplicadores do projeto nas escolas. Além disso, pretendeu-se evitar a elaboração de um curso que fosse difícil até mesmo para os professores, como foi reconhecido o PSSC.

Apesar da ênfase no conteúdo de Física - característica metodológica reconhecida pela equipe - diferentemente do PSSC, não intencionou “encaminhar, necessariamente, o aluno a ser um Físico ou professor de Física" (BITTENCOURT, 1977, p. 17). Em contraposição a essa ideia, tinha como propósito se destinar a discentes que, em sua maioria, não mais estudariam Física e buscou adaptar-se às condições das escolas e dos professores de $2^{\circ}$ Grau do Brasil. Intencionou-se levar o aluno a conhecer alguns fenômenos e conceitos da Física de modo que ele fosse capaz de aplicar esses conceitos na sua vida diária. (PACCA, 1976; BITTENCOURT, 1977).

Segundo consta na introdução do primeiro conjunto Mecânica 1,

O PEF destina-se aos alunos do ensino médio, ou seja, alunos que, em geral, não mais estudarão física, vencido esse nível. Julgamos assim importante proporcionar ao aluno um contato com assuntos que, com toda probabilidade, não mais serão abordados em sua formação subsequente. Dessa maneira, procuramos levar o aluno a conhecer o método científico através do estudo de alguns fenômenos e conceitos específicos da física; ele deverá ser capaz de trabalhar com esses conceitos, resolver problemas e realizar experiências simples. (PEF-MECÂNICA 1, 1973, s.p.).

Quanto à organização, conteúdo e metodologia, o PEF teve como pressupostos iniciais:

$\rightarrow$ A participação ativa do aluno;

$\rightarrow$ Elaboração de material completo (textos e material experimental) de baixo custo;

$\rightarrow$ Textos e experimentos indissociáveis;

$\rightarrow$ Linguagem simples visando uma melhor compreensão do aluno (NÃO do professor); 
$\rightarrow$ Ampliação da responsabilidade do aluno na execução das tarefas (leituras, resolução das questões, realização de cálculos e execução dos experimentos);

$\rightarrow$ Sequência diferenciada em relação ao currículo tradicional.

Os objetivos do PEF foram influenciados pela Tecnologia do Ensino e o projeto se utilizou também da Instrução Programada, que era um método de ensino em debate e ensaio na USP, coordenado pelo Professor Cláudio Z. Dib que participou da elaboração do Projeto Piloto da UNESCO. Assim, os objetivos foram definidos em termos dos comportamentos esperados dos alunos e do conteúdo da disciplina. São os objetivos de curto alcance, como coloca Bittencourt (1977). A proposta minimiza o papel do professor como expositor de conteúdos, como coloca Pacca (1976):

Com um programa como o PEF, a atividade do professor deixa de ser a de simples expositor e os alunos é que desenvolvem as atividades, individualmente ou em grupo. A função do professor, no caso, é a de esclarecer dúvidas, orientar discussões sobre pontos importantes, produzir novos materiais, fazer as avaliações dos alunos. (PACCA, 1976, p. 09).

Conforme essa autora, o curso, teoricamente, exigiria dos alunos como pré-requisitos o domínio das quatro operações fundamentais e a capacidade de compreensão de texto escrito em linguagem coloquial.

O período de elaboração do projeto coincide com as alterações de organização curricular nos termos na Lei 5.692/1971, quando ocorre uma redução de carga horária das disciplinas da Educação Geral para inclusão de disciplinas da Formação Especial nos cursos de $2^{\circ}$ grau. De nossa pesquisa, verificamos que a carga horária de Física ficou em média com duas aulas semanais e ainda havia cursos em que se tinha Física somente no $1^{\circ}$ ano, sobretudo nos cursos que possivelmente os alunos "não mais estudariam Física", mesmo que prosseguissem com estudos superiores, como exemplo, alunos do Curso Normal que seguissem a carreira na Pedagogia.

Ainda que se tenha buscado adequar o currículo à realidade brasileira, no que tange ao treinamento dos docentes, às condições de aprendizagem dos alunos (exigindo prérequisitos de grau baixo) e a falta de estrutura material (sugerindo textos e kits experimentais de baixo custo), a carga horária pode ter configurado como fator de entrave para um desenvolvimento satisfatório desse projeto nas escolas brasileiras. O requisito tempo é de extrema importância na execução do currículo, e de pouco controle, pelos professores, na determinação deste para as atividades escolares. De um modo geral, a organização do tempo das atividades escolares vem de decisões verticalizadas. 


\subsubsection{Conhecendo o PEF}

Nosso estudo recaiu sobre os materiais impressos do projeto PEF, em todos os textos destinados ao aluno e no Guia do Professor. Os textos destinados ao aluno foram localizados no acervo da Biblioteca do Programa de Pós-graduação Interunidades em Ensino de Ciências, no IFUSP. Já o Guia do Professor foi gentilmente cedido pelo Professor Nilson Marcos Dias Garcia, da Universidade Federal Tecnológica do Paraná (UFTPR). As versões analisadas foram:

UNIVERSIDADE DE SÃO PAULO. Instituto de Física/IFUSP. Projeto de Ensino de Física -Mecânica 1. $1^{a}$ ed. Rio de Janeiro: FENAME, 1973. UNIVERSIDADE DE SÃO PAULO. Instituto de Física/IFUSP. Projeto de Ensino de Física - Mecânica 2. $1^{a}$ ed. Rio de Janeiro: FENAME, 1974. UNIVERSIDADE DE SÃO PAULO. Instituto de Física/IFUSP. Projeto de Ensino de Física - Eletricidade. $2^{\text {a }}$ ed. Rio de Janeiro: FENAME, 1981. UNIVERSIDADE DE SÃO PAULO. Instituto de Física/IFUSP. Projeto de Ensino de Física - Eletromagnetismo. $1^{\text {a }}$ ed. Rio de Janeiro: FENAME, 1976. UNIVERSIDADE DE SÃO PAULO. Instituto de Física/IFUSP. Projeto de Ensino de Física - Guia do Professor. Rio de Janeiro, FENAME, 1980.

Passaremos a uma caracterização geral dos materiais acima listados, a partir de uma primeira análise exploratória. Na sequência, daremos enfoque aos elementos de nossa análise de conteúdo que caracterizam as dimensões epistemológica e educativa. Denominaremos os manuais ao longo do texto com as seguintes siglas: Mecânica 1 (PEF-MEC 1); Mecânica 2 (PEF-MEC 2); Eletricidade (PEF-ELETRIC); Eletromagnetismo (PEF-ELETROMAG) e Guia do Professor PEF (GP-PEF).

\subsubsection{Caracterização geral dos manuais do PEF}

O projeto PEF foi estruturado em quatro conjuntos de textos constituídos por fascículos separados correspondendo aos capítulos, somando ao todo 27. Compunha ainda de um Guia do Professor (GP-PEF) em volume único, com 231 páginas. Cada conjunto de texto (Mecânica 1, Mecânica 2, Eletricidade e Eletromagnetismo) vinha acompanhado de um fascículo inicial com 8 páginas (separado do primeiro fascículo do conjunto), trazendo o expediente, nome dos autores, ficha catalográfica, sumário geral e seções sobre como utilizar o material e esclarecimentos sobre o Projeto (com exceção do fascículo de Mecânica 2, que apresenta apenas o sumário dos fascículos - capítulo 7 ao 12). A figura a seguir traz as capas dos fascículos iniciais e do Guia do Professor. 

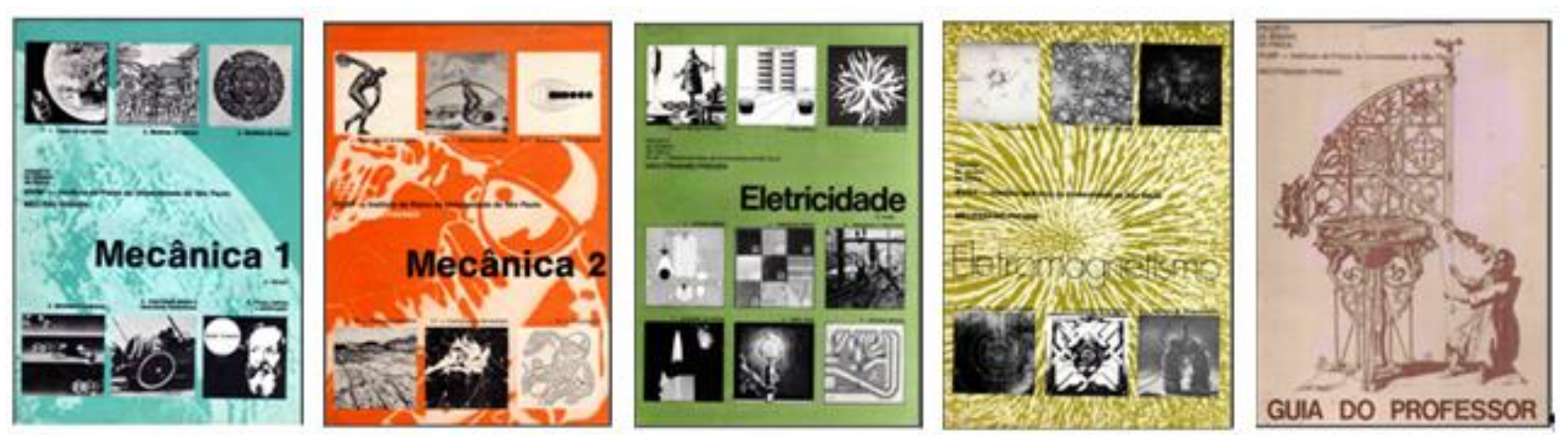

FIGURA 3 - Capas dos fascículos iniciais dos Conjuntos de textos e Guia do Professor do PEF

Fonte: foto-escaneamento dos originais ${ }^{100}$

Os conjuntos de textos destinados ao aluno foram intitulados por três dos grandes temas da Física: Mecânica, Eletricidade e Eletromagnetismo. O primeiro, Mecânica, intitula dois conjuntos, sendo cada um deles com seis capítulos, enumerados sequencialmente do 1 ao 12. O conjunto Eletricidade traz nove capítulos, e Eletromagnetismo seis, sendo estes com enumeração dos capítulos independentes, iniciando cada um pelo capítulo 1 . O número de páginas dos fascículos varia de 13 a 37, sendo a maioria com 21 páginas ${ }^{101}$.

Cada fascículo traz uma capa com alguma figura ou foto que contextualiza o tema geral tratado no mesmo, e na contracapa apresenta dados técnicos do projeto e um pequeno texto explicativo sobre o significado da figura da capa (cf. Figura a seguir). Tais textos foram também considerados em nosso estudo, pois neles também foi possível identificar elementos de nossa análise de conteúdo.
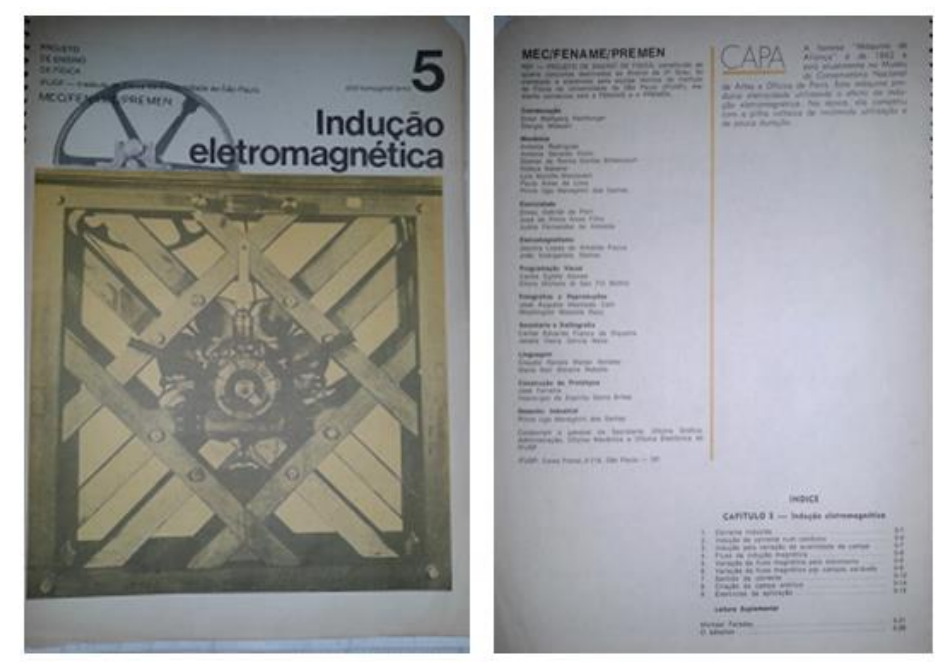

FIGURA 4 - Capa e contracapa do fascículo referente ao capítulo 5 do PEF Eletromagnetismo.

Fonte: Foto/escaneada pela autora

\footnotetext{
${ }^{100}$ Cedidos por Renata Ribeiro e Nilson Garcia, do IFUSP e UFTPR, respectivamente.

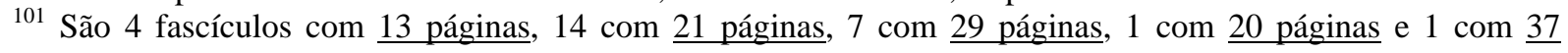
páginas.
} 
O desenvolvimento de cada conjunto foi inicialmente previsto para cerca de 50 horas de aulas (PEF-MEC 1, 1973) o que corresponde a uma média de 60 aulas (de 50 min) para cada conjunto. No Guia do Professor esta distribuição aparece da seguinte forma: 108 aulas para os dois conjuntos Mecânica, 83 a 85 para o conjunto Eletricidade e 48 para o conjunto Eletromagnetismo.

O GP-PEF traz orientações de caráter técnico quanto ao desenvolvimento do projeto como um todo, explicando os objetivos do curso, a forma de apresentação dos textos, do trabalho do professor, duração do curso, orientações para verificação de pré-requisitos ${ }^{102}$, formas de avaliação, etc. Traz ainda orientações mais específicas para cada conjunto de textos e para cada capítulo, listando os conteúdos (sumário), objetivos, número de aulas previstas ${ }^{103}$, pré-requisitos ${ }^{104}$, sugestões para avaliação, comentários de seções ou questões, sugestões de discussões, sugestões para outras experiências e bibliografia sugerida ao professor (o projeto PSSC e a obra de Alvarenga e Máximo são constantemente sugeridos na lista de bibliografias).

De modo geral, os objetivos dos capítulos são expressos iniciados por verbos no infinitivo impessoal (definir..., calcular..., explicar..., enunciar..., descrever..., etc...) encabeçados pela frase: “Ao final do capítulo o aluno deverá ser capaz de: [...]”.

Informa ainda o GP-PEF (p.14) que o PEF foi planejado para ser integralmente aplicado em três anos letivos, com três aulas semanais. Entretanto, para as escolas em que o terceiro ano fosse diversificado, salientou-se a possibilidade de supressão de algumas partes os textos optativos e as leituras suplementares - nos dois primeiros anos deixando-as para serem trabalhadas no terceiro ano, com acréscimo de materiais suplementados pelo professor. Já nas escolas que contassem com somente duas aulas semanais, o projeto deveria ser desenvolvido nos três anos fazendo uso dos textos principais, podendo o professor incluir alguns dos textos optativos. Essa orientação se remete às diferenças de organizações curriculares em razão da Lei 5.692/1971.

Como parte integrante do projeto, projetaram-se três conjuntos experimentais relativamente simples, pensados para o uso em grupos de quatro ou cinco alunos. Conforme consta no prefácio do CONJUNTO-MECÂNICA 1, o kit dos conjuntos MECÂNICA 1 e 2

\footnotetext{
${ }^{102}$ Os pré-requisitos a que se refere a orientação mais geral seriam verificados por meio de testes sugeridos no Guia, antes de iniciar o estudo de cada conjunto de textos.

${ }^{103}$ O número de aulas previstas aparece em um planejamento geral para cada conjunto de textos, e também no planejamento por capítulo. Assim, sugere o quantitativo de aulas para os diversos textos dos capítulos - texto principal, texto optativo, exercícios de aplicação e leitura suplementar.

${ }^{104}$ Pré-requisito aqui se refere ao domínio de conhecimentos necessários ao entendimento do assunto tratado em cada capítulo.
} 
era composto por: uma calha de alumínio com pista de aço; duas esferas de aço; um cronômetro de areia; um tubo de latão; cinco ganchos de ferro; um frasco de óleo de máquina; uma escala em etiqueta auto-adesiva (PEF-MEC 1, 1973) .

Para acompanhamento do CONJUNTO-ELETRICIDADE, os materiais do kit eram: resistores de vários tipos (LDR, NTC, etc.); Diodo BY-127; fios de cobre esmaltado de diferentes bitolas; fios de níquel-cromo de diferentes bitolas; lâmpadas; soquete; pilhas; fios de ligação; placa de zinco; feltro; pinos; elásticos; grampos; placa perfurada; multímetro; vidro com sulfato de cobre e molas (PEF-ELETRIC, 1981). A lista do kit para o conjunto ELETROMAGNETISMO constou de: ímã em forma de ferradura; arruela; carretel de plástico; núcleo de ferrite; bússola; ímãs de barra; frasco com limalha de ferro; lâmpada neon; suporte de rotores; chapa de níquel cromo; barra de alumínio; barra de latão; pregos; pilha; porta-pilhas; placa de plástico; fios com garra jacaré; vela e fios. (GP-PEF, p. 184). Segundo consta no Guia do Professor, o material experimental seria vendido nos postos da FENAME.

O PEF não contou com guia de laboratório, e nem mesmo o GP-PEF traz detalhamento de execução dos experimentos, com exceção de algumas "Sugestões para outras experiências" que aparece no Guia nas orientações de alguns capítulos, que orienta o professor na realização das mesmas. O Guia afirma que: "cada fascículo serve, simultâneamente, como livro texto, como caderno de exercícios e como manual de laboratório." (GP-PEF, p. 16). O projeto não contou também com filmes ou outros recursos complementares, além dos fascículos e Kits experimentais. Sugere, no Guia, listas de bibliografias para o professor, e também para "recomendar aos alunos mais interessados" (GP-PEF, 1980, p.14).

O GP-PEF esclarece que os textos dos fascículos se apresentam da seguinte forma: texto principal dividido em seções; exercícios de aplicação; texto optativo, também dividido em seções; e leitura suplementar. Consta ainda que tais tipos de textos se diferem no tamanho das letras (grande, menor, pequena). De uma observação nos textos dos fascículos, constata-se que a diferença tipográfica entre o texto principal e o optativo é pouco perceptível. Além disso, não há nenhuma informação que destaque as seções como texto optativo. Essa informação aparece no GP-PEF, e nota-se dela que, os textos colocados como optativos são seções sequenciais dos textos principais. Segundo consta no Guia, o conteúdo dessas seções objetivou aprofundar assuntos tratados no texto principal. No que pese as leituras suplementares, pretendeu-se que servissem como motivação para o estudo da Física, e foram pensadas, principalmente, para trabalho extracurricular (GP-PEF, 1980, p.13). 
Os capítulos (nos fascículos do aluno), subdivididos em seções, começam com uma introdução mais conceitual, geralmente descrevendo alguma situação/exemplo do cotidiano, ou por uma síntese histórica ou teórica a respeito do tema explorado. De um modo geral, nessa introdução esclarece ainda o objetivo de cada capítulo. Ao longo dos textos apresenta perguntas enumeradas por Q1, Q2, Q3,.., etc. em que as respostas, se corretas, complementariam as ideias do texto, assumindo características do método de Instrução Programada. Nas proximidades das perguntas, reservou-se um espaço para as respostas dadas pelo aluno, enumeradas por R1, R2, R3,..., etc. As respostas às perguntas são apresentadas em página posterior em caixas de texto. A seguir, um recorte de texto do projeto que mostra essa estrutura.

\section{2. Órbita de um satélite}

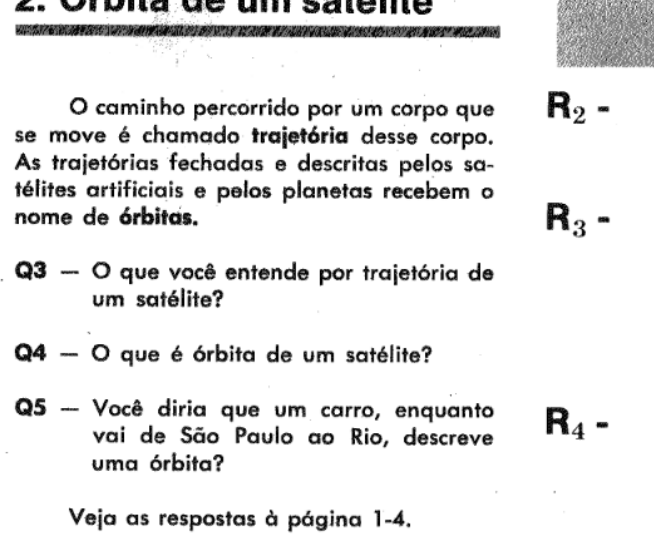

\section{RESPOSTAS}

FIGURA 5 - Recorte de texto do PEF Mecânica 1, capítulo 1, p. 03. Fonte: Do material analisado

As questões que permeiam o texto são de diversas naturezas: requerem respostas qualitativas e/ou quantitativas, algumas vezes como parte de uma pequena investigação ou atividade experimental. Além disso, compõem o texto principal, de modo que se impôs a importância de o aluno ter os "seus fascículos completos e preenchidos corretamente, caso contrário encontrará dificuldades para um estudo anterior a uma prova ou para recapitulação." (GP-PEF, p. 15).

Recomendou-se que o aluno não lesse as respostas antes de tentar responder sozinho. "Você não deve se importar se a resposta que você der a uma certa questão estiver errada [...], às vezes se aprende melhor depois de se errar e verificar o porquê do erro" (PEF, MEC1, p.1-1). Nas orientações sobre o trabalho dos alunos, no GP-PEF, reforça-se que " $E$ ' muito importante que o aluno tome consciência de que esse método conduz à aprendizagem, $e$ que ele pouco aprenderá se consultar muito cedo as respostas impressas." (GP-PEF, p. 15).

Ao final de algumas seções ou dos capítulos, apresenta-se uma série de EXERCÍCIOS DE APLICAÇÃO (E1, E2, E3, etc.) em que as respostas vêm em página 
seguinte em caixa de texto. Também no final dos capítulos traz a seção LEITURA SUPLEMENTAR. Algumas leituras são bem extensas, e, de modo geral, abordam temas bem relacionados/articulados com o assunto do capítulo, como aprofundamento das ideias discutidas, contextualização com o momento histórico da época, apresentação de um tema novo (Supercondutividade, por exemplo) ou relatos da história da Ciência: "As leituras suplementares tratam de outros campos da Física e de seu relacionamento com a sociedade; seu objetivo é motivar os alunos e ajudá-los a alargarem seus horizontes." (GP-PEF, 1980, p.23).

\subsubsection{As dimensões Epistemológica e Educativa no PEF}

Da dimensão Epistemológica

\section{Ciência como processo}

No PEF, constata-se que as concepções de ciência como processo estão mais evidenciadas nos conjuntos de Mecânica, mas se estendem de forma mais implícita nos demais. No que se refere ao desenvolvimento histórico das ideias básicas da ciência/Física, o aspecto é presente em quase todos os capítulos, ora de forma sucinta, na maioria das vezes no início dos capítulos; ora nas leituras suplementares, onde dedica mais espaço para relatos de descobertas científicas e história da vida dos cientistas. Esses relatos aparecem ainda em alguns dos textos curtos das contracapas dos fascículos, como descrição contextualizada da figura ou foto da capa.

A relação Física/tecnologia/sociedade é evidenciada em uma leitura suplementar no primeiro capítulo. A referida leitura traz as seções A CIÊNCIA NA CULTURA; CIÊNCIA E TECNOLOGIA e A FÍSICA NO BRASIL. Esse texto evidencia também o processo mutável da ciência, com suas mudanças de paradigmas (KUHN, 1998), o papel da ciência para o ser humano, concepção de método científico, o modo como o homem faz uso da ciência por meio da tecnologia, etc. Citamos alguns excertos que, a nosso ver, sintetizam a visão dos autores sobre o processo de construção do conhecimento em ciência/Física e sua relação mais ampla com outros campos da sociedade como um todo.

$\rightarrow$ Concepções sobre o papel do ser humano na busca de conhecimento sobre a natureza conhecer para controlar. Concepção de método científico indutivo-empirista.

Para compreender e controlar esse mundo, e para colocar a ciência a serviço do homem, é necessário conhecer essa ciência. [...]. 
A necessidade de compreender o mundo em que vivemos parece ser uma necessidade fundamental do homem. (PEF MEC1, Cap. 1, p.09).

Aos poucos o conhecimento do mundo foi se tornando mais completo e organizado até que, no século XVII, se desenvolveu um modo sistemático de desvendar os chamados "segredos da natureza". Tal método baseia-se na aplicação do raciocínio lógico às observações na natureza (sejam experiências realizadas especialmente para o estudo, seja na vida cotidiana), na construção de teorias baseadas nas observações e na verificação da validade dessas teorias em novas observações. É o método científico. (PEF MEC1, Cap. 01, p. 09, grifo dos autores).

Um dos objetivos do estudo de Física é entender e interpretar o mundo natural baseado em leis que, em geral, decorrem da observação e generalizações de que certos acontecimentos ocorrem de maneira semelhante. (PEF MEC2, Cap. 9, Contracapa).

\section{$\rightarrow$ Relação da Ciência com a tecnologia e a sociedade.}

Os satélites artificiais e as viagens espaciais são apenas algumas das realizações da nossa era científica e tecnológica. E não só a tecnologia, mas todos os aspectos da vida e do pensamento modernos são profundamente influenciados pela ciência. (PEF-MEC 1, Cap. 01, p. 01).

[...] a ciência fornece os conhecimentos que a tecnologia usa para avançar. Essa relação de dependência, entretanto, não se verifica apenas em um sentido. (PEF MEC1, Cap. 01,p,11)

\section{$\rightarrow$ Ciência não isenta de influências políticas e econômicas.}

A interdependência entre ciência e tecnologia é hoje tão importante que, nos países desenvolvidos, todo o complexo industrial de alguma significação conta com um centro de pesquisas científicas. A situação é bem outra nos países menos desenvolvidos, onde as grandes indústrias são quase todas estrangeiras. (PEF-MEC 1, Cap. 01, p. 11)

Infelizmente, os avanços científicos e tecnológicos não estão à disposição de todos os homens; a organização social, política e econômica do mundo não permite ainda que a humanidade, como um todo, seja beneficiada pelas conquistas científicas. (PEF MEC1, Cap. 01, p. 01).

Talvez você também tenha percebido como se processa a evolução científica, em paralelo com o desenvolvimento da sociedade. [...] Essas invenções [pilha, interação eletromagnética, motores, etc.], tendo aparecido num momento em que a sociedade européia estava em processo de aumento de consumo de energia em rápida incorporação de novas técnicas no processo produtivo (revolução industrial), foram rapidamente aplicadas em grande escala e contribuíram para o aparecimento do mundo tecnológico em que vivemos. (PEF-ELETRIC, cap. 09, p. 17).

$\rightarrow$ Contextualização histórica e influência de determinados grupos na sistematização das ideias sobre a natureza, neste caso, a Igreja.

A importância que as idéias científicas podem adquirir no âmbito político-social é exemplificada pelos destinos de Jordano Bruno e Galileu Galilei na Itália renascentista. Bruno foi queimado vivo como herege, em 1600; uma de suas heresias foi advogar o sistema heliocêntrico de Copérnico, isto é, a crença de que a Terra e os demais planetas giram em torno do Sol. Ora, isso entrava em contradição com os ensinamentos da Igreja; assim, esta, por intermédio da Santa Inquisição, condenou Bruno à fogueira. [...] Entretanto, quando assuntos científicos adquirem importância social imediata, ainda se registram, às vezes, situações semelhantes. (PEF MEC1, cap. 1, p.09) 
$\rightarrow$ Ideia de ciência mutável com rupturas e mudanças de paradigmas; conhecimento inacabado.

A visão que o homem tem do universo e da posição nesse universo sempre se altera quando uma nova concepção científica vem substituir uma velha maneira de pensar. Como consequência, em todo campo de atividade e de pensamento ocorre uma mudança de perspectiva. (PEF MEC1, Cap. 01, p. 09).

As grandes conquistas científicas alcançadas nos últimos séculos dão aos cientistas a sensação de que os mistérios de hoje serão desvendados amanhã, que as dúvidas que o preocupam hoje desaparecerão no futuro. No entanto, muito deles têm consciência de que cada porta que se abrir trará novos problemas, e que nunca chegará um momento em que o homem poderá dizer que compreende o mundo em sua totalidade. (PEF MEC1, cap. 1, p. 10).

Atualmente há ainda assuntos da Física muito pouco compreendidos para os quais não se tem uma visão global satisfatória e não há teorias para provar e explicar os fenômenos. (PEF-ELETRIC, Contracapa)

$\rightarrow$ Relação da Ciência com a cultura.

As grandes alterações induzidas pelas conquistas científicas sobre a cultura não se restringem à épocas tão remotas quanto o século XVII. Em nosso próprio tempo descobertas no campo da mecânica quântica vieram modificar drasticamente a visão que temos do mundo. (PEF MEC1, cap. 1, p.09).

Dentre outros exemplos da relação ciência/cultura (figuras das capas, trecho de roteiro de filme, citações de costumes de tribos indígenas, etc.), destacamos um, apresentado no início do capítulo 2, introduzindo o tópico Medida de espaço. Traz a famosa gravura de Leonardo da Vinci, o Homem Vitruviano, e explica um pouco sobre a vida do pintor, evidenciando sua atuação no campo da Física. A abordagem intenciona mostrar a importância das medidas em várias áreas do conhecimento, tomando a arte como exemplo. Após o breve histórico sobre o pintor, coloca-se:

A gravura acima, de autoria de Leonardo da Vinci, exemplifica a importância que as medidas adquiriram a partir do século XVII. Do Renascimento em diante, as questões levantadas pelos filósofos naturais (cientistas) deixaram de se referir apenas aos aspectos qualitativos dos fenômenos, focalizando-se também os aspectos quantitativos: [...].(PEF MEC1, cap. 2, p.01).

$\rightarrow$ Contextualização cotidiana - a tecnologia é colocada como consequência prática da aplicação da ciência no cotidiano.

Como consequência, a influência da tecnologia sobre a vida do homem comum cresceu, de tal forma que hoje o telefone, os tratores, a eletricidade e uma infinidade de outras conquistas tecnológicas são encontradas mesmo nos lugares mais remotos e atrasados.

No caso de elementos que evidenciem a relação do sujeito na construção do conhecimento científico, nota-se presente, embora seja na perspectiva interna à ciência e não do mundo vivencial do estudante. 
O relacionamento entre movimento e suas causas foi um problema que preocupou os homens de ciência desde a mais remota antiguidade. De Aristóteles até Newton,

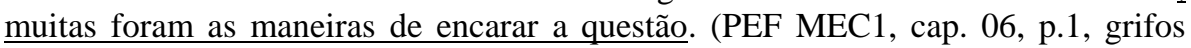
nosso).

Uma das hipóteses que se aventou foi considerar a velocidade como medida da quantidade de movimento. De acordo com a necessidade filosófica, a velocidade deveria se conservar. (PEF MEC2, cap. 9, p. 02).

Esses elementos são notados também em duas leituras suplementares. A primeira fala sobre medidas do raio terrestre realizadas em diferentes épocas, por Anaxágoras e Erastóstenes de Cirene. Ressalta-se o fato de essas pessoas terem chegado a resultados iguais partindo de argumentos matemáticos semelhantes; porém evidencia os equívocos do primeiro em relação à ideia de que a Terra seria plana. O texto corrobora a influência das crenças do sujeito do conhecimento na produção da ciência e conclui que "Este é um bom exemplo de como raciocínios matemáticos podem tanto levar a conclusões corretas quanto falsas, dependendo das hipóteses que forem feitas." (PEF-MEC 1, cap. 02, p. 21).

A segunda, fala da relatividade nas medidas partindo do exemplo do movimento da Terra e a trajetória observada: "Esse é o nosso primeiro exemplo de como as observações, as nossas medidas, dependem não apenas daqueles fatores já mencionados [...] como também da nossa posição como observadores.” (PEF-MEC 1, Cap. 05, p.17). Esse trecho se traduz na ideia de que a interferência do observador pode levar a interpretações particulares sobre a natureza, pois dependem, também, das situações ambientais em que se encontra o sujeito, o que pode resultar em divergências de ideias em determinado campo científico.

No que se refere às situações de aplicação da Física no cotidiano próximo ou remoto, por exemplo, identificamos várias passagens. O foco dessa contextualização se concentra mais em aparatos tecnológicos relacionados ao Espaço Sideral (satélites ${ }^{105}$, sondas espaciais, radiotelescópio, telescópio, etc.); e à produção e uso da energia elétrica (usinas de energia, dispositivos que usam energia elétrica de diferentes modalidades, tais como motor elétrico, impressoras eletrostáticas, pulverizadores de tinta e inseticidas, etc.).

Além disso, traz também exemplos de outros inventos e eventos em voga no momento, contextualizando o conteúdo com o momento histórico, (computador, fotos da evolução de laboratórios de Física, uso da TV, chegada do homem à Lua, recorte de notícias

\footnotetext{
${ }^{105}$ No primeiro capítulo, a existência de satélites é evidenciada logo no início, ressaltando suas aplicações na transmissão de grandes eventos pela TV, tais como a Copa do Mundo e a chegada do homem à Lua, bem como em pesquisas geológicas e até mesmo espionagem internacional. (PEF-MEC 1, Cap. 1, p. 01).
} 
de jornal sobre exploração do Espaço Sideral ${ }^{106}$ ) buscando evidenciar os aspectos qualitativos dos fenômenos que participam dos princípios físicos de funcionamento de alguns desses aparatos. No caso do computador, um texto complementar explica seus princípios físicos e matemáticos de funcionamento e suas aplicações em coisas do cotidiano - em bombas de postos de gasolina, caixa de supermercado e no controle de processos industriais (PEFELETRIC, Cap. 05, p.19).

Os excertos anotados são apenas alguns dos vários exemplos encontrados no PEF que caracterizam os elementos de análise na categoria Ciência como processo. Em resumo, entendemos que, de um modo geral, o referido projeto cuidou, em nível significativo, de mostrar a ciência/Física como um processo em evolução, abrangendo diversos fatores, internos e externos, que permeiam a construção da ciência. Entretanto, cabe ressaltar que, em razão das sugestões de desenvolvimento dos textos do projeto, para se adequar às situações de carga horária reduzida nas escolas, uma significativa parte dos textos, que melhor abrange os aspectos que denotam o processo de construção do conhecimento científico (textos optativos e leituras suplementares), poderia ser suprimida dos estudos dos alunos.

\title{
A Física e a experimentação
}

O PEF tem em sua gênese o método experimental, que parece ser entendido no projeto como sinônimo de método científico. Repetimos aqui um trecho, já citado anteriormente, que traz essa perspectiva.

\begin{abstract}
Aos poucos o conhecimento do mundo foi se tornando mais completo e organizado até que, no século XVII, se desenvolveu um modo sistemático de desvendar os chamados "segredos da natureza". Tal método baseia-se na aplicação do raciocínio lógico às observações da natureza (seja nas experiências realizadas especialmente para estudo, seja na vida cotidiana), na construção de teorias baseadas nas observações e na verificação da validade dessas teorias em novas observações. É o método científico. (PEF-MEC 1, Cap. 01, p. 09).
\end{abstract}

O texto do PEF já inicia o primeiro capítulo com uma atividade prática - desenhar a órbita do satélite Kosmos 159, lançado pela União Soviética em maio de 1967. A escolha evidencia o contexto da época, a corrida pela conquista do Espaço Sideral pelas grandes potências mundiais (Estados Unidos e União Soviética). Em todos os capítulos há proposição

\footnotetext{
${ }^{106}$ Destacamos a introdução do tópico Quantidade de Movimento (PEF, MEC 2, Cap. 9, p. 01) que traz um fragmento de uma reportagem do Jornal O Estado de São Paulo, de 13-11-1971, falando do envio da sonda Mariner-9 à Marte, por cientistas americanos. Na introdução fala dos resultados decepcionantes da aventura tecnológica ao tentar fotografar o planeta, devido a uma tempestade de areia em Marte. Menciona sobre as pesquisas de Galileu a respeito das manchas solares e suas alterações de posição em razão do movimento de rotação do Sol, com o objetivo de inter-relacionar os fenômenos (tempestade em Marte, rotação do Sol e viagem da sonda Mariner-9) como exemplos de fenômenos de movimento (grifo dos autores).
} 
de algum tipo de atividade experimental e/ou de observação, contemplando, na maioria das vezes, a interpretação de resultados de medidas.

O estudo de Mecânica indica ter assumido papel fundamental no PEF, ao pretender, em um de seus objetivos gerais, "levar o aluno a conhecer o método científico" (GP-PEF, 1980, p.23). É no estudo desse tema no projeto que se desenvolveu, enfaticamente, os procedimentos de medidas e a apreciação de resultados.

Localizamos cerca de meia centena de propostas experimentais, considerando as pequenas investigações distribuídas nas QUESTÕES que permeiam o texto. Nos conjuntos de Mecânica, além das questões que ora ou outra trazem alguma pequena investigação, alguns experimentos são destacados em seção específica, sendo 8 (oito) propostas experimentais apresentadas desta forma (sete em Mecânica 1 e uma em Mecânica 2). Nos demais conjuntos, todas as experiências aparecem ao longo dos textos, sem destaque em seção específica.

Com frequência, ao final do desenvolvimento de algumas experiências, expõem-se conclusões que podem levar o aluno à ideia de que as leis da física são obtidas da experimentação.

A experiência com os três carrinhos permite concluir que a aceleração é proporcional à força aplicada ao corpo. (PEF-MEC 1, cap. 6, p.15).

Neste capítulo você realizará experiências para chegar a uma simples lei da Física que relaciona as dimensões e o material de fios condutores com suas resistências elétricas. (PEF-ELETRIC, cap. 06, p. 01).

As experiências que você fez confirmam que a resistência elétrica $\mathrm{R}$ do fio:

1. ${ }^{\circ}$ ) é inversamente proporcional à área da sua seção: $\mathrm{R} \alpha 1 / \mathrm{A}$;

2. ${ }^{\circ}$ ) é diretamente proporcional ao comprimento do fio: $\mathrm{R} \alpha \ell$.

(PEF-ELETRIC, cap. 06, p.05).

Você fará uma experiência deste tipo [aquecimento da água com aquecedor elétrico], para verificar que as expressões encontradas para a energia dissipada num circuito são corretas. (PEF-ELETRIC, cap. 8, p. 15).

As experiências realizadas mostraram então que, para representar o campo magnético, devemos utilizar uma grandeza física que especifique uma direção determinada para cada ponto da região ao redor do ímã. (PEF-ELETROMAG, cap. 3, p. 5).

Efetuando experiências em que se varia o ângulo $\theta$, conclui-se que $\mathrm{F}$ depende de $\mathrm{B}$, $\mathrm{i}$ e $\theta$, de acordo com a relação

$$
\mathrm{F}=\mathrm{i} \ell \mathrm{B} \operatorname{sen} \theta
$$$$
\text { (PEF-ELETROMAG, cap. 4, p. 7) }
$$

Embora esses aspectos tenham sido constatados, o PEF contempla características que explicitam a existência de um método científico experimental na produção do conhecimento em ciência/Física. 


\section{Modelos explicativos formais}

O PEF afirma que:

Hoje [1960/1970], a física trata principalmente de medidas, isto é, números que representam as grandezas e que podem ser submetidas a operações matemáticas. Foi a combinação das medidas com tratamento matemático que propiciou o notável desenvolvimento da ciência após o Renascimento. (PEF-MEC 1, cap. 02, p. 01).

Os três primeiros capítulos evidenciam a importância da matemática, ao dedicar-se às medidas; mas estas se dão de forma contextualizada e com discussão de resultados. Não apresenta nenhum capítulo especial para revisão de tópicos de matemática. Utiliza bastante de gráficos para explicitar a relação entre as grandezas físicas: "Quando estudamos um fenômeno físico, procuramos encontrar relações entre as grandezas que intervêm no fenômeno." (PEF-MEC 1, cap. 4, p. 19).

Discute-se detalhadamente o comportamento dos dados expressos nos gráficos e equilibra a abordagem conceitual com a apresentação de equações após discussão das grandezas envolvidas. Por outro lado, não se exprime no texto a importância dos modelos. Os exercícios contemplam questões dissertativas/qualitativas e também numéricas. Assim, o PEF não dispensa o formalismo matemático, entretanto evidencia o fenômeno, propõe medidas e interpretação qualitativa para, posteriormente, sintetizar o conhecimento em modelos matemáticos. De modo geral, podemos dizer que a matemática, nesse projeto, sobressaiu como descrição dos fenômenos.

\section{Conteúdos/áreas da Física}

No PEF, os temas foram subdivididos em capítulos conforme a seguir:

$\rightarrow$ Mecânica 1: 1 - Órbita de um satélite; 2 - Medidas de espaço; 3 - Medidas de tempo; 4 - Movimento uniforme; 5 - Velocidade média e velocidade instantânea; 6 - Força, inércia e aceleração.

$\rightarrow$ Mecânica 2: 7 - Segunda lei de Newton; 8 - Grandezas vetoriais; 9 - Quantidade de movimento; 10 - Energia e Trabalho; 11 - Conservação de energia; 12 - Gravitação.

$\rightarrow$ Eletricidade: 1 - Cargas e estrutura da matéria; 2 - Campo elétrico; 3 - Potencial Elétrico; 4 - Corrente elétrica; 5 - Resistência elétrica; 6 - Resistência e resistividade; 7 - Condução nos sólidos; 8 - Efeito Joule; 9 - Circuitos elétricos. 
$\rightarrow$ Eletromagnetismo: 1 - Eletricidade e ímãs; 2 - Estrutura dos ímãs; 3 - O campo magnético; 4 - Corrente em campos magnéticos; 5 - Indução eletromagnética; 6 Aplicações do eletromagnetismo.

O projeto contemplou basicamente dois dos grandes temas da Física: Mecânica e Eletromagnetismo (Eletricidade + Magnetismo). Em Mecânica, traz tópicos que abrangem medidas e relações entre grandezas, estudo de movimentos, Leis de Newton, Gravitação Universal, Leis de Conservação da Energia e da Quantidade de Movimento Linear. Suprimem-se os estudos de hidrostática e hidrodinâmica e também não se discute Quantidade de Movimento Angular no estudo dos movimentos circulares.

Não traz também capítulos específicos para o estudo de Óptica, Ondas, Termologia. Sobre este último, encontra-se uma breve abordagem do tópico Energia Térmica no capítulo que trata da Conservação da Energia. O estudo de Termodinâmica se restringe a uma breve explicação sobre a teoria Cinética dos gases, no mesmo capítulo que menciona Energia Térmica. Entretanto, tais assuntos aparecem em seções que poderiam ser colocadas como "textos optativos", no caso de o professor não dispor de carga horária suficiente, conforme orientações do GP-PEF.

As leis da Conservação da Energia e da Quantidade de Movimento Linear são tratadas, sendo a primeira com destaque em capítulo específico, prevalecendo a abordagem qualitativa e ilustrada por um trecho de um texto de Richard Feynman (a conhecida historinha dos blocos que somem do quarto de uma criança). A segunda ganha uma seção no capítulo 9 (Quantidade de Movimento), em duas páginas, e traz somente discussão conceitual/qualitativa sem apresentação de nenhum argumento matemático.

No estudo do conjunto Eletricidade, o enfoque é o "Efeito Joule", como ressalta o GP-PEF. Os tópicos que compõe os capítulos a partir do quinto evidenciam tal fenômeno. Enfatiza o estudo dos resistores, a transformação da energia e circuitos com lâmpadas, além de dedicar um capítulo específico para o estudo do Efeito Joule. No Guia informa que os quatro primeiros capítulos, mais o que trata do efeito Joule, são básicos e essenciais, não podendo ser suprimidos (GP-PEF, p. 113). Este conjunto apresenta uma abordagem mais teórica nos dois primeiros capítulos com poucas sugestões experimentais. A partir do terceiro capítulo, explora-se bastante a experimentação, sendo a maior parte do texto composta por discussão de resultados de experiências, ora descritiva, ora como proposta para o aluno realizar. 
Não destaca a Lei da Conservação da Carga, mas encontra-se explicação do fenômeno que a envolve, inclusive relacionando-o à Conservação da Energia. Ao falar de Eletrização, um trecho traz que:

Quando se esfregam dois corpos entre si (como no caso do pente com os cabelos), ambos ficam eletrizados, um negativa e outro positivamente. Isso se deve ao fato de que, no processo de esfregar, há transferência de elétrons de um corpo a outro, transferência esta feita às expensas da energia muscular de quem esfrega. (PEFELETRIC, cap. 01, p. 13)

No conjunto Eletromagnetismo, exploraram-se os fenômenos magnéticos e eletromagnéticos com abordagem mais qualitativa e interpretação microscópica. Fala de ímãs e suas estruturas; propriedades magnéticas dos átomos; ímãs não permanentes (eletroímãs); indução eletromagnética; aplicações desses fenômenos em coisas do cotidiano (guindastes para levantar sucatas de ferro, motores, transformadores, geradores de usinas, etc.).

Embora enfatize a estrutura da matéria no primeiro capítulo do conjunto Eletricidade, muito pouco se debate sobre assuntos mais específicos de Física Moderna, restringindo-se a mencionar algumas descobertas, como exemplo, as propriedades radioativas do elemento rádio, por Marie e Pierre Curie, e por Ernest Rutherford, no início do século XX.

\section{$\underline{\text { Da dimensão educativa }}$}

Objetivos do ensino de Física

No PEF os objetivos se voltaram para uma formação científica básica, para aprendizagem dos conceitos da ciência/Física, não se atendo às relações homem-mundo. Sua ênfase metodológica é condizente com alguns dos discursos pedagógicos em voga no momento em que foi elaborado, sobretudo o da defesa do currículo baseado na estrutura fundamental da matéria de ensino, mediado pelo método da redescoberta e pela tecnologia educacional: "[...] levar o aluno a conhecer o método científico através do estudo de fenômenos e conceitos específicos da Física” (PEF, 1973, Apresentação). Adotaram-se alguns temas selecionados como relevantes, uma vez que o projeto se destinou a "alunos que, em geral não mais [estudariam] Física”. Assim, indicava não ser um curso com pretensões propedêuticas aos estudos superiores. Em um de seus objetivos mais gerais traz que se pretendeu: "levar o aluno a conhecer alguns fenômenos e conceitos da Física, de modo que possa operar com esses conceitos, resolver problemas e realizar experiências simples." (GPPEF, p. 12). 
Não se percebe preocupação com a cultura inicial dos estudantes. Preocupou-se com pré-requisitos de conteúdos para a aprendizagem dos temas propostos. Apesar de privilegiar uma abordagem mais conceitual/qualitativa, explorando as relações com o cotidiano próximo e remoto, sobressai a perspectiva de formação científica.

Não se encontram no PEF elementos que coloquem o ensino da Física como contributo para a formação do cidadão, consciente de seu papel no mundo, estando de posse dos conhecimentos científicos. Ademais, esse não parecia ser o objetivo do ensino de ciências naquele período. A formação científica almejada na lei era de caráter técnico; tinha como pressuposto preparar o aluno para dominar os recursos decorrentes dos avanços científicos e tecnológicos. Não suscita preocupação com julgamento de valor. O PEF parece se adequar a tal perspectiva.

\title{
Concepção de aluno/professor
}

O PEF busca colocar o aluno em contato com as ideias da ciência, não somente pela transmissão de informações, mas alocando-o numa posição de maior atividade no processo de aprendizagem.

\begin{abstract}
Elaboramos este curso para que você possa aprender Física de um modo ativo. Isto significa que você vai realizar experiências, analisar e discutir os resultados obtidos, responder a perguntas e resolver problemas. [...] 1. Você pode trabalhar sozinho ou então, em pequenos grupos de até 5 alunos. [...] 2. Leia o texto com atenção, tentando responder sozinho a cada uma das questões [...] 3. Depois de responder a cada questão, discuta com os seus colegas se a resposta esta correta, e por quê. 4. O professor, ou o próprio texto, indicará o momento em que você deve comparar sua resposta com as respostas corretas impressas [...]. (PEF/MECÂNICA, 1973, grifo itálico do original).
\end{abstract}

A linguagem do texto dos fascículos é direcionada ao aluno; em nenhum momento sugere que o mesmo solicite explicação do professor.

A participação do aluno seria, principalmente, focada na experimentação. As atividades experimentais propostas no PEF eram de fácil execução, com materiais de baixo custo, e planejadas e orientadas entremeio ao texto dos capítulos, compondo-os. A proposta era de que as experiências, sendo parte das atividades como um todo, não poderiam deixar de ser realizadas, sob pena de comprometer o andamento do curso. Como traz a apresentação do PEF, “o equipamento experimental não deve ser encarado como um apêndice acessório ao texto, mas como parte integrante do curso, sem a qual ele fica mutilado." (PEF, MEC1, Apresentação). Isso é reforçado também no GP-PEF (1980, p. 16), “as experiências fazem parte integrante do curso, sendo impossível ao aluno prosseguir sem tê-las realizado.”. Em 
relação às condições físicas das escolas, destaca como sendo uma situação ideal para a aplicação do PEF, a existência de sala ambiente de Física ou laboratório equipado de mesas e cadeiras.

A proposta era de que os alunos realizassem as experiências, analisassem e discutissem os resultados (PEF-MEC 1, Apresentação ao estudante). No segundo capítulo, enfatiza a importância da análise de dados e propõe uma experiência simples para praticar. Tal experiência (contextualizada) consiste em medir a distância do centro da órbita do satélite Kosmos 159, desenhada em uma atividade de um capítulo anterior. Pede que os alunos preencham uma tabela e faz perguntas:

Q1 - Todos os resultados são iguais?

Q2 - Cite alguns fatores que, na sua opinião, contribuíram para o fato de os resultados não serem todos iguais.

(PEF-MEC 1, Cap. 2, p. 02).

Prossegue sugerindo que os alunos discutam os resultados entre si. Debate em seguida os fatores que podem ocasionar resultados diferentes: pontas do lápis, a régua utilizada, o cuidado na execução da medida, iluminação do ambiente, etc. Discute a questão das incertezas e da importância de considerá-la ao expressar os resultados. Entretanto, deve-se ressaltar que as questões qualitativas colocadas no desenvolvimento das experiências que, em tese, gerariam importantes reflexões a respeito do fenômeno observado, trazem respostas prontas em página seguinte.

É no GP-PEF que melhor define, na perspectiva do projeto, o papel concedido ao professor no processo de ensino, comparado à linha tradicional. Conforme traz o Guia, " [...] o professor atua principalmente como coordenador, organizador, orientador, avaliador e muito pouco como expositor da matéria". Por outro lado, coloca que "disso não decorre que sua participação na sala de aula seja passiva; ao contrário, a participação ativa do professor também é uma característica da aplicação do PEF." (GP-PEF, p. 16).

Advertiu-se que a participação docente perpassasse pela valorização do acompanhamento dos alunos, incentivando-os a adquirir nova postura diante da especificidade do projeto que requeria mudança nos moldes de desenvolvimento dos conteúdos em sala de aula, tirando de cena as aulas expositivas e colocando o aluno para "trabalhar por conta própria" (GP-PEF, p. 16). Orienta: "Durante o trabalho em classe, o professor deve percorrer a sala auxiliando cada aluno em seu trabalho, ocasião em que pode verificar as dificuldades mais comuns entre os alunos". (GP-PEF, p. 16). 
O Guia do professor sugeriu ainda, um acompanhamento mais particularizado para os alunos com habilidades mais excepcionais, de modo que os mesmos poderiam ser consentidos a avançar nos capítulos seguintes, e ainda motivados a atuarem como monitores para os alunos "mais atrasados". A respeito disso, Garcia (2007, p. 06) observa que, "ao mesmo tempo em que o projeto se inseria no contexto tecnicista do momento, seus elaboradores se preocupavam com o rendimento de cada um dos alunos em particular".

Ao professor competiam ações de natureza mais técnica do que pedagógicas: conduzir discussões gerais, estabelecer prazos, definir objetivos a serem alcançados (por semana ou por aula), a fim de assegurar a uniformidade de tempo para desenvolvimento dos assuntos, e avaliar. Cabia ainda incentivar o aluno a adquirir certa independência no seu processo de aprendizagem.

\footnotetext{
O professor não deve dar imediatamente resposta a pergunta que lhe sejam feitas, sem antes verificar se o aluno realmente leu o texto com cuidado. Normalmente, o texto é suficiente para fornecer os elementos necessários à resolução das questões; não sendo esse o caso, o professor deve formular novas perguntas para conduzir o raciocínio do aluno, levando-o a resolver sua dúvida. (GP-PEF, p. 16).
}

A avaliação dos alunos deveria "ser realizada por intermédio de provas e do trabalho em classe. É necessário, assim, que cada aluno responda às questões do texto, resolva os exercícios propostos e realize as experiências.” (GP-PEF, p.18). As avaliações seriam preparadas ao final dos capítulos devendo também abranger, além dos conteúdos de cada um, habilidades e conceitos desenvolvidos em capítulos anteriores. O professor deveria conduzir a revisão da matéria a partir da discussão das questões das provas, depois de realizadas.

\subsection{O Projeto Física Auto-Instrutivo (FAI)}

\subsubsection{Breve histórico de elaboração}

O projeto Física Auto-Instrutivo (FAI) teve início em 1970, por um grupo de professores denominado Grupo de Estudos em Tecnologia do Ensino de Física (GETEF), coordenado pelos professores Fuad Daher Saad, Paulo Yamamura e Kazuo Watanabe, sendo estes professores do IFUSP. Contou ainda com outros colaboradores, dentre os quais citamos: J. A. P. Angotti, Marcelo Tassara, Eda Tassara, Shozo Motoyama e Alberto Gaspar.

A produção do FAI se deu com apoio financeiro do próprio GETEF, e, apesar de ter como coordenadores professores ligados à USP, não era um projeto oficial da instituição (RODRIGUES; HAMBURGER, 1993, p. 4). 
Conforme Saad (1977), o surgimento do projeto partiu de egressos do curso de Licenciatura em Física da USP que estavam preocupados com os baixos índices de aprendizagem de Física por parte de alunos da rede estadual de ensino de São Paulo. Essa foi a motivação para a criação do GETEF, com o objetivo de buscar formas de melhorar a qualidade e eficiência nas aulas de Física. As aulas, quando faziam uso de textos, eram baseadas em livros didáticos e apostilas de vestibulares que não apresentavam nenhuma preocupação com os aspectos metodológicos relativos ao ensino de Física. Segundo o autor, com base em pesquisa realizada com professores da rede estadual de São Paulo, antes da elaboração do projeto, uma significativa parcela de professores dispensava o uso de livros didáticos em seus cursos. Constatou-se ainda a centralidade do ensino no Professor.

A elaboração do projeto pautou-se nas novas tecnologias de ensino em voga naquele período. Influência esta, alentada pela experiência da graduação na USP, quando alguns dos participantes do Projeto cursaram a disciplina Tecnologia do Ensino de Física, ministrada por Cláudio Z. Dib, que participou da elaboração do Projeto Piloto da UNESCO ${ }^{107}$. O enfoque era a inserção dos métodos e técnicas de ensinos modernos, baseados no comportamentalismo, ainda praticamente desconhecidas em nosso meio educacional.

A proposta do FAI, com objetivos educacionais similares aos dos outros projetos, buscava colocar o aluno no centro do processo de ensino-aprendizagem. Para isso, apostou-se nos princípios da Instrução Programada Linear, na mesma linha do projeto Piloto da UNESCO. Propôs um curso auto-instrutivo, de modo que professor teria um papel mais secundário; passaria a direcionar a aprendizagem dos alunos em suas atuações ativas com o uso do material instrucional.

Segundo Saad (1977), o FAI foi elaborado atendendo os seguintes objetivos:

$\rightarrow$ Oferecer ao professor uma nova metodologia de trabalho em sala de aula;

$\rightarrow$ Propiciar ao aluno a oportunidade de realizar uma aprendizagem efetiva através do trabalho realizado;

$\rightarrow$ Situar o professor como, orientador, motivador e avaliador do processo de aprendizagem;

$\rightarrow$ Colocar à disposição do aluno materiais de laboratório adequados à realidade educacional local, bem como recursos audiovisuais;

\footnotetext{
${ }^{107}$ Mencionamos, no APÊNDICE A, a experiência do Professor Cláudio Z. Dib com as Tecnologias do Ensino.
} 
$\rightarrow$ Permitir ao estudante, através da inclusão de textos redigidos com abordagem histórica, uma visão da forma pela qual a ciência se desenvolve no decorrer do tempo.

Como dito, a proposta na linha da teoria behaviorista foca o comportamento do aluno frente aos desafios, num processo de estímulo e respostas, aplicado da seguinte forma:

$\rightarrow$ Estudar e resolver o texto preenchendo as lacunas com os dados, conceitos, pequenas fórmulas, ou escolher entre as alternativas dentro dos parênteses que completam o texto - RESPOSTA.

$\rightarrow$ Acertar na escolha da resposta correta e avançar para as próximas questões ESTÍMULO.

Esse processo era condicionado pelas características do texto que apresentavam os conteúdos com nível gradativo de dificuldade para evitar que o aluno cometesse erros. Além disso, a proposta era situar o aluno como agente ativo no processo de ensino, com seu tempo individual de aprendizagem, e o professor ganha o papel de direcionador para atuar ativamente no processo de autoinstrução. Como toda instrução programada, suscita certo grau de "esvaziamento" da figura do professor, embora um de seus idealizadores, Fuad Daher Saad, defenda o contrário em sua análise do projeto no seu texto de dissertação de mestrado: “Convém salientar a importância do papel do professor nessa forma de ensino, não lhe bastando dominar o assunto ou ser um bom expositor. Sua função é ampliada cabendo-lhe orientar todo o processo instrucional" (SAAD, 1977 apud GAMA; HAMBURGER, 1990, p. 63).

O material do projeto FAI se compunha de cinco textos auto instrutivos (FAI 1, FAI 2, FAI 3, FAI 4 e FAI 5), proposta de aula experimental no laboratório e recursos audiovisuais. Foi elaborado ainda um Manual do Professor, em formato de pequeno fascículo, que se resume em orientações de natureza mais técnica.

Os recursos audiovisuais tinham como objetivo motivar o estudante no desenvolvimento do programa. Foram produzidos dois filmes: "O Pêndulo" (1974) de aproximadamente 5 minutos; e o "Laboratório Sem Paredes/Sem Fronteiras" (1977) de aproximadamente 30 minutos. Levantaram-se ainda outros materiais dessa categoria, já existentes no setor de mídia, para aproveitamento nas aulas de Física, como recurso motivador (SAAD, 1977).

Segundo Saad (1977), o material experimental foi construído com aproveitamento de "sucata" e material de baixo custo, buscando uma melhor adequação às condições estruturais das escolas. 
O laboratório não foi colocado como parte imprescindível do processo de ensinoaprendizagem. Essa opção se deve ao fato de os autores considerarem as dificuldades encontradas pelos professores nas escolas, ao ensaiarem atividades experimentais, pela falta de infraestrutura, de materiais didáticos e formação adequada. (PINHO-ALVES, 2000).

As primeiras versões do projeto foram testadas em alguns colégios da região de São Paulo e passou por revisões, sendo suas versões finais publicadas em 1973 (FAI 1, FAI 2, FAI 3 e FAI 5) e 1974 (FAI 4) pela Editora Saraiva.

Saad (1977) mostra dados que revelam uma boa aceitação do FAI nas escolas brasileiras. Segundo ele, entre janeiro de 1973 e junho de 1976, cerca de 500.000 estudantes brasileiros utilizaram o projeto, superando os índices de utilização do PSSC. Uma pesquisa feita na capital do Estado de São Paulo, com cerca de 5.000 estudantes, mostrou que 65\% deles gostaram do projeto, $23 \%$ não gostaram, e os demais não tinham opinião a respeito ou eram indiferentes. A boa aceitação foi constatada também em entrevista com professores. Dados, que segundo o autor, indicaram a viabilidade de utilização do ensino programado na área de física (SAAD, 1977). Por outro lado, o fato de o projeto ter sido pensado para currículos com carga horária média de quatro aulas semanais de Física, nas três séries do ensino secundário (situação rara, mas possível, antes da Lei 5.692/1971), tornou-se inviável após tal lei, uma vez que houve redução das cargas horárias de Física nos currículos. Contudo, Saad (1977) recomendou que a metodologia pudesse ser utilizada na elaboração de outros cursos mais adequados às organizações curriculares após a reforma de 1971.

Gaspar informa que o fim do projeto se deu de forma brusca, com a proibição por parte do MEC da utilização de textos descartáveis. Esse tipo de texto é inerente ao modelo de instrução programada. Mas outros fatores também contribuíram para o fim desse método de ensino, mesmo em países onde os textos descartáveis não foram proibidos: a mudança de enfoque nas ideias que respaldam os discursos pedagógicos, como exemplo, a influência das concepções construtivistas de Jean Piaget, conforme aponta Gaspar (2004).

\subsubsection{Conhecendo o FAI}

A análise foi feita nos cinco volumes publicados do projeto FAI, que são os textos destinados ao aluno, bem como no Manual do Professor, que denominaremos aqui de MPFAI. Os manuais do projeto (originais) foram obtidos por compra em Sebos via Internet. Já o Manual do Professor foi obtido na biblioteca do Programa de Pós-graduação Interunidades em Ensino de Ciências no IFUSP. As versões analisadas foram: 
SAAD, Fuad Daher, et al.. Física Auto-Instrutivo - FAI 1. São Paulo: Editora Saraiva, 1974.

SAAD, Fuad Daher, et al.. Física Auto-Instrutivo - FAI 2. São Paulo: Editora Saraiva, 1973.

SAAD, Fuad Daher, et al.. Física Auto-Instrutivo - FAI 3. São Paulo: Editora Saraiva, 1973.

SAAD, Fuad Daher, et al.. Física Auto-Instrutivo - FAI 4. São Paulo: Editora Saraiva, 1974.

SAAD, Fuad Daher, et al.. Física Auto-Instrutivo - FAI 5. São Paulo: Editora Saraiva, 1973.

SAAD, Fuad Daher, et al.. Física Auto-Instrutivo - FAI - Manual do Professor. São Paulo: Editora Saraiva, 1973.

Do mesmo modo que na análise do projeto apresentado anteriormente, passaremos a uma caracterização geral dos materiais acima listados. Na sequência, daremos enfoque aos elementos de nossa análise de conteúdo que caracterizam as dimensões epistemológica e educativa nos manuais do FAI.

\subsubsection{Caracterização geral dos manuais do FAI}

O material textual do projeto FAI foi composto por cinco volumes de textos: FAI 1, com 3 capítulos em 159 páginas; FAI 2, com 2 capítulos em 128 páginas; FAI 3 com 2 capítulos em 150 páginas; FAI 4 com 3 capítulos em 317 páginas e FAI 5, com 2 capítulos em 301 páginas. O projeto contou ainda com um Manual do Professor (MP-FAI), contendo 19 páginas. Com perspectiva bastante técnica e resumida, tal manual cuidou de descrever as características do projeto, esclarecer sobre o método utilizado, orientar sobre avaliações e formas de conduzir os estudos do aluno. A figura a seguir se refere às capas externas dos manuais da coleção do projeto FAI.
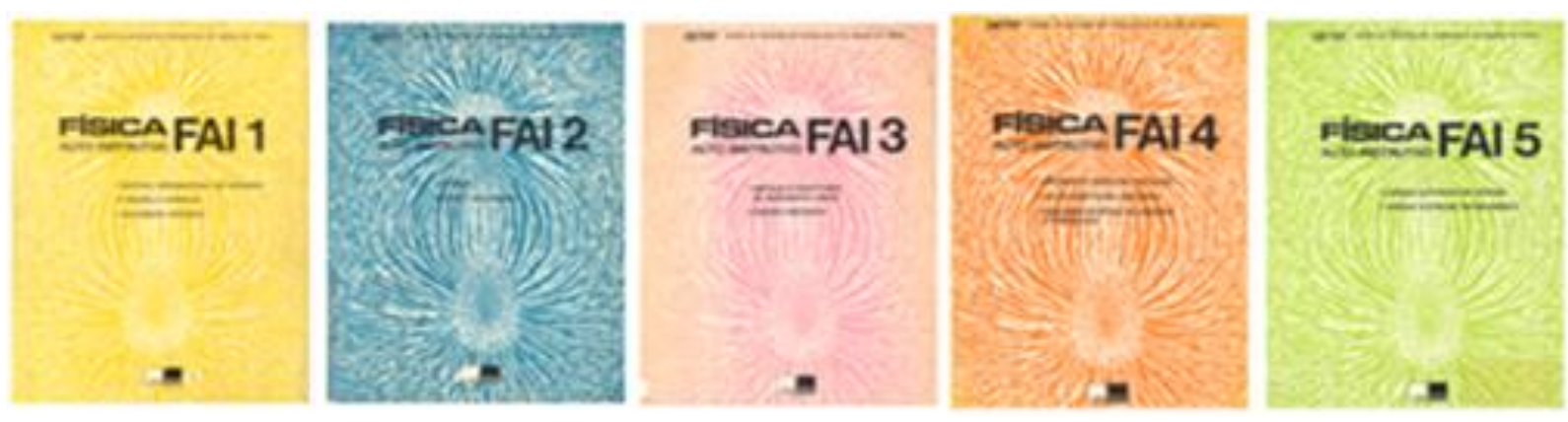

FIGURA 6 - Capas dos manuais do Projeto FAI

Fonte: http://paje.fe.usp.br/ mef-pietro/fai_capas.htm 


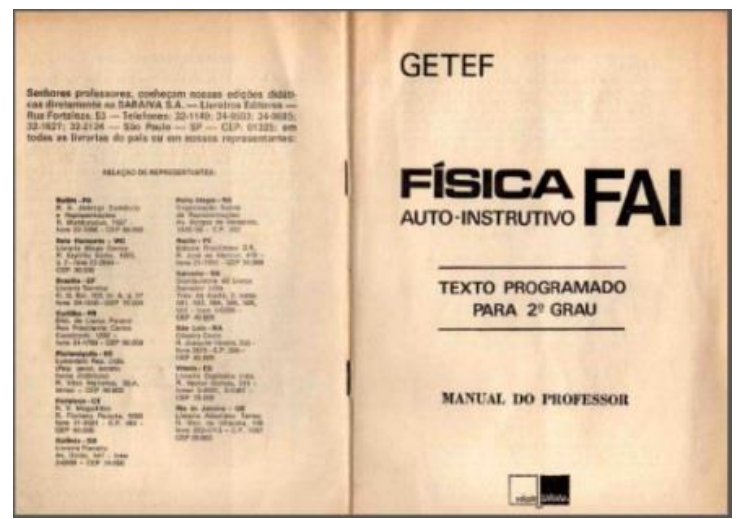

FIGURA 7 - Manual do Professor FAI

Fonte: Imagem escaneada do original

Os 12 capítulos do projeto são enumerados sequencialmente e os títulos dos mesmos são expostos na capa externa dos volumes. Nota-se a aglutinação de grande quantidade de tópicos em um mesmo capítulo. Os capítulos estão subdivididos em seções e subseções nas quais os títulos indicam o assunto que está sendo explorado nas questões para resolver. De modo geral, iniciam com a apresentação dos objetivos - algumas vezes com uma lista extensa, a exemplo do capítulo que trata da Lei da Gravitação Universal que traz 19 itens com objetivos - denominados no MP-FAI de "Comportamentos terminais”, e encabeçados por frases do tipo: "No final deste capítulo o estudante deve estar apto para: [...]" (FAI 1, 1974, Cap. I, p. 09). Essa definição de objetivos aparece também no início de algumas seções ao longo dos textos, a partir do FAI 3, e também após a seção QUESTÕES DE ESTUDO com conclusões do tipo: “Após isso, você estar apto para: [...]” (FAI 4, 1974, p.29).

$\mathrm{Na}$ maioria dos capítulos, um texto introdutório de caráter teórico, em linguagem objetiva, antecede o início da primeira seção, entretanto, isso não é uma regra. Algumas vezes o texto introdutório aparece no início das seções intermediárias. Em súmula, na maioria das vezes, há uma informação (em geral, muito sucinta) antes de iniciar as questões a resolver. Assim, o texto se completa por questões, que são na verdade uma lista extensa de exercícios, já trazendo as respostas logo abaixo de cada uma. Tais atividades são enumeradas e, em regra, aparecem nas formas: para completar um espaço com a resposta correta e/ou para marcar (talvez circular) uma das alternativas corretas apresentadas entre parênteses, que caberia em determinada passagem, de modo a complementar o texto corretamente. Nos dois casos, a resposta correta aparece em seguida, após uma fileira de estrelinhas. Um recorte extraído do projeto mostra o formato das questões principais, que caracterizam o texto do mesmo. 
36 - A experiência mostra que, numa mesma localidade, o peso ou a força gravitacional da Terra sobre objetos é (diretamente; inversamente) proporcional à massa dos objetos.

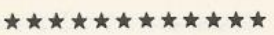

diretamente

37 - Se, num determinado local, como nesta sala, o peso de $1,0 \mathrm{~kg}$ for igual a 9,70 newtons, o peso de 2,0 kg será igual

a e o peso de um objeto de massa m será

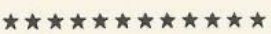

$19,4 \mathrm{~N} ; \mathrm{m} \cdot 9,70 \mathrm{~N}$

FIGURA 8 - Recorte de questões do texto do FAI 2 (1973, p. 77)

Em todos os volumes, as questões principais que compõem os textos, seguem o padrão acima colocado. Recomendou-se que o aluno procurasse completar as questões sem olhar a resposta correta, que aparece próximo às mesmas. "Uma olhadela à resposta correta, ainda que bem intencionada, só poderá dificultar sua tarefa no futuro.” (FAI, Apresentação ao estudante).

Para tapar a resposta correta antes de responder às questões, o aluno recebia uma régua de papel denominado máscara (figura a seguir), que deveria ser utilizada para garantir um "aprendizado eficiente".

\section{Use esta máscara para cobrir as respostas corretas.}

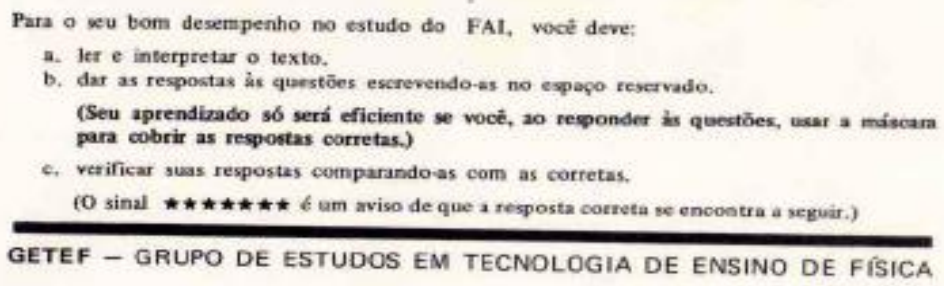

FIGURA 9 - Modelo de Máscara utilizada no desenvolvimento das atividades do projeto FAI Fonte: Manual do Professor FAI, 1973.

Além das atividades nestes modelos, que compõem a maior parte do texto dos manuais do aluno, apresenta ainda outros exercícios (variando a frequência com que aparecem) sob os títulos: EXERCÍCIOS DE REVISÃO; QUESTÕES DE ESTUDO; PROBLEMAS PROPOSTOS; RESOLVA; PROBLEMAS RESOLVIDOS e PROBLEMAS A RESOLVER. Destes, somente as QUESTÕES DE ESTUDO não trazem respostas e informa ao aluno que o objetivo de tal seção é permitir que ele "verifique a sua fluência quanto ao entendimento do assunto que acabou de estudar”, e que, em caso de dificuldade, “poderá verificar a resposta exata voltando ao texto" (FAI 4, 1974, p.55). Os demais tipos apresentam as respostas logo na sequência de cada um ou no final da lista. Não há uma 
diferença clara no projeto, em termos de objetivos, entre as atividades para completar e os demais exercícios dispostos nas referidas seções.

Ao final de alguns capítulos, comumente na última seção, traz um texto caracterizado como histórico. Tais textos abordam relatos históricos sobre o tema desenvolvido no capítulo. São alguns exemplos de títulos, dentre outros: "Pesos e Medidas - Histórico" (FAI 1, p. 44); “A Eletricidade através dos tempos - Histórico” (FAI 5, p.292); “Eureka! - Histórico” (FAI 4, p. 200); "A teoria da Gravitação Universal - Histórico" (FAI 4, p.174); "Evolução do conceito de energia” (FAI 3, p.149).

Do mesmo modo que o PEF, o FAI também não contou com um guia de laboratório. As propostas experimentais estão dispostas no final dos livros, com exceção do FAI 2, que as traz antes da finalização do último capítulo do manual, e do FAI 3, que não apresenta nenhuma proposta experimental. O MP-FAI não traz informações sobre a composição dos kits experimentais. Encontramos em Saad (1977) a informação de que o projeto FAI desenvolveu conjuntos experimentais de baixo custo, com uso de materiais de "sucata".

No que concerne à estrutura gráfica, os textos e as ilustrações (figuras e esquemas) são todos em contornos de cor preta, com exceção das figuras de resistores, que trazem faixas coloridas para identificação de código de cores. Não identificamos nenhuma foto como ilustração.

Passaremos às descrições dos resultados de nossa análise de conteúdo no projeto FAI, com um enfoque mais apurado em elementos que evidenciam as dimensões interativas já mencionadas, tal como fizemos no estudo do PSSC e do PEF.

\subsubsection{As dimensões Epistemológica e Educativa no FAI}

Da dimensão Epistemológica

\section{Ciência como processo}

No FAI, notam-se poucos elementos de texto que transmitem a ideia de ciência como processo. Os elementos que caracterizam essa categoria aparecem de forma bastante pontual, como os exemplos que apontaremos a seguir.

Não há um texto específico que busque conceituar a natureza da Ciência, exprimir suas relações com outras áreas e com a sociedade mais ampla. No início de uma seção do primeiro capítulo, afirma-se que: 
O enorme crescimento do conhecimento humano nos últimos séculos está relacionado com a habilidade dos homens em medir os fenômenos que ele observa. Medindo fenômenos observáveis, formulam leis. [...]. Para comprovar ou derrubar uma teoria científica deve-se construir dispositivos experimentais e realizar medições. (FAI 1, p. 27).

O capítulo X, FAI 4, no estudo de temperatura e calor, inicia colocando que os tópicos abordados são "de fundamental importância para conhecermos mais intimamente a Natureza que nos rodeia. Conhecer a natureza e colocá-la a serviço do homem tem sido uma preocupação constante da Ciência.” (FAI 4, Cap. X, p. 176).

Das citações anteriores, ao mesmo tempo em que se denotam características filosóficas baconeanas - estudar a Natureza para dominá-la (BRAGA; GUERRA; REIS, 2004) e formulação de leis a partir da experimentação -, a visão de método na produção do conhecimento científico se difunde à outra vertente filosófica - o falsificacionismo popperiano.

Os poucos elementos que insinuam uma relação com outros campos da sociedade se resumem em fragmentos de textos. Pouco busca contextualizar a Física com situações cotidianas. O excerto a seguir é um exemplo raro de elementos do projeto que relaciona ciência e cotidiano, evidenciando situações em que determinado fenômeno físico se aplica. Ao introduzir o capítulo, que traz o estudo de calor e temperatura, coloca-se:

Os fenômenos térmicos são de vital importância para a sobrevivência do próprio
homem. Deparamo-nos na vida diária com fatos corriqueiros que se processam
graças a utilização sistemática quer direta, quer indiretamente das fontes de calor:
cozer alimentos, obter aquecimentos domésticos, fazer funcionar poderosas
máquinas térmicas, mover veículos através de motores à explosão, etc... os próprios
processos biológicos (nascimento e desenvolvimento celulares) dependem da forma
como ocorrem as trocas de calor entre as células e o ambiente, e também da forma
de sua utilização. Nas indústrias, de modo geral, a utilização dos fenômenos
térmicos é vital: utilização de combustíveis diversos, produção de metais a partir de
minérios, produção de ligas metálicas, soldas, produção de gelo, liquefação de gases
a baixas temperaturas, construção de estufas, fornos, etc..., além dos inúmeros
fenômenos meteorológicos que se processam através das mudanças de temperatura.
(FAI 4, p. 176).

Embora se encontre, ora ou outra, algum fragmento de texto nessa linha, ou alguma questão que aplica algum princípio físico em uma situação cotidiana, isto não parece ter a intenção de promover discussão; tem uma perspectiva mais informativa.

A relação ciência/tecnologia é pouco presente, embora aponte que a tecnologia é colocada a serviço da ciência: "O avanço da tecnologia auxilia cada vez mais as técnicas experimentais, permitindo aos cientistas verificarem com maior precisão as predições contidas em suas teorias.” (FAI 1, p.27). Em um trecho do FAI 4, a ideia de ciência a serviço da tecnologia também é discursada. Ao falar do fenômeno de expansão térmica, traz que: "Este fenômeno é de grande interesse da tecnologia desde o assentamento de tacos em pisos, 
pastilhas em paredes, passando pela engenharia de construção de diques, pontes, viadutos, etc., até os mais sofisticados instrumentos de engenharias de precisão e cirurgia.". (FAI 4, p.201).

Contrapondo-se ao discurso, diferentemente dos outros projetos analisados, pouco menciona os aparatos tecnológicos da época. Num contexto em que se difundiam no mercado os aparelhos de TV, que funcionavam com válvula eletrônica, por exemplo, uma questão sobre tal dispositivo se restringe a mostrar uma figura esquemática do aparato e a análise do fenômeno, de modo totalmente descontextualizado:

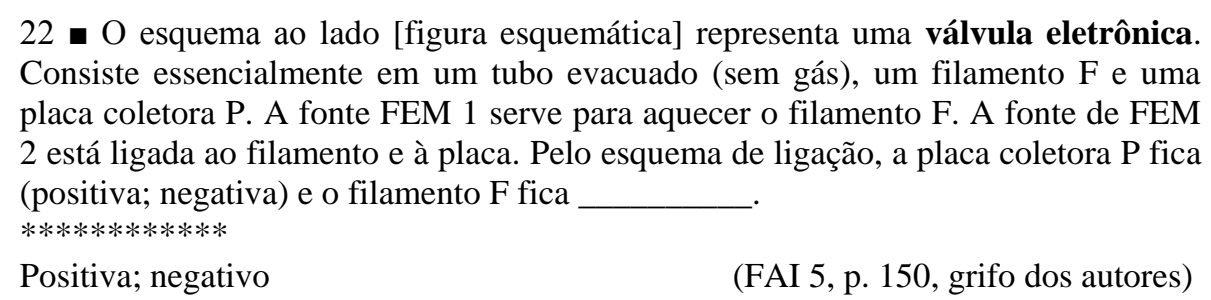

Ressalte-se que tal aparato não é mencionado antes da referida questão. Nesta mesma linha, muitas outras questões que exploram dispositivos eletrônicos, não cuidam de mostrar suas aplicações cotidianas. Não se observam fotos de foguetes, usinas, automóveis, etc., com exceção de uma figura (em desenho) de um satélite artificial em que a informação sobre ele se resume em uma legenda que afirma que seu "movimento também obedece às leis da gravitação universal” (FAI 4, p.175).

Nada é abordado sobre a relação da ciência com a cultura e sociedade mais ampla.

O reconhecimento do papel do homem no processo de construção do conhecimento é infimamente notado e aparece de forma bastante implícita, em um trecho que, sucintamente, debate a história das evoluções das ideias no que se refere à Teoria da Gravitação Universal, no final do capítulo IX. Em tal trecho mencionam-se as diferentes concepções sobre os corpos celestes, de Aristóteles a Newton.

Outra passagem de texto chama a atenção, ao evidenciar o processo de construção do conhecimento científico como uma ruptura do conhecimento baseado no senso comum, para a assunção de um conhecimento baseado no estudo da realidade.

[...], se pensarmos em termos da nossa experiência comum, vamos observar que o movimento da Terra não é tão óbvio assim, que mais facilmente aceitaríamos a imobilidade da Terra e o movimento dos astros ao seu redor.

Este é um simples exemplo que nos mostra que o conhecimento que hoje temos da Terra, dos planetas, do Universo, se afasta de um conhecimento baseado no senso comum. [...]. Relembrando as dificuldades que os cientistas enfrentaram neste caminho, deixa mesmo de parecer absurdo, para nós, que até o século XVI de nossa era o homem ainda acreditava que a Terra estava parada, ocupando o centro de um Universo fechado. (FAI 4, 1974, p, 174). 
Não se menciona a natureza das "dificuldades" enfrentadas pelos cientistas, de modo que não esclarece se tratam de fatores externos, como conflitos de natureza religiosa, por exemplo, ou se se refere às questões mais internalista da Ciência, como a tecnologia, ou conhecimento científico, insuficientes.

O aspecto presente no excerto citado não é uma característica comum nos textos do projeto. De modo geral, a forma de desenvolvimento dos textos denota uma visão de conhecimento pronto e acabado. A apresentação dos conceitos se dá de forma abstrata e sem contextualização. Prevalecem as definições e apresentação sumária de leis na forma textual ou de equações. Citamos como exemplo um trecho do capítulo Cargas elétricas em repouso, quando menciona, pela primeira vez no capítulo, a lei de Coulomb, já na forma de questão para resolver:

9 - A seguir, estudaremos de forma quantitativa o comportamento das cargas quando próximas umas das outras. Para isto, vamos admitir o caso em que os corpos eletrizados possuem dimensões desprezíveis em relação à distância que os separa. Daí essas cargas serem chamadas de cargas puntiformes. A lei que rege a ação entre cargas foi estabelecida por Charles Augustin Coulomb em 1785 e recebeu o nome de Lei de Coulomb. Coulomb verificou que a força elétrica entre duas cargas puntiformes Q e q, é diretamente proporcional ao produto das cargas e inversamente proporcional ao quadrado da distância entre elas (r).

Matematicamente: $\mathrm{F}=\mathrm{k} \cdot \frac{\mathrm{Q} \cdot \mathrm{q}}{\mathrm{r}^{2}}$

Onde $\mathrm{k}$ é a constante de proporcionalidade positiva que depende da escolha da unidade de carga e do meio onde as cargas se encontram.

Quando Q e q possuírem o mesmo sinal, a força F terá sina + e será de (atração; repulsão).

$* * * * * * * * * * * *$

Repulsão

(FAI 5, p. 37)

A partir da questão citada, outras são apresentadas com aplicação numérica na equação da lei apresentada; algumas já começando com a equação, como a que se segue:

$12 \square \mathrm{F}=\mathrm{k} \cdot \frac{\mathrm{Q} \cdot \mathrm{q}}{\mathrm{r}^{2}}$.

Dados $Q=+2 \times 10^{-6} \mathrm{C}, \mathrm{q}=-3 \times 10^{-3} \mathrm{C}, \mathrm{r}=3 \mathrm{~cm}$. Calcule o valor da força entre as cargas. Interprete o sinal obtido.

$\mathrm{F}=$

$* * * * * * * * * * * *$

$\mathrm{F}=\mathrm{k} \cdot \frac{\mathrm{Q} \cdot \mathrm{q}}{\mathrm{r}^{2}}=\frac{\left(9 \times 10^{9} \mathrm{~N} \cdot \mathrm{m}^{2} / \mathrm{C}^{2}\right)\left(+2 \times 10^{-6} \mathrm{C}\right)\left(-3 \times 10^{-5} \mathrm{C}\right)}{\left(3 \times 10^{-2} \mathrm{~m}\right)^{2}}=-6 \times 10^{2} \mathrm{~N}$

O sinal negativo de F significa que a força é de atração. (FAI 5, p. 38)

Em resumo, de modo geral, a Física é tratada no projeto FAI como um conhecimento pronto, linear, neutro, isento de interferências políticas, sociais e econômicas. Embora apresente textos classificados no projeto como históricos, ao final dos capítulos, ou pequenas sínteses no início de alguma seção, eles não se articulam com o conteúdo desenvolvido nas questões; os assuntos são abordados de forma fragmentada. 


\title{
A Física e a experimentação
}

No desenvolvimento do FAI, a experimentação foi posta como recurso secundário. O projeto apresentou ao todo 20 (vinte) propostas experimentais distribuídas nos quatro volumes: FAI 1 - sete; FAI 2 - duas; FAI 4 - cinco; e FAI 5, também com cinco. As experiências são simples e com materiais acessíveis aos alunos; aparecem quase sempre no final dos capítulos e trazem roteiros típicos, com margem marcada como um formulário, contendo OBJETIVOS, MATERIAL, PROCEDIMENTOS, ANÁLISE, QUESTÕES e RELATÓRIO. A análise se resume à construção de gráficos e tabelas, e realização de cálculos.

O MP-FAI traz sucintas informações sobre o laboratório didático e como este deveria ser entendido como parte do projeto instrucional. Considerando as limitações de custos e a precária situação das escolas, o manual ressaltou a não necessidade de muitas unidades de equipamentos de um mesmo tipo para a realização das atividades experimentais, incentivando o trabalho em dupla de alunos. Afirma que:

\begin{abstract}
As experiências devem ser planejadas dentro dos recursos disponíveis. A sua eventual pequena quantidade não irá prejudicar substancialmente os objetivos do ensino de Física. O texto programado não é consequência de uma experiência de Física que deve ser feita. Pelo contrário, a experiência é um recurso para mostrar determinados princípios básicos já explorados pelo aluno, como acontece também com recursos audiovisuais e conferências. (MP-FAI, p. 08, itálicos do original).
\end{abstract}

Deu-se liberdade ao professor para planejar outras experiências úteis, além daquelas colocadas no "contexto da obra", mas que "o único cuidado importante é de que cada experimento seja solicitado do aluno após este ter estudado o assunto” (MP-FAI, p. 08). Em outra passagem do MP-FAI, reforçou-se novamente que cada experiência fosse colocada “após o conhecimento de princípios físicos sobre os quais é baseada." (MP-FAI, 1973, p. 11). Desse modo, os experimentos tinham caráter de comprovação de leis e conceitos; “...um eventual complemento ao processo de ensino" (PINHO-ALVES, 2000, p. 51).

Constata-se de nossa análise que o projeto FAI não exaltou a experimentação no ensino de Física, contrapondo-se à tendência dos projetos inovadores da época. Optou-se pela apresentação da Física como um conjunto de notas conceituais preponderantemente quantitativas. 


\section{Modelos explicativos formais}

O FAI dedica dois capítulos para assuntos que preparam para o uso de modelos matemáticos: estudo de notação científica; Sistema Internacional de unidades; precisão de medidas, funções e gráficos, etc. No capítulo Funções e Gráficos, expressa a importância da matemática na descrição dos fenômenos.

\footnotetext{
Uma das preocupações do cientista, ao focalizar um determinado fenômeno, é representá-lo de forma simples e racional, de tal modo que ele possa ser entendido e imediatamente analisado nos pontos considerados importantes. A representação deve ser, portanto, universal, suficientemente clara e tão completa quanto possível.

Ao descrever um evento físico, os primeiros elementos que o representam são as medidas das grandezas envolvidas. Uma descrição de vários eventos envolvem grandezas variáveis, obedecendo leis naturais, que estamos interessados em descrevê-las. Os dados obtidos experimentalmente poderão ser expressos, dinamicamente, por uma representação gráfica, fácil de ser visualizada.

A partir de gráficos pode-se obter analiticamente (outra maneira de representação de fenômenos) a função correspondente. (FAI 1, p. 49).
}

Observe que o termo "leis naturais" no contexto da citação passa a ideia de que as leis estão na natureza e ao cientista cabe encontrá-las; que estas não são uma construção do homem.

Prossegue afirmando que a representação gráfica é imprescindível na descrição e análise dos fenômenos físicos. As atividades que seguem após essa breve introdução do capítulo, não propõe estudo de um fenômeno, anotação de dados, construção e análise do gráfico e discussão das relações e comportamentos das grandezas; restringem-se em apresentar questões com gráficos prontos para identificação de dados que respondem às questões.

Apesar de discursar sobre a importância da matemática como descrição dos fenômenos, o desenvolvimento dos tópicos seguiu na contramão dessa ideia, e as equações foram, em geral, apresentadas de forma sumária.

Tomamos como exemplo a forma de abordagem para apresentação do conceito de velocidade média. Na seção anterior a tal assunto, é apresentado um quadro, que traz um esquema do trecho de uma estrada representada por uma reta marcada a partir do marco zero, e posições variando de $30 \mathrm{em} 30 \mathrm{~m}$, com indicações de tempo para cada posição. As questões que se desenvolvem a partir do quadro são para cálculos de intervalos de tempo e variações de posição. Assim, a seção VELOCIDADE MÉDIA E VELOCIDADE INSTANTÂNEA, começa da seguinte forma: 
1 - Releia atentamente o Quadro A. Definiremos velocidade média de um móvel, e
a representaremos por $\mathrm{v}_{\mathrm{m}}$, como sendo a relação entre o deslocamento de um móvel
e o correspondente intervalo de tempo para efetuar tal deslocamento:
$\mathrm{v}_{\mathrm{m}}=\frac{\Delta \mathrm{d}}{\Delta \mathrm{t}}$
(FAI 1, p. 103)

Prossegue solicitando o cálculo da velocidade média entre dois intervalos de tempo marcados no referido Quadro A.

A maioria dos exercícios no texto do projeto são aplicações diretas de equações ou valores memorizados para completar espaços. Não dá margem para discussão de exemplos cotidianos e construção de ideias que possibilitassem compreender as relações entre as grandezas envolvidas, ainda que fossem a partir de um modelo.

Desse modo, entendemos que o formalismo matemático, da forma como foi explorado no FAI, assumiu mais a função de ferramenta de cálculos.

\section{Conteúdos/áreas da Física}

O FAI também não contemplou todos os temas da Física comumente encontrados nos programas do ensino médio. Abordou três: Mecânica, Termologia e Eletricidade, com destaque para o primeiro que ganhou maior espaço no projeto, ocupando praticamente quatro dos cinco volumes da coleção. Os capítulos foram intitulados, conforme a seguir:

FAI 1: I - Sistema Internacional de Unidades; II - Funções e gráficos; III Movimento retilíneo.

FAI 2: IV - Vetores; V - Força e Movimento.

FAI 3: VI - Impulso e Quantidade de Movimento Linear VII - Energia Mecânica.

FAI 4: VIII - Movimento Angular e Rotação; IX - Lei da Gravitação Universal; X Equilíbrio estático de líquidos e Termologia.

FAI 5: XI - Cargas elétricas em repouso; XII - Cargas elétricas em movimento.

Os conteúdos foram apresentados nos moldes da Instrução Programada. Segundo traz o MP-FAI (1973), na estrutura geral foi considerada a organização em tópicos básicos, tópicos diversificados e tópicos avançados, conforme o esquema a seguir: 


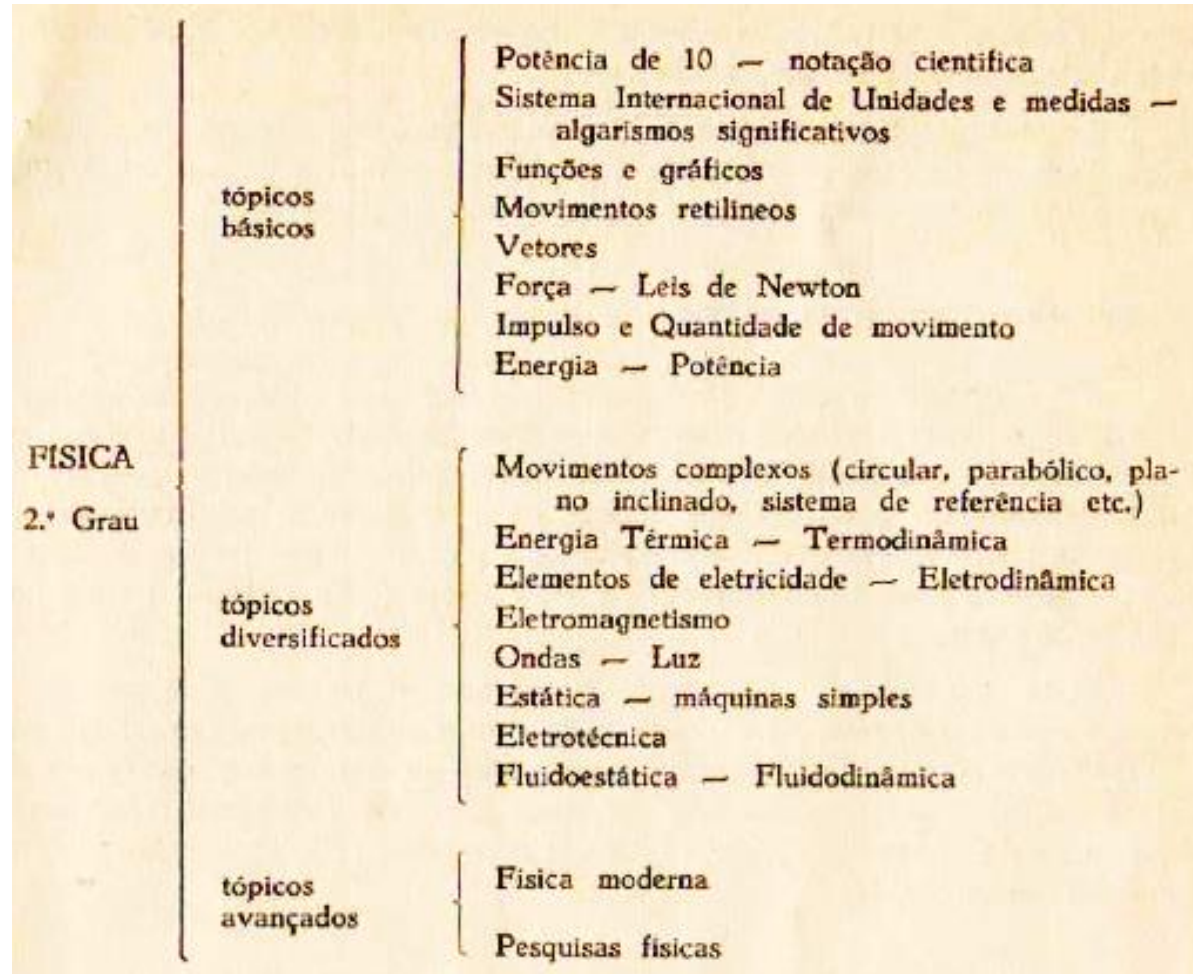

FIGURA 10 - Esquema de organização dos conteúdos no FAI, conforme MP-FAI Fonte: Manual do Professor FAI, 1973, p. 09.

Explica o MP-FAI (p. 09) que, “os tópicos básicos compreendem um programa fundamental e são pré-requisitos para a parte diversificada". Já os tópicos diversificados seriam para atender as diversidades curriculares de cada escola, dependendo das tendências profissionalizante ou acadêmica - de modo que a seleção dos assuntos dependeria de tais tendências. Os tópicos avançados, que trariam assuntos de Física Moderna e temas atuais das pesquisas, pareciam ter indicação de livre escolha.

Contudo, alguns dos temas listados no esquema acima, não aparecem nos manuais do aluno, como exemplo: Ondas; Luz; Máquinas simples; Eletromagnetismo; Eletrotécnica; Fluidodinâmica; Física Moderna e Pesquisas Físicas. Não identificamos, por exemplo, nada relacionado ao que é colocado a seguir:

Introduzimos em tópicos avançados assuntos relacionados com a mecânica quântica e relatividade, desenvolvidos de ponto de vista conceitual e prático. Acompanham "reportagens" das principais pesquisas físicas em andamento nos principais centros científicos do Brasil. (MP-FAI, 1973, p.09).

De nosso estudo nos manuais do FAI, constatamos que estes não trazem todo o repertório de conteúdos testados nas escolas entre os anos de 1970 e 1972 conforme afirmam os autores.

Notamos em nossas experiências, que os alunos, após vencerem o programa, independentemente de terem realizado a prova geral antes do tempo, prosseguem o estudo das unidades seguintes do programa geral de Física. Tivemos casos em que no final do $2^{\circ}$ ano alguns alunos já haviam terminado o capítulo sobre 
Eletromagnetismo. Foram-lhe fornecidas, então, textos de Física Moderna para completarem o tempo preestabelecido. (MP-FAI, 1973. p. 06).

Esta colocação contradiz o que traz o material publicado, uma vez que não se identificam tópicos de Eletromagnetismo ${ }^{108}$ nos manuais do projeto. Parece subentender que houve a pretensão de elaborar um sexto volume (ou outros mais) para a coleção; algo que não ocorreu. Ressalte-se que, se houve tal pretensão, esta não é mencionada no MP-FAI.

Os títulos dos capítulos dos volumes indicam o seu conteúdo interno. Os quatro primeiros trazem assuntos de Mecânica e os tópicos abordados seguem a sequência tradicional começando com cinemática (após o estudo de alguns tópicos matemáticos) e passando ao estudo de dinâmica. Já o último volume traz assuntos de Eletricidade, também na sequência tradicional, começando por Eletrostática trazendo, em síntese, os seguintes assuntos: processos de eletrização, forças elétricas entre cargas, campo elétrico, potencial elétrico e energia potencial elétrica. Prossegue com eletrodinâmica, abordando fonte de força eletromotriz, corrente elétrica, resistência, resistores, estudo de circuitos e capacitores. Como já dito, não contempla Eletromagnetismo.

As principais leis de conservação são abordadas, ainda que de forma muito abreviada. A Lei da Conservação da Energia é um pouco mais destacada que as demais. Após a apresentação do assunto, por meio de questões para completar, apresenta um Apêndice em duas laudas que, saindo do padrão do modelo de questões (instrução programada), descreve e discute uma experiência sobre pêndulo simples para ilustrar o fenômeno. A conservação da energia é abordada novamente, na solução de problemas, no estudo das trocas de calor no capítulo Equilíbrio estático de líquidos e Termologia.

A Lei da Conservação da Quantidade de Movimento Linear é apresentada em seção específica após a apresentação de questões sobre sistema isolado e definição de Quantidade de Movimento Linear, a partir do conceito de impulso. Apresenta um exemplo com esquema de dois carrinhos ligados por um fio e com uma mola comprimida entre eles. Sugere que o fio seja rompido e apresenta questões para responder, sobre o fenômeno ilustrado (FAI 3, p. 51).

O estudo de movimento circular abrange um capítulo inteiro com 75 páginas, dividido em duas partes. A $2^{\mathrm{a}}$ parte intitulada de Dinâmica do Movimento Circular aborda a Quantidade de Movimento Angular. Apresenta atividades sobre Momento de Força, mas não menciona o Princípio da Conservação do Momento Angular. Os tópicos sobre movimento

\footnotetext{
${ }^{108}$ As versões do Manual do Professor e do volume que trazem assuntos de Eletricidade (FAI 5) analisadas são ambas de 1973. Em nenhum dos volumes, inclusive o FAI 4 que foi publicado após o FAI 5, não há assuntos de Eletromagnetismo.
} 
circular aparecem antes do estudo de Gravitação Universal e indica terem sido organizados assim para servirem como pré-requisitos.

A Gravitação Universal é um dos tópicos do projeto que mais contempla descrição textual. Após apresentar a Lei da Gravitação na forma matemática, e desenvolvimento de uma extensa lista de questões, apresenta um texto que trata dos modelos planetários, Sistema Solar, características dos planetas, Leis de Kepler e movimento planetário em órbitas circulares; em torno de quatro laudas deixa-se de notar questões programadas. Após isso, o assunto é complementado, novamente, na forma de questões para resolver.

A Lei da Conservação da Carga é também abordada. Em uma seção específica para o assunto, com questões para resolver, descreve:

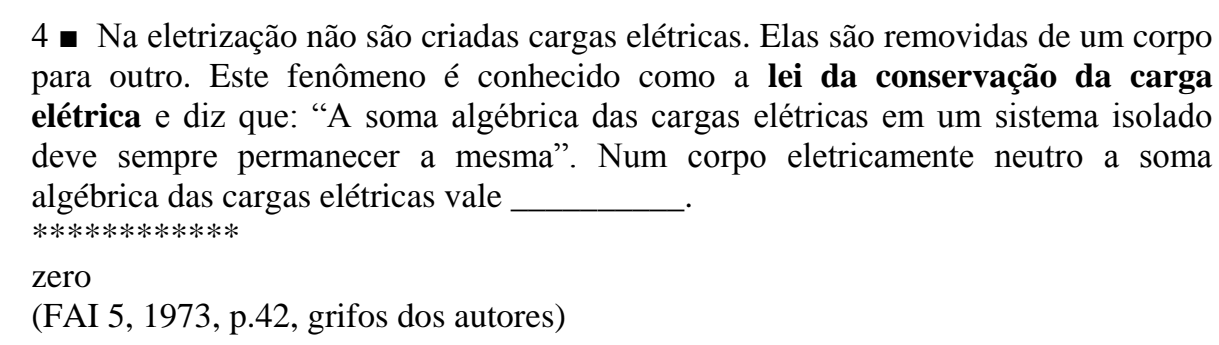

Na questão seguinte a esta, afirma-se que tal lei tem sido confirmada através de experiências e que não existe nenhuma exceção à mesma. A questão trata da análise do fenômeno de aproximação entre um elétron e um pósitron e da possível conversão de suas massas em energia, de acordo com a relação da mecânica relativística $\boldsymbol{E}=\boldsymbol{m} \cdot \boldsymbol{c}^{\mathbf{2}}$. Para completar os espaços da questão solicita respostas que informem a carga resultante antes da interação, e se houve conservação da carga e da massa. Nota-se que se suscitou abordar a conservação da energia em seu sentido mais abrangente ao mencionar o princípio da equivalência entre massa e energia. Entretanto, não ressaltou o seu limite de aplicação, situação em que a massa é tratada como energia dentro de um sistema isolado. A questão poderia ter sido estendida, para evidenciar que, no âmbito da Mecânica de Newton, massa e energia se distinguem, sendo necessário pensar em conservação da energia (em sentido mais restrito) e conservação da massa, separadamente. Curioso é que a questão cita o modelo de energia de Albert Einstein, mas nem mesmo menciona o nome do cientista. O assunto se encerra nas duas questões exemplificadas. 


\section{Da dimensão educativa}

\section{Objetivos do ensino de Física}

O FAI traz em sua apresentação ao estudante que o material objetiva dar condição ao aluno de "aprender uma parte substancial da Física Fundamental". No MP-FAI, os autores expressam que "ensinar é, sobretudo dispor de contingências sob as quais o comportamento muda, seja nos conhecimentos específicos, seja nas habilidades ou atitudes" (MP-FAI, p. 1112, grifo nosso). No que tange as habilidades e atitudes, os autores logo tratam de destacar dois aspectos comportamentais dessa natureza: o verbal (expressão oral e escrita) e o não verbal (laboratório). Desse modo, tais aspectos, de natureza bastante específica, não demonstram preocupar com uma formação focada, também, no dinamismo das circunstâncias sociais.

Fica claro que os objetivos se restringem a uma aprendizagem dos conteúdos de Física com a finalidade de obtenção de informação sobre o corpo de conhecimentos desta ciência. Nota-se que a ênfase pedagógica é extremamente tecnicista a julgar pela supervalorização do planejamento da sequência linear dos conteúdos, com foco nos comportamentos terminais. Coloca-se que "O texto programado expressa claramente os objetivos mínimos que o aluno deve atingir no final de cada capítulo” (MP-FAI, p. 11-12). De fato, é o que se nota ao longo dos textos dos manuais do aluno; objetivos bem definidos voltados exclusivamente para os conteúdos da Física, e não objetivos que ambicionem uma formação mais ampla. Como exemplo, cita-se a seguir uma lista de supostos objetivos alcançados ao final da seção Conceito de Resistência Elétrica - Lei de Ohm:

\footnotetext{
Após isso, você deve estar apto para: a. conceituar resistência elétrica. b. enunciar a Lei de Ohm. c. caracterizar os condutores de acordo com a Lei de Ohm (resistência). d. definir a unidade de medida de resistência elétrica. e. definir condutor ôhmico. f. resolver problemas propostos. (FAI 5, p. 168).
}

Na mesma linha dos demais projetos analisados (PSSC e PEF), no desenvolvimento dos conteúdos, não se considera o corpo de conhecimentos que o aluno traz de sua história social. Também do mesmo modo, preocupou-se com pré-requisitos de conteúdos, já que busca apresentar certa ordem sequencial de assuntos em "grau de complexidade crescente" (MP-FAI, p. 10). Contudo, ao contrário dos outros projetos, privilegia mais a abordagem quantitativa, com exploração de grande quantidade de questões com cálculos, sem discussão de resultados. Afirma que o aluno "aprende melhor se aplica imediatamente o que aprendeu" (MP-FAI, p. 10). Tal aplicação se refere à resolução de exercícios, sendo a maioria, 
numéricos, repetitivos e descontextualizados. Também no desenvolvimento do texto, pelo fato de a metodologia ser a instrução programada, o aluno aplicaria imediatamente o que aprendeu, preenchendo as lacunas ou dando respostas imediatas.

Cabe ressaltar que a postura curricular adotada no projeto FAI - a Tecnologia do Ensino, que abrange modelos didáticos baseados em contingências de reforço (SKINNER, 1972) - não se confunde com conceito de tecnologia. De fato, o projeto não demonstrou expressivo apelo ao conhecimento científico tecnológico. Pouco se explorou nos textos os avanços tecnológicos da época. Diferentemente dos demais projetos analisados, sobretudo o PSSC, não evidenciou a tecnologia como sinônimo de progresso científico.

\section{Concepção de aluno/professor}

O FAI também priorizou a participação ativa do aluno no seu processo de aprendizagem. Na apresentação da estrutura geral do projeto ao professor, no MP-FAI, denota que se trata de um método individualizado mais extremo que o PEF. De certa forma, acolhe a ideia de isolamento do aluno e o autodidatismo: “c) Cada aluno, independentemente dos demais colegas, tendo em mãos o guia ${ }^{109}$ e o texto programado, trabalha desenvolvendo comportamentos de ler, interpretar, escrever, responder perguntas formuladas no texto, autoavaliar-se e realizar experiências." (MP-FAI, 1973, p. 05). A proposta do FAI se respalda na Tecnologia de Ensino de Skinner; a teoria do reforço, de modo que a cada etapa bem sucedida o aluno se sentiria estimulado a continuar, em seu rítmo próprio, motivados por reforços positivos: "O adolescente tem tendência de se apegar a oportunidades para mostrar o que é capaz de fazer, desde que para isso contigências favoráveis sejam criadas. Por esse motivo, a utilização de penalidades pelos insucessos torna-se insuportável.” (MP-FAI, 1973, p. 08). Assim, o desempenho do aluno seria respondido pelo professor com "palavras de elogio", caso obtivesse acerto de $100 \%$ nos testes, por exemplo, ou de estímulo para estudar até obter o resultado desejado.

Tem-se, enfaticamente, uma mudança de referencial em relação ao papel do aluno e do professor em sala de aula: "O aluno passa a ser o foco da atenção. Ele deixa de ser um elemento passivo para ser um elemento que participa ativamente no processo de

\footnotetext{
${ }^{109}$ Consta no MP-FAI que aluno se utilizaria de um guia de estudo, em que eram apresentados e indicados os objetivos de cada unidade, as leituras necessárias, o conjunto mínimo de exercícios e experiências, uma coleção sequencial de questões, orientação de leitura do texto e informações sobre o processo de avaliação (MP-FAI, p. $07)$.
} 
aprendizagem, ou seja, o que o aluno aprende é consequência de seu próprio trabalho." (MP-FAI, 1973, p. 06).

O professor passa a ser gerenciador do processo de ensino, com atribuições de natureza mais técnica. Ele “deixa de ser apenas 'o ator principal' no palco de uma sala. [...] passa a ser um orientador e avaliador dos trabalhos executados e fundamentalmente criador de contigências favoráveis através das quais o aprendizado se realiza." (MP-FAI, 1973, p. 06). Na apresentação ao estudante, essa perspectiva é claramente comunicada ao aluno:

\begin{abstract}
Se começar a notar que suas respostas não estão sendo correspondidas, é possível que você não tenha estudado o texto atentamente. Nesse caso, reestude o texto, antes de passar adiante. Se persistir a dificuldade, talvez você não esteja utilizando o texto adequadamente. Para sanar eventuais falhas peça auxílio do professor. (FAI, Apresentação ao estudante).
\end{abstract}

O auxílio do professor parece se referir à forma de utilização do texto. Assim, não recomendou ao aluno recorrer ao professor para tirar dúvidas, debater possíveis respostas, mas sim para orientá-lo no uso do material instrucional. Reforça ao aluno que o curso é um desafio, e que ele "é o responsável pelo seu aprendizado.". E prossegue: "Livre de esquemas tradicionalmente conhecidos, você irá trabalhar para criar dentro de si a satisfação de uma auto-realização, de ter enriquecido seu repertório e de sentir o sabor de um êxito constante cada vez maior." (FAI, Apresentação ao estudante).

Ao falar da importância de aulas consecutivas para um melhor rendimento, afirma que " a carga de trabalho do professor dilui-se mais, dando-lhe oportunidade de obter uma maior interação com cada um dos alunos.” (MP-FAI, 1973, p. 06). Fica a dúvida sobre o tipo de interação possível. Afinal, o projeto era fechado, o texto era auto-instrutivo e discursado como suficiente a uma aprendizagem individualizada e auto-ritmada.

O MP-FAI informa que o aluno teria a liberdade de propor o momento de sua avaliação, livre de tensões geradas pelas provas agendadas. Afirma que, "a interação professor-aluno, em termos de aprendizagem, terá tanto mais sucesso quanto mais eficiente for o diagnóstico que fizer de seus alunos e da aula em si.". Ou seja, os resultados do rendimento dos alunos, em tese, refletiria na interação, criando um ambinete agradável e favorável à promoção "de entusiasmo, interesse e propósito, provenientes do reforçamento originado de contingências favoráveis criadas pelo educador.” (MP-FAI, p.12). Quanto aos resultados, era "Teoricamente, exigido $100 \%$ de desempenho para cada unidade programada." (MP-FAI, 1973, p. 05). 
Um trecho do discurso do MP-FAI, a nosso ver, parece contraditório ao próprio modelo de ensino adotado. Se lêssemos tal fragmento em outro contexto qualquer, não diríamos que poderia se referir ao projeto em questão.

A criatividade cresce na medida em que a aprendizagem é feita a partir do trabalho efetivo do próprio aluno. Trabalho criativo (enriquecimento de repertório) só é possível desde que a liberdade seja oferecida. Ou seja, liberdade para trabalhar e criar. O aluno deve ter a liberdade para cometer enganos, fazer perguntas, contar suas experiências e revelar seus sentimentos reais. Em consequência, o aluno poderá sentir-se auto-realizado e autoconfiante, sentir que seu trabalho é importante em termos de sucesso e por fim sentir emergir de si o verdadeiro significado de liberdade, trabalho e responsabilidade, elementos importantes no processo de aprendizagem em uma sala de aula. (MP-FAI, 1973, p. 12).

Com algumas ressalvas na primeira frase, o trecho acima poderia fazer parte de um discurso em que se defende um ensino mais dialógico; o que sem dúvida, não era o caso do modelo adotado no projeto FAI. Termos como criatividade, experiências (pessoais?) e liberdade parecem não condizer com o método de ensino adotado. No modelo de instrução programada não há espaço para considerar as experiências vividas pelo aluno. Sua visão de mundo não é levada em conta; não propicia momentos de desconstrução e reconstrução de suas interpretações do senso comum sobre determinados fenômenos.

Apresentamos no quadro a seguir, uma síntese de nossa análise nos dois projetos de ensino de Física brasileiros. 
QUADRO 10 - Síntese da análise no PEF e no FAI

\begin{tabular}{|c|c|c|c|}
\hline \multirow[t]{2}{*}{ Dimensões } & \multirow[t]{2}{*}{ Categorias } & \multicolumn{2}{|c|}{ RESULTADOS } \\
\hline & & PEF & FAI \\
\hline \multirow[t]{4}{*}{$\begin{array}{l}\text { Epistemo- } \\
\text { lógica }\end{array}$} & $\begin{array}{l}\text { Ciência } \\
\text { como } \\
\text { processo }\end{array}$ & $\begin{array}{l}\text { Apresenta elementos que evidenciam a } \\
\text { ciência como processo, relaciona a Física } \\
\text { com outras áreas do conhecimento e com } \\
\text { a tecnologia. Traz alguns aspectos } \\
\text { históricos, mas pouco cuida de mostrar a } \\
\text { relação do sujeito com o conhecimento. }\end{array}$ & $\begin{array}{l}\text { A ciência/física é tratada mais como } \\
\text { produto do que como processo. Ciência } \\
\text { neutra, desvinculada da realidade } \\
\text { cotidiana e dos aspectos histórico- } \\
\text { sociais. }\end{array}$ \\
\hline & $\begin{array}{l}\text { A Física e a } \\
\text { experimentaç } \\
\text { ão }\end{array}$ & $\begin{array}{l}\text { Expressiva ênfase experimental, ainda } \\
\text { que com caráter de verificação das } \\
\text { teorias; explicita a existência de um } \\
\text { método científico experimental no } \\
\text { desenvolvimento da Ciência. }\end{array}$ & $\begin{array}{l}\text { Apresenta sugestões de de experimentos, } \\
\text { mas sem dar destaque à experimentação } \\
\text { como um método em Ciência. Não é } \\
\text { foco. Prioriza a teoria. }\end{array}$ \\
\hline & $\begin{array}{l}\text { Modelos } \\
\text { explicativos } \\
\text { formais } \\
\end{array}$ & $\begin{array}{l}\text { Sobressai o formalismo matemático } \\
\text { como descrição dos fenômenos numa } \\
\text { perspectiva similar ao PSSC. }\end{array}$ & $\begin{array}{l}\text { Sobressai o formalismo matemático } \\
\text { como ferramenta de cálculos. }\end{array}$ \\
\hline & $\begin{array}{l}\text { Conteúdos/ } \\
\text { áreas da } \\
\text { Física }\end{array}$ & $\begin{array}{l}\text { Aborda basicamente três grandes temas } \\
\text { (Mecânica, Eletricidade e e } \\
\text { Eletromagnetismo). Articula conceitos, } \\
\text { retoma assuntos, busca certa unidade } \\
\text { lógica. Nível conceitual relativamente } \\
\text { simples, compatível com o nível de } \\
\text { ensino. }\end{array}$ & $\begin{array}{l}\text { Também aborda basicamente três } \\
\text { grandes temas (Mecânica, Termologia e } \\
\text { Eletricidade). Assuntos tratados de modo } \\
\text { mais fragmentado. }\end{array}$ \\
\hline \multirow[t]{2}{*}{ Educativa } & $\begin{array}{ll}\text { Objetivos } & \text { do } \\
\text { ensino } & \text { de } \\
\text { Física } & \end{array}$ & $\begin{array}{l}\text { Apresentar ao aluno a ciência e um } \\
\text { pouco do seu processo de construção. O } \\
\text { ensino é também propedêutico ao } \\
\text { prosseguimento nos estudos, ainda que } \\
\text { não discurse sobre isso. }\end{array}$ & $\begin{array}{l}\text { Função preponderantemente informativa. } \\
\text { Propedêutica. Ensino com características } \\
\text { de treinamento. }\end{array}$ \\
\hline & $\begin{array}{l}\text { Concepção de } \\
\text { aluno/ } \\
\text { Professor }\end{array}$ & 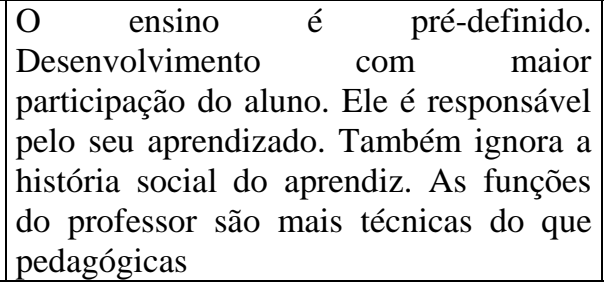 & $\begin{array}{l}\text { O ensino é também pré-definido. O } \\
\text { aluno é o centro do processo de ensino, } \\
\text { sendo praticamente o único responsável } \\
\text { pelo seu aprendizado. Não considera sua } \\
\text { história social e conhecimentos de sua } \\
\text { cultura inicial. O professor tem funções } \\
\text { meramente técnicas. }\end{array}$ \\
\hline
\end{tabular}




\section{OS CURRÍCULOS OFICIAIS ESTADUAIS - ENTRE INOVAÇÃO E CONTINUIDADE - E O QUE DEVERIA SER ENSINADO NAS ESCOLAS PÚBLICAS}

Neste capítulo trataremos dos currículos oficiais de Física (estaduais) elaborados nos termos das legislações vigentes no período investigado.

Conforme mostramos no Capítulo 2, os Estados da federação lograram certa autonomia para definir seus quadros curriculares a partir da LDB/1961, obedecendo algumas restrições impostas pelo poder público federal, na forma da lei. Vimos que isso foi mais ou menos levado a cabo, como por exemplo, na Reforma do ensino do Estado de São Paulo em 1968. A questão da composição do currículo como um conjunto de disciplinas, e demais normas relacionadas à carga horária, distribuição por séries, etc. pareceu bem balizada e compreendida naquele contexto. Entretanto, pouco se falou em "Programas de ensino", nas normas que regulamentaram a LDB/1961 e a Lei 5.692/1971, com exceção da disciplina Educação Moral e Cívica e da prática educativa/atividade Educação Física, que tiveram os seus programas elaborados pelo CFE, e que tratavam de um interesse puramente político, com clara intenção de imposição ideológica, com controle legitimado por lei.

A primeira Lei, a LDB/1961, traz que a atribuição de definição dos programas das disciplinas seria do CFE. Mas como já mencionado anteriormente, este se eximiu de tal encargo restringindo-se a expedir orientações gerais por meio da Indicação de Outubro de 1962, denominada Amplitude e Desenvolvimento das Matérias Obrigatórias. Nesse documento, o CFE deixa evidente que essa atribuição seria das escolas (BRASIL, 1962e, p.01, datilografado).

É interessante observar que, no referido documento, após a informação de que a elaboração dos programas das disciplinas ficaria a encargo das escolas, aparece no item seguinte: “III - É assegurada plena liberdade aos autores de livro didático" (BRASIL, 1962e, p.01, datilografado).

Cabe questionar se esse detalhe no documento foi intencional. Estar-se-ia suscitando que o livro didático poderia (ou continuaria) ser o suporte pedagógico adequado ao desenvolvimento do currículo nas salas de aula? De fato, as pesquisas indicam que tal instrumento pedagógico, há muito tempo, tem sido a forma mais usual de transmitir os conteúdos legitimados como verdadeiros (APPLE, 1997; WUO, 2000) nas escolas das mais diversas realidades educacionais. Referindo-se às décadas de 1960 e 1970, Chiquetto e Krapas 
(2012, p. 178), em uma discussão retrospectiva sobre o currículo de Física do Ensino Médio no Brasil, assumem o pressuposto de que, naquele período, "na falta de um currículo oficial, a referência primária para a disciplina de Física no Brasil foram os livros didáticos".

Não identificamos outras orientações quanto a esta questão em nenhum outro documento do CFE ou do MEC, referente ao período estudado. Talvez, por razão do regime de governo que se fazia, autoritário e centralizador de decisões, e que tomou a educação como lugar de demonstração de força e controle social, não tenha configurado espaço para a elaboração de propostas curriculares de conteúdos por iniciativa das escolas ou das demais instâncias imediatamente superiores, como os Conselhos e Secretarias Estaduais de Educação. O fato é que não identificamos nenhuma proposta curricular de conteúdos de Física, oficial, referente à década de 1960.

No que se refere à Lei 5.692/1971, esta também não determinou uma instância responsável por elaborar os currículos das disciplinas. Não há, em nenhum trecho do corpus documental por nós analisado, um artigo que determine, de forma exata e imperativa, de quem seria essa responsabilidade. O Parecer $n^{\circ} 853 / 1971$ deixa claro que o CFE se abnegou dessa tarefa, antes, na reforma de 1961, e também nessa reforma, mas não esclarece se tal tarefa ficou para os Conselhos Estaduais, Secretarias Estaduais ou para os professores nas escolas. Nesse Parecer, há um indício de que essa responsabilidade ficou para os professores, mas essa determinação não foi colocada na Resolução oriunda do Parecer.

Qualquer, porém, que seja o adiantamento atingido ao longo da escolarização, a integração dos estudos representa, sobretudo uma questão de método a traduzir-se em programas que se entrosem no seu conteúdo e no seu desenvolvimento. Em última análise, será um problema de professores. (BRASIL, 1971c, Documenta $\mathrm{n}^{\circ}$ 132, p. 172).

Com opinião bastante diversa dos conselheiros do CFE, Maia ${ }^{110}$ (1973) critica, veementemente, a ausência de um programa mínimo nacional para o ensino de Física no $2^{\circ}$ grau: “Julgamos indesejável uma tal situação, pois que a existência de um programa mínimo, de âmbito nacional, quando nenhum outro mérito tivesse, teria ao menos o de facilitar a adaptação de alunos que vissem na contingência de se transferirem de uma para outra escola. (MAIA, 1973, p. 13).

Para esse autor, a preocupação com as especificidades regionais teria fundamento quando se tratasse de disciplinas profissionalizantes. Para o caso do ensino de Física para o $2^{\circ}$ grau, sendo disciplina de caráter geral, considerou a flexibilidade do currículo "inteiramente

\footnotetext{
${ }^{110}$ Esse autor esteve por muito tempo envolvido na elaboração de material didático de Física, sobretudo nas décadas de 1960 e 1970, em parceria com o MEC-FENAME. É dele a elaboração dos Cadernos MEC 1 e 2 Física (1969 e 1970) e do Guia Metodológico p/ cadernos MEC - Física (1973).
} 
improcedente, e até mesmo sem significado pedagógico". Afirma ainda que as disciplinas de caráter geral, "por sua própria natureza e finalidade", estão "acima de contingências regionais" (MAIA, 1973, p. 14).

Em nossas buscas identificamos poucas propostas curriculares elaboradas no período em questão. No que concerne ao ensino de Ciências/Física, tivemos acesso aos textos de somente quatro Estados: Minas Gerais (1976) e Paraná (1972-1977), primeiro grau, e São Paulo (1978) e Rio de Janeiro (1977), primeiro e segundo graus. Não se pode afirmar que os demais Estados da Federação não elaboraram suas propostas curriculares. Acreditamos que possam ter ocorrido reformas restritas ao primeiro grau em outros Estados da federação, como as que ocorreram em Minas Gerais e Paraná. Já para o segundo grau, ao que indica, outros Estados brasileiros começaram a elaborar suas propostas curriculares oficiais abrangendo esse nível de ensino somente a partir da década de 1990, como exemplo, Minas Gerais, Paraná, Santa Catarina e Rio Grande do Sul.

A compreensão da Psicologia evolutiva em que se baseou a proposta federal na reforma curricular de 1971 pode ser fator que justifique a dificuldade de desenvolvimento de propostas curriculares pelos Estados da federação, e principalmente, pelos professores. A Psicologia evolutiva foi a proposta de suporte teórico-metodológico para que as escolas ajustassem o currículo com suas composições - matérias, atividades, áreas de estudo e disciplina - nas séries do $1^{\circ}$ e $2^{\circ}$ graus, em função do grau de crescimento psicológico dos alunos.

[...] O desenvolvimento das matérias, "da maior para a menor amplitude", e o seu escalonamento progressivo em "atividades, áreas de estudo e disciplina" estão em consonância com a conceituação destas categorias, curriculares que, por sua vez, refletem as comprovações da Psicologia Evolutiva. A velha marcha "do concreto para o abstrato" apresenta-se hoje — na Psicologia Genética de Piaget, por exemplo - sob a forma tríplice de um período "sensório-motor", seguido de uma fase de "operações concretas" que leva, na adolescência, às "operações formais... móveis e reversíveis". (BRASIL, 1971c, Documenta nº 132, p. 185, grifo aspas do original).

A tradução das ideias da epistemologia genética de Piaget para aplicação nos diferentes conteúdos de ensino não nos parece uma tarefa fácil. Uma simples conceituação nos documentos orientadores - do que representa os estágios de desenvolvimento da criança, conforme a proposição, não se mostra suficiente para que os professores se apossem de uma teoria de grande complexidade como é a de Piaget. A compreensão de tal teoria exige estudos bastante aprofundados, ao ponto de permitir mudança de postura para a adoção de uma prática pedagógica nessa linha; e tais estudos precisariam estar muito bem desenvolvidos nos cursos de formação de professores, ou pelo menos em programas efetivos de educação continuada. Outro fator que pode ser apontado, quiçá a principal razão pelas dificuldades de elaboração de 
currículos de Física, foi a própria mudança de objetivos do ensino médio - a profissionalização. Que Física ensinar para a formação de técnicos, de diversas especificidades ocupacionais, e ao mesmo tempo?

\subsection{Conhecendo as Propostas Curriculares (oficiais) de Física}

Nesta seção apresentaremos os resultados de nossa análise de conteúdo nas Propostas Curriculares de Física (PCF) localizadas no período. Ressalte-se que tal análise foi também direcionada pelos objetivos propostos e expostos na Introdução da presente tese, bem como pelas dimensões/categorias/elementos predefinidos (cf. subseção 1.2.3.1 do Capítulo 1).

No que se refere ao ensino de Física para o segundo grau, localizamos, no período em estudo, somente as propostas do Estado do Rio de Janeiro (1977) e de São Paulo (1978). Começaremos com uma descrição dos aspectos mais gerais de cada proposta, e, em seguida, traremos os resultados de uma exploração mais aprofundada nos aspectos mais internos aos textos, de modo a extrair elementos que evidenciem as visões de ciência e educação registrada nas mesmas, a partir das ideias implícitas e/ou explícitas. Os documentos analisados foram:

RIO DE JANEIRO (Estado). Currículos 2 Reformulação de Currículos, $2^{\circ}$ volume, $2^{\circ}$ Grau (77). Rio de Janeiro, Secretaria de Estado de Educação e Cultura. Niterói, Imprensa Oficial do Estado, 1978.

SÃO PAULO (Estado) Secretaria da Educação. Coordenadoria de Estudos e Normas Pedagógicas. Proposta Curricular de Física para o $2^{\mathbf{0}}$ grau; coord. Ernst W. Hamburger. São Paulo, SE/CENP, 1978.

SÃO PAULO (Estado) Secretaria da Educação. Coordenadoria de Estudos e Normas Pedagógicas. Subsídios para implementação da Proposta Curricular de Física para o $2^{\circ}$ grau; coord. Ernst W. Hamburger. São Paulo, SE/CENP, 1979/1980/1981.

\subsubsection{Aspectos gerais das PCF analisadas}

\section{$\underline{\text { A PCF do Rio de Janeiro }}$}

A proposta curricular de Física do Estado do Rio de Janeiro constituiu parte de uma série de documentos de reforma curricular, para todas as áreas, denominada Reformulação de Currículos, iniciada em 1975, e que teve sua elaboração pelo Laboratório de Currículos vinculado à Secretaria de Estado de Educação e Cultura (SEEC/RJ).

Obtivemos dois documentos relacionados à reformulação do currículo do referido Estado. O primeiro, denominado Currículos 1 Reformulação de Currículo - Síntese (1976), traz as primeiras informações quanto às diretrizes metodológicas e aos conteúdos 
programáticos do Projeto. Segundo consta no livreto, as orientações na íntegra seriam editadas posteriormente. $\mathrm{O}$ outro documento adquirido se refere a um dos documentos posteriormente publicados. Trata-se do título Currículos 2 Reformulação de Currículos, $2^{o}$ Volume, $2^{o}$ grau (1978), com 364 páginas, onde constam os conteúdos programáticos para as disciplinas de Educação Geral, algumas da Parte Diversificada e do curso de Formação de Professores. Embora na última página desse livro conste que sua impressão ocorreu em 1978, a apresentação informa que a implementação em toda a rede escolar do Estado seria a partir de 1977 (no $2^{\circ}$ grau, começando pela $1^{\text {a }}$ série), e em sua capa consta, como imagem ilustrativa, em tamanho grande o número 77, dando a entender que tal material foi elaborado para vigorar a partir do referido ano.
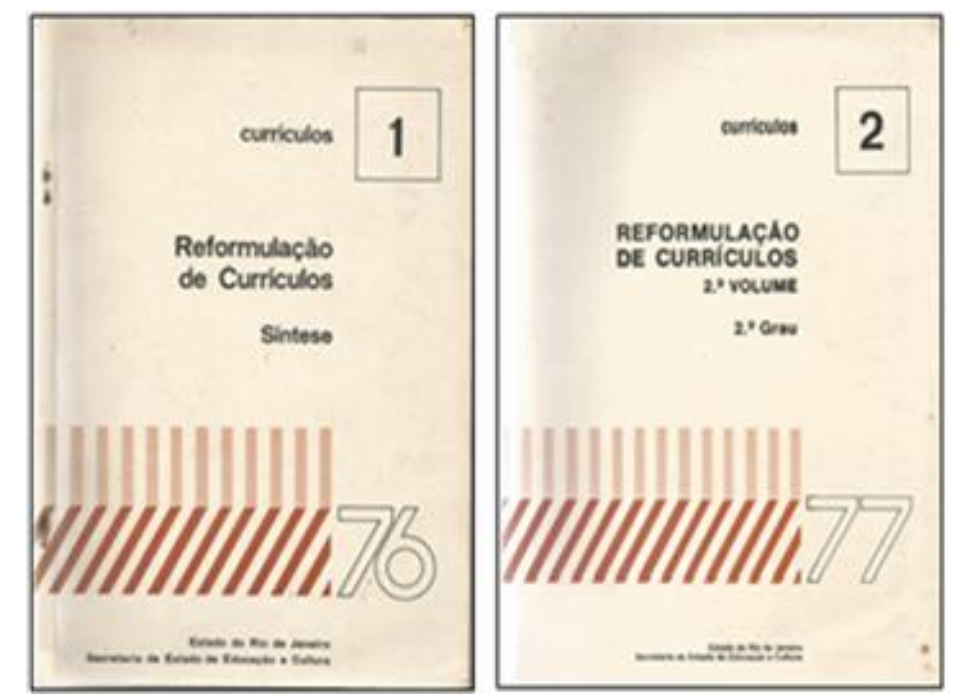

FIGURA 11 - Capa dos documentos localizados referentes à Proposta Curricular do RJ $(1976,1977)$

Segundo nos informa Lobo e Faria (2005), o livro Currículos 1 Reformulação de Currículos - Síntese é o primeiro documento de uma série publicada pela Imprensa Oficial do Estado do Rio de Janeiro, de autoria do Laboratório de Currículo da SEEC/RJ, e destinado aos professores, após um intenso trabalho de mapeamento da situação do ensino de $1^{\mathrm{o}}$ e $2^{\mathrm{o}}$ graus no recém-criado Estado do Rio de Janeiro ${ }^{111}$. Na sequência, publicou-se os volumes da série 2: Currículos 2 Reformulação de Currículos, Pré-Escolar e $1^{\circ}$ Grau - $1^{o}$ volume e Currículos 2 Reformulação de Currículos, $2^{\circ}$ volume, $2^{\circ}$ Grau - este último organizado por disciplinas e Habilitações Profissionais.

As informações de alguns trabalhos que mencionam esses documentos divergem em termos de sequência de publicação dos volumes das propostas, como consta em Rivas (1977)

\footnotetext{
${ }^{111}$ Estado surgido com a fusão dos antigos Estados da Guanabara e do Rio de Janeiro pela Lei Complementar n 20 de $1^{\text {o }}$ de julho de 1974 que determinou a fusão a partir de 15 de março de 1975.
} 
e Faria e Lobo (2005). O que se sabe é que outros textos, em número de oito, referentes ao $1^{\circ}$ grau, foram publicados, organizados por atividades e áreas de estudos ${ }^{112}$. Além desses, foram publicados ainda volumes específicos para os cursos profissionalizantes e outros, sendo ao todo dezesseis títulos, abrangendo as áreas de educação pré-escolar, alfabetização, ensino de $1^{\circ}$ e $2^{\circ}$ graus, formação especial, ensino profissionalizante, proposta metodológica para as seis primeiras séries do $1^{\circ}$ grau, novas metodologias para o ensino rural e ensino de francês no $2^{\circ}$ grau (FARIA; LOBO, 2005).

Atemo-nos às orientações dos dois documentos adquiridos, Currículos 1 Reformulação de Currículo: Síntese; e Currículos 2 Reformulação de Currículos, $2^{o}$ volume, $2^{\circ} \mathrm{Grau}$, com maior atenção ao segundo documento. O primeiro traz as informações teóricometodológicas gerais e grades curriculares. Já o segundo traz, também, uma breve introdução teórico-metodológica, às grades curriculares reformuladas (do primeiro) e os programas de ensino das disciplinas do núcleo comum, e algumas da parte diversificada de formação de professores. Sobretudo, focalizaremos a parte de nosso maior interesse que são as orientações para o ensino de Física, denominada neste texto de PCF/RJ.

A reformulação de currículo do Estado do Rio de Janeiro, na linha das recomendações do Parecer $n^{\circ}$ 853/1971, teve como embasamento teórico as ideias de Jean Piaget, servindo-se de tal teoria para nortear a escolha dos objetivos almejados nos três níveis de ensino: educação pré-escolar, $1^{\circ}$ e $2^{\circ}$ graus.

Apostou-se, em nível de discurso, na metodologia de ensino construtivista com ênfase nas estruturas cognitivas do sujeito aprendiz, partindo das proposições de que tais estruturas não estão, desde sempre, prontas no ser humano, mas que são ativamente desenvolvidas a partir da interação do indivíduo com o meio, por um processo de adaptação em que equilibra assimilação e acomodação; o desenvolvimento das estruturas obedece a estágios de acomodação sucessivos que levam à maturação do organismo, podendo esta ocorrer em maior ou menor grau, estando dependente do meio e do tempo de amadurecimento mental próprio de cada indivíduo (RIVAS, 1977).

Segundo consta na proposta, a organização dos conteúdos está fundamentada em “concepções psicológicas e lógicas” permitindo diversas formas de variações de organização do conteúdo, fundamentado "em ao menos dois aspectos do desenvolvimento atual da ciência: a) o desenvolvimento do educando e, consequentemente, as leis do processo de ensino-

\footnotetext{
${ }^{112}$ Encontramos no Google Books informações de vários volumes das séries de publicações dessa reformulação curricular pelo Laboratório de Currículos da SEEC/RJ, entretanto, indisponíveis para visualização interna do texto. De qualquer forma, foi possível concluir pela existência de diversos volumes para cada nível de ensino.
} 
aprendizagem; b) a estrutura própria de cada campo do conhecimento, dentro da estrutura lógica do conhecimento humano" (RIO DE JANEIRO, 1976, p.17). É notável, no item b, a presença de ideias convergentes com as de Jerome Bruner, identificadas nos projetos de ensino de Ciências/Física das décadas de 1960 e 1970.

Ressaltemos as observações concernentes ao $2^{\circ}$ grau na perspectiva piagetiana:

No nível do $2^{\circ}$ grau, os alunos que tiverem favorecidas, no seu desenvolvimento, as operações concretas, estarão nesse período de vida escolar capacitados para o uso das operações formais. O adolescente é capaz de deduzir operatoriamente a partir de simples hipóteses enunciadas verbalmente. [...] A aplicação dessa proposta metodológica visa à ativação do raciocínio hipotético-dedutivo. (RIO DE JANEIRO, 1977, p. 41).

$\mathrm{Na}$ linha das ideias adotadas, a forma de promover a dedução se daria pelos conteúdos teóricos das Ciências. Por orientação do professor, o aluno poderia identificar "o vocabulário de bases das teorias, suas noções primeiras e noções definidas a partir dessas, os axiomas, as regras lógicas ou de transformação e as proposições derivadas.” (RIO DE JANEIRO, 1977, p. 42).

A organização curricular da proposta da SEEC/RJ abrangeu 10 Habilitações Básicas na parte de Formação Especial, mais o curso de Formação de Professores de $1^{\mathrm{a}}$ a $4^{\mathrm{a}}$ séries. A grade curricular da proposta do $2^{\circ}$ grau é a que apresentamos na FIGURA 12. Os campos da linha de formação especial no quadro da figura a seguir (parte limpa) se referem ao espaço para inclusão das disciplinas das Habilitações Básicas que, por sua vez, se apresentam dispostas em pequenos quadros curriculares separados no documento de Reformulação de Currículos. Segundo a SEEC/RJ, dispôs-se assim para evitar a repetição de toda a grade para cada habilitação básica, no documento.

Importa ressaltar que nesta organização curricular não traz a área de estudo CFB, que seria tratada como disciplina no $2^{\circ}$ grau, seguindo as orientações da Resolução nº 08/1971. Tal área/disciplina já aparece desmembrada em subáreas (as disciplinas científicas específicas) na parte de Educação Geral. 


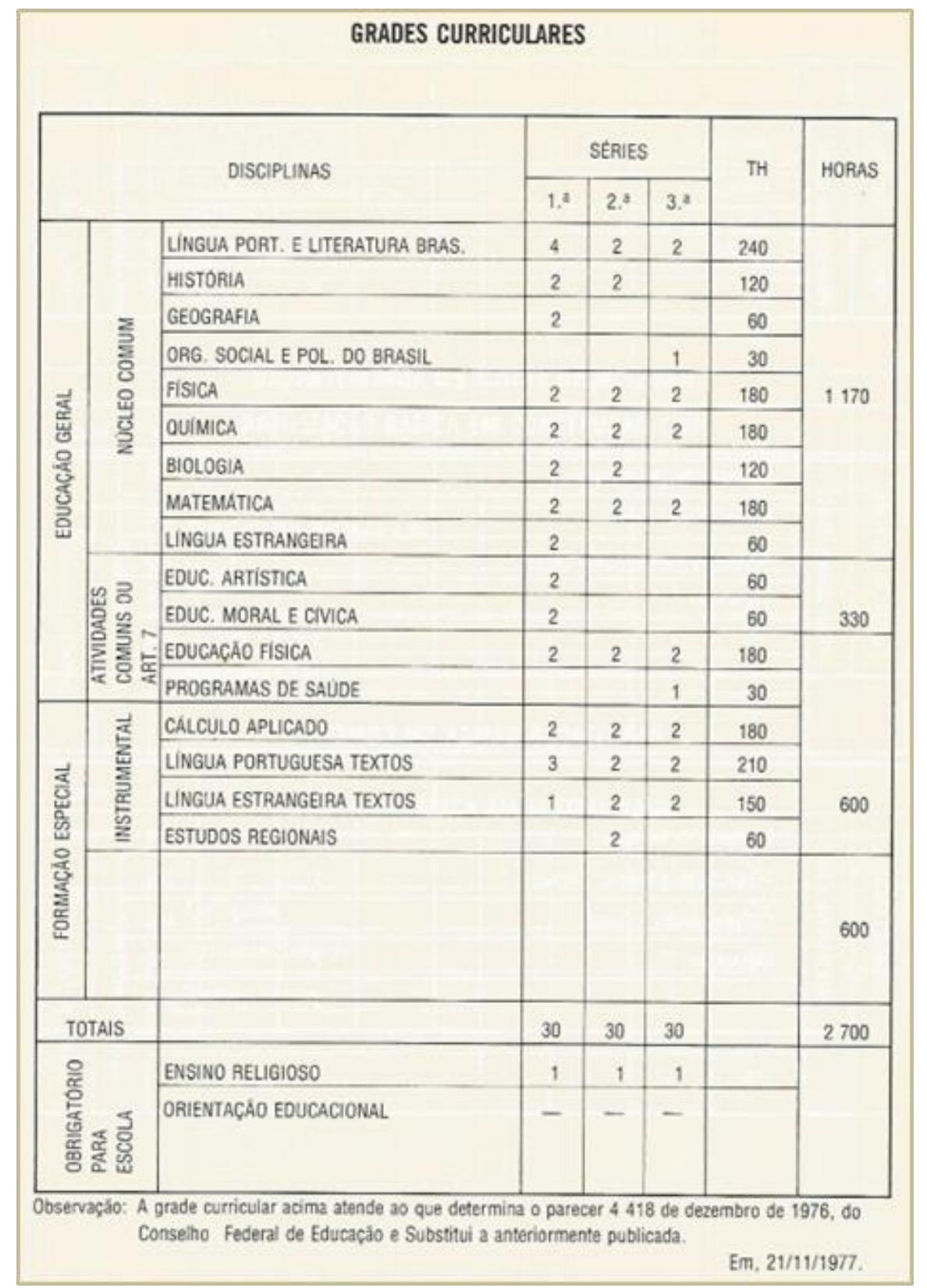

FIGURA 12 - Grade curricular do $2^{\circ}$ grau na Reformulação de Currículo do Estado do Rio de Janeiro, em 1977.

Fonte: RIO DE JANEIRO, 1977, p. 45.

Como pode ser observado no quadro, a carga horária destinada à Física nesse

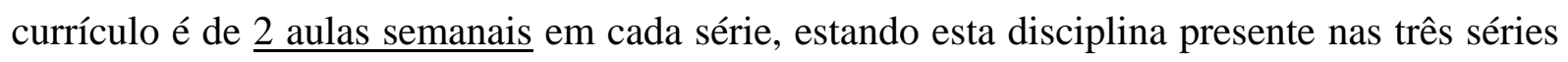
do $2^{\circ}$ grau. As outras disciplinas científicas também aparecem com duas aulas semanais, entretanto, uma delas, a Biologia, não está presente em todas as séries. Nota-se que, a partir da $2^{\mathrm{a}}$ série, algumas disciplinas da Formação Geral saem do currículo, indicando ser para acomodar outras da parte de Formação Especial, uma vez que, em todas as grades curriculares das Habilitações Básicas, as disciplinas estão previstas a partir da $2^{\text {a }}$ série. Um tema da Física aparece como disciplina na parte de Formação Especial, em uma das 10 habilitações básicas adotadas pela SEEC/RJ, conforme mostra a grade curricular abaixo: 


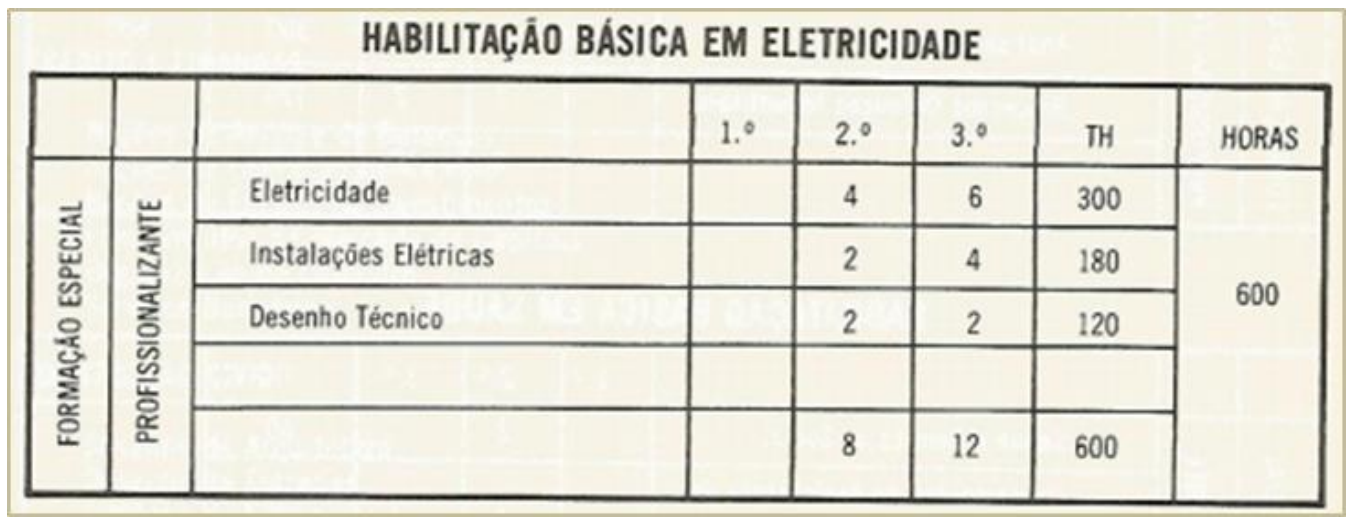

FIGURA 13 - Grade curricular da parte de Formação Especial referente à Habilitação Básica Eletricidade, do $2^{\circ}$ grau do Estado do Rio de Janeiro, 1977.

Fonte: RIO DE JANEIRO, 1977, p. 47.

A Física aparece ainda no quadro curricular do curso de Formação de Professores, sem indicação da carga horária específica de cada disciplina. Adotou-se para esse curso o sistema de créditos, de modo que um conjunto de oito disciplinas do núcleo comum comporta 62 créditos (930 horas). O núcleo comum é praticamente o mesmo dos cursos das Habilitações Básicas, com exceção de Língua Estrangeira, que neste passou para a parte instrumental. Pensando em uma média de carga horária, pode-se considerar que a Física não logrou espaço maior do que o dos cursos das Habilitações Básicas. É possível que tenha sofrido redução, como indica o próprio documento: "A carga horária relativa às disciplinas de Educação Geral para o curso de Formação de Professores teve de ser reduzida, em relação à dos currículos de Habilitações Básicas, devido à diferença da natureza dos cursos." (RIO DE JANEIRO, 1977, p. 274).

O texto traz, na sequência dos quadros curriculares, as diretrizes gerais por áreas. No caso, a matéria Ciências é tratada como área desdobrada em disciplinas, e as diretrizes vêm com o título: Diretrizes Gerais para as Disciplinas da Área Ciências. Em pouco mais de uma lauda, apresentam-se alguns pressupostos teóricos que embasaram a elaboração dos programas das disciplinas das Ciências. Na sequência, apresenta os quadros com os conteúdos programáticos das disciplinas Matemática, Física, Química, Biologia e Programa de Saúde. Os quadros trazem Objetivos, Conteúdos Programáticos e Sugestões de Estratégias, dos quais, para a Física dispomos o quadro completo no ANEXO VI. Mais adiante (Quadro 11) apresentamos a relação dos conteúdos propostos.

A proposta não traz um currículo de Física específico para o curso de Formação de Professores, visto que Física está na Educação Geral nessa habilitação, no núcleo comum. Não tivemos acesso ao volume que traz os conteúdos programáticos das disciplinas profissionalizantes (Formação Especial das Habilitações Básicas). Assim, não apresentaremos análise dos conteúdos programáticos da disciplina Eletricidade. 
Não identificamos material didático como suporte pedagógico para execução da proposta curricular elaborado pelo Estado do Rio de Janeiro. Desse modo, nosso olhar recai sobre as diretrizes gerais para a área de Ciências, o texto de apresentação dos conteúdos e o quadro que traz os objetivos específicos, a lista de tópicos da Física e instruções aos professores (sugestões de estratégias). Tentamos extrair elementos que revelem a visão de educação e ciência na proposta do currículo.

\section{$\underline{\text { A PCF do Estado de São Paulo }}$}

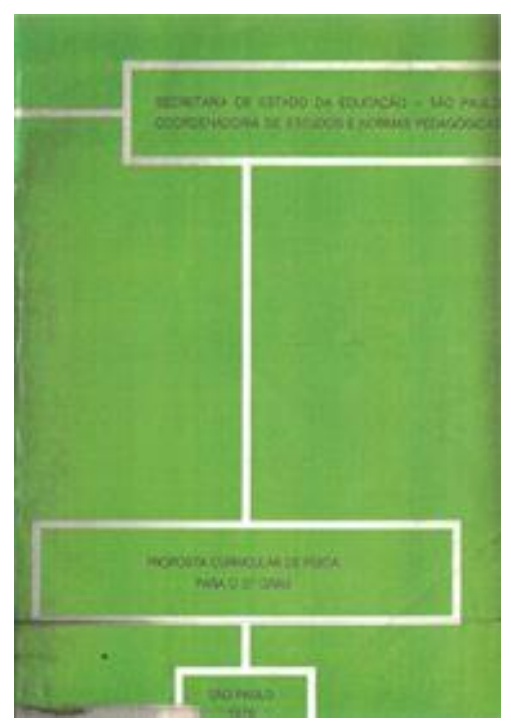

FIGURA 14 - Capa da PCF/SP (1978)

A proposta curricular de Física para o $2^{\circ}$ grau do Estado de São Paulo (PCF/SP) foi organizada por áreas, sendo a de Física por uma equipe coordenada pelo Professor Ernst W. Hamburger, e publicada em 1978 pela SEE/SP, em volume isolado.

O Capítulo I do texto da proposta curricular traz informações sobre a presença da Física na Educação Geral e na Formação Especial; número de aulas semanais; explicação sobre a seleção dos conteúdos nas séries; orientação metodológica; importância dos experimentos; pré-requisitos; relação da Física com as outras matérias ${ }^{113}$; sugestões de bibliografias de pesquisa sobre o ensino de Física e Planejamento do curso.

O texto da proposta se inicia com esclarecimentos sobre a configuração da Física na Educação Geral integrando o núcleo comum, e na Formação Especial como conteúdo instrumentalizado e também como conteúdo específico profissionalizante.

\footnotetext{
${ }^{113} \mathrm{O}$ termo "matérias" é mencionado na proposta com sentido de disciplinas.
} 
Buscando justificar a apresentação da Física como disciplina científica desmembrada de CFB, coloca:

Certos autores, e inclusive certos textos legais, preconizam o ensino de "Ciência Integrada" em substituição às disciplinas científicas de Física, Química e Biologia e Matemática. Entretanto, esta integração é muito controvertida, havendo muitos pronunciamentos contrários. Parece-nos que seria prematuro, se a "Ciência Integrada" fosse adotada repentinamente em todo o Estado, já porque não há professores preparados para ministrar tal disciplina. (SÃO PAULO, 1978, p. 13).

A colocação acima, trazida na proposta, evidencia que houve resistências quanto às recomendações do Parecer $n^{\circ}$ 853/1971 e Resolução ${ }^{\circ}$ 08/1971 referente à disciplina CFB no ensino de $2^{\circ}$ grau. Isso justifica a inconsistência entre as organizações curriculares por nós identificadas, e o texto das normas. Cabe lembrar que, conforme frisamos no Capítulo 2, a disciplina Física, na forma desmembrada da CFB, não estava prevista como componente do núcleo comum, mas sim da parte diversificada da Educação Geral para o sistema federal de ensino $^{114}$ até 1986, quando a Resolução $\mathrm{n}^{\circ}$ 06/1986 veio alterar e revogar a doutrina de currículo nos termos da Resolução nº 08/1971, passando as disciplinas específicas Física, Química e Biologia a configurarem no núcleo comum com tais nomenclaturas.

A distribuição da carga horária semanal da Física nas suas três configurações, por série e formação profissionalizante, é apresentada conforme a Tabela 2 adiante, transcrita na íntegra do documento oficial.

TABELA 2 - Número de aulas por semana de Física, Física Aplicada e Eletricidade para as diversas modalidades de escola do $2^{\circ}$ grau do Estado de São Paulo.

\begin{tabular}{|c|c|c|c|c|}
\hline & \multicolumn{3}{|c|}{$\begin{array}{l}\text { FORMAÇÃO } \\
\text { BÁSICA }\end{array}$} & \multirow{2}{*}{$\begin{array}{l}\text { HABILITAÇÃO } \\
\text { PARA O } \\
\text { MAGISTÉRIO } \\
\text { Magistério }\end{array}$} \\
\hline & $\begin{array}{l}\text { Setor } \\
\text { Primário }\end{array}$ & $\begin{array}{l}\text { Setor } \\
\text { Secundário }\end{array}$ & $\begin{array}{l}\text { Setor } \\
\text { Terciário }\end{array}$ & \\
\hline $1^{\circ}$ Ano & $\begin{array}{l}\text { Física } \\
2\end{array}$ & $\begin{array}{l}\text { Física } \\
2\end{array}$ & $\begin{array}{l}\text { Física } \\
2\end{array}$ & $\begin{array}{l}\text { Física } \\
2\end{array}$ \\
\hline $2^{\circ}$ Ano & $\begin{array}{l}\text { Física } \\
\text { Aplic. } \\
3\end{array}$ & $\begin{array}{l}\text { Física } \\
\text { Aplic. } \\
3\end{array}$ & $\begin{array}{l}\text { Física } \\
2\end{array}$ & $\begin{array}{l}\text { Física } \\
2\end{array}$ \\
\hline $3^{\circ}$ Ano & $\begin{array}{l}\text { Física } \\
\text { Aplic. } \\
3\end{array}$ & $\begin{array}{l}\text { Física } \\
\text { Aplic. } \\
4\end{array}$ & - & - \\
\hline & - & $\begin{array}{l}\text { Eletric. } \\
2\end{array}$ & - & - \\
\hline
\end{tabular}

Fonte: SÃO PAULO, 1978, p. 10 (transcrita como a original)

Nessa organização curricular, nota-se que foi dado maior relevo à Física como disciplina instrumental em duas das três modalidades de curso, uma vez que esta aparece com maior carga horária (Física Aplicada). Esse caráter instrumental dado às disciplinas

\footnotetext{
${ }^{114}$ Parecer n ${ }^{\circ} 871 / 1972$.
} 
científicas, a partir da reforma de 1971, segundo Krasilchik (2000), representou uma descaracterização da função de tais disciplinas no currículo.

A organização curricular por setor se respalda no Parecer $n^{\circ} 45 / 1972$ e Parecer $n^{\circ}$ 76/1975, que listam um grande número de habilitações básicas como opção de profissionalização obrigatória para o $2^{\circ}$ grau.

O setor primário acomoda as habilitações básicas relacionadas às atividades de produção através da exploração de recursos naturais (agricultura, mineração, pesca, pecuária, etc.). O Setor Secundário se refere às Habilitações Básicas que representam na economia a transformação das matérias-primas (produzidas pelo setor primário) em produtos industrializados (roupas, máquinas, automóveis, alimentos industrializados, eletrônicos, casas, etc). Ressalte-se que, nas habilitações relacionadas a estes dois setores, os conhecimentos científicos são de relevância incontestável, de modo que a Física possui papel primordial na atuação deles, tanto na exploração dos recursos naturais, quanto na produção e no produto final de bens de consumo duráveis e não duráveis. Talvez por esta razão, na proposta curricular paulista fez-se a opção de conceder maior carga horária à Física Aplicada, e não atribuir essa disciplina na $3^{\text {a }}$ série das Habilitações do Setor Terciário e Magistério. O Setor Terciário está relacionado à prestação de serviços (comércio, educação, saúde, serviços de limpeza, serviços de alimentação, turismo, transportes, telecomunicações, etc.).

O embasamento teórico da proposta curricular do Estado de São Paulo indica ser, pelo menos em parte, o mesmo da proposta do Estado do Rio de Janeiro, ou seja, a psicologia evolutiva. Embora o documento da proposta curricular de Física não apresente uma fundamentação teórica, é possível identificar nuances da teoria piagetiana, quando diz: “As atividades de laboratório devem estar intimamente ligadas às atividades teóricas para facilitar a passagem do pensamento concreto para o formal" (SÃO PAULO, 1978, p. 12).

Tal proposta se referencia em alguns pressupostos metodológicos do Projeto de Ensino de Física (PEF), e também no PSSC, especialmente no que alude às atividades experimentais, inclusive sugere a utilização de alguns aparatos que fazem parte dos referidos projetos: marcador de tempo, cronômetro de areia, tatuzinho no tubo de vidro, etc..

Nota-se ainda uma preocupação com o conteúdo, ou seja, a estrutura do conhecimento físico, seguindo a linha dos projetos de ensino.

$\mathrm{O}$ ensino de Física no $2^{\circ}$ grau usualmente exige muitos pré-requisitos que deveriam ter sido adquiridos no $1^{\circ}$ grau. Entretanto, a experiência de muitos professores vem mostrando que grande parte dos alunos que ingressaram no $2^{\circ}$ grau têm lacunas em sua formação. É conveniente que o professor comece o ano letivo fazendo uma avaliação de pré-requisitos para levantar o perfil da classe. (SÃO PAULO, 1978, p. 12). 
Sugere como bibliografias sobre o ensino de Física, os trabalhos dos $\mathrm{SNEF}^{115}$ e as publicações da Revista Brasileira de Ensino de Física e Revista "Ciência e Cultura". Tais sugestões denotam certa expectativa em relação ao professor, quanto à mudança de postura, procurando incentivá-lo a ter contato com o campo das pesquisas em ensino de Física. Ao longo do quadro de conteúdo curricular são mencionadas, várias vezes, os projetos de ensino de Física da década de 1960 e 1970 (PSSC, IPS, PEF, FAI, PBF ${ }^{116}$ ), especialmente no que se refere aos aparatos experimentais desses projetos, que são sugeridos para utilização. Cita ainda como referência bibliográfica o livro "Física" dos autores Udmir Pires Santos e Lenine Riguetto.

Quanto ao planejamento do curso, é explicada a forma de apresentação dos quadros de programação que vêm nos capítulos III, IV e V da proposta. Explica a distribuição dos temas e tópicos de conteúdos esclarecendo que cada quadro/bloco corresponde de 1 a 4 aulas para execução, sendo possível ser trabalhado em até 2 semanas, considerando a carga horária de duas aulas semanais. Os quadros apresentados nos capítulos III, IV e V estão organizados da seguinte forma: $1^{\mathrm{a}}$ coluna - assunto; $2^{\mathrm{a}}$ coluna - objetivos; $3^{\mathrm{a}}$ coluna - sugestão de atividades. Essa estruturação é similar a da Proposta Curricular do Rio de Janeiro, com apenas inversão de colunas, no que se refere ao assunto e objetivos. A proposta apresenta em seu capítulo II, a divisão dos conteúdos - lista de tópicos dos temas gerais - por série e curso. Transcrevemos a seguir tal divisão em temas, suprimindo os tópicos, para uma visualização mais clara da distribuição destes por série na FORMAÇÃO PROFISSIONALIZANTE BÁSICA E HABILITAÇÃO PARA O MAGISTÉRIO.

1 Série (Setor Primário - Setor Secundário - Setor Terciário - Magistério): MECÂNICA I

$2^{\circ}$ Série - (Setor Primário e Setor Secundário): MECÂNICA II; TERMOLOGIA Para o setor primário poderá substituir TERMOLOGIA por CALOR E GASES HIDROSTÁTICA ou ÓTICA GEOMÉTRICA - ONDAS [de acordo com os tópicos de conteúdos dos blocos listados para o Setor Terciário e Magistério];

(Setor Terciário e Magistério): Escolher 4 blocos, dentre os 8, considerando um por bimestre: A - ELETRICIDADE; B- ELETROMAGNETISMO; C - CALOR E GASES; D- ÓTICA GEOMÉTRICA; E - ONDAS; F- HIDROSTÁTICA; GGRAVITAÇÃO; H - VETORES - QUANT. DE MOVIMENTO - COLISÕES.

$3^{\circ}$ Série - (Setor Primário): ELETROSTÁTICA; ELETRODINÂMICA; ELETROMAGNETISMO;

Setor Secundário: ELETROSTÁTICA ; ÓTICA GEOMÉTRICA; OSCILAÇÕES, ONDAS E ÓTICA FÍSICA.

(PCF/SP, 1978, p. 15-16)

\footnotetext{
115 Simpósio Nacional de Ensino de Física

${ }^{116}$ Referindo-se à unidade Eletricidade do Projeto Brasileiro para Ensino de Física (PBEF) publicado com o título de Projeto Brasileiro de Física (PBF), em 1973.
} 
Nesta primeira divisão, os tópicos dos temas acima colocados são apresentados ainda de forma mais geral. Nos quadros do Planejamento Curricular trazidos nos capítulos III, IV e $\mathrm{V}$ da proposta curricular, os temas/tópicos são um pouco mais detalhados. Por exemplo, a lista de conteúdos para a $1^{\text {a }}$ série aparece nesta primeira divisão em 13 tópicos (omitidos na lista acima); já no quadro de Planejamento Curricular, a lista de tópicos contém 25 itens (assuntos) conforme apresentaremos mais adiante.

Na próxima seção, apresentaremos os resultados de uma análise mais minuciosa dos quadros de Planejamento Curricular completos ${ }^{117}$ (o planejamento mais detalhado apresentado na proposta curricular), a partir das categorias de análises que pré-definimos. Tal análise inclui ainda os cadernos de atividades publicados pela Coordenadoria de Estudos e Normas Pedagógicas da Secretaria de Estado da Educação de São Paulo, entre 1979 e 1982, como suporte pedagógico para implementação da proposta. Tais cadernos, que consistem em uma coletânea de atividades dirigida ao professor, estão estruturados em oito ${ }^{118}$ volumes. O enfoque desse material é a atividade experimental. Apresentam breves resumos dos tópicos de conteúdos com predomínio de roteiros de atividades experimentais trazendo procedimentos detalhados.

Os títulos gerais de cada volume são: Volume 1 - Medidas e Movimento (1978); Volume 2 - Forças e Energia (1978); Volume II - Quantidade de Movimento e Gravitação (1978); Volume IV - Termologia (1978); Volume V - Óptica Geométrica (1979); Volume VI - Ondas e Óptica Física (1979); Volume VII - Eletrodinâmica (1981) e Volume VIII Eletromagnetismo e Eletrostática (1982).

Ainda que os dois últimos volumes tenham sido publicados no início da década de 1980, são também nossas fontes de estudo, já que os mesmos se referem ao suporte pedagógico da proposta curricular da década anterior.

\subsubsection{As dimensões Epistemológica e Educativa nas Propostas Curriculares}

No que tange a proposta curricular de Física do Estado do Rio de Janeiro (PCF/RJ), nossa análise de conteúdo focou o texto das diretrizes relacionadas às disciplinas da área de Ciências; o pequeno texto de apresentação dos conteúdos programáticos de Física e o quadro

\footnotetext{
${ }^{117}$ A princípio cogitou-se trazer esses quadros completos da PCF/SP em um anexo deste texto, entretanto, pela extensão do documento, optamos por suprimi-lo. A versão desse documento pode ser localizada no acervo da Biblioteca da Faculdade de Educação da Universidade de São Paulo, Campus Butantã - SP.

${ }^{118} \mathrm{Na}$ apresentação do Volume I - Medidas e Movimento consta que seriam nove volumes. No entanto, publicaram-se oito, uma vez que se juntou ao tema Eletrostática, previsto incialmente para um volume, com Eletromagnetismo.
} 
de conteúdos da Física para o $2^{\circ}$ grau. Para a proposta curricular do Estado de São Paulo (PCF/SP), consideramos o texto da proposta (O livreto), o quadro de Planejamento Curricular contido nele, e os cadernos de atividades (SPCF/SP).

\section{Da dimensão epistemológica}

\section{Ciência como Processo}

As Diretrizes Gerais para as Disciplinas da Área Ciências da PCF/RJ apontam as diferentes abordagens utilizadas na introdução dos alunos ao ensino de Ciências, argumentando que tais abordagens dependem da posição que se tem em relação ao conhecimento científico. As abordagens são assim colocadas:

a) Se o conhecimento dos fatos naturais e das leis que os regem são aquisições exógenas apreendidas passivamente pelo sujeito, através da observação desses fatos, a experiência científica se origina e permanece no nível do empírico e o método científico ficaria restrito à indução. Seria suficiente a apresentação aos alunos do conhecimento estruturado, facilitando-se sua incorporação através de instrumentos programados ou recursos audiovisuais.

b) Se, ao contrário, considera-se que a Ciência é uma construção progressiva em que a atividade do sujeito tem papel destacado, poderá haver uma tendência inatista em que as estruturas que permitem o conhecimento e o raciocínio lógico estariam pré-moldados desde o nascimento do indivíduo, aparecendo em um momento determinado, havendo então pouco a ser elaborado pela educação.

c) Outra tendência é considerar que a capacidade de criar a Ciência se desenvolve nos indivíduos gradativamente através de etapas necessárias que permitem formar determinadas estruturas cognitivas até chegar a operar sobre hipóteses, ultrapassando a pura percepção. (RIO DE JANEIRO, 1977, p. 196)

As formas de abordagens são mencionadas como uma reflexão crítica e chamam a atenção para a última, que, embora possibilite um desenvolvimento constante e contínuo dos alunos na aprendizagem dos conhecimentos científicos, é reconhecida na proposta como uma tarefa difícil de ser cumprida.

A princípio, a concepção de ciência processual é claramente presente no discurso das diretrizes, restando saber se tal discurso foi levado a termo na forma como se propôs os conteúdos no currículo das disciplinas. A compreensão da natureza do trabalho do cientista seria prejudicada pela
apresentação do conhecimento pronto, pelo professor, como algo de acabado e
absoluto, seja através de aulas expositivas, seja através de demonstrações de
"experiências". (RIO DE JANEIRO, 1977, p. 196).

Ressalte-se a presença de concepções condizentes com as de Karl Popper no discurso sobre o método das ciências, e que acaba por considerá-la um processo linear, com acúmulo 
gradativo dos conhecimentos, algo que é contestado por outros filósofos, como Thomas Kuhn, por exemplo.

O domínio prévio de um vocabulário básico, específico de cada Ciência, a compreensão da relação entre seus axiomas e a etapa experimental que verifica as hipóteses, confirmando-as ou refutando-as, facilitarão a compreensão da Ciência como instrumento que cada vez mais se aperfeiçoa, para a explicação do Universo. (RIO DE JANEIRO, 1977, p. 196).

Adotam-se ideias híbridas sobre o conceito de método científico, quando afirma que a compreensão dos fenômenos elementares das Ciências pode ser obtida "através da combinação de dados da experiência e raciocínio dedutivo, isto é, depois de passarem os alunos por estágios em que proporão soluções que posteriormente parecerão errôneas a eles próprios." (RIO DE JANEIRO, 1977, p. 196). Contradizendo o que trazem as diretrizes, na Apresentação dos Conteúdos Programáticos de Física na PCF/RJ, nota-se a ideia de ciência como um produto pronto, rematado, para ser transmitido e, quando muito, "comprovado" por meio de experiências simples ou percebido em algumas coisas cotidianas.

Espera-se que o aluno familiarize-se com o Método das Ciências: identificação de um vocabulário básico das teorias, as suas noções iniciais e as definidas a partir destas. Os axiomas, as regras lógicas e as suas consequências. A fase de comprovação, a experiência, pode ter como laboratório, na maioria das vezes, a própria Natureza e a criatividade dos professores e dos alunos. (RIO DE JANEIRO, 1977, p. 215)

A PCF/RJ, por iniciar com os tópicos: "o que é Física", "O fenômeno físico" e "O modelo da Física", implicitamente, suscita a possibilidade de discutir aspectos históricos dessa ciência ao desenvolvê-los. Entretanto, os objetivos colocados para tais tópicos dispersam tal possibilidade: "Conceituar a Física como Ciência da Natureza; Diferenciar um fenômeno físico de um químico ou biológico" (p.216). Nada é sugerido sobre abordagem de aspectos históricos.

A ausência de elementos históricos desvela a concepção de ciência como produto e não como um processo dinâmico que envolve pessoas em debates que ultrapassam a questão espaço-temporal, e também de ideias condicionadas à cultura, à política e à economia de uma sociedade em um dado momento da história. A proposta pouco recomenda relacionar a Física às tecnologias mais amplas, que fazem parte da vida cotidiana dos alunos, bem como as relações dos fenômenos com as questões de ordem política, econômica e social. Ainda que não existissem naquela época os Smartfones, dispositivos tão comuns na vida dos adolescentes atualmente, mas já existia a TV em cores, telefones, aparelhos de vídeo K7, geladeira, e outras tecnologias. Essas relações são timidamente sugeridas em alguns trechos - 
nos objetivos ou nas sugestões de estratégias de ensino ou de atividades - dos documentos, como por exemplo:

Utilizar os resultados da Física sempre que possível em situações do dia-a-dia. (PCF/RJ, p. 215).

Por meio da projeção de slides e filmes mostrar as diversas formas de utilização da energia elétrica na vida cotidiana. (PCF/RJ,p.224).

Debater sobre as contribuições da conquista do espaço a partir de artigos impressos, filmes, slides, etc. (PCF/RJ,p. 218).

Saber calcular os gastos de energia sabendo o . $^{\circ}$ de KWh e o preço do mesmo. (PCF/RJ,p. 224).

Interessante observar o tratamento dado à convenção adotada para diferenciar cargas elétricas, ou seja, o conceito de que "cargas elétricas de mesmo sinal se repelem e as de sinais contrários se atraem". A Lei de Du-Fay ${ }^{119}$ é colocada como um dos tópicos da unidade Constituição da matéria. Parece-nos um exagero enfatizar o "enunciar" dessa lei como um tópico da unidade, em detrimento de tantas outras possibilidades de propor o desenvolvimento do tema eletricidade estática de forma mais significativa. Conforme já ressaltado, a proposta não contempla contextualização histórica dos fenômenos. Poucos livros mencionam esse conceito como Lei de Du-Fay, e, possivelmente, muitos professores de Física nem sabiam [ou sabem?] quem foi esse cientista. Que significado teria "Enunciar a Lei de Du-Fay e aplicá-la a casos simples"? Ainda cabe o questionamento sobre como seria a aplicação dessa lei a casos simples. Não esclarece se seria em problemas matemáticos [qual tipo? Lei de DuFay/Coulomb?] ou em situações cotidianas em que se pode observar a atração/repulsão entre corpos eletrizados.

Esses questionamentos se aplicam a outras situações em que propõe "Enunciar a lei de [fulano de tal]...”, mas nada propõe sobre a contextualização histórica e conflitos de ideias na construção dos conhecimentos sobre os fenômenos estudados pelos "descobridores" de tais leis. De um modo geral, a proposta suscita que enunciar uma lei seria apresentá-la na forma de equação para aplicação em problemas numéricos, ou uma frase para memorizar um conceito.

A contextualização com a realidade mais imediata é mais ou menos incentivada na PCF/RJ. Citemos alguns elementos presentes:

Procurar na construção civil material para que seja compreendido o conteúdo da unidade. (PCF/RJ, p. 219). [se referindo à Unidade Sistema de muitas partículas].

\footnotetext{
${ }^{119}$ A formulação desse conceito é atribuída ao Químico francês Charles Du-Fay, que "descobriu”, em 1737, a eletricidade positiva e negativa, e descreveu pela primeira vez em termos de cargas elétricas a existência de atração e repulsão (BOSS; CALUZI, 2007).
} 
Organizar um quadro mural que demonstre a utilização da dinâmica na vida diária. (PCF/RJ, p. 217).

Por meio da promoção de palestras sobre a ótica elementar do olho humano familiarizar os alunos com os principais defeitos de visão, sua correção e os métodos preventivos. (PCF/RJ, p. 220). [se referindo à Unidade Ótica Geométrica].

Por meio da projeção de slides e filmes, mostrar as diversas formas de utilizações de energia elétrica na vida cotidiana; Familiarizar os alunos com o manuseio de resistores, inclusive montagem e desmontagem de um ferro ou chuveiro elétrico; Mostrar circuitos em curto para que os alunos sintam os perigos das ligações mal feitas, mostrando como evitar e porque ocorrem curtos-circuitos. (PCF/RJ, p.224).

A relação da ciência/Física com a cultura e com outras grandes áreas do conhecimento é praticamente ignorada; e com outras disciplinas da mesma grande áreaCiências - em que se insere a Física, se restringe à Matemática.

Na PCF/SP, a visão de ciência pode ser extraída dos objetivos, estratégias de ensino e dos cadernos de atividades, que foram elaborados para subsidiar a proposta, sendo um pouco mais explícita neste último componente da orientação curricular. A maioria dos volumes dos cadernos de atividades inicia-se com uma síntese teórica, seguido das atividades experimentais, geralmente precedidas de um texto de fundamentação e estruturadas em objetivos, pré-requisito, material, orientação ao professor, introdução, procedimento, respostas às questões e complementação.

Há volumes da coletânea que iniciam diretamente com os roteiros de atividades experimentais, sem síntese teórica, como é o caso dos dois últimos. Elementos que retratam a visão de ciência expressa na proposta é um pouco mais presente na síntese teórica do primeiro volume da coletânea, contudo ainda de forma bastante ínfima. Nos demais volumes, as fundamentações trazem apenas conceitos e equações denotando um caráter instrumental para o ensino de Física. Na verdade, a ausência de situações que evidenciam a visão de ciência, acaba por denunciá-la, como uma visão de construção de um conhecimento neutro, com supressão dos sujeitos, desvinculado da realidade cotidiana, sem processo histórico.

O volume I - Medidas e movimento - inicia, em sua síntese teórica, conceituando a Física como "ciência fundamental da natureza" (p. 03). Aponta os sentidos humano como ponto de partida para descrever os fenômenos, revelando assim uma concepção indutivista sobre o método de construção do conhecimento.

A proposta não contempla explicitamente a contextualização histórica, ou seja, não propõe abordagem sobre a história da ciência, de modo a mostrar a ciência como um processo de evolução de ideais sobre a natureza. 
Alguns poucos objetivos ou temas suscitam a possibilidade de abordar a história da construção do conhecimento em Física, entretanto de forma muito implícita. Não sugere tópico para conceituação da ciência/Física e inicia a Mecânica pelo estudo de gráficos a partir de medidas. Pontos que suscitam possibilidade de uma abordagem histórica se restringem a: “Explicar as teorias ondulatória e corpuscular da luz.” (PCF/SP, p. 38) e "Descrever teorias que antecederam as de Kepler e Newton." (PCF/SP, p. 43 e 50).

De modo mais explícito, apresenta um único ponto que pode ser classificado como elemento histórico, na apresentação do tema Calor e Trabalho, quando fala da evolução do conceito de calor.

A relação com a tecnologia se apresenta de forma ínfima, similar à PCF/RJ. Identificamos estes poucos pontos.

Reconhecer os resultados de projetos como o "Projeto Apollo" e outros; Reconhecer a utilização de fotografias obtidas por satélites (por ex: previsão de tempo). (PCF/SP, p. 44)

Discutir o funcionamento de uma hidrelétrica. (PCF/SP, p. 35).

A Física é a grande responsável pelo aparecimento de novos e mais precisos instrumentos, que tornam seus usuários cada dia mais competentes em aplicações e diagnósticos, através da interpretação dos resultados das medidas. (SUBSÍDIOS...PCF/SP, VOL. I, p. 03).

A relação com o cotidiano mais próximo de uma realidade possivelmente vivida pelo aluno, na PCF/SP, se resume a: "Descrever o olho humano; Caracterizar os principais defeitos da visão e suas correções [em aplicações dos instrumentos ópticos]” (p.39 e p. 63); e "Reconhecer as fontes de energia consumida pela população" (p.54).

A PCF/SP também não relaciona ciência/Física com a cultura. Contudo, no que se refere à articulação com outras disciplinas da mesma grande área e até mesmo outras grandes áreas do conhecimento, a proposta ressalta essa importância, pelo menos em nível de discurso. O texto introdutório da proposta (Capítulo I) incentiva o trabalho interdisciplinar entre a Física e outras disciplinas científicas e também das humanidades. Indica como possibilidade, por exemplo, o entrosamento com a Matemática ao ensinar os conteúdos de Movimento uniforme (funções lineares e proporcionalidade) e Movimento uniformemente variado (Trinômio do $2^{\circ}$ grau). Com a Química, sugere como exemplo o estudo da Lei dos Gases, que pode ser trabalhado tanto em uma quanto na outra, e, com a Biologia e Química, o estudo da Energia em suas várias formas (PCF/SP, p.13). 


\section{A Física e a experimentação}

Na PCF/RJ, embora na apresentação dos objetivos gerais não se realce o método experimental como metodologia de ensino para o desenvolvimento dos conteúdos, ao longo do quadro de conteúdo programático, nas sugestões de estratégias de ensino, propõe-se uma quantidade significativa de atividades de cunho experimental, contabilizando cerca de 20 sugestões, dentre um total de 43 itens listados como estratégias. Entretanto, é preciso ressaltar que, apesar do quantitativo de sugestões nessa linha, tal proposta não concede à Física o status de ciência inerentemente experimental. As atividades indicam ter a função de "comprovar" os conceitos apresentados, e que são tratados como "embasamento teórico", e/ou reforço para memorização de tais conceitos.

Com a participação dos alunos, fazer medições de deslocamentos e intervalo de tempo, com uso do "metro" e de um cronômetro (por exemplo: queda dos corpos). Aplicar as conclusões ao embasamento teórico. (PCF/RJ, p. 216) (grifo nosso).

Utilizar os conceitos desta unidade e o material elaborado pelos alunos, durante o desenvolvimento da unidade anterior, para "comprovar" o modelo teórico adotado. (PCF/RJ, 217) (grifo nosso).

Fazer experiências sobre mudança de fase usando, por exemplo, a água. Aplicar as conclusões ao embasamento teórico.( PCF/RJ, p. 220) (grifo nosso).

Ressalte-se ainda a proposição de atividades que se mostram inexequíveis, dada as condições materiais das escolas. Realizar experimentos para "comprovar a Lei de Coulomb" usando uma balança de torção, por exemplo, é um projeto que pareceu bem utópico, dado os problemas apontados como fatores de entrave no desenvolvimento dos currículos no Estado do Rio de Janeiro, naquele contexto (falta de recursos materiais e de pessoal capacitado), conforme traz a própria proposta curricular (RIO DE JANEIRO, 1977, p.30 e 37).

Os métodos da ciência são vistos de forma muito simplista, passando uma ideia de que qualquer indivíduo, em qualquer condição (ambiente) poderia verificar/comprovar as leis científicas de modo fácil e pouco exigente. A proposta de realização de "experimentos simples" para verificação de fenômeno não tão simples demonstra certa banalização do trabalho científico.

Criar condições para que os alunos façam experiências com a balança de torção comprovando a Lei de Coulomb. (PCF/RJ, p.222)

Auxiliar os alunos a elaborar 'guias' para as experiências sobre conservação da energia mecânica e demonstrar a validade do modelo matemático para as leis. (PCF/RJ, 218). 
A sugestão acima citada traz implícita a ideia de formar o pequeno cientista. Ainda que seja importante dar ao aluno a responsabilidade de planejar os experimentos, é preciso cuidar para que estes não sejam vistos como uma receita pronta, sem possibilidades de insucesso, infalível em qualquer circunstância. Essa concepção de ensino se mostra deturpada à medida que não colabora para formação do pensamento lógico e crítico do estudante, que por sua vez, consiste em um processo formativo complexo, e que demanda um longo tempo (FRACALANZA; AMARAL; GOUVEIA 1987).

A PCF/SP destaca veementemente as atividades experimentais. No quadro de planejamento curricular, bem como nos cadernos de atividades do SPCF/SP, a experimentação é enfoque do currículo. O texto da proposta afirma que as atividades experimentais devem estar intimamente ligadas às atividades teóricas e que devem ser realizadas à época do assunto relacionado às mesmas.

Os cadernos de atividades (SPCF/SP) foram elaborados com a finalidade de propor sugestões de experimentos para auxiliar o professor. Muitas destas com sugestão de uso de aparatos do PSSC, PEF, FAI e $\mathrm{PBF}^{120}$. Para a grande maioria dos tópicos, sugeriu-se um ou mais experimentos; alguns com o uso de objetos corriqueiros de fácil obtenção por parte dos alunos; outros com o uso de equipamentos de laboratório, para os quais se sugeriu os desenvolvidos pelos projetos de ensino de Física citados.

$\mathrm{O}$ texto dos cadernos de atividades da $\mathrm{PCF} / \mathrm{SP}$ ressaltou a necessidade de realização de medidas por meio de instrumentos para conclusões mais precisas, de modo a permitir a compreensão do Universo (idade da Terra, do Sol, duração de um raio, diâmetro do átomo de hidrogênio, etc.).

Apesar do enfoque na experimentação, o que em tese denotaria o reconhecimento do caráter experimental da Física, as atividades, da forma como são apresentadas, bem como os conceitos e equações que as precedem, demonstram ser somente para que o aluno compreenda os conceitos, bem como passa a ideia de que as leis são extraídas da experimentação. Tomamos, como exemplo, a proposta de experimentação para mostrar a Lei de Ohm, utilizando pilhas, medidor de corrente, resistores e fios, colocando que "esta é uma excelente oportunidade para se chegar a uma lei através de resultados experimentais” (PCF/SP, p.33). A definição de resistência, comumente tratada como Lei de Ohm já está presente no medidor

\footnotetext{
${ }^{120}$ Referindo-se à unidade Eletricidade do Projeto Brasileiro para Ensino de Física (PBEF) publicado com o título de Projeto Brasileiro de Física (PBF), em 1973.

Interessante observar que a PCF/RJ não menciona os projetos de ensino de Física.
} 
de corrente e voltagem, assim os alunos não estariam redescobrindo uma lei, mas sim já se utilizando dos princípios que regem tal fenômeno. Cabe lembrar que, de um modo geral, quando se propõe uma atividade experimental, já se tem um modelo.

Em suma, as propostas de atividades experimentais, nas duas propostas curriculares analisadas, da forma como foram sugeridas, configuraram como sugestões de estratégias para apresentação de conteúdos e verificação de princípios já formulados. Não contribuíam, satisfatoriamente, para evidenciar a Física como uma ciência inerentemente experimental. Por outro lado, ambas tiveram o mérito de pretender colocar o aluno em uma posição mais ativa no processo de ensino-aprendizagem, por meio da participação na realização dos experimentos.

\section{Modelos explicativos formais}

As diretrizes para a área de Ciências na PCF/RJ defendem a aplicação de métodos ativos e a prática da interdisciplinaridade como meio de mudar o quadro de desinteresse e dificuldades demonstrado pelos alunos no estudo das disciplinas científicas. Entende a Matemática como uma ponte entre as disciplinas: "No ensino da Matemática, a inclusão de noções de Lógicas é importante para uma perspectiva interdisciplinar, pois, como estudo das condições de validade de todo o saber, estará presente em todas as Ciências ditas naturais." (RIO DE JANEIRO, 1977, p. 196). E reforça:

O insucesso escolar poderá ser amenizado no ensino elementar das Ciências, se se der mais atenção ao domínio das estruturas qualitativas da Matemática e dos problemas levantados por cada uma das Ciências, com a compreensão através do raciocínio lógico antes da passagem à forma quantitativa, às equações matemáticas. (RIO DE JANEIRO, 1977, p. 196).

Assim, discursa sobre o uso de modelos explicativos como síntese dos fenômenos. Na apresentação dos conteúdos de Física, texto do autor do Programa de Física, recomenda que "se evite a memorização de inúmeras fórmulas quase sempre inúteis, quando não prejudiciais" (RIO DE JANEIRO, 1977, p.215). Em contrassenso às ideias colocadas, a proposta de conteúdos do quadro curricular dá significativa ênfase aos modelos matemáticos, numa perspectiva diferente do que se propõe no discurso. Da forma como propõe os conteúdos, leva à ideia de que os modelos matemáticos servem somente para aplicação de cálculos utilizando as fórmulas prontas, desarticuladas dos fenômenos estudados.

Calcular a posição do centro de massa de sólidos homogêneos de formas simples.

Calcular o momento de forças em relação a um ponto.

Calcular massa específica, dada a massa e o volume de uma substância.

Calcular a pressão em um ponto devido ao apoio de sólidos em equilíbrio. 
Resolver problemas envolvendo os conhecimentos práticos da frequência, velocidade, comprimento de onda e período ( $\mathrm{v}=\lambda . \mathrm{f}$ e $\lambda=\mathrm{v} . \mathrm{t})$.

Resolver problemas sobre circuitos simples, calculando: d.d.p. entre dois pontos; intensidade de corrente; energia dissipada; potência associada. (PCF/RJ, 1978)

Poucos são os objetivos que suscitam um tratamento fenomenológico antes de enunciar uma equação como lei física ou que buscam estabelecer as relações entre as grandezas de modo qualitativo. Identificamos os citados a seguir:

Expressar matematicamente uma lei física, conhecidas as relações de dependência entre as grandezas relevantes ("a menos" da constante de proporcionalidade). (PCF/RJ, p. 216).

Enunciar a Lei de Newton da Gravitação Universal, sabendo interpretá-la qualitativamente e quantitativamente. [Como sugestão de estratégia propõe:] Utilizar-se da noção básica de campo de força e, a partir daí, caracterizar o campo gravitacional como um campo de força de interação da forma $1 / \mathrm{d}^{2}$. (PCF/RJ, p. 218).

Conhecer a lei de Coulomb verbal e analiticamente; Identificar na lei as grandezas relacionadas; Saber como variar a força entre cargas quando variamos as grandezas relevantes. (PCF/RJ, p. 222).

Enunciar a Lei de Ohm e Lei de Joule, sabendo identificar as grandezas relacionadas. (PCF/RJ, p. 223).

A PCF/SP também dá ênfase ao formalismo matemático e traz alguns objetivos similares aos da PCF/RJ - calcular, definir, resolver, determinar... Do mesmo modo, observam-se algumas situações em que se busca dar atenção às relações entre as grandezas, que definem uma lei física, ou situações que partem de uma análise qualitativa para posterior definição conceitual e/ou algébrica. Como exemplo: Antes de "Enunciar a $2^{a}$ Lei de Newton" propõe "Relacionar, força, massa e aceleração" a partir da observação do movimento de “carrinhos em que pode variar ou a força aplicada, ou a massa” (PFC/SP, p. 28). Outros exemplos de sequência de objetivos podem também ilustrar essa característica:

Descrever qualitativamente o movimento dos elétrons livres dentro de um fio condutor ligado aos terminais de uma pilha; Descrever as condições em que o movimento de elétrons em um fio é considerado uma corrente elétrica; Definir intensidade de corrente elétrica. (PCF/SP, p. 33).

Descrever o processo de armazenamento de energia potencial elétrica em um condensador carregado; Definir diferença de potencial elétrico. (PCF/SP, p. 32).

No primeiro exemplo sugere a observação do brilho de uma lâmpada ao variar a intensidade da corrente elétrica; no segundo, sugere a construção de uma pilha utilizando feltro ou papel absorvente embebido em sulfato de cobre e colocado entre duas placas de cobre e zinco. 
No caderno de atividades dos SUBSÍDIOS... Vol. I da PCF/SP, o autor coloca que, além do ato de medir, "outro instrumento importante da Física é a matemática. Ela fornece a maneira mais adequada para estabelecermos as medidas, sistematizando-as de modo a tornar seu uso universal." (p. 03). Para o autor, a Matemática é a ferramenta mais adequada para o físico sintetizar as suas medidas, relacionando grandezas por meio de uma equação. A proposta foi de utilização do método da descoberta [redescoberta?], para que os estudantes fizessem medidas, tabelas, interpretação dos dados e tradução para a representação gráfica, interpolação e previsão de comportamentos por interpolação. Esse mesmo caderno de atividades traz ainda: "Assim, as leis da dinâmica ou a lei da gravitação universal, após um trabalho de intensa observação, acompanhada de um grande número de medidas, se traduzem com relativa simplicidade, através de sínteses gerais, em fórmulas muito compactas." (SPCF/SP, Vol. 1, p.03).

Embora tais trechos demonstrem certa propensão em considerar a matemática como modelo explicativo dos fenômenos, no geral, apresenta as equações prontas nas introduções contidas nos roteiros das atividades experimentais.

Em resumo, a PCF/SP apresenta, em maior nível que a PCF/RJ, alguns elementos que concebem os modelos matemáticos como síntese dos fenômenos, mas não se trata de uma característica da proposta. O tratamento do formalismo matemático como ferramenta de cálculos sobressai.

\section{Conteúdos/áreas da Física}

O quadro de Conteúdos Programáticos de Física para a Educação Geral na PCF/RJ é precedido de uma apresentação que se resume ao trecho compilado a seguir:

\section{Apresentação dos Conteúdos Programáticos de Física}

No $2^{\circ}$ grau a finalidade do estudo da Física é dar condições ao aluno para a aprendizagem dos conceitos da Física como uma ciência da Natureza, seu método e alguns de seus resultados.

O programa abrange as diversas partes dos cursos usuais de Física, como conteúdos de Mecânica, Termologia, Ótica, Eletricidade e Ondas. Não é um "Projeto de Ensino de Física". Espera-se que o aluno familiarize-se com o Método das Ciências: identificação de um vocabulário básico das teorias, as suas noções iniciais e as definidas a partir destas. Os axiomas, as regras lógicas e as suas consequências. A fase de comprovação, a experiência, pode ter como laboratório, na maioria das vezes, a própria Natureza e a criatividade dos professores e dos alunos.

Que se evite a memorização de inúmeras fórmulas quase sempre inúteis, quando não prejudiciais.

Objetivos Gerais:

- Identificar a Física como uma ciência da Natureza.

- Permitir acesso aos elementos fundamentais do método das ciências.

- Utilizar os resultados da Física sempre que possível em situações do dia-a-dia. 
Autor do Programa LUIZ FABIANO PINHEIRO ${ }^{121}$ (RIO DE JANEIRO, 1977, p. 215)

No quadro a seguir, apresentamos a lista dos tópicos de conteúdos extraídos do quadro curricular completo, que incluem os objetivos e as sugestões de estratégias de ensino, o qual é apresentado no ANEXO VI deste trabalho.

QUADRO 11 - Tópicos de conteúdos de Física da Proposta Curricular do Rio de Janeiro (1977).

\begin{tabular}{|c|c|}
\hline \multicolumn{2}{|c|}{ TOPICOS DE CONTEUDOS PCF/RJ } \\
\hline 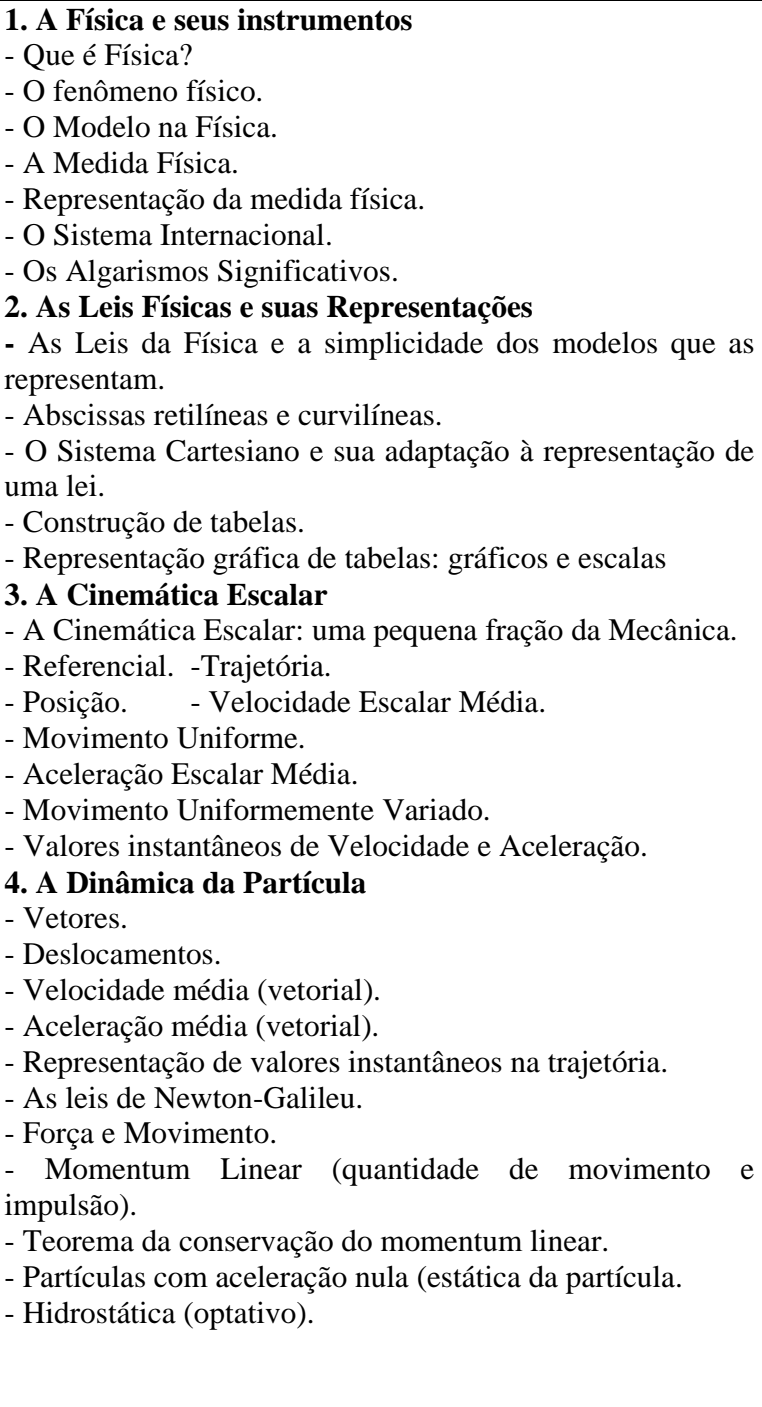 & 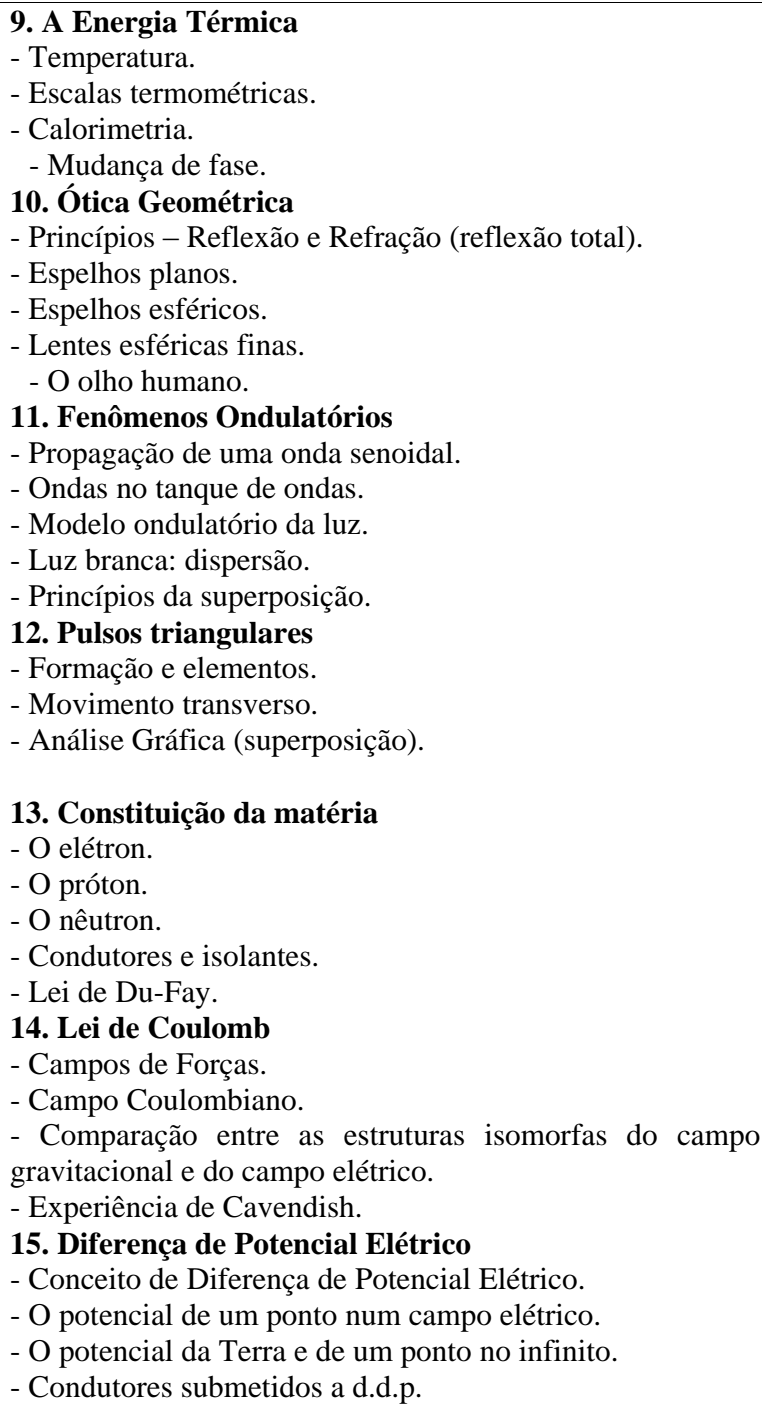 \\
\hline
\end{tabular}

Continua...

\footnotetext{
${ }^{121}$ Não há nenhuma informação sobre a formação acadêmica e nem a vinculação institucional desse autor no documento. Contudo, em pesquisa via internet, identificamos que tal autor não possui formação específica em Física, e sim em Matemática. Embora isso, tem produções didáticas com temas da Física. Em sua atuação profissional esteve vinculado à SEEC/RJ (1972-1978) atuando no Laboratório de Currículos de 1974 a 1978, além de outras instituições públicas e privadas de ensino - nível médio e superior - desde 1963 a 2006, nas disciplinas de Matemática e Física, quando se aposentou das atividades no Colégio Pedro II. Segundo consta no Currículo Lattes do autor, este ainda se encontra em atividade cursando o doutorado no Instituto Nacional de Matemática Pura e Aplicada (IMPA-RJ). Fonte: http://lattes.cnpq.br/7404840536129889.
} 


\begin{tabular}{l|l}
\hline \multicolumn{1}{c}{ TÓPICOS DE CONTEÚDOS PCF/RJ } \\
\hline \hline 5. A Energia & 16. Corrente Elétrica \\
- A Energia: um conceito primitivo. & - Finalidade dos geradores. \\
- As diversas formas de energia. & - Resistores Lineares (Lei de Ohm). \\
- Trabalho e Potência. - A Energia Cinética. & - Associação de resistores em série, em paralelo e mista. \\
- A Energia Potencial Gravitacional. & - Energia e Potência (efeito joule e Lei de Joule). \\
- Teorema da Variação da Energia Cinética. & - Circuitos simples. \\
- Interações Unidimensionais (referencial do centro de & 17. Geradores \\
massa). & - Força eletromotriz de um gerador. \\
6. A Gravitação Universal & - Energia fornecida. - Potência. \\
- Histórico. & - Rendimento. \\
- A Lei de Newton da Gravitação Universal. & - Associação de geradores iguais. \\
- As Leis de Kepler. & - Circuitos simples. \\
- A Força Centrípeta. & 18. Circuitos elementares \\
- Movimentos de satélites em órbitas circulares. & - Conhecimento operacional. \\
- Os vôos espaciais e sua contribuição para a Humanidade. & 19. Campo Elétrico Uniforme \\
7. Sistema de muitas partículas (sólido) & - Superfícies equipotenciais. \\
- Centro de massa de um sólido. & - Diferença de potencial entre dois pontos do campo. \\
- Momento de forças coplanares. & - Movimento de uma carga em um campo elétrico uniforme. \\
- Estática (condições de equilíbrio de um corpo rígido). & 20. Campo Magnético \\
8. Sistema de muitas partículas (Líquido) & - Campo magnético terrestre. \\
- Massa específica. & - Pressão. \\
- Pressão em um fluido em equilíbrio. & \\
- Teoremas de Stevin. & \\
- Princípios de Pascal e Arquimedes. & \\
- Equilíbrio de corpos flutuantes. & \\
\hline &
\end{tabular}
Fonte: RIO DE JANEIRO (1977)

A PCF/RJ não sugere divisão dos conteúdos por série; nem mesmo menciona os procedimentos de distribuição. Fica subentendido que tal divisão caberia ao professor. Se tal distribuição seguisse a sequência tradicionalmente praticada, diríamos que os tópicos de 1 a 8 seriam desenvolvidos na $1^{\mathrm{a}}$ série, de 9 a 12 na $2^{\mathrm{a}}$ série e de 13 a 20 na $3^{\mathrm{a}}$ série. Entretanto é preciso considerar que a carga horária por série no currículo era de duas aulas semanais, ou seja, quantitativos iguais para todas as séries. Assim, talvez fosse necessária uma divisão mais equânime, já que nos parece inexequível desenvolver todos os temas de Mecânica proposto na $1^{a}$ série, pois, não deixa de ser notável o predomínio de tópicos desse tema, que corresponde a praticamente metade do total de tópicos de toda a lista.

O desenvolvimento dos assuntos em termos de sequência é semelhante a dos livros didáticos utilizados em cursos superiores. Primeiro traz os tópicos introdutórios, tais como: conceito de Física, tipos de fenômenos, medidas, Sistema de Unidades, algarismos significativos, gráficos, etc., depois segue com os conteúdos dos grandes temas da Física: Mecânica (Cinemática e Dinâmica); Termologia; Ótica; Ondas; e Eletricidade.

Em mecânica, as leis da Conservação da Energia e da Quantidade de Movimento Linear são sugeridas; e é ausente o tópico Quantidade de Movimento Angular e sua lei de conservação. Outro tema ausente da Mecânica é a Fluidodinâmica .

Chama-nos a atenção a ausência de tópicos de Termodinâmica e de Eletromagnetismo, assuntos estes, tradicionalmente tratados nos cursos de Física do ensino 
médio. Fato curioso, considerando o contexto de grandes avanços tecnológicos que se processava. Muitos desses avanços faziam [fazem] uso da aplicação da Termodinâmica (motores de automóveis, geladeira e outras máquinas a vapor) e do Eletromagnetismo nas grandes usinas de produção de energia elétrica em larga escala e outros dispositivos eletrônicos, já desenvolvidos naquele contexto. Além desses dois temas, que eram bem comuns em livros didáticos da época (não entrando no mérito da abordagem), não contempla também tópicos de Física Moderna, numa época em que a física nuclear era um dos temas de grande relevância.

No geral, não parece ter tido preocupação em abordar assuntos relacionados ao contexto do desenvolvimento científico e tecnológico da época, já que temas atuais se restringem à menção das viagens espaciais, em um tópico denominado "Os vôos espaciais $e$ sua contribuição para a Humanidade" no estudo de Gravitação Universal.

Os tópicos de conteúdos da PCF/SP são os que trazemos no quadro a seguir:

QUADRO 12 - Temas e tópicos de Física nas séries do $2^{\circ}$ grau - Habilitações Básicas e Magistério na Proposta Curricular do Estado de São Paulo (1978).

\section{TÓPICOS DE CONTEÚDOS - PCF/SP}

MECÂNICA I

$1^{\circ}$ semestre

1- Gráficos - utilização de papel milimetrado

2 -Representação gráfica e linguagem analítica

3- Medidor de tempo

4 -Medidas de distância

5- Introdução ao conceito de velocidade (média)

6 -Conceito de velocidade (média)

7- Velocidade média e velocidade instantânea

8- Movimento Retilíneo Uniforme (MRU)

9- Introdução ao conceito de aceleração

10- Aceleração constante e variável - gráficos

11- Movimento uniformemente variado (MUV): equação da velocidade

12- Movimento uniformemente variado: equação horária $1^{\text {a }}$ série - núcleo comum
$2^{\circ}$ semestre
13- Conceito de Força
14- Composição de forças
15- Princípio da Inércia
16- $2 .^{\text {a }}$ Lei de Newton
17- 2. ${ }^{\text {a }}$ Lei de Newton [aplicação]
18- Força peso
19- 2. ${ }^{\text {a }}$ Lei de Newton força-peso
20- Conceito de Energia
21- Trabalho
22 -Energia Cinética
23- Energia Potencial Gravitacional
24- Energia Potencial de uma mola
25- Conservação de energia

$2^{\mathrm{a}}$ série - núcleo comum Setor Terciário e Magistério

1. ELETRICIDADE

1 - Cargas Elétricas

2 - Processos de eletrização

3 - Campo elétrico

4 - Diferença de potencial elétrico

5 - Corrente elétrica

6 - Resistores e circuitos simples

7 - Efeito joule

3. CALOR E GASES

1 - Temperatura e Calor

2 - Quantidade de calor e calor específico

3 - Mudança de estado

4 - Gases: transformação isotérmica

5 - Gases: transformação isobárica

6 - Gases: outras transformações
Deveria escolher 4 blocos, dentre os 8 , considerando um por bimestre

2. ELETROMAGNETISMO

1- Propriedade dos ímãs - Bússola

2- Efeito magnético da corrente elétrica

3- O campo magnético

4- Força sobre condutores

5- Motor elétrico

6- Indução eletromagnética

7- Geradores

4. ÓTICA GEOMÉTRICA

1 - Natureza e propriedade da luz

2 - Leis da reflexão

3 - Espelhos

4 - Leis da refração

5 - Lentes

6 - O olho humano

Continua... 


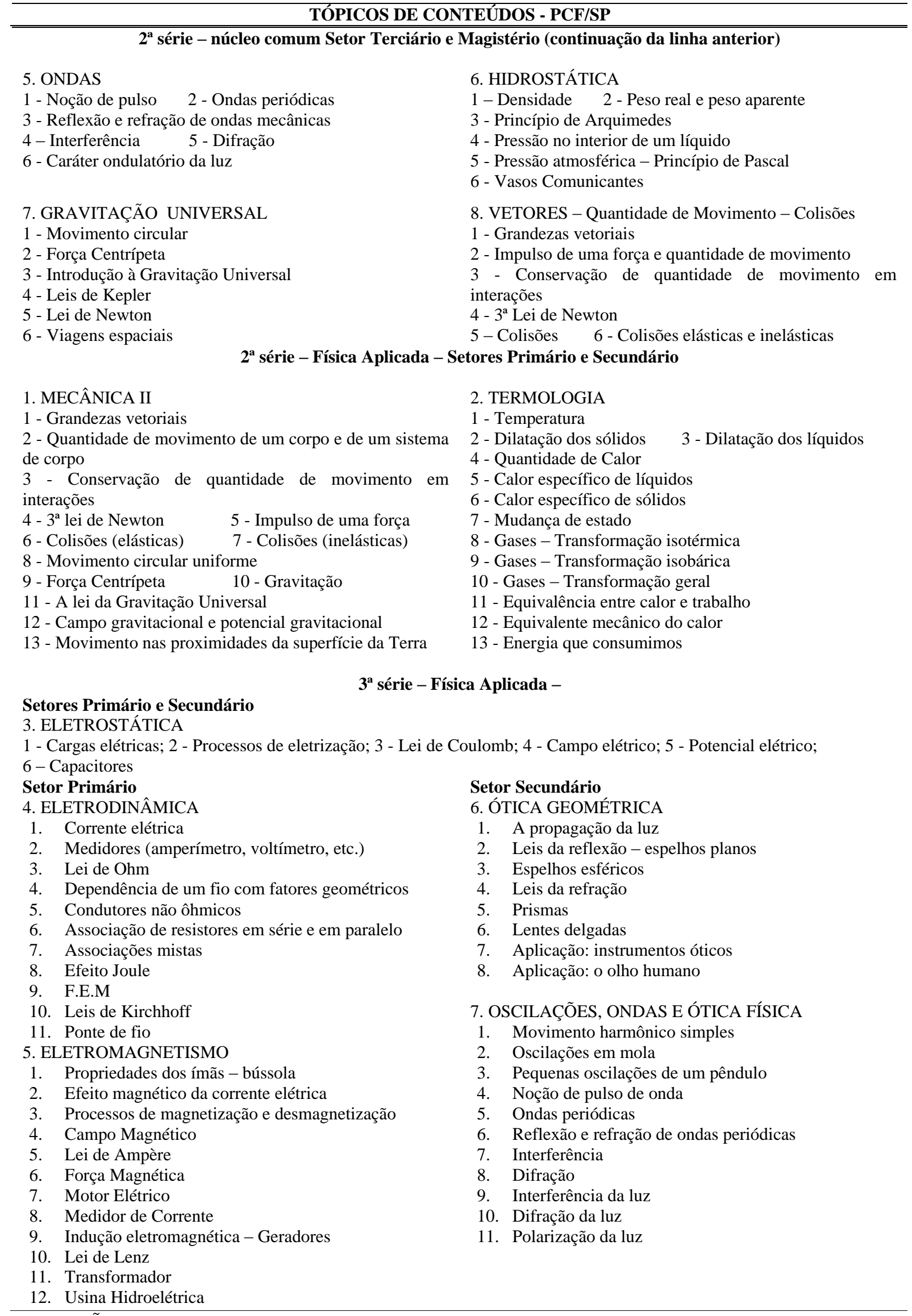

Fonte: SÃO PAULO, 1978, p. 15-16. 
A divisão dos temas e tópicos na PCF/SP levou em conta a carga horária reduzida para a $1^{\mathrm{a}}$ série, e, em razão disso, foi feita a opção de excluir os aspectos vetoriais no estudo da Dinâmica para garantir o desenvolvimento do tema Energia ainda nesta série (cf. PCF/SP, 1978). A complementação da Dinâmica seria feita na $2^{\mathrm{a}}$ série para os alunos que optassem por cursos dos setores Primários e Secundários, onde a disciplina tinha maior número de aulas (três semanais) como Física Aplicada. A escolha dos conteúdos para a 2a série, nos cursos de Formação Profissionalizante do setor Terciário e na Habilitação para o Magistério, foi também moldada à carga horária. Entre escolher cortar tópicos ou tratar vários temas com menor profundidade, escolheu-se a segunda opção, por julgar que “estes estudantes provavelmente nunca mais [estudariam] Física e [deveriam] ter uma visão mais geral do assunto." (SÃO PAULO, 1978, p. 31).

Para as $2^{\mathrm{a}}$ e $3^{\mathrm{a}}$ séries dos cursos profissionalizantes dos setores Primário e Secundário, que contavam com três aulas semanais, propôs-se planejamento único com um semestre de Mecânica II e um de Termologia. Considerando que os alunos do setor Primário só veriam eletricidade e magnetismo na $3^{\mathrm{a}}$ série, foi dada a flexibilidade de o professor substituir o semestre de Termologia por dois bimestres com assuntos distintos: Calor e Gases e Hidrostática ou Ótica geométrica e Ondas.

A formação básica do setor Primário na $3^{\mathrm{a}}$ série, por não contemplar a disciplina Eletricidade, mas somente Física Aplicada, abarcou um currículo mais completo de Eletromagnetismo. Para o setor Secundário, possivelmente, considerando que os alunos iriam estudar temas de eletricidade em uma disciplina específica profissionalizante ${ }^{122}$, o currículo foi mais reduzido, trazendo Eletrostática (mesmos tópicos do setor Primário), Ótica Geométrica, Ondas e Ótica Física ${ }^{123}$.

O diferencial da sequência desta proposta era a possibilidade de trabalhar assuntos de Eletricidade e Magnetismo na $2^{\mathrm{a}}$ série dos Setores Terciário e Magistério, uma vez que o professor poderia escolher quatro temas, dentre os oito sugeridos: Eletricidade; Eletromagnetismo; Calor e Gases; Ótica Geométrica; Ondas; Hidrostática; Gravitação e Vetores - Quantidade de Movimento - Colisões. Para a $3^{\mathrm{a}}$ série, predominaram-se os assuntos de Eletricidade e Magnetismo nos cursos do Setor Primário, e Ótica e Ondas nos cursos do Setor Secundário.

\footnotetext{
${ }^{122}$ A proposta curricular não traz os conteúdos para a disciplina profissionalizante "Eletricidade".

${ }^{123}$ No quadro de planejamento curricular o tema Eletromagnetismo é colocado como se fosse também para a $3^{\mathrm{a}}$ série do setor secundário, no entanto, todas as demais informações da proposta, inclusive um quadro que apresenta o esquema de temas para a $3^{\text {a }}$ série, deixa claro que nesta série do setor Secundário não contempla tal tema. Indica ser um erro de digitação no título do quadro.
} 
Os conteúdos dessa proposta são os grandes temas tradicionalmente desenvolvidos no ensino de Física, com exceção de Física Moderna, que não é contemplada; porém numa sequência diferenciada por séries, particularmente nas $2^{\mathrm{a}}$ e $3^{\mathrm{a}}$. Em Mecânica, traz tópicos de Cinemática e Dinâmica com estudo de movimentos, Leis de Newton, Trabalho e Energia, Gravitação Universal e Hidrostática. Propõe tópicos que trata das leis da Conservação da Energia e da Quantidade de Movimento Linear, com relativa ênfase, o que se depreende dos objetivos que são detalhados em maior quantidade. Do mesmo modo que na PCF/RJ, não sugere os tópicos Quantidade de Movimento Angular e Fluidodinâmica.

Nos demais grandes temas, os assuntos tratados são os costumeiramente encontrados nos livros didáticos, de certa forma, contemplados de modo bastante extensivo em termos de quantidade/desmembramento de tópicos. Diferentemente dos projetos de ensino da época e da PCF/RJ, não houve significativa supressão de assuntos.

Assuntos relacionados ao desenvolvimento científico-tecnológico também são praticamente ignorados, do mesmo modo que a PCF/RJ; restringe-se aos inventos da tecnologia espacial, propondo um tópico denominado "Viagens espaciais", no estudo de Gravitação Universal.

Outro ponto a ressaltar na PCF/SP se refere aos conteúdos colocados para a Física Aplicada. Não há nos objetivos ou nas sugestões de atividades, elementos que caracterizam tais conteúdos como "aplicados". São apresentados do mesmo modo tradicionalmente trazidos nos currículos de Física destinados ao ensino não profissional.

Comparando as duas propostas curriculares analisadas, em termos de tópicos dos temas abordados nota-se que a diferença maior está no fato de a PCF/RJ não trazer os temas Termodinâmica e Eletromagnetismo, além de alguns tópicos de Óptica, que também vem mais resumida comparada à PCF/SP. Nos demais temas, a diferença se estabelece no detalhamento dos temas em tópicos, o que faz parecer que o programa de Física na PCF/SP é muito mais extenso do que a PCF/RJ. O que ocorre é que na PCF/RJ, os tópicos que intitulam as unidades, em alguns casos, são mais abrangentes, o que suscita a ideia de que poderiam ser desmembrados ao serem desenvolvidos, portanto, podendo ter uma diferença quantitativa de assuntos tratados, menor do que parece ser. 


\section{$\underline{\text { Da dimensão educativa }}$}

\section{Objetivos do ensino de Física}

Os objetivos do ensino dos conteúdos de Física, nos dois currículos analisados, a nosso ver, não se traduzem em possibilidades de promover a aprendizagem por meio da curiosidade, da reflexão crítica, da busca dos significados para a vida prática. Estão claramente voltados para os conteúdos. Na PCF/RJ, o discurso está explícito na apresentação do programa:

No $2^{\circ}$ grau a finalidade do estudo da Física é dar condições ao aluno para a aprendizagem dos conceitos da Física como uma ciência da Natureza, seu método e alguns de seus resultados. (PCF/RJ, p.215).

A PCF/SP não apresenta objetivos mais gerais para o ensino da Física, uma vez que o texto da proposta é preponderantemente técnico. Não traz explicitamente nenhum discurso pedagógico que justifique o modelo de currículo adotado. Finalizando as instruções da proposta, ao falar do planejamento do curso, põe-se clara a importância dada aos conteúdos:

É importante que em cada assunto os objetivos essenciais sejam atingidos. $\mathrm{Na} 1^{\text {a }}$ série, no Núcleo Comum, é essencial que o conceito de Energia e sua conservação sejam discutidos com certo detalhe. Para que isto seja possível, recomenda-se que a parte de cinemática seja abordada totalmente no $1^{\circ}$ semestre. (PCF/SP, p. 14).

A forma como os objetivos específicos são enunciados nas propostas levam à ideia de que o aluno precisa saber, mas quase nada sugere para que sirva esse conhecimento. Assim, denuncia a finalidade informativa e propedêutica do ensino, pouco se diferenciando das concepções de educação praticada em meados do século XX - perspectiva esta, que ainda encontra eco nas escolas da atualidade (CHIQUETTO, 2011). Priorizou-se a preparação do cidadão idealizado naquele contexto, com domínio de conceitos científicos e, até mesmo, capaz de lidar com os recursos tecnológicos provenientes da atividade científica, mas sem reflexão crítica acerca dos fatos da ciência. Convém ressaltar que, naquele contexto já surgiam debates sobre questões ambientais (problemas decorrentes da revolução da indústria), crise energética, ética na ciência e outros temas de ordem social (KRASILCHIK, 2000).

Termos como "saber aplicar...[conceitos]”, "resolver problemas... [numéricos]”, "saber calcular...", "enunciar...[leis e conceitos]", “definir", “caracterizar", faz dessas propostas curriculares de Física uma simples reprodução da prática de ensino em que o enfoque é o produto da ciência, e não o processo; e tem a ciência como um fim nela mesma. 
Concepção de aluno/professor

Nas diretrizes para a área de Ciências na PCF/RJ, foi recomendado dar condição para que o aluno realizasse "experiências verdadeiras", e que o papel do professor seria indispensável para propiciar os "pontos de partida, criando situações favoráveis, colocando problemas significativos para a compreensão de uma Ciência específica. Além disso, ele [complementaria] as descobertas dos alunos com contra-exemplos.” (RIO DE JANEIRO, 1977, p. 197).

Desse modo, esses discursos trazidos nas diretrizes, se aplicados particularmente à Física, seguiram as tendências de ensino presentes nos projetos de ensino de Física das décadas de 1960 e 1970, em que o professor teria um papel mais secundarizado e que o aluno se comportaria como um pequeno cientista em sala de aula.

Também, em nível de discurso, a reformulação curricular da SEE/RJ adotou o cognitivismo que, em tese, evidenciaria uma maior participação do aluno no processo de aprendizagem com trabalhos em grupo, realização de experimentos, atividades lúdicas (jogos), problematização prévia do conteúdo e o conteúdo dosado conforme o nível cognitivo dos alunos. Contudo, as sugestões de estratégias e atividades não pareciam pretender sempre que os alunos realizassem os experimentos. Não há orientações claras que pressupõem estimular a problematização prévia e trabalho em equipe. Também, quanto à dosagem do conteúdo ao nível cognitivo dos alunos, não se nota orientações claras nessa linha. Há sugestões que suscitam a ideia de que o professor realizaria os experimentos com a participação do aluno, mas não que o aluno conduziria o planejamento das atividades experimentais.

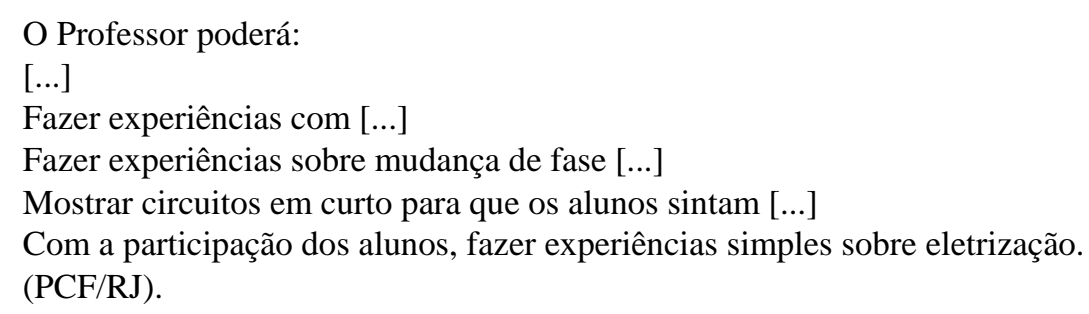

Outra contradição entre o discurso inicial e o desenvolvimento da proposta é a proposição de adoção de atividades lúdicas (como jogos, por exemplo) para desenvolver maiores recursos mentais nos estudantes. Um recurso que, segundo consta na introdução do texto Currículos 1 Reformulação de Currículo - Síntese (1976), seria um meio de ativar o processo cognitivo dos aprendizes com o argumento de que "o jogo é o exercício pleno das estruturas vivenciais" (RIO DE JANEIRO, 1976, p. 23). Contudo não identificamos propostas 
de atividades nessa linha no currículo de Física analisado. Essa contradição revela o distanciamento entre o "nível de propósito" e o "nível de fato", conforme discute Fracalanza (2006). Neste caso, o distanciamento ocorre na mesma instância, ou seja, no âmbito da prescrição.

Na apresentação dos conteúdos na PCF/RJ, notam-se características do modelo de ensino tecnicista, pelos objetivos definidos e expressos por verbos (fazer com que o aluno...., mostrar que ..., levar o aluno a..., reconhecer, familiarizar os alunos..., etc...) e ainda o uso de recursos das novas tecnologias educacionais da época: frisou-se bastante o uso de slides e filmes. A forma dos objetivos leva a entender que o processo seria conduzido pelo professor. Assim, denota a proposição de um ensino expositivo voltado para os conteúdos da ciência/Física - conhecimento formal e previamente estruturado, o produto - sem preocupação com a abrangência deste na vida social do aluno - característica do ensino tradicional.

Percebe-se na proposta a heterogeneidade das concepções de educação que conduziram a formação científica nas escolas nas décadas de 1960 e 1970 . Uma mistura de modelos pedagógicos, conforme aponta Fracalanza, Amaral e Gouveia (1987).

$* * *$

A PCF/SP não expõe explicitamente os níveis de protagonismos discentes e docentes no processo de ensino-aprendizagem. Indica prevalecer a ideia da autonomia do professor na escolha dos conteúdos, dentre um bloco sugerido, e no desenvolvimento desses em sala.

Nem todas as atividades sugeridas poderão ser incluídas na programação anual do professor. Compete a ele elaborar um elenco de atividades de maior importância para serem realizadas em classe. Além destas, o professor poderá programar atividades complementares a serem realizadas pelos alunos como tarefas extraclasse. (PCF/SP, 1978, p. 14).

O material elaborado como subsídio era destinado ao professor. Elementos que sugerem uma participação mais ativa do aluno se referem às recomendações para as atividades experimentais. Os objetivos e sugestões no quadro curricular não esclarecem se as execuções das experiências seriam feitas pelos alunos, mas no texto introdutório da proposta traz: "Embora experimentos de demonstração, realizados pelo professor sejam interessantes e úteis, os experimentos realizados pelos alunos são, em geral, mais efetivos na aprendizagem" (PCF/SP, 1978, p. 12). Mais adiante coloca que: "É importante também que o professor discuta com os alunos o planejamento e os resultados de cada experimento" (PCF/SP, p. 12).

De fato, as sugestões de atividades experimentais poderiam condicionar a participação mais efetiva do aluno no processo de ensino-aprendizagem, uma vez que as 
sugestões de atividades eram simples, com recursos fáceis de serem adquiridos por eles, com o uso de coisas bem comuns do cotidiano, tais como papel laminado, feltro, fios de cobre, pilhas, carrinhos, relógios, etc. Por outro lado, a forma como os conteúdos foram estruturados, trazendo os temas tradicionalmente pré-definidos, sem maiores recomendações de problematização e contextualização, não deixavam margens para um planejamento de trabalho que visasse uma postura mais dialógica nas interações entre professor-aluno-objeto de conhecimento.

Em síntese, as duas propostas, no geral, mantinham o professor no centro do processo de ensino, e o aluno um seguidor das regras, ou seja, uma concepção de educação que pouco ou nada se diferenciava do ensino tradicional já consolidado. As orientações ao professor não incentivava a inserção do sujeito do conhecimento no processo de fazer ciência dialogando com ela no contexto em que este estava inserido. Cabe ressaltar que, estas concepções precisariam estar bem claras nos objetivos. Em contrassenso, os objetivos descritos nas propostas são, na verdade, um detalhamento dos temas e tópicos em subtópicos. Essa característica é notada nos quadros de conteúdos das duas propostas analisadas.

Apresentamos no quadro a seguir uma síntese da análise nas propostas curriculares oficiais, permitindo ao leitor uma melhor percepção dos resultados. 
QUADRO 13 - Síntese da análise nas Propostas Curriculares oficiais

\begin{tabular}{|c|c|c|c|}
\hline \multirow[t]{2}{*}{ Dimensões } & \multirow[t]{2}{*}{ Categorias } & \multicolumn{2}{|c|}{ RESULTADOS } \\
\hline & & PCF/RJ & PCF/SP \\
\hline \multirow[t]{4}{*}{$\begin{array}{l}\text { Epistemo- } \\
\text { lógica }\end{array}$} & $\begin{array}{l}\text { Ciência } \\
\text { como } \\
\text { processo }\end{array}$ & \multicolumn{2}{|c|}{$\begin{array}{l}\text { As duas propostas limitam-se ao produto da atividade científica; Não contempla: aspectos } \\
\text { históricos dos fenômenos, Realidade social, relação do sujeito com o conhecimento. } \\
\text { Pouca relação com as tecnologias, cultura e sociedade e outras grandes áreas do } \\
\text { conhecimento (mencionam: viagens espaciais, satélites, funcionamento de usinas) }\end{array}$} \\
\hline & $\begin{array}{l}\text { A Física e a } \\
\text { experimentação }\end{array}$ & $\begin{array}{l}\text { Experimentos para comprovação e } \\
\text { compreensão de conceitos, apresentação de } \\
\text { conteúdos e verificação de princípios já } \\
\text { formulados. }\end{array}$ & $\begin{array}{l}\text { Experimentos para comprovação } \\
\text { compreensão de conceitos, verificação de } \\
\text { princípios já formulados, redescoberta de leis } \\
\text { físicas. }\end{array}$ \\
\hline & $\begin{array}{l}\text { Modelos } \\
\text { explicativos } \\
\text { formais }\end{array}$ & $\begin{array}{l}\text { O formalismo matemático é ferramenta de } \\
\text { cálculos. Enunciados de leis (equação, } \\
\text { memorização de conceitos) }\end{array}$ & $\begin{array}{l}\text { Perspectiva similar à PCF/RJ, contudo, traz um } \\
\text { pouco de análise qualitativa (Relações entre as } \\
\text { grandezas é um pouco mais presente que na } \\
\text { PCF/RJ), mas sobressai a matemática como } \\
\text { ferramenta de cálculo. }\end{array}$ \\
\hline & $\begin{array}{l}\text { Conteúdos/ } \\
\text { áreas da Física }\end{array}$ & $\begin{array}{l}\text { Traz os grandes temas: Mecânica; } \\
\text { Termologia; Ondas; Ótica; Ondas; } \\
\text { Eletricidade e um pouco de Magnetismo } \\
\text { (conceitos iniciais). } \\
\text { Ausência dos temas: Quantidade de } \\
\text { Movimento Angular; Fluidodinâmica } \\
\text { Termodinâmica; Eletromagnetismo e } \\
\text { tópicos de Física Moderna. }\end{array}$ & $\begin{array}{l}\text { Traz os grandes temas: Mecânica; Termologia; } \\
\text { Ondas; Ótica; Ondas; Eletricidade e } \\
\text { Eletromagnetismo. } \\
\text { Diferencial da proposta: Eletricidade e } \\
\text { Magnetismo na 2a série (dependendo do setor). } \\
\text { Conteúdos de "Física Aplicada" = "Física". } \\
\text { Temas ausentes: Quantidade de Movimento } \\
\text { Angular; Fluidodinâmica e tópicos de Física } \\
\text { Moderna; }\end{array}$ \\
\hline Educativa & $\begin{array}{l}\text { Objetivos } \\
\text { ensino } \\
\text { Física }\end{array}$ & \multicolumn{2}{|c|}{$\begin{array}{l}\text { Nas duas propostas o ensino é pré-definido, sem preocupação com significação para a vida } \\
\text { prática; ênfase nos Conteúdos; Enfoque no produto; Ensino propedêutico. } \\
\text { Neutralidade do sujeito do conhecimento. } \\
\text { Não levam em conta os conhecimentos do mundo vivencial do aluno; se encerra na } \\
\text { perspectiva de formação científica, mas não formação científica consciente do papel do } \\
\text { homem no mundo. }\end{array}$} \\
\hline & $\begin{array}{ll}\text { Concepção de } \\
\text { aluno/ } \\
\text { professor }\end{array}$ & \multicolumn{2}{|c|}{$\begin{array}{l}\text { O desenvolvimento das duas propostas sinaliza a ideia de que o professor permaneceu como } \\
\text { expositor de conteúdos e o aluno como receptor de conhecimentos prontos; neutralidade do } \\
\text { sujeito em relação ao objeto de conhecimento. }\end{array}$} \\
\hline
\end{tabular}





\section{LIVROS DIDÁTICOS DE FÍSICA - PERMANÊNCIA DO QUE EXISTIA OU CONTINUIDADE COM INOVAÇÃO?}

Neste capítulo trataremos do terceiro tipo de referencial curricular tomado como fonte de estudo mais aprofundado nesta pesquisa: os livros didáticos de Física.

Segundo Apple (1997), o livro didático é um "artefato que desempenha um papel de importância primordial na definição da cultura de que grupos é ensinada" (APPLE, 1997, p. 73). É um instrumento do poder, que determina o que conta como conhecimento cultural a ser transmitido nas escolas.

Livros-textos são, na realidade, mensagens para e sobre o futuro. Como parte do currículo, participam em nada menos que do sistema organizado de conhecimento da sociedade. Participam da criação do que a sociedade reconhece como legítimo e verdadeiro. (APPLE, 1997, p. 77).

Nessa perspectiva, o livro didático se apresenta em duas posições representativas dos diferentes níveis hierárquicos (produção e reprodução) do currículo no contexto educacional. Se por um lado se insere no currículo prescrito, na medida em que os conteúdos trazidos neles seguem a lógica dos conhecimentos socialmente produzidos, nos diversos segmentos da sociedade, num dado momento da história, além de compor o "pacote" das políticas públicas educacionais (APPLE, 1997), por outro, é notadamente o "fazer pedagógico" dos docentes. É o currículo praticado na escola (GOODSON, 1995; APPLE, 1997; WUO, 2000).

Nossa opção em tomar o livro didático como componente importante de nosso aporte teórico/documental, buscando compreender a história da disciplina escolar Física, também, por meio deles, encontra eco nas percepções de Bittencourt (2003) e Choppin (2004) que concordam que o livro didático é um produto que carrega a identidade do seu tempo/espaço, com diversas interferências em todo o processo que o envolve, desde sua elaboração até o seu uso nos diferentes contextos, e de forma complexa, delibera ideias, ações, hábitos, enfim, identidades culturais e tradições.

Assim, a análise de livros didáticos fornece amplas interpretações, já que os seus textos podem - e geralmente ocorre - estabelecer relações com outros textos e com o contexto histórico-sócio-cultural de cada tempo, o que dá ao pesquisador a possibilidade de interpretar, inferir, reconceptualizar o ensino, em cada momento da história (BITTENCOURT, 2003).

Ao tratar do livro didático de Física, consideramos relevante apresentar um resumo sucinto da trajetória da política do livro didático no Brasil, a partir do início do século XX, que culminou com a universalização da distribuição gratuita aos alunos do atual Ensino 
Médio, contemplando, em 2009, a disciplina Física. Na seção que se segue traremos esse breve resumo, que evidencia a relevância dada a esse recurso pedagógico no âmbito educacional. Na sequência, trataremos de mostrar a presença do livro didático de Física no mercado editorial nas décadas de 1960 e 1970. Como destaque do capítulo, apresentaremos os resultados de nossa análise de conteúdo feito em uma amostra do acervo histórico desse importante referencial curricular de presença marcante nas escolas brasileiras.

\subsection{Síntese da trajetória do Programa do Livro Didático no Brasil}

O que se denomina atualmente de Programa Nacional do Livro Didático (PNLD) no Brasil, em sua trajetória, passou por diversas formas, tendo sua execução coordenada por diversos órgãos (HÖFLING, 2006). Em 1929, o Estado brasileiro criou o primeiro órgão específico "para legislar sobre políticas do livro didático, o Instituto Nacional do Livro (INL), contribuindo para dar maior legitimidade ao livro didático nacional e, consequentemente, auxiliando no aumento de sua produção.” (BRASIL, 2015).

A origem de um programa gerenciador deu-se em meados de 1938, com a instituição da Comissão Nacional do Livro Didático ${ }^{124}$ estabelecendo as condições para produção, importação e circulação do livro didático no país. Na década de 1950, as funções da comissão foram redimensionadas e o Estado passou a assumir o controle sobre o programa em todos os estabelecimentos de ensino do território nacional. Uma função que foi gradativamente se descentralizando, com a criação de Comissões Estaduais do Livro didático, em alguns estados (HÖFLING, 2006).

A Fundação Nacional do Material Escolar (FENAME) é criada em 1967, pela transformação da Campanha Nacional de Material de Ensino (CNME) que existia desde 1956, e tinha como função produzir e distribuir o material didático às instituições escolares, a preço de custo, com postos de distribuição em todo o país. Sem uma organização administrativa e recursos financeiros, não deu conta de desempenhar tais funções. Assim, foi implantado o sistema de coedição de obras didáticas com as editoras nacionais, através da Portaria Ministerial $n^{\text {o } 35 / 1970 . ~ S i s t e m a ~ q u e, ~ e m ~ 1972, ~ r e c e b e u ~ u m ~ r e f o r c ̧ o ~ d o ~ I n s t i t u t o ~ N a c i o n a l ~ d o ~}$ Livro Didático (INL) em ação conjugada com as editoras (HÖFLING, 2006).

A partir desse programa de coedição, desde 1975, o Estado, ampliando mais o controle, acumula os papeis de censor e de financiador dos livros didáticos. A seleção das

\footnotetext{
${ }^{124}$ Decreto-Lei n ${ }^{\circ} 1.006$, de 30 de Dezembro de 1938.
} 
obras didáticas também passa a ser precedida por especialistas da FENAME, através de instrumentos de avaliação determinados por eles.

Em 1983, foi criada a Fundação de Assistência ao Estudante (FAE), que acumulou as funções da FENAME e do INL, órgãos vinculados ao Ministério da Educação, incorporando o Programa do Livro Didático. O MEC passou a comprar os livros produzidos pelas editoras. Foi a partir do ano de 1985 que o programa recebeu a denominação de Programa Nacional do Livro Didático (PNLD). Seus objetivos foram ampliados, sendo que a meta seria o atendimento a todos os alunos do Ensino Fundamental das escolas públicas de todas as esferas de governo, priorizando os componentes básicos de Português (Comunicação e Expressão) e Matemática. A FAE foi extinta em 1997, passando a execução do PNLD a ser assumida pelo FNDE (Fundo Nacional de Desenvolvimento da Educação Básica) ${ }^{125}$, ligado ao MEC. Deu-se continuidade ao programa com a gradativa expansão de atendimento aos demais componentes curriculares, bem como pela estruturação de instrumentos de avaliação das obras.

Em 2003, é instituído o Programa Nacional do Livro para o Ensino Médio (PNLEM) (BRASIL, 2003 Art. $1^{\circ}$, Res. 038/2003). Como projeto piloto, o programa atendeu, em 2004, os componentes curriculares de Português e Matemática para os alunos da $1^{\text {a }}$ série do Ensino Médio do Norte e do Nordeste. Em 2005, a distribuição de livros para estes componentes curriculares se estendeu às demais séries e regiões. Em 2006, houve reposição e complementação dos livros de Matemática e Português, distribuídos anteriormente, além da compra integral dos livros de Biologia. Em 2007 o programa passou a atender mais duas disciplinas - História e Química. Em 2008 foram incluídas as disciplinas de Geografia e Física no processo de escolha, sendo as obras distribuídas para as escolas no início de 2009, completando, assim, a universalização do atendimento do ensino médio em relação à aquisição de livros didáticos para os componentes curriculares da educação geral (BRASIL, 2015).

A trajetória do livro didático no Brasil, construída sob um arsenal de leis, decretos e resoluções, e ainda intervenções externas oficializadas por acordos políticos (HÖFLING, 2006), revela o grau de importância desse objeto escolar como política pública, o que é bastante compreensível, se acolhermos o fato de que esse instrumento pedagógico, sendo peça de destaque no âmbito escolar, é, em razão disso, poderoso organismo de controle social pela transmissão de valores de grupos dominantes em cada época; é "parte de um sistema de regulação moral” (APPLE, 1997, p.85).

${ }^{125}$ Criado em 1968, pela Lei $\mathrm{n}^{\mathrm{o}} 5.537$. 
Por outro lado, é importante reconhecer outras facetas do livro didático, que além de representar um crucial apoio no trabalho pedagógico, também se configura como uma “estratégia mais ampla de democratização" (APPLE, 1997, p.85).

\subsection{Os livros didáticos de Física no Brasil no contexto investigado}

Hosoume, Martins e Nicioli Jr. (2007) fizeram um levantamento e análise da presença dos livros didáticos de Física no Brasil no período compreendido entre a Reforma Capanema e a Lei de Diretrizes e Bases da Educação Nacional de 1996. No que se refere às décadas de 1960/1970, ao compará-las com as décadas anteriores, esses autores verificaram que houve uma grande expansão de publicações de obras nacionais a partir de 1960, e introdução de coleções coletivas a partir da década de 1970, ocasionando um significativo domínio da participação de autores brasileiros na elaboração de livros didáticos de Física, no período que compreende as duas décadas.

Assim, tomando como referência o trabalho desses autores, buscamos complementar a tabela por eles apresentada, no que se refere às décadas de 1960 e 1970. Identificamos mais algumas obras, das quais o levantamento completo está disposto nas Tabelas 3 e 4, logo adiante. Reconhecemos a possibilidade de que nosso levantamento não tenha identificado todas as produções das décadas em estudo, porém, acreditamos que este consta de grande maioria, o que o torna dado significativo para a pesquisa.

A identificação dos livros didáticos de Física das décadas em questão foi feita através do Banco de Dados LIVRES (Livros Escolares Brasileiros) e em sítios eletrônicos de Sebos virtuais. O LIVRES está alojado no sítio da Faculdade de Educação da USP (FEUSP). Segundo consta na página do sítio eletrônico, esse banco de dados:

\footnotetext{
Disponibiliza acesso a livros didáticos das diversas disciplinas escolares brasileiras do século XIX aos dias atuais, considerando a sua história e as especificidades da produção escolar. Referencia obras de diversas bibliotecas do país, caracterizando-se por ser alimentado e ampliado constantemente pelas pesquisas de uma equipe de especialistas da área, que analisam o livro didático em suas diferentes vertentes. Reúne (sic) fontes relacionadas à produção didática como legislação, programas curriculares, catálogos de editoras e bibliografia de pesquisas nacionais e internacionais sobre o tema. (FEUSP, 2015).
}

Levantamos um total de 37 produções, destas, duas são de volume único e três se referem aos cadernos MEC publicados separadamente, sendo um por ano (1969 - Caderno 1; 1970 - Caderno 2; 1973- Guias para Cadernos MEC). Este total corresponde, em média, a 100 volumes (unidades de exemplares), uma vez que a maioria das coleções é de três volumes, existindo ainda coleções de quatro e cinco volumes. 
TABELA 3 - Livros didáticos de Física da década de 1960.

\begin{tabular}{|c|c|c|c|}
\hline AUTOR (RES) & ANO & EDITORA & CIDADE \\
\hline BLACKWOOD, O.H. at al (trad.) & 1962 & INEP & \multirow{14}{*}{ São Paulo } \\
\hline FREITAS, A & 1960 & Melhoramentos & \\
\hline GONÇALVES, Dalton & $1960 / 62 / 64 / 65 / 66 / 67 / 68$ & Ao Livro Técnico S.A & \\
\hline GABRIADES, E. & 1960 & Massa Ohno & \\
\hline ANTUNES, Arnaldo Augusto Nora & 1969 & \multirow[t]{2}{*}{ Editora Moderna } & \\
\hline MAIA, L.P. M & 1964 & & \\
\hline 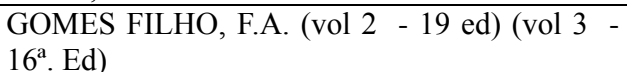 & $1961 / 1965$ & \multirow[t]{2}{*}{$\begin{array}{l}\text { Companhia } \quad \text { Editora } \\
\text { Nacional }\end{array}$} & \\
\hline SANTOS, Udmyr Pires dos & 1967 & & \\
\hline TEIXEIRA JUNIOR, A.S. (11 ${ }^{\mathrm{a}}$. e14 ${ }^{\mathrm{a}}$. Ed) & $1964 / 1966$ & Editora do Brasil & \\
\hline MARISTAS & 1965 & \multirow[t]{2}{*}{ F.T.D } & \\
\hline F.T.D & 196- & & \\
\hline JOHNSON, T.O.F. & $196-$ & Livraria Nobel & \\
\hline RODRIGUES, E.C. at al 17a. e 19a. Ed & 196- & Clássico Científica & \\
\hline SALMERON, R. & 1962 & Não identificada & \\
\hline MAIA, L. P. M. - Caderno MEC 1 & 1969 & FENAME & Rio de Janeiro \\
\hline
\end{tabular}

Fonte: Dados da pesquisa

TABELA 4 - Livros didáticos de Física da década de 1970

\begin{tabular}{|c|c|c|c|}
\hline AUTOR (RES) & ANO & EDITORA & CIDADE \\
\hline ALVARENGA, Beatriz; MÁXIMO, Antônio & 1970 & Bernardo Álvares & Belo Horizonte \\
\hline FARJADO, Sérvulo & $1973 / 1975 / 1976$ & Editora Vega S.A & \\
\hline MAIA, L. P. M. - Caderno MEC 2 & 1970 & \multirow[t]{2}{*}{ FENAME } & \multirow{5}{*}{$\begin{array}{l}\text { Rio de Janeiro } \\
\text { Rio de Janeiro }\end{array}$} \\
\hline MAIA, L. P. M. - Guia p/ cadernos MEC & 1973 & & \\
\hline GONÇALVES, Dalton & 1970 & \multirow[t]{3}{*}{ Ao Livro Técnico S.A } & \\
\hline GONÇALVES, Dalton & 1974 - vol. único & & \\
\hline $\begin{array}{l}\text { BONFIM, Heiser Anderson; GONÇALVES, } \\
\text { Dalton }\end{array}$ & $1978 / 1979$ & & \\
\hline KLEIBER, J. (tradução) & 1976 & \multirow[t]{2}{*}{ Editora Globo } & \multirow[t]{2}{*}{ Porto Alegre } \\
\hline MAIZTEGUI, A.P.( tradução ) & 1972 & & \\
\hline ALVARENGA, Beatriz; MÁXIMO, Antônio & 1979 & Harbra & \multirow[t]{13}{*}{ São Paulo } \\
\hline OMOTE, Noriyasu & $1976 / 1977$ & \multirow[t]{4}{*}{ Editora Moderna } & \\
\hline ANTUNES, Arnaldo Augusto Nora & $1970 / 1972$ & & \\
\hline UENO,Paulo Toru; YAMAMOTO, Issao & 1977 & & \\
\hline $\begin{array}{l}\text { RAMALHO JUNIOR, Francisco; SANTOS, } \\
\text { José I. Cardoso; FERRARO, Nicolau Gilberto; } \\
\text { SOARES, P. A. de Toledo }\end{array}$ & $\begin{array}{l}1976 / 1977 / \\
1979\end{array}$ & & \\
\hline SANTOS, Udmyr Pires dos & 1972 & \multirow{2}{*}{$\begin{array}{ll}\text { Companhia } & \text { Editora } \\
\text { Nacional } & \\
\end{array}$} & \\
\hline FERREIRA, Luiz Carlos & $1975 / 1976$ & & \\
\hline SANTOS, Udmyr Pires dos; RIGUETTO, L. & 1977 & \multirow[t]{2}{*}{ Atual } & \\
\hline $\begin{array}{l}\text { FERRARO, N.G.; SOARES, P. A.T.; } \\
\text { SANTOS, J. I.C. }\end{array}$ & 1979 & & \\
\hline $\begin{array}{l}\text { DELL'ACIPRETE, Nicolangelo; GRANADO, } \\
\text { Nelson Vilhena }\end{array}$ & $1977 / 1979$ & \multirow[t]{4}{*}{ Ática } & \\
\hline MORETTO, Vasco Pedro & $1978 / 1979$ & & \\
\hline U. Lenz; MORETTO, Vasco Pedro (2a.ed.) & 1979 & & \\
\hline MERINO, Djalma & 1979 & & \\
\hline
\end{tabular}

$$
\text { Fonte: Dados da pesquisa. }
$$

Conforme constatado também por Hosoume, Martins e Nicioli Jr. (2007), nota-se, pelos dados, uma hegemonia da cidade de São Paulo como sede das editoras, abarcando um total de 14 publicações na década de 1960 e 13 na década de 1970. São ao todo 18 editoras, sendo 12 delas da Cidade de São Paulo. Constata-se a presença de aproximadamente 33 autores $^{126}$ brasileiros no mercado do livro didático, em obras de autoria isolada ou de

\footnotetext{
${ }^{126}$ Esse número é realmente aproximado, pois há produções em que não foi possível identificar os autores.
} 
parcerias, nas duas décadas. Nota-se ainda que é pequena a presença de obras traduzidas, diferentemente do que ocorria no início do século, quando a maioria das obras de Física era estrangeira, com prevalência das produções francesas (NICIOLI Jr., 2007; SAMPAIO, 2004; MARTINS, 2014).

De nosso levantamento, observa-se que as autorias mudaram bastante, pois se tem a permanência de somente três autores de uma década para a outra. Por outro lado, ocorre uma expansão das produções na década de 1970, correspondendo a um acréscimo de aproximadamente 50\% em relação à década anterior.

O Acordo MEC/SNEL/USAID, em 1966, que teve como compromisso colocar nas escolas brasileiras 51 milhões de livros no período de 1967 a 1970 (ROMANELLI, 1985, p. 213) incrementou o aumento da produção de obras didáticas na virada da década. Embora o acordo tenha findado em 1970, ao que indica, os efeitos mercadológicos do mesmo permaneceram postos. A implantação do sistema de coedição de obras didáticas, em 1970, representou um excelente negócio para as editoras e autores, que explodiram em produções de parcerias, levando as editoras à produção de livros de uma mesma disciplina, por grupos de autores diferentes (HOSOUME; MARTINS; NICIOLI Jr.,2007). Em alguns casos, um mesmo autor participou de diferentes produções de uma mesma editora e também de editoras diferentes, num mesmo ano, como pode ser constatado nos dados das tabelas mostradas.

\subsection{Análise dos livros didáticos}

É fato que o ensino de Física sofreu mudanças ao longo dos anos em função das inovações curriculares, uma vez que toda proposta nova tem uma visão de educação, de ciência física e de ensino/aprendizagem de cada momento da história. Apesar disso, é opinião de vários autores que, quando se consideram os conteúdos de Física, em termos de temas, evidenciam-se poucas alterações apresentadas aos alunos por meio dos livros didáticos (MEGID NETO; PACHECO, 1998; WUO, 2000).

Talvez, a prevalência da apresentação dos conteúdos dessa disciplina do modo como tem ocorrido, mesmo após importantes inovações ocorridas, em parte, deve-se à forma como o livro didático participa do processo de ensino-aprendizagem. As pesquisas indicam que esse recurso pedagógico tem permanecido, ao longo do tempo, como base curricular para muitos professores, quiçá a única (WUO, 2000; CHOPPIN, 2004; FRACALANZA; MEGID NETO, 2006; DELIZOICOV; ANGOTTI; PERNAMBUCO, 2007) 
Se o livro didático, como parte integrante do currículo, é historicamente construído e socialmente contextualizado, por qual razão a estruturação dos conteúdos nos livros didáticos de Física permanece praticamente imutável ao longo do tempo, como afirmam alguns autores? Em que sentido não se observam mudanças? Em quais aspectos esse material didático é realmente contextualizado?

Esta pesquisa não cuida de responder todos esses questionamentos, além de outros que cabem a respeito do livro didático, mas pelo menos dois deles podem ser sintetizados em uma questão mais geral, que se insere em nossos propósitos de investigação: Que visão de Ciência/Física e de educação os livros didáticos de Física transmitem em um dado momento da história?

Tal questionamento se insere na questão principal de nosso estudo nos referenciais curriculares das décadas de 1960 e 1970, nos quais se inclui também o livro didático.

\subsubsection{A amostra}

Delimitamos nossa análise para produções didáticas de grande destaque no mercado editorial, sendo uma delas com presença marcante em todo o recorte temporal investigado: a obra "Física do Científico e do Vestibular", de Dalton Gonçalves. As outras produções escolhidas são de autorias que ingressaram no mercado dos livros didáticos na década de 1970, sendo a elaboração de tais produções inspiradas nos materiais que faziam parte dos recursos de trabalho dos autores destas, desde a década anterior, bem como em suas experiências profissionais. Referimo-nos às obras das parcerias Beatriz Alvarenga e Antônio Máximo, "Física" (início da década de 1970) ${ }^{127}$ e "Curso de Física" (final da década de 1970); e do grupo formado pelos autores Francisco Ramalho Jr, Nicolau Gilberto Ferraro, Paulo Antônio de Toledo Soares e José Ivan Cardoso dos Santos, "Fundamentos da Física" (meados da década de 1970).

Sobre a obra de Alvarenga e Máximo, optamos por analisar as coleções lançadas no início e no final da década de 1970, uma vez que tal obra sofreu alteração de título, editora, formato e estruturação. Além desses aspectos a considerar, analisar as obras desses autores referentes aos dois momentos da década, permite-nos verificar possíveis influências de acontecimentos da década anterior e da atual ao contexto de produção do segundo título da obra.

\footnotetext{
${ }^{127}$ Localizamos citação de bibliografia desta obra no Guia do Professor do PEF, indicando edição do ano de 1969. Contudo não localizamos nenhuma versão da mesma, anterior a 1970.
} 
As obras analisadas foram adquiridas por compra em Sebos virtuais, embora estas, em grande parte, estejam disponíveis no acervo do LIVRES na Biblioteca da Faculdade de Educação da USP e também na Biblioteca do Programa de Pós-Graduação a que se vincula a presente pesquisa. Nosso interesse em adquirir as obras visou facilitar a administração do tempo para análise, o que permitiu uma maior tranquilidade na exploração dos textos.

Persistimos na procura de coleções completas por edição ou ano, entretanto nem sempre obtivemos êxito. A respeito disso, tivemos a oportunidade de verificar alguns exemplares, de mesmo volume, de uma mesma obra, mas de edições/anos diferentes, dentro do limite temporal de estudo, e não se observam alterações na organização dos conteúdos. No caso da coleção de Dalton Gonçalves, tivemos acesso a duas edições de cada volume, de 1968 a 1978 (com exceção do volume 5), e, observam-se alterações somente no quantitativo de exercícios de vestibulares trazidos no último capítulo dos exemplares.

A cada nova edição, esse quantitativo era atualizado, com a inclusão de questões de vestibulares mais recentes de todo Brasil. Do exposto, acreditamos que as diferenças nas edições/anos não comprometem os resultados da pesquisa. Assim, os materiais tomados como fontes da análise que será apresentada neste capítulo, nos termos das dimensões/categorias/elementos já colocados, são conforme a seguir:

LD1 - GONÇALVES, Dalton. Física do Científico e do Vestibular. Vol. 1 (1970,1978), 2 (1968, 1970), $3(\mathbf{1 9 7 0}, 1972), 4(\mathbf{1 9 7 0}, 1974)$ e 5 (1969). Rio de Janeiro: Ao Livro Técnico.

LD2 - ALVARENGA, B.; MÁXIMO, A. Física. Vol. 1 (1970), 2 (1974) e 3 (1971). Belo Horizonte: Bernardo Álvares.

LD3 - AlVAREnGA, B.; MÁXIMO, A. Curso de Física. Vol. 1, 2 e 3. São Paulo: Harbra, 1979.

LD4 - RAMALHO JUNIOR, F. et al.. Os Fundamentos da Física. Vol. 1 ( $3^{\text {a }}$ ed. 1979), 2 (1 ${ }^{\mathrm{a}}$ ed. 1976) e 3 ( $2^{\mathrm{a}}$ ed. 1979). São Paulo: Editora Moderna. 


\subsubsection{Aspectos gerais das obras analisadas}

\section{LD1 (Dalton Gonçalves, 1969...)}

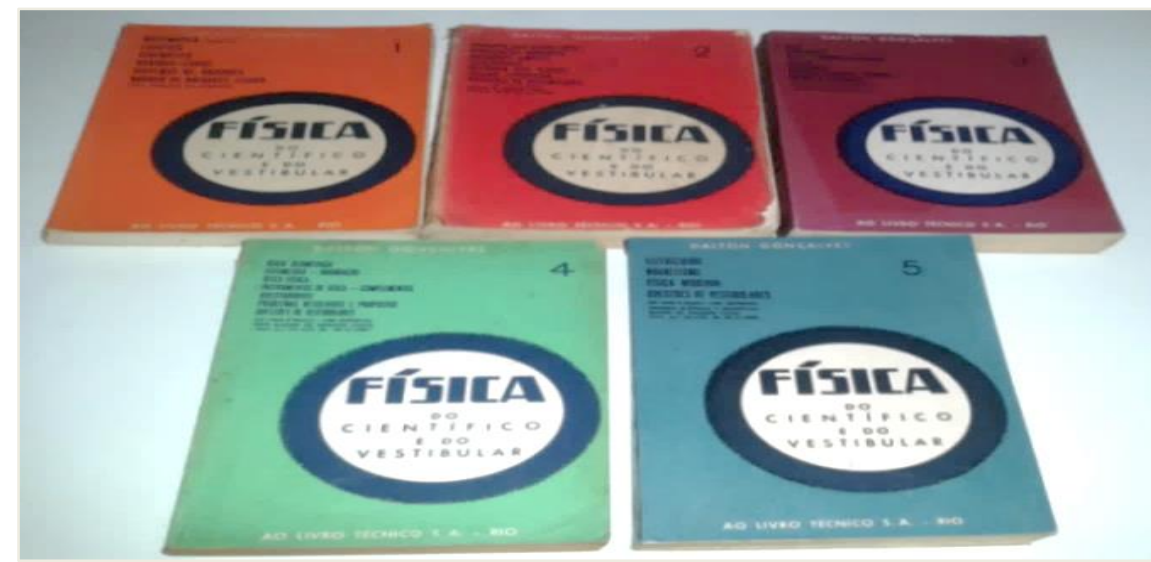

FIGURA 15 - Manuais da coleção de Dalton Gonçalves (1970/1970/1970/1974/1969) Fonte: Foto da autora

A coleção "Física do Científico e do Vestibular" foi publicada pela primeira vez em 1961, conforme informa os dados técnicos de uma das edições analisada ( $7^{\mathrm{a}}$ edição), bem como o PREFÁCIO DA $1^{\text {a }}$ EDIÇÃO apresentado no Volume 1, datado de maio de 1961.

Nesse prefácio o autor ${ }^{128}$ informa que a ideia de escrever a obra foi motivada por uma pergunta de um aluno: "Porque não faz um livro de Física para o vestibular?”. Assim, a obra nasceu da experiência do autor com seu trabalho de preparação dos alunos para o vestibular, segundo ele, com excelentes resultados. Assinala que o livro foi elaborado não somente para o vestibular, mas também para o curso científico ${ }^{129}$, pois, segundo ele "Não éo programa do vestibular o mesmo do científico?"

A coleção compõe-se de cinco volumes, fato pouco comum na elaboração de manuais didáticos de Física para o ensino médio, que geralmente distribuía (ainda distribui) os temas em, no máximo, 3 volumes. $\mathrm{O}$ autor justifica esta opção:

A divisão da FÍSICA DO CIENTÍFICO E DO VESTIBULAR em três volumes pareceu-nos, inicialmente, a mais natural. Cada volume cobriria o programa de uma das séries do curso científico: MECÂNICA para a primeira série, ACÚSTICA E TERMOLOGIA para a segunda e ELETRICIDADE E ÓTICA para a terceira.

Analisando mais de perto o fator PREÇO vimos a conveniência de subdividir o primeiro e o terceiro volumes em duas partes que pudessem ser adquiridas separadamente. (GONÇALVES, 1970, Prefácio, destaque em maiúscula do autor).

\footnotetext{
${ }^{128} \mathrm{Na}$ contracapa do livro de Dalton Gonçalves consta que o autor (já falecido) era engenheiro químico e professor da Escola Fluminense de Engenharia e do Centro Educacional de Niterói.

${ }^{129}$ Cabe ressaltar que, a obra surgiu antes da promulgação da LDB/1961, que reestruturou os níveis de ensino suprimindo a modalidade "curso científico" passando a segunda etapa do ensino médio a se chamar somente "Colegial". Contudo não houve alteração do título nas edições posteriores.
} 
Deste modo, a coleção se organiza da seguinte forma: Volumes 1 e 2 trazem o estudo de Mecânica em nove Unidades e 18 capítulos; o volume 3, Termologia e Ondas/Acústica em 14 capítulos; o volume 4, Ótica em 19 capítulos; e volume 5, Eletricidade, Magnetismo e Física Moderna em 16 capítulos.

$\mathrm{Na}$ organização interna da obra, quatro textos antecedem o ÍNDICE (sumário geral): PREFÁCIO; COMO ESTUDAR FÍSICA; COMO RESOLVER PROBLEMAS NUMÉRICOS e ADVERTÊNCIA AO ALUNO. Todos estes textos indicam dirigirem-se ao aluno.

Os prefácios dos volumes 1 e 2 trazem o mesmo texto que justifica as motivações para a elaboração da obra, bem como apresenta o tema desenvolvido na mesma, e informações sobre a forma de organização dos exercícios/problemas. A partir do volume 3, o prefácio suprime as justificativas e motivações e começa pela apresentação do que trata o exemplar, seguindo com explicações sobre a distribuição dos exercícios, da mesma forma que nos primeiros volumes.

Os dois primeiros volumes organizam o conteúdo em Unidades e Capítulos. As unidades trazem um tema mais geral - por exemplo, CINEMÁTICA - e os capítulos trazem os desdobramentos (ex. Movimento Retilíneo, Movimento Curvilíneo Plano). Os capítulos subdividem-se em seções com tópicos bastante específicos.

Os demais volumes não trazem uma primeira divisão em Unidades. Já se organizam por Capítulos como unidade maior, subdivididos em seções, também com tópicos bem específicos. A quantidade de seções, se vistas a partir do sumário, faz a obra parecer ainda mais extensa, embora o tratamento seja, via de regra, bastante superficial. Citamos, por exemplo, a forma como a obra traz Os princípios da Ótica. Utiliza-se de seis seções; uma para falar da existência de cinco princípios, e as demais seções para explicar cada um deles, em uma abordagem bem sucinta em cada uma. Outro exemplo de subdivisões do texto é colocado a seguir:

\section{7 - A campainha}

Se retirarmos o secundário do esquema da bobina de induģ̄o, obteremos o esquema da campainha.

13.8 - Correntes de Foucault

FIGURA 16 - Recorte de texto da obra de GONÇALVES (1969, vol.. 5, cap. 13, p. 178).

Ao final dos capítulos, de modo geral, é apresentada uma lista de exercícios intitulados Problemas, e, na sequência, um Questionário. O questionário é colocado como 
forma de resumo após a finalização de alguns capítulos (na maioria deles), por considerá-lo uma "boa norma didática". O autor explica que este deveria "ser feito pelo ALUNO" (GONÇALVES, 1970, Prefácio). As questões dos questionários bem como os problemas (também presente na maioria dos capítulos) aparecem em duas categorias denominadas séries "A" e "B". Quanto às perguntas do questionário, as da série "A" seriam respondidas facilmente pelos alunos, após a leitura do texto; "As da série " $B$ ”, menos diretas, prestam-se a debates em aula" (GONÇALVES, 1970, Prefácio). Já "Os PROBLEMAS da série " $A$ " destinam-se ao CIENTÍFICO; os da série “B”, ao VESTIBULAR”. O autor prossegue sugerindo que "Os bons alunos da primeira série do curso científico podem encarar os problemas da série “B” como desafio." (GONÇALVES, 1970, Prefácio, maiúsculo do original).

Em todos os exemplares da coleção, a partir do volume 2, o último capítulo se dedica, exclusivamente, às QUESTÕES DE VESTIBULARES abrangendo questões de exames de diversos Estados brasileiros, desde o ano de 1957 até o último ou penúltimo ano anterior à edição a que se refere o exemplar. Há volumes em que tal capítulo ocupa quase a metade de páginas do exemplar.

A apresentação tipográfica da obra é toda em cor preta. Localizamos ao todo quatro figuras na forma de fotografias, sendo estas em escala de cinza. Não há informação nos volumes da obra que indiquem a existência de um manual do professor.

\section{LD2 (Alvarenga e Máximo, 1970...)}

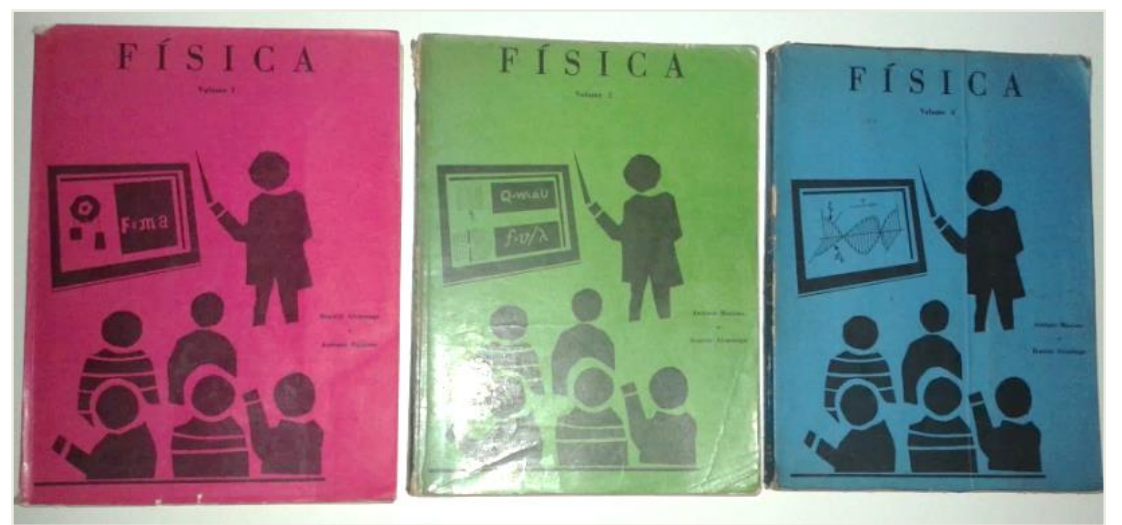

FIGURA 17 - Foto de manuais da coleção de Alvarenga e Máximo (1970/1974/1971)

Fonte: Foto da autora 
A primeira versão da coleção de Alvarenga e Máximo ${ }^{130}$ teve sua primeira publicação em 1970. Intitulada "Física", divide-se em três volumes (I, II e III), com 182, 200 e 208 páginas, respectivamente. Cada volume começa pelo Prefácio (após páginas de informações técnicas), seguido do Índice (na verdade, o sumário) e prossegue com a apresentação dos Capítulos.

Os volumes da coleção se organizam pelos grandes temas da Física, sendo que o volume I trata do estudo de Mecânica, o volume II de Calor e Termodinâmica, Ótica e Ondas, e o volume III, assuntos de Eletricidade/Eletromagnetismo e Noções de Física Moderna.

Os textos de toda a obra estão estruturados em 32 capítulos, intitulados por um tópico mais geral e seções com subtópicos. Ao final de cada capítulo traz uma seção (não muito longa) de EXERCÍCIOS para aplicação do assunto desenvolvido. Não traz seção de leitura suplementar ou algo similar.

O prefácio, igual nos três volumes, indica se dirigir ao professor. Expõe as aspirações que levaram os autores à elaboração da obra. Segundo os autores, a experiência de trabalho lhes mostrou que havia uma demanda ansiosa pela elaboração de um programa completo de Ensino de Física, coerente com as necessidades do ensino secundário brasileiro. Deixa subentendido que tais necessidades perpassavam pela falta de estrutura das escolas, insuficiência de carga horária, desinteresse pelo estudo de Física por parte dos alunos e exigências dos cursos superiores. Afirmam que nas suas experiências profissionais de vários anos, no magistério e como membros de comissões examinadoras de vestibular e concursos de professores, observaram a unanimidade das reclamações pela "existência de um completo programa de Ensino de Física, que satisfaça as necessidades de nossa realidade do ensino secundário." (ALVARENGA; MÁXIMO, 1970, Prefácio).

Os autores mencionam que os problemas do ensino de Física já eram discutidos em diversos eventos com o intento de melhorar a situação do ensino dessa disciplina no país. Destacam a preocupação e participação de cientistas na reforma do Ensino de Ciências em todo o mundo, por julgarem que tal ensino estava "muito distanciado da própria filosofia das ciências em nosso século [o século XX], tão diferente da que nos precedeu”" (ALVARENGA; MÁXIMO, 1970, Prefácio).

Apontam ainda que os programas organizados em outros países, traduzidos, mostraram-se inviáveis de serem adotados, seja pelas dificuldades materiais que acarretariam,

\footnotetext{
130 Beatriz Alvarenga é graduada em Engenharia Civil pela Universidade de Minas Gerais. Foi, por muitos anos, professora de Física no Colégio Universitário da UFMG. Atualmente é professora emérita desta mesma instituição. Antônio Máximo Ribeiro da Luz é bacharel e licenciado em Física pela Universidade de Minas Gerais (UFMG) e professor adjunto do Departamento de Física desta mesma universidade.
} 
ou por serem inadequados à realidade do sistema educacional do país. Passam a falar da origem e da característica geral da obra:

Em meados de 1967, nos propusemos a organizar um programa completo de ensino da Física para as escolas secundárias, com livros-textos para os estudantes, guias para professores, guia de laboratório, materiais auxiliares de ensino de um modo geral, etc. Não temos a pretensão de estar realizando uma obra completamente nova ou absolutamente original. Nossa intenção é fazer um trabalho que, sendo moderno, pois dá ênfase às leis gerais, reduz a informação ao mínimo necessário, procura desenvolver o gôsto pela experiência e o raciocínio lógico - seja, ao mesmo tempo, real, não se constituindo numa utopia - tem extensão compatível com o tempo médio que se dispõe para o ensino da matéria, é adequado a nosso sistema de ensino que prevê três anos para o ensino da Física nas Escolas Secundárias, satisfaz às exigências de nossos cursos superiores, não desenvolve conceitos excessivamente profundos, cuja compreensão estaria fora do alcance da maioria dos estudantes, não lança mão de recursos materiais caros ou complicados. (ALVARENGA; MÁXIMO, 1970, Prefácio)

Desta colocação, percebe-se que os autores assumem as influências do que estava sendo produzido no momento em termos de materiais didáticos inovadores: ênfase às leis gerais, redução de tópicos, guias de orientação, etc. Ao que indica, as pretensões se constituíam em um projeto mais amplo. Não foi possível saber se tal projeto foi totalmente concretizado pelos autores. Alguns aspectos parecem não terem sido vinculados à obra em questão. Propostas de experimentação para o aluno realizar, por exemplo, aparece em quantidade ínfima; não localizamos também informações sobre a existência de guia de laboratório e outros materiais auxiliares.

A representação gráfica (tipografia) se dá nas cores preta e vermelha e as eventuais fotos são apresentadas na escala de cinza; em raras exceções apresenta fotos ou figuras em cores.

Não se identifica nos volumes da obra nenhuma informação sobre a existência de um manual do professor. 


\section{LD3 (Alvarenga e Máximo, 1979)}

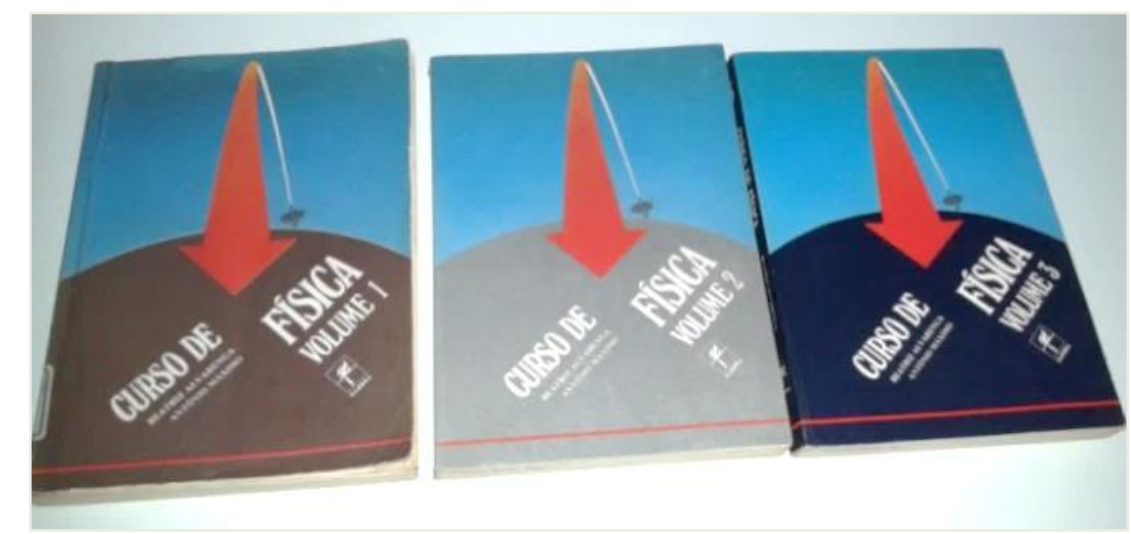

FIGURA 18 - Foto dos manuais da coleção de Alvarenga e Máximo (1979) Fonte: Foto da autora

Esta coleção, publicada a partir de 1979, trata de uma versão renovada da obra anterior. Sofreu alteração de título e mudança de editora. Passou à denominação de "Curso de Física" e permaneceu estruturada em três volumes, com os mesmos grandes temas da Física. A obra traz mudanças também nas suas dimensões físicas e apresentação gráfica; ganhou um aspecto mais moderno, com o livro em tamanho menor em termos de dimensões das páginas. Em termo de cores, perdeu os destaques em vermelho (nos títulos e partes de figuras) ficando a tipografia apenas em preto e fotos em escala de cinza.

Os volumes têm também uma estruturação textual interna um pouco diferente da coleção anterior. As páginas pré-textuais trazem, além de dados técnicos, o sumário denominado Conteúdo, um texto de apresentação Ao professor e outro Ao estudante. Em cada volume apresenta, além do sumário do volume em questão (mais detalhado em Unidades, Capítulos e Seções), os sumários gerais dos demais volumes da obra, indicando, somente, os títulos das Unidades e dos Capítulos.

Os textos dos manuais estão estruturados em Unidades, subdivididas em Capítulos, ambos enumerados sequencialmente na coleção como um todo. $\mathrm{O}$ mesmo ocorre com a paginação, que é contínua de um volume a outro; o volume 1 vai até a página 275, o volume 2 até a 607 e o volume 3 até a 930. São 25 capítulos ao todo, subdivididos em seções e tópicos. Ao final de cada seção apresenta uma lista de EXERCÍCIOS DE FIXAÇÃO, e, no final dos capítulos traz seções não enumeradas intituladas REVISÃO (exercícios), LEITURA, ALGUMAS EXPERIÊNCIAS SIMPLES..., PROBLEMAS E TESTES e PROBLEMAS SUPLEMENTARES. Apresenta ainda respostas dos exercícios de todas as seções.

$\mathrm{Na}$ apresentação da seção LEITURA, os autores informam que os textos são relacionados ao conteúdo do capítulo e que a sua leitura poderá proporcionar algumas 
informações adicionais interessantes. Recomenda que o aluno procure interpretar a leitura, fazer um resumo e comentar com os colegas. Os textos trazem aprofundamento de algum assunto tratado, temas recentes da Física (as noções de Física Moderna, p. ex.), curiosidades ou aspectos históricos.

Nota-se ainda que, na reestruturação da coleção, alguns capítulos e tópicos foram suprimidos ou aglutinados, bem como novos tópicos foram incluídos. Ocorreu ainda, ora resumo, ora expansão de alguns tópicos que permaneceram. No balanço das alterações o quantitativo de capítulos da coleção, antes com 32, passou para 25, acrescido de um apêndice no volume 3. Houve mudança também na alocação de alguns capítulos, de maneira que não segmentou a Mecânica somente no volume 1, como ocorria na coleção LD2, conforme veremos mais adiante.

$\mathrm{Na}$ apresentação Ao professor, os autores fazem entender que as mudanças ocorreram em razão das alterações processadas a partir da reestruturação do ensino secundário em $1^{\circ}$ e $2^{\circ}$ graus. A diversidade de carga horária é um fator apontado pelos autores como justificativa de mudanças nos conteúdos programáticos na escola. Contudo, a nova proposta dos autores pareceu não ter condição de minimizar problemas que envolvessem tal questão. Os livros da coleção foram publicados em tamanho menor nas dimensões das páginas, mas incluíram-se mais seções (leitura, experiências, etc.), e, sobretudo, um grande quantitativo de exercícios e testes; inclusive aumentou a espessura dos manuais. A soma de páginas da coleção, antes com 590 folhas, passou para 930; um acréscimo de cerca de 58\%. Embora tenha diminuído as dimensões das páginas, podemos dizer que a redução em si não foi responsável pelo aumento de laudas, já que o tamanho da fonte tipográfica também foi reduzido significativamente. Percebe-se que o aumento de tópicos tratados e a inclusão de mais seções de exercícios foram determinantes para o aumento de páginas dos manuais da coleção, apesar da diminuição no número de capítulos.

Um notável diferencial desta versão é a quantidade de propostas experimentais apresentadas; cerca de uma centena de experimentos simples se distribui nos capítulos da obra, estando presente em todos. Na coleção anterior identificam-se cerca de uma dezena de propostas experimentais, algumas bastante simples.

Não localizamos para as duas coleções de Alvarenga e Máximo, o manual do professor, e não se identifica nos volumes das obras nenhuma informação sobre a existência deste. 


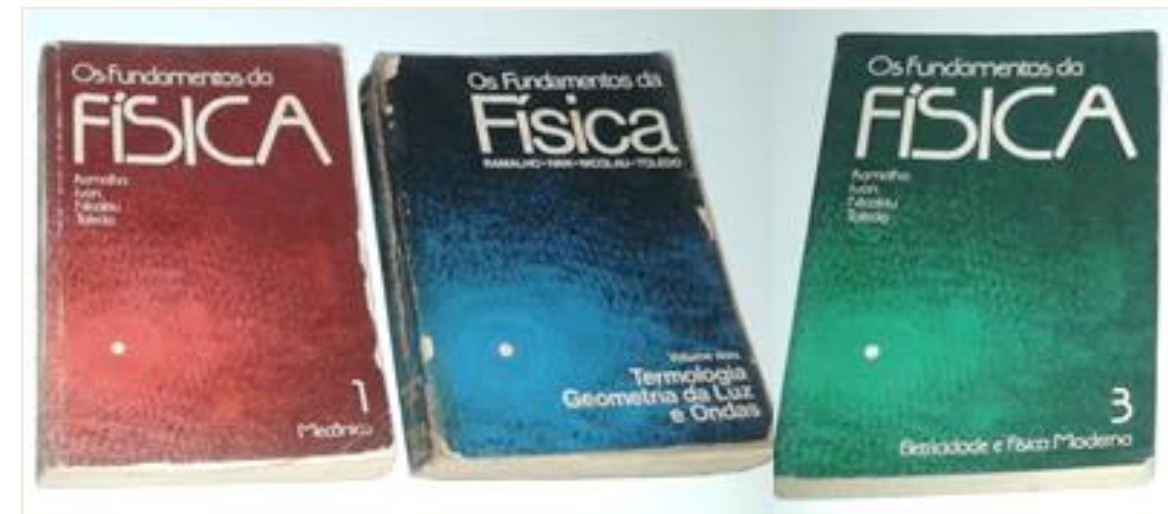

FIGURA 19 - Foto dos manuais da coleção de Ramalho et al. (1979/1976/1978)

Fonte: Foto da autora

A coleção de Ramalho Junior et al. ${ }^{131}$, intitulada "Os Fundamentos da Física", cuja a primeira edição foi publicada em 1974 (conforme um dos autores) ${ }^{132}$, é organizada em 3 volumes: Volume 1- Mecânica; Volume 2 - Termologia, Geometria da Luz e Ondas; e Volume 3- Eletricidade e Física Moderna. Trazem a divisão dos assuntos em Partes (Parte I, Parte II,..., etc.) e estas se subdividem em Capítulos e seções, somando ao todo 53 capítulos.

Os manuais se iniciam por um Prefácio que, até certa altura (o $3^{\circ}$ parágrafo) possui texto igual para todos os volumes; a partir deste ponto passa a esclarecer o que será tratado no volume em questão. Nele informa que "A utilização didática deste livro é analisada no Livro do Mestre, onde são feitas sugestões e recomendações sobre a abordagem da teoria, dos exercícios e dos testes." (RAMALHO JUNIOR et al., 1979, Prefácio). Contudo, não localizamos o exemplar desse livro, e não há outras informações sobre ele no manual do aluno. Não foi possível saber, seguramente, se cada volume tinha um Livro do Mestre correspondente e se tal livro trazia todo o conteúdo do livro do aluno; quanto ao conteúdo, acreditamos que não, pela fala de um dos autores, Professor Nicolau Gilberto Ferraro, em entrevista a Chiqueto e Krapas (2012): “A primeira edição já saiu com livro do mestre. Era

\footnotetext{
131 Dos quatro autores desta obra, somente um possui formação em Física: Nicolau Gilberto Ferraro, Engenheiro metalurgista graduado pela Escola Politécnica da USP, licenciado em Física pelo IFUSP e mestre em Engenharia Mecânica pela Escola Politécnica da USP; José Ivan Cardoso dos Santos é graduado em Engenharia Civil; Paulo Antônio de Toledo Soares (já falecido) era graduado em Medicina (fonte: http://osfundamentosdafisica.blogspot.com.br/2012/01/historia.html Acesso em: 22 Mar. 2016.); Francisco Ramalho Junior, que encabeça a lista de autores da obra (inclusive esta é amplamente conhecida pelo seu sobrenome), cursou Engenharia Eletrônica na Politécnica da USP, mas não chegou a concluir o curso, segundo relato do próprio autor, constante no livro "Francisco Ramalho Jr. Éramos apenas paulistas" de Celso Sabadin (2009).

${ }^{132}$ Histórico da obra disponível em : http://osfundamentosdafisica.blogspot.com.br/2012/01/historia.html Acesso em: 22 Mar. 2016.
} 
muito simples, mas já dava um caminho para o professor. Tinha a resolução dos principais exercícios." (CHIQUETTO; KRAPAS, 2012, p. 184, grifo sublinhado nosso).

O sumário dos volumes desta obra é também intitulado Conteúdo. Os títulos das Partes são mais gerais e os dos capítulos são os desdobramentos em temas mais específicos. No interior da obra, os capítulos são ainda subdivididos em seções. Entremeio às seções de conteúdos teóricos há a seção de Exercícios resolvidos, e, ao final dos capítulos, as seções de exercícios propostos, exercícios propostos de recapitulação e testes propostos, bem como as repostas (resultados finais sem resolução) de todas as categorias de exercícios.

Alguns capítulos (onze) da coleção contemplam a seção LEITURA. A primeira leitura traz um breve relato da história da Física; as demais abordam: aprofundamento de algum assunto (Ex: Natureza física das forças de contato, Crítica à noção de força, correntes amperianas); curiosidades físicas (Ex: Comportamento anômalo da água, Refração da luz na atmosfera, Miragem, Arco-íris), funcionamento de aparatos tecnológicos (Ex: O motor de explosão do automóvel, Termômetro Legal, Solução Giauque, Parte elétrica de um automóvel); avanços da tecnologia (Ex: Aproveitamento do potencial elétrico do Brasil, Telecomunicações no Brasil).

Passaremos aos resultados de nossa análise de conteúdo nas obras didáticas caracterizadas até aqui, com enfoque nas dimensões Epistemológica e Educativa.

\subsubsection{As dimensões Epistemológica e Educativa nos livros didáticos}

\section{Da dimensão Epistemológica}

Ciência como processo

A obra LD1 ignora quase que totalmente o caráter processual da construção do conhecimento. Não menciona aplicações de conhecimentos da Física nas tecnologias, e infimamente remete aos aspectos históricos das evoluções das ideias. Ora ou outra, na introdução de algum conceito, menciona o nome do cientista que estudou o fenômeno e "descobriu" uma lei, mas sem discutir o processo das descobertas. Somente no volume 4 encontra-se uma abordagem histórica um pouco mais extensa (cerca 3 laudas), tratando da evolução das ideias sobre a NATUREZA DA LUZ. Descreve sinteticamente a Teoria ondulatória, a Teoria eletromagnética de Maxwel, a Teoria dos quanta ou de Planck e a 
Mecânica ondulatória de De Broglie, Heisemberg, Schrödinger e outros (GONÇALVES, 1974, vol. 4, p. 138-141).

Não relaciona a Física com a cultura, política ou sociedade e nem com outras áreas do conhecimento. A contextualização é pouco explorada; se limita, em poucas ocasiões, a citações de exemplos de coisas do cotidiano em que se aplicam algum conceito apresentado. Citemos um exemplo: Em um exercício resolvido, para aplicação do conceito de resistência elétrica traz o exemplo de utilização de linhas de cobre ou alumínio nas instalações domiciliares. Após propor e resolver cálculos com dados característicos do alumínio e do cobre traz uma observação que diz:

Vemos, por êste problema que um fio de alumínio capaz de substituir um de cobre
possui seção reta maior, mas em compensação possui praticamente metade de sua
massa. Além disso, o preço do alumínio (por unidade de massa) é mais baixo que o
do cobre. (Esta conclusão tem alguma importância econômica para o Brasil?)
(GONÇALVES, 1969, vol. 5, p. 36-37).

Esta observação, após o exercício em questão, levanta a possibilidade de promover uma discussão mais abrangente em sala de aula, levando em conta os aspectos econômicos e políticos vinculados à ciência e tecnologia. Contudo, o tema se encerra com a seguinte explicação após a pergunta da citação acima: “Apesar do alumínio ser um grande concorrente do cobre, êle não pode substituí-lo inteiramente. O cobre é bem mais resistente à tração e à corrosão que o alumínio." (GONÇALVES, 1969, vol. 5, p. 37).

O modo como os assuntos são apresentados não faz perceber a importância do sujeito na construção do conhecimento. A Física é apresentada a partir de conceitos e definições inquestionáveis, produto pronto, com finalidade em si mesma.

$* * *$

Na obra LD2, a ideia de ciência como processo está presente de forma mais ou menos explícita. Em seu primeiro capítulo, ressalta a impossibilidade de definição precisa do que seja a Física e considera mais importante a compreensão do que já se desenvolveu nesse campo, e a capacidade de essa ciência explicar uma grande variedade de fenômenos.

A Física é ressaltada como ciência mais antiga da natureza e como suporte para compreensão das teorias relacionadas a outras ciências: Química, Biologia, Astronomia, Geologia, História, Arqueologia, etc.

A concepção de ciência como um processo dinâmico, com rupturas de pensamentos sobre o conhecimento da natureza e com relevantes interpretações particulares é contemplada ao longo da obra. No entanto, em uma primeira análise, no início do primeiro volume, encontramos um trecho que, a nosso ver, sintetiza as percepções dos autores: 
Os físicos têm de estar alertas e o constante reexame de velhos e bem estabelecidos conceitos conduz, muitas vêzes, a consideráveis alterações. Algumas vêzes, estas alterações são tão chocantes e tão contrárias ao senso comum, que elas custam a ser aceitas, constituindo surprêsa para os próprios físicos. Por isso mesmo, o cientista tem de desconfiar daquilo que parece óbvio e do senso comum, pois êste é um produto do cérebro humano, e nem sempre a natureza se curva a êle. (ALVARENGA; MÁXIMO, 1970, Vol. 1, p. 11-12).

Outros trechos como os descritos abaixo, que também são elementos que denotam os aspectos históricos da Física, dentre outros, revelam que a ciência é processo inacabado, coletivo e carregado de conflitos:

As relações entre força e movimento não são evidentes para nós e nem o foram para os antigos, que sempre se preocuparam em determiná-las. Os escolásticos, na Idade Média, que seguiam as idéias de Aristóteles, postulavam que, [...]." "Os dogmas de Aristóteles, à primeira vista, parecem corretos, pois [...] Galileu conseguiu interpretar [...]. (ALVARENGA; MÁXIMO, 1970, vol. 1, p.75)

O cientista polonês, Copérnico (1473-1543), reviveu a teoria heliocêntrica e mostrou, através de cálculos, que esta teoria, bem mais simples, poderia explicar os fatos conhecidos [...]. O próprio Copérnico ainda não estava satisfeito com seu trabalho [...]. Tycho Brahe,[...] não aceitou as idéias de Copérnico, pois suas observações astronômicas, bastante precisas e abundantes, iam de encontro a elas. [...]. Enquanto Kleper desenvolvia sua teoria na Alemanha, na Itália, seu amigo e correspondente Galileu defendia entusiasticamente a teoria heliocêntrica. (ALVARENGA; MÁXIMO, 1970, vol. 1, p.114).

A história da Física, das descobertas dos fenômenos é contemplada ao longo dos textos da obra, geralmente na introdução de um tema mais geral. Aparece também em coluna paralela ao texto principal em pequenos resumos, como legendas de figuras ou fotos de cientistas.

A ideia de participação/interferência do sujeito/observador na construção do conhecimento científico, caracterizando a ciência como conhecimento não neutro, distribuise nos textos. A própria explicação para a divisão da Física em ramos, pressupõe essa interação com o sujeito. Fala da importância do cotidiano como ponto de partida para compreensão do Universo e evidencia os sentidos como primeiras ferramentas de contato com o meio, para formação de conceitos, chamando à atenção para as conclusões errôneas que geralmente são assimiladas. Expõem os ramos da Física - Óptica, Acústica, Termologia e Mecânica, segundo os autores, historicamente classificadas com base nos sentidos - visão, audição e tato - e pela observação mais comum do cotidiano - o movimento. $\mathrm{O}$ eletromagnetismo é apresentado como ramo organizado somente a partir do século XIX e a Física Moderna a partir do século XX, por não consistirem em fenômenos perceptíveis sensorialmente.

Citemos outro trecho que ilustra a ideia de relação do sujeito com o objeto de conhecimento: "Quando um cientista analisa uma situação física, êle deve, em primeiro 
lugar, selecionar os aspectos que lhe parecem essenciais e abandonar outros, que considere supérfluos." (ALVARENGA; MÁXIMO, 1970, vol. 1, p. 73).

A relação Física/tecnologia/sociedade é contemplada com a apresentação de fotos distribuídas ao longo da obra. Algumas delas aparecem em página anterior à introdução dos volumes, antecedidas pela frase (em caixa alta): “ESTES MODERNOS EQUIPAMENTOS SÃO FERRAMENTAS IMPORTANTES PARA USO DOS CIENTISTAS E TÉCNICOS EM SEUS TRABALHOS” (p.10). As fotos se referem a: reator atômico, computador IBM, aparelhagem de ressonância magnética nuclear, Central Elétrica da CEMIG, antena parabólica de estação de comunicações, Microscópio eletrônico Zeiss da escola de Medicina da UFMG, e outros.

Outras imagens são apresentadas, distribuídas nos capítulos, conforme o assunto abordado (astronauta em câmara de teste de gravidade, Satélite Sputinik, Telescópio de Hale, motores de geladeira, Usina hidrelétrica de Três Marias/MG, câmara de raios X, etc.). A foto da referida usina, bem como da central elétrica da CEMIG, evidencia uma tentativa de contextualização a partir de algo próximo da realidade dos autores do material e também dos mais prováveis estudantes que os utilizaria. Os autores eram professores de uma universidade do estado de Minas Gerais (UFMG).

Traços sutis da relação Física/sociedade/cultura são notados, de modo geral, por meio de fotos, como forma de contextualizar os assuntos abordados. Como exemplo, citamos a discussão sobre as qualidades fisiológicas do som. Apresentam fotos de um piano sendo manuseado, duas orquestras musicais (em uma delas, um dos membros é o físico Albert Einstein), uma foto de Richard Feynman tocando pandeiro e também de outro grupo de homens negros tocando esse mesmo instrumento.

Em síntese, o caráter da ciência como um processo dinâmico é evidenciado nas explicações dos conceitos e teorias já formuladas, nas introduções de cada assunto com menções de ideias convergentes ou contraditórias dos cientistas, rupturas de concepções e evolução da ciência nas aplicações tecnológicas.

\section{$* * *$}

A obra LD3, em seu conteúdo, traz características similares à primeira versão da coleção (LD2); algumas seções trazem o mesmo texto, ora mais resumido, ora reestruturado com acréscimos de informações.

A concepção de ciência como processo é mais explícita que na versão anterior pela inclusão de mais elementos. Os aspectos históricos, por exemplo, ganham destaque; além de vir distribuídos ao longo dos textos principais (na apresentação dos conteúdos teóricos) e em 
resumos em colunas paralelas aos textos principais acompanhados de fotos de cientistas, ganham maior ênfase também nas Leituras complementares ao final dos capítulos. As características de tais leituras permitem ainda perceber a atuação do sujeito na construção do conhecimento. Além disso, denotam traços político-sociais em torno do desenvolvimento científico. A leitura que fala da vida de Einstein é um exemplo disso. Os autores mostram uma famosa foto do físico com a seguinte legenda: "Einstein nos últimos anos de sua vida. A grande tristeza que se revela em seu olhar é atribuída ao pesar que sentia percebendo que as descobertas científicas estavam sendo utilizadas em armas de guerra que iriam dizimar milhares de pessoas." (ALVARENGA; MÁXIMO, 1979, vol. 1, p. 194).

O texto apresentando ao lado da referida foto fala da carta que Einstein enviou ao presidente dos EUA, no início da Segunda Guerra Mundial, alertando-o sobre a ameaça de construção da bomba atômica pelos alemães. O alerta ajudou os EUA sair na frente na construção de tal arma de destruição em massa, a partir da estruturação de um intenso plano de trabalho. O desfecho disso resultou na destruição de duas cidades no Japão com a perda de muitas vidas. Algo que deixou Einstein imensamente abalado. Trata-se de um fato em que a ciência foi colocada a serviço de grandes interesses políticos, sem julgamento de valor. De certo modo, o texto exime o cientista da culpa, direcionando-a ao sistema político.

Como forma de contextualização com a tecnologia, esta versão da obra explora ainda mais a exposição de fotos de aparatos tecnológicos. Repete várias da versão anterior, e apresenta outras mais atualizadas. Alguns desses aparatos são mostrados e discutidos na seção LEITURA ao final dos capítulos.

Os exemplos cotidianos, citados com frequência, denotam a relação da Física com a cultura geral. O texto se destaca ainda pela grande quantidade de ilustrações esquemáticas que contribuem para o entendimento das explicações dos conceitos.

$* * *$

Elementos que denotam a ciência como processo na obra LD4 são, praticamente, inexistentes. Embora destaque a importância da Física como sendo "uma ciência tão presente em nossa vida, que não podemos dispensá-la” (RAMALHO JUNIOR et al., 1978, vol. 1, p. 1), não menciona as relações diversas que esta possui com o modo de vida das sociedades (cultura, política, economia, etc...). Conceitua a Física "como ciência que estuda a natureza" (vol. 1, p. 01). Expõe os ramos da Física em texto idêntico à Obra LD1, evidenciando os sentidos humanos como recursos inspiradores da classificação dos fenômenos, ou seja, da divisão dessa ciência em ramos. 
A visão de ciência acabada pode ser ilustrada com um exemplo que fala sobre a composição do Universo por pequenas partículas, vista como hipótese na antiguidade, e, colocada como fato "efetivamente comprovado" na atualidade (vol. 1, p. 02).

Aspectos históricos da Física se restringem a uma única LEITURA ${ }^{133}$ no final do primeiro capítulo do volume 1 (p. 10-11) e em esporádicas e curtas notas de rodapé ao longo dos volumes da coleção. Um quadro cronológico comparativo, apresentado nas duas primeiras folhas dos livros, de forma muito simplificada, mostra o desenvolvimento linear da Física e de outras áreas do conhecimento.

A relação Física/tecnologia está limitada à apresentação de fotos (pranchas) de alguns aparatos tecnológicos, que suscita a intenção de mostrar a aplicação da Física na construção de máquinas, sem nenhum texto explicativo ou correlação com os conceitos apresentados. Mostra fotos de reator nuclear e painel de controle (vol. 1, p.03), higrômetros (vol. 1, p. 84-85), roda gigante (vol. 1, 144-145), túnel aerodinâmico (vol. 1, p. 224-225), usina hidrelétrica (vol. 1, p. 379-380) e lunetas e teodolito (vol. 1, p. 396-397).

Um boxe intitulado "Astronáutica" (vol. 1, p. 392) configura um ensaio de contextualização com o contexto histórico, trazendo uma breve descrição técnica dos satélites artificiais produzidos entre 1957 e 1958 pela Rússia e Estados Unidos, do primeiro voo humano orbital e da chegada do homem à Lua. Ressalve-se que, o conteúdo do boxe, mesmo estando ao lado da seção VELOCIDADE DE ESCAPE, não se articula com os conceitos apresentados, nem mesmo se faz referência a ele no corpo do texto.

A obra não traz elementos que podem ser caracterizados como relação da Física com a sociedade de modo mais amplo, como a cultura e os aspectos políticos, econômicos e sociais. Em súmula, passa a ideia de que a ciência é somente um produto rematado e neutro; isento de relações contextuais.

\section{A Física e a experimentação}

Na obra LD1 o autor afirma que "A Física emprega o método experimental, que por sua vez, usa a observação e a experimentação" (GONÇALVES, 1970, Vol. 1, p.169). Após citar exemplos sobre a queda dos corpos, diferencia leis qualitativas de quantitativas e ressalta importância da experimentação para o estabelecimento das leis quantitativas por meio das medidas das grandezas físicas que participam do fenômeno: "Observemos que as leis

\footnotetext{
${ }^{133}$ A referida leitura trata da evolução de algumas explicações dos fenômenos relacionados ao movimento dos corpos (especialmente os celestes) a partir do ponto de vista de alguns "expoentes" da área.
} 
quantitativas são mais importantes que as qualitativas." (Vol. 1, p. 170). Para o autor, "o objeto fundamental da Física é estabelecer leis físicas." (Vol. 1, p.171). Afirma ainda que a Física se preocupa em saber “como" os fenômenos se processam, mas não o "porque” eles se processam (Vol. 1, p.171).

Embora o breve discurso em defesa da experimentação, localizamos não mais que uma dezena de atividades que podem ser consideradas propostas experimentais, a maioria no volume 3, no estudo de Termologia. Estas aparecem ao longo do texto, sem maiores orientações sobre a preparação, advertências, análise de dados e discussão. Vejamos alguns exemplos:

A avaliação de uma temperatura por intermédio do seu efeito fisiológico merece pouca confiança. Você se convencerá realizando duas experiências clássicas.

a) Mergulhe a mão direita em água gelada e, a esquerda, em água quente. Em seguida, coloque ambas as mãos em água morna. Você observará que a água morna parece quente para a sua mão direita e fria para a esquerda.

b) Toque um bloco de madeira e um bloco de metal, estando ambos à mesma temperatura. Você observará que o bloco metálico parece mais frio que o de madeira.

Vemos assim que, para avaliar uma temperatura com certo rigor, temos que recorre a outros efeitos.

(GONÇALVES, 1970, vol. 3, p. 21)

Podemos imaginar e construir diversos tipos de termoscópio. Vejamos um, relativamente simples. Você pode construí-lo (Figura 1.1) [é mostrada uma figura de um balão de vidro].

Consiga um balão de gargalo comprido e estreito. Com um pouco de habilidade você conseguirá introduzir, no gargalo, uma gôta de um líquido colorido qualquer. Leve o termoscópio para um ambiente mais quente. $\mathrm{O}$ ar contido no seu interior se aquece e aumenta de volume. A gôta colorida vai se deslocando para cima até que o equilíbrio térmico seja atingido. Se o tivesse levado para um ambiente mais frio a gôta desceria, em lugar de subir. (GONÇALVES, 1970, vol. 3, p. 23).

O vidro do espelho é usado como uma proteção transparente para a camada metálica situada em sua parte posterior. [...] Uma camada de verniz superposta à camada metálica completa a proteção. Procure retirar esta camada metálica de um espelho de bôlsa, (Que acontece?). (GONÇALVES, 1970, vol. 4, p. 17).

Poderíamos fazer um esquema da pilha sêca. Achamos preferível, porém, que você mesmo o faça, depois de abrir uma pilha. (GONÇALVES, 1970, vol. 5, P. 100).

A rapidez com que um corpo se resfria permite explicar o comportamento, aparentemente anormal, de um pedaço de papel na experiência citada.

Enrole, apertando bem, um pedaço de papel em tôrno de uma barra de cobre. Chegue ao papel a chama de uma vela. O papel não se inflama (experimente). Como explicar isto? [na sequência passa a explicar a razão pela qual o papel não se inflama]. (GONÇALVES, 1970, vol. 3, p. 117).

De modo geral, os resultados que se esperam que o aluno perceba na experiência, são apresentados na sequência da proposta.

Observamos ao longo do texto outras situações que não alvitram o aluno a fazer a experimentação, mas na explicação dos conceitos, de modo mais ou menos explícito, sugere a 
possibilidade de observação do fenômeno por meio de uma determinada experiência. Estas não estão contabilizadas no quantitativo mencionado acima, por não propor a atividade ao aluno.

\begin{abstract}
Para determinar a densidade de um líquido conduzimos a operação do seguinte modo: a) enche-se o vaso com o líquido cuja densidade se quer determinar;... [prossegue com os demais procedimentos] (GONÇALVES, 1970, vol. 2, p. 339).

Outra experiência demonstrativa clássica consiste em esticar um fio de cobre e, em seguida, fazer uma corrente elétrica atravessá-lo. A corrente elétrica aquece o fio e êste se torna bambo, em virtude do aumento de comprimento. (GONÇALVES, 1970, vol. 3, p. 36).
\end{abstract}

[Na seção Tensão Superficial] Há uma experiência que comprova esta conclusão: coloca-se um laço de linha sôbre uma película de água com sabão; furando-se a película no interior do laço êste adquire forma circular. (GONÇALVES, 1970, vol. 2, p. 358)

Usando limalhas de ferro, podemos, facilmente, evidenciar as regiões polares [do ímã] (GONÇALVES, 1969, vol. 5, P. 149).

As propostas experimentais apresentadas objetivam ilustrar ou comprovar uma afirmação sobre um conceito. A pequena quantidade delas, bem como a forma de condução das mesmas, não sustenta o discurso apresentado no início do capítulo 10 (vol. 1) da obra quando evidencia a importância da experimentação como método em Física.

$$
* * *
$$

No capítulo de introdução à Física na obra LD2, os autores discursam que formar conceitos simplesmente lendo livros escritos pelos físicos configura um grave erro que alguns estudantes cometem. Segundo os autores, é preciso passar algumas horas no laboratório; é preciso compreender as diferenças das medidas e suas unidades. Defendem que "O treino de laboratório torna o estudante mais consciente da realidade" (ALVARENGA; MÁXIMO, 1974, vol. 1, p. 12).

Contudo apresenta poucas sugestões de atividades experimentais para o aluno realizar. A maioria delas, quando não estão dispostas na seção de Exercícios, aparecem no meio do texto, de modo que, numa primeira análise superficial, não foram identificadas. Uma análise mais cuidadosa permitiu-nos localizar 11 sugestões de atividades que podem ser classificadas como propostas diretas de experimentação. São aquelas em que o aluno é solicitado a realizar o experimento. Porém, outras situações apresentadas poderiam ser consideradas como "possibilidades" de experimentação. Aparecem como esquemas e descrição de experiências e, embora não solicite que o aluno faça, fica implícita a sugestão.

No volume 1 identifica-se uma proposta experimental que requer medidas com uso de um instrumento, e outra de observação. A primeira, na seção Algarismos Significativos 
sugere a medição das dimensões do livro e de uma folha do mesmo, utilizando uma régua. A segunda pede: "Você já deve ter observado muitas vêzes uma gôta de chuva cair verticalmente. Preste atenção, porém, na queda da gôta de chuva quando você estiver num carro em movimento. Compare suas observações." (vol. 1, p. 67).

No volume 2, localizam-se ao todo 4 propostas de experimentos simples, sendo todas na seção de Exercícios. Citamos uma delas:

5- Faça a seguinte experiência:

a) Coloque dois espelhos planos em ângulo reto e verifique que se formam três imagens de um objeto situado entre eles. Trace um diagrama mostrando a marcha dos raios luminosos que dão origem a cada uma dessas imagens.

b) Varie o ângulo formado pelos espelhos e verifique o que ocorre com o número de imagens. Você consegue contar o número de imagens quando os espelhos estiverem paralelos? (Esta multiplicidade de imagens em espelhos que formam um ângulo entre si é usada dos caleidoscópios). (ALVARENGA; MÁXIMO, 1974, vol. 2, p. 114).

No terceiro volume localizam-se cinco propostas experimentais diretas. Algumas nos textos, outras na seção de Exercícios. Uma delas é a que se segue.
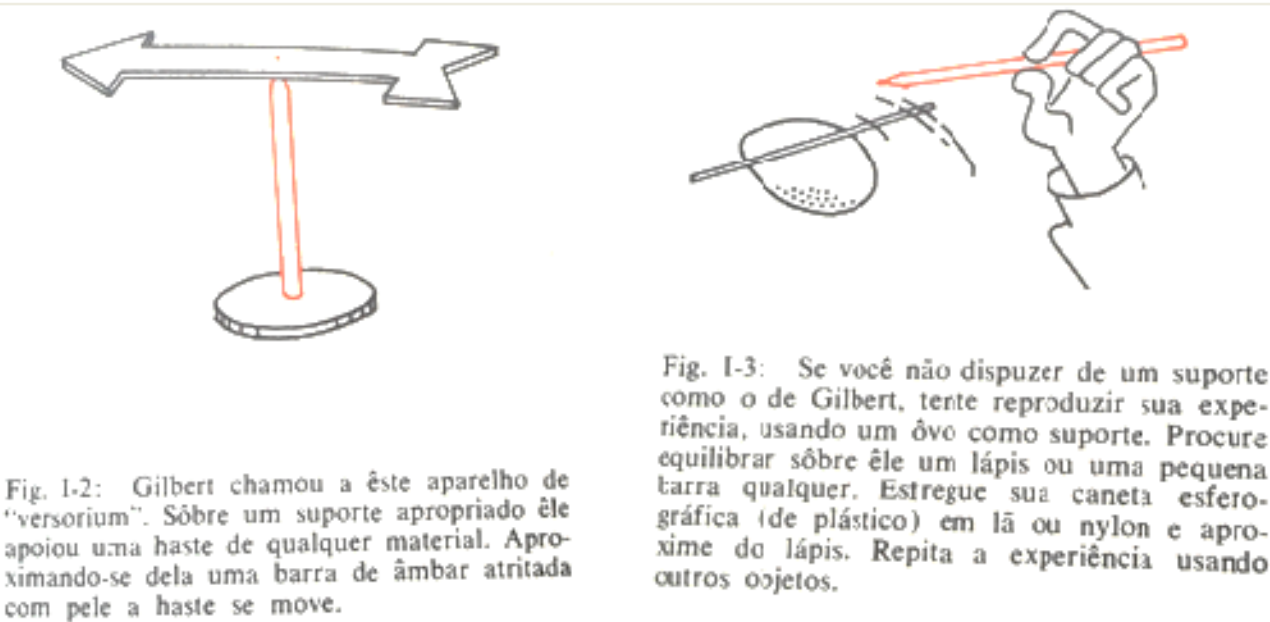

FIGURA 20 - Exemplo de atividade experimental na obra Alvarenga e Máximo (1971, vol. 3, p. 12.)

Os autores não definem um método científico para construção do conhecimento em Ciências, mas acabam por assumir a concepção empírico-indutivista quando afirmam: "Você concordará que, para uma teoria científica, é importante que ela consiga explicar o maior número possível de fenômenos, com um mínimo de fatos básicos experimentais" (ALVARENGA; MÁXIMO, 1971, vol. 3, p. 119).

Ainda que apresente poucas sugestões experimentais, a obra demonstra um esforço em apresentar a Física como uma ciência experimental uma vez que ao longo dos textos, nas explicações dos conceitos, traz uma abordagem mais fenomenológica, e, de modo geral, recorrem às descrições detalhadas de experimentos já realizados por cientistas. 
Em que pese à experimentação, a obra LD3 traz um diferencial em relação à versão anterior (LD2); propõe um grande número de propostas experimentais, desta feita, em seção específica e com orientação clara e sucinta para a realização. Sugere perto de uma centena de EXPERIÊNCIAS SIMPLES ao final dos capítulos, variando de 2 a 7 propostas em cada um. São 24 experiências no primeiro volume, 39 no segundo e 36 no terceiro.

As experiências propostas trazem as características do método da redescoberta. De modo geral, não apresentam os resultados, deixando a pergunta em aberto, subentendendo a possibilidade de discussão em sala de aula.

Você poderá verificar facilmente que as ideias de Galileu sobre a queda dos corpos são corretas, realizando a seguinte experiência:

$\left.1^{\circ}{ }^{\circ}\right)$ Deixe cair, simultaneamente, de uma mesma altura um livro pesado e uma folha de papel. Observe a queda de ambos e verifique qual deles chega ao solo em primeiro lugar.

$\left.2^{\circ}{ }^{\circ}\right)$ Segure o livro, ..., com a folha de papel sobre ele. Solte o livro e observe a queda. O livro e a folha caíram juntos, conforme afirmava Galileu? Explique porque isso não aconteceu quando objetos caíram separadamente. (ALVARENGA; MÁXIMO, 1979, vol. 1, 82).

Algumas experiências vêm com uma breve fundamentação teórica, às vezes trazendo informações históricas sobre as mesmas e proposta de simulação.

Entretanto, as experiências não parecem ser colocadas como recurso imprescindível no desenvolvimento dos conteúdos. Considerando a possibilidade de carga horária reduzida, estas ficariam de fora da programação. No texto de apresentação Ao professor, os autores colocam:

Em algumas escolas, onde a carga horária é mais reduzida, a programação de cada capítulo poderá ser feita de maneira que seu desenvolvimento não ultrapasse as questões de revisão. Caso haja um pouco mais de tempo disponível, as leituras e as experiências poderão ser incluídas na programação. (ALVARENGA; MÁXIMO, 1979, Apresentação Ao Professor).

Embora isto, do mesmo modo que a versão mais antiga (LD2), o conteúdo desta obra contribui para convencer o aluno da existência de um método científico experimental na evolução dos conhecimentos em Física.

\section{$* * *$}

A obra LD4, embora discurse que a experimentação é a única forma de construção do conhecimento em Física, praticamente não contempla atividades experimentais. Abaixo mostramos um trecho de texto de uma seção do primeiro capítulo da coleção que evidencia a concepção sobre método de construção do conhecimento científico.

\section{MÉTODO EM FÍSICA}

A Física estuda determinados fenômenos que ocorrem no Universo. O método que utiliza para conhecer esses fenômenos é simplificadamente o seguinte: observa repetidas vezes o fenômeno destacando fatos notáveis. Utilizando aparelhos de medida, desde o relógio para medir o tempo e a fita métrica para medir 
comprimentos até instrumentos mais sofisticados, determina a medida das principais grandezas presentes no fenômeno. Com essas medidas procura alguma relação existente no fenômeno, tentando descobrir alguma lei ou princípio que o rege. Eventualmente essas leis ou princípios são expressos por fórmulas, [...]. (RAMALHO JUNIOR et al., 1979, vol. 1, p. 05, grifo dos autores).

Ao afirmar que "o método de apreensão do conhecimento da Física" ocorre basicamente pelas três etapas acima marcadas, evidencia que a concepção de método científico assumida pelos autores é também o empírico-indutivista.

Ainda que de forma muito resumida, não deixa de ser interessante o que os autores colocam sobre as diferenças ambientais em que se podem observar os fenômenos naturais.

\footnotetext{
Muitas vezes repetimos o fenômeno em Laboratórios em condições consideradas ideais em relação às condições de sua ocorrência. Por exemplo, podemos estudar idealmente a lei da queda de um corpo, deixando-o cair em Laboratório, num aparelho vertical onde se faz o vácuo (tubo de Newton); com isso estudamos a queda sem interferência do ar. (RAMALHO JUNIOR et al., 1979, vol. 1, p. 05, grifo dos autores).
}

A colocação acima seria pertinente se a obra contemplasse propostas experimentais, e que na realização delas concedesse espaço para discutir o que é afirmado. Contudo, na obra, a assertiva fica somente no nível do discurso. Localizamos somente duas situações que podem ser consideradas sugestões de experimentação; uma no volume 2 e outra no volume 3. A primeira se refere ao conceito de condução térmica. Inicia a seção solicitando: "Segure a extremidade A de uma barra de ferro $A B$ [apresenta uma figura ao lado] e leve a outra extremidade a uma chama. Após um intervalo de tempo relativamente curto, a extremidade que você segura estará quente.” (RAMALHO JUNIOR et al., 1976, vol.2, p. 104). A segunda aparece na introdução do estudo de eletrostática.

Considere um bastão de vidro e atrite-o com um pano de lã. Suspenda o bastão de vidro por meio de um barbante, conforme a Fig. 1 [apresenta ao lado do texto a figura], e aproxime o pano de lã de uma das extremidades do bastão. Este será atraído pela lã. A seguir, atrite um segundo bastão de vidro com outro pano de lã e aproxime-o do primeiro. Agora o primeiro bastão será repelido [remete a outra figura]. Suspenda, finalmente, um dos panos de lã e aproxime o outro [outra figura]. Novamente, haverá repulsão. (RAMALHO JUNIOR et al, 1979, vol. 3, p. 01).

As atividades experimentais mostradas têm natureza ilustrativa. Não discute resultados, apresenta-os na sequência da descrição dos procedimentos. Fica evidente que o prosseguimento do assunto independe de o aluno fazer ou não a experimentação sugerida. A irrelevante quantidade de sugestões experimentais mostra que a obra não sustenta o discurso inicial, ou seja, não evidencia a Física como ciência experimental. 
Modelos explicativos formais

Na obra LD1, em uma das páginas introdutórias denominada ADVERTÊNCIA AO $A L U N O$, evidencia-se a matemática como pré-requisito essencial para compreender a Física: "Se você tiver a base matemática necessária, fique certo, achará a física muito fácil. Em caso contrário...".

As reticências indicam estigmatizar a lógica saber matemática/compreender Física, embora na sequência o autor tranquilize o aluno quanto ao nível da matemática exigido para compreensão da obra afirmando que, para "dominar a FÍSICA DO CIENTÍFICO E DO VESTIBUAR. Bastam conhecimentos rudimentares". (GONÇALVES, 1970, vol. 1, ADVERTÊNCIA AO ALUNO).

Uma grande parte do volume 1 é dedicada aos tópicos de matemática (os cinco primeiros capítulos) para revisão de conceitos de aritmética, álgebra, geometria, geometria analítica, trigonometria e noções de cálculo vetorial. Os capítulos seguintes abordam temas da Física, com bastante ênfase no formalismo matemático. Somente o capítulo 10, que o autor denominou de Lei Física - Médias - Erros, apresenta uma definição da Física, segundo ele, compatível como o objetivo da obra: "Física é o ramo da Ciência que estuda a matéria (suas propriedades gerais) e a energia." (vol. 1, p.169).

A apresentação dos conteúdos nesta obra ocorre de forma demasiadamente abstrata. Os assuntos são abordados de forma muito objetiva, com breves definições, sem contextualização, discussão dos modelos e relações entre grandezas, limites de aplicação, apresentação de exemplos cotidianos, etc.. Citamos como exemplo, o trecho em que o autor apresenta os conceitos Quantidade de Movimento:

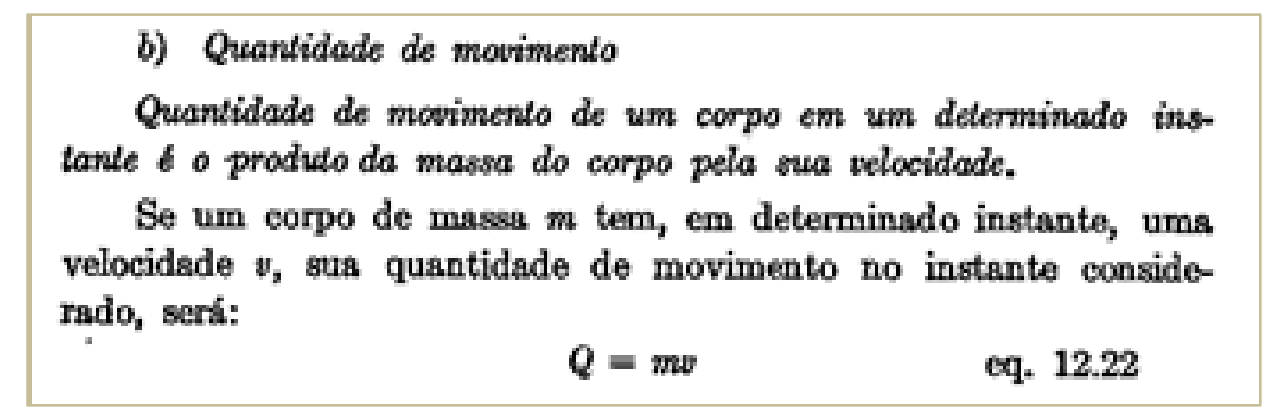

FIGURA 21 - Recorte de texto da obra de Gonçalves (1970, vol. 2, p. 247).

Em algumas situações exige o conhecimento de noções de cálculo integral. Quanto a isso, em uma das situações em que deduz equações utilizando cálculo integral, o autor coloca: "Se você ainda não estudou as primeiras noções de cálculo integral, naturalmente não entendeu a dedução acima. Mas, não precisa se preocupar. Você poderá voltar a êste assunto 
mais tarde, logo após ter dado cálculo integral." (GONÇALVES, 1969, vol. 5, p. 127). Esta observação contradiz o que o autor afirma no início da obra, sobre o nível de conhecimento matemático exigido, pois cálculo integral está longe de ser considerado "conhecimentos rudimentares" em matemática.

As aplicações das noções de cálculo aparecem na conceituação de Impulsão, nas deduções de fórmulas no estudo das transformações gasosas (volume 3) e no cálculo da d.d.p. entre dois pontos, e da Energia de capacitor (ambos no volume 5). Tais noções não são abordadas nos capítulos de revisão de matemática no primeiro volume da obra. Possivelmente, esperava-se que fossem estudadas no curso de Matemática ${ }^{134}$.

$$
* * *
$$

A obra LD2 dedica um capítulo com 10 páginas para assuntos que permitem dar condição ao aluno de analisar os fenômenos por meio de modelos explicativos formais (proporção, variação com o quadrado e o cubo, linearização de gráficos, relações inversas e mudanças de escalas). As relações matemáticas são apresentadas como formas de descrição de fenômenos. Segundo os autores, "o problema central de análise de um fenômeno físico consiste em se estabelecer uma relação entre duas ou mais grandezas que estejam associadas ao fenômeno." (ALVARENGA; MÁXIMO, 1970, vol. 1, p. 21). Explica que a relação entre duas grandezas pode ser analisada por meio de gráficos e equações matemáticas, e que o capítulo em questão objetiva "apresentar [ao aluno] as equações e gráficos que aparecerão frequentemente no estudo de Física, descrevendo os fenômenos que [iriam] estudar." (vol. 1, p. 21).

Em um momento pontual, chama a atenção para o fato de que a descrição dos fenômenos se dá por meio de modelos idealizados. Ao falar das Leis do Movimento, colocam que: "Essas leis, como a maioria dos princípios da Física, foram estabelecidos por meio de idealizações e abstrações próprias dos processos científicos de descrição da natureza." (vol. 1, p. 73).

Na versão de 1979 (LD3), "Curso de Física” essas características são mantidas. Permaneceu o capítulo denominado Funções e Gráficos que subentende a pretensão de familiarizar o aluno com a descrição dos fenômenos por meio do formalismo matemático.

Ao longo do texto das duas obras, a apresentação das grandezas, por meio de modelos formais, é precedida de exemplos e explicações detalhadas, relacionando fenômeno, conceitos e modelos matemáticos.

\footnotetext{
${ }^{134}$ No currículo oficial obrigatório vigente anteriormente à LDB/1961 previa o ensino de noções de Cálculo Diferencial e Integral no programa de Matemática (BRASIL, 1951c).
} 
A importância que os autores da obra LD4 dão à Matemática na Física pode ser notada desde a apresentação dos assuntos do volume no prefácio. A Parte II do primeiro volume, que "analisa os movimentos através de suas funções horárias de modo algébrico e gráfico" é caracterizada pelos autores como "[...] uma aplicação física dos conhecimentos matemáticos que o estudante está adquirindo paralelamente em seu curso de Matemática (funções do $1^{\circ}$ e $2^{\circ}$ grau)” (RAMALHO JUNIOR et al., 1979, vol. 1, Prefácio).

Em uma interpretação mais rigorosa, diríamos que a Física estaria servindo como exemplos ilustrativos dos conhecimentos matemáticos. Mais adiante, na introdução, é exaltada a importância atribuída à matemática no estudo dos fenômenos: "ajuda muito a Física, simplificando a compreensão dos fenômenos.” (vol. 1, p. 04). Justifica a afirmação com o exemplo da equação da energia cinética.

\begin{abstract}
Uma longa explicação é necessária para chegarmos ao fato de que a energia de um corpo em movimento depende de sua massa e de sua velocidade; no entanto, recorrendo à Matemática, obtemos a fórmula [...]. Essa fórmula diz que a energia $\mathbf{E}$ é diretamente proporcional à massa $\mathbf{m}$ e diretamente proporcional ao quadrado da velocidade $\mathbf{v}$; diz também que a energia depende da massa m e da velocidade $v$. Assim, aos poucos, você terá que aprender a ler uma fórmula e utilizá-la a seu favor. (RAMALHO JUNIOR et al., 1979, vol. 1, p. 04, grifo sublinhado nosso).
\end{abstract}

Considerando a forma como os conceitos são apresentados ao longo do texto da obra, e o que traz a citação anterior, entende-se que o apelo matemático adotado é recurso para evitar longas explicações conceituais/fenomenológicas. Traz a ideia de que a Matemática é vista como recurso de simplificação textual. Ao que parece, espera-se que o aluno compreenda um fenômeno apenas observando a relação matemática entre as grandezas a partir de uma fórmula, sem necessidade de maiores discussões.

De modo similar à obra LD1, esta privilegia a apresentação de conceitos e definições sem discussão das grandezas física envolvidas. Vejamos o exemplo da apresentação do conceito de Quantidade de Movimento.

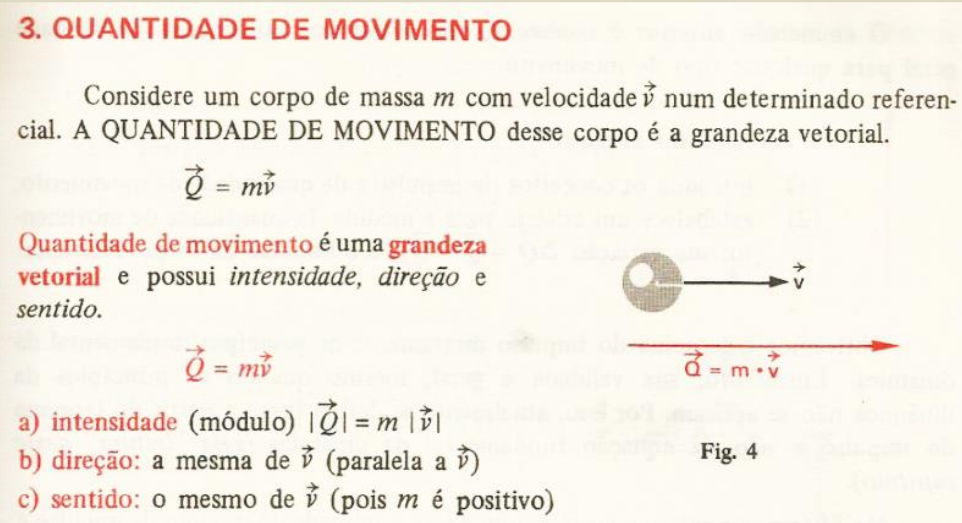

FIGURA 22 - Recorte de texto da obra de Ramalho Junior et al. (1979, vol. 1, p. 343). 
Este recorte é toda a parte do texto que apresenta o tópico em questão. Na sequência vem outra seção que, do mesmo modo abreviado, apresenta o conceito de Impulso. De modo geral, ao longo de toda a obra, os conceitos são apresentados nestes termos, e na sequência, os exercícios propostos requerem a aplicação das "fórmulas".

Ainda que suscite, no discurso inicial, a ideia de o formalismo matemático ser uma síntese do conhecimento sobre os fenômenos instiga o seu uso como ferramenta de desenvolvimento de cálculos. As equações, sempre realçadas com cor, algumas em caixas de texto, e exercícios com cálculos, são predominantes no texto da obra.

\section{Conteúdos/áreas da Física}

A obra LD1 tem um diferencial em relação às demais analisadas, em termos estruturais; como já dito, distribui os conteúdos em cinco volumes, enquanto as outras agregam seus capítulos e tópicos em três. Embora essa extensão não represente, necessariamente, maior aprofundamento dos assuntos abordados, já que o primeiro volume da obra é mais dedicado a tópicos de matemática do que a assuntos da Física, e, em todos os volumes a partir do segundo, traz um capítulo somente com exercícios de vestibulares que, no geral, ocupam significativo espaço nos exemplares. O Quadro a seguir traz os assuntos abordados na obra de Dalton Gonçalves: 
QUADRO 14 - Organização dos conteúdos na obra LD1.

\begin{tabular}{|c|c|c|}
\hline Tema Geral & Vol. & Assuntos \\
\hline Mecânica & 1 & $\begin{array}{l}\text { Unidade } 1 \text {-Revisão de matemática (1. Aritmética; 2. Álgebra; 3. Geometria; 4. Geometria } \\
\text { Analítica e Trigonometria; 5. Noções de Cálculo Vetorial) } \\
\text { Unidade } 2 \text { - Estática (6. Introdução; 7. Equilíbrio) } \\
\text { Unidade } 8 \text { - Cinemática (8.Movimento retilíneo; 9. Movimento curvilíneo plano) Unidade } 4 \\
\text { - Introdução á Física (10. Lei Física, Medidas, Erros; 11. Sistema de Unidades e Equações } \\
\text { Dimensionais) }\end{array}$ \\
\hline Mecânica & 2 & $\begin{array}{l}\text { Unidade } 5 \text { - Dinâmica das Translações (12. Dinâmica das Translações) } \\
\text { Unidade } 6 \text { - Complementos (13. Gravitação Universal; 14. Máquinas Simples; } \\
\text { 15.Elasticidade) } \\
\text { Unidade } 7 \text { - Mecânica dos Fluidos (16. Mecânica dos fluídos) } \\
\text { Unidade } 8 \text { - Tensão Superficial e Capilaridade (17.Tensão Superficial e Capilaridade) } \\
\text { Unidade } 9 \text { - Questões de Vestibulares (18. Problemas Suplementares). }\end{array}$ \\
\hline Termologia & 3 & $\begin{array}{l}\text { 1. Termometria; 2. Dilatação Térmica; 3. Calorimetria; 4. Mudança de estado; } 5 . \\
\text { Calorímetros; 6. Transmissão de Calor; 7. Estudo dos Gases perfeitos, 8. Higrometria; } 9 . \\
\text { Gases reais; 10. Termodinâmica. }\end{array}$ \\
\hline Acústica (ondas) & 3 & 11. M.H.S; 12. Movimento Ondulatório; 13. Acústica; 14. Questões de Vestibulares \\
\hline Ótica & 4 & $\begin{array}{l}\text { 1. Introdução à Ótica geométrica; 2. Reflexão da Luz e Espelho Plano; 3. Reflexão da Luz e } \\
\text { Espelhos Esféricos; 4. Refração da Luz; 5. Refração da Luz - Dioptro Plano; 6. Refração da } \\
\text { Luz - Dioptro Esférico; 7. Natureza da Luz; 8. Fotometria; 9. Irradiação; 10. Dispersão da } \\
\text { Luz - Espectros; 11. Interferência da Luz; 12. Difração da Luz; 13. Polarização da Luz; } 14 . \\
\text { Aberrações nas Lentes; 15. O Olho Humano e a Visão; 16. Instrumentos de Ótica; 17. Cor; } \\
\text { 18. Complementos; 19. Questões de Vestibulares. }\end{array}$ \\
\hline Eletromagnetismo & 5 & $\begin{array}{l}\text { 1. Carga elétrica; 2. Lei de Coulomb; 3. Corrente Elétrica e Resistência Elétrica; 4. Circuitos } \\
\text { de Corrente Contínua; 5. Eletroquímica; 6.Termoeletricidade; 7. Medidas elétricas; 8. Campo } \\
\text { elétrico; 9. Capacitores (ou Condensadores). } \\
\text { 10. Magnetismo; 11. Eletromagnetismo: Campo magnético criado por uma corrente elétrica; } \\
\text { 12. Eletromagnetismo: Ação do campo magnético sobre uma corrente elétrica; } 13 . \\
\text { Eletromagnetismo: Indução eletromagnética; 14. Noções de corrente alternada.; } 15 . \\
\text { Complementos (traz assuntos de eletricidade e magnetismo, entre outros); 16. Questões de } \\
\text { Vestibulares. }\end{array}$ \\
\hline Física Moderna & 5 & $\begin{array}{l}\text { No estudo da natureza da luz no volume } 4 \text { (Teoria dos quanta de Planck, Produção de } \\
\text { radiações eletromagnética) } \\
\text { Em Complementos (cap. 15): Efeito termoiônico, Efeito fotoelétrico, Raios catódicos, Raios } \\
\text { canais (de Goldstein), Raios X, etc. }\end{array}$ \\
\hline
\end{tabular}

Fonte: Gonçalves (1969-1974)

A coleção LD1 segue a divisão clássica constituída por seis grandes áreas da Física Mecânica, Termologia, Acústica (ondas), Ótica, Eletromagnetismo e Física Moderna. Um dos diferenciais de organização destas áreas na obra está no posicionamento do estudo da Ótica em volume separado do estudo de Ondas, ficando subentendido que seria tratado em séries distintas. Dessa forma, na proposta do autor, a distribuição ao longo das séries do Colegial, ficaria: Mecânica (vol. 1 e 2) na $1^{\mathrm{a}}$ série; Termologia e Acústica (vol. 3) na 2a ; e Ótica, Eletricidade, Magnetismo e Física Moderna (vol. 4 e 5) na $3^{\mathrm{a}}$.

À primeira vista, no quadro, já se nota que esta obra é maior em desdobramentos de tópicos que as demais. A obra se destaca mais ainda na quantidade de assuntos abordados dentro de cada capítulo; embora se note certo exagero nas subdivisões dos capítulos, com abertura de seções, muitas vezes desnecessárias, tratando de um mesmo assunto.

Curiosa a disposição dos conteúdos de Mecânica na obra, dividida em estática, cinemática e dinâmica. Em estática, após a unidade de revisão de matemática, conceitua-se a Mecânica, fala se sobre suas divisões, conceitua força e apresenta equações, etc. Na sequência apresenta a primeira e terceira lei de Newton no estudo de equilíbrio. Dá continuidade com 
cinemática, trazendo o estudo de Movimentos (retilíneo e curvilíneo), e, somente depois traz a unidade denominada Introdução à Física, quando passa a falar de método, leis físicas, medidas, erros, etc. Após isso, em outra unidade denominada sistemas de unidades equações dimensionais volta a tratar de aspectos matemáticos da Física.

A obra traz tópicos e termos pouco comuns em outras obras, tais como: Pêndulo Composto; Pêndulo Reversível; Módulo de Young, no estudo de Elasticidade; alguns desdobramentos de Mecânica dos fluidos -Vaso de Pisani, Picnômetros, Areômetros; Tensão Superficial e Capilaridade - Lei de Jurin, Lei de Tates; em Ótica - Polarização da Luz (desdobrada em 19 seções); em Calorimetria - Lei de Dulong e Petit, lei de Woestyn e lei de Delaroche-Berard); em Eletricidade - Termoeletricidade, e mais outros assuntos.

No que se refere às leis e princípios, são abordados de modo sumário por uma definição geralmente acompanhada de uma equação. Não há contextualização histórica, desse modo, não fornece ao aluno maiores informações sobre os "autores" destas leis.

As principais leis de Conservação são abordadas. Em Dinâmica das translações traz a Lei da Conservação da Energia e da Quantidade de Movimento. No caso da primeira, é mencionada ainda no estudo da Termodinâmica. O Princípio de conservação da carga elétrica também é enunciado em uma seção específica do volume 5.

Assim como as demais obras, esta não traz o estudo de Quantidade de movimento angular; ao contrário das outras, traz o estudo de dinâmica dos fluidos, ainda que muito resumidamente.

Assuntos de Física Moderna são pincelados em dois volumes (p. ex. no estudo da natureza da luz no volume 4, e em Complementos no volume 5) de forma muito resumida, sem nenhuma contextualização histórica. Não traz estudo da Teoria da Relatividade.

Os tópicos de conteúdos se assemelham ao programa oficial de Física anterior a 1961 (vide ANEXO I), o que é justificável, já que a obra foi inicialmente elaborada na vigência desse programa oficial obrigatório. Ao que parece, o autor manteve fidelidade também aos programas de vestibulares; é o que justifica o autor apresentar o conceito de "Forças Vivas", mesmo não concordando com a veridicidade do mesmo. Após definir a referida grandeza em uma seção específica (em poucas linhas), traz a observação: "Infelizmente, os programas insistem em incluir a fôrça viva. Esta denominação, além de imprópria (não se trata de uma força), é arcaica. Os livros modernos já a abandonaram." (GONÇALVES, 1970, vol. 2, p. 238). 
A obra se caracteriza pela extensão (grande quantidade de tópicos) e superficialidade (pouca profundidade e discussão). Os conteúdos são apresentados de forma fragmentada, com pouca ou nenhuma correlação entre as partes que compõem os capítulos.

Para uma melhor visualização e comparação da distribuição dos conteúdos/áreas da Física nas duas coleções de Alvarenga e Máximo (LD2 e LD3), dispomos os títulos dos capítulos e unidades em colunas paralelas no quadro, a seguir. Desse modo, descreveremos as características desta categoria de modo unificado para as duas obras.

QUADRO 15 - Organização dos conteúdos nas obras LD2 e LD3

\begin{tabular}{|c|c|c|c|}
\hline \multirow[t]{2}{*}{ Tema Geral } & \multirow[t]{2}{*}{ Vol. } & \multicolumn{2}{|c|}{ Assuntos/Capítulos } \\
\hline & & Versão $1970 \ldots$ (LD1) & Versão 1979 (LD2) \\
\hline Mecânica & 1 & $\begin{array}{l}\text { Capítulo I - Uma Introdução } \\
\text { Capítulo II - Funções e Gráficos } \\
\text { Capítulo III - Vetores } \\
\text { Capítulo IV - Cinemática } \\
\text { Capítulo V - Leis de Newton - Equilíbrio } \\
\text { Capítulo VI - Leis de Newton: Força e } \\
\text { aceleração } \\
\text { Capítulo VII - Gravitação Universal } \\
\text { Capítulo VIII - Trabalho e Energia } \\
\text { Capítulo IX - Conservação da } \\
\text { Quantidade de Movimento } \\
\text { Capítulo X - Hidrostática }\end{array}$ & $\begin{array}{l}\text { Unidade I - Introdução } \\
\text { 1.Algarismos significativos } \\
\text { 2. Funções e gráficos } \\
\text { Unidade II - Cinemática } \\
\text { 3. Movimento Retilíneo } \\
\text { 4. Vetores - Movimento curvilíneo } \\
\text { Unidade III - Leis de Newton } \\
\text { 5. Primeira e terceira leis de Newton } \\
\text { 6. Segunda lei de Newton } \\
\text { 7. Gravitação Universal } \\
\text { 8. Hidrostática }\end{array}$ \\
\hline Mecânica & 2 & (2: & $\begin{array}{l}\text { Unidade IV- Leis de Conservação } \\
\text { 9. Conservação da Energia } \\
\text { 10. Conservação da Quantidade de Movimento }\end{array}$ \\
\hline Termologia & 2 & $\begin{array}{l}\text { Capítulo I - Temperatura e Dilatação } \\
\text { Capítulo II - Comportamento dos Gases } \\
\text { Capítulo III - } 1^{\text {a }} \text { Lei da Termodinâmica } \\
\text { Capítulo IV - Mudanças de fase } \\
\text { Capítulo V }- \text { Segunda lei da } \\
\text { Termodinâmica } \\
\text { Capítulo VI - Teoria Cinética dos Gases }\end{array}$ & $\begin{array}{l}\text { Unidade V - Temperatura- Dilatação-Gases } \\
\text { 11. Temperatura e dilatação } \\
\text { 12. Comportamento dos gases } \\
\text { Unidade VI - Calor } \\
\text { 13. Primeira lei da termodinâmica } \\
\text { 14. Mudanças de fase }\end{array}$ \\
\hline Ótica & 2 & $\begin{array}{l}\text { Capítulo VII - Comportamento da Luz } \\
\text { Capítulo VIII - Reflexão - Espelhos } \\
\text { Capítulo IX - Refração }\end{array}$ & $\begin{array}{l}\text { Unidade VII - Ótica e Ondas } \\
\text { 15. Reflexão da luz } \\
\text { 16. Refração da Luz } \\
\end{array}$ \\
\hline Ondas & 2 & $\begin{array}{l}\text { Capítulo X - Movimento Ondulatório } \\
\text { Capítulo XI - Interferência } \\
\text { Capítulo XII - O Som } \\
\end{array}$ & 17. Movimento Ondulatório \\
\hline Eletricidade & 3 & $\begin{array}{l}\text { Capítulo I - Carga Elétrica - Lei de } \\
\text { Coulomb } \\
\text { Capítulo II - O Campo Elétrico } \\
\text { Capítulo III - Potencial elétrico } \\
\text { Capítulo IV - Capacitância - Capacitores } \\
\text { Capítulo V - Corrente Elétrica } \\
\text { Capítulo VI - Força Eletromotriz - } \\
\text { Circuitos simples }\end{array}$ & $\begin{array}{l}\text { Unidade VIII - Campo e Potencial elétrico } \\
\text { 18. Carga elétrica } \\
\text { 19. Campo elétrico } \\
\text { 20. Potencial elétrico } \\
\text { Unidade IX - Circuitos elétricos de corrente } \\
\text { contínua } \\
\text { 21. Corrente elétrica } \\
\text { 22. Força eletromotriz }\end{array}$ \\
\hline Eletromagnetismo & 3 & $\begin{array}{l}\text { Capítulo VII - O Campo Magnético } \\
\text { Capítulo VIII - O Campo Magnético de } \\
\text { uma Corrente Elétrica } \\
\text { Capítulo IX - Indução Eletromagnética }\end{array}$ & $\begin{array}{l}\text { Unidade } X-\text { Eletromagnetismo } \\
\text { 23. O campo magnético }-1^{\mathrm{a}} \text { parte } \\
\text { 24. O campo magnético }-2^{\mathrm{a}} \text { parte } \\
\text { 25. Indução e Ondas eletromagnéticas } \\
\text { Apêndice - Capacitores e Capacitância }\end{array}$ \\
\hline Física Moderna & 3 & $\begin{array}{l}\text { Capítulo X - Noções de Física Moderna } \\
\text { (Quantização de Energia, Estrutura do Átomo, } \\
\text { O Núcleo-Radioatividade, e Relatividade) }\end{array}$ & - \\
\hline
\end{tabular}

Fonte: Alvarenga e Máximo (1970/1971/1974); Alvarenga e Máximo (1979) 
Do Quadro 15, nota-se que a sequência de conteúdos nas duas obras de Alvarenga e Máximo sofreram algumas alterações de uma versão à outra. Cabe ressaltar que, listamos somente os títulos dos capítulos. Alguns assuntos não aparecem intitulando capítulos no sumário, mas intitulam seções, de modo que as mudanças não são tão perceptíveis se olharmos somente para os títulos dos capítulos no quadro acima. Passaremos a apontar algumas mudanças principais percebidas, focando também os títulos das seções, bem como o conteúdo interno das obras LD2 e LD3.

Em Mecânica, as diferenças se fazem no deslocamento do capítulo que trata do estudo de Vetores. Antes em capítulo separado e antecedendo a Cinemática, passa para depois do estudo de Movimento Retilíneo, sendo ambos os assuntos tratados dentro da Unidade Cinemática na coleção mais recente. Outra mudança ocorre também com os estudos de Trabalho e Energia, e Conservação da Quantidade de Movimento, antes apresentados após o estudo da dinâmica de forças, como é comumente na maioria dos livros didáticos, passa a ser colocado após a Hidrostática e é deslocado para o volume 2 da obra.

Em Termologia, suprimiu-se o estudo da Segunda Lei da Termodinâmica que vinha em capítulo específico ocupando 10 laudas; o tema passou a ser abordado em uma das Leituras suplementares, de modo mais sucinto (menos de quatro laudas) e sem discussão da grandeza Entropia. Outro assunto, deste mesmo grande tema e que foi resumido é o que traz o capítulo Teoria Cinética dos Gases. Passou a ser tratado como uma seção denominada Modelo Molecular de um Gás, no capítulo Comportamento dos Gases, e de modo mais sintético, suprimindo, por exemplo, as explicações sobre calor específico de um gás.

Em Eletricidade, o capítulo "Capacitância - Capacitores" deixa de ser tratado no corpo principal do texto e é deslocado para o final do volume 3 como APÊNDICE, sem perdas de conteúdo em relação à versão mais antiga.

O capítulo "Noções de Física Moderna” presente no volume 3 da coleção mais antiga é suprimido na nova coleção e os assuntos são disseminados ao longo da obra, passando a ser abordados, de modo geral, na seção LEITURA, e, sobretudo no terceiro volume da obra.

Como pode ser notada, a organização dos conteúdos nestas duas coleções é também clássica: Mecânica, Termologia, Ótica, Ondas, Eletromagnetismo e Física Moderna. Os autores explicam essa organização afirmando que tal divisão tradicional é uma "comodidade didática [...] respeitada na maioria dos textos de ensino de Física” (ALVARENGA; MÁXIMO, 1979, vol. 1, p. 06). Contudo alertam que, 
[...] esses ramos não constituem compartimentos estanques. Pelo contrário, os fenômenos estudados nos diversos ramos estão relacionados entre si através de um pequeno número de princípios básicos, sendo possível, então, encarar esses ramos como um todo, tornando a Física uma estrutura lógica e consistente. (ALVARENGA; MÁXIMO, 1979, vol. 1, p. 06).

A sequência de exposição do estudo das Leis de Newton é similar à obra LD1: primeiro trata da Primeira e Terceira Lei de Newton, e, em capítulo separado, traz o estudo da Segunda Lei e suas aplicações. Essa sequência é adotada nas duas versões analisadas, e, pela análise de Wuo (2000) ${ }^{135}$, bem como pelo conhecimento que temos das versões mais atuais, esta estruturação permaneceu ao longo do tempo.

O diferencial crucial da obra de Alvarenga e Máximo está na forma de apresentação dos textos. Detalha mais nas explicações dos fenômenos, nos significados cognitivos das teorias, contextualiza com situações cotidianas e evidencia os aspectos históricos e tecnológicos da Física, principalmente nas leituras complementares, de forma articulada com o texto principal. Traz ainda muitos exercícios de questões "abertas", que possibilitam ao aluno expor suas percepções sobre os conceitos físicos estudados, e, ao professor, promover debates a partir das possíveis diferenças nas respostas dos alunos.

$* * *$

Conforme já mencionado na caracterização geral das obras, a LD4 traz os conteúdos organizados por Partes (o que seria equivalente as Unidades na estruturação da obra LD3, p. ex.), subdividas em Capítulos, conforme quadro a seguir:

\footnotetext{
135 Wuo (2000) analisou uma edição de 1997, quando a obra ainda permanecia com o título Curso de Física. Posteriormente a coleção dos autores passou ao título "Física" novamente sem significativas alterações na organização dos temas.
} 
QUADRO 16 - Organização dos conteúdos na obra de Ramalho Junior et al. (1979, 1976, 1978)

\begin{tabular}{|c|c|c|}
\hline Tema Geral & Vol. & Temas das Partes (Título dos Capítulos) \\
\hline Mecânica & 1 & $\begin{array}{l}\text { Parte I - Introdução Geral (1 - Introdução geral à Física e à Mecânica). } \\
\text { Parte II - Descrição do Movimento: Cinemática (2 - O Movimento: Estudo do Movimento } \\
\text { Uniforme; } 3 \text { - Movimentos com Velocidade Variável; O Movimento Uniformemente } \\
\text { Variado; } 4 \text { - Exercícios Gerais; } 5 \text { - Queda Livre dos Corpos; } 6 \text { - Gráficos; Gráficos do } \\
\text { UM e do MUV.). } \\
\text { Parte III - Vetores e Grandezas Vetoriais (7- Vetores; 8- Velocidade e Aceleração } \\
\text { Vetoriais; 9- Movimento Circulares). } \\
\text { Parte IV - Forças em Dinâmica (10- Os Princípios Fundamentais; 11- Forças Resistentes; } \\
\text { Empuxo de Arquimedes; 12- Forças em Trajetórias Curvilíneas). } \\
\text { Parte V - Os Princípios da Conservação (13- Trabalho; 14- A Energia; 15- Impulso e } \\
\text { Quantidade de Movimento). } \\
\text { Parte VI - Gravitação Universal (16- A gravitação Universal).; }\end{array}$ \\
\hline Termologia & 2 & $\begin{array}{l}\text { Parte I - Introdução à Termologia (1- Introdução à Termologia). } \\
\text { Parte II - A Temperatura e seus efeitos ( 2- A Medida de Temperatura - Termometria; 3- } \\
\text { Dilatação Térmica de Sólidos e Líquidos; 4- Estudo dos Gases). } \\
\text { Parte III - Calor - A Energia Térmica em Trânsito (5- A Medida do Calor - Calorimetria; } \\
\text { 6- Propagação do Calor; 7- As Leis da Termodinâmica; 8- Mudanças de fase). }\end{array}$ \\
\hline Geometria da Luz & & $\begin{array}{l}\text { Parte IV - Geometria da Luz (9- Introdução à Óptica Geométrica; 10- Reflexão da Luz - } \\
\text { Espelhos Planos; 11- Espelhos Esféricos; 12- Refração Luminosa; 13- Lentes Esféricas } \\
\text { Delgadas; 14- Instrumentos Ópticos). }\end{array}$ \\
\hline Ondas & & $\begin{array}{l}\text { Parte V - Ondas (15- Movimento Harmônico Simples (MHS); 16- Ondas; 17- } \\
\text { Interferência de Ondas; 18- Som). }\end{array}$ \\
\hline Eletromagnetismo & 3 & $\begin{array}{l}\text { Parte I - Cargas Elétricas em Repouso (1- Eletrização - Força Elétrica; 2- Campo Elétrico; } \\
\text { 3- Trabalho e Potencial Elétrico; 4- Exercícios Gerais; 5- Propriedades dos Condutores em } \\
\text { Equilíbrio Eletrostático - Capacidade Eletrostática). } \\
\text { Parte II - Cargas Elétricas em Movimento (6- Corrente Elétrica; 7- Resistores; 8- } \\
\text { Associação de Resistores; 9- Medias Elétricas; 10- Geradores e Receptores; 11- Gráficos; } \\
\text { 12- Capacitores). } \\
\text { Parte III - Eletromagnetismo (13- Campo Magnético; 14- Força Magnética; 15- Indução } \\
\text { Eletromagnética; 16- Noções de Corrente Alternada }\end{array}$ \\
\hline Física Moderna & & $\begin{array}{l}\text { Parte IV - Introdução à Física Moderna (17- Radiação Eletromagnética; 18- Relatividade; } \\
\text { 19- Quanta). }\end{array}$ \\
\hline
\end{tabular}

Fonte: Ramalho Junior et al. (1979/1976/1978).

Conforme o quadro acima, a organização do conteúdo por grandes áreas segue a mesma linha das demais obras analisadas; quanto aos tópicos abordados é bastante parecida com a obra LD3, com pequenas diferenças de sequências dentro de um mesmo tema.

Assim como a obra LD3, o estudo de Hidrostática vem antes do estudo dos Princípios de Conservação, inserido no tema mais geral Forças em Dinâmica, e também não traz o estudo de dinâmica dos fluidos (ou hidrodinâmica).

Apesar da semelhança com a obra LD3 na sequência dos temas e tópicos, esta obra (LD4) é relevantemente mais sucinta no desenvolvimento dos conteúdos, embora a estrutura física em termos de número de páginas seja maior. Os assuntos são abordados por breves sínteses teóricas, com definições sucintas auxiliadas por figuras esquemáticas e equações. A obra se complementa por um grande número de exercícios, via de regra, com análise e resultados quantitativos.

Esporadicamente, busca articular conceitos, como exemplo, ao falar de OUTRAS FORMAS DE ENERGIA, além da mecânica (elétrica, radiante, química e nuclear), menciona a teoria da relatividade de Einstein e apresenta a equação $\mathrm{E}=\mathrm{mc}^{2}$. Após isso enuncia o Princípio da Conservação da Energia (PCE): “A energia não pode ser criada ou destruída, 
mas unicamente transformada. $O$ aparecimento de certa forma de energia é sempre acompanhado do desaparecimento de outra forma de energia em quantidade igual." (RAMALHO JUNIOR et al., 1979, vol. 1, p.326).

Ainda que de modo sucinto, a discussão conceitual busca mostrar o PCE num sentido mais abrangente. Como exemplo de aplicação, apresenta um desenho que simula o esquema de transformação de energia no ambiente, no processo de produção e distribuição de energia elétrica, começando pela energia radiante do Sol.

Os autores apresentam também uma discussão mais aprofundada na seção LEITURA no final da Parte III (vol. 1), sob o título "Crítica à noção de força”. Evidencia as limitações da Mecânica Newtoniana quando se trata de velocidades altas, comparáveis à da luz, onde invalida a hipótese de massa constante. Novamente fala da equação de Einstein e da conveniência de definir força a partir da noção de Quantidade de Movimento, por ser mais genérica. Usando a equação na forma diferencial $\vec{F}=\frac{d \vec{Q}}{d t}=\frac{d}{d t}(m \vec{v})$ chega à igualdade $\vec{F}=$ $m . \vec{a}$, na hipótese de uma massa constante (baixas velocidades). Explica que a associação desta equação com a de Einstein, chega-se a equação da massa relativística $m=\frac{m_{0}}{\sqrt{1-v^{2} / c^{2}}}$. A dedução da equação nos parece complexa para o nível de ensino em questão, mas os autores alertam para isto, dizendo que o estudo de derivada está além do propósito do livro.

O debate é interessante à medida que mostra outra perspectiva de entendimento do conceito de força, mais coerente com a ciência de referência. Geralmente, essa abordagem da lei de Newton a partir do conceito de Quantidade de Movimento é ignorada no estudo de Dinâmica em muitos livros didáticos, inclusive nas demais obras analisadas. Nota-se ausente, assim como nas demais obras, o estudo da Conservação da Quantidade de Movimento Angular.

Assuntos de Física moderna abrangem o estudo de tipos de ondas eletromagnéticas, relatividade de Einstein, efeito fotoelétrico e uma breve síntese sobre o efeito dual da luz. Na parte que trata das Ondas, contextualiza com um pequeno texto na seção LEITURA intitulado TELECOMUNICAÇÕES NO BRASIL. Neste, explica-se sucintamente o papel da Empresa Brasileira de Telecomunicações S.A (EMBRATEL) no processo de transmissão de sinais por satélite no sistema global de comunicação. 


\section{Da dimensão educativa}

\section{Objetivos do ensino de Física}

Os objetivos do ensino de Física nas obras didáticas analisadas são mais claramente explícitos no prefácio ou outros textos iniciais de apresentação.

O caráter instrumental e propedêutico da obra LD1 é evidenciado nos cinco textos de apresentação da obra (PREFÁCIO, COMO ESTUDAR FÍSICA, COMO RESOLVER PROBLEMAS NUMÉRICOS e ADVERTÊNCIA AO ALUNO), começando pela justificativa que motivou a elaboração de uma obra destinada ao científico e ao vestibular, pois, segundo o autor, os programas destas duas modalidades de ensino seriam iguais. (GONÇALVES, 1970, Prefácio).

Nessa linha metodológica, o livro inclui uma bateria de exercícios - questionários, problemas resolvidos e questões de vestibulares de todo o Brasil atualizadas em quantidade a cada nova edição. Considerando as edições analisadas, tem-se que os capítulos QUESTÕES DE VESTIBULARES ocupam cerca de $30 \%$ das páginas ${ }^{136}$ da obra.

Além dessa ênfase por meio de questões já contempladas em vestibulares anteriores, buscou-se adequar os conteúdos às exigências do exame: "Para atender aos VESTIBULARES inserimos diversos parágrafos de nível um pouco acima do exigido no científico." (GONÇALVES, 1970, Prefácio). Em síntese, a obra é assumidamente destinada à preparação para o acesso ao ensino superior.

$* * *$

No prefácio da primeira versão da obra de Alvarenga e Máximo (LD2) traz que:

Nossa intenção é fazer um trabalho que, sendo moderno, pois dá ênfase às leis
gerais, reduz a informação ao mínimo necessário, procura desenvolver o gosto pela
experiência e o raciocínio lógico [...] satisfaz às exigências de nossos cursos
superiores, não desenvolve conceitos excessivamente profundos, cuja compreensão
estaria fora do alcance da maioria dos estudantes, não lança mão de recursos
materiais muito caros ou complicados (ALVARENGA; MÁXIMO, 1970, Prefácio,
grifo nosso).

A versão de 1979 (LD3) mantém as características da anterior em termos de proposta pedagógica. No texto de apresentação Ao estudante traz que a obra visou atender "tanto aos jovens que pretendam seus estudos em uma carreira ligada às ciências exatas, como àqueles

\footnotetext{
${ }^{136}$ A coleção possui no total 1.546 páginas, excetuando as páginas de apêndices e anexos (cerca de 20 em cada volume). Deste total, 461 são ocupadas com questões de vestibulares. Esse quantitativo não inclui as demais questões das séries A e B que são trazidas no final dos capítulos.
} 
que provavelmente não mais terão outro contato com o estudo de Física" (ALVARENGA; MÁXIMO, 1979, Prefácio). Ressalta a importância de se estudar Física argumentando que

O conhecimento das leis e fenômenos físicos constitui um complemento indispensável à formação cultural do homem moderno, não só em virtude do grande desenvolvimento científico e tecnológico do mundo atual, como também porque o mundo da Física nos rodeia por completo. (ALVARENGA; MÁXIMO, 1979, Apresentação ao estudante, grifo nosso).

Em ambas as versões, a obra demonstra cuidado em inter-relacionar os assuntos, minimizando a fragmentação do conhecimento, numa vertente diferenciada da maioria dos livros de Física da mesma época. É bastante comum nos textos das mesmas, encontrar referências a assuntos tratados anteriormente, buscando certa continuidade e reforço dos conceitos apresentados.

A obra enseja uma nova visão de ensino, mais voltado para a análise qualitativa dos fenômenos da Natureza, as aplicações cotidianas e os aspectos históricos e tecnológicos da ciência/Física. Reúne características que podem propiciar o desenvolvimento do pensamento lógico. Contudo, cabe ressaltar que, em termos de objetivos, não se liberta totalmente da concepção de ensino na linha tradicional; demonstra preocupação também com a transmissão de conteúdos sistematizados, atendendo aos objetivos do sistema educacional: "Esperamos que este texto auxilie os professores em sua luta constante para colocar seus cursos em dia com os novos rumos do ensino da Física." (ALVARENGA; MÁXIMO, 1979, Prefácio).

$$
* * *
$$

Na obra LD4 os autores iniciam o prefácio dizendo:

Nosso propósito ao escrever Os Fundamentos da Física foi apresentar a Física como uma ciência contemporânea e de profunda importância na interpretação de fenômenos diversos, como a estrutura da matéria, a eletricidade, os movimentos, a luz e o calor. Com esse propósito, o livro é destinado a estudantes que seguirão carreiras que necessitarão da Física em sua formação profissional e que enfrentarão, ao fim de seu curso secundário, os exames vestibulares às escolas superiores. Por isso, muitos assuntos foram tratados no nível de profundidade exigido por esses exames (RAMALHO JUNIOR et al., 1979, Prefácio, grifo sublinhado nosso).

Assim, os objetivos do ensino de Física são claramente propedêuticos, voltados para a preparação para o vestibular. Esse propósito inicial se mostra coerente com a forma como os conteúdos são apresentados ao longo de toda a obra, seguindo de perto a linha das apostilas de cursinho. Enfatizam o lado abstrato da Física, ou seja, apresenta os conceitos e definições de forma sintética, com raras e incipientes situações de contextualização, as fórmulas, e depois, os exercícios de aplicação de cálculos, sendo muitos de vestibulares anteriores. 


\section{Concepção de aluno/professor}

Todos os textos que figuram na apresentação da obra LD1 indicam que o livro foi escrito para o aluno. Embora a obra tenha tido a sua primeira edição em 1961, de certa forma, acomoda uma das características de uma das concepções pedagógicas difundidas no contexto - a de que o aluno seria o responsável pelo seu processo de aprendizagem. Nas instruções de "Como estudar Física" indica centrar no aluno; ou pelo menos incentiva certo autodidatismo. Recomenda reler capítulos, escrever princípios e leis que forem aparecendo, escrever as equações, símbolos, responder os questionários, resolver os exercícios. Pressupõe um processo de aprendizagem individualizado quando reporta ao aluno que: "Se surgir alguma dificuldade procure resolvê-la sozinho. Consulte outros livros. Discuta o assunto com os colegas. Se a dificuldade persistir, recorra ao professor. [...] Sempre que houver oportunidade procure ensinar aquilo que já sabe (ou pensa que sabe)." (GONÇALVES, 1970, s.p.). O professor seria solicitado em último caso.

Por outro lado, é preciso considerar que o texto da obra se adequa também, e muito bem, ao ensino tradicional, em que o professor conduz o processo de ensino - expondo conceitos, definições, fórmulas, etc. - o qual o aluno acompanha com o livro. Nesta perspectiva, a participação ativa do aluno fica restrita à resolução dos exercícios.

É relevante ressaltar que o incentivo à condução da aprendizagem por um método mais individualizado, claramente notado nas páginas iniciais da obra, indica conferir menos destaque ao professor no processo de ensino/aprendizagem. Essa concepção de ensino assumida na obra, possivelmente, não foi influenciada pelas mesmas ideias que permearam os inovadores materiais didáticos da mesma época (os projetos de ensino), inspirados em parte, no behaviorismo de Skinner. É mais oportuno conjecturar que o método assumido pelo autor tenha origem na sua experiência como professor nos cursinhos pré-vestibulares. Nessa modalidade de ensino, pela excessiva quantidade de conteúdos a serem assimilados, o aluno necessitaria, também, estudar sozinho sem a presença e auxílio do professor, como meio de preparação para as provas.

$* * *$

As obras LD2 e LD3 (mesmos autores) permitem uma maior possibilidade de interação do aluno com os conhecimentos/conteúdos da ciência apresentada. A passividade do sujeito do conhecimento é menos evidente pelo formato dos textos, que é mais conceitual e parecem "chamar" mais o aluno para acompanhar o desenvolvimento dos conteúdos propostos, passando a ideia de atividade e interação. Termos como "Agora que já sabemos 
que...", "Como já vimos...", "No capítulo anterior vimos que...", "Começaremos pelo estudo da...”, são bastantes presentes. São termos que se traduzem numa visão mais interativa do aluno com o conteúdo do conhecimento disposto no livro.

Os autores das obras não assumem as mesmas como material de auxílio a um ensino individualizado; o papel do professor parece ser relevante. Na apresentação Ao Professor, nota-se que a obra é apresentada como uma escolha para o docente tentar contornar as diversidades circunstanciais do sistema educacional. Demonstra também conferir maior possibilidade de uma relação mais interativa entre professor e aluno no processo de ensinoaprendizagem. Consideramos exemplos disso, o discurso dos autores no texto de apresentação Ao Professor:

Preocupamo-nos em dar ênfase às leis gerais, reduzindo substancialmente as informações de caráter especifico, utilizando linguagem simples e redação concisa, de maneira a torná-la acessivel e a não enfadar o estudante.

$[\ldots]$

[...] O título de cada bloco indica seu conteúdo e a simples leitura destes títulos poderá servir como orientação ao professor na confecção de seu plano de aula.

[...]

Julgamos importante que o professor faça com que os alunos leiam e compreendam estes exemplos, talvez pela indicação, em cada caso, de um estudante para apresentá-los e discuti-los com seus colegas.

$[\ldots]$

O professor, antes de passar à seção seguinte, deverá analisar e discutir, com os estudantes, as soluções destes exercícios de fixação.

(ALVARENGA; MÁXIMO, 1979, AO PROFESSOR, grafia itálico do original).

$* * *$

Já a obra LD4 não define explicitamente o papel do professor, como também o do aluno. A apresentação da obra (o Prefácio) não tem uma linguagem de direcionamento definido. Não traz, por exemplo, um texto especificamente direcionado ao aluno ou ao professor, como faz as obras LD1 e LD3, bem como não contempla elementos que insinuam a interação do aluno com o texto. Assim como a obra LD1, indica ser um texto que se adequa bem ao ensino tradicional: o aluno acompanha com o livro as aulas ministradas pelo professor (ou estuda sozinho); resolve exercícios e testes e faz avaliações.

Apresentamos no quadro a seguir uma síntese da análise perpetrada nos livros didáticos. 
QUADRO 17 - Síntese da análise nos livros didáticos

\begin{tabular}{|c|c|c|c|c|c|}
\hline \multirow[t]{2}{*}{ Dimensões } & \multirow[t]{2}{*}{ Categorias } & \multicolumn{4}{|c|}{ RESULTADOS } \\
\hline & & $\begin{array}{l}\text { LD1 - } \\
\text { Dalton Gonçalves } \\
(1968 . . .)\end{array}$ & $\begin{array}{c}\text { LD2 } \\
\text { Alvarenga e Máximo } \\
(1970 . . .)\end{array}$ & $\begin{array}{c}\text { LD3 } \\
\text { Alvarenga e Máximo } \\
\text { (1979) }\end{array}$ & $\begin{array}{l}\text { LD4 } \\
\text { Ramalho Junior et al. } \\
(1976 \ldots)\end{array}$ \\
\hline \multirow[t]{4}{*}{$\begin{array}{l}\text { Epistemo- } \\
\text { lógica }\end{array}$} & $\begin{array}{l}\text { Ciência } \\
\text { como } \\
\text { processo }\end{array}$ & $\begin{array}{l}\text { Ciência/física como } \\
\text { produto. Não menciona } \\
\text { aplicações de } \\
\text { conhecimentos da Física } \\
\text { nas tecnologias, e } \\
\text { infimamente remete aos } \\
\text { aspectos históricos das } \\
\text { evoluções das ideias. }\end{array}$ & $\begin{array}{l}\text { Apresenta alguns } \\
\text { elementos que } \\
\text { evidenciam a ciência } \\
\text { como processo de forma } \\
\text { mais ou menos } \\
\text { explícita; relaciona a } \\
\text { Física com outras áreas } \\
\text { do conhecimento e com } \\
\text { a tecnologia. Traz } \\
\text { alguns aspectos } \\
\text { históricos. }\end{array}$ & $\begin{array}{l}\text { Apresenta mais } \\
\text { elementos que } \\
\text { evidenciam a ciência } \\
\text { como processo; relaciona } \\
\text { a Física com outras áreas } \\
\text { do conhecimento e com a } \\
\text { tecnologia. Abrange mais } \\
\text { aspectos históricos que a } \\
\text { versão anterior. }\end{array}$ & $\begin{array}{l}\text { Elementos praticamente } \\
\text { inexistentes. A } \\
\text { ciência/física é } \\
\text { apresentada como } \\
\text { produto pronto, } \\
\text { desvinculada da } \\
\text { realidade cotidiana e dos } \\
\text { aspectos histórico- } \\
\text { sociais. }\end{array}$ \\
\hline & $\begin{array}{l}\text { A Física e a } \\
\text { experimen- } \\
\text { tação }\end{array}$ & $\begin{array}{l}\text { Reconhece a física como } \\
\text { uma ciência empírica, } \\
\text { mas sugere poucas } \\
\text { propostas de } \\
\text { experimentação. }\end{array}$ & $\begin{array}{l}\text { Tem a física como uma } \\
\text { ciência empírica, mas } \\
\text { sugere poucas propostas } \\
\text { de experimentação, } \\
\text { contudo, tem uma } \\
\text { abordagem que é mais } \\
\text { fenomenológica que, de } \\
\text { certo modo, explicita a } \\
\text { existência de um } \\
\text { método científico } \\
\text { experimental. }\end{array}$ & $\begin{array}{l}\text { Do mesmo modo que a } \\
\text { anterior, tem abordagem } \\
\text { fenomenológica; sugere } \\
\text { muitas propostas de } \\
\text { experimentação, mas não } \\
\text { as colocam como } \\
\text { prioridade. Poderiam } \\
\text { ficar de fora da } \\
\text { programação em função } \\
\text { de carga horária reduzida }\end{array}$ & $\begin{array}{l}\text { Reconhece a física como } \\
\text { uma ciência empírica, } \\
\text { mas não sugere } \\
\text { propostas de } \\
\text { experimentação. }\end{array}$ \\
\hline & $\begin{array}{l}\text { Modelos } \\
\text { explicativos } \\
\text { formais }\end{array}$ & $\begin{array}{l}\text { Modelos matemáticos } \\
\text { como ferramenta de } \\
\text { cálculos }\end{array}$ & \multicolumn{2}{|c|}{$\begin{array}{l}\text { Os modelos matemáticos são, de modo geral, } \\
\text { precedidos de exemplos e explicações detalhadas, } \\
\text { relacionando fenômeno, conceitos e modelos } \\
\text { matemáticos. }\end{array}$} & $\begin{array}{l}\text { Perspectiva claramente } \\
\text { voltada para a execução } \\
\text { de cálculos }\end{array}$ \\
\hline & $\begin{array}{l}\text { Conteúdos/ } \\
\text { áreas da Física }\end{array}$ & $\begin{array}{l}\text { Traz os grandes temas da } \\
\text { Física de forma bastante } \\
\text { desmembrada em tópicos: } \\
\text { Mecânica, Termologia, } \\
\text { Acústica (ondas), Ótica, } \\
\text { Eletromagnetismo e } \\
\text { Física Moderna. Traz } \\
\text { tópicos e termos pouco } \\
\text { comuns em outras obras. }\end{array}$ & \multicolumn{3}{|c|}{$\begin{array}{l}\text { Abordam os grandes temas da Física: Mecânica, Termologia, Ótica, Ondas, } \\
\text { Eletromagnetismo e Física Moderna (na obra LD3 de forma disseminada nos } \\
\text { capítulos e não mais em capítulo específico). } \\
\text { Sequência de conteúdos similar (entre as três), mas com tratamento diferente. } \\
\text { As obras LD2 e LD3 são mais explicativas e demonstram cuidado em inter- } \\
\text { relacionar os assuntos, minimizando a fragmentação do conhecimento. Já a } \\
\text { LD4 é extremamente sucinta, com breves sínteses teóricas e pouca articulação } \\
\text { de conceitos. }\end{array}$} \\
\hline \multirow[t]{2}{*}{ Educativa } & $\begin{array}{ll}\text { Objetivos } & \text { do } \\
\text { ensino } & \text { de } \\
\text { Física } & \end{array}$ & $\begin{array}{l}\text { Caráter instrumental e } \\
\text { propedêutico ao vestibular }\end{array}$ & \multicolumn{2}{|c|}{$\begin{array}{l}\text { Enseja uma nova visão de ensino: análise } \\
\text { qualitativa dos fenômenos da Natureza, aplicações } \\
\text { cotidianas e aspectos históricos e tecnológicos da } \\
\text { ciência/física. Reúne características que podem } \\
\text { propiciar o desenvolvimento do pensamento lógico. } \\
\text { É também propedêutica ao prosseguimento nos } \\
\text { estudos. }\end{array}$} & $\begin{array}{l}\text { Caráter instrumental e } \\
\text { propedêutico ao } \\
\text { vestibular. }\end{array}$ \\
\hline & $\begin{array}{l}\text { Concepção de } \\
\text { aluno/ } \\
\text { professor }\end{array}$ & $\begin{array}{l}\text { Incentiva à condução da } \\
\text { aprendizagem por um } \\
\text { método mais } \\
\text { individualizado, mas } \\
\text { também se adequa ao } \\
\text { ensino expositivo, } \\
\text { centrado no professor. }\end{array}$ & \multicolumn{2}{|c|}{$\begin{array}{l}\text { Permitem uma maior possibilidade de interação do } \\
\text { aluno com os conhecimentos/conteúdos da ciência } \\
\text { apresentada. O formato dos textos, que é mais } \\
\text { conceitual contribui para uma maior interação com } \\
\text { a ciência. O professor parece ter papel relevante. }\end{array}$} & $\begin{array}{l}\text { Não define } \\
\text { explicitamente o papel } \\
\text { do professor, como } \\
\text { também o do aluno, } \\
\text { contudo, do mesmo } \\
\text { modo que a obra LD1, } \\
\text { indica se adequar bem } \\
\text { ao ensino tradicional } \\
\text { (expositivo) }\end{array}$ \\
\hline
\end{tabular}





\section{CONSIDERAÇÕES FINAIS}

Esta pesquisa buscou compreender parte da história do ensino de Física no Brasil no contexto dos anos de 1960 e 1970, focando a legislação educacional e os diferentes referenciais curriculares que, em tese, nortearam a prática educativa nas salas de aula do contexto em questão.

Nas linhas e entrelinhas das legislações educacionais e seus documentos regulamentadores, buscamos saber da importância dada ao conhecimento científico, focando a presença das disciplinas da área de Ciências nas reformas ocorridas nas duas décadas. Nos materiais orientadores da prática educativa em sala de aula, buscamos compreender como se propuseram as interações cognitivas entre sujeito e objeto de conhecimento, ou seja, o que se pretendeu, em termos de formação científica (no que concerne a Física), com o projeto educativo idealizado e levado a cabo naquele momento histórico.

Do estudo nos documentos legais que normatizaram o ensino escolar no período delimitado nesta pesquisa, constatamos a contradição entre o discurso das Leis maiores e as formas de organização dos quadros curriculares orientadas pelas instruções e normas educacionais que as regulamentaram, uma vez que não se concedeu às disciplinas científicas o devido espaço no currículo escolar nos termos das promessas ditadas. No caso de Física, vimos que, das orientações gerais de organização curricular emanadas do poder público central e de alguns currículos analisados, em todo o período, a carga horária da disciplina no segundo ciclo do ensino médio, posteriormente $2^{\circ}$ grau, na maioria das situações analisadas, variavam entre 2 e 3 horas/aulas semanais, não representando assim, aumento em relação à situação que vinha sendo praticada antes da LDB/1961.

Observamos, por exemplo, que, embora o ensino secundário passasse a ter Ciências a partir do $1^{\circ}$ ano do ciclo Ginasial, não contemplou a disciplina em todas as séries desse ciclo, representando um acréscimo, em termos de presença, de somente uma série em relação ao currículo oficial anterior à LDB. No ciclo Colegial, disciplinas da área - Ciências Físicas e Biológicas ou as específicas Física, Química e Biologia - foram contempladas, como obrigatórias, em somente duas séries (antes da LDB apareciam em três séries). Assim, podese concluir que não houve aumento em termos de presença das disciplinas das Ciências da Natureza no currículo, quando se compara com a sistemática anterior.

Mostramos ainda alguns exemplos que nos levam a concluir que não houve, também, aumento em relação à carga horária. Nossas verificações se opõem às afirmações de alguns 
autores que asseveram que as disciplinas científicas ganharam maior espaço nos currículos, inclusive com aumento de carga horária nas escolas, com o advento da referida lei, conforme citado neste texto.

Vimos que outros fatores contribuíram para que ocorressem importantes tentativas de melhoria no ensino da área de Ciências e que redefiniram o papel atribuído às disciplinas científicas no contexto investigado: a flexibilidade da Lei e as influências políticas e filosóficas do movimento renovador para o ensino de Ciências em nível global. Movimento este, aderido por grupos de professores e pesquisadores, com significativo apoio do poder público.

Destarte, apesar de as Ciências não terem logrado espaço privilegiado nos quadros curriculares em termos de presença e carga horária, deve-se reconhecer a abertura trazida na LDB/1961 ao permitir experiências pedagógicas nas escolas (cf. BRASIL, 1961, Art. 20), antes limitadas pelos preceitos das legislações anteriores. Essa abertura foi, indiscutivelmente, importante para que ocorressem as tentativas de inovação no ensino de Ciências nas décadas de 1960 e 1970 com a profusão de diversas propostas inovadoras, amparadas por programas vinculados ao governo federal, das quais trouxeram densas mudanças na forma de se pensar o ensino de disciplinas da área, particularmente o de Física. Fato que motivou a desencadeamento da pesquisa em ensino de Física no Brasil com a formação de grupos institucionalizados; ações que vêm conferindo importante contribuição para o delineamento de novas diretrizes para o ensino desta disciplina.

A tradução e adaptação dos projetos estrangeiros de ensino de Física, bem como a elaboração de projetos nacionais, foram exemplos de tentativas de inovação curricular ensaiadas em nosso país, a partir de experiências de grupos que, além de seus ideários educativos mais pessoais pelos seus contatos, sejam diretos ou indiretos, com a realidade escolar, refletiram nelas, também, concepções políticas de ordem maior.

Tais tentativas podem ser consideradas exemplos de que as decisões das instâncias superiores às escolas não devem ser renegadas no âmbito escolar, sem uma reflexão crítica, como bem alerta Goodson (1995). Diversos grupos participam das definições curriculares, e muitos podem ter intenções louváveis na busca de um ensino de qualidade, fazendo refletir nelas, pelo menos em parte, os seus anseios educativos. A visão negativa da prescrição, que muitas vezes alimentamos, leva-nos a desconsiderar a construção social do currículo e, muitas vezes, a renegá-lo (GOODSON, 1995, p. 79). 


\section{Algumas considerações sobre os referenciais curriculares analisados}

Teceremos algumas considerações a partir da análise nos referenciais curriculares; análise esta focada nas dimensões epistemológica e educativa do conhecimento. Começaremos pelos projetos de ensino seguindo a sequência com que os materiais objetos de análise foram tratados nesta pesquisa.

\section{Sobre os projetos de ensino}

No que se refere ao PSSC, cabe primeiramente pontuar que, analisamos o material utilizado no Brasil. Ao que tudo indica, a versão brasileira sofreu poucas adaptações, sendo bastante fiel à proposta original. Assim, as concepções de ciência e educação inferidas deles podem não representar necessariamente as ideias dos educadores brasileiros envolvidos em seu processo de implementação no Brasil. Contudo o fato de ter sido adotado (ou pelo menos tentado) como uma proposta de inovação curricular em nosso país, subentende a ratificação das ideias originais do projeto.

O estudo nos manuais do PSSC mostra que o conhecimento sobre a Natureza é acatado como um processo dinâmico, embora alguns aspectos desse processo sejam pouco explorados (aspectos históricos, relações contextuais no desenvolvimento das ideias, por exemplo), o que acaba por conceder à ciência/Física um caráter de neutralidade. A tecnologia é bastante enfatizada como símbolo de progresso científico. A experimentação é a gênese do projeto (tratada como método científico) que, entre outras possibilidades de pretensões, pode ser vista como uma tentativa de simular na sala de aula os procedimentos da pesquisa científica; ou seja, estimular a formação de novos cientistas, fazendo com que o aluno, desde cedo, se colocasse como um cientista mirim. Em termos de abordagem dos conteúdos, é bastante conceitual/fenomenológico.

Constata-se um enfoque especial no ensino de tópicos voltados para a Física Nuclear. A nosso ver, esse enfoque e a ênfase na experimentação como meio de chegar às leis científicas, têm um pano de fundo; ideação de longo prazo com interesses fortemente políticos - preparar futuros pesquisadores para a busca do alto conhecimento científico como arma de defesa da nação. Perspectiva que corrobora a ideia de que não há neutralidade na escolha dos conteúdos do currículo escolar, como defendem Goodson (1995), Apple (1997), Delizoicov, Angotti e Pernambuco (2007) e outros. As características mencionadas acabam por sancionar a forte conexão do projeto com o contexto político-histórico-social de sua elaboração. 
Quanto à escolha dos assuntos abordados, o PSSC indica assumir a premissa de que não é sustentável tentar ensinar todo o rol de conteúdos da Física, seguindo o curso de desenvolvimento dessa ciência. Ao que parece, essa opção, de reduzir tópicos, é reflexo de acordos nascidos na conjuntura do movimento renovador estadunidense ${ }^{137}$ na segunda metade da década de 1950. Embora abranja a maioria dos grandes temas da Física, busca articular um número mais reduzido de tópicos em cada um deles, conferindo profundidade e rigor intelectual no tratamento dos mesmos, ao invés de extensão e superficialidade.

O PEF também tem a ciência como um processo dinâmico, um empreendimento humano e coletivo, ainda que, também, pouco conectado com os contextos de desenvolvimento das ideias. Abrange aspectos históricos mais que o PSSC, mas numa perspectiva interna à própria ciência Física; timidamente vincula o desenvolvimento da ciência aos fatores externos (políticos, econômicos e sociais). O desenvolvimento de conteúdo também se aproxima da proposta do PSSC, com uma abordagem bastante conceitual/fenomenológica de modo que o formalismo matemático se mostra bem equilibrado com os conceitos. A experimentação - parte integrante do desenvolvimento do projeto em sala de aula - se caracteriza mais como meio de compreensão dos conceitos físicos do que como forma de simular a pesquisa científica, mas traz também um pouco da ideia do aluno como pequeno cientista. São convergentes também no significativo apelo tecnológico. Do mesmo modo que o PSSC, restringiu-se à quantidade de conteúdos tratados; contudo, diferentemente do primeiro, assume basicamente dois temas (Mecânica e Eletromagnetismo); não avoca tanto rigor intelectual como o seu precursor, mas tem certo grau de profundidade e significativa articulação de tópicos.

Já o FAI passa claramente a ideia de Ciência como produto pronto, linear, desvinculado de relações contextuais. Tem muito apelo aos modelos matemáticos e, diferentemente dos outros dois projetos analisados, não enfatiza a experimentação. Embora inclua atividades experimentais, não as têm como fio condutor da sua proposta de ensino, de

\footnotetext{
${ }^{137}$ Em 1956, um Seminário ocorreu no Carleton College em Northfield, Minnesota, EUA, realizado pela American Association of Physics Teachers. Tal seminário teve como escopo discutir a melhoria da qualidade e eficácia dos cursos de física introdutórios (nível de ensino acima do secundário). O relatório da referida conferência, intitulado Improve the quality and effectiveness of introductory courses in physics recomendou uma redução drástica do número de tópicos, pois, segundo alerta, a Física tem [já tinha naquela época] um corpo de conhecimento demasiadamente vasto para ser tratado adequadamente em um curso introdutório. Coloca como guia algumas conclusões principais a que chegaram os conferencistas. A primeira de uma lista de cinco itens defende que, "Uma completa e rigorosa cobertura de um número limitado de tópicos é mais eficaz do que uma introdução enciclopédica e vistosa para uma vasta gama de assuntos." . (Report a of Conference Carleton, The American Journal of Physics, Vol. 25 (7) - Oct 1, 1957, p. 417, tradução nossa).
} 
modo que tais atividades são vistas como recurso secundário e, se desenvolvidas, tinham claramente o objetivo de verificação de leis e conceitos.

A princípio, pareceu não intencionar reduzir drasticamente a quantidade de tópicos no FAI. Conforme mostramos, o Manual do Professor previa o tratamento de uma ementa longa de assuntos, aumentando linearmente o nível de complexidade. Entretanto, constata-se que parte da lista de temas/tópicos pretendidos não aparece nos manuais do projeto, limitando-os em três grandes temas (Mecânica, Termologia e Eletricidade). Ao que parece, a redução de assuntos não foi por opção influenciada pelas ideias que indicam ter norteado a organização dos conteúdos dos projetos PSSC e PEF. Fica subentendido que houve um descompasso no caminho da produção editorial do projeto, visto que o Manual do Professor não foi a última publicação da coleção.

No que tange às concepções de método de desenvolvimento da Ciência, entendemos que os projetos mesclam diferentes ideias filosóficas, mas são preponderantemente indutivistas, sobretudo o PSSC e o PEF que colocam a experimentação - ostentada como sinônimo de método científico - como ponto de partida no estudo da natureza, e que esta seria condição imprescindível para a validade do conhecimento (concepções baconeanas). Esta constatação é sustentada pelos trechos dos discursos dos projetos que apresentamos nos resultados da análise.

$\mathrm{Na}$ visão de Gaspar (2004), a extrema aposta na experimentação nos referidos projetos como forma de fazer o aluno chegar às leis científicas foi a razão principal do "fracasso" dos mesmos. As escolas e os professores não estavam preparados para tal inovação. No caso do PSSC, outra razão apontada para as dificuldades de aceitação, e que de fato constatamos em nossa análise, é que os textos trazem profundidade nos conceitos, ou seja, o nível conceitual é relativamente avançado, podendo ser incompreensível até mesmo para professores. A respeito disso, é consenso que tal fator tenha constituído uma dificuldade no desenvolvimento do projeto não somente no Brasil, mas também em seu país de origem. Em entrevista a Chiquetto e Krapas (2012), a Professora Beatriz Alvarenga, que participou de um curso de formação para o PSSC, nos Estados Unidos, dá sua opinião a respeito das dificuldades de implementação da referida inovação. A fala de Beatriz Alvarenga aponta que, mesmo "os instrutores norte-americanos, em contato direto com o grupo do PSSC, tinham dificuldades, e que havia casos em que a distância entre o que se esperava transmitir aos professores e a real condição destes era tão grande que essa transmissão se tornava inviável." (CHIQUETTO; KRAPAS, 2012, p. 186). 
O Professor Rodolpho Caniato, que participou de cursos sobre o PSSC aqui no Brasil e da tentativa de implementação, também em entrevista a Chiquetto e Krapas aponta a complexidade do projeto como fator que dificultou a aceitação do mesmo pelos professores brasileiros. Na visão do Professor Caniato, o projeto era simples para quem gosta e quer estudar Física. Para um professor despreparado, não disposto a encarar as situações imprevisíveis que poderiam ser geradas, principalmente com as atividades experimentais, o projeto não era nada simples. Esse professor se sentiria mais seguro dando suas aulas utilizando fórmulas, pois não tem surpresas, "não acontece nunca nada, ninguém erra nada. Não tem desvio, tá tudo certo, CQD."138 (CANIATO, 2010 apud CHIQUETTO; KRAPAS, 2012, p. 186).

Além dessas dificuldades apontadas, a integração de diferentes recursos metodológicos pode também ter configurado como um dos fatores relevantes que dificultaram a implementação do PSSC nas escolas.

É preciso considerar ainda, não somente quanto ao PSSC (década de 1960), mas também ao PEF e FAI (década de 1970), a questão da carga horária de Física nas escolas brasileiras, que indica não ter sido suficiente para a execução dos projetos na integralidade, uma vez que os mesmos previam tempos maiores do que os disponíveis para a Física nos quadros curriculares.

$\mathrm{Na}$ perspectiva educacional, constata-se que, quanto aos objetivos do ensino de Física, os projetos priorizavam a transmissão do conhecimento científico, ou seja, conhecer fenômenos e conceitos da física, as ideias fundamentais (no caso do PSSC, cabem controvérsias à ideia de que partir do estudo do Cosmo seja uma forma de abordagem simples das ideias fundamentais da Física), aspectos da Física Contemporânea, estabelecer contato com o método científico. Para isso, adotaram-se o modelo de planejamento sequencial e fechado, com objetivos definidos vinculados à avaliação de resultados de aprendizagem. $\mathrm{O}$ PSSC e o PEF apresentam objetivos um pouco mais abertos, contudo vinculados ao escopo da própria ciência/física. No FAI, os objetivos se fecham mais na perspectiva informativa limitada pela fronteira disciplinar e bastante fragmentados dentro da própria disciplina.

Seria a determinação de objetivos específicos nos projetos de ensino também inspirada nas convenções do movimento renovador estadunidense?

O relatório da Conferência de Carleton, em 1956, (já citado aqui em nota) traz um tópico específico que trata da definição de objetivos ao elaborar os currículos: Importance of

\footnotetext{
${ }^{138}$ Trecho de entrevista concedida a Marcos José Chiqueto e Sônia Krapas no ano de 2010.
} 
clearly formulated aims (Importância de objetivos claramente formulados). Defende que os objetivos de um curso devem ser claros e explicitamente formulados antes mesmo da definição dos conteúdos a ser tratados, do tempo para o desenvolvimento dos mesmos e do método a ser utilizado. Desta forma, o relatório indica se referir a objetivos mais gerais, ainda que internos ao escopo da ciência/Física.

A determinação de objetivos definidos foi uma característica do ideário educativo que permeou o sistema educacional, em nível macro, a partir da década de 1960; uma educação tecnicista focada numa formação mais pragmática e pautada na objetividade dos processos (SAVIANI, 1986). Nessa perspectiva educativa, na determinação de objetivos para o ensino de Física, não parecia relevante considerar aspectos mais amplos de ordem social, política e econômica, o contexto temporal (a evolução de ideias e o progresso técnicocientífico), bem como o contexto espacial com suas especificidades características da cultura.

No que se refere aos projetos genuinamente brasileiros, o enfoque em objetivos específicos era, de certa forma, esperado em nossa análise. Cabe lembrar que esses projetos nasceram em um momento em que, no Brasil, o ideário educativo otimizou sua vertente tecnicista, estando condizente com a agenda desenvolvimentista do programa de governo assumido no regime militar. Passou-se a almejar uma formação cidadã, em termos de domínio dos recursos científicos e tecnológicos, ainda mais especializada; domínio este que perpassava pela utilização de tais recursos para uma finalidade produtiva mais imediata no mercado de trabalho. Daí a afinidade do currículo com métodos de ensino que traziam características de treinamento, como eram os fundamentados no behaviorismo skinneriano que se valiam de módulos instrucionais no modelo de Instrução Programada - recurso da Tecnologia do Ensino.

O PEF e o FAI fazem uso desse recurso nos textos. O primeiro com questões programadas entremeadas aos textos, mas com uma abordagem mais explicativa e associada às propostas experimentais e de investigação; o FAI assume, exclusivamente, esse recurso no desenvolvimento dos conteúdos apresentados com uma perspectiva bastante linear, basicamente por meio de exercícios, em maior parte, numéricos, com respostas prontas ao final de cada um.

Gaspar (2004), que participou da elaboração do FAI e trabalhou com o projeto em sala de aula, avalia esse método como uma experiência frustrante, e tal frustração não se resumia à sua sensação de inutilidade em sala de aula, já que os alunos mal notavam sua presença, mas também em termos de resultados de aprendizagem dos alunos. Segundo ele, o envolvimento dos alunos na interação com o texto mascarava uma situação de falsa 
aprendizagem. Ele afirma: "Com o tempo, percebi que a aprendizagem dos alunos era estranhamente passageira, algo que não se consolidava [...]” (GASPAR, 2004, p. 79).

$\mathrm{Na}$ estrutura dos três projetos analisados, a Tecnologia do Ensino ${ }^{139}$ aparece agregada ao racionalismo acadêmico (GARCIA; AZEVEDO, 1984), embora, em alguns aspectos, tais posturas curriculares se mostrem antagônicas e, também, com diferentes alcances nos projetos. Percebe-se o racionalismo acadêmico pela organização dos conteúdos da Física nos textos. Enfatiza os pré-requisitos e vai apresentando novos conhecimentos a serem apreendidos por comparação com conhecimento anterior objetivando elaborar generalizações e posterior aplicação (exercícios de verificação da aprendizagem). Assim, a Física apresentada tem um caráter de finalidade em si mesma, de conhecimento neutro e objetivo, atemporal e a-histórico (principalmente no FAI e em menor nível no PSSC e PEF).

Embora o PSSC e o PEF considerem a ciência como um processo dinâmico, confere pouca ou nenhuma atenção aos diversos fatores que permeiam a construção dos conceitos e teorias, como exemplo, o embate de ideias, os percursos abandonados, os equívocos, as influências sociais, a história social dos elaboradores da ciência, os interesses de grupos dominantes no andamento das pesquisas científicas, etc.. Também, não evidencia a importância do papel do sujeito aprendiz e sua história social na apreensão do conhecimento científico constituído, exceto pelo fato de terem uma linguagem mais fenomenológica, o que, de certo modo, considera a possibilidade de significação do objeto pela visão do sujeito.

Cabe lembrar que, no caso do PSSC, nossa análise focou os manuais traduzidos/disponibilizados para uso nas escolas brasileiras. Talvez, os aspectos históricos da ciência/Física tenham sido abordados em maior extensão nos textos indicados para leituras complementares (que não foram analisados nesta pesquisa).

Enfim, os projetos analisados, sobretudo os brasileiros, em alcances diferentes, trazem, também, características de um ensino tradicional, em que se prioriza a aquisição do conhecimento acadêmico - o produto da ciência - para fins predominantemente propedêuticos. Nesse caso, um ensino propedêutico mediatizado por métodos inovadores - meios mais eficientes para facilitar a transmissão do conhecimento sistematizado. Tem-se desse modo, a consonância entre as diferentes posturas curriculares mencionadas: privilegiam mais os processos de ensino do que as finalidades educativas mais amplas (GARCIA; AZEVEDO, 1984).

\footnotetext{
${ }^{139} \mathrm{Na}$ Tecnologia do Ensino, além do uso de módulos instrucionais e textos programados, inclui também os recursos audiovisuais. Vale-se de técnicas sistematizadas, linguagem objetiva, esquemas, resumos, figuras, etc., e de recursos modernos (filmes, loops, instrumentos para experimentos) para promover a aprendizagem, em um processo mais individualizado. Desse modo, o PSSC também faz uso desse princípio pedagógico.
} 
Já o aspecto antagônico entre elas se evidencia, quando se atenta aos papéis do professor e do aluno. Enquanto numa o professor é o centro do processo e o aluno é passivo, noutra a atenção se volta para o aluno, e o papel do professor é mais periférico, com a função de programar e controlar o processo de aprendizagem. Os projetos brasileiros analisados adotam explicitamente esta segunda vertente.

\section{Sobre os currículos oficiais estaduais}

A análise na Proposta Curricular oficial do Estado do Rio de Janeiro mostra que, em vários aspectos, houve um distanciamento entre o discurso pedagógico das diretrizes da área e o desenvolvimento dos conteúdos na proposta específica de Física (PCF/RJ). No discurso das diretrizes, a concepção de ciência processual é claramente exaltada, contudo algumas concepções sobre o método das ciências acabam por considerá-la um processo linear, com acúmulo gradativo dos conhecimentos. Adota certo hibridismo conceptual. No que se refere ao conceito de método científico, por exemplo, defende a combinação de indução e dedução.

No desenvolvimento da proposta, a ideia de ciência é apresentada como um produto pronto e finalizado. As sugestões de experiências simples e de exemplos cotidianos são colocadas como recurso de comprovação dos conceitos afirmados. Ainda que alguns títulos de tópicos suscitem a possibilidade de abarcar aspectos históricos, os objetivos não caminham nesse sentido. A tecnologia é infimamente evidenciada e menos ainda as questões mais amplas de ordem política, econômica, social e cultural. Estimula uma inter-relação entre a Física e a Matemática, contudo, ao que indica, a preocupação era avalizar fluidez no uso da matemática como ferramenta de cálculos e não como descrição dos fenômenos físicos.

$\mathrm{Na}$ PCF/SP a ausência de elementos que evidenciam a visão de ciência denuncia a ideia de construção de um conhecimento neutro, rematado, sem processo histórico. Seguindo a tendência da época, a proposta investiu nas atividades experimentais também numa perspectiva de verificação e comprovação de conceitos. Pouco relaciona a Física com as coisas cotidianas e com a cultura. Percebe-se preocupação em articular os conteúdos da Física com os de outras disciplinas do currículo, mas a título de recomendação no discurso inicial. A princípio parece exaltar o trabalho interdisciplinar, todavia, no desenrolar da proposta, não retoma tal ideia.

A duas propostas trazem similaridades do ponto de vista de uma análise epistemológica. A construção do conhecimento físico não é apresentada como um processo dinâmico, mas sim como um produto corporificado, sem história processual. Ambas não 
destacam assuntos relacionados à tecnologia da época; apresentam-se descontextualizadas com o momento histórico.

A restrição de tópicos de conteúdos também foi adotada nas propostas curriculares oficiais, principalmente na $\mathrm{PCF} / \mathrm{RJ}$, mas, ao que parece, a razão disso foi devido à redução de carga horária com o advento da profissionalização do $2^{\circ}$ grau. As propostas abrangem, com algumas diferenças sequenciais, os grandes temas da Física tradicionalmente organizados, com exceção da Física Moderna, que não aparece em nenhuma delas e do tema Eletromagnetismo, que não é abordado na PCF/RJ.

$\mathrm{Na}$ perspectiva educacional, as duas propostas são claramente voltadas para os conteúdos. A Física é apresentada como um produto da ciência, com uma finalidade nela mesma. Assim, os objetivos se voltam para a aprendizagem dos conceitos prontos com vistas a prosseguimento nos estudos. Nem mesmo a PCF/SP, que traz os conteúdos para a disciplina Física Aplicada, propõe os assuntos com aplicabilidade específica de forma a demonstrar relação com as coisas cotidianas, do mercado de trabalho, por exemplo.

No nível de discurso a PCF/RJ parece seguir as tendências de ensino da época: aluno com participação mais ativa e o professor como um auxiliador do processo de aprendizagem. No desenvolvimento do programa, essa tendência é deslembrada e a proposta assume uma perspectiva de ensino tradicional, sem inovações, exceto pelo fato de propor uma quantidade significativa de atividades experimentais, embora a maioria pressuponha execução demonstrativa. Assim, considerando o discurso e o desenvolvimento, a proposta assume diferentes pressupostos pedagógicos: cognitivismo, tecnicismo e ensino propedêutico.

A PCF/SP não definiu o papel do aluno e do professor. Pressupõe certo grau de autonomia do professor na escolha dos conteúdos, mas dentro de um planejamento definido. Não propôs material para o aluno e a participação deste no processo de ensino-aprendizagem parece indicar que seria através das atividades experimentais que eram simples e de fácil execução. As influências do movimento renovador são notadas somente pela ênfase na experimentação, inclusive com uso de aparatos experimentais elaborados pelos projetos de ensino da época.

Em síntese, nas duas propostas o ensino é pré-definido; dá primazia ao produto da ciência e tem o sujeito do conhecimento como recebedor da informação sem preocupação com a serventia de tal conhecimento para a vida social. 


\section{Sobre os livros didáticos}

Da análise nos livros didáticos observamos que a concepção de ciência como um processo dinâmico é mais evidente nas obras de Alvarenga e Máximo (LD2 e LD3). Nas demais obras, elementos que denotam essa visão são praticamente inexistentes.

Todas as obras analisadas, em termos de discurso, têm uma visão da Física como uma ciência empírica; alude a experimentação como método de construção do conhecimento, mas somente uma delas - a obra LD3 - faz jus ao discurso trazendo um grande número de sugestões de experiências, ainda que estas tenham caráter verificacionista. A obra de Dalton Gonçalves (LD1) e a obra Alvarenga e Máximo (LD2) apresentam poucas sugestões, cerca de uma dezena de atividades cada uma; já a obra de Ramalho Junior et al. (LD4) contempla somente duas situações que se caracterizam como sugestões de experimentação.

Quanto ao uso dos modelos matemáticos, o apelo é mais evidente nas obras de Dalton Gonçalves (LD1) e Ramalho Junior et al. (LD4), sobretudo na primeira, a julgar pela extensão dedicada a revisão de tópicos da área e preocupação com dedução de fórmulas. A obra LD4 enfatiza bastante a matemática no desenvolvimento dos conteúdos, mas não traz capítulos específicos de revisão. Estas obras não concebem as relações matemáticas como modelos explicativos dos fenômenos naturais. Os modelos formais são apresentados a partir de deduções de fórmulas, precedidos de breves caracterizações dos conceitos. A perspectiva é claramente voltada para a execução de cálculos.

No que tange aos conteúdos/áreas da Física, de modo geral, as obras seguem a estrutura tradicional de apresentação, todas organizadas por seis grandes temas da Física, embora a Física Moderna não se apresente em duas delas como um tema separado. Quanto aos tópicos contemplados por área, os materiais se assemelham, alterando algumas sequências e ênfases, e no caso da obra LD1, tem-se uma gama maior de subtópicos, de modo que muitos desdobramentos não são comumente encontrados em outros livros do ensino médio da mesma época.

Em termos de sequência e títulos de tópicos, nota-se similaridade entre as obras LD3 e LD4. Interessante observar que, ao falar dos sentidos (visão, audição, tato) como ponto de partida para entender o mundo, as duas obras mencionadas trazem um discurso parecido com o que encontramos no PSSC (no Cap. 2 do projeto). Já na forma de apresentação dos conteúdos, no modo sintetizado de tratá-los, percebe-se bastante diferença entre as duas. Neste aspecto, há convergência entre as obras LD1 e LD4 que se assemelham às apostilas destinadas a cursinhos pré-vestibulares; priorizam definições, fórmulas e exercícios para 
aplicação. Já as duas obras de Alvarenga e Máximo trazem um maior equilíbrio entre a exposição conceitual e o formalismo matemático: opção metodológica parecida com o PSSC e PEF.

Conclui-se que a visão de ensino das obras didáticas analisadas é exclusivamente propedêutica nas obras LD1 e LD4. Nas obras LD2 e LD3 é mais inovadora (para a época), principalmente em LD3, que apresenta a Física como parte de uma cultura geral, propõe experimentação, evidencia a tecnologia, exemplos cotidianos, linguagem textual mais conceitual/fenomenológica, contextualização com o momento histórico (usando, principalmente, o recurso da imagem, mostrando fotos de aparatos tecnológicos da época) e aborda aspectos históricos da ciência. Entendemos essas características metodológicas como sendo influências do contexto do movimento renovador do ensino de ciências, já que a abordagem dos conteúdos é similar aos projetos de ensino PSSC e PEF. Todavia, este último surgiu após a elaboração da primeira versão da obra em questão, inclusive, tal obra é nele citado, nas referências bibliográficas gerais (no Guia do Professor PEF).

Podemos dizer que a obra de Alvarenga e Máximo e o PEF assumem características não somente do PSSC, mas também de outros projetos, como exemplo, o Projeto Harvard (1962-1970), que se fundamentava nos aspectos históricos da ciência (cf. APÊNDICE A).

Além disso, também, de modo similar aos projetos mencionados, enfatiza termos que se traduzem numa visão mais interativa do aluno com o conteúdo do conhecimento disposto no livro. O texto se destaca ainda pela grande quantidade de ilustrações esquemáticas que contribuem para o entendimento das explicações dos conceitos.

Um aspecto comum entre os livros didáticos analisados é a não preocupação com conhecimentos da cultura inicial dos estudantes. Isso também é notado nos demais tipos de referenciais curriculares explorados.

As obras LD1 e LD4 são claramente voltadas para a acumulação de conteúdos, sem possibilidade de promover diálogo, sem considerar as necessárias rupturas e continuidades para que ocorra a aquisição do conhecimento como condicionante transformador. Enfatizam o lado abstrato da Física, e não relacionam os conceitos às coisas cotidianas. Estas trazem um modelo de ensino focado exclusivamente na transmissão do conteúdo, de modo objetivo e quantitativo, com pouca ou nenhuma ênfase na experimentação, sem contextualização cotidiana e histórica.

Incentivam a memorização de fórmulas, definições e conceitos ao estilo das apostilas preparatórias para vestibular. Acabam concorrendo para a ideia de inutilidade dos saberes da ciência, caracterizados como inquestionáveis, sem elo com o mundo vivencial do estudante, 
sem potencial para contribuir com a resolução de problemas do cotidiano (DELIZOICOV; ANGOTTI; PERNAMBUCO (2007). As obras LD2 e LD3 permitem uma maior possibilidade de interação do aluno com a ciência apresentada; buscam retomar conceitos discutidos anteriormente, estabelece uma maior articulação entre as partes dos textos e relações com as coisas cotidianas, mas também predomina a perspectiva informativa dos aspectos internos à ciência. Assim, não colocam o ensino da Física como contributo para a formação cidadã em seus aspectos mais amplos, como exemplo, o preparo para o exercício consciente da cidadania (BRASIL, 1971b).

Constatamos que a obra de Dalton Gonçalves (LD1) e a obra de Ramalho Junior et al. (LD4) são condizentes com outra demanda educacional do momento histórico a que pertencem. Se por um lado, havia as demandas políticas pelo desenvolvimento científico e tecnológico e pela valorização da imagem da ciência, que sustentaram as inovações curriculares, por outro, havia outro pleito de grande peso: a demanda social pela educação superior, em parte, influenciada pelo desenvolvimentismo e pelas mudanças de modelo econômico (ROMANELLI, 1985). Período em que ocorreu o boom dos cursos preparatórios para o vestibular (CHIQUETTO; KRAPAS, 2012). As metodologias utilizadas por professores que atuavam nos cursinhos preparatórios para o vestibular se transformaram em livros didáticos. É o caso das duas obras em questão.

Em nossas leituras, deparamo-nos com uma opinião, de certo modo curiosa, a respeito do autor Dalton Gonçalves; sobre a concepção do mesmo em que pese a experimentação no ensino de Física. Fonte Boa (2008), ao falar de sua própria experiência como professor de Física na Aldeia Curumim - escola fundada em 1973 pelos professores Dalton Gonçalves e Lúcia Catarino Gonçalves - traz em uma nota de rodapé:

[...], destaco a contribuição/referência do saudoso professor Dalton Gonçalves que, já nos anos 1960, entre outras, propunha alternativas ao ensino tradicional da Física, particularmente no nível básico, sugerindo alterações na ordem, abordagem e desenvolvimento dos conteúdos.

Dalton estimulava a abordagem inicial da Física através de seus aspectos fenomenológicos, apoiada por experimentos, e fugindo ao início tradicional via Mecânica, sugeria iniciar pela apresentação da Óptica Geométrica e/ou da Termologia.

Se por um lado, a motivação fenomenológica e experimental não constituía novidade, por outro, a "inversão" da ordem tradicional colocando Óptica ou Termologia antes da Mecânica era singular. (FONTE BOA, 2008, p. 16, grifo nosso).

Esse trecho da história de vida profissional do autor Dalton Gonçalves se revela, por um lado, surpreendente, já que uma de suas obras, a mais difundida nas escolas brasileiras (a que tratamos neste trabalho), não se mostra condizente com o que foi a sua prática como 
professor, revelada no trecho acima. Afinal, a obra pouco contempla a experimentação, não evidencia os aspectos fenomenológicos da ciência/Física, como também não apresenta significativas inovações na sequência dos conteúdos; diferencia-se pela quantidade de tópicos, estando mais próxima das recomendações do currículo oficial que vigorava antes da LDB/1961.

Por outro lado, esse paradoxo denota a faceta mercadológica do livro didático (APPLE, 1997; CHOPPIN, 2004; FLORES, 2010), pois, as editoras trabalham no sentido de atender às demandas do momento, nesse caso, o vestibular. Os autores, muitas vezes, procuram se adequar às exigências das editoras e do público alvo, afastando-se assim de suas crenças como educadores.

A obra de Dalton Gonçalves (não somente ela, mas sobretudo ela) reforça ainda a função curricular do livro didático, conforme defende Chopin (2004), na medida em que esse recurso didático, muitas vezes, se apresenta como uma "[...] fiel tradução do programa [...]" (CHOPPIN, 2004, p. 553). Um exemplo disso é o conceito de "forças vivas", que, mesmo não concordando com a presença dele nos programas, o autor da obra insistiu em mantê-lo, conforme citamos na análise.

A pesquisa nos leva a concluir que, se por um lado as disciplinas científicas não lograram significativo espaço nos quadros curriculares, por outro, a flexibilidade da LDB/1961 contribuiu significativamente para o movimento que buscou melhorar o ensino de Ciências no Brasil, ao permitir experiências educacionais nas escolas, propiciando assim, a entrada e experimentação de propostas inovadoras, bem como a elaboração de propostas nacionais com diferentes perspectivas, pautadas em diferentes tendências, concepções e métodos de ensino, como exemplo:

$\rightarrow$ Propostas baseadas na estrutura fundamental dos diversos campos da ciência física e com expressiva ênfase em atividades experimentais (PSSC e PEF);

$\rightarrow$ Propostas com abordagem tecnicista, com objetivos específicos e desenvolvimento bem definidos, pautadas na Tecnologia do Ensino - o FAI assume mais claramente tais características; os demais projetos de ensino, em alguns aspectos;

$\rightarrow$ Propostas na linha do ensino tradicional, com abordagem objetiva, com enfoque no produto da ciência (livros didáticos e propostas curriculares oficiais);

$\rightarrow$ Propostas que reconfiguraram o papel do professor, deslocando-o do centro do processo para uma posição mais periférica, passando este a atuar como organizador, administrador e assistente do processo de aprendizagem; o aluno com participação mais ativa (todos os projetos de ensino analisados); 
$\rightarrow$ Propostas que pouco ou nada inovam em relação ao papel do aluno e do professor, subentendendo um ensino expositivo (livros didáticos e propostas curriculares oficiais).

Percebe-se ainda que as proposições não são idênticas, mas trazem elementos comuns metodologicamente. Como exemplo, notam-se algumas influências dos projetos de ensino em outras proposições curriculares: a experimentação nas propostas curriculares oficiais e abordagem mais conceitual/fenomenológica nas obras de Alvarenga e Máximo (LD2 e LD3). Algumas proposições trazem características do ensino tradicional anterior à década de 1960: ensino auxiliado pelo manual didático tendo o aluno como receptor de conhecimentos prontos (ex.: FAI, LD1 e LD4);

As proposições curriculares, no geral, trazem semelhantes visões de ciência/Física a ser ensinada na escola, a ciência dos cientistas, algumas com atenção ao processo, outras com enfoque somente no produto, sem preocupação com o significado do conhecimento na vida social do estudante, sem julgamento de valor, uma ciência neutra.

Os aspectos que caracterizam a concepção de ciência apresentada estão em diferentes níveis de abordagem, bem como se tem a supressão de alguns. Há propostas que trazem aspectos históricos, mas do ponto de vista interno à Ciência. Outras trazem mais contextualização com o momento histórico de elaboração, geralmente com menção à tecnologia e quase nada sobre as questões políticas, econômicas e sociais. Há ainda aquelas que nada contextualizam. Quanto aos objetivos do ensino de Física, num espectro mais geral, todos visaram à aprendizagem dos conteúdos do conhecimento físico numa perspectiva mais informativa do que formativa. Assim, o ensino nestes termos poderia educar um cidadão "informado, mas desqualificado para o trabalho transformador e impulsor de uma nova sociedade. Em suma, um brasileiro descientifizado.” (ALMEIDA JUNIOR, 1980, p.73).

\section{Finalizando...}

Concordamos com Goodson (1995) sobre a importância de estudarmos o currículo para compreender a sua construção social, pensando o currículo como algo que deve ser reconceptualizado a partir de reflexões sobre sua evolução ao longo do tempo. Investigar o currículo prescrito pode ser uma forma de buscar respostas que possibilitem mudanças para uma proposta mais democrática e aplicável, vencendo paradigmas e focando a realidade escolar.

Os professores/as precisam se reconhecer como parte desse processo de reconstrução. Muitas vezes, sem consciência de sua importância, fazem da sua própria ação um objeto de 
pesquisa desencadeador de conflitos que podem contribuir para uma efetiva melhoria na qualidade do ensino e aprendizagem, "forçando", de modo positivo, modificações na prescrição. A nosso ver, isso ocorreu de forma grandiosa no passado, nas décadas investigadas. As propostas curriculares inovadoras surgidas no Brasil, motivadas ou não por fatores externos, foram ações coordenadas e conduzidas por professores que conheciam os problemas da realidade escolar. Suas experiências estavam ali projetadas. Os erros e acertos constituíram experiências que, certamente, refletiram no ensino de Física a partir daquele marco histórico.

Enaltecemos as palavras de Almeida Junior (1980, p. 73), quando diz que "Nenhum esforço em aperfeiçoar a educação científica será supérfluo. Nenhuma experiência planejada e vivenciada em qualquer escola será infrutífera.”. Esta colocação nos leva a refletir sobre o termo "fracasso", que é bastante depreciativo para designar a não continuidade das propostas inovadoras surgidas nas décadas de 1960 e 1970. A tentativa valeu, e acreditamos que valeu muito!

É preciso reconhecer ações que geram modificações no currículo praticado, que buscam alternativas para estreitar as distâncias e ampliar as relações entre escolas e universidades, de forma a criar um elo entre a pesquisa e o cotidiano escolar. Isso foi plantado e tem sido regado de lá para cá nos grupos de pesquisas em Ensino de Ciências que se formaram.

Os resultados aqui apresentados apontam para a necessidade de continuidade de trabalhos nessa linha histórica, com investigações que ampliem o universo das fontes de análises com foco na temática em questão, bem como o recorte temporal (para até o final da vigência da lei 5.692/1971, por exemplo), buscando assim, conhecer a história da disciplina Física no contexto das grandes inovações curriculares, por meio dos currículos oficiais prescritos, materiais didáticos, o currículo reproduzido e atores do processo. Sugerimos, por exemplo, que essa perspectiva de investigação abranja outras proposições curriculares após a década de 1970, como o GREF. E ainda, que amplie, também, a amostra dos livros didáticos, uma vez que as décadas investigadas acomodam um grande número de produções. 


\section{REFERÊNCIAS}

\section{Geral}

ABRANTES, A. C. S.. Ciência, Educação e Sociedade: o caso do Instituto Brasileiro de Educação, Ciência e Cultura (IBECC). 2008. 287 f. Tese (Doutorado em História das Ciências e da Saúde) - Casa de Oswaldo Cruz/Fiocruz, Rio de Janeiro, 2008.

ABRANTES, A. C. S.; AZEVEDO,N. O Instituto Brasileiro de Educação, Ciência e Cultura e a institucionalização da ciência no Brasil, 1946-1966. Boletim Museu Paraense Emílio Goeldi. Ciências Humanas, vol.5 n.2, Belém, May/Aug. 2010.

ABREU, A. A. A Imprensa e o engajamento político no final do século XX. In: XXIV Encontro Anual da ANPOCS. Petrópolis, 23 a 27 de outubro de 2000. Anais.... Petrópolis, 23 a 27 de outubro de 2000 Disponível em: http://biblioteca.clacso.edu.ar/ar/libros/anpocs00/gt08/00gt0813.doc. Acesso em 12 Fev. 2015.

ALMEIDA FILHO, W. R.. Física, pedagogia e poder: uma análise histórica dos livros didáticos de Física (1940-1980). 1992. 116f. Dissertação (Mestrado em Educação) UFBA Faculdade de Educação, Salvador.

ALMEIDA JUNIOR, J. B. A evolução do ensino de Física no Brasil. Revista de Ensino de Física, São Paulo, v.1, n.2, p. 45-58, out.1979.

ALMEIDA JUNIOR, J. B. A evolução do ensino de Física no Brasil. Revista de Ensino de Física, São Paulo, v.2, n.1, p. 55-73, fev.1980.

ÁLVARES ALVARENGA, B. . Livro didático - Análise e seleção. In: MOREIRA, M. A.; AXT, Rolando. (org). Tópicos em ensino de ciências. Porto Alegre: Sagra, 1991.

ALVES, M. L.. Considerações sobre a influência de Skinner na educação brasileira. In: SMITH, Louis M. Frederic Skinner. (org.) Maria Leila Alves - Coleção Educadores. Fundação Joaquim Nabuco. Recife: Editora Massangana, 2010.

AMARAL, I. A. Conhecimento formal, experimental e estudo ambiental. Ciência \& Ensino, Campinas, n. 3, dez. 1997.

AMARAL, I. A. Ensino de geologia introdutória: raízes e desdobramentos da mudança curricular em 1973 na USP. Terræ Didática, 10-3, p. 161-170, 2014.

AMBRÓZIO, M. L.. Outra óptica para o ensino de óptica. São Paulo, 1990. 2v.,506p. Dissertação (Mestrado em Ensino de Física) Universidade de São Paulo - Instituto de Física e Faculdade de Educação, São Paulo.

AMERICAN ASSOCIATION OF PHYSICS TEACHERS. Improve the quality and effectiveness of introductory courses in physics - Report of a Conference Sponsored by the American Association of Physics Teachers (Received July 10, 1957). American Journal of Physics, Vol. 25 (7) - Oct 1, 1957.

APPLE, M. W. Conhecimento Oficial: A Educação Democrática Numa Era Conservadora. Tradução de Maria Isabel Edelweis Bujes. Petrópolis,RJ: Vozes, 1997.

APPLE, M. W. Ideologia e Currículo. Tradução de Vinicius Figueira. $3^{\mathrm{a}}$ ed. Porto Alegre: Artmed, 2006.

ARANHA, M. L. A. História da educação. São Paulo: Moderna, 1989.

ARANHA, M. L. A. Filosofia da educação. 2. ed. São Paulo: Moderna, 1996. 
AZEVEDO, F. [et al.]. Manifestos dos pioneiros da Educação Nova (1932) e dos educadores (1959). Recife: Fundação Joaquim Nabuco, Editora Massangana, 2010.

BACHELARD, G.. La formation de l'ésprit scientifique.Paris: J.Vrin, 1947. Tradução por Estela dos Santos Abreu. A formação do espírito científico. Rio de Janeiro: Contraponto, 1996.

BANDEIRA FILHO, F.. Exercícios resolvidos nos livros didáticos de Física do Ensino Médio: sua utilização como recurso pedagógico. 2010. Dissertação (Mestrado em Ensino de Ciências e Matemática) - Pontifícia Universidade Católica de Minas Gerais, Belo Horizonte.

BARDIN, Laurence. Análise de conteúdo. Lisboa: Ed. 70, 2009.

BARRA, V. M.; LORENZ, K. M. Produção de materiais didáticos de ciências no Brasil: período: 1950 a 1980. Ciência e Cultura, v. 38, n. 12, p. 1970-1983, dez. 1986.

BENETI, A.C. A História do Ensino de Física no Brasil no Século Xix: As Academias Militares e o Colégio Pedro II. 2014. 153f. Tese (Doutorado em Educação para a Ciência) UNESP, Faculdade de Ciências, Bauru, 2014.

BITTENCOURT, C.M.F.. Disciplinas escolares: história e pesquisa. In: OLIVEIRA, M.A.T.; RANZI, S.M.F..(Org.) História das disciplinas escolares no Brasil: contribuição para o debate. Bragança Paulista: EDUSF, 2003, p.09-38.

BITTENCOURT, D. R. S.. Uma análise do Projeto de Ensino de Física - Mecânica. 1977. 151p. Dissertação (Mestrado) - Universidade de São Paulo - Instituto de Física e Faculdade de Educação, São Paulo.

BOCASANTA, D. M.. Dispositivo da tecnocientificidade: a iniciação científica ao alcance de todos. 2013. 233f. Tese (Doutorado). Unidade de Pesquisa e Pós-graduação, Universidade do Vale do Rio dos Sinos - UNISINOS, São Leopoldo.

BONETTI, M. C.. As imagens em movimento e sua contribuição para o ensino das ciências físicas no Brasil - 1800-1960. 2013. 172f. Tese (Doutorado)- Universidade de São Paulo. Programa de Pós-Graduação Interunidades em Ensino de Ciências, São Paulo.

BORGES, R. M. R; IMHOFF, A. L.; BARCELlOS, G. B. (Orgs.). Educação e Cultura Científica e Tecnológica: centros e museus de ciências no Brasil. Porto Alegre: EDIPUCRS, 2012.

BRAGA, M.; GERRA, A. ; REIS, J. C. Breve História das Ciências Moderna, Vol. 2: das maquinas do mundo ao universo-máquina (séc. XV a XVII). Rio de Janeiro: Jorge Zahar editor, 2004.

BRANDÃO, C. R.. Paulo Freire, educar para transformar: fotobiografia. São Paulo: Mercado Cultural, 2005.

BRASIL, SEMTEC. PCN+ Ensino Médio: orientações educacionais complementares aos Parâmetros Curriculares Nacionais. Brasília: MEC, SEMTEC, 2002.

BRASIL. Ministério da Educação. Programa Nacional do Livro Didático - Histórico. 2015. Disponível em: http://www.fnde.gov.br/programas/livro-didatico/livro-didaticohistorico. Acesso em 20 fev. 2015.

BRUNER, J.. O Processo da Educação. São Paulo: Companhia Editora Nacional, 1978.

CAJU, V. .. Análise da disciplina sociologia na educação profissional: Reflexões a partir de um estudo de caso. 2005. Dissertação de Mestrado. Rio de Janeiro: Universidade Federal do Rio de Janeiro, 2005. 
CANIATO, R. Um Projeto Brasileiro para o Ensino de Física. 1973. 4v. 586f. Tese (Doutorado) - Faculdade de Filosofia, Ciências e Letras de Rio Claro, UNESP, Rio Claro.

CANIATO, R.. Projeto Brasileiro para o Ensino de Física - O céu - Vol. I. Campinas: Fundação Tropical de Pesquisas e Tecnologia, 1978.

CANIATO, R.. Mecânica - Projeto Brasileiro para o Ensino de Física - Vol. II. Campinas: Fundação Tropical de Pesquisas e Tecnologia, 1979.

CAPANEMA, G.. Exposição de motivos. Decreto-Lei $\mathbf{n}^{\mathbf{0}}$ 4.244, de 9 de abril de 1942. Disponível em: http://www2.camara.leg.br/legin/fed/declei/1940-1949/decreto-lei-4244-9abril-1942-414155-133712-pe.html. Acesso em 20 Jan. 2015.

CARVALHO, A.M.P. O ensino de Física na Grande São Paulo: Estudo sobre um processo de transformação. 1972. 173p. Tese (Doutorado) - Universidade de São Paulo: Faculdade de Educação, São Paulo.

CHASSOT, A. O Ensino de ciências no começo da segunda metade do século da tecnologia. In: O currículo de ciências em debate. Campinas, SP: Papirus, 2004.

CHERVEL, A. História das disciplinas escolares: reflexões sobre um campo de pesquisa. Teoria e Educação, Porto Alegre, v. 2, p. 177-229, 1990.

CHIQUETTO, M. J. O currículo de Física do ensino médio no Brasil: discussão retrospectiva. Revista e-curriculum, São Paulo, v.7 n.1 Abril/2011.

CHIQUETTO, M. J.; KRAPAS, S. Livros didáticos baseados em apostilas: como surgiram e por que foram amplamente adotados. Revista Brasileira de Pesquisa em Educação em Ciências, v. 12, n.3, p. 173-191, 2012.

CHOPPIN, A.. História dos livros e das edições didáticas: sobre o estado da arte. Educação e Pesquisa, São Paulo, v. 30, n. 3, p. 549-566, set./dez. 2004.

CUNHA, L. A.. O ensino profissional na irradiação do industrialismo. 2. ed. São Paulo: Editora UNESP; Brasília, DF: FLACSO, 2005.

CUNHA, N.; ABREU, J.. Currículo ginasial secundário no Brasil, depois da Lei de Diretrizes e Bases. Revista Brasileira de Estudos Pedagógicos, Rio de Janeiro, v.44, n.100, p.295-309, out./dez. 1965.

CURY, C. R. J... A educação básica como direito. Cadernos de Pesquisa, v. 38, n. 134, p. 293-303, maio/ago, 2008.

CURY, C. R. J.. et al.. A profissionalização do ensino na Lei $n^{\circ}$ 5.692/71. Trabalho apresentado pelo INEP à XVIII Reunião Conjunta do Conselho Federal de Educação com os Conselhos Estaduais de Educação. Brasília, 1982. Anais... Brasília, 1982, 76p.

CURY, C. R. J.. Alguns apontamentos em torno da expansão e qualidade do ensino médio no Brasil. In: Brasil. Ministério da Educação. Secretaria de Educação Básica. Ensino Médio como educação básica. São Paulo: Cortez; Brasília: SENEB, 4, 1991.

DEL CARLO, S.. Duas propostas de ensino de segundo grau e suas formas de compreender a eletricidade. Dissertação (Mestrado em Ensino de Física) Universidade de São Paulo -São Paulo, 1997.

DELGADO, M. P.. Música e Política no Brasil, de Zelão ao Divino, Maravilhoso (19601968). CES Revista, v. 25, Juiz de Fora, 2011, p. 127- 145.

DELIZOICOV, D.; ANGOTTI, José André; Pernambuco, MARTA. M. Ensino de Ciências: fundamentos e métodos. São Paulo: Cortez, 2007. 
DIB, C. Z.. Schenberg e a pesquisa educacional em Física. Sociedade Brasileira de Física, São Paulo, Boletim Informativo nº1, Ano 22, Junho 1991, p. 1- 8.

DIB, C. Z.. Tecnologia da Educação e a aprendizagem de Física. 1972. 241p. Tese (Doutorado) - Universidade São Paulo - Instituto de Física, São Paulo.

FARIA, L.; LOBO, Y.. Identidade e Campo de Produção: laboratório de currículos da Secretaria de Estado de Educação e Cultura do Rio de Janeiro (1975-79). In: VII Congresso Ibero-Americano de História de la Educácion Latinoamericana. Universidad Andina Simón Bolívar: Quito, Equador, 2005. Anais... Universidad Andina Simón Bolívar: Quito, Equador, 2005.

FAZENDA, I. C. A.. Educação no Brasil anos 60. O pacto do silêncio. São Paulo: Loyola, 1985.

FERRETI, C. J.. A inovação na perspectiva pedagógica. In: GARCIA, Walter. (Coord.) Inovação educacional no Brasil: problemas e perspectivas. São Paulo: Cortez/Autores Associados, 1980.

FERRARI, M. B. F. Skinner, o cientista do comportamento e do aprendizado. Revista Nova Escola. Disponível em: http://revistaescola.abril.com.br/formacao/skinner428143.shtml?page=3. Acesso em 04 Jun. 2015.

FIOD, E. G.M.. Ensino de $2^{\circ}$ grau, hoje: a reafirmação do óbvio. Perspectiva; r. CED, Florianópolis, 1(1), 99.103 Ago./dez. 1983.

FLORES, I. E. Livros didáticos de física nas primeiras décadas do século XX: estudo preliminar sobre concepções de ciência e ensino. 2010. 59 f. Dissertação (Mestrado em História da Ciência) - Pontifícia Universidade Católica de São Paulo, São Paulo.

FONTE BOA, M. C.. Examinando os saberes da experiência: um estudo de caso no ensino de Física de nível médio. 2008. 93 f. Dissertação (Mestrado) - Universidade Federal Fluminense, Faculdade de Educação, Niterói-RJ.

FONTOURA, A.. A reforma do ensino. Rio de Janeiro: Ed. Aurora, [1979?]

FRACALANZA, H. Livros Didáticos X Projetos de Ensino. In: FRACALANZA, H. e NETO, J. M. (Org.). O livro didático de ciências no Brasil. Campinas: Editora Komedi, 2006.

FRACALANZA, H. e NETO, J. M. (Org.). O livro didático de ciências no Brasil. Campinas: Editora Komedi, 2006.

FRACALANZA, H; AMARAL, LA.; GOUVEIA, M.S.F. O ensino de ciências no primeiro grau. São Paulo: Atual, 1987. (Projeto Magistério)

FREIRE, P. R.. Pedagogia da autonomia: saberes necessários à prática educativa. São Paulo: Paz e Terra, 1996.

FREIRE, P. R.. Pedagogia do oprimido. 44. ed. Rio de Janeiro: Paz e Terra, 2005.

FUNBEC. Projeto Brasileiro de Física - Eletricidade (unidade do PBEF). São Paulo: Edart, 1973.

GALVÃO, P.. A ciência na educação segundo John Dewey. Philosophica 12, Lisboa, 1998, pp 129-144. Disponível em: http://www.centrodefilosofia.com/uploads/pdfs/philosophica/12/8.pdf. Acesso em 22 out. 2015.

GARCIA, N.M.D. Ensinando a ensinar física: um projeto desenvolvido no Brasil nos anos 1970. In: IV Congresso Brasileiro de História da Educação. Goiás, 2006. Disponível em: <http://www.sbhe.org.br/novo/congressos/cbhe4/index.htm> acesso 25 de fev. de 2015. 
GARCIA, N.M.D.; GARCIA, T.M.F.B.; HIGA, I. O Projeto de Ensino de Física (PEF): um modo brasileiro de ensinar Física da década de 1970. In: Simpósio Nacional de Ensino de Física, 17, São Luis, MA, 2007.

GARCIA, R. L.; AZEVEDO, J. G. A orientação educacional e o currículo. Caderno de Pesquisa, São Paulo (48), 29-37, fev. 1984.

GASPAR, A. Cinquenta anos de ensino de Física: muitos equívocos, alguns acertos e a necessidade recolocar o professor no centro do processo educacional. EDUCAÇÃ̃o, ano13, n.21, dez. 2004.

GASPAR, A.. Uma nova proposta curricular de física para o ensino de segundo grau. 1982. 199p. Dissertação (Mestrado) - Universidade de São Paulo - Instituto de Física e Faculdade de Educação, São Paulo.

GATTI, B. A; BARRETTO, E. S. de S. Professores do Brasil: impasses e desafios. Brasília: UNESCO, $2009 . \quad$ Disponível em: <http://unesdoc.unesco.org/images/0018/001846/184682por.pdf>. Acesso em 20 Dez. 2014.

GOODSON, I.. Currículo: teoria e história. Petrópolis: Vozes, 1995.

GOODSON, I.. A construção social do currículo. Lisboa: Educa, 1997.

HABER-SCHAIM, U.. PSSC PHYSICS: A Personal Perspective. PSSC 50 Years Later. American Association of Physics Teachers. Disponível em: http://www.compadre.org/portal/pssc/docs/Haber-Schaim.pdf. Acesso em 12 jul. 2015.

HAIDAR, M. L. M.. O ensino secundário no Brasil Império. 2. Ed. São Paulo: Edusp, 2008.

HÖFLING, E. M.. A trajetória do Programa Nacional do Livro Didático do Ministério da Educação no Brasil. In: FRACALANZA, Hilário; MEGID NETO, Jorge. (Org.). O Livro Didático de Ciências no Brasil. Campinas: Editora Komedi, 2006, p. 19-31.

HOSOUME, Y. ; MARTINS, Maria Inês; NICIOLI Jr., Roberto Bovo. Livros didáticos de Física (1940 a 1990): seus autores e editoras. In: XVII Simpósio Nacional de Ensino de Física, 2007, São Luis. Anais... São 2007. http:/www.sbf1.sbfisica.org.br/eventos/snef/xvii/. São Paulo : Sociedade Brasileira de Física, 2007. p. 1-10.

HOSOUME, Y. et al.. Um panorama das pesquisas em livros didáticos de Física a partir dos resumos de teses e dissertações. In: XII Encontro de Pesquisa em Ensino de Física, 2011 Foz do Iguaçu. Anais... Foz do Iguaçu, Jun. 2011.

KISHIMOTO, T. M.. Apresentação: cultura como meta John Dewey. Pro-Posições, v.22, n.2, p.209-213, 2011. Disponível em: http://www.producao.usp.br/bitstream/handle/BDPI/6456/art_KISHIMOTO_Apresentacao_c ultura_como_meta_John_Dewey_2011.pdf?sequence=1\&isAllowed=y. Acesso em 09 set. 2015.

KRAFZIK, M. L. A.. Acordo MEC/ USAID - A Comissão do Livro Técnico e do Livro Didático - COLTED (1966/1971). 2008. Dissertação (Mestrado em Educação) Universidade Estadual do Rio de Janeiro (UERJ), Rio de Janeiro.

KRASILCHIK, M. O professor e o currículo das ciências. São Paulo, EPU: EDUSP, 1987.

KRASILCHIK, M. Reformas e realidade: o caso do ensino de Ciências. São Paulo em Perspectiva. vol. 14 n. 1. São Paulo Jan./Mar. 2000, p. 85-93. 
KRASILCHIK, M. Inovação no ensino das ciências. In: GARCIA, Walter. (Coord.) Inovação educacional no Brasil: problemas e perspectivas. São Paulo: Cortez/Autores Associados, 1980.

KUHN, T. S. A estrutura das revoluções científicas. 5a ed. Tradução: Beatriz Vianna Boeira e Nelson Boeira. Coleção Debates. São Paulo: Editora Perspectiva S. A., 1998.

LOPES, J.. Jean Piaget. Nova Escola. a. XI, n. 95, ago. 1996.

LORENZ, K. M. Ação de instituições estrangeiras e nacionais no desenvolvimento de materiais didáticos de ciências no Brasil: 1960-1980. Revista Educação em Questão, Natal, v. 31, n. 17, p. 7-23, jan./abr. 2008.

LORENZ, K. M.; VECHIA, A. Estudo sumário das ciências no currículo da escola secundária brasileira: 1838-1971. V Reunião da Sociedade Brasileira de Pesquisa Histórica (SBPH),1986, São Paulo. Anais... São Paulo, 1986.

LYRA, M. A. F. M.. Analise do Uso de um texto Didático Sobre o Conceito de Calor numa Abordagem Kellyana. 2006. Dissertação (Mestrado em Ensino das Ciências) Universidade Federal Rural de Pernambuco, Pernambuco.

MAIA, L. P. M. Guia Metodológico para cadernos MEC - Física. Rio de Janeiro: FENAME, 1973.

MARQUES, G. C. (org). IFUSP: passado, presente e futuro. São Paulo: Editora Livraria da Física, 2005.

MARTINS, M. I. ; HOSOUME, Y. . Livros didáticos de Física no Brasil: editoras, autores e conteúdos disciplinares - da Reforma Capanema à LDB de 1996. In: Simpósio Internacional Livro didático: Educação e História, 2007, São Paulo. Anais... São Paulo: Faculdade de Educação da USP, 2007. v. 1. p. 1106-1123.

MARTINS, V. R.. O ensino de física moderna nos livros didáticos do início do século XX. São Paulo, 2014. 90f. Dissertação (Mestrado) - Universidade de São Paulo - Faculdade de Educação, Instituto de Física, Instituto de Química e Instituto de Biociências, São Paulo.

MATTHEWS, M. R.. História, filosofia e ensino de Ciências: a tendência atual de reaproximação. Caderno Catarinense de Ensino de Física, v. 12, n. 3, p. 164-214, dez. 1995.

MATUCHESKI, S. Elaboração das propostas curriculares de matemática do Ensino de $1^{\circ}$ Grau ( $5^{\mathrm{a}}$ a $8^{\mathrm{a}}$ série) do Estado do Paraná na década de 1970. Dissertação (Mestrado em Educação em Ciências e em Matemática), Universidade Federal do Paraná, Curitiba, 2011.

MEGID NETO, J.; PACHECO D. Pesquisas sobre o ensino de Física do $2^{\circ}$ grau no Brasil: concepção e tratamento de problemas em teses e dissertações. In: NARDI, R. (Org.). Pesquisas em Ensino de Física. São Paulo: Editora Escrituras, 1998. cap. 1, p. 5-20.

MEGID NETO, J. (Coord.) O ensino de ciências no Brasil: catálogo analítico de teses e dissertações 1972-1995. Faculdade de Educação, FORMAR-Ciências/CEDOC. Campinas, 1998. 220p. Disponível em: https://www.fe.unicamp.br/cedoc1/catalogoparadownload.html. Acesso em 15 jan. 2015.

MINAS GERAIS (Estado). Secretaria de Estado da Educação. Programa de Ensino de 1. ${ }^{\circ}$ Grau - Ciências- 2. ${ }^{\circ}$ Volume. Belo Horizonte: Imprensa Oficial, 1973.

MINAS GERAIS (Estado). Secretaria de Estado da Educação. Manual de orientação currículo de $1^{\circ}$ grau - Ciências Físicas e biológicas: primeira a oitava série. Belo Horizonte: Imprensa Oficial, 1976. 
MOREIRA, A. F. B.. Currículo: Questões Atuais. 14ª ed. Campinas: Papirus, 1997. (Série Magistério Formação e Trabalho Pedagógico).

MOREIRA, A. F. B.. Currículos e programas no Brasil. Campinas: Papirus, 2001.

MOURA, D. G.. Reflexão sobre o currículo de física na escola secundária do Brasil: subsídios para planejamento de currículo. 1985. 140f. Dissertação (Mestrado) - Universidade de São Paulo - Instituto de Física e Faculdade de Educação, São Paulo.

NAGLE, J. A reforma e o ensino, São Paulo, EDART, 1973.

NAPOLITANO, M.. A arte engajada e seus públicos (1955/1968). Estudos Históricos, Rio de Janeiro, $\mathrm{n}^{\circ}$ 28, 2001, p. 103-124.

NARDI, R. (Org.) Pesquisa em ensino de Física. São Paulo: Escrituras, 1998.

NARDI, R.. Memórias da Educação em Ciências no Brasil: a pesquisa em ensino de Física. Investigação em Ensino de Ciências - V10(1), PP. 63-101, 2005.

NASCIMENTO, T. R. A criação das Licenciaturas Curtas no Brasil. Revista HISTEDBR On-Line, v. 12, n. 45, 2012.

NASSIF, L. A. L.. O conceito de ciência veiculado por materiais didáticos: uma análise do curso de física do PSSC. 1976. 156f. Dissertação (Mestrado) - Pontifícia Universidade Católica de São Paulo, São Paulo.

NICIOLI JUNIOR, R. B. O conteúdo de cinemática nos livros didáticos de 1810 a 1930. 2007. 170 f. Dissertação (Mestrado em Ensino de Física) - Universidade de São Paulo, São Paulo.

NICIOLI JUNIOR, R. B.; MATTOS, C. R. Uma análise de livros didáticos de Física das décadas de 50 e 60. In: X Encontro de Pesquisa em Ensino de Física, 2006. Caderno de resumos. Londrina. SBF: São Paulo, 2006.

NOGUEIRA, M. A. A Sociologia da educação do final dos anos 60/ início dos anos 70: o nascimento do paradigma da reprodução. Em aberto. Brasília, ano 9, n 46, abr.-jun.1990.

NUFFIELD FOUNDATION. Nuffield Physics 1962 [histórico]. 2015. Disponível em: http://www.nuffieldfoundation.org/nuffield-physics-1962. Acesso em 20 Jan. 2015.

NUNES, M. T.. Ensino secundário e sociedade brasileira. Rio de Janeiro: Instituto Superior de Estudos Brasileiros, 1962.

OLIVEIRA, B. J.; FREIRE Jr., Olival. Uma conversa com Gerald Holton. Caderno Brasileiro de Ensino de Física, v. 23, n. 3: p. 315-328, dez. 2006.

PACCA, J. L. A.. Análise do desempenho de alunos frente a objetivos do PEF. 1976. 124p. Dissertação (Mestrado) - Universidade de São Paulo - Instituto de Física e Faculdade de Educação, São Paulo.

PARANÁ (Estado). Secretaria de Educação e Cultura. Currículos do Ensino Médio Fixados pela S.E.C. para os estabelecimentos estaduais de ensino médio no ano letivo de 1962. Curitiba: 1962.

PARANÁ (Estado). Ciências e Matemática. Currículo. Curitiba, PR, ano 2, n. 15, 1975.

PENA, F. L. A.. Sobre a presença do Projeto Harvard no sistema educacional brasileiro.

Revista Brasileira de Ensino de Física, v. 34, n. 1, 1701,2012. 
PERINI, L.; FERREIRA, G. K.; CLEMENTE, L.; Projeto de Ensino PSSC: uma análise dos exercícios/problemas. In: XVIII Simpósio Nacional de Ensino de Física (SNEF), 2009, Vitória. Anais... Vitória, ES, 2009.

PEREIRA, J. A. Uma reelaboração de conteúdo de Física do Segundo Grau: a eletricidade como exemplo. 1995. Dissertação (Mestrado) Universidade de São Paulo Instituto de Física/Faculdade de Educação, São Paulo.

PIASSI, L. P. C.. Que Física ensinar no segundo grau? Elementos para uma reelaboração de conteúdo. 1995. 208p. Dissertação (Mestrado). Universidade de São Paulo - Instituto de Física/Faculdade de Educação, São Paulo.

PILETTI, N.. Ensino de $2^{\circ}$ grau. Educação geral ou profissionalização. SÃO PAULO: EPU, 1988.

PIMENTA, S. G.; GONÇALVES, C. L. Revendo o ensino de $\mathbf{2}^{\circ}$ grau, propondo a formação do professor. São Paulo: Cortez, 1990.

PINHO, A. BRASIL. CFE. Parecer no 931, de 12 de novembro de 1965. Inquérito sobre o ensino de ciências nos estabelecimentos de grau médio. Documenta, Rio de Janeiro, Conselho Federal de Educação, n. 43, novembro/1965. p. 85-103. 1965 b.

PINHO-ALVES, J. Atividades Experimentais: do método à prática construtivista. 2000. 302 f. Tese (Doutorado) - Universidade Federal de Santa Catarina, Santa Catarina.

POPPER, Karl. A lógica da pesquisa científica. Tradução de Leônidas Hegenberg e Octanny Silveira da Mota. São Paulo: Editora Cultrix, 1975.

PROJETO PILOTO DE FÍSICA DA UNESCO - IBECC. Física da luz, São Paulo, 1964.

RIBEIRO, M. W.. História da disciplina escolar de geografia em Curitiba de 1964 a 1985: percursos, desafios e representações de professores. 2014. 301f. Tese (Doutorado) - Pontifícia Universidade Católica do Paraná. Programa de Pós-graduação em Educação, Curitiba.

RIO DE JANEIRO (Estado). Secretaria de Educação e Cultura. Reformulação de Currículos - Síntese. Rio de Janeiro, Laboratório de Currículos, 1976.

RIO DE JANEIRO (Estado). Secretaria de Educação e Cultura. Reformulação de currículos. v. 2, 2 Grau. Rio de Janeiro, Laboratório de Currículos, 1978.

RIVAS, C. N.. Piaget e uma proposta metodológica em educação. Arq. bras. Psic. apl., Rio de Janeiro, 29 (2): 43-57, abr./jun. 1977.

RODRIGUES, M. A.. Brincando de ser cientista: Uma forma lúdica de vivenciar o método científico. Lat. Am. J. Phys. Educ. Vol. 7, No. 1, March 2013.

RODRIGUES, I. G.; HAMBURGER, E. W. O "Grupo de Ensino" do IFUSP: histórico e atividades. Instituto de Física. Universidade de São Paulo. Publicações. IFUSP/P-1035, Março/1993.

ROMANElli, Otaíza de Oliveira. História da Educação no Brasil: 1930/1973 $7^{\text {a }}$ ed. Petrópolis: Vozes, 1985.

RONCA, A. C. C. Teorias de ensino: a contribuição de David Ausubel. Temas em Psicologia, 3, p.91-95, 1994.

ROSA, C. W.; ROSA, Á. B.. O ensino de ciências (Física) no Brasil: da história às novas orientações educacionais. Revista Iberoameriacana de Educacion, n. ${ }^{\circ}$ 58/2, 15/ fev. 2012. 
SAAD, F. D.. Análise do projeto FAI: uma proposta de um curso de Física Auto-Instrutivo para o $2^{\circ}$ grau. 1977. 146p. Dissertação (Mestrado) - Universidade de São Paulo - Instituto de Física e Faculdade de Educação, São Paulo.

SAAD, F. D.. Repensando o ensino de Física e seus problemas: sua instrumentação e sua tecnologia da educação. 1990. 156 p. Tese (Livre-Docência) - Universidade de São Paulo Instituto de Física, São Paulo.

SABADIN, Celso. Francisco Ramalho Jr. Éramos Apenas Paulistas. Coleção Aplauso. São Paulo: Imprensa Oficial, 2009.

SACRISTÁN, J. G.; PÉREZ GÓMEZ, A. I. Compreender e Transformar o ensino. 4.ed. Porto Alegre: Artmed, 1998.

SACRISTÁN, G.. O Currículo, uma reflexão sobre a prática. Porto Alegre: Editora Artmed, 2000.

SAMPAIO, G. M. D'Elia. A história do ensino de Física no Colégio Pedro II de 1838 até 1925. 2004. 161p. Dissertação (Mestrado). Universidade Federal do Rio de Janeiro, Rio de Janeiro, 2004.

SANTA CATARINA (Estado). Proposta Curricular: uma contribuição para a escola pública do Pré-Escolar, $1^{\circ}$ Grau, $2^{\circ}$ Grau e educação de adultos. Florianópolis, SC: IOESC 1991.

SANTOS, Z. T. S.. Ensino de Entropia: um enfoque histórico e epistemológico. 2010. 166

f. Tese (Doutorado em Educação) - Universidade Federal do Rio Grande do Norte, Natal.

SÃO PAULO, C. Uma perspectiva sócio-histórica do conteúdo de Física Moderna nos Livros didáticos para O Ensino Médio no Brasil 1950 -2000. 2004. 240f. Dissertação (Mestrado em Ensino, Filosofia e História das Ciências) - Universidade Federal da Bahia, Universidade Estadual de Feira de Santana, Salvador, Feira de Santana.

SÁTIRO, M. S. W.. "Reaquecendo" o ensino de Física Térmica. 1989. Dissertação (Mestrado em Ensino de Física). 1989. Universidade de São Paulo - Instituto de Física/Faculdade de Educação, São Paulo.

SAVIANI, D.. O Congresso Nacional e a educação brasileira: significado politico da ação do Congresso Nacional no processo de elaboração das leis n. 4024/61, 5540/68 e 5692/71. Tese (Livre-Docente em Educação). 1986. Universidade Estadual de Campinas (UNICAMP).

SAVIANI, D.. As concepções pedagógicas na história da educação brasileira. Texto elaborado no âmbito do projeto de pesquisa "O espaço acadêmico da pedagogia no Brasil", para o "projeto 20 anos do Histedbr". Campinas, 25 de agosto de 2005. Disponível em: http://www.histedbr.fe.unicamp.br/navegando/artigos_pdf/Dermeval_Saviani_artigo.pdf.

Acesso em 10 Abr. 2015.

SAVIANI, D.. História das Ideias Pedagógicas no Brasil. 2. ed. Campinas: Autores Associados, 2008.

SAVIANI, D.. Escola e Democracia- Edição comemorativa. Campinas: Cortez \& Autores Associados, 2008b.

SHERMAN, J. E. The Relative Effectiveness of Two Methods of Utilizing Laboratory-Type Activities in Teaching Introductory Physical Science. Technical Report $\mathbf{n}^{\mathbf{0}} \mathbf{6 5}$. Wisconsin Research and Development Center for Cognitive Learning The University of Wisconsin, Wisconsin/Madison: November, $1968 . \quad$ Disponível em: http://files.eric.ed.gov/fulltext/ED065361.pdf. Acesso em 20 Fev. 2015. 
SILVA, Arnaldo de Moura Vaz. Estrutura e função do laboratório. 1989. 190p. Dissertação (Mestrado). Universidade de São Paulo - Instituto de Física e Faculdade de Educação, 1989.

SKINNER, B.F. Tecnologia do ensino. São Paulo: Ed. da Universidade de São Paulo, 1972. (Coleção Ciências do Comportamento).

SOUZA, R. A. S.; MARTINELLI, T. A. P.. Considerações históricas sobre a influência de John Dewey no pensamento pedagógico brasileiro. Revista HISTEDBR On-line, Campinas, n.35, p. 160-162, set.2009.

SOUZA, R. F.. História da organização do trabalho escolar e do currículo no Século XX: ensino primário e secundário no Brasil. São Paulo, SP: Cortez, 2008.

TAGLIEBER, J. E. O Ensino de Ciências nas Escolas Brasileiras. Perspectiva; r. CED. Florianópolis. 1(3), 91-111. Jul./Dez. 1984.

TAVARES, L. A.. A imagem impressa e ciência: ilustrações em livros didáticos de Física (séculos XIX e XX). 2005. Dissertação (Mestrado História da Ciência) - Pontifícia Universidade Católica de São Paulo, São Paulo.

TENÓRIO, N. C.. Curricularização da Moral e do Civismo no Ensino Médio no Estado do Paraná 1961-1971. Dissertação (Mestrado) - Universidade Federal de Mato Grosso do Sul , Programa de Pós-Graduação em Educação. Campo Grande, MS. UFMS, 2009. 161f.

TERRAZZAN, E. A. Perspectivas para a Inserção da Física Moderna na Escola Média. 1994. 241f. Tese (Doutorado em Educação). Universidade de São Paulo - Faculdade de Educação, São Paulo.

TOSCANO, C.. Acendendo algumas "luzes" e tomando uns "choques": a proposta para o ensino do eletromagnetismo do GREF numa perspectiva de formação continuada de professores. 1991. 263p. Universidade Federal de São Carlos - Centro de Educação e Ciências Humanas,São Carlos.

TURA, Maria de Lourdes Rangel. Conhecimentos escolares e a circularidade entre culturas. In: LOPES, Alice Cassimiro; MACEDO, Elizabeth (Org.). Currículo: debates contemporâneos. São Paulo: Cortez, 2002. Cap. 7. p. 150-173. (Cultura memória e currículo, v. 2).

UNIVERSIDADE DE SÃO PAUlO. Instituto de Física. Ensino de Física no Brasil: catálogo analítico de dissertações e teses (1972-1992). Vol. 1. São Paulo : [s.n.], 1992. 110p.

UNIVERSIDADE DE SÃO PAULO. Instituto de Física. Ensino de Física no Brasil: catálogo analítico de dissertações e teses (1992-1995). Vol. 2. São Paulo: [s.n.], 1996. 67p.

UNIVERSIDADE DE SÃO PAULO. Instituto de Física. Ensino de Física no Brasil: catálogo analítico de dissertações e teses (1996-2006). Vol. 3. São Paulo: Instituto de Física da USP / PROFIS, 2009. 243p.

UNIVERSIDADE DE SÃO PAULO - [INTERUNIDADES] mestrado e doutorado em ensino de ciências. PROFIS (Espaço de Apoio, Pesquisa e Cooperação de Professores de Física), 2015. Disponível em: http://fep.if.usp.br/ profis/pos_ensino.html. Acesso em 04 Mar. 2015.

VECHIA, A.; LORENZ, K. M. Programa de ensino da escola secundária brasileira: 1850-1951. Curitiba: Ed. do Autor, 1998.

VILLANI A.; PACCA Jesuina Lopes de Almeida. Construtivismo, conhecimento científico e habilidade didática no ensino de ciências. Revista da Faculdade de Educação, vol. 23, n. 1- 
2, São

Paulo, Jan./Dec. 1997.

Disponível

em: http://www.scielo.br/scielo.php?script=sci_arttext\&pid=S0102-25551997000100011. Acesso em 20 Dez. 2014.

VIOLIN, A. G.. O Projeto de Ensino de Física (PEF): Mecânica 1 em um curso programado individualizado. 1976. 97p. Dissertação (Mestrado) - Universidade de São Paulo - Instituto de Física e Faculdade de Educação, São Paulo.

WUO, W.. A Física e os livros: uma análise do saber em Física nos livros didáticos adotados para o ensino médio. São Paulo: EDUC/FAPESP, 2000.

ZAPPA, R.; SOTO, E.. 1953-1968: eles só queriam mudar o mundo. Rio de Janeiro: Jorge Zahar Ed., 2008.

ZOTTI, S. A. Sociedade, educação e currículo: dos Jesuítas aos anos de 1980. Campinas, SP; Autores Associados; Brasília, DF: Editora Plano, 2004.

\section{Legislação Consultada}

BRASIL. Governo Provisório da República dos Estados Unidos do Brasil. Decreto ${ }^{\circ}$ 19.890, de 18 de abril de 1931. Dispõe sobre a organização do ensino secundário. Rio de Janeiro, Diário Official - 1.5.1931, Página 6945 (Publicação Original). Disponível em: http://www2.camara.leg.br/legin/fed/decret/1930-1939/decreto-19890-18-abril-1931-504631publicacaooriginal-141245-pe.html. Acesso em 10 ago. 2014.

BRASIL. Constituição dos Estados Unidos do Brasil, de 10 de novembro de 1937. D.O.U 10.11.1937, republicada em 11.11.1937, republicado 18.11.1937 e republicado 19.11.1937. Disponível em: http://www.planalto.gov.br/ccivil_03/constituicao/constituicao37.htm. Acesso em 20 jan. 2015.

BRASIL, Decreto-Lei n ${ }^{\circ} 1.006$, de 30 de Dezembro de 1938. Estabelece as condições de produção, importação e utilização do livro didático. D.O.U de 05.01.1939, p. 277 (Publicação Original). Disponível em: http://www2.camara.leg.br/legin/fed/declei/19301939/decreto-lei-1006-30-dezembro-1938-350741-publicacaooriginal-1-pe.html. Acesso em 10 out. 2014.

BRASIL. Decreto-Lei no 4.244 - Lei Orgânica do Ensino Secundário. D.O.U - Seção 1 10.04.1942, Página 5798 (Publicação Original). Disponível em: http://www2.camara.leg.br/legin/fed/declei/1940-1949/decreto-lei-4244-9-abril-1942-414155publicacaooriginal-1-pe.html. Acesso em 10 Jan. 2015.

BRASIL. Ministério da Educação e Cultura. Portaria Ministerial $n^{\circ}$ 05, de 2 de Janeiro de 1946. Dispõe sobre a limitação e distribuição do tempo dos trabalhos escolares no ensino secundário, e dá outras providências. Publicada no D.O.U de 10-01-1946. Ensino Secundário no Brasil (Organização, Legislação Vigente, Programas). INEP, Publicação $n^{\circ}$ 67, 1952. 1946 a. (cópia enviada pelo Conselho Nacional de Educação).

BRASIL. Constituição dos Estados Unidos do Brasil, de 18 de setembro de 1946. D.O.U de 19.9.1946, republicado em $\mathbf{2 5 . 9 . 1 9 4 6}$ e $\mathbf{1 5 . 1 0 . 4 6} . \underline{1946 \mathrm{~b}}$. Disponível em: http://www.planalto.gov.br/ccivil_03/constituicao/constituicao46.htm. Acesso em 20 jan. 2015. 
BRASIL. Lei $\mathrm{n}^{\circ}$ 1.076, de 31 março de 1950. Assegura aos estudantes que concluírem curso de primeiro ciclo do ensino comercial, industrial ou agrícola, o direito à matrícula nos cursos clássico e científico e dá outras providências. D.O.U - Seção 1 - 12/4/1950, Página 5425 (Publicação Original). 1950. Disponível em: http://www2.camara.leg.br/legin/fed/lei/1950-1959/lei-1076-31-marco-1950-363480publicacaooriginal-1-pl.html. Acesso em 03 mar. 2015.

BRASIL. Ministério da Educação e Cultura. Portaria Ministerial $n^{\circ}$ 614, de 10 de maio de 1951. Incumbe a Congregação da elaboração dos programas do ensino secundário. Diário Oficial da República dos Estados Unidos do Brasil, de 17 jul. 1951. 1951a.

BRASIL. Ministério da Educação e Cultura. Portaria n ${ }^{\circ}$ 996, de 2 de outubro de 1951. Aprova o Programa de Ensino do Colégio Pedro II de 1951 e dá instruções metodológicas para a execução dos respectivos programas. RBEP, Vol. XVI Outubro-Dezembro, 1951, n. 44, p. 249-273. $1951 \mathrm{~b}$. Disponível em http://www.dominiopublico.gov.br/download/texto/me001654.pdf . Acesso em 25 dez. 2015.

BRASIL. Ministério da Educação e Cultura. Portaria no 1.045, de 14 de dezembro de 1951. Expede os planos de desenvolvimento dos programas mínimos de ensino secundário e respectivas instruções metodológicas. Diário Oficial da República dos Estados Unidos do Brasil, de 22.02.1952. 1951c. Disponível em: http://www.jusbrasil.com.br/diarios/2375333/pg-65-secao-1-diario-oficial-da-uniao-dou-de22-02-1952/pdfView. Acesso em 25 jan. 2015.

BRASIL. Lei $\mathrm{n}^{\circ} 1.821$, de 12 de Março de 1953. Dispõe sobre o regime de equivalência entre diversos cursos de grau médio para efeito de matrícula no ciclo Colegial e nos cursos superiores. Secretaria de Informação Legislativa do Senado Federal. 1953a. Disponível em:

http://legis.senado.gov.br/legislacao/ListaTextoIntegral.action?id=82251\&norma=108803. Acesso em 25 jan. 2015.

BRASIL. Decreto $n^{\circ} 34.330$, de 21 de outubro de 1953. Regulamenta a Lei $n^{\circ} 1.821$, de 12 de março de 1953. Secretaria de Informação Legislativa do Senado Federal. Rio de Janeiro, 21 de outubro de 1953. 1953b. Disponível em: http://legis.senado.gov.br/legislacao/ListaNormas.action?numero=34330\&tipo_norma=DEC

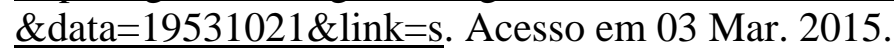

BRASIL. Lei 4.024/61. Fixa as Diretrizes e Bases da Educação Nacional. Diário Oficial da União de 20 de Dezembro de 1961. D.O.U. de 27.12.1961, p. 11.429. 1961a. Disponível em: http://www.planalto.gov.br/ccivil_03/leis/14024.htm. Acesso em 10 de Janeiro de 2015.

BRASIL. Indicação s/n\%/62, de 21 de fevereiro de 1962. Normas para o ensino médio nos termos da Lei 4024/61, MEC/CFE/CEMP. D.O.U. de 24.04.1962. 1962a. Disponível em: http://www.jusbrasil.com.br/diarios/2773094/pg-41-secao-1-diario-oficial-da-uniao-dou-de24-04-1962/pdfView. Acesso em 10 Ago. de 2014.

BRASIL. Comissão de Ensino Primário e Médio. Parecer no 12, de 14 de março de 1962. Sobre a verificação da aprendizagem no ensino secundário. Documenta $n^{0}$ 1, mar./1962. $\underline{1962 b}$ (cópia enviada pelo Conselho Nacional de Educação).

BRASIL. CFE. Parecer no 53, de 11 de maio de 1962, do CFE. Currículo da $3^{\text {a }}$ série colegial. Documenta $\mathbf{n}^{\circ}$ 04, Rio de Janeiro, Jun.1962. 1962c. (cópia enviada pelo Conselho Nacional de Educação). 
BRASIL. CFE. Parecer n ${ }^{\circ} 131$, de 30 de julho de 1962, do CFE. Disciplinas e práticas educativas. Documenta, $\boldsymbol{n}^{\circ}$ 7, Rio de Janeiro, Set.1962. p. 42-43. 1962d (cópia enviada pelo Conselho Nacional de Educação).

BRASIL. Indicação s/n\%/62, s.d. Amplitude e desenvolvimento das matérias obrigatórias, MEC/CFE/CEMP. Documenta no 8, out. 1962 e n 11, jan/fev. 1963. 1962e. Disponível em: http://www.histedbr.fe.unicamp.br/. Acesso em 13 jan. 2015.

BRASIL. Lei $n^{\circ}$ 4.464, de 9 de novembro de 1964. Dispõe sobre os Órgãos de Representação dos estudantes e dá outras providências. D.O.U de 11.11.1964. Disponível em: http://www.planalto.gov.br/ccivil_03/leis/1950-1969/L4464.htm. Acesso em 10 abr. 2015.

BRASIL. CFE. Parecer no 81, de 12 de janeiro de 1965. Dispõe sobre o Currículo mínimo Licenciatura Ciências do $1^{\circ}$ grau. 1965a. Documenta, Rio de Janeiro, Conselho Federal de Educação, n. 34, fevereiro/1965. p. 96-98 (cópia enviada pelo Conselho Nacional de Educação).

BRASIL. CFE. Parecer $\mathrm{n}^{\circ}$ 931, de 12 de novembro de 1965. Inquérito sobre o ensino de ciências nos estabelecimentos de grau médio. Documenta, Rio de Janeiro, Conselho Federal de Educação, n. 43, novembro/1965. p. 85-103. 1965b. (cópia enviada pelo Conselho Nacional de Educação).

BRASIL. Decreto-Lei $\mathbf{n}^{\mathbf{0}}$ 53, de 18 de novembro de 1966. Fixa princípios e normas de organização para as universidades federais e dá outras providencias. Diário Oficial da União Seção 1 - 21/11/1966, Página 13416 (Publicação Original) - Coleção de Leis do Brasil - 1966, p. 99 Vol. 7 (Publicação Original). Disponível em: http://www2.camara.leg.br/legin/fed/declei/1960-1969/decreto-lei-53-18-novembro-1966373396-publicacaooriginal-1-pe.html. Acesso em: 05 mar. 2015.

BRASIL. Decreto-Lei $\mathbf{n}^{\mathbf{0}} \mathbf{2 5 2}$, de 28 de fevereiro de 1967. Estabelece normas complementares ao Decreto-Lei $\mathrm{n}^{\circ}$ 53, de 18 de novembro de 1966, e dá outras providências. Diário Oficial da União - Seção 1 - 28/2/1967, Página 2443 (Publicação Original) - Coleção de Leis do Brasil - 1967, Página 415 Vol. 1 (Publicação Original). Disponível em: http://www2.camara.leg.br/legin/fed/declei/1960-1969/decreto-lei-252-28-fevereiro-1967376151-publicacaooriginal-1-pe.html. Acesso em 14 Fev. 2015.

BRASIL. Lei $\mathrm{n}^{\circ}$ 5.379, de 15 de dezembro de 1967. Provê sôbre a alfabetização funcional e a educação continuada a adolescentes e adultos. D.O.U de 19.12.1967. Disponível em: http://www.planalto.gov.br/ccivil_03/leis/1950-1969/L5379.htm. Acesso em 22 mar. 2015.

BRASIL. Lei no 5.540, de 28 de novembro de 1968. Fixa normas de organização e funcionamento do ensino superior e sua articulação com a escola média, e dá outras providências. D.O.U de 23.11.1968 e retificado no D.O.U de 3.12.1968 Disponível em: http://www.planalto.gov.br/ccivil_03/leis/15540.htm. Acesso em 12 fev. 2015.

BRASIL. Ministério da Educação e Cultura. Diretoria do Ensino Secundário. Consolidação da Legislação do Ensino Secundário, após a Lei de Diretrizes e Base da Educação Nacional. São Paulo: Companhia Editora Nacional, 1969.

BRASIL, Decreto ${ }^{\circ}$ 68.908, de 13 de julho de 1971. Dispõe sôbre Concurso Vestibular para admissão aos cursos superiores de graduação. Publicado no D.O.U. de 14.7.1971. 1971a. Disponível em: http://www.planalto.gov.br/ccivil_03/decreto/1970-1979/D68908.htm. Acesso em 12 dez. 2014.

BRASIL. Lei $\mathrm{n}^{\circ}$ 5.692, de 11 de agosto de 1971. Fixa as diretrizes e bases para o ensino de $1 .^{\circ}$ e 2. ${ }^{\circ}$ graus e dá outras providências. D.O.U de 12.8.1971. $\underline{1971 b}$. Disponível em: 
http://www2.camara.leg.br/legin/fed/lei/1970-1979/lei-5692-11-agosto-1971-357752publicacaooriginal-1-pl.html. Acesso em 20 dez. 2014.

BRASIL. CFE. Parecer no 853, de 12 de novembro de 1971, do CFE. Núcleo-comum para os currículos do ensino de $1^{\circ}$ e $2^{\circ}$ graus. A doutrina do currículo. Documenta $n^{o} 132$, Rio de Janeiro, nov.1971. 1971c. Disponível em: http://www.histedbr.fe.unicamp.br/ . Acesso em 10 out. 2014.

BRASIL. CFE. Resolução n ${ }^{\circ}$ 08, de 12 de novembro de 1971. Fixa o núcleo-comum para os currículos do ensino de $1^{\circ}$ e $2^{\circ}$ graus e a doutrina do currículo nos termos da Lei 5.692/1971. Documenta $n^{o}$ 133, Rio de Janeiro, dez.1971. 1971d. Disponível em: http://www.histedbr.fe.unicamp.br/ . Acesso em 10 out. 2014.

BRASIL. CFE. Parecer $n^{\circ}$ 871, de 11 de agosto de 1972, do CFE. Matérias da parte diversificada do currículo do $1^{\circ}$ e $2^{\circ}$ graus, para o sistema federal. Documenta $n^{o} 141$, Rio de Janeiro, Ago.1972. Disponível em: http://www.histedbr.fe.unicamp.br/ . Acesso em: 29 out. 2015.

BRASIL. CFE. Parecer $n^{\circ} 1.687$, de 07 de junho de 1974. Dispõe sobre o Curso de Licenciatura em Ciências, Mínimos de Conteúdo e Duração, Indicação No 46/74, Aprovada em 07-06-74. In: AGUIAR, José Márcio de. CFE: Pareceres Básicos - Reforma-Ensino I/II Graus. Vol. II, $1^{a}$ ed. Belo Horizonte: MAI Editora S.A, 1975, p. 103-110. 1974a.

BRASIL. CFE. Resolução no 30, de 11 de julho de 1974. Fixa os mínimos de conteúdo e duração a observar na organização do curso de licenciatura em Ciências. In: AGUIAR, José Márcio de. CFE: Pareceres Básicos - Reforma-Ensino I/II Graus. Vol. II, $1^{\text {a }}$ ed. Belo Horizonte: MAI Editora S.A, 1975, p. 112-114. 1974b.

BRASIL. Lei complementar $n^{\circ} 20$, de $1^{\circ}$ de julho de 1974. Dispõe sobre a criação de Estados e Territórios (Determina a Fusão da Guanabara com o Estado do Rio de Janeiro a partir de 15 de março de 1975). D.O.U. de 01.07.1974 Disponível em: http://www.planalto.gov.br/ccivil_03/leis/lcp/Lcp20.htm. Acesso em 20 de jan. 2015.

BRASIL. Lei $\mathrm{n}^{\circ} 7.044$, de 18 de outubro de 1982. Altera dispositivos da Lei $\mathrm{n}^{\circ} 5.692$, de 11 de agosto de 1971, referentes a profissionalização do ensino de $2^{\text {o }}$ grau. D.O.U. de 19.10.1982. Disponível em: http://www.planalto.gov.br/ccivil_03/lEis/L7044.htm. Acesso em 05 Jan. 2015.

BRASIL. CFE. Parecer $n^{\circ} 785$, de 06 de novembro de 1986. Reformulação do núcleo comum para o ensino de $1^{\circ}$ e $2^{\circ}$ graus. In: RANGEL, Mary. Currículo de $1^{\circ}$ e $2^{\circ}$ graus no Brasil. Petrópolis: Vozes, 1988. 1986a. Disponível em: http://www.histedbr.fe.unicamp.br/. Acesso em: 20 mai. 2015.

BRASIL. CFE. Resolução $n^{\circ}$ 06, de 26 novembro de 1986. Reformula o núcleo comum para o ensino de $1^{\circ}$ e $2^{\circ}$ graus. 1986b. In: RANGEL, Mary. Currículo de $1^{\circ}$ e $2^{\circ}$ graus no Brasil. Petrópolis: Vozes, 1988. 1986b. Disponível em: http://www.histedbr.fe.unicamp.br. Acesso em: 20 mai. 2015.

BRASIL. Lei $\mathrm{n}^{\circ}$ 9.394, de 20 de dezembro de 1996 (e suas alterações). Estabelece as diretrizes e bases da educação nacional. D.O.U de 23.12.1996. Disponível em: http://www.planalto.gov.br/ccivil_03/leis/19394.html. Acesso em 10 Abr. 2015.

BRASIL. Ministério da Educação - Fundo Nacional de Desenvolvimento da Educação FNDE. Resolução CD FNDE no .38 , de 15 de outubro de 2003. Institui o Programa Nacional do Livro Didático para o Ensino Médio (PNLEM). D.O.U. de 23.10.2003. Disponível em: 
http://www.fnde.gov.br/programas/livro-didatico/livro-didatico-historico. Acesso em 20 Fev. 2015.

BRASIL. Lei $\mathrm{n}^{\circ} 11.741$, de 16 de julho de 2008. Altera dispositivos da Lei no 9.394, de 20 de dezembro de 1996, [...], para redimensionar, institucionalizar e integrar as ações da educação profissional técnica de nível médio, da educação de jovens e adultos e da educação profissional e tecnológica. D.O.U de 17.07.2008. Disponível em: http://www.planalto.gov.br/ccivil_03/_Ato2007-2010/2008/Lei/L11741.html. Acesso em 10 Abr. 2015.

SÃO PAULO (Estado). Resolução n ${ }^{\circ}$ 7, de 23 de dezembro 1963. Conselho de Educação do Estado de São Paul. Estabelece normas para a organização dos currículos dos cursos de grau médio e dá outras providências. Revista Brasileira de Estudos Pedagógicos. v.44, n.100, 1965, p. 99-121. Disponível em: http://www.dominiopublico.gov.br/download/texto/me001678.pdf. Acesso em 15 Dez. 2014.

SÃO PAULO (Estado). Lei $\mathbf{n}^{\mathbf{0}} \mathbf{1 0 . 0 3 8}$, de 5 de fevereiro de 1968. 1968a. Dispõe sôbre a organização do Sistema de Ensino do Estado de São Paulo. Publicada na Assessoria TécnicoLegislativa. 1968a. Disponível em: http://www.al.sp.gov.br/repositorio/legislacao/lei/1968/lei-10038-05.02.1968.html. Acesso em 12 Mar. 2015.

SÃO PAULO (Estado). Decreto $\mathbf{n}^{\mathbf{0}} \mathbf{5 0 . 1 3 3}$, de 2 de agosto de 1968. Regulamenta a Lei $\mathrm{n}$. 10.038, de 5 de fevereiro de 1968, na parte relativa ao ensino colegial: secundário e normal. Publicado na Casa Civil. 1968b. Disponível em: http://www.al.sp.gov.br/repositorio/legislacao/decreto/1968/decreto-50133-02.08.1968.html. Acesso em 12 Mar. 2015.

SÃO PAULO (Estado). Conselho Estadual de Educação. Resolução CEE/SP no 36, de 30 de Dezembro de 1968, homologada pelo Ato $\mathrm{n}^{\circ} 09$ de 10 de Janeiro de 1969. Estabelece normas para a organização do Colégio Integrado e do Ciclo Colegial secundário e normal, e dá outras providências. 1968c. Disponível em: http://www3.fe.usp.br/secoes/inst/novo/acervo_jmpa/PDF_SWF/28.pdf. Acesso em 12 Mar. 2015.

SÃO PAUlO (Estado). Conselho Estadual de Educação. Ato no 24, de 29 de Janeiro de 1969. Baixa instruções para aplicação das normas estabelecidas pela Resolução CEE $n^{\circ} 36 / 38$, para as duas primeiras séries do ciclo colegial secundário e normal. Disponível em: http://www3.fe.usp.br/secoes/inst/novo/acervo_jmpa/PDF_SWF/28.pdf. Acesso em 12 Mar. 2015. 



\section{APÊNDICE A \\ Outros projetos de ensino de física das décadas de 1960 e 1970}

\section{Projetos Internacionais}

Apresentaremos a seguir alguns aspectos mais gerais de mais três projetos internacionais para o ensino de Física do Colegial (ou $2^{\circ}$ grau) que adentraram o Brasil nas décadas de 1960 e 1970: o Introductory Physical Science (IPS), o Nuffield Physics Project e o Harvard Physics Project. Essa descrição será mais a título de informação sobre a existência de tais projetos, uma vez que os mesmos não tiveram significativa repercussão no país, sendo que alguns nem mesmo chegaram a ser traduzidos e editados no Brasil. Ainda assim, constituem peças importantes da história do processo inovador para o ensino de ciências em nosso país. Por delimitação da pesquisa, eles não compuseram nossas fontes empíricas de análise de conteúdo.

Não se encontram no estado da arte análises mais profundas sobre a presença de tais projetos no Brasil, talvez pela pouca difusão deles no meio escolar brasileiro. Os trabalhos que os mencionam se limitam à descrição de dados gerais, inserindo-os no contexto do movimento renovador para o ensino de Ciências. Vários autores, como exemplo, Carvalho (1972), Barra e Lorenz (1986), Pinho-Alves (2000), Abrantes (2008), Lorenz (2008), Pena (2012), e ainda outros mencionam tais projetos em suas pesquisas e apresentam similares informações sobre eles (ora um ou uns, ora outro ou outros), demonstrando ser o que se tem de pesquisa a respeito no meio acadêmico brasileiro. Assim, não trazemos aqui nada de inédito, portanto as descrições que apresentaremos, a seguir, baseiam-se quase na totalidade nos trabalhos desses autores. Não recusamos, no entanto, informações obtidas de outros trabalhos, inclusive estrangeiros, bem como de uma análise superficial nos arquivos dos projetos.

Por meio do IBECC e dos Centros de Ciências, ainda na primeira metade década de 1960, outros projetos da área de Ciências foram traduzidos, adaptados, publicados e difundidos, tais como: o CBA, o Chem Study e o BSCS (Versão Azul e Versão Verde). Conforme coloca Krasilchik (1980, p. 172), “Os livros foram publicados, equipamentos construídos e cursos de treinamento ministrados difundindo as ideias novas sobre o ensino de Ciências [...]". Além desses, o IBECC traduziu e publicou também o projeto de ensino de Matemática, o SMSG, no mesmo período, e o de Geociências, o ESCP, alguns anos depois. 
Este último, lançado nos Estados Unidos no início dos anos de 1960, teve sua versão preliminar publicada no Brasil na segunda metade da mesma década e versão final no início da década de 1970, fruto da colaboração entre o CECISP e a Escola Preparatória de Cadetes da Aeronáutica (EPCA), de Barbacena, MG (AMARAL, 2014).

Dado o escopo da presente pesquisa, prenderemo-nos aos projetos específicos para o ensino de Física.

$\underline{\text { Introductory Physical Science - IPS }}$

Identifica-se, na história dos projetos de ensino de Física, o Introductory Physical Science (IPS), elaborado nos Estados Unidos a partir de 1963 e ingressado no Brasil no final da década de sessenta do século passado. Esse projeto objetivava o ensino de Física que seria ministrado em nível equivalente ao nosso curso Ginasial. No sistema de ensino brasileiro, vigente naquela década, seria correspondente às duas últimas séries do Ginasial na disciplina Ciências Físicas e Biológicas, e, a partir de 1971, nas últimas séries do primeiro grau na área de estudo de mesma nomenclatura.

O IPS surgiu no Programa de Física do projeto PSSC e a motivação para a elaboração desse projeto veio dos resultados de avaliações da aplicação do PSSC e dos novos currículos de Química e Biologia, no ensino secundário dos Estados Unidos (CARVALHO, 1972; BORGES; IMHOFF; BARCELLOS, 2012). Dadas as dificuldades apresentadas, os elaboradores dos relatórios de avaliação sugeriram que um projeto para introdução de conhecimentos mais básicos de Física fosse criado, para possibilitar "aos estudantes a necessária aptidão para enfrentar um curso de Física mais moderno" (CARVALHO, 1972, p. 113). O IPS foi inicialmente financiado pelo Educational Services Incorporated (ESI), e, posteriormente, com manutenção a encargo da NSF. Assim como o PSSC, o IPS também teve como base o empirismo e o indutivismo como principais meios de aquisição do conhecimento científico. Não trazia conteúdos teóricos e a proposta era de utilização do método da redescoberta mediada pela investigação/experimentação (BORGES; IMHOFF; BARCELLOS, 2012).

Sobre a estrutura e característica do projeto, Carvalho (1972) relata que o material era composto de um livro-texto para o aluno, um guia para o professor e alguns filmes. A autora coloca que: "o livro-texto é, ao mesmo tempo, um guia de laboratório, de tal forma que muitas das conclusões e generalizações obtidas como resultado do trabalho experimental tornam-se partes essenciais do texto.” (CARVALHO, 1972, p. 113). 
Conforme Shaim ${ }^{140}$ (1965 apud CARVALHO, 1972, p. 113), dois propósitos tracejaram o curso IPS: por um lado, buscou proporcionar aos estudantes uma base sólida para futuros estudos nos cursos de Física, Química e talvez Biologia; e por outro, fornecer base suficiente na essência, no espírito e na substância da ciência física, de modo que fosse um bom curso terminal para aqueles que não iriam mais estudar ciência física.

Conforme Sherman (1968), os objetivos específicos do curso IPS foram proporcionar aos alunos habilidades básicas de laboratório, experiência em observação e aplicação dos resultados, além da capacidade de desenvolver sínteses de ideias em uma situação concreta. A proposta era de que o aluno obtivesse o conhecimento a partir da fonte original, ou seja, da própria natureza. Isto demandava uma investigação real, o uso do laboratório. Assim, o método proposto para alcançar os objetivos foi o experimental, com a participação ativa do aluno, orientada pelo professor, de modo a estimular o raciocínio a partir dos resultados dos experimentos. $\mathrm{O}$ guia do aluno trazia as experiências a serem executadas e exigir-se-ia serem levadas a termo para uma boa compreensão do curso (SHERMAN, 1968).

Ainda citando Sherman (1968), “o tema central do curso IPS é o estudo da matéria, o desenvolvimento de evidencias básicas para o desenvolvimento de um modelo atômico da matéria" (SHERMAN, 1968, p.18, tradução nossa). Segundo esse autor, as ênfases nos três primeiros capítulos do guia, que exigia cerca de um semestre para ser concluido, estavam em Quantidade de matéria e suas propriedades.

A entrada do IPS no Brasil se deu a partir de 1967. O CECISP realizou um curso para apresentação do referido projeto, e, a partir daí, os demais Centros de Treinamentos de Professores de Ciências passaram a disseminar cursos sobre o mesmo (CARVALHO, 1972). Segundo Carvalho, a tradução do livro-texto do IPS foi feita pelos professores Antônio Teixeira Jr., Manoel Jorge Filho e Maria J. de Almeida, membros da equipe do IBECC, e editada pela Edart, em 1969.

Ao descrever o projeto, Carvalho (1972) sugeriu que ele fosse uma alternativa para o curso de Ciências Integradas (CFB) no $1^{\circ}$ ano do segundo ciclo, conforme a sistemática adotada no Estado de São Paulo desde 1968, com a criação dos colégios pluricurriculares e posteriormente consolidada na Lei 5.692/1971. A autora demonstra partir do pressuposto de que a integração das disciplinas Física, Química e Biologia resultou em uma nova perspectiva para o ensino de Física para o Colegial, com abordagem mais geral dos conteúdos.

\footnotetext{
${ }^{140}$ SHAIM, Uri Haber. Objectives and Content of the Introductory Physical Science Courses. ESI Quartely Report, Massachusetts: Summer Fall, 1965.
} 
Carvalho não menciona em que circunstância tal projeto foi desenvolvido nas escolas brasileiras [se é que foi]. No texto escrito em 1972, a autora afirma: "Este curso também está sendo ministrado em diversos cursos de Ciências de Faculdades de Filosofia do Estado de S. Paulo, como por exemplo, em Santo André, Rio Claro, Marília e Avaré.” (CARVALHO, 1972, P. 114). Não identificamos trabalhos que analisam resultados de aplicação desse projeto no Brasil.

\section{$\underline{\text { Harvard Physics Project }}$}

A política curricular de implementação do PSSC nos Estados Unidos com o objetivo de atrair os jovens para Física mostrou-se frustrada, não correspondendo aos resultados esperados. Enquanto alguns países periféricos se maravilhavam com o referido projeto tentado programá-lo em contextos tão díspares, em seu país de origem buscavam-se novas alternativas para revigorar o ensino de Física, com vistas a um ensino mais atrativo, até mesmo para os jovens que tinham vocações para as áreas de humanidades.

No período de 1962 a 1970, auxiliados pela National Science Foudation e o Departamento de Educação dos Estados Unidos, três renomados professores da Universidade de Harvard - Geraldo Holton, James Rutherford e Fletcher Watson - e com apoio de outros colaboradores (professores secundaristas, historiadores, filósofos e educadores) de diversas partes dos Estados Unidos, trabalharam para o desenvolvimento de um segundo grande projeto para o ensino de Física: O Project Physics Course, conhecido também como Harvard Physics Project, que chamaremos aqui de Projeto Harvard.

As motivações principais para a elaboração desse grande projeto foram as mesmas que levaram à elaboração do PSSC, principalmente, a falta de interesse dos estudantes pela área de ciências, uma vez que "mais de $80 \%$ dos estudantes secundários não faziam Física nos Estados Unidos" ${ }^{\prime 41}$ (CARVALHO, 1972, p. 119). Tal realidade, possivelmente, comprometia o projeto político de superioridade científica e tecnológica, abalado pela vitória da União Soviética na corrida pela conquista do Espaço, com o fenômeno Sputnik. Outros propósitos e objetivos permearam a elaboração do Projeto Harvard, conforme lista Carvalho (1972, p. 119):

1) a necessidade de diversificação nos currículos de física, disponíveis para o curso secundário;

2) o problema da matrícula... [conforme citado anteriormente];

3) promover a familiaridade com a ciência e com o pensamento científico;

\footnotetext{
${ }^{141}$ No sistema de ensino estadunidense, os alunos do High School (Ensino Médio) tem a liberdade de optar por quais disciplinas querem cursar.
} 
4) atrair os alunos que estudam no colegial - humanidades ou ciências sociais. [...].

Gerald Holton, físico e historiador, e figura proeminente na demarcação das concepções curriculares do Projeto Harvard, em entrevista a Oliveira e Freire Jr. (2006), explica a gênese da perspectiva curricular que caracterizou o projeto. Segundo Holton, o projeto foi inspirado em um livro que ele escreveu em 1952, o Introduction to concepts and theories in physical science, destinado ao ensino superior, objetivando desenvolver nos alunos uma visão de mundo científica. Holton explica que essa ideia inicial proveio de James Conant, presidente de Harvard, que desde 1945 propunha o desenvolvimento de um curso de introdução geral, para cada uma das três áreas - ciências, humanidades e ciências sociais.

A ideia era ensinar não aquilo que todo estudante de Física tem que aprender, leis de Newton, átomos etc., mas algo mais abrangente, que mostrasse os vínculos históricos e técnicos, assim como as conexões com as outras ciências vizinhas. (HOLTON apud OLIVEIRA; FREIRE Jr., 2006, p. 318 - 319).

Holton justifica o seu entusiasmo por essa perspectiva, a partir de sua experiência pessoal quando estudante secundarista no Ginásio de Viena, onde teve a oportunidade de estudar um pouco de tudo: História, Física, Biologia, Matemática, Literatura, como preparação para ingresso na Universidade. Um exemplo claro da não neutralidade do sujeito na produção do conhecimento e na elaboração do currículo a ser transmitido na escola (cf. DELIZOICOV; ANGOTTI; PERNAMBUCO, 2007).

Acho que trouxe um pouco dessa perspectiva para meu livro e meu curso. [...]. Assim, era lógico que tal livro correspondesse às minhas necessidades como professor e às dos estudantes. [...] No inicio dos anos 60, a National Science Foudation solicitou minha ajuda na elaboração de um curso desse tipo para o ensino médio, o Project Physics, que seguia aquele livro-texto que eu havia escrito para o público universitário. É importante frisar que, aqui nos EUA, os cursos de Física são geralmente no final do ensino médio, quando os estudantes têm 17 anos, e no ano seguinte estarão nas faculdades como calouros. Portanto, o mesmo livro pode se adequar a esses dois públicos. Assim, o Project Physics, que tinha sido idealizado para o ensino médio, foi também adotado nas faculdades e foi muito bem até o começo dos anos 70. (HOLTON apud OLIVEIRA; FREIRE Jr., 2006, p. 318 319).

Assim surge o Projeto Harvard desenvolvido entre os anos de 1962 e 1970, que, baseado nas ideias de James Conant, teve o mérito de introduzir a História da Ciência no currículo de Física do ensino secundário. O objetivo primordial do curso era promover uma formação em Física com ênfase humanística, para assim, angariar interessados em adentrar essa área como atividade profissional, como por exemplo, mulheres, que pouco se interessavam em construir carreira na Física. O Projeto Harvard é considerado por muitos autores (MATTHEWS, 1995; PENA, 2012, entre outros) como sendo o precursor da inserção da História da Ciência no ensino médio. O Projeto é fundamentado em princípios históricos, 
atentando para os aspectos culturais e filosóficos da ciência sem, no entanto, abrir mão de abordar um núcleo de conhecimentos básicos importantes e úteis para prosseguimento em estudos posteriores (CARVALHO, 1972).

O Projeto Harvard ganhou o mercado editorial nos Estados Unidos em 1970, com o título "Introduction to Physics Project". Conforme Holton, o projeto foi amplamente utilizado como introdutório também em curso superior, no começo da década de 1970, por cerca de 200 mil alunos a cada ano, e foi traduzido para italiano, chinês, russo, e português, este último pela Fundação Gulbenkian de Portugal.

Matthews (1995) afirma que tal projeto, em seu auge atingiu 15\% dos alunos do ensino médio nos Estados Unidos. Holton cita percentuais maiores e faz uma comparação entre o seu projeto e o PSSC, em termos de aceitação.

Era o tempo da histeria do Sputnik, em que se pensava ser necessário ter mais cientistas que os russos. Cursos e ótimos textos foram elaborados para a formação de futuros físicos, mas o resultado disto é que menos de $4 \%$ dos estudantes nos Estados Unidos cursaram PSSC. Foi por isso que a NSF solicitou minha ajuda, para tentar fazer algo mais abrangente, que alcance um público maior, por exemplo, envolvendo as estudantes, que raramente cursavam Física. Tentamos atraí-las incluindo história de mulheres que tinham se sobressaído nas ciências. Acho que tivemos um certo sucesso. Mesmo assim muitos alunos ficaram de fora, pois apenas 20 a $25 \%$ dos estudantes daquele período seguiram nosso curso. Mas isso já era um avanço considerável comparado com os $4 \%$ do PSSC. (HOLTON, In OLIVEIRA; FREIRE Jr., 2006, p. 320).

Holton ressalta que o Projeto Harvard funcionou enquanto houve treinamento para professores, o que ele considera de suma importância na implementação desse tipo de proposta, principalmente devido à perspectiva de abordagem conectiva.

O Projeto Harvard foi estruturado em áreas temáticas, em número de seis. As áreas foram dispostas em volumes (livros-texto e guias do professor), sendo elas: Conceitos de Movimento; Movimento nos Céus; O Triunfo da Mecânica; Luz e Eletromagnetismo; Modelos do Átomo; O Núcleo. Trazia ainda um guia de laboratório, caderno de exercícios do tipo instrução programada, transparências, filmes e kits experimentais.

Os textos principais apresentavam uma abordagem mais contextual da Física, com matematização moderada, enfoque teórico e muita ênfase ao aspecto histórico-filosófico, buscando transmitir uma visão de ciência como processo vinculado aos meios culturais e sociais, e promovendo a conexão da Física com outros campos de estudo - daí a abordagem conectiva defendida por Holton. Os diferentes recursos que compunham o projeto objetivaram reduzir a dependência do texto como único suporte pedagógico. É notável na concepção desse projeto, o relevante papel do professor, que dada a flexibilidade do curso e a especial atenção 
nas formas de orientações nos guias do professor, permitia uma maior atuação deste no processo de ensino e aprendizagem (CARVALHO, 172).

O Projeto Harvard foi extinto em seu país de origem alguns anos depois de sua implementação, por determinação do presidente Richard Nixon. Os treinamentos de professores foram cancelados e, conforme afirma Holton, sem treinamento não seria possível dar continuidade ao projeto em grande escala para o ensino secundário (HOLTON apud OLIVEIRA; FREIRE Jr., 2006, p.321).

O Professor Giorgio Moscati, do Instituto de Física da USP (IFUSP) coordenou o processo de apresentação do Projeto Harvard no Brasil, a partir de 1969, com o objetivo de discutir a viabilidade de adaptação às escolas brasileiras. A apresentação, inicialmente no CECISP, se deu por meio de seminários semanais com a participação da equipe de Física desse Centro de Ciências, estagiários e outros convidados. O processo de apresentação contou ainda com um seminário e um curso, ambos ocorridos no IFUSP em 1970, sendo este último apoiado pela Organização dos Estados Americanos (OEA). A participação no curso do Projeto Harvard foi condicionada à atuação como professores "treinadores" dos Centros de Ciências e escolas de graduação de professores, visando assegurar a disseminação do projeto (CARVALHO, 1972).

Dessa iniciativa, efetivou-se a tradução dos livros-texto do projeto, contudo estes nunca foram editados. Não se sabe os reais motivos de abandono da ideia de testar essa inovação nas escolas brasileiras, todavia Pena (2012) teoriza que se revelou pequena sensibilidade, por parte dos professores e pesquisadores, face às características do texto do projeto, que trazia uma "abordagem contextual ao ensino de ciências, [...] capaz de explorar mais o uso da historia e da filosofia da ciência [...] que parecia não encontrar eco expressivo na mencionada comunidade" (PENA, 2012, p. 03). Para o autor, sua conjectura encontra consistência quando se leva em conta que os projetos de ensino de Física, brasileiros, da década de 1970, especialmente o PEF e o FAI, secundarizam as contribuições da história da ciência no ensino de Física. No que tange ao PEF, discordamos do autor, pois o mesmo aborda em nível razoável, os aspectos históricos da Física.

Destarte, o Projeto Harvard ficou restrito ao meio acadêmico nas universidades, e, conforme Pena (2012, p. 04), a partir de sua tradução para o idioma português, em Portugal, passou a despertar o interesse de pesquisadores em ensino de Física, especialmente na linha de História e Filosofia da Ciência, dada a abordagem histórico-filosófica do projeto. 


\section{$\underline{\text { Nuffield Physics Project }}$}

A Inglaterra, embora tenha concordado com os objetivos gerais do projeto de reforma do ensino de Ciências iniciado nos EUA no final dos anos de 1950, optou por produzir seus próprios projetos. O cuidado para a não transferência do produto educacional estadunidense para o sistema de ensino inglês pode ser entendido como forma de preservação da soberania científica e acadêmica e para a manutenção do controle das instituições inglesas e de suas antigas colônias, que têm a Inglaterra como núcleo cultural (KRASILCHIK, 2000).

Segundo consta no sítio eletrônico da Nuffield Foundation ${ }^{142}$, no final dos anos 1950, os educadores em Física, na Inglaterra, acreditavam que o conteúdo do programa dessa disciplina, bem como os métodos utilizados para ensiná-la nas escolas secundárias, mal tinha mudado desde o século XIX. A Física ensinada na escola secundária tinha pouca relação com os novos desenvolvimentos do mundo científico exterior, incluindo a fissão nuclear e exploração do espaço. Acreditavam ainda que os estudantes precisavam experimentar a Ciência, por si mesmos, através do trabalho prático, ao invés de apenas ler sobre ela.

O governo britânico realizou a intervenção por meio da Nuffield Foundation. Essa Fundação se incubiu de criar a equipe para fazer o trabalho e fornecer o financiamento que levou ao desenvolvimento de materiais para o ensino de Física com conteúdos e abordagens de ensinos modernos, que foram testados nas escolas britânicas. A inovação curricular patrocinada pela Nuffield Foundation abrangeu ainda as disciplinas de Química e de Biologia, por equipes constituídas por profissionais das respectivas áreas.

O Nuffield Physics foi desenvolvido no início da década de 1960, organizado por Eric M. Rogers ${ }^{143}$ e EJ Wenham, e começou a ser experimentado nas escolas britânicas em 1962. Tinha como ênfase o pensamento ativo do aluno, a experimentação e a discussão para o entendimento dos conceitos físicos (NUFFIELD FOUNDATION, 2015).

Os projetos Nuffield foram destinados a todas as séries em que o ensino de ciências era obrigatoriamente estudado, nos termos dos preceitos educacionais daquele país, ou seja, cinco anos de estudo (PINHO-ALVES, 2000). Conforme declara Lewis ${ }^{144}$ (1965 apud Carvalho, 1972), a base metodológica do projeto inglês de Física foi inegavelmente inspirada no PSSC.

\footnotetext{
142 http://www.nuffieldfoundation.org/nuffield-physics-1962

143 Eric M. Rogers era Professor da Universidade de Princenton e foi membro da equipe que elaborou o PSSC (CARVALHO, 1972).

144 LEWIS, John L. Science Teaching in England, E.S.I. Quartely Report, Summer Fall, 1965, vol. III, nº 3 pp. 183-191.
} 
O trabalho do PSSC mostrou que o que realmente importava era o método pelo qual o assunto era ensinado, mais do que o conteúdo sumário. Havia uma grande complacência quanto aos métodos de ensino na Inglaterra [...] e chamar atenção para este fato foi talvez o efeito mais estimulante do trabalho do PSSC. (LEWIS, 1965, p. 183-191 apud CARVALHO, 1972, p.136).

Os recursos didáticos do Nuffield Physics se compunham de manuais para alunos (guias de experiências e livro de questões) e de guias para os professores, onde constavam orientações para a experimentação demonstrativa e para desenvolvimento dos conteúdos dos temas a serem abordados. Traziam ainda kits experimentais organizados para uso pelos alunos (1 kit para cada dois alunos), e audiovisuais, sendo alguns, filmes exclusivos para os professores. A organização dos kits nesse quantitativo foi uma estratégia de levar o aluno para o centro do processo de ensino, minimizando a prática de experimentos demonstrativos pelo professor. Tal prática ainda foi mantida para demonstrações de experimentos mais difíceis de serem realizados pelos alunos e que necessitassem de materiais mais sofisticados (PINHOALVES, 2000). Seguindo a tendência que permeou todos os projetos da época, "a preocupação dos realizadores do projeto era criar condições para que o aluno se comportasse como um cientista, especialmente nas atividades ligadas ao laboratório didático." (PINHOALVES, 2000, p.36).

O material impresso - do professor e do aluno - foi dividido em cinco partes, sendo cada parte correspondente a um ano de estudo de ciências. As partes I e II, ou Anos I e II, exploravam temas mais gerais e o objetivo principal era colocar o aluno em contato com o método científico fazendo uso da experimentação. As demais partes traziam o aprofundamento dos conceitos e exploravam mais a estrutura fundamental da disciplina, ainda que abordando teorias simples, mas fazendo uso de modelos matemáticos.

Dos conteúdos adotados, destaca-se a abordagem da teoria cinética dos gases, que ganhou especial atenção (CARVALHO, 1972), apossando-se de uma moderna teoria cinética com o estudo de um modelo de moléculas em movimento aleatório utilizado na discussão de difusão, viscosidade, condução térmica e calores específicos moleculares. A radioatividade foi usada como um exemplo de modelos especulativos sobre a natureza da matéria e da energia (NUFFIELD FOUNDATION, 2015).

Inicialmente, a metodologia utilizada buscou vencer o paradigma do texto único. Assim, o livro-texto do aluno não apresentava textos sobre o conteúdo a ser estudado, mas sim questões para que os estudantes respondessem a partir de conclusões após realizarem os experimentos propostos ou de fazerem as pesquisas sugeridas no livro do aluno. Os conteúdos eram apresentados somente no guia do professor (ALVARENGA, 1991). A princípio, a 
Nuffield Foundation não patrocinou os livros do aluno. Estes foram produzidos pelas editoras que trabalharam com os membros da equipe do projeto (NUFFIELD FOUNDATION, 2015).

Devido à dificuldade de efetivação da proposta na prática, em razão dessa característica peculiar, posteriormente, foram elaborados textos com conteúdos selecionados para o manual do aluno, retrocedendo um pouco aos métodos tradicionais, embora tenha mantido o apelo à experimentação e grande incentivo à pesquisa em outros textos (ALVARENGA, 1991). Essas alterações ocorreram em 1970, com o patrocínio de livros do aluno (pela Nuffield Foundation) no pacote de recursos, e a inclusão [neles] de conteúdos a serem estudados (NUFFIELD FOUNDATION, 2015).

Os professores recebiam apoio para desenvolvimento profissional de conselheiros/cientistas e autoridade de educação local. O curso levou ainda ao desenvolvimento de novas abordagens para a avaliação "dentro do espírito do novo curso" e foram desenvolvidas em parceria com as bancas examinadoras de avaliação nacional (NUFFIELD FOUNDATION, 2015). Segundo consta em uma seção histórica do site da Nuffield Foundation, cerca de $20 \%$ das escolas secundárias britânicas experimentaram o projeto.

Pinho-Alves (2000, p.36), coloca que "a divulgação do Projeto Nuffield ficou bastante restrita à Grã-Bretanha e suas antigas Colônias, não obtendo repercussão maior em outros países.”. Em 1968, por proposta do IBECC, cogitou-se a possibilidade de traduzir o projeto. Entretanto, pela avaliação de um importante professor/pesquisador da área - o Professor José Goldemberg, do IFUSP, tal intenção foi abandonada. Segundo Carvalho (1972, p. 119), a opinião do referido Professor era de que se tratava de um "material prolixo e não adaptável às condições brasileiras” (CARVALHO, 1972:119).

O Nuffield Physics teve menos repercussão no Brasil do que o projeto Harvard, uma vez que nem mesmo chegou a ser traduzido para o português ${ }^{145}$, nem mesmo em versão preliminar em âmbito acadêmico, como ocorreu com o Projeto estadunidense. Conforme afirma Pinho-Alves (2000, p.36), "ficando apenas conhecido no âmbito de grupos com interesses maiores em ensino de Física e algumas bibliotecas.”.

\footnotetext{
${ }^{145}$ Esse projeto não foi traduzido no Brasil e nem em Portugal.
} 


\section{Projetos Nacionais}

\section{$\underline{\text { O Projeto Piloto de Física da UNESCO: meio nacional meio estrangeiro }}$}

Marques (2005) afirma que a iniciativa de desenvolvimento do que se denominou Projeto Piloto de Física da UNESCO (PPFU) ${ }^{146}$ surgiu da não aceitação do PSSC como inovação curricular, pela sua inadequação à realidade do ensino nos diversos contextos dos países periféricos em que se deu a implantação do referido projeto, particularmente na América Latina.

Esse projeto de ensino de Física foi o primeiro no Brasil após o advento do PSSC. Conforme Carvalho (1972), foi a necessidade de renovação do ensino de Física introduzida pelo PSSC, que gerou a “'fome' de novos projetos que se adaptariam aos problemas e condições brasileiras, mas que tivessem as características fundamentais renovadoras do ensino que foram trazidas pelo PSSC." (CARVALHO, 1072, p. 106). O início dos trabalhos de elaboração do PPFU é concomitante à finalização do trabalho de tradução do PSSC pelo IBECC e publicação pela Universidade de Brasília (UnB).

Damos a palavra a um participante da elaboração do PPFU, o Professor Cláudio Zaki Dib:

Na realidade, o objetivo principal de Albert Baez, então Diretor da Divisão de
Ensino de Ciências da UNESCO, em Paris, e principal idealizador do projeto, era
verificar a possibilidade de um grupo de professores de física latino-americanos de
produzir, com uso de Tecnologia da Educação, materiais instrucionais para a
aprendizagem de física, de forma ajustada às suas condições e necessidades. (DIB,
1991, p. 02)

Assim sendo, "Sob os auspícios da UNESCO, e com a colaboração do IBECC (Instituto Brasileiro de Educação Ciência e Cultura - Seção de São Paulo)” (PPFU, 1968, p. V), o plano de trabalho denominado inicialmente de "Projeto Piloto sobre Novos Métodos e Técnicas de Ensino da Física”, desenvolveu-se no período de julho de 1963 a junho de 1964, com a participação de 26 professores de Física de vários países latino-americanos (Argentina, Brasil, Chile e Equador). Do grupo de professores, pelo menos cinco eram brasileiros: Cláudio Zaki Dib, Fuad Karim Miguel, Manoel Jorge Filho, Paulus Aulus Pompéia e Maria Tereza A. Silva (PPFU, 1968, p. V).

O projeto foi sediado no Departamento de Física da Faculdade de Filosofia, Ciências e Letras da Universidade de São Paulo e contou com o Serviço de Recursos Audiovisuais do Centro Regional de Pesquisas Educacionais de São Paulo para a produção dos filmes

\footnotetext{
${ }^{146}$ Sigla elaborada por nós a partir do nome do projeto no livro do aluno.
} 
didáticos, produzidos sob orientação do Dr. Albert Baez, da equipe UNESCO. Os trabalhos estiveram sob a orientação de dois professores ligados à UNESCO e do Prof. Paulus Aulus Pompéia do Centro Técnico da Aeronáutica (ITA). Do trabalho final dessa densa equipe de cientistas e professores/pesquisadores, resultou uma série de livros denominada Física da Luz, em que o assunto é exposto sob a forma de instrução programada e é acompanhado de um conjunto de kits para a realização das experiências sugeridas nos livros, um filme e alguns "loops".

Carvalho (1972) informa que, a escolha desse tópico de ensino se deu por ser este o mais importante da Física Moderna, por proporcionar maiores possibilidade de ilustrar as relações entre teoria e experimento, e ainda, por possuir "íntima conexão entre os vários ramos da Física" (CARVALHO, 1972, p. 109). A série de livros do projeto constou de cinco unidades: Unidade 0 - Experiências e gráficos; Unidade 1 - Algumas Propriedades da Luz; Unidade 2 - Modelo Corpuscular da Luz; Unidade 3 - Modelo Ondulatório da Luz; Unidade 4 - Ondas Eletromagnéticas e Fótons.

Os recursos audiovisuais do pacote curricular constaram de onze filmes curtos (loops), sem áudio, com apresentação de uma ou mais experiências que envolviam conceitos simples e um filme de 30 minutos de duração nas versões português e espanhol sob o título “Luz... é Onda?" (CARVALHO, 1972). Além dos filmes, foram preparados também programas de TV para ensinar como utilizar os filmes e os experimentos nas aulas de Física.

O PPFU traz uma concepção de ensino "à prova de professor" (VILLANI; PACCA, 1997). Isso está explícito na apresentação do livro ao estudante:

O processo de aprendizagem com que você vai se familiarizar neste livro provavelmente o intrigará a princípio. Mas estamos certos que, à vista da simplicidade com que os conhecimentos vão sendo assimilados, sua apreciação contribuirá para difundir esta moderníssima norma de aprendizagem, metódica e coordenadamente "programada". Este livro será para você um "professor amigo", na Escola ou no Lar. (PPFU, 1968, p. VII, grifo nosso)

Embora pouco disseminado, o PPFU é apontado por Dib (1991) como uma importante abertura para entrada de novas técnicas aplicadas ao ensino que fomentaram a pesquisa educacional, que, mais tarde, motivaram a elaboração de outros projetos surgidos no Brasil, baseados nas metodologias do PPFU. Segundo ele:

O Projeto Piloto da UNESCO para o Ensino de Física foi certamente o maior projeto para o ensino de física desenvolvido no Brasil e na América Latina, influenciando de inúmeras maneiras pessoas e instituições universitárias e constituindo o elemento gerador de uma nova e promissora direção de pesquisa e desenvolvimento. (DIB, 1991, p. 06)

E ainda acrescenta: 
Se hoje existem no Brasil e na América Latina dezenas de grupos de pesquisa trabalhando em ensino de física em instituições universitárias, certamente o Projeto Piloto da UNESCO para o Ensino da Física teve grande parcela de responsabilidade, já que foi através do mesmo que surgiram os primeiros pesquisadores em Educação em Física, grupos ativos de pesquisadores foram constituídos, abrindo-se, assim as pesadas portas de instituições tradicionais em pesquisa em Física para uma nova e promissora área de trabalho. Em ocasião recente, Amélia Império Hamburger, professora e pesquisadora do Instituto de Física da USP, ao referir-se à existência de uma área de pesquisa em ensino nessa instituição, assim se manifestou: "O Projeto Piloto, afinal, foi o início de tudo...” (DIB, 1991, p. 08)

\section{Projeto Brasileiro de Ensino de Física (PBEF)}

O PBEF foi idealizado por Rodolpho Caniato e apresentado como tese de doutoramento em 1973, após ensaiar sua metodologia em várias escolas de Campinas/SP.

Segundo o autor, a ideia surgiu de sua experiência como professor nos cursos de formação de professores de Matemática e Física na antiga Faculdade de Filosofia e Letras da Universidade Católica de Campinas, de 1957 até 1969, e de sua participação na implementação de projetos estrangeiros no Brasil, como, por exemplo, o PSSC. Em ensaios realizados com pós-vestibulandos, o autor percebeu que muitos não tinham conhecimentos básicos dos fenômenos e apresentavam muita dificuldade em aplicar os conceitos às situações concretas. Para o autor, era importante propor alternativas para suprir essas lacunas no ensino, de forma condizente com a realidade brasileira, diferentemente dos projetos dos quais ele havia tido contato: PSSC e Harvard (CANIATO, 1973).

A ideia evoluiu para a elaboração de um projeto denominado Projeto Brasileiro para o Ensino de Física com pretensão inicial de se compor de cinco unidades: O Céu; Mecânica (Interação do Universo); Eletricidade (O trabalho dos elétrons); Luz e ondas; Átomos e estrutura da matéria. Conforme traz Caniato (1973), as partes projetadas até a defesa de sua tese foram somente as três primeiras unidades. No entanto, somente as duas primeiras unidades são apresentadas em sua tese, como anexos.

As duas primeiras unidades foram publicadas pela Fundação Tropical de Pesquisas e Tecnologia, em volumes separados ${ }^{147}$ : Volume I - O Céu; Volume II - Mecânica - trazendo como autor de capa o idealizador do projeto, e sob o nome Projeto Brasileiro para o Ensino de Física. Estas unidades traduzem explicitamente a proposta do autor trazida em sua tese de doutoramento. O projeto contou com o apoio da FUNBEC e da FAPESP.

\footnotetext{
${ }^{147}$ Tivemos acesso à $3^{\mathrm{a}}$ edição desses volumes, além da tese original que traz tais textos como anexos.
} 
A terceira unidade parece ter saído somente em versão preliminar ${ }^{148}$. Localizamos tal versão que traz como título "Projeto Brasileiro de Física - Eletricidade", publicado pela EDART - São Paulo, em 1973. Nesta versão consta que a obra foi elaborada pela FUNBEC sendo a coordenação e elaboração do texto de Verenice Leite Ribeiro. O Professor Rodolpho Caniato é citado como um dos coordenadores gerais do projeto, juntamente com os Professores Antônio Teixeira Jr. e José Goldemberg. Ressalte-se que, nas contracapas dos volumes das primeiras unidades publicadas - "O Céu" e "Mecânica" (edições de 1978/1979), os nomes destes professores aparecem na COORDENAÇÃO INICIAL DO PROJETO.

Outros nomes aparecem como participantes do projeto, com algumas alterações deles nos volumes das três unidades, configurando uma equipe relativamente grande, que comportou professores universitários, sendo alguns vinculados à USP e à UNICAMP, e também do ensino médio, sendo que a participação de alguns se limitou à aplicação em sala de aula. Da proposta inicial, no que se refere aos conteúdos das unidades que posteriormente foram publicadas, traz o autor:

\begin{abstract}
A primeira unidade, "O CÉU" utiliza a Astronomia como meio para desenvolvimento de ideias utilizáveis de modo geral em ciência e tem uma abordagem predominantemente histórica e humanista.

A segunda Unidade, "MECÂNICA" que começa pelas "Linguagens da Física" procura ir diretamente aos assuntos considerados de importância central, não pretendendo esgotar os assuntos dessa área, mas oferecer os elementos e conceitos mais importantes sobre as leis importantes e utilizáveis da Física.

[...]

A terceira Unidade, "ELETRICIDADE" - (o trabalho dos elétrons) deverá desenvolver, desde o início, o entendimento básico de circuito elétrico, desenvolvendo, portanto, um aspecto eminentemente prático e operacional. Simultaneamente deverá ser desenvolvida a ideia de modelo em Física, para explicar os fenômenos elétricos. (CANIATO, 1973, p. 25-27)
\end{abstract}

Os textos das duas primeiras unidades apresentam uma linguagem simples, bastante coloquial, e apresentam três níveis de desenvolvimento. Primeiro, o nível de "Leitura", traz um texto para introdução dos conceitos. Após a leitura e atividades relacionadas, seguem-se as seções "Se você quiser saber um pouco mais" e "Um pouco mais ainda". Nestas o aluno teria a oportunidade de aprofundar um pouco mais nos temas trazidos na leitura e atividades anteriores. Apela pouco para os modelos explicativos formais (equações matemáticas), sendo mais presente nas seções de aprofundamento, particularmente na seção "Um pouco mais ainda", com abordagem matemática mais rigorosa (CANIATO, 1973). As unidades, ou volumes, não são sequencias; assim, o curso poderia ser iniciado por qualquer uma delas. Entretanto, isoladamente, apresentam uma sequência interna. Inclui atividades experimentais que demandam equipamentos de baixo custo montados com materiais que poderiam ser

\footnotetext{
${ }^{148}$ Não identificamos uma versão definitiva da terceira unidade do projeto.
} 
adquiridos pelos alunos em seu cotidiano. Desse modo, o projeto não incluiu Kits experimentais prontos. Notam-se nesse projeto alguns aspectos convergentes com o projeto Harvard: experiência do autor como motivação para a elaboração do projeto, um pouco de abordagem histórica e profundidade de conceitos.

O PBEF também se ampara na concepção de educação centrada no aluno, tal quais os outros projetos de ensino de Física já citados. Na opinião do autor, o aluno não é um copista, e assim, deveria ter uma intensa participação no processo de aprendizagem. Essa participação incluía a tarefa de providenciar materiais de baixo custo para utilização nas aulas experimentais. O texto do projeto incentiva o trabalho em grupo, e o papel do professor deixa de ser um repetidor de conceitos prontos e passa a ser coordenador e incentivador das atividades dos alunos. Suscita uma tendência cognitivista mesclada às concepções behavioristas, embora não declare isso explicitamente. Essas ideias de ensino - fazendo uso do processo estímulo-resposta com reforço, no caso, sempre positivo, e com nuances cognitivistas, estão presentes nos trechos a seguir, extraídos das páginas de apresentação dos livros (volumes I e II) do projeto:

[...] Aqui a atuação do PROFESSOR será indispensável tanto para ordenar a discussão como para evitar que uns fiquem com a palavra em prejuízo dos outros. Diante das perguntas, o PROFESSOR não deve simplesmente dar a resposta, mas sim conduzir a discussão para que as respostas sejam provocadas nos alunos.

$[\ldots]$

Sempre que um aluno manifeste uma AÇÃO considerada desejável pelo PROFESSOR este deverá manifestar ao aluno, de alguma maneira, sua aprovação e sempre que possível registrar a contribuição na folha de registro de trabalho.

[...]

Desaconselha inteiramente que o PROFESSOR use qualquer método coercitivo ou que represente ameaça, ainda que simplesmente a de um ZERO. (CANIATO, 1978/1979, pg. Apresentação, grifos e maiúsculos dos originais).

A terceira unidade, dividida em dois capítulos (Circuitos Elétricos e Eletromagnetismo), traz uma estrutura bastante diferente das anteriores, denotando a mudança de orientação do texto (PINHO-ALVES, 2000). Não traz as mesmas apresentações introdutórias presentes nas duas primeiras unidades (“AO PROFESSOR" e "PROCEDIMENTOS") onde explicita a proposta metodológica, embora não fuja totalmente da proposta inicial do idealizador do projeto, que trazia no texto de sua tese (1973): “A terceira unidade, "ELETRICIDADE" - (o trabalho dos elétrons) deverá desenvolver, desde o início, o entendimento básico de circuito elétrico, desenvolvendo, portanto um aspecto eminentemente prático e operacional." (CANIATO, 1973, p.27). 
Essa terceira unidade, a saber, elaborada sem a participação de Rodolpho Caniato, compõe-se, basicamente, de roteiros de atividades experimentais, com textos introdutórios resumidos, figuras (desenhos), questões para responder/resolver, mas não se estrutura em níveis, conforme proposto por Caniato (1973). Manteve-se a abordagem mais conceitual, com referência às coisas cotidianas e pouco apelo ao formalismo matemático (ainda menos que as unidades anteriores), no entanto, suprimiram-se totalmente os aspectos históricos, ainda que fossem pouco abordados nas unidades I e II. Tal versão preliminar se assemelha mais a um manual didático para aulas experimentais, que, de acordo com a proposta, seriam desenvolvidas em sala de aula, com materiais simples, sem necessidade de laboratório (PBF, 1973, versão preliminar).

Nos dois primeiros volumes do projeto consta uma lista com um número significativo de instituições nas quais o projeto fora ensaiado, cerca de 30, no período de 1970 a 1979, incluindo instituições ${ }^{149}$ de outros países latinos. Apesar de o autor afirmar ter havido sucesso com os ensaios, o projeto não teve continuidade, de modo que as demais unidades não foram editadas. Possivelmente, essa descontinuidade constitui uma das razões pelas quais o projeto não fora difundido no país, sendo bem menos conhecido que os projetos PEF e FAI.

\footnotetext{
${ }^{149}$ Dependendo da edição esse dado é alterado. No volume "O Céu”, $3^{\text {a }}$ edição, embora conste ano de 1978, traz informação de ensaio até 1979.
} 


\section{ANEXOS \\ ANEXO I - Programa de Física da Portaria n 966, de 2 de outubro de 1951.}

PROGRAMAS DE FÍSICA A QUE SE REFERE A PORTARIA No 966, DE 2 DE OUTUBRO DE 1951

\section{CURSO CIENTÍFICO}

$1^{a}$ Série

1. Introdução ao estudo da física. Matéria: propriedades. Lei da Física. Fenômeno físico. Medidas. Erros.

2. Mecânica: Fôrças. Sistemas de fôrças e sua resolução. Momento. Trabalho e potência. Deformações elásticas. Máquinas simples. Rendimento. Atrito. Conservação do trabalho.

3. Movimento retilíneo. Velocidade e aceleração. Gráficos. Composição de movimentos. Movimento circular.

4. Princípios fundamentais da dinâmica: fôrça e aceleração. Quantidade de movimento e impulso. Energia cinética. Teorema da fôrças vivas. Fôrças no movimento curvilíneo. Choque.

5. Gravitação universal. Gravidade. Pêso e massa. Equilíbrio dos corpos. Balanças. Queda dos corpos. Pêndulo.

6. Sistema de unidades. Homogeneidade. Legislação metrológica brasileira.

7. Pressão. Estudo dos líquidos. Distribuições das pressões no líquidos em equilíbrio. Equilíbrio dos líquidos. Corpos imersos e flutuantes. Densidade. Escoamento dos líquidos. Fenômenos devidos às fôrças moleculares.

8. Estudo dos gases. Pressão atmosférica. Compressibilidade e expansibilidade. Mistura de gases. Resistência do ar. Princípio de Arquimedes aplicado aos gases. Bombas de gases e de líquidos.

\section{$2^{a}$ Série}

1. Movimento vibratório. Composição de vibrações. Propagação ondulatória. Superposição de ondas.

2. Natureza, propagação e velocidade do som. Reflexão, refração e interferência do som. Qualidades fisiológicas dos sons. Escalas musicais. Fontes sonoras.

3. O calor e seus efeitos. Temperatura, sua avaliação. Dilatação dos sólidos, líquidos e gases. Gases perfeitos.

4. Quantidade de calor. Calor específico. Calorimetria.

5. Propagação do calor nos sólidos, líquidos e gases. Irradiação.

6. Mudanças de estado físico e suas leis. Soluções. Higrometria.

7. Transformação do calor em trabalho e vice-versa. Princípios da termodinâmica. Máquinas térmicas.

\section{$3^{\text {a }}$ Série}

1. Propagação retilínea da luz. Sombras. Reflexão da luz. Espelhos planos e curvos. Refração da luz. Lâminas, prismas e lentes. Instrumentos de ótica.

2. Estudo físico da luz. Velocidade da luz. Energia radiante. Espectros das radiações. Espectroscopia. Fotometria.

3. Difração. Interferência luminosa. Dupla refração. Polarização da luz. Polarimetria.

4. Carga elétrica. Campo elétrico. Indução eletrostática. Condensadores.

5. Massas magnéticas. Campo magnético. Magnetismo terrestre.

6. Corrente elétrica. Grandezas características. Lei de Ohm. Efeitos térmicos da corrente elétrica. Efeitos químicos. Pilhas e acumuladores. Correntes derivadas. Medidas das resistências. Circuito de corrente contínua.

7. Campo magnético das correntes elétricas. Solenóides e eletroímãs. Ação recíproca das correntes e ímãs. Indução eletromagnética. Geradores e motores de corrente contínua.

8. Noções sôbre correntes alternadas. Geradores e motores de corrente alternada. Transformadores. Noções sôbre oscilações elétricas. Ondas eletromagnéticas.

9. Condução de eletricidade através dos gases. Raio X. Efeitos termoiônico e fotoelétrico. A radioatividade. Noções sôbre a constituição da matéria. Teorias modernas da Física.

Todas as vêzes que o curso comportar a presença dos alunos no gabinete de física em horas extracurriculares, ser-lhes-á facultado o uso de aparelhos, bem como a execução dos seguintes trabalhos:

\section{$1^{a}$ Série}

a) Práticas com o Vernier retilíneo e curvilíneo;

b) Prática com o paquímetro, palmer, parafuso, micrométrico e esferômetro;

c) Medidas de comprimentos e espessuras;

d) Medidas de áreas por pesagens;

e) Medidas de volumes de sólidos;

f) Medidas de ângulos;

g) Medida da capacidade de um vaso por pesagem;

h) Densidade de sólidos e líquidos;

i) Práticas com a prensa hidráulica;

j) Práticas com barâmetro

\section{$2^{a}$ Série}

a) Determinação da altura de um som;

b) Medidas de temperaturas;

c) Verificação dos pontos fixos de um termômetro; 
d) Determinação do calor específico de um sólido;

e) Estabelecimento do gráfico de uma fusão;

f) Medida do estado higrométrico do ar. $\mathbf{3}^{a}$ Série

a) Determinação da distância focal de um êspelho côncavo- esférico;

b) Determinação de um índice de refração;

c) Distância focal de uma lente;

d) Revelação e impressão fotográficas;

e) Prática com o microscópio;

f) Prática com o espectrocópio;

g) Comparação de intensidades luminosas;

h) Prática com a bússola;

i) Montagem e associação de pilhas;

j) Medida de uma resistência elétrica.

\section{$2^{a}$ Série}

\section{CURSO CLÁSSICO}

1. Introdução ao estudo da física. Matéria: propriedades. Lei da Física. Fenômenos físicos. Fôrças. Sistemas de fôrças. Equilíbrio das fôrças. Trabalho e potência. Máquinas simples. Rendimento. Conservação do trabalho.

2. Movimento retilíneo. Velocidade e aceleração. Gráficos. Movimento circular. Fôrça e aceleração. Quantidade de movimento e impulso. Energia cinética. Fôrças no movimento curvilíneo.

3. Gravidade. Pêso e massa. Equilíbrio dos corpos. Balanças. Queda dos corpos. Pêndulo. Sistema de unidades. Legislação metrológica brasileira.

4. Pressão. Estudo dos líquidos. Distribuições das pressões no líquidos em equilíbrio. Equilíbrio dos líquidos. Corpos imersos e flutuantes. Densidade. Escoamento dos líquidos. Fenômenos devidos às fôrças moleculares.

5. Estudo dos gases. Pressão atmosférica. Compressibilidade e expansibilidade. Mistura de gases. Resistência do ar. Princípio de Arquimedes aplicado aos gases. Bombas de gases e de líquidos.

6. O calor e seus efeitos. Temperatura, sua avaliação. Dilatação dos sólidos, líquidos e gases. Gases perfeitos.

7. Quantidade de calor. Calor específico. Calorimetria. Propagação do calor. Mudanças de estado físico e suas leis.

8. Transformação do calor em trabalho e vice-versa. Princípios de termodinâmica. Máquinas térmicas.

\section{$3^{a}$ Série}

1. Movimento vibratório. Composição de vibrações. Propagação ondulatória e superposição de ondas. Natureza do som. Propagação, percepção e velocidade do som. Qualidades do som. Fontes sonoras.

2. Propagação retilínea da luz. Sombras. Reflexão da luz. Espelhos planos e curvos. Refração da luz, prismas e lentes. Instrumentos de ótica.

3. Estudo físico da luz. Velocidade da luz. Energia radiante. Espectros das radiações. Fotometria. Difração, interferência, dupla refração e polarização da luz.

4. Carga elétrica. Campo elétrico. Indução eletrostática. Condensadores.

5. Massas magnéticas. Campo magnético. Magnetismo terrestre.

6. Corrente elétrica. Grandezas características. Lei de Ohm. Correntes derivadas. Efeitos térmicos da corrente elétrica. Efeitos químicos da corrente elétrica.

7. Campo magnético das correntes elétricas. Solenóides e eletroímãs. Ação recíproca das correntes e ímãs. Indução eletromagnética. Geradores e motores de corrente contínua. Noções sôbre correntes alternadas. Noções sôbre oscilações elétricas e ondas eletromagnéticas.

8. Condução de eletricidade através dos gases. Raio X. Efeitos termoiônico e fotoelétrico. Radioatividade. Noções sôbre as constituição da matéria. Teorias modernas da Física. 


\section{ANEXO II - Indicação do Conselho Federal de Educação de 21-02-1962- Normas para o ensino médio nos termos da Lei 4024/1961.}

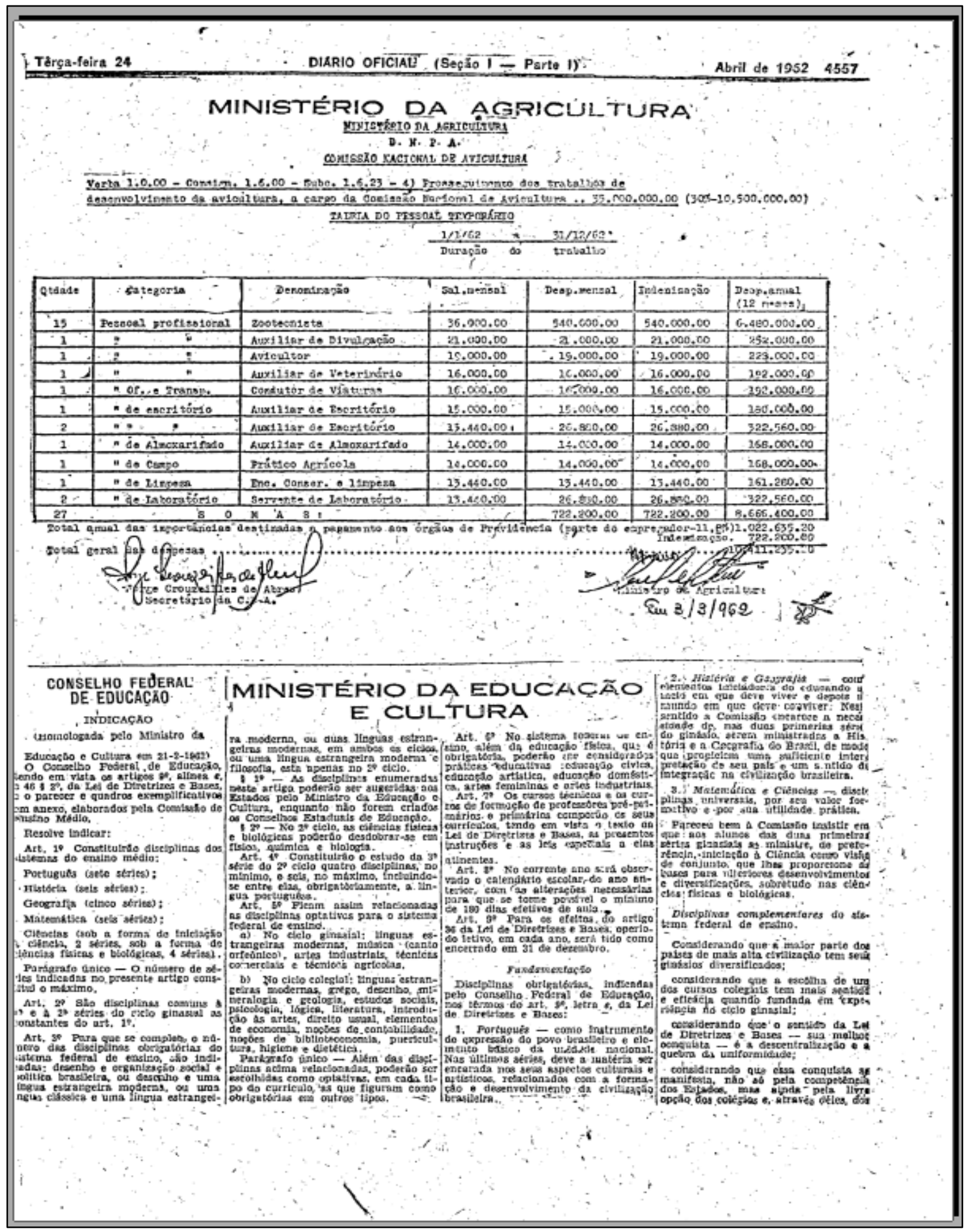

Continua... 
Conclusão.

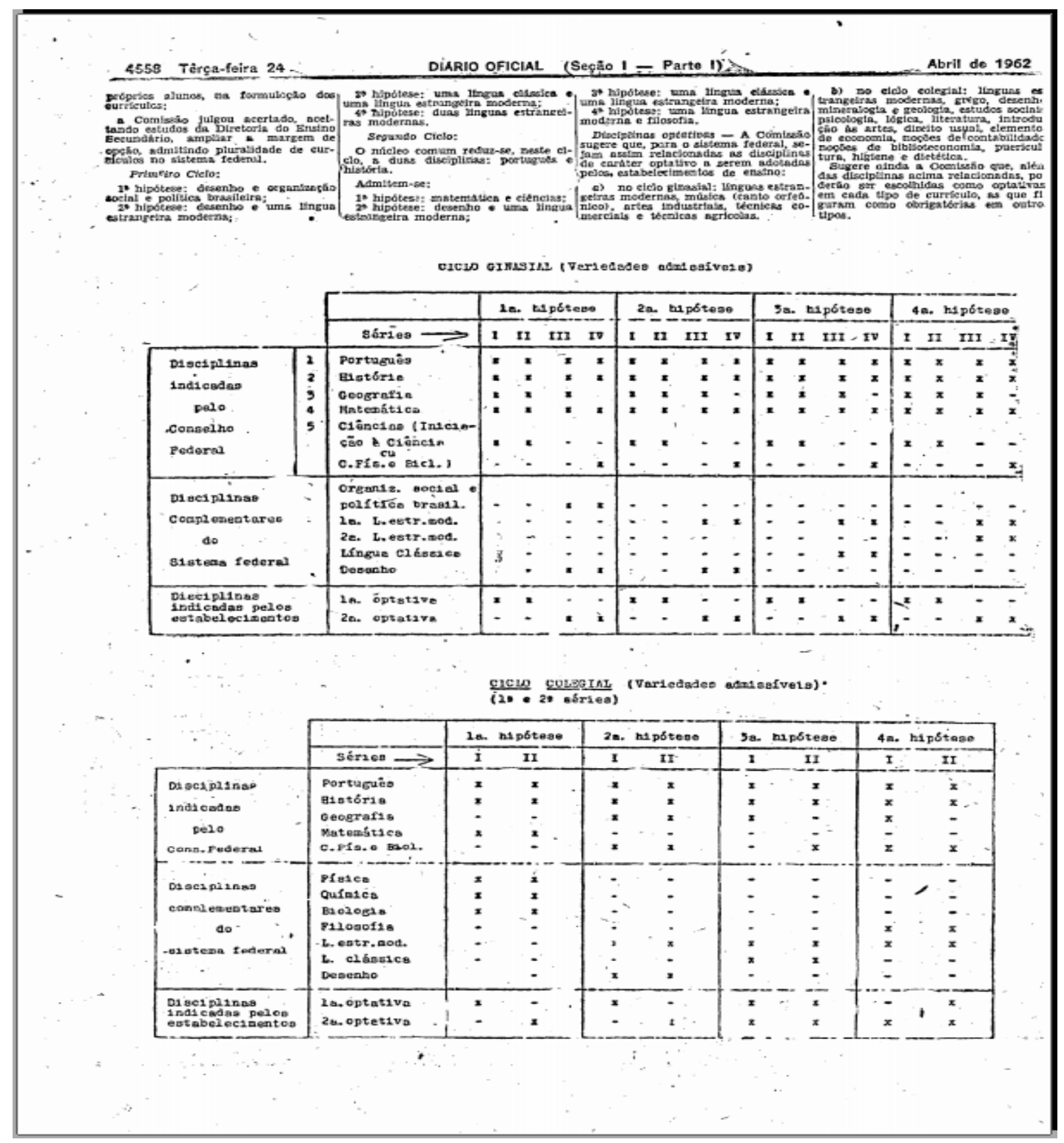

Fonte: http://www.jusbrasil.com.br/diarios/2773094/pg-41-secao-1-diario-oficial-da-uniaodou-de-24-04-1962/pdfView. Acesso em 15 Ago. 2014. 


\begin{abstract}
ANEXO III - Quadros exemplificativos do CFE, a que se refere a Indicação de Fevereiro de 1962, trazidos no documento Consolidação da Legislação do Ensino Secundário, após a Lei de Diretrizes e Bases da Educação Nacional(1969).
\end{abstract}

\title{
ANEXO I
}

CICLO GINASIAL (Variedades admissiveis) PLANOS OU HIPÓTESES TITDICIT ADEC

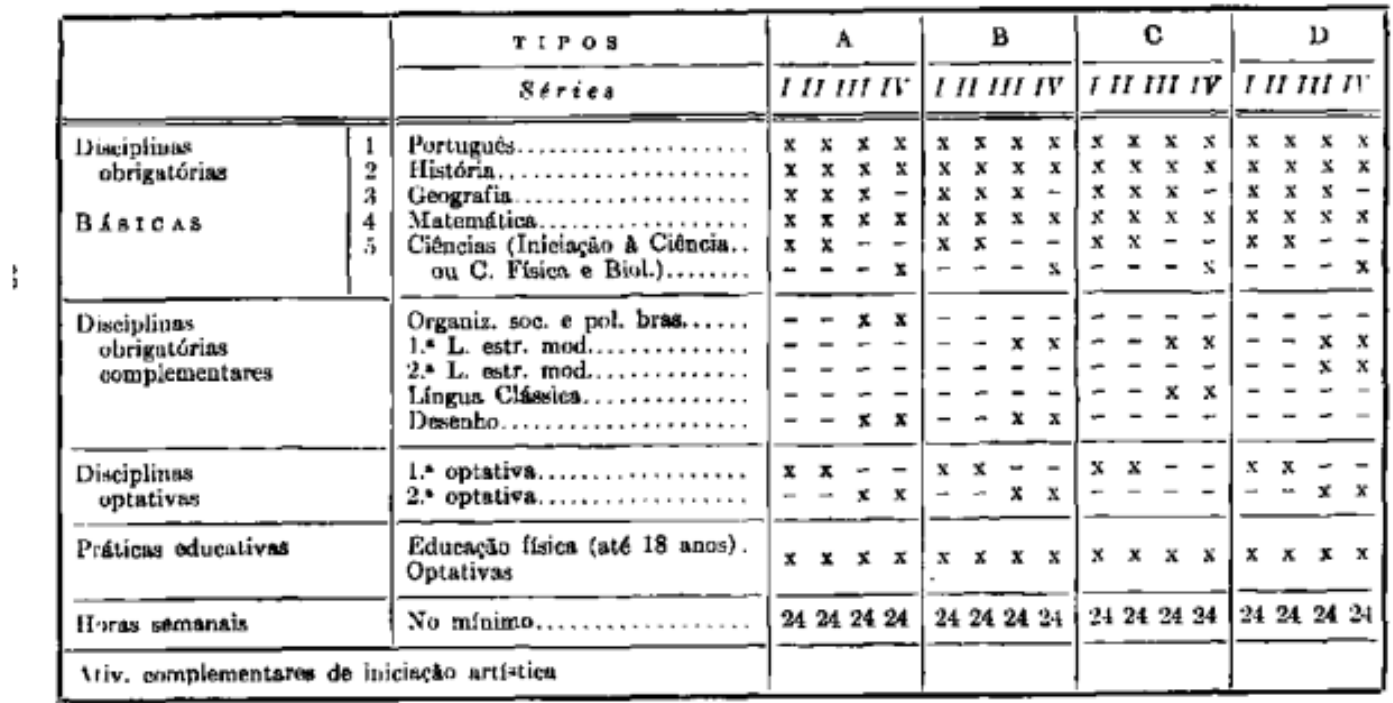

ANEXo II

CICLO COLEGIAL (Variedades admissíveis)

(1. e 2. series) PLANOS OU HIPÓTESES

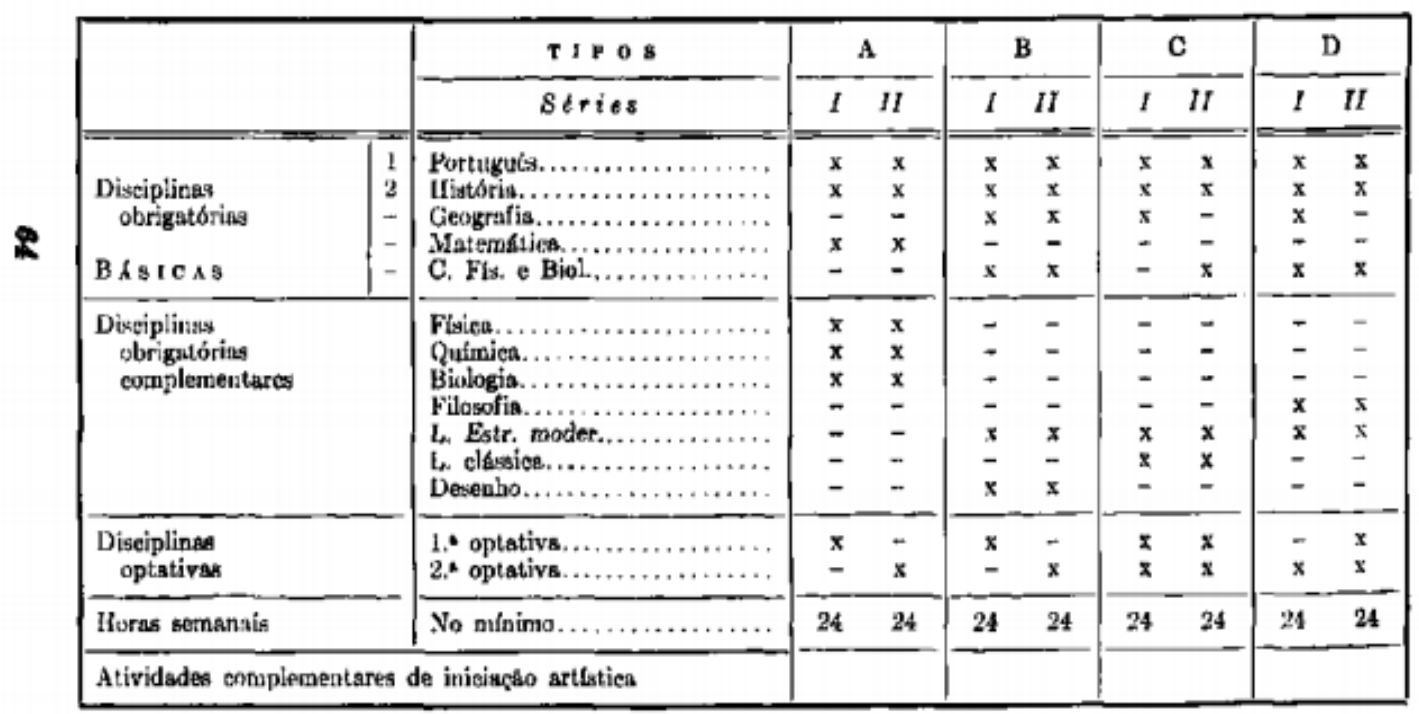

Fonte: (BRASIL, 1969, p. 63-64) 


\section{ANEXO IV - Recorte de histórico Escolar de ex-estudante do Estado do Rio de Janeiro}
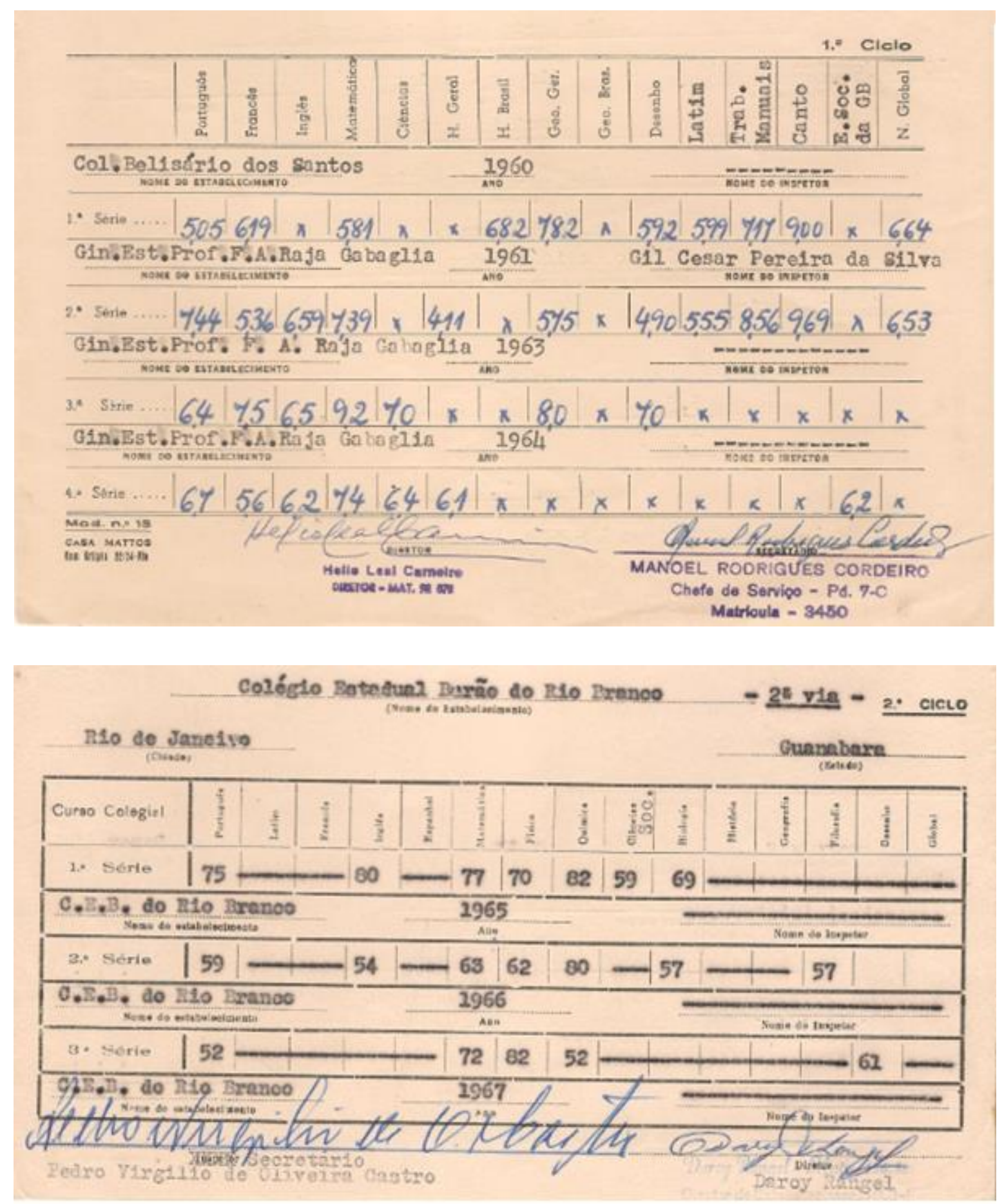

Fonte: Cedido pela proprietária do documento por meio de sua filha, também pesquisadora, via e-mail em 07 de abril de 2015. 
ANEXO V - Quadros exemplificativos de organização curricular dos Colégios Pluricurriculares do Estado de São Paulo, a que se refere a Resolução nº 07, de 23.12.1963, do Conselho de Educação do Estado de São Paulo (CEE/SP).

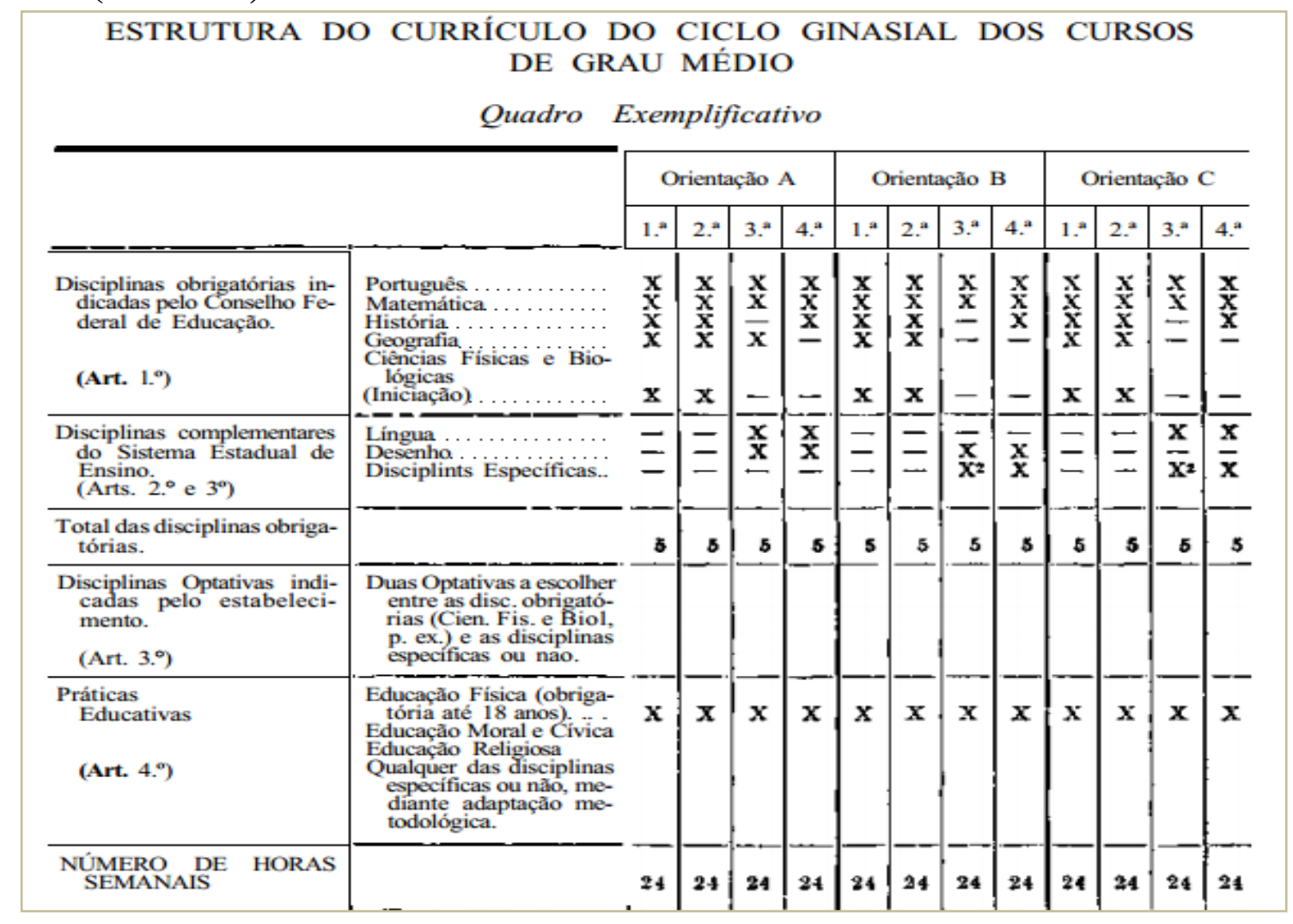

\section{ESTRUTURA DO CURRÍCULO DO CURSO COLEGIAL SECUNDÁRIO Quadro Exemplificativo}

\begin{tabular}{|c|c|c|c|c|c|c|c|c|c|c|}
\hline \multirow{2}{*}{\multicolumn{2}{|c|}{$\begin{array}{l}\text { ORIENTAÇÕES } \\
\text { Séries }\end{array}$}} & \multicolumn{3}{|c|}{ A (Eclético) } & \multicolumn{3}{|c|}{ B (Científico) } & \multicolumn{3}{|c|}{ C (Clássico) } \\
\hline & & 1." & $2 .^{2}$ & 3." & 1." & $2^{a}$ & 3) & $1^{a}$ & 2." & 3..$^{2}$ \\
\hline $\begin{array}{l}\text { Disciplinas obrigatórias indi- } \\
\text { cadas pelo Conselho Fe- } \\
\text { deral de Educaçăo. } \\
\text { (Arts. } 8 \text { e 9) }\end{array}$ & 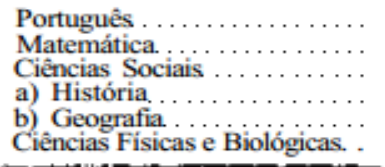 & $\begin{array}{l}\mathbf{x} \\
\mathbf{x} \\
\mathbf{x} \\
- \\
-\end{array}$ & $\begin{array}{l}\stackrel{\mathbf{x}}{\mathbf{x}} \\
\underline{\bar{z}} \\
\overline{\mathbf{x}}\end{array}$ & $\begin{array}{l}x \\
= \\
=\end{array}$ & $\begin{array}{l}\mathbf{x} \\
\mathbf{x} \\
\mathbf{x} \\
\bar{x}\end{array}$ & $\begin{array}{l}\frac{x}{x} \\
\bar{x} \\
\bar{x}\end{array}$ & $\begin{array}{l}\frac{x}{z} \\
\Xi\end{array}$ & $\begin{array}{l}\frac{x}{-} \\
\bar{x} \\
\underline{x}\end{array}$ & $\frac{\frac{x}{x}}{\frac{\pi}{x}}$ & $\begin{array}{l}\frac{x}{z} \\
=\end{array}$ \\
\hline $\begin{array}{l}\text { Disciplinas complementares } \\
\text { do Sistema Estadual. } \\
\text { (Art. 10) }\end{array}$ & $\begin{array}{l}\text { Filosofia } \ldots \ldots \ldots \ldots \ldots \ldots \ldots \\
\text { Línguas } \ldots \ldots \ldots \ldots \ldots \ldots\end{array}$ & $\underset{\mathbf{x}}{\mathbf{x}}$ & $\stackrel{\mathbf{x}}{\mathbf{x}}$ & 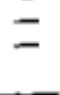 & $\bar{x}$ & $\frac{x}{x}$ & 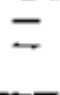 & $\frac{x}{x}$ & $\stackrel{x}{\mathbf{x}}$ & $\bar{z}$ \\
\hline $\begin{array}{l}\text { Total das disciplinas obriga- } \\
\text { tórias. }\end{array}$ & & 5 & 5 & & 5 & 5 & & 5 & 5 & \\
\hline $\begin{array}{l}\text { Disciplinas Optativas indi- } \\
\text { cadas pelo estabelecimento } \\
\text { (Art. 11) }\end{array}$ & $\begin{array}{ll}1^{2} & \text { Optativa } \\
2^{\mathrm{a}} & \text { Optativa }\end{array}$ & & & & & & & & & \\
\hline $\begin{array}{l}\text { Práticas } \\
\text { Educativas } \\
\text { (Art. 12) }\end{array}$ & $\begin{array}{l}\text { Educaçăo Física (obrigatória } \\
\text { até } 18 \text { anos) ............. } \\
\text { Outras }\end{array}$ & $\mathbf{x}$ & $x$ & & $\mathbf{x}$ & $\mathbf{x}$ & & $\mathrm{x}$ & $x$ & \\
\hline $\begin{array}{l}\text { NÚMERO DE HORAS } \\
\text { SEMANAIS }\end{array}$ & & 24 & 24 & 24 & 24 & 34 & 24 & 34 & 24 & 24 \\
\hline
\end{tabular}




\begin{tabular}{|c|c|c|c|c|c|}
\hline \multicolumn{6}{|c|}{$\begin{array}{l}\text { ESTRUTURA DO CURRÍCULO DO CURSO COLEGIAL } \\
\text { INDUSTRIAL DE MÁQUINAS E MOTORES } \\
\text { Quadro Exemplificativo }\end{array}$} \\
\hline & & $\begin{array}{c}1 . .^{\mathrm{a}} \\
\text { serie }\end{array}$ & $\begin{array}{l}2^{a} \\
\text { série }\end{array}$ & $\begin{array}{l}3 .^{\circ} \\
\text { série }\end{array}$ & $\begin{array}{l}4{ }^{2} \\
\text { série }\end{array}$ \\
\hline $\begin{array}{l}\text { Disciplinas do Curso Colegial Secundário } \\
\text { obrigatórias. } \\
\text { (Art. 15) } \\
\text { Disciplina escolhida pelo estabelecimento } \\
\text { (Parágrafo único do artigo 15) }\end{array}$ & 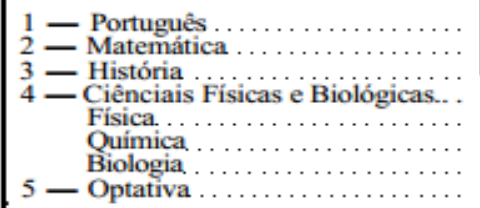 & $\begin{array}{l}\mathbf{x} \\
\mathbf{x} \\
\mathbf{x} \\
\mathbf{x} \\
\mathbf{x}\end{array}$ & $\underset{\mathbf{x}}{\mathbf{x}}$ & $\mathbf{x}$ & 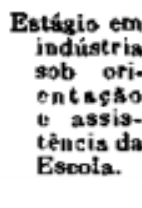 \\
\hline $\begin{array}{l}\text { Disciplinas especificas dos Cursos Colegiais } \\
\text { Técnicos Industriais. } \\
\text { (Parágrafo único do artigo } 9 .^{\circ} \text { ) }\end{array}$ & 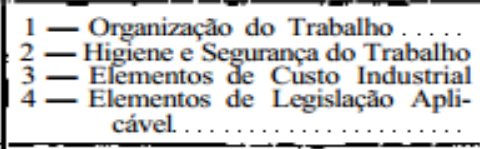 & & & $\begin{array}{l}x \\
x \\
x\end{array}$ & \\
\hline $\begin{array}{l}\text { Disciplinas especificas do Curso Colegial } \\
\text { Técnico Industrial de Máquinas e } \\
\text { motores. } \\
\text { (Art. 9.) }\end{array}$ & 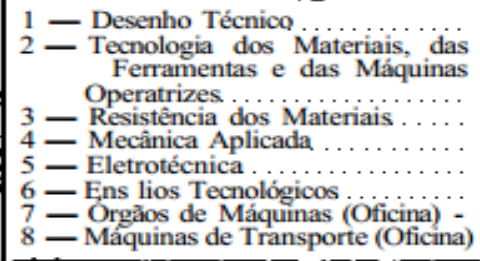 & $\begin{array}{l}\mathbf{x} \\
\mathbf{x} \\
\mathbf{x} \\
\mathbf{x}\end{array}$ & $\begin{array}{l}\mathrm{x} \\
\mathrm{x} \\
\mathrm{x} \\
\mathrm{x} \\
\mathrm{x}\end{array}$ & $\begin{array}{l}\mathrm{x} \\
\mathrm{x} \\
\mathbf{x}\end{array}$ & \\
\hline $\begin{array}{l}\text { Práticas Educativas } \\
\text { (Artigo 20) }\end{array}$ & 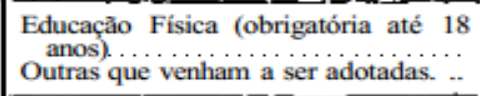 & $\mathbf{x}$ & $x$ & $\mathbf{x}$ & \\
\hline NÚMERO DE HORAS SEMANAIS & & 33 & 33 & 33 & $\rightarrow$ \\
\hline
\end{tabular}

\section{ESTRUTURA DO CURRÍCULO DO CURSO TÉCNICO DE CONTABILIDADE Quadro Exemplificativo}

\begin{tabular}{|c|c|c|c|}
\hline & 1. a série & 2." série & 3. série \\
\hline $\begin{array}{l}\text { Disciplinas do colégio secundário in- } \\
\text { dicadas pelo Conselho Estadual } \\
\text { de Educação. } \\
\text { (Art. 23) }\end{array}$ & $\begin{array}{l}1 \text { - Português } \\
2 \text {-- Matemática }\end{array}$ & $\begin{array}{l}1 \text { - Português } \\
2 \text { - Matemática } \\
3 \text { - Geografia }\end{array}$ & $\begin{array}{l}1 \text {-- Português } \\
2 \text {-- História }\end{array}$ \\
\hline $\begin{array}{l}\text { Disciplina escolhida pelo estabele- } \\
\text { cimento. } \\
\left.\text { (Art. } 23, \S 11^{\circ}\right)\end{array}$ & 3-- Optativa & 4- Optativa & \\
\hline $\begin{array}{l}\text { Disciplinas especificas do ensino téc- } \\
\text { nico comercial. } \\
\text { (Art. 24) }\end{array}$ & $\begin{array}{c}\text { ContabilidadeGeral, } \\
\text { Comercial e Le- } \\
\text { gislaçào Fiscal } \\
5 \text { - - Elementos de Di- } \\
\text { reito } \\
6 \text { - - Elementos de Eco- } \\
\text { nomia } \\
7 \text { - - Organização e Ad- } \\
\text { ministração de } \\
\text { Empresas }\end{array}$ & $\begin{array}{l}\text { 5- Contabilidade Geral } \\
\text { e Legislaçăo Fisca! } \\
\text { 6- Contabilidade In- } \\
\text { dustrial e Legis- } \\
\text { laçâo Fiscal } \\
7 \text { - Elementos de Di- } \\
\text { reito }\end{array}$ & 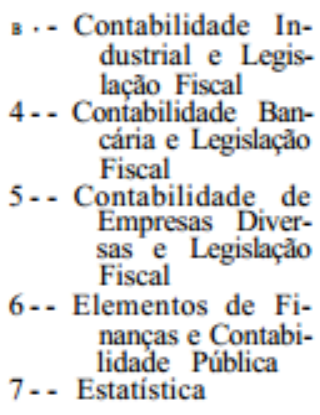 \\
\hline $\begin{array}{l}\text { Disciplina optativa. } \\
\text { (Art. 25) }\end{array}$ & \multicolumn{3}{|c|}{ Uma dentre a relação apresentada } \\
\hline $\begin{array}{l}\text { Práticas Educativas. } \\
\text { (Art. 28) }\end{array}$ & \multicolumn{3}{|c|}{$\begin{array}{l}\text { Educação Física (obrigatória até } 18 \text { anos nos cursos diumos) } \\
\text { Outras dentre a relaçăo apresentada }\end{array}$} \\
\hline Número de aulas. & \multicolumn{3}{|c|}{24 para os cursos diurnos e 20 pará os noturnos } \\
\hline
\end{tabular}




\begin{tabular}{|c|c|c|c|}
\hline \multirow[t]{2}{*}{ ESTRUTURA DO } & \multicolumn{2}{|c|}{$\begin{array}{c}\text { ÍCULO DO CURSO TÉCN } \\
\text { Quadro Exemplificativo }\end{array}$} & \multirow{2}{*}{$\begin{array}{l}\text { SECRETARIADO } \\
\text { 3. série }\end{array}$} \\
\hline & $I^{a}$ série & $2 . *$ série & \\
\hline $\begin{array}{l}\text { Disciplinas do curso colegial secun- } \\
\text { dário indicadas pelo Conselho Es- } \\
\text { tadual de Educação. } \\
\text { (Art. 20) }\end{array}$ & $\begin{array}{l}1 \text { - Português } \\
2 \text { - Matemática }\end{array}$ & $\begin{array}{l}1 \text { - Português } \\
2 \text { 二 Matemática } \\
3 \text { - Geografia }\end{array}$ & $\begin{array}{l}1 \text { - Português } \\
2-\text { História }\end{array}$ \\
\hline $\begin{array}{l}\text { Disciplina escolhida pelo estabele- } \\
\text { cimento. } \\
\text { (Art. 23, \& 1.9) }\end{array}$ & 3 - Optativa & 4 - Optativa & 3 - Optativa \\
\hline $\begin{array}{l}\text { Disciplinas especificas do ensino téc- } \\
\text { nico comercial. } \\
\text { (Art. 26) }\end{array}$ & $\begin{array}{l}4 \text { - Elementos de Di- } \\
\text { reito } \\
5 \text { - Estudos Sócio-Eco- } \\
\text { nomicos } \\
6 \text { - Elementos de Orga- } \\
\text { nizaçào e Admi- } \\
\text { nistração de Em- } \\
\text { presas }\end{array}$ & $\begin{array}{l}5 \text { - Contabilidade Geral } \\
6 \text { - Esteno-Dactilogra- } \\
\text { fia } \\
7 \text { - Psicologia das Re- } \\
\text { lações Humanas }\end{array}$ & $\begin{array}{c}\text { 4 - Elementos de Esta- } \\
\text { tatística } \\
5 \text { - Elementos de Orga- } \\
\text { nizaçăo e Admi- } \\
\text { nistração de Bi- } \\
\text { bliotecas e Ar- } \\
\text { quivos } \\
6 \text { - Relaçôs Humanas } \\
\text { no Trabalho } \\
7 \text { - Prática Profissional }\end{array}$ \\
\hline $\begin{array}{l}\text { Disciplina optativa. } \\
\text { (Art. 26, } \$ 2^{\circ} \text { ) }\end{array}$ & & $\begin{array}{l}\text { Uma dentre a relação } \\
\text { apresentada }\end{array}$ & \\
\hline $\begin{array}{l}\text { Práticas educativas. } \\
\text { (Art. 28) }\end{array}$ & \multicolumn{3}{|c|}{$\begin{array}{l}\text { Educação Fisica (obrigatória até } 18 \text { anos aos cursos diumos) } \\
\text { Outras dentre a relaçăo apresentada }\end{array}$} \\
\hline Número de aulas & \multicolumn{3}{|l|}{$\begin{array}{l}24 \text { para os cursos diurnos } \\
20 \text { pará os cursos noturnos }\end{array}$} \\
\hline
\end{tabular}

\begin{tabular}{|c|c|c|c|c|}
\hline \multicolumn{5}{|c|}{$\begin{array}{c}\text { ESTRUTURA DO CURRÍCULO DA ESCOLA NORMAL } \\
\text { Quadro Exemplificativo }\end{array}$} \\
\hline & & $\begin{array}{l}1 . .^{a} \\
\text { série }\end{array}$ & $\begin{array}{l}2 .^{\mathrm{a}} \\
\text { série }\end{array}$ & $\begin{array}{l}3 .{ }^{a} \\
\text { série }\end{array}$ \\
\hline $\begin{array}{l}\text { Disciplinas obrigatórias comuns ao segundo } \\
\text { ciclo de ensino médio } \\
\text { (Art. 29) }\end{array}$ & 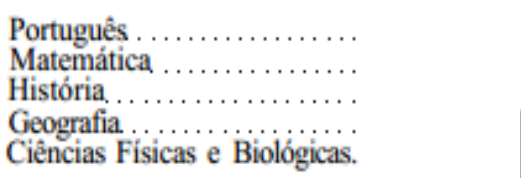 & $\frac{x}{\frac{x}{x}}$ & $\begin{array}{l}\mathrm{x} \\
\stackrel{x}{\mathrm{x}} \\
\leftarrow\end{array}$ & $\begin{array}{l}\frac{x}{x} \\
\frac{-}{-}\end{array}$ \\
\hline $\begin{array}{l}\text { Disciplinas complementares do Sistema Es- } \\
\text { tadual. } \\
\text { (Art. 30) }\end{array}$ & $\begin{array}{l}\text { Metodologia e Prática do Ensino Primário } \\
\text { Psicologia da Educaçăo } \ldots \ldots \ldots \ldots \ldots \ldots \\
\text { Sociologia da Educação } \ldots \ldots \ldots \ldots \ldots \ldots \\
\text { Biologia Educacional ................. }\end{array}$ & $\begin{array}{l}\mathbf{x} \\
\frac{\mathbf{x}}{-} \\
-\end{array}$ & $\frac{\stackrel{x}{x}}{\bar{x}}$ & $\begin{array}{l}\mathrm{x} \\
\mathbf{x} \\
\mathrm{X} \\
-\end{array}$ \\
\hline Total das disciplinas obrigatórias. & & 5 & 5 & 6 \\
\hline $\begin{array}{l}\text { Disciplinas Optativas indicadas pelo estabe- } \\
\text { lecimento. } \\
\text { (Art. 31) }\end{array}$ & Uma ou duas dentre a relação apresentada & & & \\
\hline $\begin{array}{l}\text { Práticas Educativas } \\
\text { (Art 32) }\end{array}$ & $\begin{array}{l}\text { Educação Física (obrigatória até } 18 \text { anos).. } \\
\text { Outras, dentre a relação apresentada }\end{array}$ & $\mathbf{x}$ & $\mathbf{x}$ & $\mathbf{x}$ \\
\hline $\begin{array}{l}\text { Número de horas semanais, não computado } \\
\text { o estágio obrigatório. }\end{array}$ & & 24 & 24 & 24 \\
\hline
\end{tabular}

Fonte: REVISTA BRASILEIRA DE ESTUDOS PEDAGÓGICOS. V.44, n.100, 1965, p. 108-11. 


\section{ANEXO VI - Quadro de Conteúdos Programáticos de Física na Reformulação de Currículos - $2^{\circ}$ Grau do Rio de Janeiro (1977).}

\begin{tabular}{|c|c|c|}
\hline OBJETIVOS & $\begin{array}{l}\text { CONTEÚDOS } \\
\text { PROGRAMÁTICOS }\end{array}$ & SUGESTÕES DE ESTRATÉGIAS \\
\hline $\begin{array}{l}\text { Ao término do estudo das diferentes unidades, o } \\
\text { aluno deve estar apto para: } \\
\text { - Conceituar a Física como Ciência da Natureza. } \\
\text { - Diferenciar um fenômeno físico de um químico } \\
\text { ou biológico. } \\
\text { - Avaliar os resultados de uma medição, sabendo } \\
\text { representá-los em notação científica (potências de } \\
\text { 10). } \\
\text { - Operar com potências de } 10 \text {. } \\
\text { - Conhecer as unidades fundamentais do SI. } \\
\text { - Efetuar operações simples de medidas, levando } \\
\text { em conta os seus algarismos significativos. } \\
\text { - Idealizar um modelo simples para representar } \\
\text { um determinado fenômeno. } \\
\text { - Expressar matematicamente uma lei física, } \\
\text { conhecida as relações de dependência entre as } \\
\text { grandezas relevantes ("a menos" da constante de } \\
\text { proporcionalidade). } \\
\text { - Construir tabelas com dados extraídos de } \\
\text { experiências simples. } \\
\text { - Usar corretamente o papel milimetrado ou } \\
\text { similar na construção de gráficos. } \\
\text { - Interpretar gráficos simples. } \\
\text { - Resolver problemas. }\end{array}$ & $\begin{array}{l}\text { 2. As Leis Físicas e suas } \\
\text { Representações } \\
\text { - As Leis da Física e a simplicidade } \\
\text { dos modelos que as representam. } \\
\text { - Abscissas retilíneas e curvilíneas. } \\
\text { - O Sistema Cartesiano e sua } \\
\text { adaptação à representação de uma } \\
\text { lei. } \\
\text { - Construção de tabelas. } \\
\text { - Representação gráfica de tabelas: } \\
\text { gráficos e escalas }\end{array}$ & $\begin{array}{l}\text { O Professor poderá: } \\
\text { - Familiarizar o aluno com o vocabulário } \\
\text { específico, através de leituras de texto sobre } \\
\text { Física, em revistas e jornais. } \\
\text { - Promover discussões sobre a importância da } \\
\text { Física e seu relacionamento com as demais } \\
\text { Ciências da Natureza, a partir da projeção de } \\
\text { slides e filmes. } \\
\text { - Com a participação dos alunos, fazer } \\
\text { medições de deslocamentos e intervalo de } \\
\text { tempo, com uso do "metro" e de um } \\
\text { cronômetro (por exemplo: queda dos corpos). } \\
\text { Aplicar as conclusões ao embasamento teórico. } \\
\text { - Comparar os resultados de uma mesma } \\
\text { medição feita com diferentes instrumentos de } \\
\text { medida. } \\
\text { - Criar condições para que os alunos façam } \\
\text { experiências sobre movimento uniforme e } \\
\text { uniformemente variado, construindo tabelas, } \\
\text { confeccionando gráficos, interpretando-os e } \\
\text { discutindo sua validade de acordo com o } \\
\text { embasamento teórico original. } \\
\text { - Levar à análise de dados já tabulados, } \\
\text { confeccionando gráficos, interpretando-os e } \\
\text { discutindo sua validade sempre através das } \\
\text { hipóteses iniciais e do seu conteúdo formal. }\end{array}$ \\
\hline $\begin{array}{l}\text { - Conhecer as subdivisões da Mecânica. } \\
\text { - Definir Cinemática Escalar, conhecendo suas } \\
\text { limitações. } \\
\text { - Definir trajetória relativamente a um dado } \\
\text { referencial. } \\
\text { - Interpretar um gráfico tempo x velocidade e } \\
\text { concluir sobre aceleração. } \\
\text { - Calcular as variações de posição e aceleração. } \\
\text { - Resolver problemas sobre movimento no plano. }\end{array}$ & 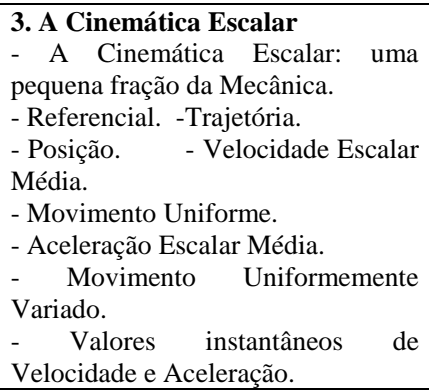 & $\begin{array}{l}\text { - Utilizar os conceitos desta unidade e o } \\
\text { material elaborado pelos alunos, durante o } \\
\text { desenvolvimento da unidade anterior, para } \\
\text { "comprovar" o modelo teórico adotado. } \\
\text { - Retornar às experiências anteriores, agora } \\
\text { com modelos mais representativos. }\end{array}$ \\
\hline $\begin{array}{l}\text { - Operar com vetores gráfica e analiticamente. } \\
\text { - Enunciar as leis de Newton-Galileu. } \\
\text { - Isolar corpos em interações simples. } \\
\text { - Definir momentum linear e impulsão. } \\
\text { - Relacionar a impulsão à variação do momentum } \\
\text { linear. } \\
\text { Resolver problemas sobre: } \\
\text { - Cálculo da resultante de um sistema de forças. } \\
\text { - Segunda lei de Newton-Galileu. } \\
\text { - Estática da partícula. } \\
\text { - Conservação do momentum. }\end{array}$ & $\begin{array}{l}\text { 4. A Dinâmica da Partícula } \\
\text { - Vetores. } \\
\text { - Deslocamentos. } \\
\text { - Velocidade média (vetorial). } \\
\text { - Aceleração média (vetorial). } \\
\text { - Representação de valores } \\
\text { instantâneos na trajetória. } \\
\text { - As leis de Newton-Galileu. } \\
\text { - Força e Movimento. } \\
\text { - Momentum Linear (quantidade de } \\
\text { movimento e impulsão). } \\
\text { - Teorema da conservação do } \\
\text { momentum linear. } \\
\text { - Partículas com aceleração nula } \\
\text { (estática da partícula. } \\
\text { - Hidrostática (optativo). }\end{array}$ & $\begin{array}{l}\text { - Desenvolver um plano de trabalho sobre } \\
\text { teoria dos vetores, integrando os conceitos com } \\
\text { os professores de matemática. } \\
\text { - Fornecer os subsídios para as experiências } \\
\text { usuais sobre medição de força com o auxílio do } \\
\text { dinamômetro. } \\
\text { - Organizar um quadro mural que demonstre a } \\
\text { utilização da dinâmica na vida diária. }\end{array}$ \\
\hline $\begin{array}{l}\text { - Definir trabalho mecânico de uma força de } \\
\text { módulo e direção constantes. } \\
\text { - Enunciar e aplicar o teorema da variação da } \\
\text { energia cinética em situações simples. } \\
\text { - Definir referencial do centro de massa (RCM). } \\
\text { - Caracterizar os choques mecânicos utilizando os } \\
\text { teoremas de conservação de momentum e energia } \\
\text { cinética. } \\
\text { - Resolver problemas e interpretar gráficos. }\end{array}$ & $\begin{array}{l}\text { 5. A Energia } \\
\text { - A Energia: um conceito primitivo. } \\
\text { - As diversas formas de energia. } \\
\text { - Trabalho e Potência. - A Energia } \\
\text { Cinética. } \\
\text { - A Energia Potencial Gravitacional. } \\
\text { - Teorema da Variação da Energia } \\
\text { Cinética. } \\
\text { - Interações Unidimensionais } \\
\text { (referencial do centro de massa). }\end{array}$ & $\begin{array}{l}\text { - Auxiliar os alunos a elaborar "guias" para as } \\
\text { experiências sobre conservação da energia } \\
\text { mecânica e demonstrar a validade do modelo } \\
\text { matemático para as leis. } \\
\text { - Criar condições para aplicação prática da } \\
\text { Física, numa pequena Feira de Ciências. } \\
\text { - Dinamizar o processo ensino-aprendizagem } \\
\text { pela projeção de slides e filmes. }\end{array}$ \\
\hline
\end{tabular}

Continua... 


\section{Continuação}

\begin{tabular}{|c|c|c|}
\hline OBJETIVOS & $\begin{array}{l}\text { CONTEÚDOS } \\
\text { PROGRAMÁTICOS }\end{array}$ & SUGESTÕES DE ESTRATÉGIAS \\
\hline $\begin{array}{l}\text { - Enunciar a Lei de Newton da Gravitação } \\
\text { Universal, sabendo interpretá-la qualitativamente } \\
\text { e quantitativamente. } \\
\text { - Enunciar as Leis de Kepler. } \\
\text { - Resolver problemas sobre: } \\
\text { - forças que atuam sobre um satélite (modelo } \\
\text { simples) em órbita circular. } \\
\text { - intensidade de campo gravitacional. } \\
\text { - peso dos corpos. }\end{array}$ & $\begin{array}{l}\text { 6. A Gravitação Universal } \\
\text { - Histórico. } \\
\text { - A Lei de Newton da Gravitação } \\
\text { Universal. } \\
\text { - As Leis de Kepler. } \\
\text { - A Força Centrípeta. } \\
\text { - Movimentos de satélites em } \\
\text { órbitas circulares. } \\
\text { - Os vôos espaciais e sua } \\
\text { contribuição para a Humanidade. }\end{array}$ & $\begin{array}{l}\text { - Utilizar-se da noção básica de campo de força } \\
\text { e, a partir daí, caracterizar o campo } \\
\text { gravitacional como um campo de força de } \\
\text { interação da forma } 1 / \mathrm{d}^{2} \text {. } \\
\text { - Debater sobre as contribuições da conquista } \\
\text { do espaço a partir de artigos impressos, filmes, } \\
\text { slides, etc. }\end{array}$ \\
\hline $\begin{array}{l}\text { - Calcular a posição do centro de massa de } \\
\text { sólidos homogêneos de formas simples. } \\
\text { - Calcular o momento de forças em relação a um } \\
\text { ponto. } \\
\text { - Resolver problemas simples de estática de corpo } \\
\text { rígido. } \\
\text { - Calcular massa específica, dada a massa e o } \\
\text { volume de uma substância. } \\
\text { - Calcular a pressão em ponto devido ao apoio de } \\
\text { sólidos em equilíbrio. } \\
\text { - Interpretar graficamente e resolver problemas } \\
\text { simples sobre os princípios de Pascal e } \\
\text { Arquimedes e sobre o Teorema de Stevin. } \\
\text { - Resolver problemas sobre equilíbrio de corpos } \\
\text { flutuantes. }\end{array}$ & $\begin{array}{l}\text { 7. Sistema de muitas partículas } \\
\text { (sólido) } \\
\text { - Centro de massa de um sólido. } \\
\text { - Momento de forças coplanares. } \\
\text { - Estática (condições de equilíbrio } \\
\text { de um corpo rígido). } \\
\text { 8. Sistema de muitas partículas } \\
\text { (Líquido) } \\
\text { - Massa específica. - Pressão. } \\
\text { - Pressão em um fluido em } \\
\text { equilíbrio. } \\
\text { - Teoremas de Stevin. } \\
\text { - Princípios de Pascal e } \\
\text { Arquimedes. } \\
\text { - Equilíbrio de corpos flutuantes. }\end{array}$ & $\begin{array}{l}\text { O professor poderá: } \\
\text { - Promover discussões sobre as melhores } \\
\text { formas de sustentação dos corpos rígidos, em } \\
\text { especial apoios simples e articulações. } \\
\text { - Procurar na construção civil material para que } \\
\text { seja compreendido o conteúdo da unidade. } \\
\text { - Por meio de experiências simples sobre o } \\
\text { conteúdo apresentado, em especial, } \\
\text { experiências com tubo em “ U”, vasos } \\
\text { comunicantes sob a forma de prensas e } \\
\text { macacos hidráulicos, evidenciar a utilização } \\
\text { prática da Hidrostática. }\end{array}$ \\
\hline $\begin{array}{l}\text { - Entender diferença entre calor e temperatura. } \\
\text { - Relacionar temperaturas nas principais escalas } \\
\text { termométricas. } \\
\text { - Resolver problemas simples de calorimetria. } \\
\text { - Entender o funcionamento dos "Calorímetros" } \\
\text { domiciliares. } \\
\text { - Caracterizar por gráfico temperatura-tempo uma } \\
\text { evolução da fase sólida a vapor de uma } \\
\text { determinada substância. }\end{array}$ & $\begin{array}{l}\text { 9. A Energia Térmica } \\
\text { - Temperatura. } \\
\text { - Escalas termométricas. } \\
\text { - Calorimetria. } \\
\text { - Mudança de fase. }\end{array}$ & $\begin{array}{l}\text { - Familiarizar os alunos com leituras de } \\
\text { temperaturas nas diversas escalas através do } \\
\text { uso dos termômetros clínicos e de "máxima e } \\
\text { mínima". } \\
\text { - Fazer experiências sobre mudança de fase } \\
\text { usando por exemplo a água. Aplicar as } \\
\text { conclusões ao embasamento teórico. }\end{array}$ \\
\hline $\begin{array}{l}\text { Ao término do capítulo o aluno deve ser apto } \\
\text { para: } \\
\text { - Enunciar as leis gerais da ótica. } \\
\text { - Saber de suas limitações. } \\
\text { - Enunciar e aplicar as leis da Reflexão e } \\
\text { Refração: construção dos raios luminosos. } \\
\text { - Resolver problemas simples e práticos sobre } \\
\text { lentes e espelhos. } \\
\text { - Conhecer a ótica elementar do olho humano } \\
\text { (principais defeitos de visão e suas correções). }\end{array}$ & $\begin{array}{l}\text { 10. Ótica Geométrica } \\
\text { - Princípios - Reflexão e Refração } \\
\text { (reflexão total). } \\
\text { - Espelhos planos. } \\
\text { - Espelhos esféricos. } \\
\text { - Lentes esféricas finas. } \\
\text { - O olho humano. }\end{array}$ & $\begin{array}{l}\text { - fazer experiências com o "banco ótico" } \\
\text { levando os alunos a determinarem posições e } \\
\text { características de imagens. } \\
\text { - Por meio da promoção de palestras sobre a } \\
\text { ótica elementar do olho humano familiarizar os } \\
\text { alunos com os principais com os principais } \\
\text { defeitos de visão, sua correção e os métodos } \\
\text { preventivos. }\end{array}$ \\
\hline $\begin{array}{l}\text { - Resolver problemas envolvendo os } \\
\text { conhecimentos práticos da frequência, } \\
\text { velocidade, comprimento de onda e período ( v = } \\
\text { ג.f e } \lambda=\text { v.t). } \\
\text { - Aplicar o princípio da superposição. } \\
\text { - Trabalhar num tanque de ondas analisando o } \\
\text { movimento de ondas circulares (reflexão, } \\
\text { refração, interferência e difração). } \\
\text { - Interpretar a experiência de dispersão num } \\
\text { prisma. } \\
\text { - Consolidar os conhecimentos obtidos na } \\
\text { aplicação do princípio da superposição. } \\
\text { - Dado um pulso triangular que se propaga com } \\
\text { velocidade conhecida em um meio não } \\
\text { dispersivo, construir os gráficos posição-tempo, } \\
\text { velocidade-tempo, velocidade-posição num dado } \\
\text { instante. } \\
\text { - Sintetizar um pulso triangular. }\end{array}$ & $\begin{array}{l}\text { 11. Fenômenos Ondulatórios } \\
\text { - Propagação de uma onda senoidal. } \\
\text { - Ondas no tanque de ondas. } \\
\text { - Modelo ondulatório da luz. } \\
\text { - Luz branca: dispersão. } \\
\text { - Princípios da superposição. } \\
\text { 12. Pulsos triangulares } \\
\text { - Formação e elementos. } \\
\text { - Movimento transverso. } \\
\text { - Análise Gráfica (superposição). }\end{array}$ & $\begin{array}{l}\text { - Fornecer subsídios para que os alunos } \\
\text { construam um tanque de ondas para estudos } \\
\text { das propagações de ondas. } \\
\text { - Com o auxílio das cordas grossas ou molas } \\
\text { estudar com os alunos a formação de pulsos e } \\
\text { ondas senoidais. } \\
\text { - Com o auxílio de cordas pesadas e vibradoras } \\
\text { em movimento uniforme poderá conseguir } \\
\text { pulsos aproximadamente triangulares. Usando } \\
\text { para observação do movimento transverso fitas } \\
\text { amarradas em pontos da corda. } \\
\text { - Por meio de projeção de filmes e slides } \\
\text { comparar os resultados obtidos com os modelos } \\
\text { projetados em classe. }\end{array}$ \\
\hline
\end{tabular}

\section{Continua ...}


Conclusão.

\begin{tabular}{|c|c|c|}
\hline OBJETIVOS & $\begin{array}{l}\text { CONTEÚDOS } \\
\text { PROGRAMÁTICOS }\end{array}$ & SUGESTÕES DE ESTRATÉGIAS \\
\hline $\begin{array}{l}\text { - Conhecer fatos fundamentais relativos à } \\
\text { constituição da matéria. } \\
\text { - Dizer quando ou não um corpo está carregado. } \\
\text { - Relacionar as partículas básicas quanto a ordem } \\
\text { de grandeza de suas massas relativas. } \\
\text { - Identificar os materiais condutores e isolantes } \\
\text { comumente usados no dia-a-dia. } \\
\text { - Enunciar a Lei de Du-Fay e aplicá-la a casos } \\
\text { simples. } \\
\text { Ao término do capítulo o aluno deve estar apto } \\
\text { para: } \\
\text { - Conhecer a Lei de Coulomb verbal e } \\
\text { analiticamente. } \\
\text { - Identificar na lei as grandezas relacionadas. } \\
\text { - Saber como varia a força entre cargas quando } \\
\text { variamos as grandezas relevantes. } \\
\text { - Entender a supremacia, em termos de força, do } \\
\text { campo elétrico sobre o gravitacional. } \\
\text { - Resolver problemas sobre a Lei de Coulomb. } \\
\text { - Definir d.d.p. enter dois pontos de um campo. } \\
\text { - Descrever o que ocorre com os elétrons e os } \\
\text { íons positivos nos condutores quando submetidos } \\
\text { a uma d.d.p. } \\
\text { - Fazer medições com um voltímetro. }\end{array}$ & $\begin{array}{l}\text { 13. Constituição da matéria } \\
\text { - O elétron. } \\
\text { - O próton. } \\
\text { - O nêutron. } \\
\text { - Condutores e isolantes. } \\
\text { - Lei de Du-Fay. } \\
\text { 14. Lei de Coulomb } \\
\text { - Campos de Forças. } \\
\text { - Campo Coulombiano. } \\
\text { - Comparação entre as estruturas } \\
\text { isomorfas do campo gravitacional e } \\
\text { do campo elétrico. } \\
\text { - Experiência de Cavendish. } \\
\text { 15. Diferença de Potencial } \\
\text { Elétrico } \\
\text { - Conceito de Diferença de } \\
\text { Potencial Elétrico. } \\
\text { - O potencial de um ponto num } \\
\text { campo elétrico. } \\
\text { - O potencial da Terra e de um } \\
\text { ponto no infinito. } \\
\text { - Condutores submetidos a d.d.p. }\end{array}$ & $\begin{array}{l}\text { O professor poderá: } \\
\text { - Criar condições para que os alunos construam } \\
\text { modelos de átomos. } \\
\text { - A partir da projeção de slides e filmes discutir } \\
\text { fatos fundamentais sobre a constituição da } \\
\text { matéria. } \\
\text { - Criar condições para que os alunos } \\
\text { determinem se um material é condutor ou } \\
\text { isolante. } \\
\text { - Com a participação dos alunos, fazer } \\
\text { experiências simples sobre eletrização. } \\
\text { - Criar condições para que os alunos façam } \\
\text { experiências com a balança de torção } \\
\text { comprovando a Lei de Coulomb. } \\
\text { - Criar condições para experiências simples de } \\
\text { atração de corpos neutros por corpos } \\
\text { eletrizados para que os alunos apliquem a Lei } \\
\text { de Coulomb, após a redistribuição de cargas no } \\
\text { corpo neutro. } \\
\text { - Mostrar através do cálculo a irrelevância da } \\
\text { constante da Lei de Newton em relação à } \\
\text { constante da Lei de Coulomb, levando os } \\
\text { alunos a compararem a força do campo } \\
\text { gravitacional com as do campo elétrico. } \\
\text { - Por meio das analogias eletromecânicas } \\
\text { "quebrar" um pouco a "abstração" dos } \\
\text { conceitos da eletricidade. } \\
\text { - Criar condições para que os alunos realizem } \\
\text { medições de d.d.p. com aparelhagem adequada. }\end{array}$ \\
\hline $\begin{array}{l}\text {-Enunciar a Lei de Ohm e Lei de Joule, sabendo } \\
\text { identificar as grandezas relacionadas. } \\
\text { - Interpretar o gráfico tensão-corrente de um } \\
\text { elemento passivo. } \\
\text { - Saber calcular os gastos de energia sabendo o } \\
\text { n. }{ }^{\circ} \text { de KWh e o preço do mesmo. } \\
\text { - Aplicar na prática as associações de resistores. } \\
\text { - Fazer medições com Amperímetro e Voltímetro. }\end{array}$ & $\begin{array}{l}\text { 16. Corrente Elétrica } \\
\text { - Finalidade dos geradores. } \\
\text { - Resistores Lineares (Lei de Ohm). } \\
\text { - Associação de resistores em série, } \\
\text { em paralelo e mista. } \\
\text { - Energia e Potência (efeito joule e } \\
\text { Lei de Joule). } \\
\text { - Circuitos simples. }\end{array}$ & $\begin{array}{l}\text { - Criar condições para que os alunos montem } \\
\text { circuitos simples com o auxílio de pilhas, } \\
\text { lâmpadas, chaves, etc. } \\
\text { - Utilizar os circuitos simples para conclusões } \\
\text { teóricas usando valores específicos. }\end{array}$ \\
\hline $\begin{array}{l}\text { - Resolver problemas sobre circuitos simples, } \\
\text { calculando: } \\
\text { - d.d.p. entre dois pontos - intensidade de } \\
\text { corrente } \\
\text { - energia dissipada - potência associada. } \\
\text { - Construir circuitos simples com um certo } \\
\text { número de elementos. } \\
\text { - Demonstrar o conhecimento operacional de } \\
\text { certas atitudes básicas frente a problemas } \\
\text { elementares na vida diária, relacionando com } \\
\text { circuitos, a saber: } \\
\text { - ligar lâmpadas - evitar curto-circuitos - } \\
\text { trocar fusíveis } \\
\text { - evitar choques, etc. }\end{array}$ & $\begin{array}{l}\text { 17. Geradores } \\
\text { - Força eletromotriz de um gerador. } \\
\text { - Energia fornecida. - Potência. } \\
\text { - Rendimento. } \\
\text { - Associação de geradores iguais. } \\
\text { - Circuitos simples. } \\
\text { 18. Circuitos elementares } \\
\text { - Conhecimento operacional. }\end{array}$ & $\begin{array}{l}\text { - Por meio da projeção de slides e filmes, } \\
\text { mostrar as diversas formas de utilizações de } \\
\text { energia elétrica na vida cotidiana. } \\
\text { - Familiarizar os alunos com o manuseio de } \\
\text { resistores, inclusive montagem e desmontagem } \\
\text { de um ferro ou chuveiro elétrico. } \\
\text { - Mostrar circuitos em curto para que os alunos } \\
\text { sintam os perigos das ligações mal feitas, } \\
\text { mostrando como evitar e porque ocorre curtos- } \\
\text { circuitos. }\end{array}$ \\
\hline $\begin{array}{l}\text { - Associar um campo uniforme a duas } \\
\text { distribuições planas e paralelas de cargas. } \\
\text { - Saber aplicar o princípio da superposição. } \\
\text { - Resolver problemas de movimentos de cargas } \\
\text { em campos uniformes. }\end{array}$ & $\begin{array}{l}\text { 19. Campo Elétrico Uniforme } \\
\text { - Superfícies equipotenciais. } \\
\text { - Diferença de potencial entre dois } \\
\text { pontos do campo. } \\
\text { - Movimento de uma carga em um } \\
\text { campo elétrico uniforme. }\end{array}$ & $\begin{array}{l}\text { O professor poderá: } \\
\text { - Por meio das analogias com o campo } \\
\text { gravitacional nas proximidades da Terra } \\
\text { determinar as propriedades do campo elétrico } \\
\text { nas vizinhanças de uma distribuição plana de } \\
\text { carga. }\end{array}$ \\
\hline $\begin{array}{l}\text { - Usar a agulha imantada, ou uma bússola. } \\
\text { - Determinar as características do campo } \\
\text { magnético de um ímã usando a bússola. } \\
\text { - Determinar as características do campo } \\
\text { magnético terrestre. }\end{array}$ & $\begin{array}{l}\text { 20. Campo Magnético } \\
\text { - Campo magnético terrestre. } \\
\text { - Bússola. }\end{array}$ & $\begin{array}{l}\text { - Familiarizar os alunos com os ímãs, fazendo } \\
\text { com que utilizem corretamente a bússola com } \\
\text { elemento orientador. }\end{array}$ \\
\hline
\end{tabular}

Fonte: RIO DE JANEIRO, 1977 


\section{ANEXO VII - Amostra de páginas dos manuais analisados}

\section{Projetos de Ensino}

PSSC, Parte III, p. 69

\section{a QUaNTIDADE DE MOVIMENTO E SUA CONSERVaç̃o}

\section{capitulo 20}

\section{3 - 1. Impulso.}

Tente imprimir a mesma velocidade a uma bola de tênis e a um tijolo. Como você sabe, é muito mais difícil mover o tijolo. Se você aplica uma fôrça $\vec{F}$ constante durante o intervalo de tempo $\triangle t$, a variaçāo de velocidade é dada por $m \Delta \vec{v}=\vec{F} \Delta t$. Assim, para obter-se o mesmo $\Delta \vec{v}$, o produto $\vec{F} \Delta t$ deve ser tanto maior quanto maior for a massa $m$ que se está tentando acelerar.

Para mover, a partir do repouso, um tijolo e dar-lhe a mesma velocidade final que a uma bola de tênis (também inicialmente em repouso), precisamos impulsioná-lo, ou com mais fôrça, ou durante mais tempo. O que se deve levar em conta é o produto $\vec{F} \Delta t$, que é a medida natural da intensidade e da duração da fôrça com que empurramos um objeto para variar seu movimento. Esse produto é chamado impulso da fôrça.

Podemos aplicar determinado impulso de diversos modos: aplicando uma fôrça intensa durante pouco tempo, ou uma fôrça menos intensa durante mais tempo, ou mesmo uma fôrça que varia enquanto atua. Na Fig. 23-1, representamos uma fôrça constante $F$ em função do tempo durante o qual ela age. O gráfico é uma linha horizontal de altura $F$ acima do eixo dos tempos e de comprimento $\Delta t=t_{2}-t_{1}$, igual ao tempo durante o qual a fôrça atua. A área do retân-

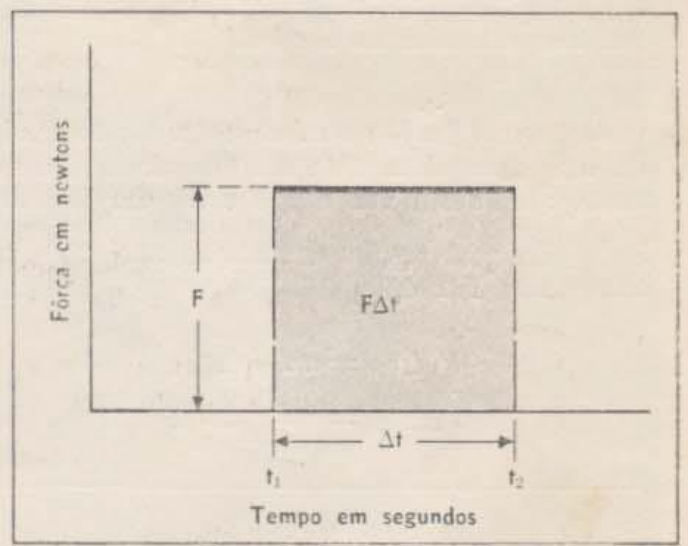

23-1 - Uma força constante $F$ está representada em função do tempo para o intervalo $t_{2}-t=\Delta t$. A área $F \triangle t$, sob a curva, da o impulso desta força no intervalo $\Delta t$.

gulo sob esta linha é $F \triangle t$, valor do impulso durante êsse intervalo de tempo. (A direçấo do impulso é a mesma que a da fôrça). Para qualquer fôrça constante que atue durante qualquer intervalo de tempo, podemos sempre obter o valor do impulso calculando a área limitada pela curva fôrça-tempo para aquêle intervalo.

Suponhamos, agora, que a forçca varie, como na Fig. 23-2. Durante o tempo $\triangle t_{1}$, a fôrça é constante e o impulso é $\vec{F}_{1} \Delta t_{1}$, que produz a 
PSSC, Parte III, p. 70

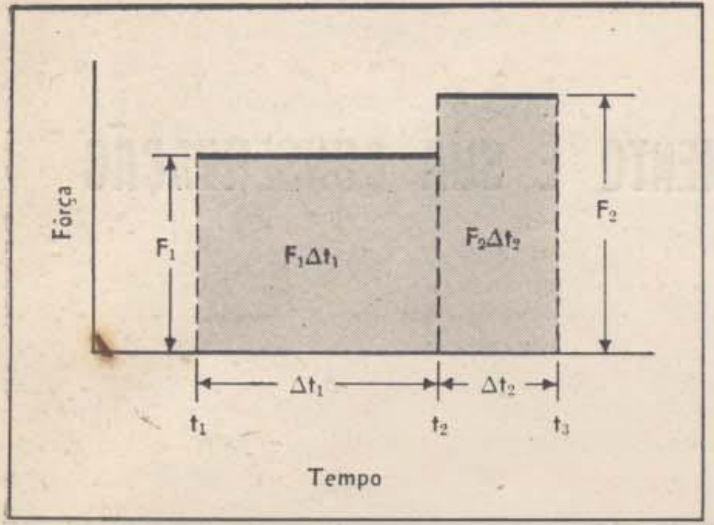

23-2 - A forca e $F_{1}$ no intervalo de tempo $\Delta t_{1}$, muda para $F_{n}$ no intervalo de tempo $\Delta t_{2 *}$ Se o sentido da força não muda, o impulso total no intervalo de tempo $\Delta t_{1}+\Delta t_{2}$ é $F_{1} \Delta t_{1}+F_{2} \Delta t_{2}$, representado pela area sombreada sob a curva.

variação $m(\overrightarrow{\Delta v})_{1}$ no movimento. No intervalo de tempo seguinte $\Delta t_{2}$, a fôrça ainda é constante, mas desta vez é $F_{2}$, e há um impulso $F_{2} \Delta t_{2}$ do qual resulta a variação $m(\overrightarrow{\Delta v})_{2}$ no movimento, Isto é,

$$
\begin{aligned}
& \vec{F}_{1} \Delta t_{1}=m(\overrightarrow{\Delta v})_{1} \\
& \vec{F}_{2} \Delta t_{2}=m(\overrightarrow{\Delta v})_{2}
\end{aligned}
$$

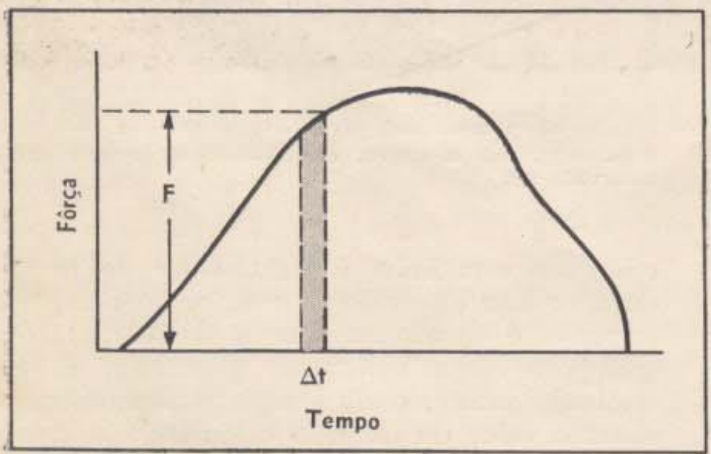

23-3 - Quando a fôrça varia continuamente, podemos decompor a área sob a curva forca versus tempo em um grande número de pequenas áreas que são quase retangulares (veja a área sombreada). Cada área $F \triangle t$ representa um pequeno impulso. O impulso total é a soma de todos esses pequenos impulsos. Portanto, desde que a direção da força permaneça constante, a área sob a curva o impulso total.
Se adicionarmos vetorialmente estas duas igualdades, teremos:

$$
\begin{aligned}
\vec{F}_{1} \Delta t_{1}+\vec{F}_{2} \Delta t_{2} & =m(\overrightarrow{\Delta \vec{v}})_{1}+m(\overrightarrow{\Delta \vec{v}})_{2}= \\
& =m\left[(\Delta \vec{v})_{1}+(\overrightarrow{\Delta v})_{2}\right]
\end{aligned}
$$

Será que podemos reunir os dois impulsos do primeiro membro da equação num único "impulso total"? Vimos anteriormente que impulso é a combinação de fôrça e tempo que produz a variação $\overrightarrow{\Delta v}$ na velocidade de determinada massa. Vemos, agora, que $\vec{F}_{1} \triangle t_{1}+\vec{F}_{2} \triangle t_{2}$ produz a variaçảo de velocidade $\overrightarrow{\Delta v}=\Delta \vec{v}_{1}+$ $\overrightarrow{\Delta v_{2}}$ que ocorre no movimento de $m$ entre a aplicação inicial de $\vec{F}_{1}$ e a remoção da fôrça $\vec{F}_{2}$. Conseqüentemente, a soma $\vec{F}_{1} \triangle t_{1}+\vec{F}_{2} \triangle t_{2}$ é igual ao impulso total durante êsse tempo. Finalmente, desde que $\vec{F}_{1} \Delta t_{1}$ e $\vec{F}_{2} \Delta t_{2}$ são os dois impulsos individuais que agem sôbre $m$ naquele intervalo de tempo, podemos concluir que o vetor soma dos impulsos sucessivos dá o impulso total.

Quando lidamos com uma fôrça que varia continuamente, podemos ainda obter o impulso total adicionando os impulsos relativos a pequenos intervalos de tempo. Podemos tomar cada intervalo de tempo tão pequeno que $\vec{F}$ seja pràticamente constante para cada um dêles. Então, o impulso total, que é a soma de todos os $\vec{F} \Delta t$ dá a variação total $m \overrightarrow{\Delta v}$ no movimento.

Quando a fôrça varia em grandeza, mas tem sempre a mesma direção, podemos adicionar os impulsos determinando a área sob a curva $\vec{F}$ versus $t$. Um caso simples está indicado na Fig. 23-2 e, na Fig. 23-3, temos um exemplo em que a fôrça muda continuamente. Se, entretanto, a fôrça muda de direção, êste método gráfico não é suficiente. Precisamos adicionar os pequenos impulsos $\vec{F} \triangle t$ com suas direções corretas. $\mathrm{O}$ impulso total entre qualquer instante inicial, $t$, e final, $t$, deve ser obtido por adição vetorial, porque cada pequeno impulso causa uma variação $m \Delta \vec{v}=\vec{F} \Delta t$ na direção da fôrça atuante. Este vetor soma dá a variação total $\vec{m} v^{\prime}-\overrightarrow{m v}$ da quantidade de movimento (usa- 
PEF - MECÂNICA 2 (Capítulo 7, p. 03)

A balança mais antiga que se

conhece, descoberta em

uma tumba pré-histórica,

foi construida 7000 anos atrás

no antigo Egito.

A foto ao lado, detalhe

do papiro egípcio do século "

descoberto em Saqqarah -

O Livro dos Mortos de Djoser -

representa a pesagem da alma,

o ritual de julgamento

dos mortos pelos deuses.

Q2 - Se o joalheiro equilibrasse a balança com o anel-modelo em um prato $e$ pequenos cilindros de latão no outro,

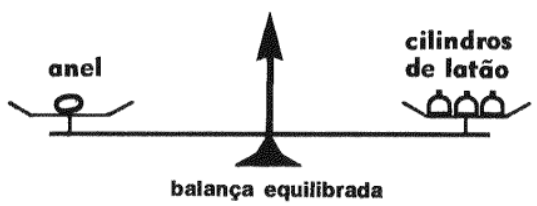

e, em seguida, equilibrasse autra vez a balança com os mesmos cilindros de latão num prato e ouro em pó no

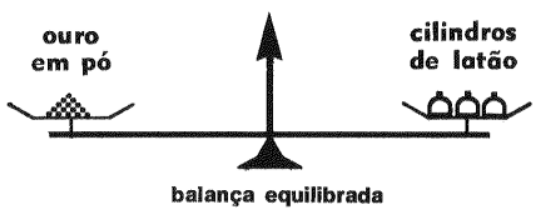

outro, estaria medindo a quantidade de ouro necessária para fazer um anel?

Dois corpos que se equilibram em uma balança de braços iguais têm a mesma massa, ou seja, a mesma quantidade de matéria.

Para que se possa medir as massas dos corpos, é necessário adotar um padrão de

massa; com esse padrão comparamos os corpos cujas massas queremos determinar. O padrão internacional de massa é o cilindro feito de uma liga de platina e irídio, que está guardado no Instituto de Pesos e Medidas, na França; a massa desse cilindro foi arbitrariamente chamada 1 quilograma ( $1 \mathrm{~kg}$ ), e canstitui a unidade de medida de massas.

A massa de um quilograma é igual à massa de 1,000027 litro de água pura (destilada) à temperatura de $4^{\circ} \mathrm{C}$ e pressão de $760 \mathrm{~mm}$ de mercúrio (veja a leitura suplementar do capítulo 3 - "Padrões de medida").

\section{A 2. ${ }^{\text {a }}$ lei de Newton}

Vejamos agora como se relacionam os conceitos de massa e de força. Suponhamos que um mesma corpo seja submetido à ação de forças diferentes. Então, existe uma relação de proporcionalidade entre as forças aplicadas e as acelerações adquiridas pelo corpo em cada caso, como vimos no capítulo 6. Portanto, a equaçãa que relaciona a força F aplicada ao corpo e a aceleração a que ele adquire é $\mathbf{F}=\mathbf{k} \cdot \mathbf{a}$, onde $\mathbf{k}$ é uma constante de proporcionalidade. Essa constante não de- 
PEF - MECÂNICA 2 (Capítulo 7, p. 04)

pende da força aplicada, pois, para um mesmo corpo, a razão $\mathbf{F} / \mathbf{a}$ permanece constante, qualquer que seja a força $\mathbf{F}$ aplicada a ele.

Entretanto, essa constante depende do corpo. Vejamos como é essa dependência. Experiências como as ilustradas na figura 14 do capítulo 6, em que um carrinho é puxado por forças de intensidades diferentes, mostram que a constante $\mathbf{k}$ não depende da forma, da cor, ou de outra propriedade do corpo, mas somente de sua massa.

Vamos verificar como a constante $\mathbf{k}$ se relaciona com a massa do corpo aplicando forças de mesma intensidade a um carrinho que rola sem atrito sobre uma superfície horizontal. Carregando-se o carrinho com massas convenientes podemos fazer com que a massa total seja duplicada, triplicada etc.

Na figura 1 temos três fotografias estroboscópicas do movimento desse carro. Em A a massa é $280 \mathrm{~g}$, em B é $560 \mathrm{~g}$ e em C é $840 \mathrm{~g}$. Nos três casos a força aplicada ao carro tem a mesma intensidade.

Q3 - Quanto valem as acelerações adquiridas pelo carro nos três casos? Utilize a escala da figura.

Q4 - Qual é a razão entre as aceleraçōes nos casos A e B? E nos casos A e C?

Essa experiência mostra que as acelerações adquiridas pelo carro são inversamente proporcionais às suar massas, pois duplicando-se a massa do carrinho, sua aceleraçãa se reduz à metade; triplicando-se a massa, a aceleração se reduz a 1/3 e assim por diante.

Embora as acelerações adquiridas pelo carro sejam diferentes, o produto $\mathbf{k}$. a permanece constante, pois a força aplicada, nos três casos, foi de mesma intensidade. Chamando de $\mathbf{a}_{1}, \mathbf{a}_{2}$ e $\mathbf{a}_{3}$ as acelerações nos casos A, B e C, temos que: $\mathbf{k}_{1} \mathbf{a}_{1}=\mathbf{k}_{2} \mathbf{a}_{2}=\mathbf{k}_{3} \mathbf{a}_{3}$.

Lembrando que $a_{2}=a_{1} / 2$ e $a_{3}=a_{1} / 3$, podemos substituir na relação acima e obte$\operatorname{mos} k_{1} a_{1}=k_{2} a_{1} / 2=k_{3} a_{1} / 3$, portanto,

$$
\mathbf{k}_{2}=2 \mathbf{k}_{1} \text { e } \mathbf{k}_{3}=3 \mathbf{k}_{1} .
$$

Verificamos, portanto, que a razão entre as constantes do carro nos três casos é igual $7-4$

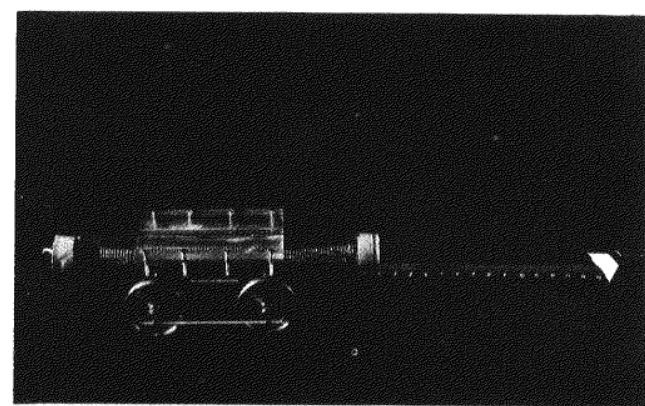

Acima, o carrinho utillzado nas experiênclas mostradas na figura 1.

A massa do conjunto carrinho + bloco de madeira (foto abaixo) é o dobro da do carrinho; a massa do conjunto carrinho +2 blocos de madeira é o triplo.

Nas três experiências, as forças aplicadas foram iguais porque as distensões da mola colocada no tubo de vidro - indicadas pela referência de forma triangula sobre a escala milimetrada — foram iguais.

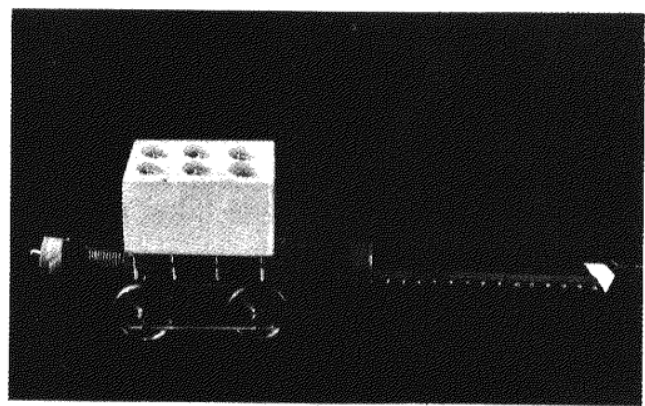

à razão entre suas massas; em outros termos:

$$
\frac{\mathbf{k}_{1}}{\mathbf{k}_{2}}=\frac{\mathbf{m}_{1}}{\mathbf{m}_{2}} \text { e } \frac{\mathbf{k}_{1}}{\mathbf{k}_{3}}=\frac{\mathbf{m}_{1}}{\mathbf{m}_{3}}
$$

Podemos então dizer que a razão $\mathbf{k}$ entre a força e a aceleração de um corpo é proporcional à massa desse corpo. Se escolhermos convenientemente a unidade de força, podemos fazer $\mathbf{k}=\mathbf{m}$. Assim: $\mathbf{F} / \mathbf{a}=\mathbf{m}$, ou

$$
\mathbf{F}=\mathbf{m a}
$$

Esta última expressão é conhecida como a segunda lei de Newton. Como ela permite prever o movimento que um corpo vai descrever, é conhecida também como lei fundamental da dinâmica. De fato, se conhecermos a posição inicial e a velocidade inicial de um corpo, podemos prever a trajetória que ele descreverá, assim como sua veloci- 
FAI 2 (1973, p.39)

\section{CAPÍTULO V}

\section{Forca e Movimento}

OBJETIVOS: Ao final deste capítulo, o estudante deve estar apto para:

a. conceituar força.

b. operar com forças; calcular a força resultante.

c. descrever a 1a Lei de Newton.

d. descrever as diversas formas em que as forças se manifestam.

e. medir forças.

f. descrever a 2a Lei de Newton.

g. resolver problemas.

No Capítulo III, analisamos e descrevemos os diversos tipos de movimentos retilíneos. Não nos preocupamos com o objeto em movimento e nem com os agentes que produziam ou alteravam os movimentos. Um avião ou um pedaço de pedra foram tratados igualmente: seu tamanho ou sua massa não foram considerados. Neste capitulo, nos preocuparemos com os agentes que podem modificar o movimento e também a massa de objetos; estudaremos, então, as forças e consideraremos a massa dos objetos. Na Física, força é uma grandeza das mais importantes. Descrever e medir forças é uma necessidade em vários ramos da Física. Devemos, portanto, ter uma compreensão exata de como as forças atuam e saber resolver os diversos problemas a ela atinentes.

\section{SEC̣ĀO 1 - ESTADO DE MOVIMENTO - FORC̣A}

1 - Se você "puxa" uma porta, inicialmente em repouso (fechada), a fim de abri-la, você está aplicando uma força sobre a porta. $\mathrm{O}$ "puxão" que a porta recebe faz com que ela, ao ser aberta, (fique parada; entre em movimento).

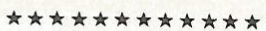

entre em movimento

2 - Um automóvel que se encontra enguiçado é "empurrado" por diversas pessoas. Enquanto é "empurrado" o automóvel sofre a ação de encontrava em repouso, entrará em . Em virtude das ações das forças, o automóvel, que inicialmente se

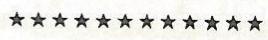

forças; movimento

3 घ Um goleiro, ao "encaixar" uma bola, impede seu movimento, e a bola, inicialmente em movimento, entrará em A bola, que possuía uma velocidade diferente de zero, sob a ação de uma aplicada contra seu movimento, ficou com velocidade igual a

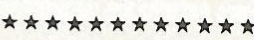

repouso; força; 0 ou zero

4 घ Uma bola de bilhar encontra-se em movimento sobre uma mesa e recebe um "empurrão" no sentido de seu movimento por um dos participantes do jogo. Durante o "empurrão", a bola recebe a ação de uma

e em conseqüência a sua velocidade (aumenta; diminui).

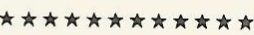

força; aumenta 
FAI $2(1973$, p.40)

5 घ Uma bola é cruzada horizontalmente em frente ao gol, durante uma partida de futebol. $\mathrm{O}$ goleiro, com um soco, aplica-lhe um "empurrão" perpendicularmente. A trajetoria da bola será (inalterada; alterada) em conseqüência da ação de uma durante o "empurrão".

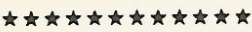

alterada; força

6 - Um objeto movimenta-se em linha reta com velocidade constante. Se o objeto não sofrer nenhum "puxão" ou "empurrão", ele (continuará em linha reta com a mesma velocidade; aumentará sua velocidade; diminuirá sua velocidade; sofrerá um desvio em sua trajetória). Nesta situação, o objeto parece não sofrer a ação de nenhuma

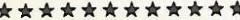

continuará em linha reta com a mesma velocidade; força

7 - Nós exercemos um "puxão" ou "empurrão" sobre um objeto para:

a) a partir do repouso, colocá-lo em
b) diminuir ou sua
c) trazê-lo ao , se ele estiver em movimento.
d) modificar sua , se ele já estiver em movimento.

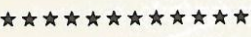

movimento; aumentar; velocidade; repouso; trajetória

8 Um objeto movimenta-se em linha reta com velocidade constante. Se ele continuar em linha reta e com a mesma velocidade, dizemos que o objeto não variou seu estado de movimento. Podemos afirmar que o objeto em questão (conservou; não conservou) seu estado de

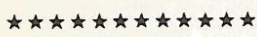

conservou; movimento

9 - Um automóvel com velocidade constante de $50 \mathrm{~km} / \mathrm{h}$ realiza uma curva na Via Anchieta. Durante a curva, o automóvel (mantém; não mantém) seu estado de movimento, porque, apesar da velocidade ser conservada a $50 \mathrm{~km} / \mathrm{h}$, sua não se manteve retilínea.

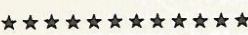

não mantém; trajetória

10 - Uma pedra que cai de uma altura de 2 metros em linha reta (aumenta; diminui; conserva) sua velocidade à medida que se aproxima do solo. O estado de movimento desta pedra (mantém-se; não se mantém) constante. Justifique.

$\hbar \hbar \hbar \hbar \hbar \hbar \hbar \hbar \hbar$

aumenta; não se mantém (Apesar da trajetória ser retilínea, a velocidade da pedra aumenta à medida que cai em queda livre.)

11 - Quando puxamos ou empurramos um objeto, nossa intenção é seu estado de movimento.

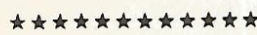

alterar, modificar, variar ou mudar

12 a Os físicos consideram o repouso como um tipo de movimento. Se você analisar o movimento em termos de velocidade, o repouso é um movimento com velocidade

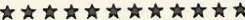

zero 


\section{Livros Didáticos}

Dalton Gonçalves (1970, p.203)

\section{Capítulo 12}

\section{DINÂMICA DAS TRANSLAÇÕES}

\section{1 - Massa}

Vimos, no $\S 11.16$, a definição, as equações dimensionais, e as unidades de massa.

Da fórmula de definição da massa, $m=F / a$, tiramos:

$$
a=\frac{F}{m}
$$

onde vemos que a aceleração adquirida por um corpo $\epsilon$ inversamente proporcional a sua massa. Isto é o mesmo que dizer: quanto maior a massa de um corpo, mais difícil será modificar o seu estado de movimento retilíneo uniforme ou de repouso (isto é, acelerá-lo ou retardá-lo).

Se o leitor reler, agora, o conceito de inércia ( $\$ 7.1$ ) poderá concluir que:

$$
\text { a massa de um corpo é uma medida da sua inércia. }
$$

\section{2 - Segunda lei de Newton}

A aceleração adquirida por um corpo é proporcional à resultante das fôrças que agem sôbre êle, inversamente proporcional à sua massa e tem a mesma direção e o mesmo sentido da fôrça resultante.

Se $m$ é a massa do corpo e $R$ a resuitante das fôrças que agem sôbre êle, teremos:

$$
\vec{a}=\frac{\vec{R}}{m}
$$

eq. 12.1 
Dalton Gonçalves (1970, p.224)

Daí tiramos:

$$
\vec{R}=m \vec{a} \quad \text { eq. } 12.2
$$

formula denominada Equação Fundamental da Dinâmica.

Uma vez subentendido que $\vec{R}$ e $\vec{a}$ são vetores de mesmo suporte e de mesmo sentido, podemos dispensar a notação vetorial e escrever apenas:

$$
R=m a
$$

Como caso particular, se sôbre o corpo a única fôrça atuante é o seu pêso, teremos:

Exemplo 1.

$$
P=m g \quad \text { eq. } 12.4
$$

Um corpo, de pêso igual a $10 \mathrm{kgf}$, move-se sôbre um plano horizontal por açăo de uma fôrça de $4 \mathrm{~N}$, paralela ao plano.

Desprezandc-se o atrito e considerando $g=9,8 \mathrm{~m} / \mathrm{s}^{2}$, pede-se a sceleração.

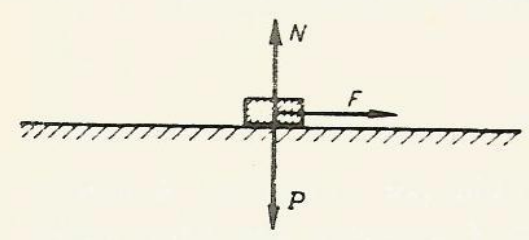

Fig. 12.1

$\mathrm{Na}$ figura 12.1 estão representadas as fôrças que agem sôbre o corpo.

Como as fôrças $P$ e $N$ se equilibram a fôrça resultante é $F$.

$$
F=m a
$$

Não conhecemos a massa, mas, sabemos o pêso:

$$
\begin{gathered}
P=m g . \because \quad m=\frac{P}{g} \\
\therefore \quad F=\frac{P}{g} \cdot a . \therefore \quad a=g \frac{F}{P}
\end{gathered}
$$

No caso $g=9,8 \mathrm{~m} / \mathrm{s}^{2}, F=4 \mathrm{~N}$, $i=10 \mathrm{kgf}=10 \times 9,8 \mathrm{~N}$. Logo:

$$
a=9,8 \cdot \frac{4}{9,8 \times 10} \quad \therefore a=0,4 \mathrm{~m} / \mathrm{s}^{2} .
$$

\section{Exemplo 2.}

Um balde cheio de concreto tem $50 \mathrm{~kg}$ de massa. Êle deve ser içado por meio de uma corda, com a maior aceleração possível. Determinar esta aceleração sabendo que a corda resiste, no máximo, a um esfôrço igual a $700 \mathrm{~N}$.,

Supor $g=10 \mathrm{~m} / \mathrm{s}^{2}$

$\mathrm{Na}$ figura 12.2 mostramos as fôr-

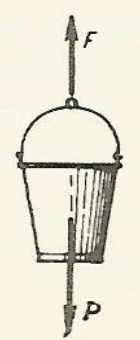

Fig. 12.2 
Dalton Gonçalves (1970, p.239)

CAP. 12

DINÂMICA DAS TRANSLAGÕHS

Assim, podemos enunciar

"O trabalho realizado pela resultante de tôdas as fôrças que agem sôbre um corpo para deslocá-lo entre dois pontos, é igual à variação da energia cinética do corpo, entre os pontos considerados".

Ao usarmos a equação 12.16 devemos interpretar o têrmo $\tau$ como sendo o trabalho realizado pela resultante do sistema constituído por TÔDAs as fôrças que agem sôbre o corpo (inclusive o seu pêso e as fôrças de atrito).

\section{Observação}

Deduzimos os teoremas das energias cinéticas para o caso da trajetória do corpo ser retilínea e da fôrça ser constante.

O teorema é, entretanto, geral.

Podemos usá-lo entre dois pontos quaisquer da trajetória, seja ela retilínea ou curvilinea, seja a fôrça constante ou variável.

\subsection{4 - Teorema das fôrças vivas \\ Podemos deduzi-lo do teorema das energias cinéticas.}

De

tiramos:

$$
\tau=\frac{1}{2} m v_{B}^{2}-\frac{1}{2} m v_{A}^{2}
$$

$$
\tau=\frac{1}{2}\left(m v_{B}^{2}-m v_{A}^{2}\right)
$$

"O trabalho realizado pela resultante de tôdas as fôrças que agem sôbre um corpo, para transportá-lo entre dois pontos, é igual à semi-variação da fôrça viva do corpo, entre os pontos considerados".

\section{Observação}

Tendo em vista a observação do $\$ 12.12$, não utilizaremos, neste livro, o teorema das fôrças vivas.

\subsection{5 - Cálculo do trabalho realizado sôbre um corpo por um agente externo}

Deduziremos agora, uma equação que, no fundo, não passa do teorema das energias cinéticas escrito sob outra forma, mas, que tem sôbre êle uma vantagem: tơrna mais cómoda a resolução de problemas.

Sunonhamos um corpo sôbre um plano inclinado. 
Alvarenga e Máximo (1970, p. 95)

CAPITULO VI

\section{LEIS DE NEWTON - FÔRCA E ACELERAÇÃO}

Como você se lembra, no Cap. IV estudamos o movimento de um corpo sem nos preocuparmos com suas causas. Fizemos uma descrição do movimento, utilizando equações e gráficos, sem nos preocuparmos em saber, por exemplo, porque o corpo havia adquirido uma certa aceleração ou porque sua trajetória era retilínea. Êste era o estudo da Cinemática. No Cap. V, foi introduzido o conceito de fôrça e a Primeira Lei de Newton foi analisada, mostrando como é o movimento na ausência de fôrças. O conhecimento da primeira lei levou-nos ao estudo do equilíbrio (Estática).

Seria natural que, agora, você se preocupasse em saber como é movimento de um corpo se a resultante das fôrças que nêle atuam é diferente de zero. A resposta a esta pergunta será encontrada na Segunda Lei de Newton, que estudaremos a seguir. Você verá que uma fôrca provoca mudanças no movimento, isto é, uma fôrça causa acelerações. Este estudo que agora continua, no qual se procura analisar as causas do movimento e de suas mudanças, denomina-se Dinâmica, como você aprendeu no capítulo anterior. O estudo de Dinâmica constitui, essencialmente, o estudo da própria Mecânica.

\section{VI.1 - A SEGUNDA LEI DE NEWTON - MASSA INERCIAL}

Como dissemos, se uma fôrça age sôbre um corpo, seu movimento será acelerado. Você pode constatar isto, analisando a fig. VI.1 (a), que mostra as posições ocupadas por uma partícula, em intervalos de tempo sucessivos e iguais, quando puxada por uma fôrça constante. A crescente separação entre duas posições sucessivas mostra que a velocidade da partícula está aumentando. Uma fôrça constante pode ser obtida, por exemplo, por meio de uma mola prêsa ao corpo, como na fig. VI-1(b). Se mantemos constante a deformação da mola, enquanto o corpo se move, uma fôrça também constante atua na partícula e obtemos o movimento acelerado mostrado na fig. VI-1(a). Nesta experiência, o corpo foi puxado sôbre uma superfície horizontal lisa, de modo que a reação normal da superfície anulava o pêso do corpo e o atrito era muito pequeno. Com isto, eliminamos a influência de tôdas as fôrças, com exceção da fôrça $\overrightarrow{\mathrm{F}}$ exercida pela mola. A aceleração observada na fig. VI-1(a) é causada, portanto, apenas por esta fôrça.

Que relação existiria, então, entre a fôrça aplicada ao corpo a aceleração por ela produzida?: A experiência poderá responder a esta pergunta. Voltemos à partícula da fig. VI-1 e chamemos de $F_{1} 0$ valor da fôrça aplicada. Este valor seria obtido diretamente com uma calibração prévia da mola, como foi estudado no capítulo anterior.
VI-1: A Segunda Lei de Newton - Massa Inercial.

VI-2: Unidades de Fôrça e Massa.

VI-3: Massa e Pêso.

VI-4: Algumas Aplicações da Segunda I.ei de Newton.

VI-5: Fôrças no Movimento Circular.

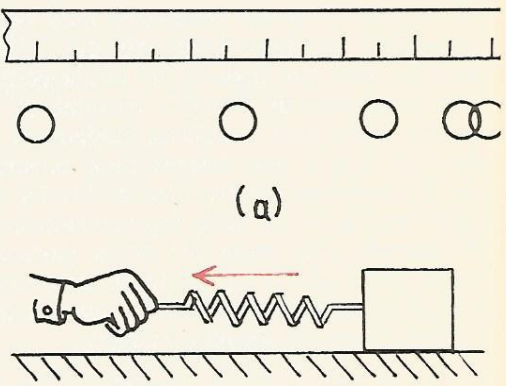

(b)

Fig. VI-1: a) Quando uma partícula é puxada por uma fôrça, seu movimento é acelerado. A fôrça pode ser exercida por meio de uma mol esticada, como em (b). 
Alvarenga e Máximo (1970, p. 96)

Uma análise do movimento da partícula, utilizando, por exemplo, a fig. VI-1 (a), permite a você medir a aceleração produzida por $\mathrm{F}_{1}$. Chamemos de $a_{1}$ o valor desta aceleração. Podemos, agora, alterar 0 valor da fôrça aplicada, alterando a deformação da mola. Seja $F_{2} \circ$ nôvo valor da fốrça. Repetindo a experiência, verificamos que o corpo se move com uma aceleração diferente, que designaremos por $\mathrm{a}_{2}$. Desta maneira, um grande número de medidas da fôrça e da aceleração do corpo podem ser obtidas. Se você analisasse estas medidas, verificaria que:

$$
\frac{F_{1}}{a_{1}}=\frac{F_{2}}{a_{2}}=\frac{F_{3}}{a_{3}}=\ldots . .=\text { constante }
$$

isto é, o quociente $\mathrm{F} / \mathrm{a}$ é uma constante. A experiência mostra, então, que a fôrça aplicada a um corpo é diretamente proporcional à aceleração que ela produz. Dobrando-se o valor da fôrça, ela produzirá uma aceleração duas vêzes maior. Desta maneira, o gráfico $\mathrm{F} \times$ a será igual ao mostrado na fig. VI-2. Os mesmos resultados são obtidos, quer o corpo esteja inicialmente em repouso, quer já esteja em movimerto a constante de proporcionalidade da relação entre $F$ e a. Esta constante chama-se massa inercial e é representada por $m$. Então:

$$
\frac{\mathrm{F}}{\mathrm{a}}=\mathrm{m} \quad \text { ou } \quad \mathrm{F}=\text { ma. }
$$

A massa inercial é, portanto, uma constante para um dado corpo. Se a experiência fôsse repetida usando-se outro corpo, o mesmo tipo de relação entre $F$ e $a$ seria encontrado, mas a constante de proporcionalidade poderia ser diferente (fig. VI-3). A massa inercial é, portanto, uma característica do corpo, definida operacionalmente* pela equação:

$$
\mathrm{m}=\frac{\mathrm{F}}{\mathrm{a}}
$$

Note que $m$ é uma grandeza escalar. Assim, suponha que, na experiência descrita, uma fôrça de $4,0 \mathrm{kgf}$ imprimisse ao corpo uma aceleração de $2,0 \mathrm{~m} / \mathrm{s}^{2}$. A massa inercial dêste corpo seria:

$$
\mathrm{m}=\frac{4,0 \mathrm{kgf}}{2,0 \mathrm{~m} / \mathrm{s}^{2}} \quad \therefore \mathrm{m}=2,0 \frac{\mathrm{kgf}}{\mathrm{m} / \mathrm{s}^{2}}
$$

Qual seria a aceleração dêsse corpo, sob a ação de uma fôrça de 6,0 $\mathrm{kgf?}$

$\mathrm{A}$ equação $\mathrm{F}=$ ma estabelece uma relação entre os módulos de duas grandezas vetoriais. Uma vez que, tanto $\vec{F}$ quanto $\vec{a}$ têm direção e sentido, será que poderia ser estabelecida alguma relação entre as direções e sentidos de $\vec{F}$ e $\vec{a}$ ? Novamente, a observação experimental responde à pergunta. Análises cuidadosas de experiências bem mais elaboradas que a que descrevemos, mostram que a direção e o sentido de $\vec{a}$ coincidem sempre com a direção e o sentido de $\vec{F}$. Isto é mostrado na fig. VI-4, onde representamos, em uma vista de cima, o vetor $\vec{F}$ exercido pela mola em nossa partícula de massa $m$, bem como o vetor aceleraçãó $\vec{a}$ da partícula, aceleração esta produzida por $\overrightarrow{\mathrm{F}}$. Este resultado experimental mostra que a relação $\mathrm{F}=$ ma pode ser escrita vetorialmente da seguinte maneira:

$$
\overrightarrow{\mathrm{F}}=\mathrm{m} \overrightarrow{\mathrm{a}}
$$

Observe que esta equação nos diz muito mais que a relação $F=$ ma. Além de ela nos fornecer a relação entre os módulos dos vetores $\overrightarrow{\mathrm{F}}$ e $\vec{a}$, como já sabemos que $\overrightarrow{\mathrm{F}}$ e $\overrightarrow{\mathrm{a}}$ têm mesma direção e mesmo sentido, concluímos que $m$ será sempre um escalar positivo.

* Dizemos que uma definição é operacional quando ela nos indica um processo de medida da grandeza que está sendo definida.

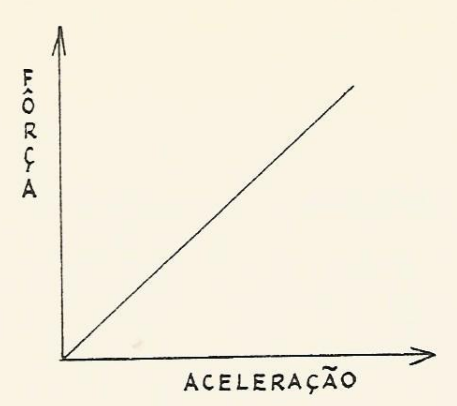

Fig. VI-2: A fôrça aplicada a uma partícula ć diretamente proporcional à aceleração que ela produz. $O$ gráfico acima representa a relação $\mathrm{F}=\mathrm{m} \cdot \mathrm{a}$.
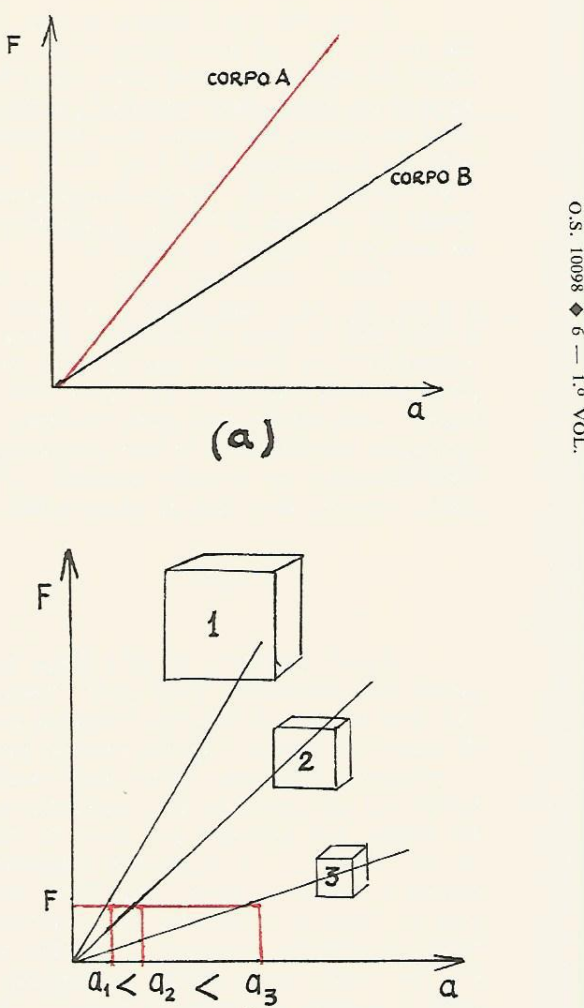

(b)

Fig. VI-3: Para qualquer corpo, a experiência mostra que $F \propto$ a, mais a inclinação do grá fico $\mathrm{F} \times$ a pode variar de corpo para corpo. $\mathrm{Na}$ figura (a), qual dos dois corpos tem maio massa inercial? Se uma mesma fôrça $\mathbf{F}$ é aplicada, sucessivamente, a cada corpo (b), qual dêles adquire maior aceleração? 
Alvarenga e Máximo (1979, p.168)

168

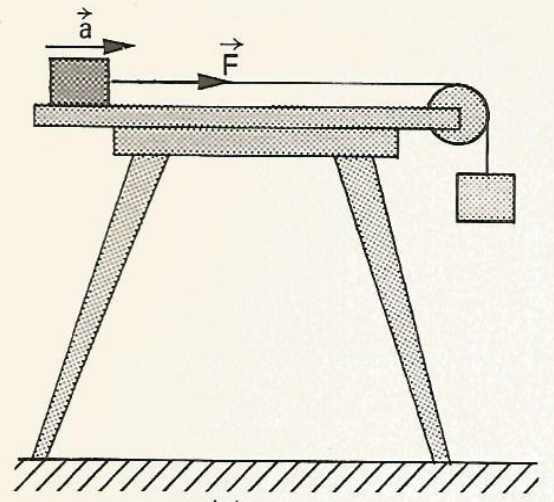

(a)

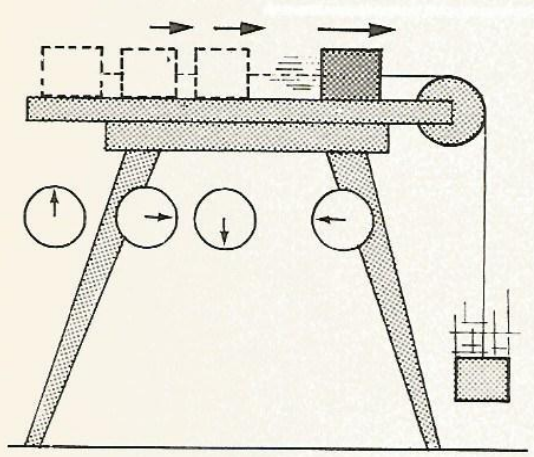

(b)

Fig. 6-1: A força $\vec{F}$ imprime ao corpo um movimento acelerado.

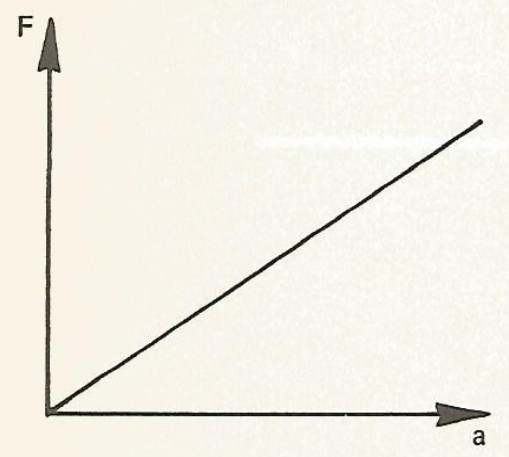

Fig. 6-2: A força aplicada a uma partícula é diretamente proporcional à aceleração que ela produz.

\section{1 - A SEGUNDA LEI DE NEWTON}

- Introdução - Vimos, quando estudamos a 1 a lei de Newton que, se a resultante das forças que atuam em um corpo for nula, este corpo estará em repouso ou em movimento retilíneo uniforme. Em qualquer destas situações, a aceleração do corpo é nula. Assim

se $\vec{R}=0$ teremos $\vec{a}=0$

Então, que tipo de movimento teria o corpo se a resultante das forças que nele atuam fosse diferente de zero? A resposta a esta pergunta pode ser encontrada através de uma experiência bastante simples. Consideremos um objeto colocado sobre uma superfície horizontal lisa (sem atrito), sendo puxado por uma força $\vec{F}$ (fig. 6-1-a). Como as demais forças que atuam no corpo (peso e reação normal) se equilibram, podemos considerar a força $\vec{F}$ como a única força que atua no corpo. A fig. 6-1-b mostra as posições do corpo tomadas em intervalos de tempo iguais, en seu movimento sob a ação da força $\vec{F}$. Como a distância entre duas posições sucessivas está crescendo, evidentemente a velocidade do corpo está aumentando, ou seja, o movimento do corpo é acelerado. Concluímos, então, que

um corpo, sob a ação de uma força única, adquire uma aceleração, isto é, se $\vec{F} \neq 0$ temos $\vec{a} \neq 0$.

- Relação entre força e aceleração - Na experiência mostrada na fig. $6-1$, para um dado valor da força $\vec{F}$ aplicada no corpo, podemos medir o valor da aceleração $\vec{a}$ que o corpo adquire. Repetindo a experiência com diversos valores da força $\vec{F}$, verificamos que

duplicando $F$, o valor de a também duplica triplicando $F$, o valor de $a$ também triplica quadruplicando $F$, o valor de $a$ também quadruplica etc.

Portanto, através da experiência, podemos concluir que

a força $F$ que atua em um corpo é diretamente proporcional à aceleração $a$ que ela produz no corpo, isto é, $F \propto a$.

Desta maneira, se construirmos um gráfico $F \times a$, com os valores obtidos através da experiência citada, obteremos uma reta passando pela origem (fig. 6-2). 
Alvarenga e Máximo (1979, p.169)

- Massa de um corpo - Sendo $F \propto a$, sabemos que a relação $F / a$ é constante e esta constante é igual à inclinação do gráfico $F \times a$.

Suponha que a experiência fosse repetida usando-se, porém, um outro corpo. Construindo o gráfico $F \times a$ para este outro corpo, obteríamos ainda uma reta passando pela origem, mas com uma inclinação diferente da anterior. De um modo geral, verificamos que, para um dado corpo, temos sempre $F \propto a$, mas a nclinação do gráfico $F \times a$ varia de um corpo para outro (fig. $6-3$ ). Portanto, o quociente $F / a$ tem um valor constante para um dado corpo sendo, assim, característico de cada objeto. Este quociente é denominado massa, $m$, do corpo. Então

massa de um corpo é o quociente entre a força que atua no corpo e a aceleração que ela produz nele, isto é,

$$
m=\frac{F}{a}
$$

Observe que a inclinação do gráfico $F \times a$ nos fornece o valor da massa $m$ do corpo. Então, na fig. 6-3, temos $m_{1}>m_{2}>m_{3}$. De $m=F / a$, obtemos

$$
a=\frac{F}{m}
$$

Esta relação mostra que, para uma dada força, quanto maior for a massa de um corpo, menor será a aceleração que ele adquire. Em outras palavras, a massa de um corpo caracteriza a "dificuldade" que ele apresenta em adquirir uma aceleração. Portanto, dados dois corpos de massas diferentes, o de maior massa apresenta maior "dificuldade" em ter sua velocidade modificada, ou seja, o de maior massa apresenta maior inércia. Lembre-se, por exemplo, que um caminhão carregado (maior massa = maior inércia), partindo do repouso, demora mais a adquirir uma certa velocidade do que se estivesse vazio (menor massa $=$ menor inércia). Do mesmo modo, se o caminhão, em movimento, "perder os freios", I mais difícil pará-lo se ele estiver carregado, uma vez que sua inércia é maior do que se ele estivesse vazio. Concluindo,

quanto maior for a massa de um corpo, maior será a sua inércia, isto é, a massa de um corpo é uma medida da inércia deste corpo.

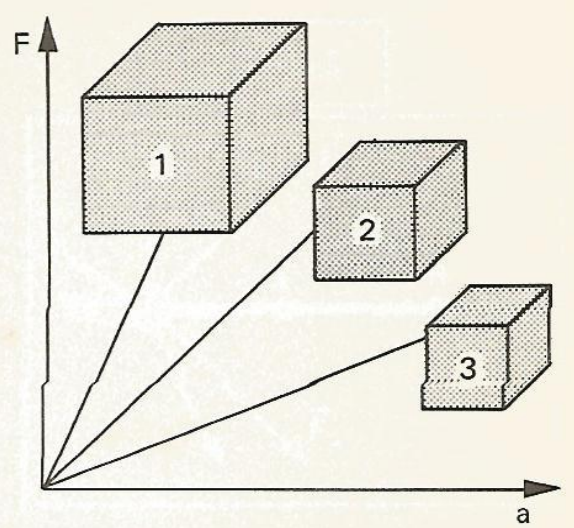

Fig. 6-3: A inclinação do gráfico $F \times a$ representa a massa do corpo. 
Ramalho et al. (1978, p. 178)

Explicamos essas interações entre os corpos afirmando que os mesmos exercem forças entre. si. Desse modo, do ponto de vista dinâmico:

FORÇAS são interações entre corpos que produzem variações em sua velocidade, isto é, provocam aceleração.

Podem existir forças quando corpos entram em contato (taco na bola de bilhar) ou mesmo quando estão à distância ( $a$ Terra atraindo um corpo em queda live).

Newton estabeleceu uma lei básica para a análise geral das causas dos movimentos, relacionando as ferças aplicadas a um ponto material de massa $m$ constante e as acelerações que provocam. Sendo $\overrightarrow{F_{\mathrm{R}}}$ a soma vetorial (resultante) das forças aplicadas e $\vec{\alpha}$ a aceleração que produz em sua direção e sentido, a lei de Newton estabelece:

A resultante das forças aplicadas a um ponto material é igual ao produto de sua massa pela aceleração adquirida:.

$$
\vec{F}_{\mathrm{R}}=m \cdot \vec{\alpha}
$$

O enunciado anterior é conhecido como princípio fundamental da Dinâmica. A igualdade vetorial $\vec{F}_{\mathrm{R}}=m \cdot \vec{\alpha}$ é a equação fundamental da Dinâmica válida num referencial inercial.

ISAAC NI:WTON - (1642-1727) Nasceu $\mathrm{em}$ Woolsthorpe (Inglaterra); foi educado na Universidade de Cambridge, onde foi aluno excelente c aplicado. Durante a grande peste de 1664-66, fechadas as Universidades, Newton com 23 anos de idade, produz intensamente: descobrimentos importantes $\mathrm{cm}$ matemática (teorema do binô. mio, cálculo diferencial), em óptica (teoria da cor) e em mecânica. l'oi presidente da Sociedade Real e Chefe da Casa Moeda da Inglaterra, ajudando na reorganização monetária de seu país.
Deixa de ser válida se a massa da partícula variar, fato que ocorre no domínio microscópico das partículas atômicas. Nos fenômenos macroscópicos de nossa vida diária, a equação fundamental da Dinâmica é suficiente para interpretações e análises.

Da equação fundamental $\vec{F}_{\mathrm{R}}=m \vec{\alpha}$, concluimos que a massa $m$ é a medida da inércia da matéria. Um corpo de grande inércia apresenta grande massa: uma pequena força $\vec{F}_{\mathrm{R}}$ provocará no corpo de grande massa ou inércia, uma pequena variação de velocidade ou aceleração. 
Ramalho et al. (1978, p. 179)

Cap. 10 - Os Princípios Fundamentais

Observe que $\vec{F}_{\mathrm{R}}=m \vec{\alpha}$ é uma igualdade vetorial, onde $\vec{F}_{\mathrm{R}}$ é a soma vetorial das forças que atuam na partícula, como se ilustra a seguir. Na Fig. $9 \mathrm{a}, \vec{F}_{\mathrm{R}}$ reduz-se à única força que atua no corpo e nas figuras seguintes, $\vec{F}_{\mathrm{R}}$ é dada pela adição vetorial das forças atuantes.

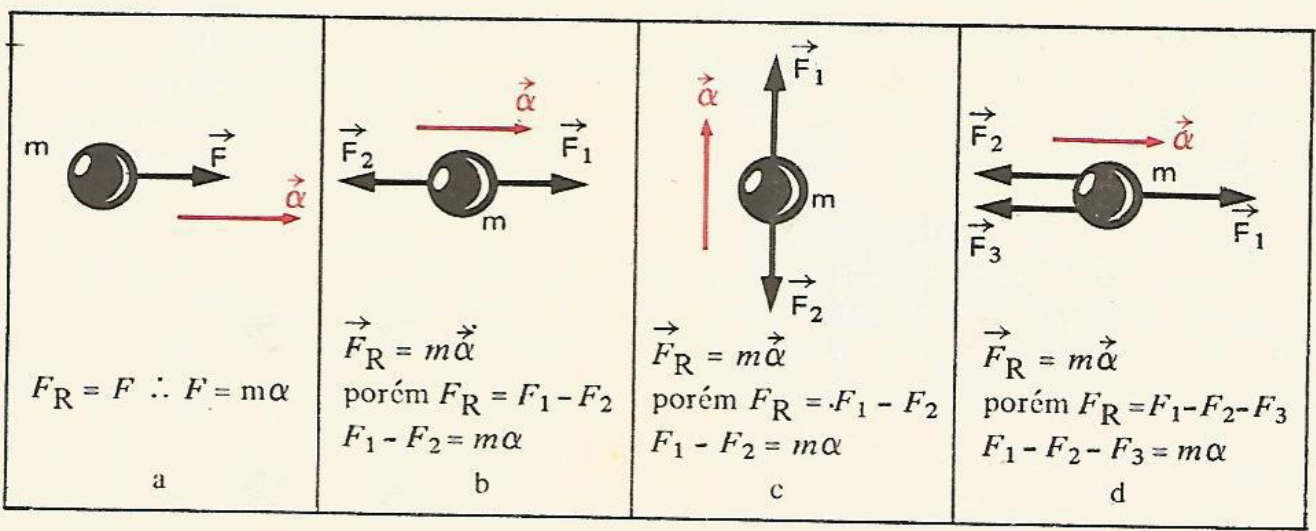

Fig. 9 - Na equação fundamental da dinâmica $\vec{F}_{\mathrm{R}}=m \vec{\alpha}, \vec{F}_{\mathrm{R}}$ é a soma vetorial das forças que atuam no corpo, $m$ é grandeza escalar e $\vec{\alpha} \dot{c}$ a aceleração adquirida.

$\mathrm{Na}$ equação fundamental, se a massa $\mathrm{m}$ estiver em quilograma $(\mathrm{kg})$ e a aceleração em $\mathrm{m} / \mathrm{s}^{2}$, a unidade de intensidade de força denomina-se newton (abreviatura: $N$ ) em homenagem ao célebre cientista inglês.

\section{O PESO É UMA FORÇA}

Os corpos próximos à superfície da Terra são atraídos por ela. Abandonados a uma determinada altura do solo, caem sofrendo variações de velocidade. Dizemos então que a Terra interage com esses corpos exercendo uma força chamada peso (Fig. 10).
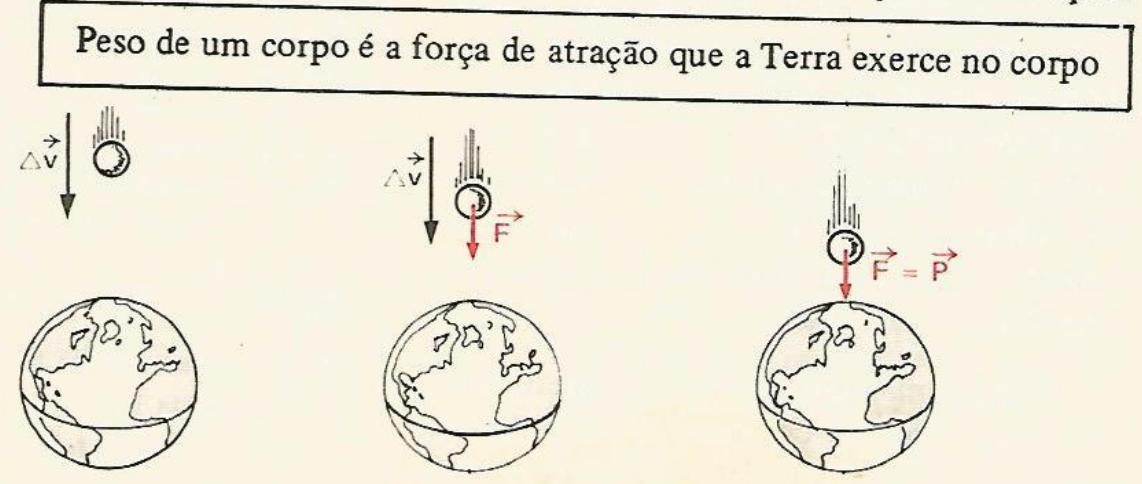

Fig. 10 - O peso de um corpo é a força de atração da Terra sobre ele. 